Szegedi Tudományegyetem Bölcsészettudományi Kar

Történelemtudományi Doktori Iskola

Jelenkortörténet

\title{
URALKODÓ MAGYAR ESZMÉK A VÁLTOZÁSBAN Erdély 1910-1922
}

\author{
Falusi Norbert
}

\author{
Témavezető: \\ Dr. Bárdi Nándor \\ MTA Társadalomtudományi Kutatóközpont \\ Kisebbségkutató Intézet \\ Tudományos fömunkatárs
}

2018.

Szeged 


\section{Tartalom}

1. BEVEZETÉS

1.1. Kutatási kérdések és módszertani megközelítések

1.2. Historiográfia: az átmenet irodalma és a továbblépés lehetőségei 17

1.2.1. A historiográfiai áttekintés néhány tanulsága 33

2. REGIONÁLIS NÉZŐPONT KIALAKULÁSA: BIRTOKPOLITIKA, VÁLASZTÓJOG, NEMZETISÉGI KÉRDÉS

2.1. Birtokpolitikai viták

2.2. A választójogi vita

2.3. A magyar nemzetiségi politika keretrendszere. Tisza István törekvései a magyar-román kiegyezésért

2.3.1. Viták és közös pontok a nemzetiségi kérdésben az Erdélyi Szövetség megalakulásáig

2.4. 1916-A fordulat éve

3. ERDÉLYI SZÖVETSÉG: INTÉZMÉNY- ÉS PROGRAMTÖRTÉNET, 1913-1918 87

3.1. Előzmények, alakuló ülés, politikai fogadtatás 87

3.2. Az Erdélyi Szövetség programja, 1914

3.2.1. Nemzeti Népszövetség: az Erdélyi Szövetség kiterjesztett keze 101

3.3. 1916-A román betörés politikai tapasztalata: az Erdélyi Szövetség „magyar terve” 104

3.4. Az Erdélyi Szövetség funkciói és tagjainak eltérő szerepfelfogása 115

4. ERDÉLYI SZEMMEL NEMZETRŐL, NEMZETISÉGI KÉRDÉSRŐL AZ ÖSSZEOMLÁSIG 121

4.1. Bethlen István: Erdély vezető politikusa 121

4.2. Jancsó Benedek: a szakértő, a publicista és a Székely Nemzeti Tanács vezetője 125

4.3. Az Erdélyi Szövetség tudós hármasa: Apáthy István, Pósta Béla, Kenéz Béla 128

4.3.1. Apáthy István: eugenetika és állami politika a nemzetépítés szolgálatában 128

4.3.2. Pósta Béla: „a magyar a turáni népekhez tartozik” 137

4.3.3. Kenéz Béla: „a nép és a föld harmóniájának megteremtése” 139

4.4. Réz Mihály: „a nép nem demokrata” 144

4.4.1. Két politikai gondolkodó vitája: Réz Mihály és Jászi Oszkár 146

4.5. Jakabffy Elemér: „a nyelv és a vallás azonossága még nem minden” 149

4.6. Pál Gábor: „Erdély mostohája Magyarországnak” 153

4.7. Gyárfás Elemér: „érdekközösségen alapuló érzelmi közösség” 157

4.8. Paál Árpád: a kossuthi függetlenségi polgári-radikális 160

4.8.1. A Székely Köztársaság alternatívája 161

5. ÁTALAKULÓ HATÁRHELYZETEK: HATALOMÁTVÉTEL-ELLENÁLLÁS, SZEMBENÉZÉS AZ ELCSATOLÁSSAL-KISEBBSÉGI ÚTKERESÉS KIJELÖLÉSE 163

5.1. Hatalomátvétel: a román Kormányzótanács és a magyar impérium megszűnése Erdélyben 164

5.1.1. Tisztviselői helyzetkép, a hüségeskü problémája 167

5.1.2. A székelyföldi vármegyék közigazgatásának román átvétele 169

5.1.3. A Szellemi Front-tisztviselőmozgalom ellenállása 174

5.2. A magyar intézményi szerkezet és lehetséges alternatívák: egyház, nyilvánosság, egyesületek és a politizálás alternatívái 176

5.2.1. A politikai önszervezés öt eltérő alternatívája 186

5.3. A politikai cselekvés értelmezése a „passzivisták” és az „aktivisták” konfliktusában 196

5.4. A romániai magyarság nemzetkonstrukciója 203 
5.4.1. Bernády György: Budapest és Bukarest között 204

5.4.2. A politikai-kulturális együvé tartozás igényének megfogalmazása 208

5.4.3. Új politikai és társadalmi kategória: nemzeti kisebbség 213

5.4.4. A Keleti Újság szerepe a kisebbségi társadalom építésének tudatosításában 219

$\begin{array}{ll}\text { 5.4.5. A Kiáltó Szó és a Magyar Szövetség } & 221\end{array}$

$\begin{array}{ll}\text { 5.5. Magyarság és zsidóság útválasztása } & 224\end{array}$

6. INTÉZMÉNY- ÉS PROGRAMTÖRTÉNET, 1920-1922: Magyar Szövetség, Erdélyi Néppárt, Magyar Nemzeti Párt és fúzió

6.1. A Magyar Szövetség előkészítése és a magyar püspökök eskütétele 233

6.2. Grandpierre Emil: Románia föderalizálása helyett nemzeti autonómia 237

6.3. Az „egy politikai közösség” igénye: magyarság, zsidóság, munkásság 240

6.4. A Magyar Szövetség megindítása $\quad 242$

6.4.1. A Magyar Szövetség alakuló nagygyülése, 1921. július 6.

6.4.2. Vidéki építkezés, Központi Népiroda felállítása és a Szövetség első memoranduma 257

6.5. Az Erdélyi Néppárt megalakítása és hatása a két magyar politikai csoport viszonyában 264

6.6. A Magyar Szövetség működésének első felfüggesztése, 1921 ősz 272

6.6.1. Értelmezési viták a Magyar Szövetségről, a politikai egységről és a pártalakításról 276

6.6.2. Diplomáciai jelentések a budapesti kormány részére 278

6.7. Részvétel az 1922. évi választásokon és a Magyar Nemzeti Párt megalakítása 283

6.7.1. Két pártban a magyarság: a Magyar Nemzeti Párt és az eltérő programok 288

6.7.2. A progresszív Keleti Újság és a Napkelet magyarországi recepciója, 1919-1922 292

6.8. Az irracionalitás politikai világa: a Magyar Szövetség másodszori felfüggesztése 299

6.9. A Magyar Szövetség politikai „örököse” a Magyar Nemzeti Párt. A fúzió útján 302

6.9.1. Az utolsó felvonás: politikamentes Magyar Szövetség? 307

6.9.2. A Magyar Nemzeti Párt: az alkotmányreform vitája és részvétel a koronázáson 310

6.10. A két magyar párt egyesülése: az Országos Magyar Párt 312

7. ÖSSZEGZÉS: FOLYTONOSSÁG ÉS ÚJPOLITIKÁK 319

8. MELLÉKLET

9. KRONOLÓGIA: 1916-1922 337

10. FORRÁSOK, IRODALOM 372

$\begin{array}{ll}\text { Szakirodalom } & 372\end{array}$

$\begin{array}{ll}\text { Levéltári források } & 379\end{array}$

$\begin{array}{ll}\text { Korabeli sajtó } & 380\end{array}$

$\begin{array}{ll}\text { Elsődleges dokumentumok } & 381\end{array}$

$\begin{array}{ll}\text { Internetes adatbázis } & 384\end{array}$

$\begin{array}{ll}\text { Köszönetnyilvánítás } & 386\end{array}$ 


\section{BEVEZETÉS}

Magyarországon a 19. és 20. század fordulójától megélénkültek a politikai és kulturális decentralizációs törekvések. A Budapest-központú intézményrendszerrel szemben pezsgés indult néhány hagyományos vidéki központban, így Kolozsváron, Marosvásárhelyen, Pozsonyban, Komáromban, Kassán, Debrecenben, sőt új kulturális és politikai központok is létrejöttek, például a gyorsan polgárosodó Nagyváradon, vagy éppen Temesváron ${ }^{1}$, ahol négy kultúra, a magyar, a német, a szerb és a román találkozott. ${ }^{2}$ A korszak általános jellemzője, hogy ekkorra tehetők a nemzetiségi mozgalmak látványos megerősödésének, illetve a kapitalista gazdaságszerkezet irányába történő átalakulás kibontakozása. A nemzetiség, a társadalom és a politikum kategóriái sajátos fúzióra léptek, ami idegen korábbi koroktól. ${ }^{3} \mathrm{~A}$ történeti Erdélyben a piaci viszonyok szélesebb körü kibontakozása az Osztrák-Magyar Monarchia más területeihez képest később indult el, egy viszonylag kedvezőtlen helyzetü régióban (vasúthálózat alacsony sürüsége, városi népesség alacsony aránya, magas írástudatlanság stb. $)^{4}$ A kialakuló etnikai rétegződést egyrészt a korábbi korszak öröksége befolyásolta, vagyis, hogy Erdély rendi társadalmában az egyes nemzetiségek milyen pozíciót foglaltak el, másrészt pedig jelentős hatással volt rá az a tény, hogy a modernizációs folyamat a magyar nemzetállamon belül játszódott le. ${ }^{5}$

Az Osztrák-Magyar Monarchia utolsó két évtizedében az erdélyi régióban azt a többosztatú helyzetet vizsgálom, amelyen belül az első világháború elvágta a Budapestről vezényelt modernizációs kibontakozást, a nemzetiségi nacionalista mozgalmak a háború hatására önálló állami politikai törekvéseikben megerősödtek, a korábbi állami struktúrát egy új uralmi struktúra váltotta fel, illetve hogy ez az átalakuló folyamat miként hatott a társadalom egyes rétegeiben és kik vettek részt ebben regionális szinten.

Bevezetőmben először (1.1.) a kutatási kérdéseket és a módszertani megközelítést tisztázom. Ezt követően (1.2.) az impériumváltás irodalmát tekintem át arra koncentrálva, hogy a nemzeti kánonok mellett a helytörténeti, regionális történetek milyen újdonságokat, illetve továbblépési lehetőségeket hozhatnak a kutatás során.

\footnotetext{
${ }^{1}$ Temesvár és a Bánság fejlődésére vonatozóan lásd: BORSI-KÁLMÁN Béla: A Bánság és Temesvár a századfordulón és az első világháború előestéjén I. rész. Pro Minoritate, 2000. Ösz-Tél, 170-205.; U. ő.: A Bánság és Temesvár a századfordulón és az első világháború előestéjén II. Pro Minoritate, 2001. Tavasz, 158-199.

${ }^{2}$ POMOGÁTS Béla: A magyar irodalom köztársasága. Irodalomtörténeti tanulmányok. Budapest, Nap Kiadó, 2014. 31.

${ }^{3}$ GYÁNI Gábor: A nemzeti történetírás válaszúton. Limes, 2012. 25. évf. 4. szám, I. kötet, 5. [Továbbiakban: GYÁNI: A nemzeti történetírás, Limes, 2012]

${ }^{4}$ Erdély alatt 1918-ig a történeti Erdélyt (a Királyhágóig), az ezt követő szövegösszefüggésben a Magyarországtól 1920-ban Romániához csatolt területeket értem.

${ }^{5}$ KISS Tamás: Támpontok az erdélyi etnikai rétegződési rendszer vizsgálatához I. Pro Minoritate, 2010. Nyár, 9.
} 


\subsection{Kutatási kérdések és módszertani megközelitések}

Ezen dolgozatban Erdély-kérdése egyszerre három nagyobb problémakört fed le. 1) Erdély állami hovatartozásának kérdése: Románia vagy Magyarország része, esetleg önálló. 2) Erdély, mint régió közigazgatási, gazdaságpolitikai helyzete egy-egy adott államalakulaton belül. 3) Az Erdélyben élő etnikai csoportok egymás közti viszonyai, a nemzetiségi problémák kezelése. Az erdélyi kérdést történetileg két további tényező is meghatározza. Egyfelől a két egymás mellett párhuzamosan végbemenő nemzet, illetve államépítési folyamat. Másfelől a nemzetépítő elitek (az erdélyi magyar, román, német elit) a nemzetállami centrumaiktól részben eltérő, saját stratégiákkal bíró regionális csoportok. ${ }^{6}$

A téma megközelítésében a hangsúly egyszerre a nemzeti (összetartó és szervezőerő) és a regionális (egy szűkebb közösség tagjainak tapasztalatai és törekvései) nézőpontokra helyeződik. A nacionalizmus azt feltételezi, hogy a társadalmak nemzeti elven szerveződnek (az egyének nemzeti csoportokba tömörülnek), míg a regionalitás azt árnyalja (vagy kiegészíti), mert más szempontok (lokális identitások, vegyes házasság, szakmai, családi és vallási közösségek, csoportok nélküli etnicitás, illetve nemzeti közömbösség stb.) is szerepet játszhatnak.

A nemzetépítésre és az ezt kritizáló megközelítésre vonatkozóan fontos tisztáznunk ezeknek a fogalmi tartalmát. A nemzetépités (nation-building) modellje a nemzetek politikai jellegét és az állampolgárok és elitek - nemzetépítók - aktív szerepét emeli ki, szemben azokkal az elméletekkel (konstruktivizmus, etnoszimbolizmus, primordializmus), amelyek elsősorban a nemzetek kialakulására keresik a választ. ${ }^{7}$

\footnotetext{
${ }^{6} \mathrm{Ha}$ az erdélyi regionális etnikai/nemzeti elitek egymáshoz való viszonyát elemezzük, látható, hogy meghatározó szerepe volt a nemzetállami centrumoknak (Bukarest, Budapest). Ezek a csoportok - sajátos érdekeiket figyelembe véve - lényegét tekintve megfeleltek saját nemzetállami központjuk törekvéseinek, amely következtében az etnikai törésvonalon túllépő közös regionális identitás (a lokális többség intézményesüléseként) nem emelkedett a politikai gyakorlat szintjére. Az erdélyi román-magyar viszonyt a párhuzamos nemzetépítési folyamatok között ezért mindvégig konfliktusok sorozata határozta meg. BÁRDI: Javaslatok, modellek az erdélyi kérdés kezelésére. (A magyar elképzelések 1918-1940). 329-330. http://www.jakabffy.ro/magyarkisebbseg/pdf/2004_12_24_bardi.pdf (Letöltve: 2017. július 17.) A tanulmány eredeti változata: Konfliktusok és kezelésük KözépEurópában. Szerk.: BÁRDI Nándor, Budapest, TLA. 2000. 137-180. [Továbbiakban: BÁRDI: Javaslatok, modellek, 2000] Az internetes verzió a tanulmány javított és bővített változatát tartalmazza.

${ }^{7}$ Ernest Gellner, Juan J. Linz, Eric Hobsbawn, Benedict Anderson által fémjelzett modernista paradigmából az következik, hogy a nemzetiesedést a modernizáció és az iparosodás hatja egy irányban, a homogén nemzetállam célja felé. A modernisták azt állítják, hogy Nyugat-Európában először az állam alakult ki, majd ezt követően a nemzet, ellenben ez Kelet-Közép-Európában fordított sorrendben következett be.

A témában lásd továbbá: GELLNER, Ernest: Nations and Nationalism. Cambridge University Press, 1983 [GELLNER, Ernest: A nemzetek és a nacionalizmus]; HOBSBAWN, E. J.: Nations and Nationalism since 1780: Programme, Myth, Reality. Cambridge, Cambridge University Press, 1990 [HOBSBAWN, E. J.: Nemzetek és nacionalizmus 1780 óta: Program, Mitosz, Valóság]; ANDERSON, Benedict: Elképzelt közösségek-Gondolatok a nacionalizmus eredetéröl és elterjedéséröl. L’Harmattan, 2006; SZÜCS Jenő: A Vázlat Európa három történeti régiójáról. Magvető, Budapest, 1983
} 
„A nemzetépités tulajdonképpen a különálló - nemzeti elven szerveződő - társadalom épitése, amely a különálló intézményrendszerre épül." ${ }^{\text {A }}$ A nemzetépítési nézőpont felülről elemzi a kérdést. Középpontban az elit szándékainak, cselekvéseinek megértése áll, hogy az miként igyekszik szervezni a társadalmat. ${ }^{9}$ A nemzetépítésnek ez az elittől lefelé terjedő modellje nem mentes minden kritikától. Rogers Brubaker a Csoportok nélküli etnicitás címü esszéjében azt a megközelítést bírálja, hogy „hajlamosak vagyunk a kulturális világot egyszínü etnikai, faji és kulturális kockákból kirakott sokszínü mozaikként beállitani." A szerző ezt a tendenciát „csoportizmusnak” nevezi, ami azt jelenti, hogy a társadalmi élet legfontosabb alkotóelemeinek, a társadalmi konfliktusok főszereplőinek és a társadalmi elemzés alapegységeinek, hajlamosak vagyunk az egymástól élesen különböző, belülről homogén és kívülről lehatárolt csoportokat tekinteni. A hétköznapi beszéd, a politikai elemzés is „,csoportista” terminusokban meséli az etnikai és nemzeti konfliktusokat, amikor etnikai csoportok, fajok és nemzetek küzdelmét írja le. Ebben az értelemben az etnikai konfliktus etnikai csoportok közötti konfliktust jelent, mert például az etnopolitikai vállalkozók (aktivisták) arra törekszenek, hogy életre hívják (objektivizálják) ezeket a csoportokat, mintha az objektív világban tényleg létező dolgok lennének. Ezek a vállalkozók akkor sikeresek, amikor az egységes csoport politikai fikciója átmenetileg, de hatékonyan ültethető át a politikai cselekvés gyakorlatába. ${ }^{10}$

A regionalizmus története Európában hosszú évszázadokra nyúlik vissza. A középkorban az európai élet szerveződésében a régiók vezető szerep töltöttek be, mert valamely terület gazdasági, kulturális és politikai megszervezését nem az állami vagy birodalmi kormányzat, hanem a helyi hatalom végezte. Ezek a regionális egységek (tartományok, országrészek) saját hagyományaikra támaszkodva fejlődtek, amelyek vagy kiváltak a feudális állam keretéből és szuverén országokká lettek, vagy megmaradtak a modern, nemzetállami keretekben. ${ }^{11}$ A régió nem állandó, statikus kategória, hanem dinamikus jelenség, annak ellenére is, ha végül is egy adott területet értünk olykor alatta.

\footnotetext{
${ }^{8}$ KÁNTOR Zoltán: Kisebbségi nemzetépítés. REGIO, 2000. 11. évf. 3. szám, 220-225. [Továbbiakban: KÁNTOR, REGIO, 2000]

${ }^{9}$ Uo. 220-225.

${ }^{10}$ BRUBAKER, Rogers: Csoportok nélküli etnicitás. Ford. Neményi László. Beszélö, 2001/7-8. 60-62.

${ }^{11}$ Németországban és Olaszországban, amely államok a 19. század második felében jöttek létre, későbbi fejlődésük során is fenntartották a belső régiók kereteit, mi több, ezek a keretek az államstruktúra felépítésében is szerepet kaptak. Németországban a Land-ok, vagy akár a legújabbkori Ausztriában, az egykori örökös tartományok formájában. Osztrák örökös tartományoknak nevezzük a Habsburg-dinasztia osztrák ágának családi birtokait. Ezek a területek képezték a későbbi Ausztria törzsterületét, de nem estek teljesen egybe azzal. Az osztrák örökös tartományok közé tartozott Alsó-Ausztria, Felső-Ausztria, Stájerország, Karintia, Krajna, Tirol, valamit az elszórtan elhelyezkedő, apró területekböl álló Elö-Ausztria. Nem volt része az örökös tartományoknak a Salzburgi Érsekség és a mai Burgenland sem. VAJNÁGI Márta: Az osztrák örökös tartományok. Szerk.: Poór János: A kora újkor története, Osiris Kiadó, 2009. 257-279.
} 
Ebben a folyamatban négy szint elkülönítése látszik célszerünek: 1) a területi keretek kialakulása (identifikáció), 2) a fogalmi keret létrejötte (területi szimbólumok), 3) az intézményes forma megteremtődése (saját intézmények), 4) intézményesülés a regionális rendszer és a regionális öntudat részeként (legteljesebb formája az önálló nemzetállam). A régió fogalmára épül a regionalizmus, amely szellemi/politikai mozgalom, és egy-egy embercsoportnak a tájegységhez, mint földrajzi kerethez való kötődését, tapasztalatait jelenti. ${ }^{12}$ A régióértelmezés kiemelt kulcsfogalma Pierre Boudieau nyomán a reprezentáció. A regionális és etnikai identitás objektív ismérveit kereső kutatása nyomán azt állítja, hogy a regionális társadalmi gyakorlatban a nyelv, a dialektus vagy a kiejtés, a mentális reprezentáció tárgyai, amelyek alapján lehet észrevenni, megismerni őket. Ezt ruházzák fel a cselekvők érdekeikkel és előfeltevéseikkel. De ezek képezik a tárgyi reprezentáció alapjait is, ami dolgokat jelent (emblémák, zászlók), illetve tetteket és a szimbolikus manipuláció olyan stratégiáit is, amelyeknek célja, hogy mások fejében alakítson ki (mentális) reprezentációt ezekről a tulajdonságokról és hordozóikról. A szimbolikus küzdelmeknek nagyon is valóságos megalapozásuk, hatásuk van, mert például a regionális nemzetépítők valóban hozzájárulhatnak a valóság fölépítéséhez, illetve átalakításához. ${ }^{13}$

Magyarországon kevésbé alakultak ki a feudális regionalizmusnak azok az intézményei és hagyományai, amelyek a kontinens nyugati és déli részén oly hatékony formáló erővel voltak jelen. A középkori magyar állam szervezetében csupán a társországi státuszt élvező HorvátSzlavónországnak, rövidebb ideig a balkáni bánságoknak, illetve az erdélyi vajdaságnak, majd fejedelemségnek volt a nyugati regionális struktúrákhoz valamelyest hasonló helyzete. Kulturális régiók azonban a történeti Magyarországon belül is létrejöttek. A két legnagyobb: Dunántúl és Erdély, mert ezeknek volt elsőrendűen magyar nemzeti jelentősége. A két kulturális tér mellett természetesen voltak a magyar kultúrának más régiói is, de azok a maguk kulturális sokféleségükben éltek és fejlődtek, például Pozsony, Kassa vagy Temesvár. A kultúrának az az egységesítő és egységesített modellje (nemzet), amelyet ma is ismerünk, amelynek keretében gondolkodnak a közép-európai népek - például a románok, a magyarok, a szerbek stb. - a polgári fejlődés keretében alakultak ki a 19. században.

\footnotetext{
Hasonló gazdasági és politikai jellegü régiók kaptak bizonyos fokú autonómiát Nagy-Britanniában, Ausztriában, Svájcban (kantonok), vagy újabban a decentralizált módon szervezett Spanyolországban. Olaszország ettől bár eltért, de egészen az olasz egyesítésig (1861) ugyancsak több különálló régiót ismert: Lombardia, Toscana, a Pápai Állam, a Nápolyi Királyság rendszere és kultúrája. POMOGÁTS Béla: A kulturális regionalizmus. REGIO, 1991. 2. évf. 2. szám, 89-91 [POMOGÁTS, Regio, 1991.]

12 ÉGER György-LANGER, Josef: Határ, régió, etnikumok Közép-Európában. Osiris-MTA Kisebbségkutató Intézet, Budapest 2001. 19-23.

${ }^{13}$ BOURDIEAU, Pierre: Az identitás és a reprezentáció. Szociológiai Figyelő, 1985. 1. évf. 1. szám, 7-23.
} 
Közép-Európát és ide értve a Habsburg Birodalmat is sok száz éven keresztül a különböző tájegységek kulturális arculata jellemezte, ahol a térképre a nyelvhatárokat pontosan fel sem lehet rajzolni (mozaik-jelenség). A 19. századtól határozott és időnként erőszakos eszközökkel végbement kulturális egységesítő törekvés jellemezte Közép-Európa életét. Ekkor jöttek létre azok a nemzeti kultúrák, amelyek egy meghatározott nemzeti nyelven, politikai keretben, értékrendben, illetve mentalitásban éltek egymás mellett, vagy éppen küzdöttek egymás ellenében (erről lásd párhuzamos nemzetépítések elméletét). A Habsburguralkodóházzal kötött 1867-es kiegyezés után, a dualista állami berendezkedés évtizedeiben Magyarország politikai, gazdasági és kulturális élete központosított módon fejlődött. A hazai kulturális élet régi, történelmi székhelyei (Debrecen, Kolozsvár, Szeged, Marosvásárhely, Kassa) sokat veszítettek korábbi szervező erejükből, és csak a századforduló után történtek kísérletek arra, hogy vidéki városokban kulturális és velük párhuzamosan politikai központok alakuljanak. Az ilyen törekvések példái volt Nagyvárad, Temesvár, illetve Kolozsvár újbóli „megerősítése”. ${ }^{14}$

Magyarország története szempontjából, 1867-et követően szükséges azt látni, hogy a modern nemzetállam egyben nemzetépítő állam is, amely a többségi nemzet kultúráját és érdekeit vette elsősorban figyelembe. A magyarországi politikai elit részben azért lépett fel nemzetiesítő szándékkal, mert így látta biztosíthatónak a kulturálisan sokszínű ország területi integritását. Másfelől ez volt a válasza arra a politikai tapasztalatra (amely részben az 18481849-et követő abszolutizmus időszakából fakadt), hogy a Habsburg-dinasztia intenzív nemzetépítést, centralizációs eszközöket vetett be legitimációja megerősítése érdekében. A birodalom és nemzet tehát nem versengő kategóriák, mert egyrészt a birodalmak is bevetettek saját érdekükben nemzetiesítő eszközöket, másrészt pedig a birodalmakon belüli nemzetépítők gyakran éppen a birodalmi kereteket használták fel céljaik eléréséhez. ${ }^{15}$

A vizsgált időszakban Erdély interetnikus viszonyai között a nemzeti közösségek egymásba ékelődő területeken éltek. Az erdélyi magyar vezető réteg, a nemzetépitők 1918 előtt nem látták értelmét, hogy hatalmi befolyásuk rovására kollektív engedményeket tegyenek a nemzetiségek felé.

${ }^{14}$ POMOGÁTS, Regio, 1991. 91-95.; POMOGÁTS Béla: Magyar kulturális régiók a Kárpát-medencében. EGYÜTT, 2007. 9. évf. 3. szám, 4-10.

15 A szakirodalom ezt az elméletet „birodalmi fordulatnak” is nevezi. A hosszú 19. században (1918-ig) a birodalmak (francia, német, orosz, brit) magterületükön intenzív nemzetépítést folytattak, ahol a birodalmi dinasztiák a nacionalizmus eszköztárához hasonló, nemzeti tartalmú eszközöket vetettek be legitimációjuk megerősítése érdekében. BERGER, Stefan-MILLER, Alexei: Building Nations In and With Empires-A Reassessment. In: Berger, Stefan -Miller, Alexei (eds): Nationalizing Empires. Central European University Press, Budapest, 16-25. 
Éles kritikával bírálták ugyanakkor a Magyar Királyság Budapestre központosított, szerintük az erdélyi magyarság kulturális és gazdasági fejlődését gátló rendszerét. A magyar-magyar, Erdély és Budapest, kormánypárt és ellenzékiek közti ellentétek enyhítésének olyan változatait mérlegelték, amelyek fenntartják az osztrák-magyar közjogi kiegyezést és biztosítható vele az erdélyi magyar szupremácia. Régiójuk bizonyos fokú önállóságára, Budapesttől nagyobb autonóm mozgásra törekedtek, anélkül, hogy kétségbe vonták volna az oszthatatlan nemzeti egység dogmáját. ${ }^{16}$ A regionális nemzetépítők céljukat tekintve a nemzetépítés tervével álltak elő, ahol nemzetépítés és regionalizmus nem csupán elválaszthatatlanok, hanem egybe is tartoznak. Az egységesnek vélt és láttatott nemzeten belül ugyanis lehettek eltérö, akár szembenálló identitásképzetek is, amit Egry Gábor szubszidiarisztikus nacionalizmusnak nevezett. ${ }^{17}$ Az erdélyi nemzetépítő aktivisták összefoglalóan tehát a nemzetépítés programjával a regionális társadalom és térszervezés közötti kapcsolatrendszer fejlesztésével, megújításával léptek fel az 1910-es években.

A vesztes világháború minden korábbi állapotot megváltoztatott Magyarország vonatkozásában, amely jelentős mértékben befolyásolta a politikai gondolkodást. A trianoni békeszerződés ratifikálását követően a romániai magyarság, tehát a magyarul beszélő, magyar nemzetiségű, fejlett nemzeti önazonosságtudattal és intézményesültséggel rendelkező csoport politikai kényszer hatására vált ki a magyar nemzetépítés folyamatából. ${ }^{18}$ Megpróbáltatásoktól terhes alkalmazkodási kényszerek között megváltozott, formálódott a romániai magyar nemzetépítés, szereplőinek gondolkodása és politikai magatartásuk jellege. A párhuzamos nemzetépítések és multietnikus nemzetállami keretek között kényszerközösségként ${ }^{19}$ tovább élő magyarságnak a következő kérdésekkel kellett szembenéznie a két világháború közti periódusban.

16 K. LENGYEL Zsolt: A kompromisszum keresése. Tanulmányok a 20. századi transzilvanizmus korai történetéhezi. Csíkszereda, Pro-Print Könyvkiadó, 2007. 5-6. [Továbbiakban: K. LENGYEL: A kompromisszum, 2007]

${ }^{17}$ EGRY, Etnicitás, 2015.

${ }^{18}$ SZARKA László: Kényszerközösségek és védtelen védhatalom. In: Magyarország és a magyar kisebbségek. Szerk.: Szarka László. MTA, Budapest, 2002, 17-30.

${ }^{19}$ 1918-ban a magyar nemzetépítésből olyan fejlett nemzettudattal bíró régiók szakadtak ki, amelyek magyarsága kényszerközösségként önálló kulturális és politikai intézményrendszert teremtett a két világháború között. Ezek a kisebbségi társadalmak bár részesei az adott ország politikai közösségének, de nem részesei az adott ország nemzetépítésének (cseh, szlovák, román, szerb politikai nemzetek). Ezekben az országokban a nemzetállamiság kiépítése éppen a magyar, német és zsidó közösségek társadalmi és gazdasági pozícióival szemben történt meg. BÁRDI Nándor: A budapesti kormányzatok magyarságpolitikai intézményrendszere és stratégiája 1918-1938. Kisebbségkutatás, 2007. 16. évf. 1. szám, 7-10. 
1) Milyen válaszok adhatóak a nemzetállami kihívásokra, amelyek a budapesti és a bukaresti kormányzatoktól párhuzamosan érkeztek, illetve mit reagálhatnak a saját magyar társadalmukon belül zajló modernizációs folyamatokra? ${ }^{20}$ 2) Miként integrálódik társadalmi és politikai szinten az új államalakulatba? 3) Milyen önálló intézményi formákat képes hosszú távon müködtetni az őt érintő társadalmi, gazdasági, kulturális kihívásokra válaszolva? 4) Milyen múlt- és nemzet értelmezés segíti a magyar politikai közösség jövőbeni „egységét” a kisebbségi társadalomépítés folyamatában? A sikeres nemzeti mozgalom érdekében a belső struktúra, illetve a belölük eredő sajátos követelések (hagyományos földbirtokos elit, progresszívabb városi szellemi elit stb.) mennyiben tudták elérni, illetve mobilizálni a domináns többséggel szemben a mozgalom tagjait a nemzeti program kiteljesítésére? ${ }^{21}$

A kutatás fókusza ebből következően nem arra irányul, hogy egy erősen fragmentált (plurális) társadalomban miért nem alakulhatott ki a különböző társadalmi csoportok között egyfajta konszociális együttmüködés (A. Lijphart ${ }^{22}$ ), hanem az, hogy az állami integráció mentén (1918-ig), illetve kényszerével szemben (Nagy-Románia egységesítése) kik léptek fel nemzetépítőként, miként fejlödött az erdélyi magyar politikai közösség gondolkodása önmagáról, a multietnikus magyarországi Erdélyről, illetve a határváltozással együtt járó uralomváltásról mint Erdély Románián belül, és az önálló erdélyi állam opcióiról.

A dolgozat az 1910-es éveket, illetve az összeomlást követő impériumváltás első néhány évét (1922-ig) vizsgálja Erdélyben, amelyet egy bővített világháborús történetnek is hívhatunk. A rövid intervallum ellenére számos meghatározó esemény történt, új folyamat indult el ebben a periódusban. 1910-ben került sor a történeti Magyarország utolsó népszámlálására, amely az adott korban részben azért volt jelentős, mert statisztikailag kimutathatóvá vált (ha minimálisan is Horvát-Szlavónország nélkül) a magyar anyanyelvűek többségbe $(51,4 \%){ }^{23}$ Nemzetközi porodon az 1904. évi angol-francia entente cordiale határozott szövetségi formát nyert (GreyCambon-egyezmény, 1912) Németországgal szemben. 1911-ben kitört az olasz-török gyarmati háború (Tripolisz olasz igénye), ahol Németország és Osztrák-Magyar Monarchia a hármasszövetség cikkelyei értelmében Olaszország mellé állt.

\footnotetext{
${ }^{20}$ BÁRDI Nándor: Összezárkózás és szétfejlődés. Kísérlet a magyar kisebbségek történetének periodizációjára. In: Nemzet a társadalomban. Szerk.: Fedinec Csilla, TLA, Budapest, 2004

${ }^{21} \mathrm{HROCH}$, Miroslav: A nemzeti mozgalomtól a nemzet teljes kifejlödéséig: a nemzetépítés folyamata Európában. REGIO, 2000. 11. évf. 3. szám, 11-15.

${ }^{22}$ LIJPHART, A.: Democracy in Plural Societies. Yale Univ. Press, New Haven-London, 1977. Magyar nyelven áttekintést ad: SALAT Levente: Etnopolitika a konfliktustól a méltányosságig. Az autentikus kisebbségi lét normatív alapja. Marosvásárhely, Mentor, 2001

${ }^{23}$ A magyar szent korona országainak 1910. évi népszámlálása. Első rész. Magyar Statisztikai Közlemények. 1912. 42. kötet, 6 .
} 
A konfliktus kiszélesedett, amikor a balkáni államok

(Szerbia, Bulgária, Görögország, Montenegró, Románia) is fegyvert fogtak 1912-1913-ban. Ez utóbbi háború nemcsak az Oszmán Birodalmat, de a hatását tekintve negatívan érintette Oroszország és a Monarchia kapcsolatát is. A balkáni kérdés a délkelet-európai nemzeti átrendeződéssel volt kapcsolatos. A viszály meggyorsította a megoldhatatlan európai nagyhatalmi ellentétek érlelődésének folyamatát, amely elvezett az első világháborúhoz. ${ }^{24} \mathrm{~A}$ Monarchián belül a háború, illetve az 1916-os román betörés érdemben befolyásolta a nemzetiségi mozgalmak radikalizmusát, amely a szeparatizmushoz vezetett. Erdélyben, az 1916-os betörés pusztítását a háború végéig nem sikerült helyreállítani, amely negatív hatással volt a mindennapok mellett a gazdasági és a közigazgatási életre vonatkozóan is. A magyar belpolitikában hatalmi vákuum alakult ki, amikor 1917 tavaszán lemondott Tisza István. 1918. november-1920. március között a román hadsereg, mint antant haderő megszállás alatt tartja Magyarország jelentős területeit, és megkezdődött a román államberendezkedés kiépítése Erdélyben.

Az erdélyi magyar elit szempontjából az 1900-as évek elején három nagy vitakérdés volt kiemelkedően fontos az országos politikából: a birtokviszonyok ${ }^{25}$, a választójogi reform problémája, illetve a Tisza István-féle megegyezési kísérletek révén a nemzetiségi kérdés megoldatlansága. A jelzett problémák nemzeti és nemzetiségi politikai törekvésekben, önazonosságot erősítő tervekben egymással összekapcsolódva bontakoztak ki.

a) Egyes politikusok és nemzetiségi kérdéssel foglalkozó szakértők (Beksics Gusztáv, Barabás Endre, Jancsó Benedek, Bartha Miklós, Réz Mihály, Moldován Gergely) arra hívták fel a figyelmet, hogy az erdélyi román nemzeti mozgalom lehetséges opciója Erdély és Románia egyesítése.

b) Az erdélyi politikai és szellemi elit részéről kétféle elképzelés bontakozott ki. Egyfelől megjelentek az Erdély önállóságát, modernizációját, sajátos nemzetiségi viszonyait történetileg alátámasztott decentralizációs, önkormányzati eszközökkel kezelhetőnek vélt döntően kulturális jellegü társadalmi és értelmiségi törekvések.

\footnotetext{
${ }^{24}$ DIÓSZEGI István: A hatalmi politika másfél évszázada. História Könyvtár, Budapest, 1997, 219-229.

${ }^{25} 1898$ és 1912 között az erdélyi (történeti) földbirtokviszonyokon belül 8,2\%-kal csökkent a magyar földbirtokok aránya. Erröl bővebben: TOKAJI László: Eladó ország. Kolozsvár, 1913; BALÁS Károly: A magyarság gazdaságpolitikai érdekei. Magyar Társadalomtudományi Szemle, 1913. VI. évf. 4. szám, 273-288.
} 
Másfelől országos és regionális szintü politikai nyomásgyakorló szervezetek alakultak az erdélyi magyar szupremácia védelmezésének szándékával (Székely Társaság, 1900, a Székely Társaságok Szövetsége, 1904, Országos Magyar Szövetség 1903, Erdélyi Szövetség 1913). ${ }^{26}$ (Lásd ezeket bővebben később.)

Erdély állami hovatartozása, illetve az erdélyi magyar politikai közösség gondolkodása szempontjából fordulópontot jelentett az 1916. évi román betörés, az októberi német Mackensen-féle ellentámadás sikere ellenére is. Szükebb keretek között értelmezve az erdélyi impériumváltást a történeti szakirodalom 1918. november (demarkációs vonal kijelölése) és 1920. június 4. (Trianoni békeszerződés) közti időszakra datálja. Tágabb folyamatba helyezve az eseményeket 1916. augusztusa politikai következményeit tekintve meghatározó volt. Az antant hatalmak a londoni titkos szerződésben Romániának ígérték Erdélyt, ha feladja addigi semleges pozícióját és megtámadja az Osztrák-Magyar Monarchiát (augusztus 17). A román offenzíva egy hónap alatt a Déva-Nagyszeben-Székelyudvarhely-Fogaras vonalig jutott el, jelentős anyagi és személyi kárt okozva a településeken, amely következtében a közigazgatás korábbi müködési formájában nem állt helyre. A 200 ezer főre becsült menekült, a pusztítás következményei (élelmiszerhiány, paraszti elszegényedés, sztrájkmozgalmak, politikai beszédmód radikalizálódása, erőszak), illetve a betörésre született politikai reakciók (kultúrzóna bevezetése, ingatlanforgalom korlátozása, rekvirálások, sorozás, ellentámadás, propaganda) mély tapasztalatot hagytak mind a hétköznapokban, mind a politikai gondolkodásban.

A vizsgált történeti problémakörben nem hagyhatóak figyelmen kívül az alkalmazkodás, a folytonosság és a kompromisszumok versus elnyomatás (eröszak) alapproblémái. Arra vagyok kíváncsi, hogy mi történik abban az átmeneti folyamatban, amikor az egyik felépítmény átadja a másiknak a helyét, mert ekkor jön létre a következő struktúra. A nemzetépítők szemszögéből az a kérdés fogalmazható meg, hogy miként próbálják megérteni, alakítani (struktúrát alakítani) a társadalom dinamikáját. Az impériumváltásban résztvevő elitek politikai szocializációja a dualizmus társadalmi és politikai viszonyai között zajlott. Az itt kialakult nemzeti tematikák, ha változtak is, az új impérium alatt bizonyos olvasatokban tovább éltek.

\footnotetext{
${ }^{26}$ BÁRDI Nándor: Az erdélyi magyar (és regionális) érdekek megjelenítése az 1910-es években. Magyar Kisebbség, 2003. VIII. évf. 2-3. szám, 93-105. [Továbbiakban: BÁRDI, Magyar Kisebbség, 2003]
} 
Az Osztrák-Magyar Monarchia összeomlását követően a romániai magyarság két világháború közti helyzetét meghatározó kulcskérdés az volt, hogy miközben a románság Erdélyben megszerezte a politikai, közigazgatási hatalmat, addig a régió társadalmi, gazdasági, kulturális életében az ott élő kisebbségek, a németek és a zsidók mellett a magyarok megőrizték domináns szerepüket. Az erdélyi románság a pozíciók elfoglalásában hátrányos helyzetbe került a bukaresti, föleg liberális párti elittel szemben. Politikai súlyuk növelése érdekében ezért keresniük kellett az együttmüködés lehetőségét Bukaresttel. Az erdélyi magyar politika a bukaresti és az erdélyi román érdekek közé ékelődve, döntően védekező magatartást tanúsított. $^{27}$ A pozícióőrzéssel jellemezhető viszonyulás egyik feltétele a Monarchia időszakából átmentett struktúrák (egyház, sajtó, társadalmi szervezetek stb.) működtetése, illetve újak létrehozása (érdekvédelmi szervezetek, oktatási intézmények, iskolahálózat stb.) volt. 1918 decemberétől (Kolozsvár katonai megszállása) 1920 novemberéig (a trianoni békeszerződés magyarországi ratifikálásáig) politikailag az inaktivitás jellemezte az erdélyi magyar politikai életet. 1920 második felében különböző fórumokon lassan megindult a szervezkedés tervezése, megbeszélésekre, sajtóakciókra, röpiratok kiadására, memorandumok megfogalmazására került sor, illetve több érdekvédő szervezet is alakult 1922 decemberéig, az Országos Magyar Párt megalakításáig (Felekezetközi Központi Tanács, Magyar Szövetség, Erdélyi Néppárt, Magyar Nemzeti Párt). Ebben a kétéves intervallumban került sor az impériumváltásra, illetve vette kezdetét a romániai magyarság önszervezödése, a kisebbségi életforma lehetséges stratégiáinak megfogalmazása.

A felvetett történeti változások kapcsán a következőkre keresem a választ: hogy alakultak át a személyes értékek és a közösségi eszmék? Milyen irányú változások következtek be az intézményekben (oktatás, közigazgatás, érdekvédelmi szervezetek stb.) a vizsgált időszakban? Miként változott az önkép (kik vagyunk) és a helyzettudat (hol vagyunk a társadalomban)?

Az értekezés egyik célkitűzése, hogy bemutassam az erdélyi magyar politikai elit magyar nemzetfogalmának megváltozását, a gondolkodásukat befolyásoló politikai és társadalmi törésvonalakat, az általuk használt nemzeti tematika diskurzusait és intézményeit az Erdélyi Szövetség (1913) megalakításától kezdve a kisebbségbe került magyarságot képviselő Országos Magyar Párt (1922) létrehozásáig.

27 BÁRDI Nándor: Otthon és haza. Tanulmányok a romániai magyar kisebbség történetéröl. Pro-Print, Csíkszereda, Magyar Kisebbség Könyvtára, 2013, 475. [Továbbiakban: BÁRDI, Otthon, 2013] 
A fogalomtörténeti (Reinhart Koselleck, Bence György) módszertani megközelítés továbbá lehetőséget nyújthat arra, hogy ne csupán hagyományos elit, illetve politikatörténeti kutatást végezzünk. ${ }^{28}$ Egyes kitüntetett fogalmak vizsgálatával lehetőségünk nyílhat a szavakon túli világgal is foglalkoznunk, mert azok az adott kor mibenlétét hordozzák magukon, és a kutatás azoknak jelentésváltozásait, társadalmi kötöttségeit, struktúrák változását, illetve politikai funkcióit tárhatja fel. A vizsgált korszakban olyan kulcsfogalmak, mint nemzet, faj, nép, nemzetiség, kisebbség, forradalom, tömeg bele voltak ágyazódva a gazdasági, a regionális és az országos hatalmi, illetve társadalmi viszonyokba. Ha sikerül feltárnunk a változó fogalmi reprezentációk tartalmát, akkor leírhatjuk a vizsgált világot s tájékozódhatunk történéseiben.

A nemzet ezek közül is kiemelt tartalom és szimbólum, amely - koselleck-i értelemben - közösségi produkció, melyben mindenki részt vesz, aki szavakat, gondolatokat termel. A nemzet kifejezést sokan sokféleképpen használták, újabb és újabb jelentésekkel töltötték fel, amelyre a változó társadalmi, gazdasági, kulturális és politikai viszonyok voltak hatással. A nemzetiség és kisebbség a téma szempontjából hasonlóan kulcsfogalom, amelyek az első világháborút lezáró párizsi békekonferencián nyerték el mai értelmükben jelentésüket. Az Osztrák-Magyar Monarchia utódállamaival megkötött 1919. decemberi Kisebbségi Szerződések (a magyar jogfelfogás szerint) új közjogi személyt hívtak életre a kisebbség fogalmával. Az erdélyi magyar kisebbségi elit nemzetről való elgondolását a demokratikus és jogkiterjesztő tartalommal párosuló kisebbség fogalma érdemben befolyásolta. Az újonnan létrehozott sajtóorgánumok (például Pásztortüz, Keleti Újság, Napkelet, Magyar Kisebbség) és a megmaradtak (például Brassói Lapok, Ellenzék, Csíki Lapok), illetve a régi és új érdekérvényesítő szerveződések (Erdélyi Magyar Néppárt, Magyar Nemzeti Párt, Magyar Szövetség, Országos Magyar Párt, Felekezetközi Központi Tanács stb.) mögött müködő kisebbségi magyarok mind formálták, alakították a nemzet jelentését, hatással voltak a közösség által képviselt eszmékre.

28 KOSELLECK, Reinhart, BRUNNER, Otto, CONZE, Werner (Szerk.): Geschichtliche Grundbegriffe: Historisches Lexikon zur politisch-sozialen Sprache in Deutschland (Történeti alapfogalmak: A német társadalmipolitikai nyelvtörténeti lexikona). Klett-Cotta, Stuttgart, 1972-1997; BENCE György: Márkus és a kulcsszavak. In: Lehetséges-e egyáltalán? Márkus Györgynek-tanítványai. Szerk.: HÁRY János. Atlantisz, Budapest, 1993. 81-98.; SZABÓ Márton-SZÜCS Zoltán Gábor: Fogalomtörténeti perspektívák. Múltunk, 2011. 2. szám, 4-19. 
A disszertációban szó lesz az Erdélyi Szövetség életre hívásának okairól, az erdélyi politikai elit tagjai által észlelt társadalmi változásokról (földkérdés, demográfiai és gazdasági változások), a szövetség programjára hatással lévő személyek társadalompolitikai gondolkodásáról (Pósta Béla, Apáthy István, Kenéz Béla, Bethlen István, Réz Mihály, Ravasz László stb.), a politikai cselekvésükre gyakorolt 1916. évi román betörés tapasztalatairól, illetve a magyar-zsidó együttélésről.

Ezt követően mutatom be a kisebbségbe kényszerült romániai magyarság nemzetépítésének kiútkereső stratégiáit, a nemzetről való gondolkodásában bekövetkezett változásokat, a kisebbségi élethelyzet tudatosításának konfliktusos vitáit a gyökeresen megváltozott új körülmények között. A hangsúly az új élet alapjainak (amely hatással lesz a későbbiekre) kezdeti berendezkedésére helyeződik. Az önértelmezési vita részben megmaradt (felekezetek), részben új (pártok, társadalmi-egyesületi élet, sajtó) intézményes keretek között folyt, hol szoros együttműködésben a budapesti politikai elit iránymutatásainak megfelelve, hol pedig a világháború előtti sajátos erdélyi hagyományok felelevenítésével, azok újragondolásával (passzivisták, aktivisták). A magyarországi belpolitikai megnyilvánulásokkal ellentétben, Erdélyben más megközelítésbe került a magyarság és zsidóság társadalompolitikai kérdése. Míg a budapesti politikai körök gondolkodását és a politikai közbeszédet áthatotta az antiszemitizmus, a faji-biológiai megközelítések extrémitása, addig az erdélyi magyar politikai elit tagjai, nemcsak a progresszívek, de többnyire a hagyományos konzervatívok is, többnyire kitartottak a dualizmus alatt létrejött ún. társadalmi szerződés mellet. ${ }^{29}$ A vizsgálat fókuszába részben olyan politikai szereplők kerültek, akik a háború előtt és alatt is tevékenyen részt vettek regionális szinten a közösségi élet formálásában (Paál Árpád, Zágoni István, Dózsa Endre, Jakabffy Elemér, Szentimrei Jenő, Ligeti Ernő, Kádár Imre, Grandpierre Emil, Kós Károly, Bernády György, Gyárfás Elemér stb.), majd 1918-at követően maguk váltak a kisebbségi élet domináns alakítóivá.

\footnotetext{
${ }^{29}$ Karády Viktor ún. ,asszimilációs társadalmi szerződés” fogalma szerint a kölcsönös előnyök racionális belátása értelmében a honi zsidóság és a hatalmi kulcspozíciókat kisajátító keresztény elit kölcsönösen érdekelt a zsidóság minél gyorsabb elmagyarosításában. Egyikük számára ez a jogilag rendezett polgári státust (az integrációt), a másik fél számára a tömeges asszimilációt jelenti abban az államban, ahol a kiegyezéskor a magyar etnikum népességbeli aránya csupán 40 százalék körüli. A zsidóság a jogvédelem talaján állami segédlettel a modernizáció teendőinek elvégzésére nyer felhatalmazást, a liberális nemesség viszont fenntartja magának az államhatalom uralmi pozícióit. GYÁNI Gábor: Polgárosodás, mint zsidó identitás (Karády Viktor: Zsidóság, polgárosodás, asszimiláció). BUKSZ, 1997. 9. évf. 3. szám, 268-274.

Lásd bővebben: KARÁDY Viktor: Zsidóság, modernizáció, asszimiláció. Cserépfalvi Kiadó, Budapest, 1997.
} 
Egy kisebbségi kultúra megőrzésének elengedhetetlen feltétele az önálló intézményes keretek biztosítása. A disszertáció ebből adódóan a magyar politikai önszerveződés kezdeti intézményesülését követi nyomon. A román politikai rendszerbe való integrálódás lehetséges útjának megtalálása az egyik legélesebb konfliktusként bontakozott ki a magyar kisebbség politikai vezetői között, amely lényegét tekintve az eltérő társadalompolitikai koncepciók közti konfliktust rejtette magában. Meg kellett találni a tartalom mellett a megfelelö formát, amelyen át biztosítható a kisebbségi elit legitimációja és a magyar közösség érdekeinek képviselete. A közösség céljainak ${ }^{30}$ megfelelően háromfelé ágazó integrációs modell állítható fel: 1) közösségi, 2) személyes, illetve 3) szervezeti. 1) A közösségi elképzelés azt jelenti, hogy a kisebbségi társadalmak (a nemzetállamhoz hasonlóan) olyan társadalmi totalitások, amelyek tagjaikat minden vonatkozásban felölelik, azoknak minden szükségletéről gondoskodni igyekeznek. (Ez a kisebbségi társadalom gondolata, amely aktív társadalomszervezö munkát jelent Sulyok István két világháború közti analógiájára utal vissza. ${ }^{31}$ ) 2) A személyes kapcsolatok felülértékelése (a társadalomszervezéssel szemben) a mindenkori kormányzattól való erőforrás- és pozíció-allokációval függ össze, vagyis, hogy milyen támogatásokat tud a magyar elit juttatni a forráshiányos magyar lakta megyéknek, intézményeknek. 3) A szervezeti jelenlét az etnikai alapú legitim (lokális és országos) képviseletben fogalmazódik meg, feltételezve az adott államban a politikai pluralizmus hosszú távú fennmaradását. ${ }^{32}$ A romániai magyarság előtt az első világháborút követően az eltérő tervek között lehetséges alternatívaként jelent meg a politikai párt, illetve a társadalmi és kulturális szegmenseket preferáló egyesületi forma. Utóbbira a román ASTRA (Asociaţiunea Transilvană pentru Literatura Română şi Cultura Poporului Român), a szlovák Matica Slovenská, a szerb Matica srpska szolgálhat példaként a dualizmus korából, illetve már az új Romániában megalakult Romániai Németek Szövetsége. A felek abban egyetértettek, hogy a Magyar Szövetség (1921) egy pártok felett álló képviseleti fórumként szervezze egységbe a romániai magyarságot, ennek ellenére a teljesen eltérő politikai mentalitás és társadalmi felfogás két párt megszervezésének nyitott utat (Erdélyi Magyar Néppárt, Magyar Nemzeti Párt).

\footnotetext{
${ }^{30}$ Rudolp-Thompson $(1989,2006)$ szerzőpáros az etnikai mobilizáció négy lehetséges célját különbözteti meg. 1,) Kormányzati pozíció és az állami erőforrásokhoz való hozzáférés az etnikai csoport számára. 2.) A döntéshozatalban való részvétel. 3.) A politikai rendszer megváltoztatása (föderalizáció stb.) a képviselt csoport érdekeinek megfelelően. 4.) A politikai közösség határainak a megváltoztatása, gyakorlatilag szecesszió. KISS Tamás-BARNA Gergő-SZÉKELY István Gergő: A társadalomépítéstől a klientúra-építésig. Az RMDSZ és a magyar választók közötti kapcsolódás átalakulása. Magyar Kisebbség, 2013. 18. évf. 68. (2.) szám, 10. [Továbbiakban: KISS-BARNA-SZÉKELY: A társadalomépítéstől a klientúra-építésig. Magyar Kisebbség, 2013]

${ }^{31}$ SULYOK István: A kisebbségi kérdés szociológiai oldala. Erdélyi Múzeum, 1931. 4-6. sz. 170-181.

${ }^{32}$ KISS-BARNA-SZÉKELY: A társadalomépítéstől a klientúra-építésig. Magyar Kisebbség, 2013. 10-40.
} 
A román nemzetállami törekvésekből fakadó kényszerhatás ezért önvizsgálatra és a korábbi álláspontok felülvizsgálatára késztette az erdélyi új magyar politikai elitet. 1922. december 28án a két párt egyesülésével megalakult az Országos Magyar Párt (OMP), amely az egységes magyar társadalom reprezentációjának és megszervezőjének tekintette magát.

A politikai tartalmat illetően sem volt egységes álláspont. A nemzeti egység jelszava alatt eltérő társadalompolitikák, kiválasztási eljárások és az önrendelkezésre vonatkozó koncepciók jelentek meg. Az anyanyelven történő oktatás a prioritások közé tartozott, de annak megvalósításában már eltérő nézetek kerültek megfogalmazásra. A tényleges politikai képviseletet ellátó (egyházi és világi) személyek kiválasztása hasonlóan ellentétes álláspontokhoz vezetett. A konzervatívok ragaszkodtak a társadalmi hierarchiát kifejező rekrutációhoz, ahol az arisztokrácia és az egyházi személyek pozícióőrzése volt megfigyelhető. Velük ellentétben állt a magát progresszívnek tekintő, egykori polgári radikális, demokratikus, illetve függetlenségi elveket valló laza szervezettségü kör, amely a társadalmi határok eltörlésében volt érdekelt. Az önrendelkezés vitájában bontakozott ki az Erdélyről alkotott eltérő kép is. Kós Károllyal az élen, a demokratikus folyamatok erősítését preferáló politikai csoportosulás, elfogadva a társadalmilag és etnikailag sokszínü Erdélyt, a regionális erdélyi autonómiát kívánták egy föderális Románián belül. Grandpierre Emil, a konzervatívok egyik vezéralakja, reálpolitikusként ezzel szemben kivitelezhetőbbnek tekintette az etnikai autonómiát, beleértve Székelyföld területi önigazgatását.

\subsection{Historiográfia: az átmenet irodalma és a továbblépés lehetőségei}

Az első világháborút követő államhatalom-változások történetére (Románia, Szerb-HorvátSzlovén Királyság, Csehszlovákia) vonatkozóan töredékes ismeretekkel rendelkezünk. Az erdélyi impériumváltásról, illetve az átmenet vizsgálatáról ez idáig kevés regionális és helytörténeti megközelítésű kutatás történt.

Mindennek ellenére 1918-1920, illetve az 1920-as évek elején bekövetkezett változások egyaránt fontos történeti problémája a magyar és a román történetírásnak. A román megközelítésben az új, megnövekedett állam eufóriája és történeti legitimációja a domináns, míg a magyar történetírás diszkrimináció- és hanyatlástörténeti központúságával a trianoni békediktátum igazságtalanságát bizonygatta. 
Főként a két világháború közti könyvtermés, de az 1990-et követően születettek között is van, amelyek Trianon okát külső (román ,irredenta” mozgalom, Franciaország) és belső (Károlyikormányzat) összeesküvéssel próbálta magyarázni. ${ }^{33}$ Lucian Boia a román történetírás Magyarország-percepciójának meghatározó vonásait a következőkben jelöli meg. 1) hasonlóan a magyar történetíráshoz, alkotóelemei gyakran az összeesküvés mítoszában szervesülnek: „,külső ellenség” (Magyarország), „,belső ellenség” (a romániai magyarság), illetve a Romániát fenyegető nemzetközi összeesküvés (értsd: ,a külföldön élő magyar diaszpóra románellenes lobbija”). 2) A Magyarországról alkotott kép negatív tartalmú, hiányoznak belőle a közös múlt és az időszakos együttmúködéseket értékelő elemek. 3) Ez a konfliktusterhes képalkotás ideológiai funkciót tölt be, amely a politikai és nacionalista legitimáció eszközeként használható (különösen 1945-1990 között). 4), Magyarország képe központi helyet foglal el a román történet- irásban: a radikális másság modelljeként a magyarokról alkotott kép közeli kapcsolatba került a románok identitásbeli kényszerképzeteivel és az önmagukról alkotott képpel. A magyarokról vallott kép igy a román önazonosságtudat ideáltipikus önképének létrehozásában a szimbolikus ellensúly szerepét tölti be."34

Magyarországon, az 1960-as évek második felétől szakmai körökben újra felmerült Trianon értelmezése. Berend T. Iván és Ránki György az Osztrák-Magyar Monarchia felbomlását az európai munkamegosztási rendszer szétesésével magyarázta. ${ }^{35}$ Szász Zoltán társadalomtörténeti megközelítése szerint az erdélyi románság mozgalma mellett a katonaforradalom és a közigazgatási vákuum teremtett arra lehetőséget, hogy Erdélyt Romániához csatolják. ${ }^{36}$ L. Nagy Zsuzsa és Ormos Mária a korabeli nemzetközi és francia külpolitika térségünket érintő, addig ismeretlen forrásokat jelentettek meg. ${ }^{37}$ A rendszerváltás hajnalán Raffay Ernő a Károlyi-kormányzat kényszerhelyzetét és társadalompolitikai vonatkozásait világította meg a román csapatok erdélyi előre nyomulásának kontextusában. ${ }^{38}$

\footnotetext{
${ }^{33}$ BÁRDI, Otthon, 2013. 35-37.

${ }^{34}$ IORDACHI-TURDA. REGIO, 2000. 11. évf. 2. szám. http://www.epa.oszk.hu/00000/00036/00036/pdf/08iord.pdf (Letöltve 2017. augusztus 6.)

35 BEREND T. Iván-RÁNKI György: A Duna-medence gazdasági problémái az Osztrák-Magyar Monarchia felbomlása után. Az MTA II. Osztályának Közleményei, 1969. 17. köt. Klny. 417-430.

${ }^{36}$ SZÁSZ Zoltán: Az erdélyi román polgárság szerepéről 1919 őszén. Századok, 1972. 2. szám, 304-333; Erdély története. Harmadik kötet. 1830-tól napjainkig. Szerk.: SZÁSZ Zoltán. Budapest, Akadémiai kiadó, 1986 [Továbbiakban: Erdély története, SZÁSZ, 1986]

${ }^{37}$ L. NAGY Zsuzsa: A párizsi békekonferencia és Magyarország 1918-1919. Budapest, Kossuth, 1965; ORMOS Mária: Padovától Trianonig 1918-1920. Budapest, Kossuth Kiadó, 1983 [Továbbiakban: ORMOS, 1983]

${ }^{38}$ RAFFAY Ernő: Erdély 1918-19-ben. Budapest, Magvető, 1987; 1989 után az összeesküvés elméletet képviselő munkái: Trianon titkai. Avagy hogyan bántak el országunkkal. Budapest, Tornado Dannenija, 1990; Szabadkömüvesek Trianon elött. Kárpátia Stúdió Kft. 2011
} 
Gheorghe Iancu és George Cipăianu román szerzők - L. Nagyhoz és Ormoshoz hasonlóan forráskötetben mutatják be Románia hadbelépését, a Román Nemzeti Tanács és az antant csapatok közti kapcsolatot, Bánát francia és Erdély román katonai megszállását, illetve az ellene irányuló, többnyire elszigetelten fellobbanó néhány magyar ellenállási kísérletet (vasútvonalak megrongálása stb.) $)^{39}$

1989-et követően a magyar történetírás egyre nagyobb figyelmet szentelt a történelmi Magyarország felbomlásáról közgondolkodásunkban kialakult kép elemzésére, illetve a Trianonhoz vezető út és a következmények feltárására. Külön kiemelendő Romsics Ignác, L. Nagy Zsuzsa, Zeidler Miklós és Hajdu Tibor e téren végzett munkássága, akik egyaránt hozzájárultak az Erdéllyel kapcsolatos történeti kutatásokhoz. ${ }^{40}$ A fiatalabb történész generáció tagjai közül Ablonczy Balázs tett kísérletet a Trianon legendák demitizálására, illetve Révész Tamás hadtörténeti alapkutatásaiban differenciálja az emlékezetpolitikában bünbakként megrögzült Károlyi-kormány hadsereg szervezését. ${ }^{41}$ E ponton kell megemlíteni azt a történetírói szándékot, amely a kultúrharcos attitüdön és magyar sérelmeken (Jancsó Benedektől Raffay Ernőig) felülemelkedve a szomszédos népek, államok történetét belülről értelmező, azok társadalmi-politikai viszonyait, müködését analitikusan vizsgáló megközelítést képviseli. ${ }^{42}$ A román-magyar kapcsolatokkal és a romániai magyar kisebbségtörténettel foglalkozó magyar történetírók közül kiemelendő Moldován Gergely ${ }^{43}$, Mester Miklós, Miskolczy Ambrus, Szász Zoltán, Borsi-Kálmán Béla ${ }^{44}$, Szarka László, Bárdi Nándor, K. Lengyel Zsolt, illetve Nagy György és Pomogáts Béla irodalomtörténészek munkássága.

\footnotetext{
${ }^{39}$ IANCU, Gheorghe-CIPĂIANU, George: La consolidation de l'union de la Transylvanie et de la Roumanie, 1918-1919: témoignages français. Bucarest, Editura Enciclopedică, 1990

${ }^{40}$ L. NAGY Zsuzsa: Trianon a magyar társadalom tudatában. Századvég, 1987. 3. szám, 5-25.; HAJDU Tibor: 1918-19 két forradalom utóélete. Medvetánc 1984. 4. szám-1985. 1. szám, 27-43; SZABÓ Miklós: Trianon mítosz. Magyar Narancs, 1993. 24. szám, 12; ZEIDLER Miklós: A reviziós gondolat. Második, bővített kiadás. Budapest, Kalligram, 2009; Trianon. Szerk.: ZEIDLER Miklós, Budapest, Osiris, 2003 [Továbbiakban: Trianon, ZEIDLER, 2003]; ROMSICS Ignác: A trianoni békeszerzödés. Budapest, Osiris, 2007; Trianon és a magyar politikai gondolkodás, 1920-1953. Szerk. ROMSICS Ignác, Budapest, Osiris, 1998

${ }^{41}$ ABLONCZY Balázs: Trianon-legendák. Budapest, Jaffa Kiadó, 2010; RÉVÉSZ Tamás: Teljes leszerelés vagy munkáshadsereg? A Károlyi-kormány kísérletei egy ütőképes haderő felállítására. Rubicon, 2015. 26. évf. 3. szám, 10-19.

${ }^{42}$ BÁRDI Nándor: Az értelmezés kereteinek keresése. REGIO, 2000. 11. évf. 2. szám, 281.

${ }^{43}$ Moldován Gergely: román származású (filomagyar) tanár, néprajzkutató, publicista. A kor szokása szerint magyarul írta nevét (románul Grigoriu Moldovan) 1845-ben Szamosújvárt született görög katolikus szülőktől. Kinevezték tanfelügyelőnek Torda-Aranyos megyébe, ahol több román iskolát alapított, és ezért királyi tanácsosi rangot kapott. 1886-ban a kolozsvári egyetemen a román nyelv és irodalom tanára lett, illetve a Bölcsészeti Kar dékánja, majd 1906-1907-ben az egyetem rektora. 1919-ig, a Ferenc József Tudományegyetem megszünéséig egyetemi tanár. Kolozsvárott halt meg 1930-ban.

Életútját lásd: KÖPECZI Béla: Egy kitagadott: Moldován Gergely (1845-1930). Kisebbségkutatás, 2000. 9. évf. 2. szám, 275-286.

${ }^{44}$ BORSI-KÁLMÁN Béla: Megközelítések. Tanulmányok a magyar-román (román-magyar) kapcsolattörténetröl és identitásról. Lucidus Kiadó Kisebbségkutatás könyvek, Budapest, 2011
} 
Nagy György az erdélyi magyar szellemi élet két világháború közti időszakáról írott háromrészes tanulmánya többek között a transzilvanista gondolkodás kialakulásáról, Kós Károlyról és a vele egy politikai platformon állók szellemiségéről nyújt átfogó képet. ${ }^{45}$ Pomogáts Béla munkásságában központi helyet tölt be Erdély. Vallomása szerint ötvennél több könyvet írt vagy szerkesztett Erdély, erdélyiség, erdélyi irodalom témával. Külön prioritást élvez az erdélyi irodalom 1918-tól 1944-ig összefoglaló mü, amelyhez szépirodalmi, erkölcsfilozófiai, irodalomtudományi, publicisztikai dokumentumokat csatolt. ${ }^{46}$ Román részről fontos megjegyezni a mítoszkritikus Lucian Boiat, Constantin Iordachit, Marius Turdát, vagy a Transylvanian Review és az Altera körül csoportosuló fiatalabb generáció tagjait (Sorin Mitu, Victor Neumann, Valeriu Leu stb.). ${ }^{47}$

A magyar történetírás Erdély elvesztésének magyarázata során több, a tudományos munka első lépcsőfokának is megfeleltethető feldolgozás született a két világháború közti években. Általában ezekről az írásokról megjegyzendő, hogy keveredik a történetírói tárgyilagosságra való törekvés és a politikai, kultúrharcos nézőpont. Jancsó Benedek a 18. század második felétől kibontakozó román nemzeti mozgalom történetét mutatta be magyar szempontból. A szerző azt a konklúziót vonta le, hogy minden nemzetiségi mozgalom végső célja a saját államiság vagy a saját államhoz való csatlakozás, tehát törekvéseikben irredenták. ${ }^{48}$ Erdély és a magyarországi belpolitika szemszögéből fordulópontot jelentő 1916. évi román betörés története, illetve Erdély megszállása az utolsó két fejezetben került megírásra. ${ }^{49}$ Rubint Dezső és Breit József az 1918-1919-es események hadtörténetét dolgozta fel. ${ }^{50}$ Mikes Imre az 1916-os román betörést és az impériumváltás hétköznapjait tárta fel. ${ }^{51}$

\footnotetext{
${ }^{45}$ NAGY György Erdélyi magyar szellemi élet a két háború között I-II-III (1918-1940). Korunk. 1999. X/2. február, X/3. március, X/5. május [Továbbiakban: NAGY, Korunk, 1999]

46 POMOGÁTS Béla: I. Magyar irodalom Erdélyben (1918-1944) II. Irodalmi dokumentumok. Csíkszereda, Pallas-Akadémia Könyvkiadó, 2008

47 IORDACHI, Constantin, TURDA, Marius: Politikai megbékélés versus történeti diskurzus: az 1989-1999 közötti román történetírás Magyarország-percepciója. REGIO, 2000. 11. évf. 2. szám, 129-157.; BOIA, Lucian: History and Myth in Romanian Consciousness. Central European University Press, 2001

${ }^{48}$ Többek között: Supplex libellus valachorum (1791); Erdély és Magyarország uniójának román megítélése 1848 és 1867 tükrében; a Román Nemzeti Párt megalakítása és programja (1881); a romániai új irodalmi irányzat, a nagyszebeni Tribuna és a Liga Culturalâ hatása az erdélyi román nemzeti törekvésekre az 1880-90-es években; a Memorandum per.

${ }^{49}$ A feltáró munka gróf Bethlen István kezdeményezésére a magyar kormány egyetértésével indult el Jancsó Benedek vezetésével 1917 tavaszán Bukarestben. Szakemberekből álló bizottság tagjai: Jancsó Benedek, dr. Ajtay József m. kir. miniszteri tanácsos, Gagyi Jenő országos allevéltáros és a bukaresti magyar misszió munkatársa, dr. Győrffy István, a Magyar Nemzeti Múzeum őre.

JANCSÓ Benedek: A román irredentista mozgalmak története. Budapest, Bocskay Szövetség, 1920 (Reprint kiadása: Máriabesnyő, Attraktor, 2004) [Továbbiakban: JANCSÓ, Erdély, 2004]

${ }^{50}$ RUBINT Dezső: Az összeomlás. Budapest, Globus, 1918; Bánlaky BREIT József: A magyarországi magyar nemzet hadtörténelme I-III. Budapest, Grill, 1929

${ }^{51}$ MIKES Imre: Erdély útja Nagymagyarországtól Nagyromániáig. 1-2. kötet. Brassó, Brassói Lapok, 1931 [Új kiadása: Sepsiszentgyörgy, H-Press, 1997]
} 
Horváth Jenő Erdély elcsatolását középpontba állítva összegezte az első világháború diplomáciatörténetét. ${ }^{52}$ A Székely Hadosztály történetét feldolgozó korabeli munkák között szerepel Koréh Endre 1929-ben, illetve Kratochvil Károly húsz év távlatából megírt ideologikus írása. ${ }^{53}$ Ugyanebben a témában, de a későbbiekben írt szakszerű munkák között említésre méltó Fogarassy László 1986-ban megjelent publikációja, illetve Gottfried Barna és Nagy Szabolcs szerzőpáros levéltári és könyvészeti anyagokra épült 2011-ben megjelent könyve. ${ }^{54}$ A romániai kisebbségek alkotmányjogi helyzetét 1866-tól a második világháborúig Nagy Lajos 1944-ben írt jogtörténeti kézikönyvéből ismerhetjük meg. A mellékletekkel ellátott munka részletesen bemutatja a kisebbségi jogok forrásait: 1886., 1923., 1938. évi alkotmányok, gyulafehérvári határozatok, párizsi kisebbségi szerződés, kisebbségi statutum, illetve az ezekből levezethető kisebbségi szabadságjogokat (tan-, gyülekezés-, vallás-, kulturális stb.). ${ }^{55}$ Mikó Imre Huszon két - az erdélyi magyarság politikai története 1918. december 1-től 1940. augusztus 30-ig az egyik legtöbbet idézett korabeli munka. Az első fejezet öt pontban tárgyalja az impériumváltás eseménytörténetét (1918-1922): Erdély elszakítása, katonai megszállása, németség csatlakozása Romániához, magyar passzív politikai magatartás, Magyar Szövetség megalakítása, részvétel a román választásokon, földbirtokreform. ${ }^{56} \mathrm{~A}$ lokális viszonyok megismerése kapcsán fontos kiemelni a kisebbségi magyar íróktól, újságíróktól, politikusoktól (Győri Illés István, Gyárfás Elemér, Szász Endre, Janovics Jenő, Gaál Gábor stb.) 1937-ben megjelent Metamorphosis Transylvaniaet. A transzilvanista szellemiséget tükröző különböző tematikájú írások (politika, társadalom, sajtó, irodalom, színház, gazdaság, sport) 17 évet foglalnak magukba, amelyek magyar szempontból a legfontosabb városokban (Kolozsvár, Nagyvárad, Temesvár, Arad, Brassó, Marosvásárhely, Szatmárnémeti) bekövetkezett változásokat tárgyalják. ${ }^{57} \mathrm{~A}$ gazdaságtörténeti folyamatokra vonatkozóan csak töredékes információkkal rendelkezünk.

\footnotetext{
52 HORVÁTH Jenő: Diplomácia történelem. 2. kötet, Budapest, Szent-István Társaság, 1921.; Uő: Felelösség a világháborúért és a békeszerzödésért. Budapest, MTA, 1939

${ }_{53}$ KORÉH Endre: A székely hadosztály és dandár története 1918-1919. I. Szenczi Kiadó, Budapest, 1922; KRATOCHVIL Károly: A székely hadosztály 1918-1919. évi bolsevikellenes és ellenforradalmi harcai a székely dicsőségért. Budapest, 1938; KRATOCHVIL Károly: A székelyt a forradalom se győzte le. In: A magyar katona. Századunk legszebb magyar csatái. Szerk.: Ajtay Endre. Budapest, 1944

${ }^{54}$ FOGARASSY László: Adalékok a Székely Hadosztály és az erdélyi kérdés történetéhez (1918-1919). Magyar történeti tanulmányok XIX., Debrecen, 1986; GOTTFRIED Barna-NAGY Szabolcs: A székely hadosztály története. Barót, Tortoma Könyvkiadó, 2011

${ }^{55}$ NAGY Lajos: A kisebbségek alkotmányjogi helyzete Nagyromániában. Kolozsvár, Erdélyi Tudományos Intézet, Minerva Irodalmi és Nyomdai Műintézet Rt., 1944

${ }^{56}$ MIKÓ Imre: Huszon két - az erdélyi magyarság politikai története 1918. december 1-töl 1940. augusztus 30-ig. Budapest, A STUDIUM kiadása, 1941

${ }^{57}$ Metamorphosis Transylvaniae (Országrészünk átalakulása 1918-1936). Szerk.: GYÖRI Illés István. Cluj, Új Transzilvánia, 1937
} 
Ebből is ki kell emelnünk Gyárfás Elemér munkásságát, aki számos publicisztikát és elemzést készített, többek között a magyar vállalkozásokat segítő erdélyi bankszindikátus megalakulásáról, céljairól. ${ }^{58}$ Kifejezetten a romániai magyar kisebbség sérelmeit gyüjtötte össze az a kiadvány, amely 1919-1922 közti esetekről készített leltárt. A Magyar-Székely Egyesület kiadása arra próbálta ráirányítani a figyelmet, hogy milyen pontokban sértette meg a román állam az 1919. december 9-én kötött kisebbségek védelméről szóló szerződést (agrárreform, oktatás, hủségeskü, ipar nacionalizálása stb.). ${ }^{59} \mathrm{Az}$ impériumváltás társadalmi, politika- és egyháztörténetéhez az Erdélyi Magyar Évkönyvek szolgálhatnak további információkkal. ${ }^{60}$ A romániai magyar politika első hat évéről, illetve hírlapokról, folyóiratokról, azok profil szerinti csoportosításáról György Lajos gyüjtése szolgál információkkal. ${ }^{61}$ Grandpierre Emil az erdélyi magyar politikai élet első éveit, az útkeresést, a szervezeti forma megtalálásával együtt járó belső konfliktusokat, stratégiákat mutatta be az Országos Magyar Párt megalakulásáig. ${ }^{62}$

A Romániához csatolt volt magyar terület lakosságának nemzetiség és felekezet szerinti statisztikai megoszlása mind a tudományos kutatás, mind pedig a politikai érdekek egyik központi kérdése közé tartozik. Az ENSZ 2007-ben kiadott népszámlálási elveinek és ajánlásainak bevezetőjében nem véletlenül szerepel a következő megállapítás: „Békeidőben a hagyományos népszámlálás a legösszetettebb és legtömegesebb hadmüvelet”. ${ }^{63} \mathrm{Az}$ állam ismeretigénye azonban nem csitul háborús időszak közepette, a területi integritás megsértése vagy a zilált közigazgatási viszonyok mellett sem az uralni vagy birtokolni kívánt terület népességéröl. ${ }^{64}$ Első ízben 1919-ben tartottak népszámlálást Romániában. Erre azért került, hogy a párizsi békekonferencián részt vevő román delegáció a területi követeléseket tartalmazó memorandumhoz csatolva kimutassa a románság többségi pozícióját Erdélyben.

\footnotetext{
${ }^{58}$ GYÁRFÁS Elemér: Az erdélyi bankszindikátus megalakulása, helyzete és törekvései. Dicsőszentmárton, 1923; Publicisztikai gyüjtemény: GYÁRFÁS Elemér: Erdélyi problémák 1903-1923. Cluj-Kolozsvár, Erdélyi Irodalmi Társaság, 1923

59 A romániai magyar kisebbség sérelmei. I. (1919-1922.) Kiadja: A Népszövetség Támogatásával Alakult Magyar-Székely Egyesület, 1922

${ }^{60}$ Erdélyi Magyar Évkönyv 1918-1929. I. évf. Szerk.: SULYOK István, FRITZ László. Kolozsvár, Juventus kiadás, 1930 [Továbbiakban: Erdélyi Magyar Évkönyv 1918-1929, 1930]

Erdélyi Magyar Évkönyv, 1937. A kisebbségi magyar polgár kézikönyve. Szerk.: KACSÓ Sándor. A „Brassói lapok” és a „Népújság” kiadása, Brassó, 1937 [Továbbiakban: Erdélyi Magyar Évkönyv, 1937]

${ }^{61}$ A romániai magyar idöszaki sajtó öt esztendeje (1919-1923) Összeállította: GYÖRGY Lajos. Cluj-Kolozsvár, Erdélyi Irodalmi Szemle, 1924; Pásztortüz Almanach. Szerk.: GYÖRGY Lajos. Cluj-Kolozsvár, Minerva Irodalmi és Nyomdai Müint. Rt., 1925

${ }^{62}$ GRANDPIERRE Emil: Az erdélyi magyarság politikai küzdelmei az egységes magyar párt megalakulásáig. Magyar Szemle, 1928. október, 130-136.

63 HOLKA László: Államalkotó népszámlálások. Statisztikai Szemle, 91. évfolyam 12. szám. http://www.ksh.hu/statszemle_archive/2013/2013_12/2013_12_1317.pdf (Letöltve: 2017. augusztus 29.) ${ }^{64}$ Uo.
} 
Másfelől az agrárreform előkészítése tette szükségessé. A soron következő népességszámbavételre 1920-ban került sor, amelyet az 1919-eshez (eredményét csak fö összegekben és nem hivatalosan adták közre) hasonlóan éles bírálatok értek. A módszertani és számítási hibák javítását először Jakabffy Elemér tette közzé 1923-ban, aki községenkénti bontásban az 1910. évi magyar népszámlálás anyanyelvi és felekezeti adataival közös táblázatokban rendezte az 1919-es és 1920-as adatokat. ${ }^{65}$ Ezeknek az ún. államalkotó népszámlálásoknak a legnagyobb problémája az, hogy az eltérő adatrögzítő, értékelő és közlési gyakorlata, illetve az egymásnak ellentmondó népszámlálási végeredmények megnehezítik a népesség etnikai megoszlásában végbement folyamatok nyomon követését és egybevetését, illetve könnyen a politika eszközévé válhatnak. Mindezt alátámasztja az az eljárás, amelyet Jakabffy és Varga E. Árpád is megállapított a magyar és a román adatfelvétel különbözőségéről. Az 1910. évi magyar népszámlálás az anyanyelvre, az 1920. évi román összeírás a nemzeti eredetre kérdezett rá. Ez utóbbi eredményének az 1919-es román memorandum adataival való egyezései jelzik, hogy a számbavétel végrehajtói a memorandum készítőihez hasonlóan járhattak el akkor, amikor a népi származás kategóriáját alkalmazva a kétséges eseteket (például magyar anyanyelvü izraeliták, görög katolikusok, ortodoxok, elmagyarosodott németek) a magyarság csökkentésére, illetőleg a románság növelésére használták fel. ${ }^{66}$ Erdély népesedéstörténetére vonatkozóan Nyárády R. Károly irathagyatéka is kiemelendő, amelyet Varga E. Árpád szerkesztett és látta el előszóval. ${ }^{67}$

$\mathrm{Az}$ átmenet történetére vonatkozó kutatások terén az elmúlt években egyre inkább a regionalizmus, a lokalitás, az identitás, a mindennapok, illetve a birodalmi állapotot felváltó nemzetállami státusz feltárása kerül az érdeklődés fókuszába. Időben kivételt képez K. Lengyel Zsolt németül publikált (1993) monografikus munkája, amely az addig irodalomközpontú (Pomogáts Béla, Nagy György) 20. századi Erdély-kutatásokkal, illetve az erdélyi sajátosságokra építő önazonosság-eszmék tematizálásával szemben jelentett áttörést. ${ }^{68}$

\footnotetext{
${ }^{65}$ JAKABFFY Elemér: Erdély statisztikája a Romániához csatolt egész volt magyar terület lakosságának nemzetiségi, felekezeti és kulturális községenkénti statisztikája az 1910. és 1920. évi hivatalos adatok alapján. Kiadja a „Magyar Kisebbség” nemzetpolitikai szemle, Lugos, Husvéth és Hoffer könyvnyomda, 1923 (Elérhetö továbbá: http://adatbank.ro/html/cim_pdf1727.pdf)

${ }^{66}$ VARGA E. Árpád: Az erdélyi magyarság föbb statisztikai adatai az 1910 utáni népszámlálások tükrében. Magyarságkutató Intézet évkönyve. Budapest, 1988, 37-123. (Elérhető továbbá: http://www.kia.hu/konyvtar/erdely/erdmagy.htm); U. ö.: Erdély etnikai és felekezeti statisztikája. Népszámlálási adatok 1850-2002 között. (Elérhető: http://www.kia.hu/konyvtar/erdely/erd2002.htm)

${ }^{67}$ NYÁRÁDI R. Károly: Erdély népesedéstörténete. Az irathagyatékot szerkesztette és az előszót írta: Varga E. Árpád. Budapest, Központi Statisztikai Hivatal Levéltára, 2003. A téma szempontjából megemlítendő Kovács Alajos munkássága a két világháború közti időszakból, illetve Dávid Zoltáné az 1980-as évekből.

68 K. LENGYEL Zsolt: Auf der Suche nach dem Kompromiß. Ursprünge und Gestalten des frühen Transsilvanismus 1918-1928. München, Verlag Ungarisches Institut, 1993
} 
A szerző a politikai transzszilvanizmust (Erdély sajátosságainak sokféle elágazó, nemzetileg, politikailag megosztott érdekképviselete) és a regionális sajátosságok összetevőit a politikai eszmetörténet magyar-román-német összehasonlító keretében vizsgálja a dualizmusban és típusait az impériumváltást követő 1920-as években. Az elvárásokkal szemben nem fogalmazza meg a transzilvanizmus definícióját, hanem annak alkati összetevőire (tipologizálás), gondolati tartalmainak körülhatárolására fókuszál. K. Lengyel két korszakot különít el: az 1918 előtti ótranszilvanizmusét és a háború utáni korai transzilvanizmusét (1920-as évek közepéig). Ezen belül konzervativ (a magyar szupremácia megőrzésére és a saját etnokulturális közösség megerősítésére irányuló) és progresszív (regionális szintű modernizációt sürgető) oldalakat különböztet meg. K. Lengyel értelmezésében ez arra utal, hogy a dekoncentráció (az államhatalmi jogosítványok regionális szintű megosztása) és a decentralizáció hagyománya (az alulról építkező regionális érdekképviselet intézményesülése) egyaránt jelen van az impériumváltás előtti erdélyi politikai gondolkodásban. A szerző a korai transzilvanizmuson belül is megkülönbözteti a konzervatív és a progresszív irányzatot (passzivisták és aktivisták), amely nem éles határvonalat jelent, hanem eltérö alternatívákat. Ennek az oka, hogy a Romániába került magyarság vezetői egy ideig éltek a belső elkülönülés világnézeti elemeivel, de ezeket az alkalmazkodás, illetve az összezárkózás kényszere fokozatosan háttérbe szorították. $^{69}$

Bárdi Nándor Otthon és haza tanulmánykötete a romániai magyar nemzeti mozgalom létrejöttét, Magyarországhoz való viszonyát és a két világháború közti budapesti kormányzatok erdélyi magyarságot támogató politikáját ismerteti. A mindennapi cselekvésvilágból magyarázza meg azt a nagyobb kisebbségtörténeti elbeszélést, amelyet az elit generációs csoportjai fogalmaztak meg, létrehozva a stratégiákat szolgáló beszédmódokat. A konstrukció létrejöttének müködése áll a figyelem központjában, amelyben elválasztásra kerül a magyarságpolitika, a kisebbségi politika, illetve a nemzetpolitika fogalma, hogy a szereplők és az érdekviszonyok megkülönböztethetők legyenek. A kötet egyik tanulmánya a székelyudvarhelyi impériumváltáson keresztül a változó helyi viszonyokba enged betekintést. Részben azzal a céllal, hogy ráirányítsa figyelmünket a helytörténeti kutatások fontosságára, illetve a megszállás alatt tanúsított eltérő magatartásokra és szituációkra. ${ }^{70}$

\footnotetext{
${ }^{69}$ K. LENGYEL: A kompromisszum keresése. Tanulmányok a 20. századi transzszilvanizmus korai történetéhez. Pro-Print Könyvkiadó, Csíkszereda, 2007, 266-280. [Továbbiakban: K. LENGYEL: A kompromisszum. 2007]

${ }^{70}$ BÁRDI Nándor: Otthon és haza. Csíkszereda, Pro-Print Könyvkiadó, 2013
} 
Egry Gábor a két világháború közti erdélyi román-magyar hétköznapi együttélés rekonstruálásában arra kereste a választ, hogy a kisebbségi elitek milyen módon alakíthatták saját csoportjaik identitását a nemzetállami központok ellenében. Fő kérdése, hogy miként látta a különböző magyarságfelfogások egyéni elfogadtatására irányuló politika a magyarságot és környezetét, és ezt képes volt-e érvényre juttatni az egyénekkel szemben akár a politikán túl, a mindennapokban is. A szerző állítása, hogy az egyének csak ritkán, többnyire végletekig kiélezett helyzetben voltak hajlandók éppen olyan módon kifejezésre juttatni önazonosságukat, ahogy azt elvárták tőlük, és sokfelé megőrződtek sokszor az új állam helyi képviselőinek segítségével nemzetileg ambivalens gyakorlatok. ${ }^{71}$

Az erdélyi zsidó nemzetépítés folyamatáról, emancipációjáról és disszimilációjáról, szoros összefüggésben a magyarság és zsidóság viszonyának kérdésével Gidó Attila forráskötetei és Carol Iancu 1919-1938 közti romániai zsidóság történetéről szóló könyve jelentenek továbblépést az identitás- és regionális kutatások területén. ${ }^{72} \mathrm{~A}$ zsidó szempontokat és az önálló nemzetépítést hangsúlyozó korabeli publikációk közül az Új Kelet Évkönyvét fontos kiemelni, amely 1921-1922-ben megjelent cikkeket foglal össze. ${ }^{73}$

Az egyesült román állam regionális különbségeit figyelembe vevő román történetírók közül Irina Livezeanut és Gheorghe Iancut kell kiemelnünk. Livezeanu társadalom-, politikaés eszmetörténeti monográfiája 1918-1930 közti időszakot tárgyalja. Bemutatja a Romániához csatolt etnikailag és politikailag sokszínủ régiókat (a román történetírás szerint provinciákat: Erdély, Besszarábia, Bukovina), a bukaresti politikai elit centralizációs és nemzetiesítő törekvéseit, illetve céljukhoz alkalmazott politikai eszközöket (asszimiláció, román nemzeti középosztály víziója, kultúrzóna, földbirtokpolitika, törvényalkotás stb.). A szerző kilép a hagyományos nemzeti történetírói szerepből, amikor a folyamatokra és az összehasonlításra helyezi a hangsúlyt. Az oktatáspolitika tárgykörében az első világháború előtti viszonyokat is szem előtt tartva elemzi az Elzász-Lotharingiában, az Osztrák-Magyar Monarchiában, majd az új román államban fellelhető nemzetiesítő struktúrákat.

\footnotetext{
71 EGRY Gábor: Etnicitás, identitás, politika. Magyar kisebbségek nacionalizmus és regionalizmus között Romániában és Csehszlovákiában 1918-1944. Budapest, Napvilág Kiadó, 2015 [Továbbiakban: EGRY: Etnicitás, 2015]

${ }^{72}$ GIDÓ Attila: Úton. Erdélyi zsidó társadalom- és nemzetépítési kísérletek (1918-1940). Csíkszereda, Pro-Print Könyvkiadó, 2009 [Továbbiakban: GIDÓ, Úton. 2009]; GIDÓ Attila: Két évtized. A kolozsvári zsidóság a két világháború között. Kolozsvár, Erdélyi Múzeum-Egyesület, 2016 (Kassa viszonylatában hasonló munka: KOVÁCS Éva: Felemás asszimiláció. A kassai zsidóság a két világháború között 1918-1938.); IANCU, Carol: Les juifs en Roumanie (1919-1938). De l'émancipation à la marginalisation. Paris-Louvain, Peeters, 1996

${ }^{73}$ Az Új Kelet Évkönyve 5682. Szerk.: Marton Ernő. Cluj-Kolozsvár, Kadima Rt. kiadása, 1921-1922
} 
Éles határt húz a döntően rurális román társadalom (20\% élt városias környezetben) és az új területek városaiban élő nem román nemzetiségek (magyar, német, orosz, zsidó stb.) között. ${ }^{74}$ Iancu két korábbi publicisztikájából ${ }^{75}$ született monográfia, a nagyszebeni román Kormányzótanács összetételéről, politikai céljairól és müködéséröl (The Ruling Council. The Integration of Transylvania into Romania: 1918-1920), amely túl mutat a címben megadott két év történetén. Erdély Romániába történő politikai integrációját mutatja be, ahogyan az erdélyi regionális struktúrák (oktatás, közigazgatás, bíróságok, politikai rendszer stb.) fokozatosan a bukaresti kormányzat befolyása alá kerültek. ${ }^{76} \mathrm{~A}$ Consiliul Dirigent tevékenységének korabeli összefoglalását adja Romul Boila: Transilvania, Banatul, Crisana, Maramuresul 1929-ben megjelent könyve. ${ }^{77}$

Az impériumváltás diplomáciai, politikai, valamint hadtörténeti vonatkozásaival, majd az azt követő társadalmi folyamatokkal (román nemzetépítés hatása a városokban) az alábbi román szerzők foglalkoznak részletesebben. Galea Autrel az erdélyi és a bánáti térség román kormányzótanácsainak megalakítását, müködését, illetve az Erdélytől nyugatra élő román lakosság viszonyait tekinti át. ${ }^{78}$ Lucian Leuştean két politikatörténeti munkájában Magyarország és Románia viszonyát ismerteti a párizsi béketárgyalások és a megváltozott nemzetközi politikai rendszer tükrében. ${ }^{79}$ Erdély 1918-1919-ben bekövetkezett katonai megszállásáról és a román hadsereg hadmüveleteiről Dumitru Preda, Vasile Alexandrescu és Prodan által írt hadtörténeti monográfiát kell kiemelni. ${ }^{80}$ Román szempontból Liviu Boar, Ioan Scurtu és Ion Agrigoroaiei járultak hozzá az etnikailag sokszínűvé vált Románia integrációtörténetének feldolgozásához, 1918-1925, illetve a két világháború közti időszak kisebbségtörténetéhez, többség-kisebbség viszonyához. ${ }^{81}$

\footnotetext{
${ }^{74}$ LIVEZEANU, Irina: Cultural Politics in Greater Romania. Regionalism, nation building and ethnic struggle, 1918-1930. Cornell University Press, Ithaca and London, 2000

${ }^{75}$ IANCU, Gheorghe: Activitatea Consiliului Dirigent in domeniul finantelor. Marisia VI. 1976, 445-477.; Uő.: Preocupari ale Consiliului Dirigent pentru reorganizarea activitatii industriale in Transilvania 1918-1920. Marisia V. 1975. 261-281.; A marosvásárhelyi Múzeumi Évkönyvben jelent meg ugyanerről az időszakról: RANCA, Paulina: Izvoare memoriale muresene privind unirea Transilvaniei cu Romania de la 1 Decembrie 1918. Marisia V. 1975, 343-357.

${ }^{76}$ IANCU, Gheorghe: The Ruling Council. The Integration of Transylvania into Romania: 1918-1920. Fundatia Culturala Romana, Cluj, 1995 [Továbbiakban: IANCU: The Ruling Council. 1995]

${ }^{77}$ BOILA, Romul: Transilvania, Banatul, Crisana, Maramuresul, 1918-1928. Bucuresti, 1929

${ }^{78}$ AUTREL, Galea: Formarea şi activitatea consiliului dirigent al Transilvaniei, Banatul si pinuturile românesti din Ungaria (2 decembrie 1918 - 10 aprilie 1920Târgu-Mureş, Tipomur, 1996

79 LEUŞTEAN, Lucian: România şi Ungaria in cadrul „Noii Europe” (1920-1923). Polirom, Iaşi 2003; LEUŞTEAN, Lucian: România, Ungaria şi Tratatul de la Trianon 1918-1920. Iaşi, Polirim, 2002

${ }^{80}$ PREDA, Dumitru, ALEXANDRESCU, Vasile, PRODAN, Costică: În apărarea României Mari - Campania armatei române din 1918-1919. Bucarest, Editura Enciclopedica, 1994

${ }^{81}$ SCURTU, Ioan-BOAR, Liviu (coord.): Minorităţile naţionale din România. 1918-1925. Documente. Arhivele Statului din Romania, Bucuresti, 1995; AGRIGOROAIEI, Ion-SCURTU, Ioan: Majoritari oi minoritari. In: Scurtu, Ioan (coord.): Istoria Românilor. Vol. VIII. România întregită (1918-1940). Editura Enciclopedica, Bucureoti, 2003, 56-68; SCURTU, Ioan: Minoritatile nationale din Romania in anii 1918-1925. In: Scurtu, Ioan
} 
Az 1918-1919-es impériumváltás történeti problémája a Román Akadémia gondozásában kiadott új román történeti szintézisben, a Románok történetében (2003) is hangsúlyos szerepet kap. ${ }^{82}$ Zahorán Csaba egy dolgozatában összevetette a cseh, a román és a magyar történelmet bemutató „nagy” összefoglaló munkák impériumváltást ábrázoló diskurzusait. ${ }^{83}$ Megállapítása szerint, amíg a cseh szerzőknél megfigyelhető a nemzeti szempont mellett a tárgyilagosság, a román történészek figyelmen kívül hagyják az eltérő értékelési alternatívákat. Magyarázatként szolgálhat a csehszlovák állam törékenyebb mivolta, hiszen itt a kisebbségi kérdéshez hozzáadott a két államnemzet (cseh és szlovák) konfliktusa is. Nagy-Romániát ellenben a román történetírás általában egységes nemzetállamként jellemzi. ${ }^{84}$ Az 1918-1921 közti románmagyar diplomáciai kapcsolatokat Alexandru Ghişa dolgozta fel. ${ }^{85}$ Románia részvételéről a párizsi béketárgyaláson, illetve a román delegáció tárgyalásairól, belső konfliktusairól Alexandru Vaida-Voedod titkára, Viorel Virgil Tilea készített naplószerű feljegyzést. ${ }^{86} \mathrm{Az}$ erdélyi születésű Iuliu Maniuról és az erdélyi román politikai elit (többek között Alexandru Vaida-Voevod, Aurel Vlad, Aurel Lăzar) életpályájáról, akik vezető szerepet játszottak az 1918-as unió megalkotásában egy francia történész, François Bocholier írt tanulmányt. ${ }^{87}$ A vizsgált korra vonatkozóan Erdélyről, mint önálló régióról két további dolgozata is használható. Az egyik a román és a magyar nemzeti aspirációk kereszttüzében álló erdélyi nemzeti elitek identitását boncolgatja román és magyar forrásokra egyaránt támaszkodva. A másik egy historiográfiai összefoglaló, amely az Erdély történetéről szóló román és magyar nyelvü írásokat teszi kritika tárgyává. ${ }^{88}$

\footnotetext{
- Boar, Liviu (coord.): i. m. 7-14.; Leuotean; Ioan Scurtu, a Román Tudományos Akadémia tagjának további munkáságát lásd: http://www.ioanscurtu.ro.

${ }^{82}$ Istoria Românilor VII/II. AGRIGOROAIEI, Ion. Coord.: Gheorghe Platon. Editura Enciclopedică, Bucureşti, 2003; Istoria Românilor VIII. BOTORAN, Constantin, FLORIN, DOBRINESCU, Valeriu. Coord.: Ioan Scurtu. Editura Enciclopedică, Bucureşti, 2003

${ }^{83}$ KLIMEK, Antonin: Velké déjiny zemí Koruny české. XIII. Paseka, Prha-Litomyšl, 2000. [A Cseh Korona országainak nagy története XIII. kötet. Szerk.: Antonin Klimek. Paseka Kiadó, 2000] KÁRNÍK, Zdeněk: České zemé v ére prvni republiky (1918-1938). I. Vznik, budováni a zlatá léta republiky (1918-1929) Libri, Praha, 2003 [Csehország az első köztársaság korszakában. Szerk.: Zdeněk Kárník.] Magyarország története 1918-1919, 1919 1945. Föszerk.: RÁNKI György. Akadémiai Kiadó, Budapest, 1984; ROMSICS Ignác: Magyarország története a XX. században. Osiris, Budapest, 2003

${ }^{84}$ ZAHORÁN Csaba: Az impériumváltás ábrázolása az új cseh és román történeti szintézisekben. In: Folyamatok a változásban. A hatalomváltások társadalmi hatásai Közép-Európában a XX. században. Szerk.: Ablonczy Balázs, Fedinec Csilla. Budapest, Teleki László Alapítvány, 2005

${ }^{85}$ GHIŞA, Alexandru: Romania and Hungary at the Beginning of $20^{\text {th }}$ : Establishing Diplomatic Relations (19181921). Centrul de Studii Transilvane, 2003

${ }^{86}$ Dr. TILEA, Viorel Virgil: Románia diplomáciai müködése 1919 novembertöl 1920 márciusáig (Fordította: Botos János). A „Magyar Kisebbség” kiadása. Husvéth és Hoffer, Lugoj-Lugos, 1926

87 BOCHOLIER, François: Iuliu Maniu nemzedéke és az impériumváltás. Folyamatok a változásban. A hatalomváltások társadalmi hatásai Közép-Európában a XX. században. Szerk.: Ablonczy Balázs, Fedinec Csilla. Budapest, Teleki László Alapítvány, 2005

${ }^{88}$ BOCHOLIER, François: La Transylvanie, de l'Autriche-Hongrie à la Grande Roumanie les élites transylvaines, entre identité régionale et essor des sentiments nationaux. Colloque Transitions, Univ. Panthéon-Sorbonne, mai
} 
Magyar szerzők írásai, amelyek az 1916-os betörés helyi következményeit, az 19181920-as impériumváltás egyes aspektusát, illetve a kisebbségi társadalom kezdeti útkeresését vizsgálták, a következőket szükséges megemlíteni. Fráter Olivér Erdélyi magyar helyzetkép 1916-1919-ben címmel megjelent írása az egyházi krónikákon (historia domus) és más, még nem publikált forrásokon keresztül nyújt képet a háborúba sodródó Erdélyről, az 1918-1919-es forradalmi események helyi hatásairól, az Erdély jövője kapcsán egymásnak ellentmondó magyar és román elképzelésekről, a Székely Hadosztály harcairól, és az erdélyi magyar tisztviselőréteg társadalmi struktúrájának lebomlási folyamatáról az impériumváltás idején. Erdély impériumváltás történetének elbeszélhetősége szempontjából Fráter könyve azért is fontos, mert azt időben a román betöréshez köti, amikor Erdélyt 1916-tól hadszíntérként ábrázolja. ${ }^{89}$ Ebbe a diskurzusba illeszkedik Eördögh István és L. Balogh Béni egy-egy publikációja az 1916-os fordulópontot jelentő eseményekről. Eördögh forrásbázisa részben a vatikáni levéltár Romániára vonatkozó feljegyzéseire épül. ${ }^{90} \mathrm{~A}$ háromszéki orbai járás és Sepsiszentgyörgy gazdasági, társadalmi viszonyainak feltárása a háborús hátországban a Székely Nemzeti Múzeum évkönyvében (Acta Siculica, 2011) három rövidebb tanulmányban került sor. ${ }^{91}$ Szász Zoltán az erdélyi román polgárság 1918 őszén betöltött szerepét nézte meg. ${ }^{92}$ Az államhatalom váltással az erdélyi közigazgatási rendszer is új keretek közé került. A székelyudvarhelyi Areopolisz Egyesület kiadásában megjelent tanulmánykötet a három székelyföldi megye közigazgatás-történetébe enged betekintést. Nagy Botond Háromszék, László Márton Maros-Torda/Maros megye, Gidó Csaba Udvarhely megye impériumváltástól impériumváltásig (1918-1940) szóló történetét dolgozta fel. ${ }^{93}$

2002, 21 p.; BOCHOLIER, François, Retour ou permanence du national ? Historiographies roumaine et hongroise de la Transylvanie sous le communisme. Colloque au Centre Marc-Bloch, Berlin, juin 2004, 11 p. Mindkét cikk elérhető: http://www1.ens.fr/europecentrale/XfichesCHERCHEURS/Bocholier.htm (Letöltve: 2017. augusztus 8.)

${ }^{89}$ FRÁTER Olivér: Erdélyi magyar helyzetkép 1916-1919-ben. Budapest, Hamvas Intézet, 2003 [Továbbiakban: FRÁTER, Erdélyi magyar helyzetkép, 2003] FRÁTER Olivér: Erdély román megszállása 1918-1919. Tóthfalu, 1999

${ }^{90}$ EÖRDÖGH István: Erdély román megszállása 1916-1920. LAZI Kiadó, Szeged, 2000; L. BALOGH Béni: 1916 - A fordulat éve. Románia hadba lépése és az erdélyi románság. Pro Minoritate, 2016. Tél, 18-25. [Továbbiakban: L. BALOGH, Pro Minoritate, 2016. Tél]

91 NAGY Szabolcs: Az 1916-os román megszállás egy sepsiszentgyörgyi patikus szemével; Uő.: Egy székely város közállapotai az első világháború végén; KOSZTA István: Ki ment, kit vittek 1916 őszén Orbai járásból. Acta Siculica, 2011, (A Székely Nemzeti Múzeum évkönyve). Főszerk.: KINDA István

92 SZÁSZ Zoltán: Az erdélyi román polgárság szerepéről 1918 őszén. Századok 1972. 2. szám

93 NAGY Botond: Háromszék közigazgatása 1918-1940 között; LÁSZLÓ Márton: Maros-Torda/Maros megye közigazgatása 1919-1938 között; GIDÓ Csaba: Udvarhely megye közigazgatás-története impériumváltástól impériumváltásig (1918-1940). In: AREOPOLISZ Történelmi és társadalomtudományi tanulmányok XIV. Szerk.: Kolumbán Zsuzsánna, Róth András Lajos. Székelyudvarhely, Areopolisz Egyesület, 2015 [Továbbiakban: NAGY: Háromszék, LÁSZLÓ: Maros-Torda/Maros, illetve GIDÓ, Udvarhely, AREOPOLISZ, 2015] 
Szabó Csongor a negyedik, aki Csík vármegye közigazgatásában bekövetkezett változásokról írt tanulmányt a Magyar Kisebbségben. ${ }^{94}$ Marosvásárhely hatalomváltásával, a magyar Nemzeti Tanács Románia és Erdély viszonyulásával elsőként Pál-Antal Sándor foglalkozott egy román nyelvü cikkben még az 1970-es évek végén. ${ }^{95}$ Hasonló témakörben Fodor János 2016-ban megvédett doktori disszertációja (Bernády György. Politikai életrajz) jelenti a továbblépést, amely azóta önálló kötetként is megjelent. A marosvásárhelyi átmenetről szóló politikatörténeti munka részletesen feltárja a román és a magyar nemzeti tanácsok működését, a város katonai megszállását, illetve a helyi politikai útkeresés lehetséges alternatíváit és Bernády György meghatározó közéleti szerepvállalását. ${ }^{96}$ A Bernády életrajhoz 1919-1920-ból adalékul szolgál továbbá Sebestyén Mihály két részes írása a Látó Szépirodalmi folyóiratban. ${ }^{97}$ Sepsiszentgyörgy város 1918-1919-re vonatkozó eseményeit levéltári és sajtóforrásokra támaszkodva Nagy Szabolcs tekintette át. A szerző kilép a Trianon sérelmi diskurzusból, amikor arra hívja fel a figyelmet, hogy Háromszék korábbi közállapota az 1916-os román hadsereg kiverését követően még 1918 végén is nagyon lesújtó képet mutatott, és részben hozzájárult az ellenséges csapatok védtelen keleti határok könnyü átlépéséhez. ${ }^{98}$ Az elhanyagolt magyar helytörténeti kutatások jelentős ürt képeznek az erdélyi impériumváltás rekonstruálásában. A lokális dimenzió az a szint, ahol az 1918-1920 közti viszonyokról kialakult emlékezet- és történetpolitikai kánonokat a konkrét átmenet momentumaival lehet szembesíteni. Ha a történeti Magyarország 30-40 elcsatolt városát, külön-külön alapkutatásokkal és összehasonítható módon megvizsgálnánk, szembe kellene nézni az átmenet sokesetűségével. Többek között a német és a zsidó polgárság szerepével, a helyi eltérő alkukkal, apparátusproblémákkal (a megszálló csapatok elől menekülő közigazgatás miatt létrejött hatalmi vákuumokkal), a hazatérő katonák és a társadalom elégedetlenségével, a Károlyikormány által kinevezettek szerepvállalásával stb.

\footnotetext{
${ }^{94}$ SZABÓ Csongor: Csík megye közigazgatása, 1918-1940. Magyar Kisebbség. 2014. XIX. évf. 3-4. szám, 209231. [Továbbiakban: SZABÓ: Csík megye. Magyar Kisebbség. 2014. 3-4. szám]

${ }_{95}$ Alexandru PÁL-ANTAL: Consiliul National Maghiar din Tirgu Mures si Atitudinea se fata de unirea Transilvanieni cu Románia. [A marosvásárhelyi Magyar Nemzeti Tanács és viszonyulása Erdélynek Romániával való egyesüléséhez.] Marisia IX. 1979, Muzeul Judetaan Mures, 383-398.

${ }^{96}$ FODOR János: Bernády György. Politikai életrajz. Marosvásárhely-Kolozsvár, Lector Kiadó, 2017; FODOR János: Impériumváltás Marosvásárhelyen 1918-1922. Múltunk, 2016. 2. szám [Továbbiakban: FODOR, Múltunk, 2016/2]

${ }^{97}$ SEBESTYÉN Mihály: Másnap. Adalékok Bernády György 1919-1920-as pályaképéhez (I-II. rész). Látó Szépirodalomi folyóirat. 1999. 10. évf. 1. szám, 71-95. és 2. szám, 86-108. [Továbbiakban: SEBESTYÉN, Látó, 1999/1-2]

${ }^{98}$ NAGY Szabolcs: Impériumváltás Sepsiszentgyörgyön 1918-1919. Acta Siculica 2012-2013, 345-356. (A Székely Nemzeti Múzeum évkönyve). http://www.sznm.ro/acta2012/345_356_nagy_szabolcs.pdf (Letöltve: 2017. szeptember 23.)
} 
Ebben az irányban történt már helytörténeti kutatás néhány felvidéki és délvidéki város államhatalom-váltás történetének feltárásara vonatkozóan. ${ }^{99}$

A romániai magyarság kezdeti útkeresésének időszakára vonatkozóan a következő munkákat tartom a legfontosabbaknak: Borsi-Kálmán Béla az első román koncepciós per történetét a temesvári levente pert dolgozta fel. ${ }^{100}$ Sas Péter vázlatos kézirata a romániai magyarság első érdekvédelmi szervezet, a Magyar Szövetség (1921-1922) történetét ismerteti. ${ }^{101} \mathrm{~A}$ kisebbségi magyar oktatás megszervezésével kapcsolatosan Barabás Endre két kiadványa a világháborúk közti időszakból mind a mai napig használatos adatgazdagsága és tárgyilagossága miatt. ${ }^{102}$ Barabás adatbázisát is használva előbb Diószegi László (1990), Balogh Júlia (1996), majd Gidó Attila dolgozta fel újból 1918-1928-1948 közti romániai magyar nyelvü oktatás intézményrendszerét és diákpopulációját. ${ }^{103}$ A román állam kereszttüzébe került unitárius egyház impériumváltás korszakára vonatkozó részleteket Pál János cikkében olvashatunk, amely az egyház angol-amerikai kapcsolatait tárja fel. ${ }^{104}$ Erdély politikai életét meghatározó személyek gazdaságpolitikai gondolkodásáról 2004-ben jelent meg egy két kötetes monográfia. Ebben Jakabffy Elemér, Gyárfás Elemér és Kós Károly gazdaságról vallott nézeteit ismerhetjük meg. ${ }^{105}$

\footnotetext{
99 FILEP Tamás Gusztáv: Föhatalomváltás Pozsonyban 1918-1920. Események, történések egy hirlap közleményeinek tükrében. Pozsony, Kalligram, 2010; MÁRCZA Mihály-SZÁMADÓ Emese: Komárom 1919. évi eseményei. Komárom - Esztergom Megyei Múzeumok Közleményei, Tata, 2009; FEDINEC Csilla: Államfordulat a hétköznapokban (Ungvár 1918-1920). In: Nemzet a társadalomban, Szerk.: Fedinec Csilla. Budapest, Teleki László Alapítvány, 2004; SCHULLER Balázs: Impériumváltás a Zsil-völgyében, 1918. Bányászati és Kohászati Lapok, 2005. 3. szám, 35-38; MISKOLCZI Miklós: Három pötty a déli országhatáron Tompa, Kelebia, Csikéria. Forrás, 2007. 6. szám, 75-82; ZSIGA Tibor: Muravidéktöl Trianonig. Lendva, Magyar Nemzetiségi Müvelődési Intézet, 1996; Élettől az életig a holokauszton át. Szerk.: Ózer Ágnes. Szabadkai Zsidó Hitközség, Szabadka, 2015; DÉVAVÁRI Zoltán: Új Partok Felé. Vajdasági Magyar Művelődési Intézet, 2014

100 BORSI-KÁLMÁN Béla: Öt nemzedék, és ami elötte következik... A temesvári levente-pör 1919-1920. Budapest, Noran-Kiadó 2004. Kft., 2006

${ }^{101}$ SAS Péter: Az erdélyi magyarság politikai szervezkedése. A politikai passzivitástól az Országos Magyar Pártig. OSZK Kézirattár 599/1987 [Továbbiakban: SAS, 1987]

102 BARABÁS Endre: A romániai magyar nyelvü oktatás elsö tíz éve 1918-1928. Lugos, Húsvéth és Hoffer Könyvnyomdája, 1929; BARABÁS Endre: A magyar iskolaügy helyzete Romániában 1918-1940. Kecskemét, Első Kecskeméti Hírlapkiadó és Nyomda Rt. 1944

${ }^{103}$ DIÓSZEGI László: Az erdélyi magyar iskolaügy 1918-1940. Varietas historiae. Tanulmányok Juhász Gyula 60. születésnapjára. Budapest, Magyarságkutató Intézet, 1990, 81-95. [Továbbiakban: DIÓSZEGI, 1990]; BALOGH Júlia: Az erdélyi hatalomváltás és a magyar közoktatás, 1918-1928. Budapest, Püski Kiadó, 1996; GIDÓ Attila: Oktatási intézményrendszer és diákpopuláció Erdélyben 1918-1948 között. Kolozsvár, Erdélyi Múzeum-Egyesület, 2013

104 PÁL János: Impériumváltás (1918-1920) az Unitárius Egyház angol-amerikai kapcsolatainak tükrében. REGIO, 2010. 4. szám, 33-71.

${ }^{105}$ Az erdélyi magyar gazdasági gondolkodás múltjából II. Kiadja: Romániai Magyar Közgazdász Társaság. Kolozsvár, Tipoholding Rt. 2004
} 
A felsorolt munkákon túl még néhány korabeli emlékirat, visszaemlékezés, napló és jelentés áll rendelkezésünkre a megváltozott erdélyi és lokális viszonyokról. Geml József Temesvár, Apáthy István Kolozsvár, Jakabffy Elemér Krassó-Szörény vármegye impériumváltás történetét jegyezte le. ${ }^{106}$ Krenner Miklós napló bejegyzéseiben 1919-1920 eseményeit örökítette meg. ${ }^{107}$ Az impériumváltásnak az életutakra és a közösségi identitásra gyakorolt hatását vizsgálva a naplók és visszaemlékezések vizsgálata fontos forrásként jelenik meg a történeti kutatások során. Megemlítendő Paál Árpád, Udvarhely megye egykori alispánhelyettesének Gondolatnaplója, Jakabffy Elemér országgyülési képviselö Lugostól Hátszegig, Vásárhelyi János erdélyi református püspök Emlékeim, Molter Károly író, illetve Kertész Jenő személyes visszatekintése. ${ }^{108}$ Ligeti Ernő író publicisztikai, illetve tanulmányírói munkásságához tartozik az 1941-ben Kolozsváron megjelent Súly alatt a pálma, nagyszabású személyes hangvételü tanulmány. Ligeti az erdélyi magyarság első kisebbségi korszakának legfontosabb közösségszervező és nemzetmegtartó intézményét, a kisebbségi irodalom és a magyar nyelvű sajtó identitás fenntartó szerepét örökítette meg. A szerző számos írása egyúttal olyan kortörténeti dokumentum, amely részben nemzedékének politikusairól ad portrét, illetve a kisebbségi élet mindennapos kihívásairól nyújt elemzést. ${ }^{109}$ Az impériumváltás időszakából két politikai röpirat váltott ki nagyobb vitát (Kós-Paál-Zágoni: Kiáltó szó, Bernády György: Nyíltlevél), amelyek eredetileg politikai programadás céljával születtek. ${ }^{110}$

\footnotetext{
106 GEML József: Emlékiratok. Helicon, Timisoara, 1924; APÁTHY István: Erdély az összeomlás után. Új Magyar Szemle 1920. 147-170.; JAKABFFY Elemér: A magyar államhatalom utolsó hónapjai Krassó-Szörény vármegyében. Lugos, Husvéth és Hoffer, é. n.; JAKABFFY Elemér-PÁLL György: A bánsági magyarság húsz éve Romániában 1918-1938. Budapest, A Studium kiadása, 1939

107 Krenner Miklós napló. 1919. október 15-től 1920. január 12-ig. OSZK Kézirattár, fond 456 Krenner Miklós (Spectator)

${ }^{108}$ A munkák kézirattári lelőhelyei: PAÁL Árpád: Gondolatnapló, OSZK Kézirattár, 625 fond, K 1951/97; PAÁL Árpád: Visszaemlékezés 1918 őszére. Haáz Rezső Múzeum, Székelyudvarhely, Paál Árpád kéziratos hagyatéka Ms 7651/337.; JAKABFFY Elemér: Lugostól Hátszegig. OSZK Kézirattár, 625 fond, K 1486/95; VÁSÁRHELYI János: Emlékeim: Erdélyi Református Egyházkerület Központi Gyüjtőlevéltára (Kolozsvár), F 22; MOLTER Károly: Erdély történelmi hangulata 1916-tól Trianonig. OSZK Kézirattár, fond 256 (volt Teleki Intézet: K1321:9/1994); KERTÉSZ Jenő: A tíz év előtti Erdély napja. Korunk 1929. 2. sz. 9-16. 3. sz. 89-98., 4. sz. 171179.

${ }^{109}$ LIGETI Ernő: Súly alatt a pálma. Egy nemzedék szellemi élete. Emlékirat. Kolozsvár, Fraternitas Rt. 1941, Uő: Erdély vallatása. (politikai portrék). Kolozsvár, 1922; Uő: Föl a bakra (regény). Kolozsvár, 1925.

${ }^{110}$ KÓS Károly: Kiáltó szó. ZÁGONI István: A magyarság útja. PAÁL Árpád: A politikai aktivitás rendszere. Cluj-Kolozsvár, 1921; BERNÁDY György: Nyiltlevél. 1920. május 15. Marosvásárhely, KOSMOS Grafikai Müintézet Rt.
} 
A budapesti kormányzat Erdélyről szóló informálását részben a különböző jelentések segítették, amelyek beszámoltak az egyes vármegyék gazdasági, társadalmi, politikai fejleményeiről, a kisebbségi magyar politikai elit mozgásáról, Budapesthez való viszonyáról, a sajtót, az oktatást ért mindennapos konfliktusokról. ${ }^{111}$

A kárpát-medencei magyar kisebbség történetének feltárásában a következő években több fontos kutatás eredményével számolhatunk. Egry Gábor vezetésével a Birodalmi átmenetek helyi kontextusban, 1918-1925 címü OTKA pályázat célja bemutatni, hogy a helyi és regionális kontextus, társadalmi, gazdasági, politikai viszonyok miként befolyásolták az első világháború végi átmenetet. Nem a nyílt, politikai és diplomáciai konfliktusok kerülnek a figyelem központjába, hanem a létező társadalmi, politikai és intézményi struktúrák és hálózatok hatása az új nemzetállamok kialakulásában. Legföbb kérdésük, hogy minként szerveződtek a helyi társadalmak, miként integrálták a különböző csoportokat, hogyan formálódott a helyi elit és milyen tőkékre támaszkodtak, illetve ezek a helyi világok miként integrálódtak az új államba. ${ }^{112}$ Szintén Egry Gábor vezetésével zajlik az a nemzetközi kutatás (ERC), amelynek célja bemutatni 1916 és 1930 között, hogy a világháborús társadalmi változások nyomán, egy korábban birodalmi keretek közt működő helyi társadalomban milyen reakciókhoz vezetett az új nemzetállamok megjelenése. Azt szeretnék az összehasonlítás révén megérteni, valójában mekkora jelentősége volt a nemzeti választóvonalaknak, mit jelentett a kontinuitás és a megszakítottság ténylegesen, az emberek életében. ${ }^{113} \mathrm{~A}$ harmadik pályázat, a Kelet-közép-európai nacionalizmusok az első világháború éveiben Szarka László irányításával folyik. Az első világháború négy évét felölelő kutatás a Habsburg Monarchia, ezen belül is, különösen a Magyar Királyság nemzet- és államépítő nacionalizmusait vizsgálja. A kutatócsoport egyik fő állítása szerint ez volt az a történeti korszak, amikor a nemzet és a terület, a nemzet és az állam a térségben ikerfogalommá vált. Az érintett etnikai elven szerveződő társadalmak (csehszlovák, ukrán, román, déli szláv) integrációs törekvéseiket elöször konkrét formában ekkor fogalmazták meg politikai programokban. ${ }^{114}$ A negyedik sok újdonságot hozható vállalkozás az MTA-Lendület Trianon 100 Kutatócsoporttól várható.

111 Papp Antal bizalmas jelentése Krassó-Szörény vármegye társadalmi viszonyairól a magyar királyi miniszterelnökség II. ügyosztály részére, 1922. május. MNL OL, K 26 1922-II.biz.-130; Speciális jelentés Udvarhely vármegyéből és a nagy román politika föszereplöiröl MNL OL K 26 1922.-II.biz.-282 ${ }^{112}$ Politikatörténeti Intézet:

http://polhist.hu/index.php?option=com_content\&view=article\&id=530\%3Abirodalmi-atmenetek-helyikontextusban-19181925\&catid=5\%3Atorteneti-kutatasok\&Itemid=103 (Letöltve: 2017 . június 14.)

113 Politikatörténeti Intézet: http://polhist.hu/nepostrans-negotiating-post-imperial-transitions/

${ }^{114}$ http://www.1914-1918.btk.mta.hu/ 
Ez a kutatás négy nagy pillér közé szerveződik: diplomáciatörténet ${ }^{115}$, a trianoni összeomlás és a magyar társadalom viszonya (gazdaság, menekültkérdés, közellátás, háborús erőszak), Trianon emlékezete a magyar társadalomban, a szociológia, az irodalomtudomány, a müvészettörténet eszközeivel, illetve a határok megszilárdulása (helyben és a térképen). Az impériumváltások lokális és regionális dimenziói az utóbbi keretében kerülnek vizsgálatra, ahol 12-15 helyszínen néznék meg a hatalomváltások hatását a helyi társadalomra (államigazgatás átvétele, a tér átalakítása, az iskolarendszer megváltoztatása). A javasolt városok között szerepel: Zombor, Szabadka, Pancsova, Arad, Gyergyószentmiklós, Nagyvárad, Szilágysomlyó, Petrozsény, Nagyszombat, Selmecbánya/Körmöcbánya, Komárom, Ipolyság, Beregszász, Rozsnyó, Késmárk. ${ }^{116}$

\subsubsection{A historiográfiai áttekintés néhány tanulsága}

Bárdi Nándor a magyar kisebbségkutatásban négy különböző értelmezést, kutatói megközelitést különít el, amely tágabb értelemben alkalmazható az 1918 előtti regionális Erdély-kutatásban is. 1) A szenvedéstörténeti megközelítés a nemzetiségeket ért sérelmekre épít. 2) A konfliktusközpontú látásmód a konfliktus okainak tipologizálására törekszik. 3) Az összehasonlitó társadalomtörténeti kutatás a helyi elitek/csoportok összevetésére fókuszál a társadalmi mutatókon (urbanizáció, családszerkezet, életszínvonal stb.) keresztül. Itt az integrációs folyamatokhoz, a modernizációhoz, illetve az önkép tisztázásához való viszony áll a középpontban. 4) A közösségépitő értelmezésben a társadalomszervezés (közösségi intézmények, hálózatok építése, müködtetése), illetve a különböző regionális és etnikai csoportok fejlődéstörténete (például az elitreprodukciója) áll a figyelem középpontjában. ${ }^{117}$

Jelen dolgozat egyszerre eszmetörténeti és köztörténeti jellegü, amelyben a regionális viszonyok (és csoportok) figyelembe vétele és a nemzetépítés döntő jelentőségűek. A magyar történetírásban a diszkrimináció- és hanyatlástörténeti megközelítést meghaladni szándékozó munkákban fokozatosan jelen van a helyi/regionális politikai- és társadalomtörténeti viszonyokra irányuló szemléletmód. A nemzeti történetet író történészek nem kerülhetik meg az internacionális, a transznacionális, vagy éppen a histoire croisée (összefonódó), valamint az entangled (egymással összekeveredő) jelzőkkel illetett programokat és törekvéseket.

\footnotetext{
${ }^{115}$ A kutatás keretében megjelent: ZEIDLER Miklós: A magyar békeküldöttség naplója. Neully-VersaillesBudapest (1920). MTA Bölcsészettudományi Kutatóközpont, 2017

$116 \mathrm{http}: / /$ trianon100.hu/ (Letöltve: 2017. június 14.)

${ }^{117}$ BÍRÓ Sándor: Többségben és kisebbségben. Az előszót írta Bárdi Nándor. Pro-Print Könyvkiadó, Csíkszereda, 2002, 9 .
} 
E történetírói megközelítések közös pontja, hogy a reálisabb történeti szemléletmódhoz a nemzeti történeti látószögön át kell törni. Tehát felül kell bírálni a nemzetállami határokhoz igazodó léptékek logikáját, mert a múlt ténylegesen zajló folyamatai és eseményei nem esnek maradéktalanul egybe a modern nemzetállamok ideológiai reprezentációival. ${ }^{118}$

A soknemzetiségű Erdélyben élö közösségekről akkor kaphatunk reálisabb képet, ha a vizsgálati szempontokat kiszélesítjük. A helyi viszonyok kutatása olyan kezdeti fázisban van, amelyek számos újdonságot hozhatnak. A feltáratlan területek közé tartozik többek között: az 1916. évi székelyföldi és szász településeket ért román támadás gazdasági és társadalmi hatása, az impériumváltás (a helyi közigazgatás átvétele, a nem román tőkéjü vállalatok román kézbe való átjátszása stb.) történetének rekonstruálása, vagy a kisebbség mindennapi életét meghatározó közeg (egyházi élet, nemzetiségi művelődés lehetőségei, állampolgári szabadságjogok, nyelvhasználat stb.) feltárása. Hasonlóan kevés információval rendelkezünk a társadalom egyes csoportjainak mindennapi valóságáról (életviszonyairól), amikor a nemzeti identitás mellett/szemben a pragmatizmus (lakhatás, élelmiszer-, fütőanyag elosztás, munkakörülmények stb.) is helyet kap az egyének döntéseiben. Egymással összekeveredö kérdés felvetésként jelenik meg például az ipari munkásság is, amelyről alig rendelkezünk információval. A munkásság pusztán politikatörténeti megragadása félrevezető, amelyet az 1918-1920 közti munkabeszüntetések eltérő céljai alátámasztanak.A sztrájkok hol a rossz életkörülmények javítására, hol a kollektív szerződések megvédésére (Temesvár stb.), hol nemzeti ellenállásra (magyar vasutasok a román impérium ellen), hol pedig politikai célokra (a szociáldemokraták az általános választójogért) irányultak.

Ez a kutatás az erdélyi magyar közösség fejlödéstörténetére koncentrál, ahol a közösségépitő értelmezés dominál. A források elemzését követően megállapítható, hogy az erdélyi magyar politikai közösség nemzetépítő konzervatív és progresszív elitje 1918-ig, ha eltérő módszereket (lásd K. Lengyel ótranszilvanista tétele) is javasoltak, az erdélyiség gondolatával összeegyeztetve a történelmi Magyarország feltétlen épségben tartandó kereteiben gondolkodtak. Trianont követően az útkeresés és a pozícióőrzés kezdeti éveiben az alkalmazkodás (integráció), a saját társadalomépítés (saját intézmények) és a magyar politikai közösség határainak (zsidóság, munkásság) kijelölése került a politikai fókuszba.

118 GYÁNI: A nemzeti történetírás, Limes, 2012. 6-7. 


\section{REGIONALIS NÉZÖPONT KIALAKULÁSA: BIRTOKPOLITIKA, VÁLASZTÓJOG, NEMZETISÉGI KÉRDÉS}

Az erdélyi magyar elit szempontjából az 1900-as évek elején három nagy vitakérdés bontakozott ki: a birtokviszonyok, a választójogi reform problémája, illetve a Tisza István-féle megegyezési kísérletek révén a nemzetiségi kérdés megoldatlansága. A jelzett problémák az alábbi nemzeti és nemzetiségi politikai törekvésekben egymással összekapcsolódva voltak jelen.

a) A nemzetiségi kérdéssel foglalkozó néhány szakértő (Beksics Gusztáv ${ }^{119}$, Barabás Endre, Jancsó Benedek, Bartha Miklós, Moldován Gergely, Réz Mihály) arra hívta fel a figyelmet, hogy az erdélyi román nemzeti mozgalom lehetséges célja, Erdély és Románia egyesítése. Felismerésükből az következett, hogy a nemzetiségi jogok kiterjesztése a régió elszakadására törekvő erőket tovább erősítené. Az erdélyi magyar politikai elit veszélyeztetettség-érzetére adott válasz volt többek között Beksics Gusztáv mezőségi telepítési és Bethlen István birtokpolitikai koncepciója.

b) Az erdélyi politikai és szellemi elit részéről kétféle elképzelés bontakozott ki. Egyfelöl megjelentek az Erdély önállóságát, modernizációját, sajátos nemzetiségi viszonyait történetileg alátámasztott (1867 előtti időkre visszautalt $\left.{ }^{120}\right)$ decentralizációs, önkormányzati eszközökkel kezelhetőnek vélt döntően kulturális jellegű társadalmi és prototranszilvanista értelmiségi törekvések.

\footnotetext{
${ }_{119}$ Beksics Gusztáv (Somogy vármegye, Gamás, 1847 - Budapest, 1906): ügyvéd, hírlapíró, politikus. 18841904 között Sepsiszentgyörgy választókerület szabadelvü párti országgyülési képviselöje. 1905-ben a (báró Bánffy Dezső alapította) Újpárt jelöltje, a sepsiszentgyörgyi születésü ügyvéd, Bene István (257 szavazattal) legyőzte Beksics Gusztávot (204 szavazat).

1905-1906. évi országgyülés. Szerk.: Fabró Henrik-Újlaky József. Sturm-féle országgyülési almanach 19051910. Budapest, 1905. 223.

Beksics nemzetiségi és ezzel összefüggésben a földbirtokpolitika kérdéseiben írt könyvei: A román kérdés és fajok harca Európában és Magyarországon. Athenaeum, Budapest, 1895; A nemzeti politika programja Erdélyben és a Székelyföldön. Athenaeum, Budapest, 1896; A magyar faj terjeszkedése és nemzeti konszolidációnk különös tekintettel a mezögazdaságra, birtokviszonyokra és a népesedésre. Athenaeum, Budapest, 1896

${ }^{120}$ 1690-ben megszünt az erdélyi fejedelemség, amely mintegy 150 éven keresztül az Oszmán és a Habsburg Birodalom között egyensúlyozva viszonylagos önállóságot élvezett. 1867-es közjogi kiegyezést követően a Magyarország és Erdély egyesitésének részletes szabályozásáról szóló 1868. XLIII. törvénycikk egyesítette Erdélyt és Magyarországot. NAGY Miklós: Erdély jövöje. 339-359. Budapesti Szemle, 1926. 204. kötet, szerk.: Voinovich Géza, 340-343.

(Nagy Miklós 1921. májusban Kós Károllyal együtt alapítója volt az Erdélyi Néppártnak, a romániai magyarság első politikai pártjának.)
} 
Ebben a gondolatkörben olyan lapok kerülhettek az olvasó közönség kezébe, amelyek szerkesztésében a későbbi kisebbségi magyarság szellemi életének meghatározó szereplői is részt vettek, mint például a Kós Károly szerkesztette Kalotaszeg ${ }^{121}$ (1912. Sztána) és a Szentimrei Imre-féle Új Erdély (1918. Kolozsvár). Hasonló tematikájú újság volt a Haladás (1911. Kolozsvár, Bárd Oszkár), de alig pár számot élt csak meg, illetve az Erdélyi Figyelö (1914. Dés) és az Erdélyi Szemle (1915. Kolozsvár).

Mind közül kiemelkedett az Erdélyi Szemle, amelynek előzménye egy fiatalabb irodalmár nemzedéket képviselő Szemle (1913). ${ }^{122}$ Utóbbi kibontakozását a háború kitörése megakasztotta, a munkatársak többségét besorozták, csak Moldován Pál és NagySütő László maradtak Kolozsváron, akik egy újabb szépirodalmi folyóiratot indítottak Kolozsvári Szemle címmel (1915. szeptember). A hozzájuk folyamatosan csatlakozó (nagyrészt hadi szolgálatot teljesítő, de segítséget nyújtó) írókkal, újságírókkal, művészekkel (Reményik Sándor, Kádár Imre, Kós Károly, Szentimrei Jenő stb.) ${ }^{123}$ megváltozott a folyóirat tematikája (magyar és egyetemes irodalmi, müvészettörténeti, társadalom- és természettudományos közleményekkel), amire 1916. november 5-én az Erdélyi Szemle címet vették fel. Kapcsolataik is kiszélesedtek, például Pilisi Lajos, a polgári radikális Világtól vagy Juhász Gyula Szegedről nyújtott támogatást. A sorsfordító események miatt 1918 karácsonyától 1919 márciusáig nem jelenhetett meg a folyóirat. ${ }^{124}$ Az újrakezdés sem volt zökkenőmentes. A Lapkiadó Vállalat (Szentimrei Jenő) előzetes szándékával ellentétben végül nem vette meg az Erdélyi Szemlét, hanem a Keleti Újság mellett egy új szépirodalmi folyóiratot, a Napkeletet indította el 1920-tól.

\footnotetext{
${ }^{121}$ A Kalatoszaeg három hónapig müködött 1912. január-március között, miután beolvadt az Erdélyi Lapokba, az Erdélyi Irodalmi Társaság gróf Bánffy Miklós (1873-1950) irányította hetilapjába. Utóbbi lap 1913-ban megszünt. K. LENGYEL: Hanyatlástól összeomlásig. A nagymagyar nemzettudat válsága az ótranszilvanizmus idején. In: Testimonio litterarum. Tanulmányok Jakó Zsigmond tiszteletére. Szerk.: Herausgegeben von Veronka Dáné, Mária Makó Lupescuné, Gábor Sipos. Kolozsvár, 2016. 211-232.

${ }^{122}$ A Szemle szerkesztöi: Merész Károly és Nyíredy Géza, a fővárosi szerkesztője a szintén erdélyi származású Remetei Fülep Dezső. Munkatársai: Sütő-Nagy László, Ábrahám Ernő, Begyáts László, Darvas János, Fligl József, Franyó Zoltán, Hatvány Pál, Jánossy-Papp Béla, Kázmér Ernő, Kovács László, Moldován Pál, Pogány Elza, Rákóczy Imre, Walter Gyula. SÜTŐ-NAGY László: Az Erdélyi Szemle történetéből. Irodalomtörténeti Közlemények, 1971. 75. évf. 41. szám, 504.

${ }^{123}$ A folyóiratban többek között megjelentették írásaikat: Bárd Oszkár, Tavaszy Sándor, Áprily Lajos, Berde Mária, Franyó Zoltán, Makkai Sándor, Nyírő József, Olosz Lajos, Sipos Domokos, Szombati-Szabó István, Sándor József (EMKE), Barabás Samu.

${ }^{124}$ Az Erdélyi Szemle ötödik évfolyamának első száma 1919. március 2-án jelent meg. Felelös szerkesztő: SütőNagy László, főmunkatársa Reményik Sándor, belső munkatársai Bárd Oszkár, Kovács László voltak. Uo. 506.
} 
Az Erdélyi Szemlét végül a Minerva Irodalmi és Nyomdai Müintézet Rt. vette át, amellyel együtt a lap szellemi részének vezetése (Reményik Sándor, Grandpierre Emil) és a neve is megváltozott, a Toldi előszavából vett Pásztortüzre. ${ }^{125}$

Az első világháború előtti, az erdélyi magyar dominancia megőrzéséért regionális politikai szintü nyomásgyakoroló szervezetek alakultak, a Székely Társaság (1900), a Székely Társaságok Szövetsége (1904), amelynek tiszteletbeli elnökévé 1908-ban Bethlen Istvánt és Jancsó Benedeket választották meg. ${ }^{126}$ Az Országos Magyar Szövetséget (1903) már Budapesten szervezték meg, amely arra törekedett, hogy Magyarországon a „magyar értelmiségnek a magyar nemzeti állam kiépitésére és megvédelmezésére szolgáló szétszórt és vidékenként elszigetelt társadalmi törekvéseket egybefoglalja, [...] e célra szervezze és tervszerüen irányítsa." 127 A szövetség elnökévé a förendiház tagját, gróf Esterházy Jánost választották meg, de tényleges vezetője Jancsó Benedeket volt. A csoport tagjai között tudhatott országgyülési képviselőket (Beksics Gusztáv, Bartha Miklós), föispánokat (Justh György Abaúj-Torna vármegye és Kassa szabad királyi város föispánja), egyetemi tanárokat (Szádeczky-Kardoss Lajos), egyházi személyiségeket (Moór Gyula esperes), ügyvédeket, birtokosokat, lapszerkesztőket (Csajthay Ferenc-Budapesti Hírlap, Gracza György-Budapest). Aktív szereplő volt Sándor József is, az Erdélyi Magyar Közművelődési Egyesület (EMKE) vezetője, magyarországi (1896-1906) és későbbi romániai (1922-1938) országgyülési képviselő. ${ }^{128}$

c) Székelyföld, illetve a belső erdélyi területek elmaradt modernizációja és a románság dinamikusan növekvő földszerzése, a magyar birtokállomány meggyengülésével veszélyeztetettség-érzetet teremtett az erdélyi magyar politikai elitben. A lehetséges válaszok között az állam által történő gazdasági beavatkozás, a magyar gazdasági érdekek direkt irányú támogatása és telepítési programok szerepeltek (Beksics Gusztáv mezőségi telepítési terve, Darányi Ignác telepítési törvényjavaslata, Bethlen István birokpolitikai koncepciója.) $)^{129}$

\footnotetext{
${ }^{125}$ A lap alapítói közé tartozott Grandpierre Emil, a volt kolozsvári törvényszéki bíró, aki Nagy Péter néven publikált. Az ő ötlete volt a Pásztortüz elnevezés. PALOTAI Mária: A Pásztortűz elődje: az Erdélyi Szemle. Kisebbségkutatás, 2003. 12. évf. 1. szám, 182-183.

${ }^{126}$ BÁRDI, Magyar Kisebbség. 2003. 2-3. szám, 94.

${ }^{127}$ Tájékoztató az Országos Magyar Szövetség céljairól, feladatairól és eszközeiről. Szerk.: JANCSÓ Benedek. Budapest, Pátria Irod. Vállalat és Nyomdai R.-társ Nyomása, 1903 [Továbbiakban: JANCSÓ, Tájékoztató, 1903] ${ }^{128}$ Uo.

129 Romsics Ignác: Bethlen István. Politikai életrajz. Magyarságkutató Intézet, Budapest, 1991. 44-58. [Továbbiakban: ROMSICS, 1991]
} 
d) Tisza István szabadelvű politikusként nem támogatta a várhatóan további konfliktusokat generáló telepítési és nemzetiségi programokat, hanem a szászokkal ${ }^{130}$ történő megegyezés mintájára kereste a kompromisszumot a román nemzeti mozgalom vezetőivel. A miniszterelnök lépése mögött minden bizonnyal közrejátszott a Monarchia nagypolitikai érdekének képviselete, Romániának a Hármasszövetséghez való csatlakozásának megőrzése is. ${ }^{131}$

A felsorolt törekvések célját tekintve megállapíthatjuk, ha más és más módszert javasoltak is K. Lengyel Zsolt nyomán - a konzervatív és progresszív ótranszilvanista csoportok a társadalmi és politikai megújulásra vonatkozóan 1918 előtt, nem kérdőjelezték meg a magyar politikai elsőbbséget, a magyar integer Magyarország kereteit, amikor a figyelmet Magyarországról Erdélyre próbálták irányítani. A központi kormányzat régiópolitikájának bírálata mellett programjaik alátámasztása érdekében világnézeti szempontok szerint, hol a középkori erdélyi fejedelemség kulturális emlékezetéhez (vallásszabadság stb.), hol a függetlenségi 1848-1849es pontokhoz, hol az 1867-es kiegyezéshez, hol pedig belső régiók (Székelyföld, Brassó, Mócvidék stb.) nyúltak.

\subsection{Birtokpolitikai viták}

Az agrárkérdés a modernkori Magyarországon az 1880-as évektől, az európai agrárválság idején került a tudományos és a politikai érdeklődés középpontjába, amikor a tengerentúli gabona, az élő és a vágott állatbehozatal ellepte az európai piacokat, és drasztikus árzuhanást okozott a mezőgazdasági termékek és termények piacán. A recesszió bár eltérő hatással volt az agrárvilág szereplőire, de összességében negatívan érintette mind a piacra termelő nagybirtokosokat, a mezőgazdaságból élő kisbirtokosokat és a földnélküliek életlehetőségeit is. A reformkori agrárvitákkal ellentétben a századfordulót követően a kiutakra nem születettek átfogó javaslatok, hanem azok elsősorban a napi gondok orvoslására, az elmaradt lehetőségek visszaszerzésére, egyes reformintézkedésekre terjedtek ki.

\footnotetext{
130 1890. június 17-én Nagyszebenben tartott szász nemzeti gyülés módosította a szász politikai programot. Elfogadta a dualizmust és az egységes magyar államot; elismerte, hogy a nemzetiségi törvény tartalmazza a nemzetiségi jogok minimumát. Kívánatosnak nyilvánították, hogy a szász értelmiség minél hathatósabban működjék közre az állam feladataiban. A szász képviselők az új program alapján beléptek a kormánypártba. $1897-$ ben azonban a helynévtörvény elleni tiltakozásul kiléptek a kormánypártból, ahová csak a Tisza Istvánnal kötött paktum után, 1903-ban tértek vissza. A koalíciós kormány idején a szász képviselők az Alkotmánypárt soraiban foglaltak helyet. KATUS László: A németek és az erdélyi szászok.

http://multunk.com/index.php?title=Tisza_Istv\%C3\%A1n\#M.C5.B1vei (Letöltve: 2018. április 23.)

${ }^{131}$ BÁRDI, Magyar Kisebbség. 2003. 2-3. szám, 93-94.
} 
Bármilyen elképzelés született is, az végeredményét tekintve az 1918-as összeomlásig nem befolyásolta a magyarországi birtokállomány aránytalanságát. A nagybirtokrendszer struktúrája végig domináns maradt. ${ }^{132}$

Az első világháborút megelőző években a birtokpolitikát övező vitákat időnként nemzet- és honmentő elképzeléseknek fogták fel, amelyek óhatatlanul a harci retorika tárgyává váltak. Az 1880-1890-es évekre a magyar és nemzetiségi publicisztika egy látens háború képét vázolta fel, amely Erdély telekkönyvi birtoklásáért folyt annak három nemzetisége között. A magyar megszólalók egy része (gróf Mikó Imre) éppen úgy veszélyesnek találta a szászokat, mint a románokat, a szászok (Friedrich Teutsch püspök, Dr. Karl Wolff, Szász Néppárt elnöke, Rudolf Thör) féltek a románok terjeszkedésétől és a magyarosítástól, a románok (George Bariţ) pedig a szász és a magyar telepítésektől. A térséget ismerő nemzetiségi szakértők, publicisták, politikusok hajlamosak voltak háborús kategóriákban gondolkodni a társadalmi-gazdasági változásokról, elismerve ezzel a démonizáló egymással ellentétes nézeteket, illetve a külön nemzetgazdaságok létét. Ez egybevágott a nemzeti elitek én- és közösségképével és az etnokulturális különbségekre építő politika programokkal. ${ }^{133}$

A nemzetiségektől való veszélyérzetre építő, mindenekelőtt a románok tudatos nemzetipolitikai birtokvásárlás stratégiáját ${ }^{134}$ feltételező álláspontot néhány szakértő (Jancsó Benedek, Bodor Antal, Tokaji László) és erdélyi politikus, főként gróf Bethlen István tematizálta. ${ }^{135}$

\footnotetext{
132 PÖLÖSKEI Ferenc: Birtokviszonyok és viták a századfordulón (Tisza István, Darányi Ignác, gróf Károlyi Sándor, Rubinek Gyula). Agrártörténeti Szemle. 2007. XLVIII. évf. 1-4. szám, 145-151. [Továbbiakban: PÖLÖSKEI, Agrártörténeti Szemle, 2007]

${ }^{133}$ EGRY Gábor: Egy önlegitimáló politikai és történeti narratíva kérdőjelei (1861-2003). Nemzetiségi bankok, nemzetiségi mozgalmak a századforduló Erdélyében. Múltunk 2006. 3. szám, 4-34. 6-11. [Továbbiakban: EGRY, Múltunk, 2006]

Varga Bálint a Bánság regionális történetét 1914-ig feldolgozó korabeli szerb, román, német és magyar müveket gyüjtötte össze. A historiográfiai áttekintő a régióban megjelent egymással versengő nemzeti kánonokat mutatja be. VARGA Bálint: Nemzeti és regionális történelem egy sokszínú térségben: a bánsági történetírás a hosszú 19. században. Korall, 2015. 16. évf. 62. szám, 150-166.

${ }^{134}$ Lásd erre vonatkozóan: HUNYADI Attila: Economic nationalism in Transylvania. REGIO, 2004. 4. évf. 1. szám, 172-193.; ÁBRAHÁM Barna: Az erdélyi románság polgárosodása a 19. század második felében. Csíkszereda, Pro-Print Könyvkiadó, 2004

135 További korabeli tanulmányok: JANCSÓ Benedek: Románia birtokpolitikai viszonyai. Magyar Társadalomtudományi Szemle, 1909. II. évf. 6. szám, 523-542., BALÁS Károly: A magyarság gazdaságpolitikai érdekei. Magyar Társadalomtudományi Szemle, 1913. VI. évf. 4. szám, 273-288.; KOVẢCS Alajos: A magyarság és a nemzetiségek erőviszonyai. Magyar Társadalomtudományi Szemle, 1913. VI. évf. május; KENÉZ Béla: Nép és föld. Budapest, 1916; gróf BETHLEN István: Az oláhok birtokvásárlásai Magyarországon az utolsó 5 évben. Budapest, 1912
} 
Bodor Antal ${ }^{136}$ a Magyar Közgazdasági Társaságban 1904. december 7-én tartott előadásában a román és a szász nemzetiségi pénzintézeteket, amelyekre a földvásárlásokat támogató intézményrendszerként tekintett, úgy jellemezte, mint a ,magyarság gyöngülésének $s$ a nemzetiségek számbeli és gazdasági térfoglalásának hathatós előmozdítói”, sőt, a román takarékpénztárakat egyenesen „titkos, államellenes aspirációkkal” vádolta. ${ }^{137}$ Figyelemre méltó ugyanebben a kérdéskörben Barabás Endre ${ }^{138}$ székelykeresztúri tanítóképző tanárának kutatása 1901-1904 közti évekből, amely a székelyföldi közgazdasági állapotokat volt hivatott felmérni, miután a Székelyegyleti Első Takarékpénztár bezárásra került. Barabás összesítette a telekkönyvileg betáblázott hitelek pénzintézetek szerinti megoszlását Udvarhely vármegye három járásában (udvarhelyi, keresztúri, homoródi). Arra a megállapításra jutott, hogy a hitelezési és a népszámlálási adatok azt igazolják, hogy a nemzetiségek célja a Székelyföld kettéosztása lehet a Nagy-Küküllő mentén nemzetiségi település-lánc révén. Szerinte előbb a szászok jelennek meg egy-egy községben, majd nyomukban a románok is. Amíg 20 évvel korábban (az 1880-as népszámlálás alkalmával) alig voltak szászok Udvarhely vármegye székely községeiben, addig 1900-ban már 44 székely községben körülbelül 1600 fönyi szászt mutattak ki, és Csík vármegyében is 1062 szászt találtak 34 községre elosztva. ${ }^{139}$ Amennyiben adatokat kell felsorakoztatni az erdélyi földbirtokviszony változása kérdésében, ma is legtöbbet hivatkozott szerző Tokaji László, az Országos Magyar Gazdasági Egyesület (OMGE), illetve az Erdélyi Gazdasági Egyesület (EGE) titkára. ${ }^{140}$ Bethlen István - elsősorban Tokaji László adatgyüjtésére támaszkodva - saját összeállítást készített a nemzetiségek földvásárlásairól.

\footnotetext{
${ }^{136}$ Bodor Antal (Kolozsvár, 1878. jan. 8. - Budapest, 1955. jan. 3.): gazdasági szakíró, a magyar falukutatás egyik úttörője. A kolozsvári Takarékpénztárnál, mint ügyészhelyettes kezdte müködését, 1905-ben a Kisbirtokosok Országos Földhitelintézetének megbízásából megszervezte a bank vidéki kirendeltségeit. 1920-tól az Országos Faluszövetség fötitkára. 1908-ban alapította és 1914-ig szerkesztette Szegeden az Alföldi Gazda és 1911-14-ben a Magyar Föld folyóiratokat. http://mek.oszk.hu/00300/00355/html/index.html (Letöltve: 2017. augusztus 20.)

${ }^{137}$ BODOR Antal: Az erdélyrészi pénzintézetek. Közgazdasági Szemle, 1904. XXVIII. évf. 32. k. 923-937. 931932.

138 Barabás Endre (Középajta, 1870. márc. 5.-Budapest, 1945. máj. 28.): tanár, újságíró. 1902-1903-ban a székelykeresztúri, 1903-21-ben a Kolozsvári Állami Tanítóképző tanára, 1911-19-ben a Dévai Állami Tanítóképző igazgatója. 1919. májusban a román hatóságok letartóztatták Nagyszebenben, majd Fogarason fogságban tartották, novemberben kiutasították Romániából. 1919-től Budapesten először a miniszterelnökségi sajtócenzúra, a Bocskai Társaság, majd a Népies Irodalmi Társaság munkatársa.

Fontosabb megjelent munkái: Az erdélyrészi népfajok birtokaránya. Közgazdasági Szemle, 1905., klny., Bp.; Erdély statisztikája. Lugos, 1924; A romániai magyar nyelvü oktatásügy elsö tíz éve 1918-28. 1929. Lugos; A magyar iskolaügy helyzete Romániában 1918-40-41. Kecskemét, 1941

http://mek.oszk.hu/00300/00355/html/index.html (Letöltve: 2017. augusztus 20.)

${ }^{139}$ BARABÁS Endre: A nemzetiségi bankok székelyföldi actiója. Közgazdasági Szemle, 1904. XXVIII. évf. 32. k. 815-825.

140 TOKAJI László: Eladó ország. Az erdélyrészi földbirtokforgalom utóbbi 10 évi adati. Az erdélyrészi földbirtokpolitika feladatai és az állam és a társadalom teendői. Kolozsvár, a szerző kiadása, 1913
} 
Mindkét szerző a nyers, súlyozatlan birtokfogalmi statisztikára koncentrálva igyekezett igazolni, hogy Erdélyben veszélyben van a magyarság, a románok és kisebb részben a szászok fokozatosan, politikai megközelítéssel élve pedig tudatosan felvásárolják a földbirtokokat, amely veszélyezteti a magyar szupremáciát. Tokaji nemzetiségi szempontból differenciálta a birtokforgalom és a birtokmegoszlás változásait a történeti Erdélyben és Szilágy vármegyében, amelyet Bethlen további kiegészítésekkel látott el az 1912-ben megjelent tanulmányában. ${ }^{141}$

Bethlen öt év adatait vette szemügyre. Egyfelől megállapította, hogy a nemzetiségi vidékeken eladásra került magyar birtokok nagy része az ott lakó, többnyire román nemzetiségű parasztság kezébe került. Másfelől a vásárlás folyamatát a román bankintézetek politikai célokkal segítették, és így egész versenyfutás alakult ki a nemzetiségiek és a magyarok közt. Egész Erdélyben, Máramaros három, Szilágy vármegyének összes járásaiban, Szatmár, Bihar, Arad vármegyék túlnyomó részében, Krassó-Szörény egészében, Temes és Torontál több járásában a román nemzetiség volt túlsúlyban. „Ezért a nagykiterjedésü területért, az ország területének közel 40\%-áért folyik tehát az élet-halálküzdelem a hazai románok és magyarok között." ${ }^{142}$ Kolozs vármegyéröl az alábbi konklúziót vonta le. A legnagyobb veszteség Kolozs vármegyében, „Erdély szívében” következett be, „Kincses Kolozsvár a magyar kultúrának erdélyi központja körül volt a román tevékenység legerösebb. Az, hogy ez lehetséges volt: elöttem az erdélyi magyar társadalom csődjével egyértelmü". ${ }^{143}$ Éles kritikát fogalmazott meg az erdélyi magyar vezetőkkel kapcsolatosan, „,nemtörődömség”, „keleti fatalizmus”, illetve a kormányzattal szemben „tudatlanság”, „tájékozatlanság” minősítéseket, amelyet egyszerre tulajdoníthatunk ellenzéki szerepének és az erdélyi politikai élet újjászervezésére irányuló szerepfelfogásának. Számításai alapján az utolsó öt évben a vármegye területén lakó magyar magánbirtokoknak 11\%-a került román tulajdonba, amely kilenc járásból ötre és 35 községre koncentrálódott. Szeben és Brassó vármegyék állapotleírásában kiemelte, hogy egyetlen egy 100 hold feletti magyar birtok sem volt magánkézben, Fogarasban mindösszesen két ilyen esetről volt információja, illetve Nagyküküllő vármegyében öt év alatt 26\%-kal csökkent a mezőgazdasági és 16\%-kal az erdőbirtok. Érdemi változás, a románság csekély száma miatt Csík, Udvarhely és Háromszék vármegyékben nem következett be. Öt év leforgása alatt a nemzetiségi területeken 96 ezer hold mezőgazdasági és 70 ezer hold erdőbirtok került román kézre. Bethlen legfőbb kivetnivalója az volt, hogy annak a korábbi szemléletnek a megszűnését látta, amely hazafias ügyként tekintett a földbirtokok kezelésére.

\footnotetext{
${ }^{141}$ EGRY, Múltunk, 2006. 10-11.

142 BETHLEN István: Az oláhok birtokvásárlásai Magyarországon az utolsó 5 évben. Budapest, Pátria Irodalmi Vállalat és Nyomdai Rt., 1912. 1.

${ }^{143}$ Uo. 11.
} 
Nagyfokú eladási hullám vette kezdetét, a birtokokat kisebb parcellákra felosztva eladásra kijelölték, amelyben egyformán részt vett bankár, ügyvéd, földbirtokos pap, tanító, nyugdíjazott katona, ügynök, fakereskedő, özvegy, egyedülálló nő, akik a földjeik eladásából próbáltak anyagi javakhoz jutni. Az elszegényedő birtokos - 100-400 holddal rendelkező - középosztály gyermekei számára a föld és a vele járó gazdálkodás egyre kevésbé nyújtott biztos jövőképet. A magyar birtokos középosztály megerősítésének szándéka Bethlen, akárcsak Réz Mihály társadalompolitikájában ezért is kapott kulcsszerepet. A történelmi osztály tagjaiként bennük látták az utolsó lehetőséget arra, amely képes lehet a nemzetiségi területeken védelmezni a magyarság befolyásának fenntartását. A földtulajdonláshoz kötődő évszázados politikai hagyományokból következően a földtulajdonhoz a megélhetésen túl egyszerre társult a társadalmi pozíció és a tekintély politikai kategóriája, így ez az Erdélyért folyó nemzetiségi küzdelmet determináló tényezővé vált. ${ }^{144}$

A századelőn készült elemzésekkel kapcsolatosan kritikusan kell eljárnunk, mert azok többnyire nem összefüggéseikben vizsgálták a kérdést, illetve sokszor a legalapvetőbb összehasonlítások is hiányoznak belölük. Az egyik gyakori hiba az adatok értékelésében az, hogy a földbirtokforgalom (vétel-eladás) nem volt egyirányú folyamat egyik nemzetiség esetében sem. Tokaji elemzéséből az is kiderült, hogy a magyarok a vizsgált időszakban közel 60.000 katasztrális holdnyi földbirtokot vásároltak, ami árnyalja a képet. A másik gyakori hiba, hogy implicit módon a teljes népességen belüli arányszámokhoz viszonyították őket. Közismert, hogy a magyar és a szász népesség körében jóval magasabb volt a városi és nem földműveléssel foglalkozó lakosság aránya, ezért ez a fajta összehasonlítás torzít. 1910-ben a magyar népesség 55,8\%-a tartozott az őstermelésböl élők közé, a szászoknak pedig 57,3\%-a, addig a románoknál ez az arány $84,6 \%$ volt. A birtokforgalmi adatokat ezért javasolt azoknak a létszámához és arányához viszonyítani, akik valóban a földmüvelésből élnek, és így potenciális vevők és eladók a földpiacon. A vizsgálat során nem lehet figyelmen kívül hagyni azt sem, hogy miként oszlott meg a földbirtok birtokkategóriák és nemzetiségek szerint. 1898ban az összes mezőgazdasági területnek mintegy fele volt magyar kézen, miközben az őstermelökön belüli arányuk jóval kisebb volt, mint a románoké. Ezen felül a teljes mezőgazdasági terület 28\%-a 100 holdon felüli magyar birtokokhoz tartozott. Nagyobb esélye volt ezért annak, hogy magyar tulajdonban lévő földbirtok kerül piacra, mint annak, hogy nemzetiségi kézen lévő, illetve annak is, hogy az egyre terjedő modern hitelezési technikák segítségével román parasztok veszik meg az eladásra kerülő birtokot.

\footnotetext{
${ }^{144}$ Uo. 11-16.
} 
Bár a magyar agrártársadalomban is jelentős aránya volt a kis- és törpebirtokosoknak, de azok leginkább a székely megyékre koncentrálódtak, ahol sem eladó nemzetiségi, sem eladó magyar közép- és nagybirtokot nem volt könnyü találni. ${ }^{145}$

Bethlen 1913 májusában, az OMGE közgazdasági ülésén az előző évben megjelent elemző tanulmányaira hivatkozva konkrét programot hirdetett A magyar birtokpolitika feladatai Erdélyben címmel. Ebben egyfelől összefoglalta a földeladás mögött meghúzódó gazdasági és társadalmi okokat (bizonytalan jövőkép, kedvezőtlen hitelviszonyok, magas kamatterhek, spekuláció). Másfelől kijelölte az erdélyi birtokpolitika két fő célját: „,megmenteni és stabilizálni a még megmenthetö közép- és nagybirtokot és [...] telepitések egész láncolata révén, egy erőteljes, egészséges magyar parasztosztály kreálása Erdély régi vármegye részeiben,” amelyek együttes célja „Erdélyt regenerálni és a magyarságnak megtartani”. ${ }^{146}$

A különböző telepítési akciókra vonatkozó elképzelések nem voltak elözmény nélküliek. A zömében nemzetiségek által lakott területeken a magyarság arányának növelése érdekében született az 1894. évi V. tc. ${ }^{147}$, továbbá a Darányi Ignác által elkészített, de törvényeröre nem emelkedett 1903-as és 1909-es törvényjavaslat. Az 1911: XV. tc. az állam feladatává tette a telepítés ellenőrzését és irányítását. Az agráriusok - Rubinek Gyula, Széchenyi István - a még mérsékeltebb, a nagybirtokosok érdekeit védelmező magántelepítéseket propagálva azonban szembeszálltak az állami telepítések megvalósításával. Emellett a hatalmon lévő szabadelvű kormányok sem voltak bőkezüek a telepítések költségvetési támogatásban. A telepeseknek például maguknak kellett volna készpénzben vagy kölcsönnel fizetniük a birtokba vett földterületért, amely egy földnélküli esetleg 1-2 holdas paraszt esetében szinte kivitelezhetetlen volt. Az 1894. évi telepítési törvény pedig csak néhány ezer hold földet jelölt ki erre a célra Kolozs, Beszterce-Naszód, Szolnok-Doboka, Krassó, Szörény, Temes, Torda-Aranyos megyékben, amelyhez csupán 6 millió korona pénzbeli támogatást nyújtott. ${ }^{148}$

\footnotetext{
${ }^{145}$ EGRY, Múltunk, 2006. 30-34.

${ }^{146}$ BETHLEN István: A magyar birtokpolitika feladatai Erdélyben. Budapest, Pátria Irodalmi és Nyomdai Rt, 1913, 3-24. [Továbbiakban: BETHLEN, 1913.]

147 1894. évi V. törvénycikk a telepitésröl: „1. § Az állam, magánbirtokosok és földbirtokot tulajdonjoggal biró községek, a jelen törvény rendeletei szerint telepeket alapithatnak, akár új községek alakitása, akár már létezö községeknek hozzátelepités által leendő megnagyobbitása céljából. 2. § Minden újonnan telepitett községnek akkora területtel kell bírnia, hogy azon legalább 150 gazdálkodó telepes elhelyezhetö legyen." https://1000ev.hu/index.php?a=3\&param=6529 (Letöltve: 2017. augusztus 30.)

148 PÖLÖSKEI, Agrártörténeti Szemle, 2007. 160-161.
} 
A telepítési politikát támogatók közé tartozott a szellemi elit több tagjai is, mint például Balás Károly egyetemi tanár ${ }^{149}$, aki az állami földpolitikától elvártakat a következőképpen foglalta össze a Közgazdasági Szemlében. A telepítési politika szerves kiegészítő része az állam által felügyelt gazdaság- és agrárpolitikának, amelynek két fó célja lehet. Az egyik a földművelő népesség társadalomgazdasági helyzetének javítása általában, a másik pedig a magyar nemzeti érdekek előbbre vitele egy nemzeti agrárpolitika segítségével. A kettő szerinte nem egy és ugyanaz, mert előbbi pusztán agrár, esetleg szociális célokat szolgál, utóbbi, amelyet nemzeti telepítésnek nevezett, elsősorban nemzeti érdekeket támogat. A kettő közti kapcsolat abban áll, hogy az állam a többségi etnokulturális szempontot elötérbe helyezve agrárpolitikai eszközökkel (földszerzés támogatása) igyekszik egy nemzetiségi terület etnikai viszonyát megváltoztatni. „A belsö telepitéseknek legnagyobb fontosságuk az ország földjének a nemzeti faj részére való meghódításában rejlik [...], nevezetesen pedig a földmüves, a birtokos parasztosztály minél nagyobb részben a nemzeti anyanyelvü népességböl kerüljön $k i . "{ }^{150}$ Balás a telepítési politika előnyei közé azt sorolta, hogy a magyar nyelv terjesztése szempontjából célravezetőbb bármely magyar nyelv tanításáról rendelkező jogszabálynál. ${ }^{151}$ Az iskolák véleménye szerint csak megtanítják - többnyire rosszul - az államnyelvet a nemzetiségi iskolákban, amelyet pár év alatt elfelejtenek a tanulók. Ha azonban a magyar nyelvi határok kitolódnak a magyar nyelvű szigetek által, mindinkább lehetővé válik az, hogy az etnikumok között az iskolában tanult magyar nyelvet használják a mindennapi érintkezés során. ${ }^{152}$

\footnotetext{
${ }^{149}$ Balás Károly (Balassagyarmat, 1877. jan. 4. - Körmend, 1961. okt. 10.): közgazdász, egyetemi tanár, az MTA tagja (1929-49). 1909-ben megalakította a Kassai Magyar Társadalomtudományi Egyesületet. Népesedési és jövedelemelosztási kérdésekkel, tőke-kamatelmélettel és szociálpolitikával, valamint pénzügytannal foglalkozott. 1939-ben a Magyar Élet Pártja programjával országgyülési képviselővé választották. http://mek.oszk.hu/00300/00355/html/ABC00523/00672.htm (Letöltve: 2017. augusztus 20.)

${ }_{150}$ BALÁS Károly: Telepítéseink föszempontja. Közgazdasági Szemle. 1909. XXXIII. évf. 41. kötet. 314-325. 324. [Továbbiakban: BALÁS, Közgazdasági Szemle, 1909]

${ }^{151} 1879$. évi 18. törvénycikk intézkedett arról, hogy az államnyelvet a nem magyar oktatási nyelvü népiskolákban is tanítani kell. „Szükséges lévén, hogy a magyar nyelvnek, mint az állam nyelvének elsajátitására, minden állampolgárnak kellő mód nyújtassék.” Berzeviczy Albert 1904-ben beterjesztette a törvényjavaslatot „a népiskolai közoktatásról szóló 1868. XXXVIII. és a népiskolai hatóságokról szóló 1876. XXVIII. tc. módositása tárgyában”. A törvényjavaslat indokolása azt mondja, hogy „a tapasztalat azt igazolja, hogy ezen kizárólag nemzetiségi tannyelvü népiskolák túlnyomó nagy részében a magyar nyelv tanitása csakis a magyar gépies írás és olvasásra terjed. Az ilyen, kizárólag nem magyar tannyelvü felekezeti népiskolákból magyarul beszélni tudó gyermek alig kerül ki." Az Apponyi-féle 1907. évi 27. törvénycikk a Berzeviczy törvényjavaslatot veszi kiindulópontjául. Annyiban tér el csak tőle, hogy még inkább szigorítja a magyar nyelv eredményes tanításának követelményeit és még több szankcióval fenyegeti eredménytelenségét. KATUS László: A Lex Apponyi. RUBICON. 2015. 26. évf. 2. szám. http://www.rubicon.hu/magyar/oldalak/a_lex_apponyi/ (Letöltve: 2017. augusztus 21.)

${ }^{152}$ BALÁS, Közgazdasági Szemle. 1909, 325.
} 
Baláshoz hasonlóan Bethlen is úgy gondolkodott, hogy az elsődleges prioritás a magyar agrárnépesség számszerü növekedésének és gazdasági erejének emelése, majd csak azt követően a városiasodást előmozdító modernizáció, mint például az ipari, a kereskedelmi és a közlekedési fejlesztések. Bethlen nem volt az urbanizáció ellensége, de mindenek elött a nemzeti elvre épülő társadalomfejlődésről vallott felfogásában vidék és város szerves kapcsolatban állt. Azt vallotta, hogy „, a magyar kultúra, a magyar városi élet, a magyar ipar és kereskedelem fundamentuma, talpköve, erötartaléka, soha ki nem apadó, neki életet adó bugyogó forrása a magyar föld". ${ }^{153}$ A városra, mint olvasztótégelyre tekintett, ahol a magyarság domináns szerepéből következően asszimiláló erővel van jelent. Bethlen a román városi társadalmat fejletlennek ítélte kevésbé tagolt, gyenge munkás, iparos és értelmiségi rétegeivel. Ezt csupán egy átmeneti állapotnak vélte, tíz-húsz évet követően jelentős fordulatra számított. Előbb ezért egy nagyszámú, magyar paraszti réteget kívánt elősegíteni, amely szemében egyszerre a vidéki és a városi társadalom utánpótlásául szolgált. A második cél ehhez szorosan füződött a magyar történelmi középosztály, a középbirtokos réteg megmentésének programja. Bethlen szemében ők jelentették a „nélkülözhetetlen” és a ,józan” konzervatív reformer erőt, akiktől azt remélte, hogy képesek a falusi román nép tömegeit távol tartani a román értelmiség, papság és tanítók nacionalista befolyásától. A régi középbirtokos társadalom megújítása lebegett szeme előtt, amely számára az erdélyi magyar szupremácia legfőbb politikai bázisát volt hivatott reprezentálni. Bethlen a májusi ülésen azt is elérte, hogy az OMGE határozatában elégtelennek minősítse a munkapárti Lukács László vezette kormány birtokpolitikáját, illetve az Erdélyre vonatkozó kettős célt (közép- és nagybirtok megmentése; telepítések révén magyar parasztosztály támogatása) további eszközökkel kiegészíttesse. Az OMGE a következő javaslatcsomagot fogadta el: egy altruista ${ }^{154}$ bank felállítására, amely fedezetet jelent az osztatlan tulajdonú földek megtartásában; a közép- és nagybirtok terheinek csökkentése; 1000 kat. hold maximumig hitbizományok létrehozása. A kormány amennyiben az ország sík területein állami, alapítványi vagy más kötött birtok eladását engedélyezné, írja elő, hogy az eladók a vételárból elsősorban Erdélyben nagyobb földterületeket vásároljanak.

\footnotetext{
${ }^{153}$ BETHLEN István: Magyar birtokpolitika. In: A keleti határról: a magyar szupremáció veszedelme Erdélyben. Szerk.: BIZONY László. 1912. (A szerző saját kiadása.) 77. [Továbbiakban: BIZONY, 1912]

154 Altruista bank: a gazdaságos müködés és a nemzeti célok összehangolása, ideológiailag elkötelezett az adott nemzet modernizációja érdekében. A magyar altruista bank a magyar gazdasági nemzetépítést segítette elő.
} 
Indítsanak egy széles körü telepítési programot, amely magába foglalja a magyar kisbirtokos réteg támogatását, tekintettel az Egyesült Államokban és Romániában élő magyarság bevonásával, évenkénti 10 millió koronás alaplétrehozását és Székelyföld népfölöslegének központilag irányított letelepítését. ${ }^{155}$

A kritikával szemben történtek kormányzati lépések, amelyekre kormányoldalról hivatkozhattak. 1911-ben hozták létre a Magyar Földhitelintézetek Országos Szövetségét, amely altruista szellemben kívánta segíteni az ipari munkásságot, a földnélküli, illetve a kisbirtokkal rendelkezőket a földhöz jutásban. A törvény a telepítések ügyét elsősorban szociális problémaként kezelte nem pedig a nemzeti küzdelem eszközeként. ${ }^{156}$ A Szövetség megkapta a telepítési alap összes be nem telepített ingatlanait 7 millió Korona értékben, amelyek nagyrészt a Mezőségen, valamint a Maros alsó folyása mentén voltak. A program sikertelen maradt, mert a birtokok megvásárlására nem jelentkeztek kellő számban magyar vevők. ${ }^{157}$ Párhuzamosan megindult a magyar pénzintézetek szervezése a vidéki körzetekben, amelyben főszerepet a Pénzintézetek Országos Egyesülése Erdélyrészi Szövetség elnöke, Lendvay Emil királyi tanácsos és főtitkára, Miklós Armand vállaltak. Célja az olcsó hitelek kihelyezése volt. ${ }^{158}$

Az Erdélyt érintő fejlesztési tervek közül meg kell még említeni a székely akciót. Székelyföld fokozatos lemaradására, gazdasági-társadalmi és értékválságára, amely a munkavállaló székelyek nagyfokú migrációjában nyilvánult meg, az 1870-1880-as években figyelt fel a magyar közvélemény. A 19. század utolsó két évtizedében a kivándorlás országos problémaként, területenként eltérő intenzitással jelentkezett. A „,nagy népvándorlás” Erdélyben érintette a román, a magyar és a német nemzetiségü lakosság szegényebb társadalmi rétegeit is. A peremhelyzetű Székelyföldön a migráció: a székelyföldi birtokrendezések (arányosítás, tagosítás), az (5 hold alatti vagy birtoktalan népességet érintő) népszaporulat, a magyar-román vámháború (1886-1891), a kisiparos és érettségizett réteg túltermelésének, illetve az ipar korlátozott munkaerő-felszívó képességének hatásaira felerősödött.

\footnotetext{
155 BETHLEN, 1913. 32-50.

${ }^{156} \mathrm{~A}$ szövetség feladatai közé tartozott az ingatlanfeldarabolásoknak, telepítéseknek és más birtokpolitikai intézkedéseknek a mindenkori földművelésügyi miniszter által jóváhagyott tervek alapján való keresztülvitele, illetve a gazdasági munkásházak építésével (1907: XLVI. tc.) kapcsolatosan felmerülő hiteligények felügyelete. 1911. évi XV. törvénycikk a Magyar Földhitelintézetek Országos Szövetségéröl és az 1894. évi V. törvénycikk némely rendelkezéseinek módositásáról, illetve kiegészitéséről. https://1000ev.hu/index.php?a=3\&param=7115 (Letöltve: 2017. szeptember 1.)

157 Székelyföld története III. kötet, 1867-1990. 136. Szerk.: BÁRDI Nándor-PÁL Judit. MTA BTK-EME-HRM, Székelyudvarhely, 2016. [Továbbiakban: Székelyföld története III. kötet. 2016]

${ }^{158}$ BIZONY, 1912. 93-94.
} 
A székely kivándorlás egyik fő iránya Moldva és Havasalföld volt (építkezések, ipar, cselédség), az amerikai a 20. század elején jelentkezett, de állandó útvonal volt a székelység vándorlása a közelebbi Brassó (és vidéke) és távolabbi vidékekre (Kolozsvár, Budapest, Bécs) is. ${ }^{159}$ A problémákat összefoglalóan megragadó „székely kérdés” a publicisztika, az emlékiratok, a kulturális és gazdasági egyesületek és a politika kiemelt témája lett, amelyek a térség állami fejlesztésének szükségességét szorgalmazták. Kiemelkedő jelentőségü volt az 1902-ben, Tusnádfürdőn tartott székely kongresszus, (amelyet 1913-ig évente megrendeztek). Először itt dokumentálták, hogy a székely kérdés nemzeti ügy, és a megoldása országos szintü szervezést igényel. A térség problémáira kidolgozták azokat az - erdélyi magyar nemzeti modernizációs társadalompolitikai - javaslatokat, amelyek az első világháborúig irányadóak voltak a kérdésben. ${ }^{160}$ A székely akció legnagyobb eredménye az volt, hogy felhívta a magyar közvélemény és a kormány figyelmét a székelység társadalmi problémáira. Átfogó és érdemi kormányzati cselekvésre ennek ellenére nem került sor, mert a soknemzetiségü országban a liberális gazdaságpolitikai gondolkodás mellett a magyar etnikum nagyszabású támogatófejlesztő politikáját nem vállalhatta fel. A székelykérdés az ellenzék kezében (az erdélyi származású függetlenségi országgyülési képviselők, Nagy György, Zakariás János, Sebess Dénes, Bethlen István) a kormányt érintő kritika formájában ugyan fennmaradt, de - eszközök hiányában - a politikai figyelem más kérdésekre terelődött. Az 1910-es években az (erdélyi) politikusok érdeklődésének előterébe elsősorban a nemzetiségi térnyerés, a magyar birtokpolitika, illetve a választójogi vita került. Az 1913-ban megalakult ellenzéki pártok képviselőit tömörítő Erdélyi Szövetség munkatervében (1914) - a felsorolt kihívások mellett fellelhetőek a székely kongresszusok határozatai is. ${ }^{161}$

\footnotetext{
${ }^{159}$ A kivándorlási statisztika szerint 1880 és 1913 között 50-60.000 fö hagyta el Székelyföldet, amely a helyi összlakosság 7-12\%-át érintette. Csík, Maros-Torda és Udvarhely megyéböl a kivándorlók (1911-1913 között): 84-87\%-a őstermelö, 4-6\%-uk a bányászatban, az iparban és a kereskedelemben dolgozott, 1-5\%-uk napszámos, 3-7\%-uk házicseléd volt. Háromszék vármegye esetében: 55\% őstermelö, $24 \%$ bányászatban, iparban, kereskedelemben dolgozott, 14\%-a házicselédként. Székelyföld története 1867-1990. 2016. 124-132.

${ }^{160}$ A székely akció megindítását Sándor József, az EMKE fötitkára javasolta először 1896 októberében. A székely társadalom legnagyobb megmozdulásai, a térség gazdasági, kulturális helyzetét megvitató székely kongresszusok voltak 1902-1913 között. Darányi Ignác földművelésügyi miniszter előterjesztésére pedig az 1902. évi költségvetésben elkülönítettek 108 ezer Koronát egy megyei hatóságok felett álló bizalmas szervezet, az ún. „székely kormánybiztosság” létrehozására Marosvásárhelyen.

BALATON Petra: A székely akció elözménye és története. http://adatbank.transindex.ro/html/cim_pdf1855.pdf (Letöltve: 2017. szeptember 1.). Lásd részletesebben: BALATON Petra: A székely akció története, 1902-1914. Állami szerepvállalás Székelyföld felzárkóztatására. Doktori (PhD) értekezés, Debreceni Egyetem BTK 2006; U. ő.: A székely társadalom önszerveződése: a székely társaságok (I-II). Korunk. 2010. január, február [Továbbiakban: BALATON, Korunk, 2010]

161 Székelyföld története III. kötet. 2016. 177.
} 
Nem hiányzott az ellenvélemény az erdélyi sajtó hasábjain sem. Gyárfás Elemér, aki később a kisebbségi magyarság egyik vezetője lett, az Ellenzékben megjelent cikkében fogalmazta meg kritikáját, amelyet majd 1918-at követően felülvizsgált. Gyárfás szerint a nemzetiségek semmi haza- és nemzetelleneset, semmi büntetőtörvénykönyvvel ellenkezöt nem tesznek, amikor földet vásárolnak. A földbirtokállomány változása természetes gazdasági folyamat, amelyben a nemzetiségeket segíti nagyobb körültekintésük, takarékosságuk, ellenben a magyarokat hátráltatja bankjaik gyengesége, megbízhatatlansága. Ugyanígy a nemzetiségek nem sérelmeket adnak elö, hanem céltudatos munkát végeznek, ráadásul azokkal az eszközökkel élnek, amelyeket Széchenyi István akart a nemzet kezébe adni, s amelyek kezeléséhez a magyarság még most sem ért. Ebből azt a következtetést vonta le, hogy a magyarságon is csak az öntudatos munka, a teljesítmény segíthet, nem pedig az erőszak. ${ }^{162}$ Voltak továbbá olyan vélemények is, amelyek legalábbis kétkedve nyilatkoztak a román földbirtokvásárlási politikai jelentőségéről és föként nemzeti tudatosságáról. Bizony László 1912-ben megjelent könyvében (A keleti határról: a magyar szupremáció veszedelme Erdélyben) többek között ezt a hangot képviselte Koós Mihály, a földművelési minisztérium székelyföldi kirendeltségének vezetője, aki szerint a közvélemény túlbecsüli a folyamat jelentőségét. Ráadásul a birtokviszonyok változásai alapjában nem is történhetnének másként, mert az eladásra került birtokok többsége románok lakta falvak határában terült el, ahol a helyiek előnyt élveznek. Hantos Elemér, országgyülési képviselő, a Pénzintézetek Országos Egyesületének igazgatója úgy fogalmazott, hogy a román és a magyar bankok közti harc szokásos üzleti küzdelem. A román bankok vezetőinek ugyanis a nyereség a fontos, és ő maga több esetről is tud, amikor román bankok a kezükbe került birtokot az államnak vagy az állami alapítású, telepítési akciók lebonyolítására létrehozott altruista banknak ajánlották fel megvételre. Majd azt is hozzátette, hogy a székely földbirtok lemorzsolódása mögött is elsősorban a foglalkozási szerkezet különbsége áll, illetve a román bankok a gyakorlatban keveset áldoznak nemzeti-kulturális célokra, amely kimerül az ASTRA támogatásában. Az említett könyvben az ő nyilatkozataik mellett azonban több országgyülési képviselő ennek pontosan az ellenkezőjét képviselte, például Burdia Szilárd, Hegedűs Lóránt, Issekutz Viktor, illetve Kádár János, a Kolozsvári Közhasznú Takarékpénztár Rt. vezérigazgatója is. Utóbbi szerint a román altruista bankok a szász pénzintézeteket másolva alakították ki bankjaikat és képviselik a román nemzeti érdekeket. ${ }^{163}$

\footnotetext{
${ }^{162}$ EGRY, Múltunk, 2006. 9.

${ }^{163}$ BIZONY, 1912. 120-136.
} 
Összefoglalva a századforduló után két álláspont rajzolódott ki. Az egyik egy olyan tudatos politikai stratégiát feltételezett a földbirtokviszonyok változásai mögött, amelyik nemzeti célokat kitüzve igyekszik érvényesíteni a románság (és kisebb részben a szászok) érdekeit, a magyarság rovására. ${ }^{164} \mathrm{Ez}$ a megközelítés kapcsolódik ahhoz az erdélyi társadalomtörténeti kutatás egyik alapkérdéséhez, hogy a régió különböző etnikumai együtt (létezik egy többnyelvű erdélyi társadalom) vagy egymás mellett (párhuzamos nemzetépítések) élnek, illetve éltek. ${ }^{165} \mathrm{~A}$ másik álláspont a szabadságra és a liberalizmus értékeire alapozva részben tagadja ezt, részben pedig elveti a háborús logikából következő jogkorlátozást. Az utóbbi felfogásban már ekkor példának tekintették a nemzetiségek önszerveződését (erdélyi román elit), ami egyfajta identitásideológiává, az erdélyiség fogalmának szerves részévé válik. A nemzetiségi pénzintézetek ebben a gondolkodásban nem azért sikeresebbek a magyaroknál, mert valami titkos tervet valósítanak meg, hanem azért, mert hajlandók áldozatot hozni a közösség érdekében. ${ }^{166}$ Továbbá pedig a Budapestről irányított magyar bankokkal szemben ezek a sajátos erdélyi birtok- és hitelgarancia viszonyokat jobban hasznosították. ${ }^{167}$

\subsection{A választójogi vita}

A választójog (a politikai akarat érvényesítője) körüli vita súlyos összeütközéshez vezetett az osztrák és a magyar politikai elit között a századfordulón. Az előbbi 1904-től kezdve el akarta érni a választójog kiterjesztését, ezt azonban az utóbbi mereven ellenezte. A politikai válság oda vezetett, hogy az utolsó jelentős szabadelvü politikus, Tisza István az 1905-ös választásokon vereséget szenvedett, a miniszterelnök lemondott, és pártját (Szabadelvü Párt) is feloszlatta. Az egységes választási koalícióba tömörült parlamenti ellenzék (többségét a 48asok adták) a dinasztia szempontjából komoly fenyegetést látott bennük az 1867-es kiegyezés rendszerére. ${ }^{168}$ I. Ferenc József uralkodó a parlamenti többséget figyelmen kívül hagyta, és 1905. június 18-án báró Fejérváry Géza táborszernagyot, a magyar királyi darabont testőrség kapitányát nevezte ki ideiglenesen miniszterelnökké.

\footnotetext{
${ }^{164}$ EGRY, Múltunk, 2006. 10-11.

165 BÍRÓ: Többségben, 2002. 7.

${ }^{166}$ EGRY, Múltunk, 2006. 10-11.

${ }^{167}$ Erre vonatkozóan Gyárfás Elemér korabeli írásai adhatnak támpontot: GYÁRFÁS Elemér: Magyar Kisebbség, 1923. 19-24. szám.

${ }^{168}$ A koalíció a programjában első helyre a választójog meghatározatlan mérvü kiterjesztését állította, másodszor közgazdasági és szociálpolitikai reformokat ígért, harmadszor a gazdasági különválás és önállóság kellő előkészítését helyezte kilátásba, végül annak a kívánságának adott hangot, hogy a magyar hadseregnek nemzeti jellege nyelvben és jelvényekben megvalósuljon.
} 
Tisza István néhány évvel később ugyan a Nemzeti Munkapárt vezetőjeként ismét miniszterelnök lett (1913-1917), de a liberális áramlat ekkoriban már sokkal erőteljesebben koncentrált a magyar szupremácia fenntartására, mintsem a liberális eszmék megvalósítására.

Magyarország kormányai 1910-1919 között ${ }^{169}$

\begin{tabular}{|c|c|c|}
\hline Kormányfö & Terminus & Párt \\
\hline gróf Tisza István első kormánya & 1903. november 3.-1905. június 18. & Szabadelvü Párt \\
\hline báró Fejérváry Géza & 1905. június 18.-1906. április 8. & Szabadelvú Párt \\
\hline $\begin{array}{c}\text { Wekerle Sándor (OAP) második } \\
\text { kormánya }\end{array}$ & 1906. április 8.-1910. január 17. & AP-FNP-KNP ${ }^{170}$ \\
\hline gróf Khuen-Héderváry Károly & 1910. január 17.-1912. április 22. & $\begin{array}{c}\text { Nemzeti } \\
\text { Munkapárt }\end{array}$ \\
\hline $\begin{array}{c}\text { Lukács László } \\
\text { gróf Tisza István második } \\
\text { kormánya }\end{array}$ & 1912. április 22.-1913. június 10. & $\begin{array}{c}\text { Nemzeti } \\
\text { Munkapárt }\end{array}$ \\
\hline $\begin{array}{c}\text { gróf Esterházy Móric (független) } \\
\text { 1913. június 10.-1917. június 15. }\end{array}$ & $\begin{array}{c}\text { Nemzeti } \\
\text { Munkapárt }\end{array}$ \\
\hline $\begin{array}{c}\text { Wekerle Sándor (48OAP) } \\
\text { harmadik kormánya }\end{array}$ & 1917. június 15.-1917. augusztus 23. & $\begin{array}{c}\text { NMP-PDP- } \\
\text { F48P-FNP-KNP }\end{array}$ \\
\hline gróf Károlyi Mihály & 1917. augusztus 23.-1918. október 31. & $\begin{array}{c}48 \text { AP (PDF- } \\
\text { F48P-FNP-KNP) }\end{array}$ \\
\hline Berinkey Dénes 31.-1919. január 19. & $\begin{array}{c}\text { F48P-SZDP- } \\
\text { PRP }\end{array}$ \\
\hline $\begin{array}{c}\text { Garbai Sándor a forradalmi } \\
\text { kormányzótanács elnöke }\end{array}$ & 1919. január 19.-1919. március 21. & $\begin{array}{c}\text { F48P-SZDP- } \\
\text { PRP-KNP-OKP }\end{array}$ \\
\hline
\end{tabular}

A magyar politikai rendszer egyik kulcsfontosságú eleme volt a nyílt szavazás, illetve a cenzus, amely meghatározta, hogy milyen anyagi (vagyoni cenzus) vagy tudásbeli (műveltségi cenzus) feltétele van a választásokon való részvételnek. A választójogról szóló 1874. évi XXXIII tc. értelmében az összlakosság 7-8\%-a járulhatott csak az urnákhoz. ${ }^{171}$ A jogszabály harmincöt éven keresztül volt érvényben, tizenegy választáson határozta meg a feltételeket 1875 és 1910 között. A magyar választójogi rendszerrel szemben Ausztriában az osztrák liberális párt javaslatára 1906-tól új, modern választójogi törvényt léptettek életbe. A következményeit elsősorban az osztrák birodalmi elsőségtudat, és maga a liberális párt szenvedte el.

\footnotetext{
${ }^{169}$ BÖLÖNY József-HUBAI László: Magyarország kormányai 1848-2004. Akadémia Kiadó, Budapest, 2004.

${ }^{170}$ Alkotmánypárt (AP), 48-as Alkotmánypárt (48AP) Nemzeti Munkapárt (NMP), Polgári Demokrata Párt (PDF), Függetlenségi és 48-as (Károlyi) Párt (F48P), Függetlenségi és Negyvennyolcas Párt (FNP), Katolikus Néppárt (KNP), Polgári Radikális Párt (PRP), Szociáldemokrata Párt (SZDP), Országos Kisgazdapárt (OKP), Magyarországi Szocialista Párt (MSZP; az SZDP és a KMP egyesüléséböl)

171 1874. évi XXXIII. törvénycikk az 1848. V. törvénycikk és az erdélyi II. törvénycikk módositásáról és kiegészitéséröl. https://1000ev.hu/index.php?a=3\&param=5645 (Letöltve: 2017. szeptember 23.)
} 
Az Ausztriához tartozó tartományokban a német ajkúak az összlakosság 36\%-át tették ki, a szláv (cseh, lengyel, szlovén stb.) együttes többséggel szemben. Az osztrákok ezt követően kisebbségbe kerültek a Birodalmi Tanácsban. ${ }^{172}$

A század első évtizedére jellemző nemzetközi feszültség és a balkáni háborúk hatására mindkét európai szövetségi rendszer, az antant és a hármasszövetség is napirendre tüzte a hadsereg és a hadiipar nagyfokú fejlesztését. A Khuen-Héderváry-kormány ${ }^{173} 1911$ májusában erre vonatkozó törvényjavaslata hatalmas parlamenti vitát indított el (a véderőtörvényt évente kellett megújítani). A Justh-párt (függetlenségi párt) új és demokratikus választójogi törvény megalkotásához kötötte a véderötörvény elfogadását, a Kossuth-párt, a Néppárt és Andrássy Gyula csoportja (Alkotmánypárt) pedig hagyományosan a függetlenségi hagyományokra épülő nemzeti engedmények megadására próbálta felhasználni a helyzetet. A vita 1912-ben obstrukciós jelleget öltött. Az általános választójog kérdésében a magyar kormányok óvatosak voltak. Úgy vélték, ha az ellenzéki oldal - a több frakcióra oszlott függetlenségiek (Kossuth Ferenc-Apponyi Albert, Justh Gyula, illetve Károlyi Mihály vezette három csoport), a szociáldemokraták, a polgári radikálisok - és a nemzetiségek mind az urnákhoz járulhatnak, az a birodalom integritását veszélyezteti. ${ }^{174} \mathrm{Az}$ általános választójog bevezetése Magyarországon a szociáldemokratáknak a parlamentbe jutása mellett az országgyülésnek a Reichsrathoz hasonló etnizálódását, a szimbolikus és valóságos nemzetiségpolitikai küzdelmek parlamenti síkra terelődését eredményezhette volna. ${ }^{175}$ Tisza István (1912-től házelnök, ezért a parlamenti vitában nem vehetett részt) a leghatározottabban ellenezte a választójog kibővítését. Lukács László miniszterelnök, az uralkodó előzetes jóváhagyását követően 1912 decemberében benyújtotta a továbbra is korlátozott (műveltségi és vagyoni cenzus) és még mindig csak a férfiakra kiterjesztett, de az 1874. évi törvénnyel szemben némileg módosult választójogi törvénytervezetet (a fővárosban és a törvényhatósági városokban elöírták a titkos szavazást). A tervezet vitája gyorsan lezajlott, részben azért, mert az ellenzék a kormány legitimitását megkérdőjelezve alig vett részt a parlamenti munkában.

\footnotetext{
172 ORMOS Mária: Politikai eszmék, politikai gyakorlatok a 20-21. században. Budapest, Napvilág Kiadó, 2009, 52-54.

173 A koalíciós Wekerle-kormány (1906-1910) lemondását követően a Szabadelvű Párt utolsó vezető kormányférfiai (Tisza István, Khuen-Héderváry Károly, Lukács László) által 1910. február 19-én megalakított Nemzeti Munkapárt elsöprő győzelmet aratott a képviselő-választásokon, és ezzel - négy és fél éves megszakítást után - további hét és félre biztosította hatalmát. A második Khuen-Héderváry-kormány: 1910. január 17.-1912. április 22., Lukács-kormány: 1912. április 22.-1913. június 10.; Tisza István második kormánya: 1913. június 10.1917. június 15.

BÖLÖNY József-Hubai László: Magyarország kormányai 1848-2004. Budapest, Akadémiai Kiadó, 2004, 54-55. 174 ROMSICS, 1991. 48.

175 KEMÉGY G. Gábor: Iratok a nemzetiségi kérdés történetéhez Magyarországon a dualizmus korában, VII. kötet, 1914-1916. Budapest, MTA Történettudományi Intézet, VI. 1999 [Továbbiakban: KEMÉNY G.: Iratok...1914-1916. 1999. VII. kötet]
} 
Az országgyülés két háza 1913 áprilisában pontot tett a Lukács-féle törvényjavaslatra, amely az 1914. évi választásokat készítette elő. A háború kitörése miatt azonban annak alkalmazására soha nem került sor. ${ }^{176}$

A választójogról szóló vitában egyszerre kulminálódott a korszak több szálon egymással összefüggésben álló társadalmi, gazdasági, politikai, és mindenek előtt nemzetiségi feszültsége. Az erdélyi és a nemzetiségi kérdés politikai törésvonal a hagyományos kormány és ellenzék közti viszonyt felülírta, illetve regionálisan más megközelítésbe helyezte. Bethlen István országgyülési képviselő, 1913-ig függetlenségi, majd alkotmánypárti politikus a választójogot erdélyi és pártok feletti ügyként interpretálta. Bethlen túl radikálisnak tartotta az ellenzéki Kossuth- és a Justh-párt által képviselt általános választójog programot, és a Lukács-féle javaslattal egyetemben azt kifogásolta, hogy egyik sem differenciál a magyarság és a nemzetiségi lakosság között. Félt, ha egyszerre kedvez a törvény a nemzetiségi és a szociális kihívásoknak, akkor Erdélyben etnikai fordulatot hozhat a román és a magyar megyék arányát illetően a Kossuth- és a Justh-féle álláspont. Erdély magyar választói többségü megyéinek száma kilencről hatra csökkenne, a román többségű megyéké pedig kettőről hatra nőne. ${ }^{177} \mathrm{Az}$ erdélyi politikus, a Budapesti Hirlapba írt publicisztikájában óvatosságra intette a képviselőtársait. „Minden erdélyi politikusnak kötelessége, hogy minden pártpolitika kikapcsolásával [...] gyakoroljon bírálatot a kormány beterjesztett választójogi javaslata fölött. [...] Az a választási törvény, amely Erdély magyarságát kiszolgáltatná a nemzetiségeknek, szét fogja rombolni a nemzeti alapokon szervezett magyar pártokat is." ${ }^{178}$ A kormánypárti Kolozsvári Hírlap is ezt a szemléletet erősítette, amikor a munkapárti Lázár Istvánt ${ }^{179}$ és az ellenzéki Bethlen Istvánt méltatta. ${ }^{180}$ Pósta Bélát, a kolozsvári egyetem tanárát, az Erdélyi Szövetség későbbi tagját ugyanez a lap már éles kritikával megfedte, mert a kolozsvári függetlenségi pártkör gyülésén azt a javaslatot terjesztette elő, hogy a helyi függetlenségi párt támogassa a szociáldemokraták általános országos sztrájkfelhívását.

\footnotetext{
${ }^{176}$ ROMSICS, 1991. 48.; Lásd továbbá: BALOGH László: Kormányformák, választási rendszerek, választások Kelet- és Kelet-Közép-Európában. Budapest, ELTE Eötvös Kiadó, 2012; ECKHART Ferenc (Mezey Barna szerkesztette): Magyar alkotmány- és jogtörténet. 2000; Szabó Dániel-BOROSS Zsuzsanna: Parlamentarizmus Magyarországon (1867- 1944). Budapest, ELTE Eötvös Kiadó, 1999; GERÖ András: Az elsöprő kisebbség. Népképviselet a Monarchia Magyarországán. Budapest, Gondolat, 1988; VÁZSONYI Vilmos: Miért kell és milyen lesz a választójog reformja? A választójogi javaslat általános indoklása. Budapest 1918 177 ROMSICS, 1991. 50-51.

${ }^{178}$ Erdélyi megnyilatkozás. Kolozsvári Hírlap, 1913. XIV. évf. 36. szám, február 12. 1-2.

${ }^{179}$ Gróf Lázár István (1864. Bánffyhunyad - 1920. Brassó): főispán, országgyülési képviselő, parlamenti alelnök 1913-1914 között, az Erdélyi Kárpát-Egyesület (EKE) alelnöke (1898), elnöke (1909-1920)

${ }^{180}$ Szilánkok. Kolozsvári Hírlap, 1913. XIV. évf. 37. szám, február 13. 1-2.
} 
Pósta azzal érvelt, hogy a szociáldemokraták támogatták a választási harcban a függetlenségi pártot és az ország más városaiban a polgárság támogatásáról biztosította a sztrájk jogosultságát. A sztrájk végül elmaradt. ${ }^{181}$

Tisza István a választási törvénytervezetről szóló általános vita utolsó parlamenti ülésén (1913. március 5.) fejtette ki véleményét. A másfélórás beszédben külön hangsúlyt kapott a nemzetiségi és a román-magyar viszony, amelyet részben Ştefan Cicio-Pop román képviselő felszólalása is indokolt. A román nemzeti párti politikus egy korábbi kijelentés ellen tiltakozott, miszerint a románok, amikor érdekeik elnyomásáról panaszkodnak, bomlasztó tendenciákat képviselnek. Tisza a román képviselővel polemizálva kijelentette, hogy az erdélyi románság a magyar állam törvényei alatt sokat fejlődött, bár a magyar-román barátság még nem jött létre, amelynek az oka, hogy a románok között vannak veszélyt keltő elemek (,konkolyhintö’’). A választójog kiszélesítése ezért olyan fenyegetettség, ahol a magyar intelligencia vezető szerepe nem tehető kockára. „Mert én a magyar intelligencia vezető szerepében - és csakis ebben látom biztositva a nemzeti szupremáciát. [...] Az általános szavazati jog föltétlenül demagóg irányzatot hozna létre és ártalmas volna a nemzetiségekre nézve is, mert például a román intelligenciát a demagógiának legutálatosabb fajtája tenné tönkre saját hazájában (értsd: Magyarországon). Nagy baj volna, ha hatvan-nyolcvan nacionalista képviselö jutna a Házba."182 Azt hangsúlyozta, hogy az általános választójog mindenütt a parlamentarizmus színvonalának süllyedését idézte elő, amely a magyar parlamentet sem kerülné el, mert azt „,inferioris” (alárendelt) elemek kezére játszaná. Védelmébe vette a cenzust, amely szerinte azt szolgálta, hogy ,a faj, amely a szupremáciára törekszik, arra képes vezetők kezében van. [...] Másfelöl mindaddig távolt tartja a ma még éretlen tömegeket, amíg a kultúra haladásával ezek is érettekké és méltókká nem válnak a politikai jogok gyakorlására". ${ }^{183}$ A Tisza-féle érvelés első olvasatra azt mutathatja, hogy kollektív alapon kívánta volna kiszorítani a választójogból például a románságot. A korabeli szabadelvü gondolkodás ezzel ellentétes volt. Tisza tisztában volt a nemzetiségi kérdés fontosságával, de egy sajátos szemüvegen keresztül szemlélte a problémát. Öt az „éretlen tömegek” politikai joggyakorlásától való idegenkedés jellemezte. Nem valamely nemzetiség volt az ellensége, hanem a falusi néptömegeket - nemzetiségi hovatartozástól függetlenül - nem tartotta alkalmasnak a politikai életben való részvételre.

\footnotetext{
${ }^{181}$ Pósta indítványa. Kolozsvári Hirlap, 1913. XIV. évf. 38. szám, február 14. 2.

${ }^{182}$ Választójogi vita. Budapesti Hírlap, 1913. XXXIII. évf. 57. szám, március 7. 3-4.

${ }^{183}$ Uo. 4.
} 
„Egyaránt megbizhatatlanok nemzeti egység, felvilágosodás és emberi haladás szempontjából. A nemzetiségi, klerikális és agrárius demagógiának mindenre kapható könnyü játékszerei."184 Tisza István fő ideológusa, a székelyföldi származású Réz Mihály ezt úgy fogalmazta meg, hogy demokratikus állam még nem teremt demokratikus társadalmat. A miniszterelnök pedig úgy, hogy jogkiterjesztést előbb anyagi emelkedésnek és nevelésnek kell megelőznie. Diagnózisának súlyponti elemeit a magyarországi társadalom elmaradottsága (mind anyagi, mind müveltségbeli) és az abban jelenlévő mély törésvonalak alkották. Egy esetleges radikális jogkiterjesztést ezért is ellenzett. ${ }^{185}$

Eltérő politikai megközelítés és tartalmi szempontból fontos forrásanyag a polgári radikálisok választójogról szóló vitasorozata (1913. február 12., 15., 18., 22., 27.), amelyről a Huszadik Század részletesen beszámolt. A folyóirat Jászi Oszkár, Szabó Ervin, Farkas Gejza, Rácz Gyula, Székely Aladár, Dániel Arnold, illetve Zigány Zoltán álláspontját közölte. Jászi Oszkár véleménye az általános választójog és a nemzetiségi kérdés kapcsolatáról az alábbiak szerint összegezhető. Szerinte a kormány abban látta a nemzetiségi kérdés megoldását, hogy minimalizálni kívánta a parlamentben a nemzetiségi képviselők számát, illetve, ha a nemzetiségi képviselet nem kap parlamenti súlyt, azzal a fennálló feszültség csökkenthető. Jászi Oszkár ezzel szemben azt vallotta, hogy egy befogadó társadalompolitikán keresztül vezet az út a többségi és a nemzetiségek közötti harmonikus együttéléshez. „Azon az elven alapszik, hogy a nemzetiségeket beillesszük az állam egész gazdasági és kulturális életébe, közös jogok és kötelességek alapján. [...] Minden olyan törekvés, amely a nemzetiségek jogfosztottságával és mesterséges magyarositásával akar eredményeket elérni csak új olajat önt a nemzetiségi gyülölködés régi tüzére."186

Kenéz Béla, illetve Zágoni István, aki később a romániai magyar újságírás egyik meghatározó személyisége volt, ${ }^{187}$ A választójog Erdélyben címmel (1913) vették szemügyre az erdélyi nemzetiségi viszonyok szempontjából a különböző választójogi törvényjavaslatokat.

184 ILLÉS, Választójogi viták 1905 után Tisza István és Jászi Oszkár között. Kommentár, 2012/6. http://kommentar.info.hu/iras/2012_6/valasztojogi_vitak_1905_utan_tisza_istvan_es_jaszi_oszkar_kozott (Letöltve: 2017. szeptember 15.)

${ }^{185}$ Uo.

${ }^{186}$ A Társadalomtudományi Társaság a kormány választójogi törvényjavaslatáról. Huszadik Század, 1913. 14. évf. XXVII. kötet, január - június, 406-407.

${ }^{187}$ Zágoni István (1887-1959): újságíró, szerkesztő. 1913-15 között a 48-as Függetlenségi Párt hivatalos lapja, $A z$ Újság főszerkesztője. 1919-1925 között a Keleti Újság, 1925-1927 között, Paál Árpád főszerkesztősége idején $A z$ Ujság felelős szerkesztője. 1921-ben Kós Károllyal és Paál Árpáddal közösen kiadta a Kiáltó szót. 1924-ben egyike az Erdélyi Szépmíves Céh alapítóinak. 1923-tól Kolozs megye képviseletében az OMP intézőbizottságának tagja. 1927-től az Erdélyi és Bánsági Kisebbségi Újságírószervezet ügyvezető elnöke. 1935-ben államellenes izgatás vádjával hadbírósági eljárást indítanak ellene. 1940 után Budapestre költözött.

Romániai magyar irodalmi lexikon. http://lexikon.kriterion.ro/szavak/5140/ (Letöltve: 2017. október 15.) 
Felrótták a kormánynak, hogy az általános választójog kibővítésének akadályaként megtévesztő módon mutatták be a nemzetiségi kérdést. Nem fogadták el azt érvelést, hogy a szükre szabott törvénykezés az erdélyi magyarság érdekeit szolgálja, ,,mert minket [erdélyieket] egyszerüen hányódó pokrócnak tekintenek [...], nemzeti szinüre festheti és lobogtathatja, mint választási kortes zászlókat". ${ }^{188}$ Egyoldalú állításnak vélték azt is, hogy az erdélyi magyarság legnagyobb gondja a rossz gazdasági környezet és azt, hogy a nemzetiségi kérdést pusztán gazdasági eszközökkel orvosolni lehetne. A bajok orvoslását az alacsonyabb osztályokhoz tartozókra vonatkozó politikai jogkiterjesztésben látták: „milliókat akarnak kirekeszteni az államéletböl. [...] Magyarország állampolgárainak, legnagyobb részben magyaroknak a politikai jogait kobozzák el az erdélyi magyarok megmentése címen". ${ }^{189}$ Véleményük szerint a javaslat valódi politikai szándéka az alföldi parasztság kormányellenes és a munkásság szociáldemokrata erőinek a visszaszorítására, illetve a kormánytöbbség fenntartására szolgált. Szóba hozták az 1910-es választásokat körül lengő korrupciós vádakat és eseteket, konkrétan a Kolozs, a Szolnok-Doboka, az Alsófehér és a Hunyad vármegyei mandátumokkal való visszaéléseket, illetve a székelyföldi falvakban történt csendőrségi erőszakos fellépéseket. Elvetették a vagyoni cenzust, amely szerintük alkalmazhatatlan volt Erdélyben. Ha magas, akkor a többséget, tehát a magyarság döntő részét is kizárja, ha alacsony, akkor pedig könnyen megszerezhető és összességében célját tekintve, a nemzetiségeket sem fogja korlátozni. ${ }^{190}$ Zágoni realitásként kezelte, hogy a nemzetiségi területekről nagy eséllyel nemzetiségi képviselőt választanak. Érvelését egy 1874. évi parlamenti vitából vett idézettel tette szemléletessé, amikor a választójog bővítését szintén a nemzetiségi veszélyre hivatkozva vetették el. Mocsáry Lajos akkor azt a kérdést tette fel, hogy „,mi a különbség a magyar állam érdekének szempontjából abban, ha ugyanazt a nemzetiségi képviselöt nem 1-3 ezer, hanem 7 8 ezer szavazó választja meg". ${ }^{191}$ Zágoni azt is felrótta a törvényjavaslattal szemben, hogy az nem reagál a magyar népesség statisztikai mutatóinak változásaira. A Lukács-féle törvény például Brassó és más szász vármegyékben, ahol a magyarság számaránya némileg növekedett a szászokat politikailag felülreprezentálta, az összlakosságon belül elfoglalt $8 \%$-os arányukhoz képest 13-18\%-ra.

188 ZÁGONI István: A választójog Erdélyben. Kenéz Béla egyetemi professzor nyilatkozatával. Kolozsvár, Gombos Ferencz könyvnyomdájában, 1913 [Továbbiakban: ZÁGONI, 1913]

${ }^{189}$ Uo. 5-6.

190 Egy korabeli kimutatás szerint a 24 éven felüli férfinépességen belül az adót-nem fizetők száma Marosvásárhelyen volt a legkedvezőbb, 18\%, azt követte Árvamegye 20\%, Miskolc és Nagyszeben 21\%, Nagyküküllő és Fogaras 22\%, illetve Alsófehér, Beszterce-Naszód, Háromszék, Kisküküllő, Udvarhely 26\%. Az ország többi vármegyéiben és városaiban ez a szám jóval magasabb volt, például Pécs 52\%, Budapest 49\%, de Győr, Kecskemét, Nagyvárad, Somogy, Csongrád stb. 30\% fölötti mutatóval bírt. Uo. 10-11.

${ }^{191}$ Uo. 13. 
Az erdélyi szász kultúrát nem kritizálta, de azt igen, hogy a szász politikai elit ellene volt a demokratikus választójognak, illetve azt is, hogy az egyenetlenül elosztott központi források következtében ,lekoldusodott” Székelyföld. Teljes mellszélességgel szállt síkra a demokratikus választójog mellett, amelynek eredményét tekintve egy széles körü és népi alapokra helyezett nemzeti egységet vizionált. „Azok, akik ilyen választójogi rendszerek mellett, mint a mostani és amilyent megakar valósítani az 1912. évi kormányjavaslat, a politikai nemzetet képezik, nem képesek az egész nemzet valóságos képviseletét soha összeállitani." 192 Ostorozta a kormányok politikáját, mert azok elhanyagolták Erdélyt, amely az országnak ,egy ázsiai tartományává süllyedt.” Az elhagyatottságból az egyetlen kiútat egy demokratikus átalakulásban, „, a radikális választójogi reformban" látta kivitelezhetőnek. Összefoglalva Kenéz és Zágoni úgy vélték, hogy a szük körü választójog egyszerre zárja ki a parasztságot és munkásságot, amely minden érveléssel ellentétben, a magyarság politikai dominanciáját erősíthetné. Ugron Gábor - MarosTorda vármegye volt főispánja, Andrássy Országos Alkotmánypártjának országgyülési képviselője - Zágonihoz hasonlóan a választójog kibővítése mellett foglalt állást. Az erdélyi nemzetiségi kérdés megoldását a vármegyék megújításában, céltudatos agrár-, és szociálpolitikában, átfogó telepítési programban és a népoktatás kiszélesítésében jelölte meg. ${ }^{193}$

Báró Horváth Emil előbb közpolitikai írásaival, majd aktív politikai szerepvállalásával (1917-től az Erdélyi Szövetség alelnöke, illetve föispánként 22 vármegye területén a román iskolaügyek kormánybiztosa) vonta magára Erdély közvéleményének figyelmét. Az első világháború előtt tanulmányt szentelt egyfelől a nemzetiségi (Erdély és az oláh kérdés, 1912), másfelől a választójogi (A választójogi reform és Erdély, 1913) kérdésnek. A politikatudományokból doktorált Horváth elkerülhetetlennek tartotta Magyarországon a Nyugat Európából kiáramló demokratikus politikai tartalmak bizonyos fokú megvalósítását. A választójog kiszélesítését oly formában támogatta, amely az erdélyi magyarság politikai vezető szerepét biztosítja. Erre vonatkozóan öt pontos javaslatot vázolt fel: 1) városi kerületek ${ }^{194}$ alakítása (oka: a német, magyar lakosság itt domináns), ahol 2) a szavazás titkos. 3) A magyarság és a szászság lehetőleg együttes politikai együttműködése. (Utalás az 1890-es szász nemzeti programra, amikor legitimálták a magyar államot.) Véleménye szerint a szászság a románság terjeszkedésétől félve egyre közeledett a magyarsághoz.

\footnotetext{
192 Uo. 38.

193 ZÁGONI, 1913. 53-55.

194 Horváth az angliai választókerületi rendszert vette alapul, ahol a grófságok 377 képviselőt küldtek a parlamentbe, a városok 284-et, illetve az egyetemek 9-et. Dr. HORVÁTH Emil báró: A választójogi reform és Erdély. Dés, Horgos és Medgyesi Könyvnyomdája, 1913, 16-18.
} 
4) A nemzetiségi többségü választókerületek magyar területekkel való kiegészítése, illetve 5) az analfabéta választók kirekesztése. ${ }^{195}$ „Különválasszuk a kulturális, a gazdasági s föleg politikai szempontokból értékesebb városi elemet Erdélyben a kevéssé müvelt s részben politikailag teljesen iskolázatlan tömegtöl."196

A választójogról kialakult vitában a két oldal egyikén azok helyezkedtek el, (például gróf Bethlen István, Réz Mihály, Horváth Emil, illetve a munkapártiak stb.), akik egy szűkített választójogon keresztül kívánták visszaszorítani a nemzetiségi mozgalmakat. Az egyébként politikailag rendkívül heterogén másik oldalhoz azok tartoztak, például Zágoni István, Apáthy István, Kenéz Béla, illetve a függetlenségiek, a szociáldemokraták és a radikálisok, akik a társadalom alsóbb osztályainak beemelése mellett szálltak síkra, s úgy vélték az nem veszélyezteti a magyar politikai közösség dominanciáját.

\subsection{A magyar nemzetiségi politika keretrendszere. Tisza István törekvései a magyar-román}

\section{kiegyezésért}

A nemzeti ébredés kora a kiegyezéssel (1867) és a nemzetiségi törvénnyel (1868) zárult le, amikor a modern román nemzet kialakult ${ }^{197}$ és Magyarország a történelmi egységét visszaszerezve, a kapitalizálódás útjára lépett. A magyarországi modern román nemzeti mozgalomban kulcsfontosságú 1848-1849 tapasztalata és az 1860-as évek törvényhozó munkában való alkalmasság bizonyítása (1867-ben majdnem 40 képviselőjük volt a magyar országgyülésben). A magyarországi román nemzet politikai-jogi helyzetét tekintve elnyomott nemzet, amely miatt politikai célját tekintve önmaga felszabadítását határozta el. Öntudatos vezető tagjai, a román nemzetépítők, ha 1918 elött nem is tudták elismertetni a román nemzetet a liberális jogállamiság keretében, de az a társadalmi erőinek lehetőséget nyújtott az önérvényesítésre. (Az állam a magánéletbe nem avatkozott, így lehetővé vált a hivatalos politikai élet alatti politikai élet kialakítása.) A bank, az egyház és az iskola voltak a román élet és társadalom fejlődését biztosító intézmények. 1871-ben, Visarion Roman szervezésének köszönhetően részvénytársasági alapon felállították az első hitelbankot, az Albinát.

\footnotetext{
195 1910-ben a hat éven felüli román férfiak 41,4\%-a, a nők 24,7\%-a tudott írni és olvasni, ellenben a magyar férfiak 82,8\%-a, a nők 75\%-a, a német férfiak 86\%-a, a nők 78,7\%-a. Magyarország társadalomtörténete. A reformkortól az elsö világháborúig 2. kötet. Szerk.: KÖVÉR György. Budapest, Nemzeti Tankönyvkiadó, 1997. 347.

196 HORVÁTH, 1913. 10.

${ }^{197}$ A Kárpátokon túli román nemzettudat fejlődését a 19. században lásd bővebben: BORSI-KÁLMÁN Béla: A román nemzettudat fejlődése a Kárpátokon innen és túl egy nemzedék készülődésének tükrében. Aetas, 1992. 8. évf. 1-2. szám, 79-125.; Román eszmetörténet 1866-1945. Önismeret és modernizáció a román gondolkodásban. Szerk.: Pászka Imre. Aetas-Századvég, 1994
} 
1914-ig még 274 pénzintézet alakult, amelyek kis- és középbirtokosoknak hiteleztek fejlesztés és földvásárlás céljából. A századfordulót követően, mint arról volt szó a magyar újságok és magyar politikusok egy része, ezt olyan tudatos lépésnek állították be, amely a magyar kis- és köznemesi birtokokra jelent veszélyt. (A századfordulón a román pénzintézetek a magyarországi bankvilág pénzügyi müveleteinek csak 1,2 \%-át bonyolították le, illetve a történeti Erdélyben a százholdas középbirtokoknak is csak egyötöde volt román. ${ }^{198}$ ) A román élet vezetője ereje a bankpolgárság volt (mintegy 500 család), amely az egyház és az egyház által fenntartott iskolahálózat müködtetésében nyújtott komoly anyagi támogatást. A modernizáció egyúttal a román bankhálózatot szorosan a budapestihez és a bécsihez kötötte. Maga a román értelmiség is annak köszönhette fejlődését, gyarapodását, hogy ezer szállal kötődött a bankpolgársághoz és az egyházhoz. A román társadalom alapvetően haszonélvezője volt az Osztrák-Magyar Monarchiának, amelynek gazdasági fejlődési szintje és üteme magasabb volt a déli és keleti államokéinál. ${ }^{199}$

A dualizmus kori modernizáció mellett a felerősödött magyarosítási törekvéseket az mutatta, hogy a nemzetiségi törvényt jórészt nem hajtották végre. Például a román nyelvet a közigazgatásból kiszorították onnan, ahol, mint például Arad és Krassó megyékben, vagy Erdélyben az 1860-as években meghonosodott. A legnagyobb román sérelmek közé tartozott az egyházi autonómia korlátozása, és a magyar nyelvnek az iskolába való bevezetése. (A mintegy 2600-2700 román népiskolában 1879-től kötelező volt a magyar nyelv tantárgyként való oktatása.) A román politikai életet befolyásolta, hogy az 1881-ben alapított Román Nemzeti Pártot (továbbiakban RNP) 1894-ben belügyminiszteri rendelet tiltotta be (választási bizottságként továbbra is fennmaradt). A század végétől a magyarországi román politika a Bukarest, Bécs, Budapest, Berlin négyszögben próbálta érdekeit érvényesíteni. A fordulatot a nagyszebeni székhelyü Tribuna (Ioan Slavici, 1884) címü román lap jelentette, amely hangnemét tekintve kilátásba helyezte a magyar nemzet ellenségeivel való szövetkezés elfogadását is. Slavici célja a román kulturális egység megteremtése volt. Az ún. tribunisták (a Monarchia föderalizálását támogatták) 1892-ben Memorandumban ismertették nemzeti tartalmú sérelmeiket. ${ }^{200}$

\footnotetext{
${ }^{198}$ A románlakta megyékben közel 900 volt a százholdas birtokosok száma, a mintegy 5000 közül. Az ezerholdas birtokok közül román csak 7\% volt. Az ország román vidékein müködő 1000 bank közül még száz sem volt román kézen. MISKOLCZY Ambrus: A modern román nemzet a „régi” Magyarországon. In: BÍRÓ, Többségben..., 2002. 512-513.

199 Uo. 512-515.

${ }^{200}$ A Memorandum a románság ezeréves jelentőségére hivatkozva sorolta fel a sérelmeiket az oktatási, az egyházi, a kulturális, a politikai stb. életterületén. Az emlékiratot Károly román is helyeselte, amit Ferenc Józsefnek kívántak átadni, de az uralkodó nem fogadta a román küldöttséget, beadványukat fel sem bontotta. A magyar
} 
A politikai fellépés azonnali sikert nem hozott, de a tribunista programpontok tovább öröklődtek, mint például az egység vagy a birodalom föderalizálásának gondolatai. A GrossÖsterreich-féle eszmék egyik legismertebb 20. századi román ideológusa, Aurel C. Popovici volt. 1906 elején jelent meg Lipcsében „Nagy-Ausztria Egyesült Államai” címü műve, amelynek elméletét Miskolczy Ambrus megállapítása szerint a 19. századi nemzetiségkultusz és a 20. században kiteljesedő rasszizmus hatotta át. A nemzetiség koncepciója az összetartozás tudatára épült. A magyar nemzetiségi politikát nem azért bírálta, mert emberi jogokat sért, hanem azzal érvelt, hogy a magyarosítás degenerálódáshoz, fajkeveredéshez vezet. Popovici a Monarchiát 15 etnikailag lehetőleg tiszta „nemzeti államra” bontotta volna. A román Erdély magába foglalta volna a Bánság, Bihar és Bukovina románlakta részeit, Székelyföld önálló állam lett volna, míg a román Erdélyhez tartozó szászok jogait az 1868-i nemzetiségi törvényhez hasonló rendelkezés biztosította volna. ${ }^{201} \mathrm{Az}$ erdélyi románok végeredményben azt remélték, hogy a Duna-menti birodalom leendő császára, Ferenc Ferdinánd lemond a dualizmusról a föderalizálás javára. ${ }^{202}$

A popovici gondolat a századfordulótól színre lépő új nemzedék számára részleges politikai programmá vált. Az egyik kiemelkedő vezéregyéniség Iuliu Maniu ügyvéd, népvezér volt, a másik Alexandru Vaida-Voevod, aki bekerült a trónörökös, Ferenc Ferdinánd bizalmasai közé. Mindketten a Román Nemzeti Pártban politizáltak, amely 1906-ban 18 választókörzetet nyert el, 1910-ben ellenben csak 5-öt, miközben kormánypárti programmal további 9 román képviselő foglalhatott helyet a parlamentben. A román fél többek között általános választójogot követelt, elmaradása esetén garanciát megfelelő számú román képviselő mandátumhoz jutásához. Ezt Tisza liberális szemlélete kizárta, mint ahogy azt is, hogy a területi autonómiára vágyó románoknak elfogadja azt a követelését, hogy a vármegyei határok az etnikai elvet kövessék. Maniuéknak az egyik a legnagyobb kihívást tehát a magyar uralkodó pártot újjászervező gróf Tisza István személyisége és politikája jelentette, aki szakított a soviniszta frazeológiával, és céltudatosan törekedett a dualizmus megszilárdítására. Tisza a magyarromán összefogást hirdette a két nép történelmi egymásrautaltságára hivatkozva (a kívülröl érkező szláv fenyegetettséggel szemben).

hatóságok „mentették” meg a román memorandisták helyzetét, mert miután a Memorandumot a sajtóban is kiadták, pert indítottak szerzői ellen, amely komoly belpolitikai és európai visszhangot váltott ki. Uo. 516.

${ }^{201}$ Uo. 515-518.

202 Aurel C. Popovici Nagy-ausztriai Egyesült Államok című könyvét a román kormány pénzügyi támogatásban részesítette. SIGMIREAN, Cornel: Átalakuló identitások a monarchia iránti hüségtől a nemzeti identitásig. Pro Minoritate, 2016. Tél, 26. [Továbbiakban: SIGMIREAN, Pro Minoritate, 2016. Tél] 
Tisza a nem magyar nemzetiségek között a román nemzeti mozgalmat tartotta a legkoherensebbnek, és egyben a legkevésbé integráltnak az országos társadalom egészébe. Miután a szászokkal sikerült megegyeznie, és azok képviselői a kormánypártban foglaltak helyet, többször is megkísérelt tárgyalni a román politikai elit tagjaival. ${ }^{203}$

A kis nemzetek államépítést célzó nacionalizmusai a 20. század elejére fokozatosan megerősödtek a délkelet-európai válságövezetben (balkáni-háborúk). A szarajevói merénylet után kialakult háborús környezetben a Tisza István vezette magyar kormány arra helyezte a hangsúlyt, hogy stabilizálja a dualizmus rendszerét, és megakadályozza a trialista, föderalista elképzelések felerősödését (Ferenc Ferdinánd ${ }^{204}$, Karl Renner ${ }^{205}$, Aurel C. Popovici), amely szemben állt a magyar államdoktrínával. A Magyar Királyság egységes, centralizált közigazgatási rendszere 1867 után a magyar nemzetállam kiépítésére törekedett. A dualizmus kori magyar nacionalizmus tehát kifelé pozícióőrző, befelé viszont erősen asszimilációra orientált volt. Az 1914 előtti magyar kormányzati nemzetiségi politika eszközrendszere (az autonóm Horvátország elismerése mellett) az 1868. évi nemzetiségi törvényben biztosított nyelvi, oktatási, egyházi jogokra (szerb és román görögkeleti egyház esetében az egyházi autonómia elismerése, támogatása) épült. Tisza, a magyar államérdek biztosításának szándékával 1913-1914-től ismét (1904-et követően) megpróbálta egyfajta paktumpolitikával átalakítani a nemzetiségi politika eszközrendszerét, és javítani Ausztria-Magyarország szomszédságpolitikáján. ${ }^{206}$

\footnotetext{
${ }^{203}$ Uo. 518-520.

204 Ferenc Ferdinánd trónörökös kiépítette a maga kapcsolatait a magyarországi nemzetiségekhez, akikkel együttmüködve kívánta korlátozni a magyar uralkodó osztályokat, illetve a dualizmussal szemben egy erősebben centralizált jellegü „Gross-Österreichet” megteremteni (föderalizált Habsburg Birodalom). KEMÉGY G. Gábor: Iratok a nemzetiségi kérdés történetéhez Magyarországon a dualizmus korában, VI. kötet, 1913-1914. Budapest, Tankönyvkiadó, 1985, VII. [Továbbiak: KEMÉNY G.: Iratok...1913-1914. 1985. VI. kötet]

${ }^{205}$ Renner, Karl (1870 - 1950) jogász, szociáldemokrata politikus. Elszegényedett kisparaszti család gyermeke. Katonai szolgálatának letöltése után kapcsolatba került a szociáldemokrata munkásmozgalommal, 1907-től birodalmi parlamenti képviselő, számos könyv szerzője, az Osztrák-Magyar Monarchia föderalista átszervezésének és a munkásság képzésének élharcosa. Az uralkodó rétegekkel szembeni fenntartásai ellenére egészen a háború végéig a dunai monarchia egységének megörzéséért szállt síkra, ellentétben a párton belüli baloldali oppozícióval. 1918-1920 között a kancellária vezetője, bel- és oktatásügyi, valamint külügyi államtitkár, majd kancellár. Az Ideiglenes Alkotmány, a választási rend és más alapvető törvények alkotója, az osztrák delegáció vezetője a saint-germain-i béketárgyalásokon. 1931-33-ig a képviselőház elnöke, 1934-ben átmenetileg letartóztatják. 1945 és 1950 között szövetségi elnök.

STEHLER György: Karl Renner elképzelései a Habsburg monarchia nemzetiségi problémájának megoldásáról. http://publikon.hu/application/essay/141_1.pdf (Letöltve: 2017. szeptember 9.)

${ }^{206}$ SZARKA László: A nemzetiségi kérdés alakváltozatai a Nagy Háború éveiben. Adalékok a magyar kormányok erdélyi politikájának történetéhez. Pro Minoritate, 2016. Tél, 3-17. 5-7. [Továbbiakban: SZARKA, Pro Minoritate, 2016. Tél];
} 
A román-magyar viszony rendezését és a Romániával való szövetség elmélyítését a balkáni háborúk rendezésére irányuló Monarchia és német diplomáciai szándékok is megerősítették. ${ }^{207}$ Ferenc Ferdinánd és II. Vilmos császár, akik egyaránt bíztak Románia szövetségesi hüségében, azt követelték a Tisza-kormánytól, hogy az erdélyi románoknak tett kulturális és politikai engedményekkel küszöbölje ki a Bécs és Bukarest közti feszültséget. ${ }^{208}$

A második Tisza-kormány ismét tárgyalásokat kísérelt meg a RNP vezetőivel (Teodor Mihali, Iuliu Maniu, Valeriu Branişte, Alexandru Vaida-Voivod), illetve Ion Metianu görögkeleti metropolitával és Demetrie Radu görög katolikus püspökkel. ${ }^{209}$ A megbeszélések tartalma 1914. január-februártól vált ismertté, de már maga a találkozó ténye is komoly belpolitikai vitát váltott ki, amelyröl és annak sikertelenségéről Tisza 1914. február 20-án személyesen számolt be a parlamentben. ${ }^{210}$ Tisza és Bethlen István nemzetközi helyzetértékelése megegyezett, mindketten szükségesnek vélték Bukaresttel normalizálni a viszonyt, és legalább Románia semlegességét megörizni. Bethlen - bár nem bízott Brătianu román miniszterelnökben - reálpolitikusként az 1913 szeptemberi kolozsvári beszédében a következőket mondta: ,külpolitikánknak ezen fenyegetö vihar elöestéjén az a törekvése, hogy a független Románia erejét barátképp sorakoztassa mellénk; és mi meg vagyunk gyözödve arról, hogy az északi és déli szláv tenger fojtó ölelése közepén a magyar és román faj egymásra vannak utalva". 211

\footnotetext{
${ }^{207}$ Románia 1883. október 30-án kötött védelmi szerződést az Osztrák-Magyar Monarchiával, amelyet 1913. február 5-én újítottak meg. Az egyezmény sohasem került ratifikálás végett a román parlament elé, és hivatalosan nem hozták nyilvánosságra. Románia Bulgária felett aratott győzelme a második balkán háborúban (1913), és Ausztria-Magyarország fellépése Bulgária mellett, majd ennek nyomában Románia és Oroszország kapcsolatainak javulása nagymértékben fokozta Románia elidegenedését névleges szövetségesétöl. (Ferenc Ferdinánd főherceg meggyilkolásával azonban Románia egy időre elveszítette reményét arra, hogy lehetőség nyílik az erdélyi románság státusának módosítására.)

VERMES Gábor: Tisza István. Budapest, Osiris Kiadó, 2001, 303-304. [Továbbiakban: VERMES, 2001]

${ }^{208}$ KEMÉNY G.: Iratok...1913-1914. VI. kötet, 1985, VII.

${ }^{209}$ ROMSICS, 1991. 54.; Lásd továbbá a román-magyar tárgyalásokat: ALBRECHT Ferencz: Forrástanulmányok gróf Tisza István román nemzetiségi politikájához. Lugos, Husvéth és Hoffer könyvnyomdája, 1933; TÖRÖK Pál: Tisza István román tárgyalásai román szemmel. Magyar Szemle, 1940. május, 372-376.; PÖLÖSKEI Ferenc: Tisza István nemzetiségi politikája az első világháború előestéjén. Századok, 1970/1. 3-34. [Továbbiakban: PÖLÖSKEI, Századok, 1970]; SZẢSZ Zoltán: A Tisza-féle magyar-román „paktumtárgyalások” feltételrendszere (1910-1914). Történelmi Szemle, 1984/1-2, 182-191; ROMSICS Ignác: Bethlen István. Politikai életrajz. Második, átdolgozott kiadás, Osiris, Budapest, 1999. 79-82; VERMES Gábor: Tisza István. Budapest, Osiris Kiadó, 2001; KEMÉGY G. Gábor: Iratok a nemzetiségi kérdés történetéhez Magyarországon a dualizmus korában, IV. kötet, 1903-1906. Budapest, Századok, 1966

${ }^{210}$ A vitában a Tisza-féle válasz elfogadását ajánló Jakabffy Elemér munkapárti képviselő, illetve az ezt elutasító Teodor Mihali román nemzetiségi képviselő határozati javaslata (II. B) állt egymással szemben. 1914. március 20án Jakabffy határozati javaslatát fogadták el. A vita bővelkedett szónokokban. Mihali-Tisza polémia (március 6.) mint a „paktumvita” bevezetése után az ellenzéki álláspontot alkotmánypárti és függetlenségi vezérszónokok körvonalazták: Bethlen István március 11-én és Désy Zoltán márc. 12-én, illetve az egyesült függetlenségi párt elnöke, Károlyi Mihály 1914. március 13-i beszédében. Tisza az ellenzéki felszólalásokra adott március 13-i válaszában részletesen megindokolta és ismételten kifejtette, miben hajlandó és miben nem hajlandó „engedményeket” tenni. KEMÉNY G.: Iratok...1914-1916. VII. kötet, 1999. 86.
}

${ }^{211}$ ROMSICS, 1991. 54. 
Bethlen a magyarországi románokkal való tárgyalásokat, amelynek egyes részleteibe Tisza beavatta, nem tartotta célravezetőnek. Álláspontja ugyanis az volt, hogy a magyarországi románság végső célja, Erdély és Románia egyesítése. Az engedmények politikája helyett ezért az erdélyi magyarság szupremáciájának biztosítását tartotta mindennél előbbre való feladatnak. $^{212}$ Tisza István a román-magyar kérdésről szóló álláspontját Ştefan Cicio-Poppal folytatott parlamenti vitában ismertette 1913. december 5-én. A balkáni és a boszniai helyzet kapcsán szükséges katonai lépések támogatása érdekében elismerte az ország társadalmának áldozatkészségét nemzetiségi különbség nélkül. Kifejtette, hogy „a román és magyar nemzet között érdekharmónia van, [...] kiegészíti egymást, hogy mi csak akkor tölthetjük be rendeltetésünket, ha támaszkodva az Európa közepén végigvonuló germán erő koncentrációra, Európa békéjét, kultúráját és szabadságát az azt fenyegetö általános pánszlávisztikus irányzattal szemben megvédjük. Ebben azonosak érdekeink". ${ }^{213}$ Tisza Bethlenhez nagyon hasonlóan a románság és magyarság közös érdekét a szláv politikától való veszélyérzettel azonosította. Azt feltételezte, hogy a magyarországi románság politikai érdekei nem ellentétesek a dualista rendszer támogatásával, és ha az állam bizonyos fokú engedményeket tesz, a területi integritás megőrizhető. ${ }^{214}$

Tisza az RNP többször bővített követelésjegyzékéből (román nyelvű oktatás autonómiája, felekezeti egyenjogúság, sajtószabadság, szabad egyesülési és gyülekezési jog, az RNP szervezkedési szabadságának engedélyezése, közigazgatás román nyelvének bevezetése, ötven román többségü választókerület megállapítása, román főispánok és államtitkárok kinevezése stb.) hajlandó volt ígéretet tenni az egyházi és az iskolai sérelmek orvoslására. Kilátásba helyezte az 1907-es népiskolai törvény revízióját s a román többségü iskolákban az anyanyelv szabadabb érvényesülését. A háború kitörését követően, az 1914. szeptember 22-én keltezett levelében, amit két román egyház püspökeinek írt, megcsillantotta azt is, hogy kész tárgyalni a választójog egyes intézkedéseinek módosításáról, illetve a nemzetiségi perek elítéltjeinek amnesztiájáról. A választókerületek javasolt beosztására (1910. évi választások után a nemzetiségi mandátumok száma 23-ról 8-ra csökkent), a végrehajtó hatalom és a közigazgatás nyelvére vonatkozó nemzetiségi követeléseket azonban nem fogadta el.

\footnotetext{
212 Uo. 54-55.

213 Képviselőházi napló, 1910. XX. kötet. 484. országos ülés, 1913. december 5., 422-426.; https://library.hungaricana.hu/hu/view/OGYK_KN-1910_20/?pg=430\&layout=s (Letöltve: 2017. szeptember 14.)

214 Uo.
} 
A választókerületek beosztását a románság elmaradottabb kulturális színvonalára hivatkozva utasította el, azzal a kiegészítéssel, hogy az idővel a románság javára módosul. A románokkal folytatott tárgyalások végül nem érték el céljukat. ${ }^{215}$

Tisza Istvánra a német kormány és hadvezetés részéről is politikai nyomás nehezedett. Berlin egyre komolyabban vette azt a román kívánságot, és 1915-1916-ban megfogalmazta követelését a magyar kormány felé, hogy az újabb frontvonal kialakulásának megakadályozása érdekében Budapest kínálja fel Erdély autonóm státuszát. Tisza ezeket a kísérleteket sorra sikeresen elhárította. Érvelésében a román kormány megbízhatatlansága, a háborús veszélyhelyzetek fegyveres megoldásának és a német-magyar katonai együttmüködés elsőbbsége, illetve az általa is felismert nemzetiségpolitikai módosításoknak a háború utáni időkre való elhalasztása jelentették a fő argumentumokat. ${ }^{216}$

\subsubsection{Viták és közös pontok a nemzetiségi kérdésben az Erdélyi Szövetség megalakulásáig}

A székely kongresszusok, amelyet 1913-ig minden évben megszerveztek, székely városok, vármegyék, illetve regionális és országos szervezetek küldöttjeinek találkozói is voltak. ${ }^{217}$ Ezek a fórumok (a tervező munka mellett) a magyar kormányok nemzetiségi - és a székelyföldi migráció okait elhanyagoló - politikájával elégedetlen, föleg függetlenségi és konzervatív érzelmű, középosztálybeli értelmiségiekre, országgyülési képviselők támogatására (báró Kemény Árpád, gróf Bethlen István stb.) támaszkodó erdélyi magyar mozgalom gyüjtőtáborának tekinthető. $^{218}$

A Székely Társaságok Szövetségének 1911. és 1913. évi közgyülései azt az igényt fogalmazták meg, hogy a regionális érdekeket országosan megjeleníteni képes érdekegyeztetésre van szükség. „A közigazgatás nagy tényezö a magyar érdekek védelmében. És el kell jönni az idönek, amikor mindnyájan egyesülünk a nagy gondolatban, hogy nekünk együtt kell dolgoznunk tovább." 219 Olyan aktív szereplökkel találkozhatunk ezeken a fórumokon, akik nemcsak az 1913-ban létrehozott Erdélyi Szövetség munkájában, hanem az impériumváltás és a két világháború közti romániai magyar kisebbség társadalomépítésében is szerepet vállalt.

\footnotetext{
215 PÖLÖSKEI, Századok, 1970. 6-19.

${ }^{216}$ SZARKA, Pro Minoritate, 2016. Tél, 10-11.

${ }^{217}$ Többek között az alábbi szervezetek képviseltették magukat: EMKE, OMGE, Országos Székely Szövetség, Székely Egyesület, EKE, EGE, Nemzeti Szövetség, Országos Közmüvelődési Tanács, Székely Társaságok Szövetség és helyi szintü csoportjai, Marosvásárhelyi Székely Társaság, Marosvásárhelyi Kereskedelmi és Iparkamara, gazda szövetkezetek, ipartestületek.

${ }^{218}$ BALATON, Korunk, 2010. 71-77.

${ }^{219}$ Jegyzőkönyv a Székely Társaságok Szövetségének 1913. évi VIII. rendes közgyüléséröl. 1913. 38.
} 
A teljesség igénye nélkül báró Kemény Árpád országgyülési képviselő, Paál Árpád vármegyei tisztviselő, Barabás Endre oktatási szakértő, Bernády György föispán, báró Szentkereszthy Béla főispán, Vákár P. Arthur, Gyergyószentmiklósi Székely Társaság vezetője, Jakabffy Elemér kisebbségpolitikus, Zakariás János brassói ügyvéd, volt országgyűlési képviselő. Továbbá Betegh Miklós Torda-Aranyos vármegye föispánja, Erdély kormánybiztosa, Gagyhy Dénes főreáliskolai tanár, később bukaresti magyar diplomata, Jancsó Benedek és Bethlen István.

A felvetett javaslatok és társadalmi, gazdasági kihívások között rendszeresen megjelenő tematikák a következők voltak: az erdélyi katonai megerősítése, a természeti erőforrások nemzeti célokat szolgáló használata, a magyarságot támogató földbirtokpolitika kialakítása, a kivándorlás megfékezése, a romániai csángók támogatása, a falvak közszolgáltatásainak és a gazdatársadalom tudásának modernizálása, telepítési akciótervek, bank-, ipar- és vasútfejlesztés, a folyók szabályozása. A helyi és a regionális közéleti tevékenységük a magyar szupremácia megőrzésére, társadalomépítkezésük a magyar dominancia fenntartására irányult. 220

A székelyföldi vasútfejlesztésről szóló terv a gazdasági fejlesztésen túl nemzeti szempontból is a közbeszéd témájává vált. A Csíki Lapok ${ }^{221}$ úgy fogalmazott, hogy a Székelyföld modern közlekedési eszközökkel való ellátása azért is fontos, mert a székely népesség számára nemcsak könnyebbé kell tenni a munkavállalást az ország belső részei felé (utalás a Romániában munkát vállaló székelyre), hanem ,értékesitheti nemzeti és faji becses tulajdonait [értsd: a maga által előállított árucikkeit - F. N.]”. ${ }^{222}$ Lukács Béla kereskedelmi miniszter 1914 tavaszán előterjesztett törvényjavaslatában előadta, hogy az államvasutak keleti vonala évtizedek óta napirenden van. A miniszter gazdasági, hadászati és nemzeti szempontokra hivatkozva szükségesnek tartotta Sepsiszentgyörgy-Brassó-MarosvásárhelySzászrégen összeköttetését megvalósítani. ${ }^{223}$ A fejlesztésre a világháború miatt azonban nem kerülhetett sor.

Az Országos Székely Szövetség a magyar-román viszonyról, az együttélés tapasztalatairól az alábbiakban foglalt állást: „A görög keleti nemzeti egyházak mindenütt rést törnek a magyar állam egységén, [...] a görögkeleti románok, támaszkodva az egynyelvü görög katolikus románságra, felülmúlják a környezö más ajkú népeket s erősen támadók.

\footnotetext{
220 Jegyzőkönyv a Székely Társaságok Szövetségének 1911. évi VI. rendes közgyüléséről. 1912. 1-84; Jegyzőkönyv a Székely Társaságok Szövetségének 1913. évi VIII. rendes közgyüléséről. 1913. 1-148;

${ }^{221}$ A Csíki Lapok (Csíkszereda, 1889. január 1.-1944. június 18.). 1899-1915 között a felelős szerkesztő dr. Fejér Antal ügyvéd, aki a lap politikai programját a szabadelvűségben határozta meg. A lap a két világháború között az OMP irányvonalát támogatta.

${ }^{222}$ A székely vasutak indokolása általában. Csiki Lapok, 1914. XXVI. évf. 12. szám, március 18. 1.

${ }^{223}$ Uo.
} 
Az erdélyi görög katolikusok - ha lehet - még dühösebb ellenségeink, mint a görög keletiek, ellenben az Erdélyen kívül élö görög katolikusok nagy része barátságos, sőt nyelvileg is azonos a magyarsággal. A többi vallásfelekezet mind a magyar nemzeti állam céljait támogatja itt is, ott is". ${ }^{224}$ A lokálisan, vármegyékhez és városokhoz kötődő székely politikai szervezetekből álló regionális érdekeket megfogalmazó politikai szövetség célját tekintve túlmutatnak a szűken vett székelyföldi, illetve történeti erdélyi kérdésen. „Ha Erdélyben székely kérdésröl van szó, ez itt nem partikuláris, nem elkülönitett törekvés; itt megváltoztatott névvel a magyarság élethalál harcáról beszélünk." ${ }^{225}$ Az erősödő román nemzetiségi mozgalom fenyegetőleg hatott az egységes magyar nemzetkoncepcióra. Az erdélyi magyar szellemi és politikai elit félelmeit ez felerősítette, és társadalmi befolyásának megtartása érdekében aktív politikai harcot indított. Politikai magatartásukban az újszerüséget az jelentette, hogy bizonyos fokon túlléptek a hagyományos parlamenti, illetve vármegyei politikai kereteken. Társadalmi mozgalmat indítottak, részt kívántak venni lokálisan és regionálisan a mindennapokban, az erdélyi kérdést átpolitizálták egy önvédelmi stratégiává, illetve kívülről és alulról támadták a kormányzó párt által müködtetett közigazgatási rendszert és azok képviselőit.

Az Országos Székely Szövetség célját tekintve a Székely Nemzeti Alap keretén belül kívánta szervezni azokat az aktív köröket, akik felkészültségükkel, anyagi forrásaikkal segíthetik a magyar nemzeti érdekeket. „Vezérletet” akartak felállítani az erdélyi magyar politikai élet megerősítésére. Mintául szolgált számukra az Alföldön folyó magyarosítási folyamat, ahol évtizedek alatt mind inkább kifelé tolódott a magyar néprajzi határ. Politikai lépéseik legitim voltát történeti előzményekre hivatkozva fogalmazták meg, amely alapján a magyarságot tartották egyedüli államalkotó tényezőnek. A magyarság eredetéről szóló vitát nem kívánták eldöntetni, egyformán elismerték a finnugor és a török rokonságot, de archeológiai és néprajzi kapcsolatokat tekintve az uráli és altaji kulturális hagyományok mellett foglaltak állást. A keleti kapcsolatok hangsúlyozása, avagy a turáni gondolat, mint azt látni fogjuk fontos hatást gyakorolt nemcsak a kolozsvári ellenzéki körök politikai gondolkodására, hanem a magyar politikai elit jelentős részére is. A magyar honfoglalás és a Kárpát-medencébe való letelepedés olyan történeti folyamat szimbólumaként jelent meg, amely során a magyarság képes volt más etnikumokat magába olvasztani és érdekeinek alárendelni. Az asszimiláció kérdésében az érvelésük következetlennek tünik.

${ }^{224}$ GÁLFFY Ignác: Az Országos Székely Szövetség és a Székely Nemzeti Alap. Miskolc, Klein és Ludvig Nyomda, 1913. 7.

${ }^{225}$ Uo. 8. 
A 800 éve Magyarországon élő németek példáját annak bizonyítékának tekintették, hogy a magyar nemzetpolitika abban az értelemben már nem törekedhet asszimilációra, mint az történt például a besenyő, a kun és a jász népelemek beolvasztásával. Egy későbbi ponton pedig úgy foglaltak állást, hogy a török veszedelem elmúltával, a Habsburg betelepítési programok ellenére, a magyarság egyfelől népszaporulatának, másfelől eltérő etnikumú népekre gyakorolt kulturális hatásának következtében válhatott domináns államalkotó nemzetté. Erdély ügyében felrótták, hogy az említett magyarosodás folyamat elmaradt, oda elsősorban nem-magyar csoportokat telepítettek, illetve a magyarsággal szemben a románság bevándorlása és népszaporulata határozta meg jelentős mértékben a népesedés alakulását. ${ }^{226}$

A szövetség az Erdélyre vonatkozó legfontosabb elveket és feladatokat is meghatározta. 1) A nemzetiségektől elvárták, hogy a területi integritás és az egységes politikai közösséggel szemben „kifelé húzó nemzetiségi törekvéseket ne szegezzenek”, saját nyelvüket és nemzetiségi kultúrájukat egyénileg, és ne kollektív politikai törekvéseken keresztül kívánják megélni. 2) Az államnyelv elsajátítását döntő tényezőnek minősítették. Az anyanyelvet, amennyiben nem az állam nyelve volt, illetve a felekezetiség kérdését magánügyként kezelték az egyéni jogok tiszteletben tartása és a szabadelvü hagyományok alapján. A többlet jogok kérdésében úgy foglaltak állást, hogy senki nem élvezhet plusz jogokat, mert arra más európai országokban sincs példa. Ebből kifolyólag „mi annyi jogot adunk a románnak itt, amennyit Románia ad a magyarnak és annyi jogot kell magunknak fenntartani a nemzetiségekkel szemben,” illetve ,a történelmi elsőbbség még Romániában is a magyarságé, ott is régibb lakó az urál-altáji nép, mint a román". ${ }^{227}$ 3) A román nacionalizmussal szemben az állami befolyásra hagyatkoztak, annak szerepét erősítették volna. A mindenkori magyar kormánytól azt remélték, hogy a városi magyar lakosság pénzügyi terheit csökkentse, kulturális, gazdasági és közegészségügyi életének fejlődését kiemelten támogassa. Továbbá a nyelvileg heterogén városokat, mint például Nagyszeben, Brassó és más nemzetiségi vidékeken élő magyarság és szászság közti együttmüködést szorosabbra füzték volna, másfelől a tisztán magyar városok közti kulturális, kereskedelmi, gazdasági stb. kapcsolatokat a közéjük ékelődött román vidékek megszakítására kívánták alkalmazni. 4) Magyarország társadalmának fejlődését olyan lineáris fejlődésként értelmezték, amelyböl egyenesen következett 60-70 éven belül az erdélyi magyarság abszolút többsége.

\footnotetext{
226 Uo. 9-28.

${ }^{227}$ Uo. 50-51.
} 
Következtetéseiket a magyar nemzeti érdekek védelmében rögzítették „védö falakat emelve": az állam nagyobb szerepvállalása a társadalomépítésben, az önkormányzati rendszer megerősítése, erőteljesebb kontrollja, a közigazgatás és az oktatás teljes államosítása, utóbbi kapcsán hatékonyabb tanítóképzés és a középiskolák tananyagának egységesítése, a közegészségügyi rendszer fejlesztése. A tervek között szerepelt a Székely Nemzet Alap pénzügyi program létrehozása is, amely egy altruista bank alapításának a kiinduló pontja volt. ${ }^{228}$ Az első világháború kitörését megelőző években a nemzetiségi (illetve a román) kérdést érintő értelmiségi véleményformálók közül kiemelkedő Moldován Gergely, Apáthy István, Réz Mihály, báró Horváth Emil és Jászi Oszkár nézőpontja. A felsorolt szereplők közül Apáthy és Jászi - aki évtizedes vitában állt Réz Mihállyal - szerepe külön figyelmet érdemel. Apáthy az 1910-es években az erdélyi politika egyik vezetőjévé vált, Jászi pedig — az ellenzéki tábor egyik leghatásosabb közvéleményformáló alakja lett. [A felsorolt személyek fejlődés pályáját tekintve az 1916 (mint fordulópont) előtti vitáikat veszem szemügyre, és az azt követő időszakot az 4. fejezetben tárgyalom, mint például a Jászi-Réz vita utolsó felvonásának tekinthető 1918-as írásaikat.]

Közös jellemző az öt személy gondolkodásában, hogy valós, bár eltérő megoldást igénylő kérdésként tekintettek a nemzetiségi kérdésre. Moldován és Réz az állami integritásra nézve komoly veszélyt látott a nemzetiségekben, utóbbi erőteljes állami szintủ fellépést javasolt. Jászi az erőszak minden formáját elutasította, és az oktatás, a kultúra, a közigazgatás és a bíráskodás területein széles körü jogok biztosításával képzelte el demokratizálni az államot. Apáthy Réz álláspontjához állt közelebb a nemzetiségek politikai mozgalmában rejlő veszélyforrást illetően, a jogkiterjesztés minden mértékét a területi integritás megóvásához kötötte. Horváth Emil javaslatai mögött sok tekintetben Bethlen István és Réz Mihály földbirtok- és társadalompolitikai elképzelései álltak. A legérdekesebb állítása mégis az, ahogyan megjeleníti Erdély és Magyarország uniójának a kritikáját.

A függetlenségi gondolkodású néprajzkutató, Moldován Gergely a románok átfogó történeti, társadalmi és néprajzi történetét feldolgozó munkájában (1913) a nagyromán állameszme ideáját politikailag valós támogatottsággal bíró mozgalomként írta le. „A dákóromán ideál nem tartozik a mesék országába, hanem tényleg létezik." ${ }^{229}$

\footnotetext{
${ }^{228}$ Uo. 408-418.

${ }^{229}$ MOLDOVÁN Gergely: A magyarországi románok története. Budapest, Nemzetiségi Ismertető Könyvtár, 1913. 74-75.
} 
A román társadalom nemzetépítése párhuzamos a magyaréval, amely önálló kulturális (ASTRA, színház, népmüvelö egyletek), gazdasági, pénzügyi (Albina, Solidaritatea, iparos és kereskedő egyletek), oktatási, vallási intézményeket, illetve politikai képviseletet müködtet (RNP). ${ }^{230}$ A filomagyar egyetemi tanár $A$ hazai románság élete és vándorlási címen tárgyalja a dákoromán kontinuitás elméletét. Szerinte a román nyelv latin eredete valós, de az nem Dáciában - a római időkben - hanem a Balkánon alakult ki, amely a románság pásztornép eredetére utal. Ezzel a nézetével természetesen szembe került a román történetírás fő vonalával. A hazai románság történetéböl könyvében az 1400-es évektől bemutatja a magyarországi románok történetét a dualizmusig, amelyben a magyar-román együttélés néhány közös pontjára kíván rámutatni (a román nemesség a magyar nemesség szerves része, Leményi püspök diákjaival a magyarok oldalán harcolt 1849-ben stb.). A világháború idején, 1916-ban hasonló szellemben jelent meg a Şaguna Andrásról címü könyve. ${ }^{231}$ Moldován az 1848-1849-es konfliktust részletesen nem tárgyalja, amely meghatározó a magyar-román viszonyban, mert a hangsúlyt az 1867-es kiegyezésre helyezte. Elítélően fogalmaz a Román Nemzeti Pártról, amely nem ismerte el az állam magyar nemzeti jellegét, de ezzel a kisebbségi állásponttal szemben a románság többsége - véleménye szerint - elfogadta az 1867-i ,alkotmányt”. (Ez utóbbival saját véleményét is közli.) Moldován aktív publicista is volt, aki vitát folytatott a bukaresti nacionalistákkal, akikről azt tartotta, hogy Oroszország befolyása alatt állnak. Szembeszállt a dáciai román eredet tézisével, szerinte Erdélyben nem volt magyarosítás. Ismertette a Liga Culturală tevékenységét, és kimutatta, hogy az nem kulturális, hanem politikai jellegü mozgalom, amely Nagy-Románia létrehozását akarta. Ezt az állítást arra alapozta, hogy a magyarországi román intelligencia döntő többsége a Tiszáig terjedő államot akar létrehozni. Moldován szerint a román köznép politikailag befolyásolható, ezért a Nagy-Románia program sikerülni is fog.

Moldován Gergely tevékenysége két részre osztható. Egyfelöl, mint kutató ismertette a román-magyar történelem közötti kapcsolatokat, és bemutatta a falusi román nép mindennapi életét. Másfelől, mint publicista aktív résztvevője a nemzetépítés diskurzusának. Történetszemlélete megegyezett a magyar historikusok álláspontjával, ezért szembe került a román nacionalizmus törekvéseivel.

\footnotetext{
${ }^{230}$ Uo. 374-400.

${ }^{231}$ Moldován úgy tartotta, hogy Şaguna András görögkeleti püspök az igazi bünös a magyar-román kapcsolatok megromlásában, aki kezdetben magyarbarátnak mutatkozott, de amikor 1848. október 18-án Puchner fơhadparancsnok kiadta magyarellenes manifesztumát, a császár mellé állt (Şaguna András egyébként 1867 után a magyar förendi háznak volt a tagja ortodox érsekként.)
} 
A nemzetiségi kérdést a magyar alkotmányosság keretében gondolta megoldani (képzett román fiatalok álláshoz juttatása kormányzati szinten, igazságszolgáltatás javítása, tanügyi revízió a felekezeti oktatás rovására, nemzetiségek közti párbeszéd stb.). ${ }^{232}$ Moldovánt az a meggyőződés vezette, hogy a magyarországi románság a hazai liberalizmus keretei között fejlődni képes (amit többek között a saját maga szerkesztette Ungaria lapban is kifejtett), miközben megőrzi kultúráját, nyelvét, és nincs szükség az elszakadásra. ${ }^{233}$

Apáthy István zoológus, egyetemi tanár nemcsak kutató és termékeny szakíró, hanem a közéleti kérdésekben véleményformáló szereplő volt. A természettudós axiómája az volt, hogy a társadalmi jelenségek és a természeti törvények egymástól el nem választhatók. Az emberi (biológiai) életet és a társadalmi fejlődést összetartozónak vélte (organikus egész), amely meghatározott, funkcionális módon, fokozatosan halad előre. ${ }^{234}$ Apáthy természettudományos gondolkodása társadalomról, nemzetről, nemzetiségi kérdésről vallott nézeteiben is megjelent. Az EME brassói vándorgyűlésén az egységes magyar nemzet és a soknyelvűség összetett problémájáról értekezett. A nemzetiségi mozgalmakra úgy tekintett, hogy a magyar és a nemzetiségi nyelvek különbsége alapvetően nem jelentenek ellentétes érdekeket, mert egy-egy kisebbségi nyelv csupán „csak különbözö föladatok elvégzésére irányul, az egy és oszthatatlan, egyés ugyanazon nemzeti gondolattól áthatott nemzet életében”. ${ }^{235}$ Állítását arra alapozta, hogy a magyar és nem-magyar nyelvek közti különbség forrása etnográfiai, és ezért az anyanyelvnek kevésbé van jelentősége, amely csupán a nyelvjáráshoz hasonlóan „lényegtelen melléktünet.” A nemzetiségek pedig ebben a kontextusban, mint pragmatikus funkció szerepét töltik be a történelem folyamatában. Erdély történetében a három nemzet, a székely, a szász és a magyar „,csak három különbözö munkakört, különbözö életmüködést jelentett, nem különbözö, nem egymásra törö érdekeket”. ${ }^{236}$ Az egyetemi tanár nézőpontjából ez a következőt jelentette: ahogy a szászt megkülönböztették a magyartól, illetve a magyartól a székelyt, csak azt bizonyította, „,hogy a szászok itt nem, mint németnyelvüek, hanem mint a honpolgároknak külön történeti és etnográfiai csoportja játszottak szerepet: mint kikülönödött testrész". 237

\footnotetext{
${ }^{232}$ KÖPECZI Béla: Egy kitagadott: Moldován Gergely (1845-1930). Kisebbségkutatás, 2000. 9. évf. 2. szám, 277286.

${ }^{233}$ KÖPECZI Béla: Moldován Gergely, a lapszerkesztő. Kisebbségkutatás, 2001. 10. évf. 1. szám, 85-94.

${ }^{234}$ APÁTHY István: A fejlődés törvényei és a társadalom. Budapest, 1912. 269-277.

${ }^{235}$ APÁTHY István: A nemzetalkotó különbözésröl. Magyar Társadalomtudományi Szemle. 1908. I. évf. 7. szám, 599.

${ }^{236} \mathrm{Uo}$

${ }^{237}$ Uo.
} 
Réz Mihály politikatudós, ideológia téren gróf Tisza István jobbkezének számított. ${ }^{238} \mathrm{~A}$ Magyar Figyelóben - konzervatív világnézetü folyóirat (1911-1918) szerkesztőbizottság elnöki tisztét Tisza látta el - rendszeresen publikált, annak központi alakjává vált. Réz Apáthy Istvánnal ellentétben a nemzetiségi kérdésben nem organikus egészet, hanem egymással szemben álló kategóriákat vélt felfedezni. Réz az állam szempontjából a népek előtt álló kihívásokra adott lehetséges válaszaikat a következőképpen osztályozta: radikálisak vagy konzervatívak, vallásilag fanatikusak vagy materiálisak, illetve ,faji törekvései államfenntartók, másutt államellenesek". ${ }^{239}$ Az eltérő reakcióikat azonban nem az egyes népek karaktere, természete adja, hanem az eltérő viszonyok okozata, amelyek lényegében kihatnak az állam működésére. Az egyes nemzeti csoportok tehát nem passzív anyagok, hanem tapasztalatokon álló aktív elemek, amellyel számolnia kell az államnak is. ${ }^{240}$ Réz számos publicisztikájában elemezte a román nemzetiség politikai mozgalmát és annak lehetséges ellensúlyozását. Mindvégig azt az álláspontot foglalta el, hogy a románságnak szeparatista törekvései vannak. A mozgalom vezetőrétege földbirtokokkal és tőkével rendelkező középosztálybeli értelmiség, amely erős felekezeti intézményre támaszkodhat. Szoros kapcsolatot ápol továbbá azokkal a román politikai körökkel, amely magyar és Monarchia ellenes oroszbarát agitáció folytat. A tudós szerint az erdélyi román kérdés megoldása ezért már nagyrészt túlhaladott ügynek tekinthető, amire esélyt látott, hogy a magyarországi románságot a magyar görög katolikus felekezeten és esetleg a szászok segítségével megnyerni a magyar állameszme szolgálatára. ${ }^{241}$ „És ezen a ponton hangsúlyoznunk kell, hogy midön a magyar szupremáciáról beszélünk, ezt a fogalmat mindig politikai értelemben kell tekintenünk. Nem a született magyarok, hanem a magyar állameszme uralma az, amit mi akarunk. Ezt kívánja Európa e pontján az európai egyensúly és az európai kultúra érdeke. És az a szász, rutén, sváb és keleti tót, aki - akár érdekböl, akár érzésböl - ennek a hive: a mi szemünkben magyar. Azok ellenben, akik a nemzetköziség elve címén ennek az állameszmének ellenségei: idegenek, bármilyen fajmagyar is legyen eredetük."242

\footnotetext{
${ }^{238}$ Maroscsapón született 1878-ban elszegényedett, református, székely köznemesi családban, azonban izraelita ösökről is tudni véltek a közelállók. Az eperjesi evangélikus jogakadémia és kolozsvári egyetem jogtudományi tanára. Dicsőszentmártonban szolgabíró 1901-1907 között. 1910-től a Magyar Tudományos Akadémia levelező tagja volt. A Magyar Figyelő lap belső munkatársaként publikált (1911-1918). 1918-1919-ben Budapestről egy rövid ideig hazatért Erdélybe, de a román hatóságok zaklatását követően el kellett hagynia Romániát. 1920-21ben Genfben a Népszövetség magyar ügyekkel foglalkozó titkárságának vezetöje. Súlyos betegségben hunyt el 1921-ben. MOROVÁN Zsolt: Réz Mihály. Valóság, 1998. 2. szám. 46-47. [Továbbiakban: MOROVÁN, Valóság, 1998]

${ }^{239}$ RÉZ Mihály: A politikatudomány határai. Magyar Társadalomtudományi Szemle. 1909. II. évf. 1. szám, 23.

240 Uo.

${ }^{241}$ RÉZ Mihály: A nemzetiségi kérdésről. Magyar Figyelö, 1912. II. évf. 4. kötet, 13-15.

${ }^{242}$ Uo. 15.
} 
Horváth Emil ${ }^{243}$ az Erdély és az oláh kérdésben (1912) két nagyobb probléma köré csoportosította az erdélyi magyar szupremáciát fenyegető kockázatokat. Egyfelől a hibás földpolitikát nevezte meg, amely következtében a századelőtől a románság nagyszámban vásárolhatta fel az egykori magyar birtokokat. A Szolnok-Doboka vármegyében élő báró számításai szerint az utolsó tíz év alatt 16 ezer kaszt. hold birtokokat juttattak idegen kézre. Eltünt közben a magyarság földbirtokos középosztálya, a magyar kis-és közepes birtokosság pedig kicserélődött románra. Előbbi a modernizáció hatására a hivatali, illetve a városokban található foglalkozási ágak valamelyikében szívódott fel. A legfőbb veszély szerinte az volt ebben a folyamatban, hogy a magyar anyanyelvü földbirtokos réteg meggyengülésével a nemzeti identitás elerőtlenedik. A városi kultúra, a művészetek, az irodalom önmagában ugyanis nem képes hatni a teljes nemzetre, amelynek valódi forrása (népi kultúra) a tradíciókat megőrző nép. Másfelől Erdély és Magyarország egységesítése során elkövetett gazdasági és politikai hibákat jelölte meg. Előbbiben az agrárreformokra (helytelen kárpótlás, átmenet nélkül végrehajtott jobbágyfelszabadítás stb.) utalt, amely a magyar földbirtokos középosztály elszegényedését vonta maga után. Az utóbbiban arra a centralizációra, amely felszámolta az évszázados helyi autonómiákat, és meggyengítette a magyar középosztály kulturális, gazdasági és politikai befolyását. Mindezt azzal a kormánykritikus véleménnyel egészítette ki, hogy a munkapárti kormánypárt a hivatalnok szakértelmét mellőzve politikai korrupcióval, erőszakkal tartja fenn hatalmát. „Fel kell szabaditani a magyar hivatalnoki intelligenciát e politikai rabszolgaság alól itt Erdélyben."244 Javaslatában Rézhez és Bethlenhez hasonlóan a magyar földbirtokos középosztály megerősítése, egy őket segítő állami támogatási rendszer felállítása (például olcsó banki hitelek), telepítési akciók kidolgozása, a kivándorlás megfékezésére foglalkoztatási programok megszervezése szerepelt. Továbbá az erdélyi hivatalnoki réteg (értelmiség) becsületének helyreállítása, akik ,egy öntudatos, de méltányos erdélyi politikának tevékeny részeseivé" kell válniuk.

\footnotetext{
${ }^{243}$ Petrichevich-Horváth Emil, báró (Dés, 1881- Budapest, 1945): ügyvéd, politikus. Az Erdélyi Szövetség (1913) egyik alapítója, 1917-1918-ban Nagyküküllő vármegye föispánja, 1919-1924 között az Országos Menekültügyi Hivatal vezetője, 1919-töl belügyi államtitkár, 1921-1926 között népjóléti államtitkár, Bethlen István politikai szövetségese. Magyar Életrajzi Lexikon, http://mek.oszk.hu/00300/00355/html/ABC11587/12174.htm (Letöltve: 2018. január 20.)

${ }^{244}$ Dr. HORVÁTH Emil báró: Erdély és az oláh kérdés. Dés, Horgos és Medgyesi Könyvnyomdája, 1912. 28-29.
} 
A nemzetiségek kulturális fejlődését biztosító és mindennapjukat érintő intézményes kereteket a következőkben összegezte: korrupció mentes közigazgatás; egyéni jogok tiszteletben tartása; egyházi autonómia; állami kontroll mellett szabad iskola fenntartás és tanítóképzés; egyesülési, gyülekezési és sajtószabadság; magasabb bírói, állami, önkormányzati hivatalok megnyitása a jól kvalifikált nemzetiségiek előtt; alsó fokú közigazgatásban az anyanyelv használata; állandó lakhellyel rendelkező, írni és olvasni tudó személyeknek választójog. Választójogi elképzelése azt is magában foglalta, hogy tabula rasa-t kell csinálni, és a feladatok ellátását a ,jövendő népparlamentre" kell bízni. A nemzetiségi iskolákban a magyar nyelv oktatását kötelezőnek vélte (Lex Apponyi), azzal a kitétellel, hogy a tanulók a négy elemi elvégzését követően a magyar nyelvet érdemben elsajátítják. A közigazgatási területek beosztásának újrarajzolását javasolta az etnikai szempontok figyelembe vételével. Beszterce-Naszód, Fogaras és Hunyad megyék kivételével, ahol állandó és nagy többségben élnek románok, minden más erdélyi vármegyében a magyarság dominanciája a biztosítandó. Horváth kezdeményezése arra épült, hogy a kormányzati politikák, ,,a jelenlegi rendszer teljesen csődöt mondott” és a nemzetiségek között meghúzódó feszültséget mielőbb oldani szükséges. „Öszinte fájdalommal nézünk az elkerülhetetlen politikai és társadalmi szakadás felé."245

A Szatmár megyei Nagykárolyban született Jászi Oszkár különvéleménye a dualizmuskori közfelfogással szemben mindvégig a szellemi elit kisebbségéhez kapcsolta. ${ }^{246} \mathrm{~A}$ teoretikus a meglehetősen heterogén ellenzéki csoportokon belül is egyedi hangot ütött meg. A függetlenül kialakított különvéleményét a nemzetfogalomról, nemzeti tudatról is tetten érhetjük. Politikai gondolkodásának fejlődésében fordulópontot jelentett 1904-1905, amikor tudatosult benne a társadalmi-szociális kérdések és a nemzeti eszme kapcsolata. E felismerés két szempontból fontos: a nemzeti gondolattömegeket mozgósító ereje erősebben hat a szocialista internacionalizmusnál. Másrészt, ennek fényében elkezdi kidolgozni a hagyományosan uralkodó, általa feudálisnak, sovinisztának tartott nemzeteszmével szemben a saját, demokratikus tartalommal megtöltött nemzet- és hazafogalmát. A nemzeti érzés és gondolat - akárcsak a radikális függetlenségi politika - az ő gondolkodásában a tömegeket mozgósító eszközként (alárendelt tényező) jelent meg, a végső célként megjelölt társadalmi változások elérésének útján.

\footnotetext{
${ }^{245}$ Uo. 26.

246 Jászi Oszkár (Nagykároly, 1875-Oberlin, USA, 1957): társadalomtudós, szerkesztő, politikus, a Magyar Nemzeti Tanács tagja, a Károlyi-kormány nemzetiségi ügyekkel megbízott tárca nélküli minisztere, majd emigráns politikus, egyetemi tanár. Lásd bővebben: LITVÁN György: Jászi Oszkár. Budapest, Osiris, 2003
} 
A nemzeti gondolat újra értelmezésével Jászi - a legtöbb kortársával ellentétben - a nemzetet és az országot demokratizálni akarta, nem magyarosítani. ${ }^{247}$ Alaptéziseit erre vonatkozóan $A$ nemzeti államok kialakulása és a nemzetiségi kérdés (1912) címü könyvében foglalta össze. ${ }^{248}$ Történelmi és nemzetközi példákon keresztül támasztotta alá, hogy a nemzetiségi mozgalmak a világon szükségszerủen lépnek fel ott, ahol a feudális állapotból az átmenet a modern polgári és kapitalista állam felé megtörténik. Másrészről ez a változás nem homogén néptömegeket talál, hanem különböző nyelvü embercsoportokat, nemzetiségeket, akik nyelvüket, kultúrájukat saját módon kívánják fejleszteni. (Jászi ezt nevezte a nemzetiségi törekvések minimumának). Azt a következtetést vonja le, hogy a sok nemzetiségü Magyarország jövője szempontjából létfontosságú a hazai nemzetiségi törekvésekkel való szembenézés. Javaslata azonban ekkor még nem az állami egység megörzésére irányult, hiszen Jászi nem tartotta a nemzetiségi mozgalmakat az ország integritása szempontjából veszélyesnek. „Ami centrifugális irányzat csak van a nemzetiségi népben, ez ma reálisan, utópia mentesen csak Gross-Österreich felé gravitálhat."249 Azt feltételezte ugyanis, hogy a magyarországi nemzetiségi elnyomatás bár szükségképp feléleszti a nemzetiségi mozgalmakat, de irányukat tekintve azok az osztrák centralisztikus föderalizmus tervekben, egy nagy államszövetségben teljesednek ki, és nem szeparatista törekvésekben. Nem lebecsülte a kérdés fontosságát, épp ellenkezőleg arról igyekezett meggyőzni a társadalmi-gazdasági progresszió híveit, hogy a feudális és nemesi előjogokat konzerváló magyar állami berendezkedés megváltoztatásához elengedhetetlen az elnyomott nemzetiségi tömegek megnyerése, akiket egy engedékenyebb politikai környezetben nyerhetnek meg maguknak. „Ezért állitom, hogy a nemzetiségi kérdés a magyar demokrácia és állami függetlenség archimedesi pontja, melynek megoldása nélkül papirosalkotmány az egész magyar parlamentarizmus." 250 A nemzetiségi kérdés megoldására vonatkozóan általánosságban azt javasolta, hogy az állam ismerje el a nemzeti nyelven történő oktatáshoz, helyi közigazgatáshoz, kultúrához és bíráskodáshoz való jogot. Jászi legeredetibb és egyben legvitatottabb tézise a nemzetek egymás mellett éléséről, integrációjáról eljövendő békés, posztnacionalista korszakról szól.

\footnotetext{
${ }^{247}$ ABLONCZY Balázs-RICHLY Gábor: Jászi Oszkár. Szerk.: Romsics Ignác: Trianon és a magyar politikai gondolkodás 1920-1953. Budapest, Osiris, 1998. 134-155, 134-136.

${ }^{248}$ Ebben a témában 1912 előtt lásd a következő Jászi cikkeket: Néhány szempont a nemzetiség kérdéshez. Huszadik Század, 1907/10; Nemzetiségi politikánk iránya. Huszadik Század, 1910/12; Magyarország, nemzetiségeink s a külföld. Huszadik Század 1910/1-2; A nemzetiségi kérdés és Magyarország jövője. Budapest, Galilei Kör Könyvtára, 1911

${ }^{249}$ JÁSZI Oszkár: A nemzeti államok kialakulása és a nemzetiségi kérdés. Budapest, 1912. 509

${ }^{250}$ Uo. 519.
} 
Szerinte a nemzeti kultúrák kifejlődése szerves, de nem öncélú folyamat, mert maga a „,nemzetiségi mozgalom végeredményét tekintve az egység, a szervesebb gazdasági és kulturális tömörülés mozgalma" egy együttmüködő, demokratikus nemzetköziségben, amelyet a föderalizmuson alapuló Európai Egyesült Államoknak nevezett. ${ }^{251}$

Apáthy Jászi könyvéröl, A nemzeti államok kialakulásáról és a nemzetiségi kérdésröl (1912) váltott levelében azzal szembesítette Jászit, hogy a nemzetiségekkel szemben túlságosan naiv álláspontot képviselt, majd saját félelmeit tárta fel. „Azt hiszem, nagyon is megbízik a nemzetiségi vezetők jóhiszemüségében és a magyar államhoz való hüségében. Nekem vannak okaim az utóbbiban kételkednem."252 Apáthy három tételben foglalta össze azt a jogot, amely szerinte megilleti Magyarország nemzetiségeit. Egyetértett Jászi azon elképzelésével, hogy az iskolának, a közigazgatásnak és a bíráskodásnak az ügyét nemzeti nyelven meg lehet oldani. Elismerte, hogy az adott kisebbség kultúráját saját nyelven fejlessze, illetve származásra, vallásra, anyanyelvre tekintet nélkül mindenki előtt biztosítani kell a magyar közéletben való részvételt. Egy kikötést fogalmazott meg a nemzetiségekkel szemben, hogy „ne tagadja meg senki magyar állampolgári mivoltát és ne törekedjék külön célokra, hanem csak az egységes állam természetéböl következö, annak minden polgára számára közös célokra. És tehetségét a közügyek terén is mindenki az egységes állam érdekében érvényesítse". ${ }^{253} \mathrm{Az}$ önkormányzatoknak minden formája, ha nem követi az egységes állami integritás elvét, szétdarabolódáshoz vezet. Ha például a román nemzetiségi kisebbségnek, amely rendelkezik egyházi önkormányzattal, müvelődési és gazdasági önkormányzatában egyre elkülönül az országnak többi részétől, az az ország integritásának felbomlásával járhat. Csak olyan helyi önkormányzatot támogatott, amely harmonikusan illeszkedett a területileg egységes magyar közigazgatás rendszerébe, ellenben az etnikai elvű autonómiát elutasította. „Ellensége vagyok a nemzetiségek szerint alakuló önkormányzatnak, mert az csak is idegen test volna a magyar állam szervezetében és a szomszédos államokhoz való húzása által szétrobbantaná Magyarországot. [...] Ön hisz olyan dolgokban, melyekben én, sajnos megtanultam kételkedni." - zárta sorait Apáthy István. ${ }^{254}$

\footnotetext{
${ }^{251}$ Uo. 529-530.

${ }^{252}$ Apáthy István levele Jászi Oszkárhoz, a Huszadik Század szerkesztöjének (Kolozsvár, 1912. május 19.) OSZK Kézirattár, Quart. Hung. 2452-2

${ }^{253} \mathrm{Uo}$

${ }^{254}$ Uo.
} 


\subsection{6-A fordulat éve}

Románia hadba lépése hónapok óta foglalkoztatta az osztrák-magyar külügyminisztériumot és a magyar kormányt. Tisza 1916. augusztus elején a bukaresti követségtől, továbbá utólag is megbízhatónak mondható bizalmas információkat kapott arról, hogy a Monarchia hadseregének oroszokkal szembeni meghátrálása kiválthatja Románia erdélyi bevonulását. Annál is inkább volt reális a román kormány terve, mert meg voltak győződve, hogy az osztrákmagyar hadsereg nem tud számottevő ellenállást kifejteni. ${ }^{255} 1916$. augusztus 27-én a román koronatanács, az antanttal megkötött bukaresti titkos egyezmény ${ }^{256}$ értelmében hadat üzent korábbi szövetségesének, az Osztrák-Magyar Monarchiának. ${ }^{257}$ A nehéz tüzérséggel nem rendelkező 250 ezres román haderővel szemben a magyar határt kis létszámú fegyveres erő védte. A korábban Erdély védelmére tartalékolt 70. honvédosztályt még márciusban átcsoportosították az orosz frontra. ${ }^{258}$

A védtelenség problémáját abból a szempontból is megítélhetjük, ha a hátországban maradt helyi társadalom szükös emberi erőforrását vesszük szemügyre. 1915. május 5-én a honvédelmi miniszter egy bizalmas rendeletben fordult az erdélyi vármegyék föispánjaihoz, hogy önkéntes csapatokat szervezzenek a belső rend biztosítására. A beérkezett válaszok kivétel nélkül arról számoltak be, hogy az önkéntesek szervezése, megfelelő ember hiányában, már a folyó év közepén sem volt lehetséges.

\footnotetext{
${ }^{255}$ 1676/c. II. Románia támadásának veszélye; 1680/a. Hírek Románia háborús készülődéseiről. Gróf Tisza István összes munkái. 4. sorozat, ötödik kötet. Budapest, Franklin-társulat, 1933

256 1916. augusztus 16-án a Brătianu-kormány Bukarestben titkos szerződésben csatlakozott az antant hatalmakhoz. Vállalta, hogy támadást indít a Monarchia ellen, illetve nem köt különbékét. A nyugati szövetségesek megígérték, hogy a szaloniki fronton és a galíciai hadszíntéren indítandó támadásokkal segítséget nyújtanak Romániának és a hadba lépésért cserébe területi engedményeket adnak (Bukovina, Bánság, a történeti Erdély, és az attól nyugatabbra fekvő területek). A szerződés szövegét közli: JANCSÓ, Erdély, 2004. 397-398.

${ }^{257}$ A hadüzenet teljes szövege olvasható: KEMÉNY G.: Iratok...1914-1916. 1999. VII. kötet, 678.

${ }^{258}$ A Román Királyi Hadsereg 4 hadseregből állt 1916 augusztusában. Ebből egy hadsereg volt Dobrudzsában, mert Bulgáriával is tisztázatlan volt Románia viszonya. Három hadsereg, amelynek létszáma 369 ezer fö volt, a Kárpátok vonalára zárkózott fel, Orsovától Bukovináig, 500 kilométeres szakaszon. Augusztus 16-tól az Erdélybe irányított magyar-német alakulatokat egységesen az osztrák-magyar 1. hadsereg-parancsnokságnak rendelték alá, amelynek élére a nagyszebeni származású Arz Arthur von Straussenburg gyalogsági tábornok került. Szeptember 9-én alakult meg a német 9. hadsereg, a frissen felmentett eddigi német vezérkari fönök, Erich von Falkenhayn gyalogsági tábornok parancsoksága alatt. Augusztus 27-re 34 ezer katona volt Erdélybe irányítva, illetve szeptember 19-én is még csak 45 ezer fös volt a haderö.

HAJDU Tibor-POLLMANN Ferenc: A régi Magyarország utolsó háborúja 1914-1918. Osiris Kiadó, Budapest, 2014. 223-230.;

Lásd továbbá: Nagybaczoni Vitéz Nagy Vilmos: A románia elleni hadjárat I-II-III. A M. Kir. Honvédelmi Ministerium kiadása, Budapest, 1922.
} 
A kényszerből fakadóan pedig a tábori hadsereg szükségleteinek kiegészítésére 43-50 éveseket is köteleztek, vagyis „a megfelelö emberanyag hiányában önkéntes csapatok nem szervezhetőek". ${ }^{259}$ A Brassó vármegyei főispán levelében azt jelentette, hogy önkéntes csapatok felállítására rendkívül korlátozott módon van lehetőség. Nemcsak a rendfenntartói feladatokra, de a nyári mezőgazdasági munkák ellátásában is munkaerőhiány mutatkozott. Apácza község jegyzője hasonló okokra hivatkozva azt jegyezte le, hogy „arra alkalmas és a földmüvelésnél nélkülözhetö férfi - a tömeges bevonulásra - nincsen”. ${ }^{260}$ Krizba község jegyzője szintén az elegendő férfi lakosság hiányát rótta fel. Brassó vármegye főszolgabírója több község nevében úgy fogalmazott, hogy a mezőgazdasági munkában munkaerőhiány van, az önkéntességre pedig nincs hajlandóság, ,a szükséges férfi anyag teljesen hiányzik, de ily védekezésre a hajlam is hiányzik". ${ }^{261}$ Brassó város főjegyzője a városi polgárság kapcsán ugyanezt válaszolta: „az önkéntes csapatba való belépésre a járásokban jelentkezés nem történt, míg erre Brassó városban is oly csekély hajlandóság mutatkozik, hogy a szervezés sikerrel nem járhat". ${ }^{262}$ Kolozs vármegye és Kolozsvár város főispánja ugyancsak a többségében bevonultakra és a mezei munkákban már résztvevőkre hivatkozva lehetetlennek ítélte meg az önkéntesek verbuválását. A miniszter pozitív választ csak az evangélikus egyház ifjúsági lövészegyesületétől kapott, amely vállalta közel 700 fő beszervezését és kiképzését. ${ }^{263}$ Érdemi változás csak 1916 őszén következett be, amikor a román betörést követően megindult a nagyobb fokú toborzás, amelyet azzal segítettek elő, hogy a korábban alkalmatlannak minősített személyeket és fiatalokat szülői engedély nélkül is kiképzésre fogták. ${ }^{264} \mathrm{Az}$ önkéntesek a délkeleten harcoló közös hadsereg pótlásában és kisebb részben portyázó különítmények kialakításában segédkeztek. Egy jelentés szerint 1917. októberig 1000 fö jelentkezett. $^{265}$

\footnotetext{
${ }^{259}$ A rendelet száma: 3014/915-eln. 1. sz. A következő vármegyékböl érkezett válasz: Szolnok-Doboka vármegye kormánybiztos, Nagy-Küküllő és Kis-Küküllő vármegye föispán, Torda-Aranyos vármegye föispán, Fogaras vármegye föispán, Csík vármegye föispán, Alsó-Fehér vármegye föispán, Hunyad vármegye föispán, Udvarhely vármegye föispán, Nagyszeben föispán, Beszterce-Naszód vármegye föispán, Kolozs vármegye és Kolozsvár város főispán. HM HIL M. kir. Honvédelmi Minisztérium iratai, első világháború korszaka, 4653. doboz. Tárgy: Önkéntes csapatok szervezése tárgyában a föispánoktól beérkezett jelentések. 361/Res. 1915. augusztus 6.

${ }^{260} \mathrm{Uo}$.

${ }^{261}$ Uo.

262 Uo.

${ }^{263}$ Uo.

${ }^{264}$ M. kir. Honvédelmi M. 17610. szám rendelet

${ }^{265}$ HM HIL, M. kir. Honvédelmi Minisztérium iratai, első világháború korszaka, 4653. doboz. Tárgy: Önként jelentkezök felvétele a népfölkelésbe
} 
A román támadás 1916. szeptemberben a Parajd-Székelyudvarhely-NagyszebenOrsova vonalig jutott el. ${ }^{266}$ Székelyföld nagy része és több fontos város, például Brassó, Nagyszeben és Fogaras is, ideiglenesen román megszállás alá került. A határmenti területek magyar és német lakossága gyalog, szekéren, vonaton pánikszerü menekülésbe kezdett. Több helyen került sor erőszakos, halállal végződő atrocitásra (pl. Gelence, Sóvárda, Szárhegy, Szováta). Nehezen pontosítható adatok szerint közel 250 ezer-300 ezer polgári lakos menekült el otthonából. Konkrét kiürítési terv nem készült, csak egy kiürítési rendeletet adtak ki, amely meghatározta, hogy a megtámadott vármegyék lakói melyik vármegyébe kellett menjenek. Például a csíkiakat Maros-Torda vármegyébe irányították, majd onnan vonatszerelvényekkel igyekeztek az embereket még tovább szállítani, így kerültek például a Csík vármegyeiek a Tiszántúlra. ${ }^{267}$

Bár a katonai hadműveletek egy aránylag szük sávban és rövid ideig zajlottak (a központi hatalmak csapatai 1916 decemberében Bukarestet is elfoglalták), az események (a román csapatok bevonulása, a pusztítás, a menekülés, a rekvirálások, az internálások ${ }^{268}$ ) mély nyomot hagytak a magyar politikai osztályban és a lokális hétköznapi viszonyokban egyaránt. 1916-tól Erdély nem csak politikailag és szimbolikusan, de katonailag is hadszíntérré vált. Románia hadüzenete nemcsak a magyar közvéleményt döbbentette meg, de a magyarországi románság vezetőit is váratlanul érte. Míg az előbbiben a támadás általánosan ellenséges válaszokat szült, addig az utóbbi kapcsán nem lehet egységes reakciókról beszélni.

\footnotetext{
${ }^{266}$ Az 1916-os betörésről számos visszaemlékezés született: PILISI Lajos haditudósító (1878-1918): A megrohant és felszabaditott Erdély. Budapest, Atheneum Irodalmi és Nyomdai Rt. 1916; VERES Emese-Gyöngyvér: Mikor Oláhország háborút izene. A barcasági csángók kálváriája. Barcasági könyvek 2. Barca Kiadó, Budapest, 2008; BATTHYẢNY Tivadar gróf: Az erdélyi betörés. Beszámolóm - I. Budapest, A szerző kiadása, 1927; PARÁDI József-SUBA János-VEDÓ Attila: A magyar-román határ és örzése 1867-1918. Budapest, Szemere Bertalan Magyar Rendvédelem-történeti Tudományos Társaság, 2011; TAMÁSI Gáspár: Vadon nőtt gyöngyvirág. Emlékezés. Bukarest, Kriterion könyvkiadó, 1971; BOTÁR Árpád: A láthatatlan hadsereg. Kémek, árulók, merénylők. Tapolcai Lapok Nyomdavállalata, 1938; VÁMSZER Géza: Szakadát. Egy Szeben megyei magyar szórvány. Kolozsvár, Erdélyi Enciklopédia kiadása, 1940; DR. NAGY András: Városkép és ami hozzá tartozik. Pallas-Akadémia; 1997; ÁDÁM Éva: Hadak útján-Az Olt partjától a Piaveig. Magyar Szépirodalmat pártolók Egyesülete, 1916

${ }^{267}$ NAGY József: Hol voltak a székelyek, amikor Románia megtámadta Erdélyt? (Feltöltve: 2016. szeptember 2.) http://itthon.transindex.ro/?cikk=26158 (Letöltve: 2017. szeptember 17.) [Továbbiakban: NAGY, Hol voltak a székelyek..., 2016]; NAGY Szabolcs: A román hadsereg 1916. évi erdélyi betörése. (Feltöltve: 2012. február 25.) http://itthon.transindex.ro/?cikk=16670. (Letöltve: 2017. szeptember 17.)

${ }^{268}$ Rekvirálásokra 1916 elött is sor került, amely fokozatosan kiterjedt az egész országra és az egyre több árucikkre. A Csíki Lapok 1917. márciusában pótrekvirálásról adott hírt. A Közélelmezési Hivatal gróf Károlyi György bízta meg egész Erdély területén a pótrekvirálás vezetésével és ellenőrzésével. (A pótrekvirálás Erdélyben. Csíki Lapok, 1917. XXIX. évf. 5. szám, március 28. 2.); A Nagybánya című lap arról számolt be, hogy a kormányrendelet értelmében a gazdáktól rekvirálják fix ár ellenében az 1916. évi gabonatermésnek a termelő teljes házi szükségletét és vetőmagkészletét. (Az egész termés rekvirálása. Nagybánya, 1916. XIV. évf. 37. szám, szeptember 14. 2.)
} 
A magyar országgyülés mindkét háza élés hangnem ítélte el Románia hadba lépését. A soron következő képviselőházi ülésen gróf Batthyány Gyula, gróf Károlyi Mihály, Justh Gyula és más ellenzéki képviselők „Elárulták Erdélyt!” felkiáltással Tisza István miniszterelnök lemondását és a magyar katonák hazahozatalát követelték. A kormány és az ellenzék képviselői, gróf Tisza István, gróf Andrássy Gyula, gróf Károlyi Mihály, gróf Apponyi Albert, Urmánczy Nándor mindettől függetlenül ugyanúgy foglaltak állást: Románia lépését példátlan orv- és hátbatámadásnak nevezték. ${ }^{269}$ Tisza a Monarchia szempontjából azért is tartotta Románia szembefordulását veszélyesnek, mert korábban Olaszország is elfordult a központi hatalmaktól. ${ }^{270} \mathrm{Az}$ országgyülés förendiháza rendkívüli ülésen tárgyalta Románia Monarchia elleni hadüzenetét. Báró Jósika Sámuel elnöki megnyitóbeszédében ítélte el a balkáni állam offenzíváját, és a képviselőházi felszólalókhoz hasonlóan Románia lépését szintén orvtámadásnak nevezte. „Románia, mely független állami élete kialakulásában, politikai és gazdasági megszilárdításában annyit köszönhet monarchiánknak és nagy szövetségesünknek, ellenségeink sorába állott, hogy rabló kézzel nyúlhasson szent koronánk legdrágább gyöngyéhez."271

Románia hadüzenete a magyarországi románság vezetőit is meglepte. Ennek az volt az oka, hogy az első világháború kitörésekor a magyarországi románság körében császárhủ érzület uralkodott. A Ferenc József Népeimhez! című kiáltványt követően, a Román Nemzeti Párt a Román nemzet fiaihoz címü felhívásában szólította fel a románokat, hogy teljesítsék katonai kötelességüket. A nagyszebeni és a brassói püspökök pedig körlevelet küldtek a parókiákra, melyekben felszólították a hívőket, hogy tegyenek eleget a mozgósító parancsnak. Közel félmillió román katona harcolta végig a Monarchia oldalán a háborút. 1914-ben a birodalmi seregben mintegy 200-250 román tiszt szolgált, akik számára társadalmi elömeneteli lehetőséget jelentett a hadsereg. ${ }^{272} \mathrm{Az}$ 1916-os betörés fogadtatása elsőre ezért váltott ki hüségnyilatkozattal felérő megnyilvánulásokat.

269 Képviselőházi napló, 1910. XXXI. kötet. 656. Országos ülés, 1916. szeptember 5., 448-477.; http://www3.arcanum.hu/onap/a110616.htm?v=pdf\&a=pdfdata\&id=KN-1910_31\&pg=0\&l=hun (Letöltve: 2017. szeptember 19.)

270 Olaszország 1916. augusztus 28 -án hadat üzent Németországnak.

271 Főrendiházi napló, 1910. IV. kötet. A förendiház LXXXII. ülése 1916. szeptember 2., 224-226. http://www3.arcanum.hu/onap/a110616.htm?v=pdf\&a=pdfdata\&id=FN-1910_4\&pg=0\&l=hun (Letöltve: 2017. szeptember 19.)

272 Többek között: M. Alexandru Barbini vezérörnagy, a 33-as gyalogezred parancsnoka, Nagyvárad helyörséggel; Teodor Gabriel vezérörnagy, a 2-es hegyi gyalogezred parancsnoka; Traian Băcilă ezredes, a 7. hadtest 34-es gyaloghadosztálya 29-es dandárjának parancsnoka; Augustin Boeriu ezredes, a 4. hadtest 53-as gyaloghadosztálya 34-es dandárjának parancsnoka; Alexandru Vidoloic ezredes, a 7. hadtest 17-es gyaloghadosztálya 39-es dandárjának parancsnoka; Ioan Boeriu ezredes, a 77-es gyalogdandár parancsnoka. SIGMIREAN, Pro Minoritate, 2016. Tél, 29-32. 
Alexandru Vaida-Voevod magyar országgyülési képviselő, az RNP egyik vezetője a román csapatok erdélyi bevonulása után a Reichspostba a következöket írta: „A román nép [...] Ausztria-Magyarországon megingathatatlanul örzi évszázadokon át kipróbált hüségét a dinasztiához és a hazához ugyanolyan öszinteséggel és szeretettel, mint a múltban. Hiszen a nép ösztöne és hagyományai nem változtathatók meg máról holnapra." ${ }^{273}$ Ștefan Cicio-Pop országgyülési képviselő az ominózus parlamenti ülésen pedig azt mondta, hogy „A magyarországi román nemzetiségi párt mély megdöbbenéssel vette a hírt, hogy a velünk szomszédos Románia hazánk ellenségei sorába lépett és monarchiánknak hadat üzent. [...] Magyarország román népének a trón és haza iránti hüsége törhetetlen". ${ }^{274}$ Megdöbbenésének adott hangot azért is, mert Románia azzal az Oroszországgal fogott össze, amely véleménye szerint leginkább veszélyeztette a román nemzetet. Az ortodox és a görögkatolikus egyházak előljárói mind hüségükről tettek tanúbizonyságot 1916-ban. Radu Demeter nagyváradi görögkatolikus püspök, a förendiház román nemzetiségü tagja így nyilatkozott: ,saját, valamint papságom és hiveim nevében igaz hazafias érzelmeinkhez képest a magas trónhoz, a dicső uralkodóházhoz és a magyar szent koronához való tántorithatatlan hüségünknek és ragaszkodásunknak kifejezést adhassak". ${ }^{275}$ A Szatmár megyei Brebán Sándor esperes egy táviratot juttatott el Tisza István miniszterelnöknek, a Nagybányának, illetve a Szamosnak ${ }^{276}$, amelyben a nagybányai és a felsőbányai görögkatolikus esperesi kerületek gyülését követően, alattvalói hüségről tanúskodott. „Biztositjuk a Szatmár megyei románságnak a magyar haza iránt való tántorithatatlan hüségéről, amely érzelmeinknek Öfelsége Apostoli Királyunk előtt is kifejezést adtunk."277

A Román Királyság háborúba lépése nem okozott látványos dezertálásokat, és a román tisztek sem tettek eleget a román vezérkar erre való felhívásának. Eleinte az erdélyi románság szimpátiája is felemás volt a bevonuló csapatok iránt, amint azt a román vagy egyes hivatalos magyar körök várták. A számos helyen tapasztalható tartózkodó, majd változó magatartásban a háború kimenetelében való bizonytalanság mellett a románokkal szemben történt tömeges internálásoknak minden bizonnyal szerepük lehetett.

\footnotetext{
273 Vajda-Voevod Sándor országgyülési képviselőnek, a Román Nemzeti Párt vezetőségi tagjának cikke a monarchiabeli románoknak Románia hadüzenetével szembeni állásfoglalásáról. KEMÉNY G.: Iratok ...19141916. 1999. VII. kötet, 105/A. irat, 681.

274 Képviselőházi napló, 1910. XXXI. kötet. 656. Országos ülés, 1916. szeptember 5., 452. http://www3.arcanum.hu/onap/a1 10616.htm?v=pdf\&a=pdfdata\&id=KN-1910_31\&pg=0\&l=hun (Letöltve: 2017. szeptember 19.)

275 Uo. 225; 452-454.

${ }^{276}$ A hazai románság és a román háború. Szamos, 1916. XLVIII. évf. szeptember 1. 2.

277 Testvérek vagyunk. Nagybánya, 1916. XIV. évf. 36. szám, szeptember 7. 2.
} 
A távozó román hadsereggel sok román értelmiségi elmenekült, Fogaras és Szeben vármegyékből főként a községi elöljárók távoztak. A román hadsereg kiüzését követően a magyar kormányzat megtorló intézkedéseket vezetett be a román lakossággal szemben. Több száz román nemzetiségü személyt, főleg értelmiségieket fogtak perbe, tartóztattak le és internáltak (A belügyminiszter 1917 őszén 825 fő internálását ismerte el.) „Kémperekre” is sor került, és abban (végre nem hajtott) halálos ítéletek is (1917. április, Kolozsvár, 9 halálos ítélet) születtek. ${ }^{278}$ 1917-ben került sor arra az elrettentésül is szolgáló ítéletre, amikor 10-10 évi szigorított börtönre ítélték Sánta Illés madéfalvi és Imre Mihály göröcsfalvi román lakosokat. A vád mindkét esetben az állam ellen elkövetett bűntett volt. A román megszállás alatt önként községi bírói tisztséget vállaltak és a helyiek állatállományát elrekvirálták a román hadsereg részére. ${ }^{279}$

Tisza miniszterelnöksége alatt az erdélyi román vonatkozásban két fontos elemet érdemes kiemelni. Folyamatosak maradtak az egyházi vezetőkkel fenntartott kapcsolatok, amelyek részben alkalmasak voltak az egyes túlkapások mérséklésére. Emellett ugyanakkor a háborús intézkedések részeként, különösen 1916 nyarától az erdélyi román vezetőkkel és intézményekkel szembeni jogkorlátozások és internálások alkalmazása a magyar kormányzat fokozódó radikalizálódását vetítette előre. ${ }^{280}$ Tisza 1917 májusi lemondását követően Apponyi Albert, az Esterházy Móric vezette kormány vallás- és közoktatásügyi minisztere a Romániával határos megyékben hozzákezdett az ún. kultúrzóna felállításához. Kilátásba helyezték, hogy az összes román felekezeti iskola helyét állami tanintézet vegye át, és mindösszesen 15-18 tanintézetet akartak meghagyni a román ortodox egyház birtokában. A magyarországi románság ellen irányuló intézkedés volt továbbá, hogy korlátozták a nemzetiségi lakosok ingatlanforgalmát. Minden ingatlaneladáshoz vagy bérbe adáshoz előbb a kolozsvári székhelyü, Bethlen István által vezetett Erdélyi Ingatlanforgalmi Bizottság engedélye kellett. ${ }^{281}$ (Az állami beavatkozásra vonatkozóan további tervek is születtek, amelyeket lásd később az Erdélyi Szövetség címü alfejezetben.)

\footnotetext{
${ }^{278}$ Pontos adatokkal nem rendelkezzünk az internált románok számáról. A magyar történetírás 1000 fő körülre teszi az internáltak számátt, de egyes román becslések 6000 föt is említenek. L. BALOGH, Pro Minoritate, 2016. Tél, 24; Erdély története, SZÁSZ, 1986. 1698.

${ }^{279}$ Az oláh bírók büntetése. Csíki Lapok, 1917. XXIX. évf. 9. szám, április 25. 1-2.

${ }^{280}$ SZARKA, Pro Minoritate 2016. Tél, 12.

${ }^{281}$ L. Balogh, Pro Minoritate 2016. Tél, 25; Erdély története, SZÁSZ, 1986. 1698-1699.
} 
Az erdélyi sajtó kiemelt helyen foglalkozott a román hadsereg erdélyi bevonulásának helyi társadalomra gyakorolt következményeivel. A hírlapok egyfelöl jelentős mennyiségü információt szolgáltatnak a veszteségekről, illetve az újrakezdés kihívásairól. Másfelől a magán- és egyéb levelek (katonalevelek stb.) mellett nagymértékben befolyásolták az otthon maradottak háborúról, Romániáról, hazafiságról, nemzetről való gondolkodását. A Románia hadüzenetét tárgyaló parlamenti felszólalások, az országos és a helyi lapok szókészlete szinte szó szerint megegyezett. „Orvtámadás”, „árulás”, „hitvány szövetséges” jelzőkkel írták le mindenhol a volt szövetséges román állam akcióját. Harag, elfogultság, gyülölet, harci szellem párosult a nemzet nagyságát propagáló retorikával. A Nagybánya lap a következőképpen számolt be a hadüzenetröl: Románia „meglepetésszerüen tette ezt, mintha gyalázatos orvtámadásával még hitvány szövetségesét, Olaszországot is túl akarta volna szárnyalni" ${ }^{282} \mathrm{~A}$ Csiki Lapok, amely hat hónapig kénytelen volt felfüggeszteni müködését, ${ }^{283}$ az újraindulásról hírt adó cikkben az „alattomos orvtámadás” utáni feladatok megszervezéséről írt (hadikárok összeírása, visszatelepítés, közélelmezés). ${ }^{284}$

A történeti források másik információgazdag csoportja a magániratok. Katona Csaba „Háború van-e már Romániával?” című tanulmányában naplókat, visszaemlékezéseket elemzett. Ezek a magániratok, mint sajátos forrásbázis nem a román-magyar világháborús harci eseményekre fókuszálnak, hanem a katona szemszögét tárja elénk. Kókay László (Szeged, 1897.-Budapest, 1972.) önkéntesnek jelentkezett Szegeden, 1915 tavaszán. Júniusban a szegedi háziezreddel Brassóba ment, ahol a kiképzőhelye volt az ezrednek, itt érte a román hadüzenet. A napló érzékletesen tükrözi az általános feszültséget, a katonák bizonytalanságát, a semmiből jövő, de hadüzenet híján mégis kétségekkel kezelt román támadás hírének hatását. ${ }^{285}$ „Visszatérve szabadságomról, feltünt az a komoly veszedelmet sejtető hangulat, mely Brassón uralkodott. Csapatszállitások, s különösen tüzérségi vonatok sürün jöttek [...] éjjel egész jól látható volt, amint a románok a Bucsecset fényszórózták, a román háború réme fenyegetöleg közeledett. [...] augusztus 27-én [...] hallottuk azt a hírt, hogy Romániával 1/2 7 óta minden közlekedés (távírda, telefon, vasút) szünetel. [...] augusztus 28-án menetfelszerelésben beérkezünk az óvárosba, a Kolostor utcára. Mindenütt ijedten futkosó nép. A tramway vágányain tehervagonok, s ebbe pakolnak sokan bútort, s egyéb dolgokat. Úgy látom, menekülni akarnak. [...]

\footnotetext{
${ }^{282}$ Románia hadat üzent. Nagybánya, 1916. XIV. évf. 35. szám, augusztus 31. 3.

${ }^{283}$ A lap korábbi föszerkesztőjét, Pál Gábort 1917. februártól Dr. Élthes Gyula váltotta. (Pál Gábor munkásságát lásd később.)

${ }^{284}$ Előfizetöinkhez. Csíki Lapok. 1917. XXIX. évf. 1. szám, február 28. 1-2.

${ }^{285}$ KATONA Csaba: „Háború van-e már Romániával?” Pro Minoritate, 2016. Tél. 37-49.
} 
Már a Bolgárszer keskeny, köves föutcáján kapaszkodunk felfele a hegyekbe. A bolgárszegi oláh lakosság bezzeg nem éljenez, egy lelket se lehet látni az utcán, be vannak zárkózva."286

A háborús pusztítás a helyi társadalom mindennapjaira gyakorolt negatív hatása az élet számos területéről vett példával illusztrálható. A visszatérő lakosság szempontjából például mielőbb pótolni kellett a gyógyszerellátmányt. Tekintettel arra, hogy a visszaköltözőket elláthassák gyógyszerekkel, előbb kártalanítani kellett a városokban és községekben kifosztott patikusokat, csak Csíkszeredán és környékén 24 károsult gyógyszerészröl kellett gondoskodni. A belügyminiszter a részükre összesen 170.000 koronát utalt ki. ${ }^{287} \mathrm{~A}$ károsultak megsegítésének több formája is létezett. Eleinte államilag ruha- és élelmiszersegélyeket utaltak ki a rászorulóknak, majd Kolozsváron és Budapesten megszervezték az Erdélyi Menekültek Segítő Bizottságát. Városokban, járásokban, falvakban helyi bizottságok szervezték a segítségnyújtást. A menekültek részére több városban jelöltek ki lakásokat, állítottak fel konyhákat. Például Nagyváradon 400 lakást és 3 iskolát biztosítottak, de hasonlóan jártak el Aradon, Szabadkán, Jászberényben, Marosvásárhelyen stb. Báró Szentkereszthy Béla, Háromszék vármegye főispánja háláját fejezte ki Bernády György marosvásárhelyi polgármesternek, hogy mintegy 10-12 ezer háromszéki menekültnek biztosított ellátást. ${ }^{288} \mathrm{~A}$ visszatelepítés segítésére, a szétzilált gazdasági és közigazgatási élet helyreállításának irányítására 1916 szeptemberében a kormány Kolozsvár központtal külön erdélyi kormánybiztosságot szervezett (elnöke Koós Mihály, aki korábban a székely akció vezetője volt). Bethlen István nemcsak katonaként szolgált ebben a biztosságban, de aktívan részt vett a társadalmi segélyezésben is, megszervezte a Pro Transsylvania mozgalmat.

\footnotetext{
${ }^{286}$ PINTÉR Csaba: „Azt hiszem, háborúba megyünk...” Kókay László brassói naplója a román hadba lépés idejéből. Nagy Háború Blog, http://nagyhaboru.blog.hu/2016/08/27/_azt_hiszem_haboruba_megyunk (Letöltve: 2017. szeptember 23.)

${ }^{287}$ A kirabolt erdélyi gyógyszertárak helyreállítása. Csíki Lapok. 1917. XXIX. évf. 1. szám, március 7. 2.

${ }^{288}$ Hogyan fogadták a brassói menekülteket Jászberényben? Brassói Lapok, 1916. 198. szám, szeptember 10.; A románok Háromszék vármegyében. Brassói Lapok, 1916. 199. szám, szeptember 14.; Mi történik a románok által megszállt határvidéken? Brassói Lapok, 1916. 200. szám, szeptember 17.; Hírek a megszállt Brassóból. Mi történik Háromszék vármegyében? Brassói Lapok, 1916. 201. szám, szeptember 21.; Kézdivásárhely megszállásának hiteles története. Brassói Lapok, 1916. 202. szám, szeptember 24.; A háromszéki föispán nyilatkozik a menekülésröl. Brassói Lapok, 1916. 204. szám, október 1.; Mi történt az oláh megszállás alatt? Menekültek lakjegyzéke. Brassói Lapok, 1916. 209. szám, október 19.; Epizódok a brassói oláh uralom idejéről. Brassói Lapok, 1916. 211. szám, október 26.; Kiket gyilkoltak meg a románok a Brassó megyei községekben? Kézdivásárhely és Székelyudvarhely az oláh uralom napjaiban. Brassói Lapok, 1916. 218. szám, november 19.; 202. A m. kir. belügyminiszter 1917. évi 63.286. számú körrendelete valamennyi vármegyei és városi törvényhatóság első tisztviselőjéhez Csík, Háromszék, Fogaras, Brassó, Szeben és Huny ad vármegyék kivételével, a törvényhatóságoknak a menekültek segélyezéséért nyilvánított köszönetéröl. Budapest, 1917. június 12. Sándor János. Magyarországi Rendeletek Tára 1867-1945. 731-733.

(https://library.hungaricana.hu/hu/view/OGYK_RT_1917/?pg=766\&layout=s\&query=Fogaras. Letöltve: 2017. szeptember 25.)
} 
Bethlen szerepvállalását Tisza István azzal honorálta, hogy Károly királlyá koronázásakor (1916. december 30.) megkapta a titkos tanácsosi címet, illetve megpróbálta bevonni kormányába. ${ }^{289}$ A károsultak kártalanítása egy következő jelentős feszültségforrás volt. A többség pénzbeli segítséget, esetleg az elpusztított javak helyreállítását remélte. Bethlen István 1917. március 3-án tartott országgyülési beszédében foglalkozott a kártérítés ügyével. Megkülönböztette a stratégiai (magyar csapatok megsemmisítette vagyontárgyakat, annak érdekében, hogy ne kerüljenek román kézre), az ellenség (megsemmisült állatállomány, lakóházak és középületek kifosztása), a helyben maradt lakosság (főként kisebb értékü vagyontárgyak elrablása), illetve a magyar csapatok (önhatalmú rekvirálások) ${ }^{290}$ által okozott károkat. Bethlen a kormánytól első lépésként azt követelte, hogy nyújtsanak természetbeni támogatást (tenyész- és igavonóállat-segélyt, élelmiszerraktárak feltöltését) a visszaköltözőknek, mielöbb kezdjék meg a lakosság kártalanítását, illetve állítsák le az önkényes rekvirálásokat. ${ }^{291}$ A Csíki Lapok 1917 nyarán arról számolt be, hogy a vármegyében a kárösszeírást követően a jóvátételi eljárás ügyében érdemi lépés nem történt, sőt, még az 1914. évi orosz betörés során kárt szenvedetteket sem tudták kárpótolni. ${ }^{292}$ Csíkszereda helyreállítása még 1919 tavaszán is komoly kihívást jelentett. Ujfalusi Jenő polgármester 1919. márciusban kelt indítványában a helyiek segítségét kérte a város újjáépítéséhez. A városvezető többek között arról tájékoztatott, hogy „, a tüzkárt szenvedett lakosság már három év óta hajléktalan. 1916. és 1917. évben épitkezni az akkori hadi helyzet miatt nem lehetett. 1918. évben részben azért, mert a város által életbeléptetett épitési tilalom miatt szünetelt az épitkezés. A folyó évben azért nem lehet épitkezni, mivel a város belsö területének rendezésével a megszervezett kormánybiztosság nem készült el.”293 1918-1919 fordulóját követően pedig a román megszállás és az átmenettel járó problémák (áruhiány, drágaság) nehezítettek bárminemű helyi aktivitást.

\footnotetext{
${ }^{289}$ ROMSICS 1991. 60-64.

${ }^{290}$ Bethlen közvetlen erdélyi információi alapján arról számolt be, hogy a magyar hadsereg önkényesen rekvirálta a takarmány- és állatállomány készletet Kis-Küküllö, Szilágy, Kolozs, Szatmár vármegyékben.

291 Képviselőházi napló, 1910. XXXV. kötet.710. Országos ülés, 1917. március 3., 6-8. http://www3.arcanum.hu/onap/a110616.htm?v=pdf\&a=pdfdata\&id=KN-1910_35\&pg=9\&l=hun (Letöltve: 2017. szeptember 27.)

${ }^{292}$ Erdély gazdasági reorganizációja és a hadikárok megtérítése. Csíki Lapok, 1917. XXIX. évf. 19. szám, július 4. 1.; A témában lásd továbbá: SUSLIK Ádám: A hadmüveleti területek sajátosságai Bereg és Ung vármegye példáján 1914-1916 között című doktori disszertációját, amely a katonai hadmüveletek mellett a polgári közigazgatásban, a gazdasági viszonyokban és az egyházi életben bekövetkezett változásokat mutatja be. http://corvina.kre.hu:8080/phd/Suslik_Adam_Javitott_kezirat.pdf (Letöltve: 2017. szeptember 26.)

${ }^{293}$ Csíkszereda újjáépítése. Csíki Lapōk. 1919. XXXI. évf. 9. szám, március 9. 1.
} 
A front elvonulását követően a mindennapi élethez szükséges intézményes müködés csak részlegesen tudott helyre állni, amelyre példa az oktatás lassú újjászervezése. Az 19161917. évi tanév több hetes, de volt olyan székelyföldi település, ahol több hónapos késéssel vette csak kezdetét. Immár azokban az erdélyi városokban is, ahová a román támadás nem ért el, - a besorozásokon, a halálhíreken, a hadi kölcsönökön, a rekvirálásokon túl - közvetlen tapasztalattá vált a háború. A katonaság az első hadsereg parancsnokság részére például Kolozsváron lefoglalta az erdélyi római katolikus státus főgimnáziumának helyiségeit, a Farkas utcát kordonnal elzárta, és a kegyesrendi kalazantinumot (tanító szerzetesrend tanárképző internátusa) kisajátította katonai hivatali célokra. ${ }^{294}$ A szamosújvári állami főgimnázium épületét szintén lefoglalták és tábori kórházzá alakították. Több iskola vezetője, köztük a szamosújvári állami fógimnázium, a kolozsvári és a marosvásárhelyi református kollégium vezetői is arról számoltak be, hogy a háború hatása nemcsak a tanulók szorgalmára és magatartására volt negatív hatással, de az általános drágaság miatt a tanulók szükös élelmezése, elszállásolása, a tantermek és a frontszolgálatot teljesítő tanárok hiánya, a menekültek ellátása komoly kihívás elé állította az oktatási intézményeket. ${ }^{295}$ Azokon a településeken, ahol fegyveres harcokra is sor került, a leírtakon túl további problémákkal kellett megküzdeni. A székelyudvarhelyi református kollégium az 1916-1917. évi tanévet, a reformáció 400. évfordulóján egy járványkórháznak használt óvoda épületében kezdte el. Az internátus (bentlakás) megsemmisült, a menekülés miatt a hallgatói létszám pedig rendkívül megfogyatkozott. Míg az előző tanévben a beiratkozott tanulók száma 279, addig a csonka évben már csak 78 rendes és 52 magántanulójuk volt. Elsősorban azoknak a tisztviselőknek a gyermekei maradtak a kollégiumban, akiket hivataluk helyhez kötött, és akik nem bírták vállalni más városban a taníttatás költségét. A váratlanul ért támadás után a politikai beszédmód is azonnal megváltozott, az erőszak szimbóluma mindjobban részévé vált a mindennapoknak.

\footnotetext{
${ }^{294}$ Az erdélyi róm. kath. státus kegyesrendiek vezetése alatt álló kolozsvári fögimnáziumának értesitője az 19161917. évi tanévről. Közzé teszi: Rietly Károly igazgató. Kolozsvár, Szent Bonaventura Könyvnyomda, 1917. 2-3. ${ }^{295}$ A szamosújvári M. Kir. Állami Fögimnáziumának 23-ik évi értesítője az 1916-1917. évröl. Közli: Dömötör János igazgató. Szamosújvár, Todorán Endre „AURORA” Könyvnyomdája,1917. 13-18; A kolozsvári református kollégium értesitője az 1916-1917. iskolai évről. Kiadja: Az elől járóság. Kolozsvár, Gombos Ferenc „Lyceum” könyvnyomda, 1917. 18-19; A marosvásárhelyi ref. kollégium államilag segélyezett fógimnáziumának értesitöje az 1916-1917-ik iskolai évröl. Kiadja: Paál Gusztáv kollégiumi igazgató. Marosvásárhely, Benkó László Kollégiumi könyvnyomda, 1917. 19-22.
} 
Bíró Sándor igazgatóhelyettes a tanévnyitó beszédében a következő szavakkal írta le a kialakult helyzetet: „testvéreink is ellenségeink lettek,” „orozva maró kutya,” „nemzetünk színe, virága, ereje elszórva idegen földeken vért izzad [...], a kenyér gondja nyom, a bizonytalanság mardos". ${ }^{296}$ A sepsiszentgyörgyi Székely Mikó Kollégium közösségét hasonlóan megrendítette a háború. Csutak Vilmos igazgató ${ }^{297}$ a front elvonulását követően, 1917. február 20-án a következő szavakkal nyitotta meg az 1916-1917. évi tanévet. „Nagy öröm ér ma bennünket, hogy iskolánknak az alattomos oláh betörés által a kitüzött időben erőszakosan félbeszakitott hazafias és kulturális munkáját újból megkezdhetjük." ${ }^{298}$ Zayzon Ferenc fögimnáziumi tanár pedig így fogalmazott: „, mindennapi kenyérért az itthoniaknak a harcolókéval [Értsd: az erdélyieknek a külföldön harcolókéval - F. N.] csaknem egyértékü küzdelmet kell szenvedniük, mikor az orvul ránk támadó ősi ellenség" támadt. ${ }^{299}$

A sajtócenzura bevezetése mellett a szabadutazás is a korlátozások közé esett, ahol mindenkire kiterjedően szigorú ellenőrzést vezettek be. A háború idején a hadsereg az egyes területeket irányítása alá vehette, kizárva a kormány szerveit, ha azok menekülésre kényszerültek. A gazdasági és a társadalmi intézmények megfelelő koordinálásához rendeleti kormányzást vezettek be. A kelet-magyarországi vármegyéket belső és külső hadműveleti területekre osztották, amelyekre vonatkozóan az utazási szabályokat a belügyminiszter állapította meg 1917 januárjában. ${ }^{300}$ A külső hadműveleti területeken belül a személyforgalom nem esett korlátozás alá, de az onnan ki- és belépést a rendőrhatóság engedélyéhez kötötték. A belső hadműveleti terület határvonalait ezzel szemben tilos volt átlépni.

\footnotetext{
${ }^{296}$ A székelyudvarhelyi Reform. Kollégium értesitöje az 1916-1917-ik iskolaévről. Szerkesztette: Bíró Sándor helyettes-igazgató. 1917. Székelyudvarhely, Becsek D. fia könyvnyomda, 10-15.

${ }^{297}$ Csutak Vilmos (Zágon, 1878.-Sepsiszentgyörgy, 1936.): latin, történelem tanár, helytörténész. 1916-tól a Székely Mikó Kollégium igazgatója, a Székely Nemzeti Múzeum őre, majd igazgatója (1916-1936). (http://mek.oszk.hu/03600/03628/html/c.htm\#CsutakVilmos. Letöltve: 2017. szeptember 21.) Az impériumváltást követően részt vesz a kisebbségi magyarság politikai képviseletének megszervezésében, Háromszéken a Magyar Nemzeti Párt egyik alapítója, 1922. február 18. (Lásd később.)

${ }^{298}$ A sepsiszentgyörgyi Református Székely Mikó-Kollégium ötvennyolcadik értesitöje. 1916-1917. Szerkesztette: Csutak Vilmos igazgató. Sepsiszentgyörgy, Jókai-Nyomda Rt. könyvnyomda, 1917. 5.

${ }^{299}$ Uo. 9.

${ }^{300}$ Hadmüveleti terület: a hadműveleti irányba eső hadszíntérnek az a része, amelyen a seregtestek - az ellenséggel közvetlen harcérintkezésben - hadmüveleteiket folytatják, harcukat vívják. Méretét, szélességben a seregtestek müködési sávjainak határai, mélységében a hadmüveleti hadtápkörletek hátsó határai szabják meg. Katonai értelmezö szótár. Budapest, Zrínyi Kiadó, 1976. 201.

Belső hadműveleti területhez tartoztak: Csík, Beszterce-Naszód, Brassó, Fogaras, Háromszék, Máramaros, Szeben vármegyék. Hunyad vármegyének petrozsényi, puji, hátszegi és szászvárosi járásai (a piski-alvinczi-vasúti vonal kivételével), Krassó-Szörény vármegyének karánsebesi, teregovai, orsovai, bozovicsi és újmoldovai járásai, Maros-Torda vármegyéből az alsó- és felsőrégeni járások. Külső hadműveleti területhez tartoztak: Alsó-Fehér, Bereg, Kisküküllő, Kolozs, Nagyküküllő, Szatmár, Szolnok-Doboka, Temes, Torda-Aranyos, Torontál, Ugocsa vármegyék, illetve Hunyad, Krassó-Szörény, Maros-Torda vármegyék (kivéve a belső területhez tartozó járásaik). I. melléklet a 3.000/1917. B. M. eln. számhoz. A hadműveleti terület ez időszerinti beosztása és határai, valamint a katonai engedély kiállítására jogosult parancsnokságok és hatóságok. Magyarországi Rendeletek Tára 18671945. 1917. 51. évf. Kiadja a Magyar Királyi Belügyminisztérium, 596-600.
} 
Kivéve azoknak, akik katonai vagy más hivatalos közügyekben jártak el, illetve a katonaságtól kivételes engedélyt kaptak. Az egyes települések közti mozgás arcképes személyazonossági igazolvánnyal történhetett, amelyre csak előzetes ellenőrzésen átesett személyek voltak jogosultak. ${ }^{301}$

301 32.000/1915. B. M. eln. szám. A hadműveleti és megszállott területekre vonatkozó utazási szabályok. Magyarországi Rendeletek Tára 1867-1945. 1917. 51. évf. Kiadja a Magyar Királyi Belügyminisztérium, 586596. 


\section{ERDÉLYI SZÖVETSÉG: INTÉZMÉNY-ÉS PROGRAMTÖRTÉNET, 1913-1918}

\subsection{Elözmények, alakuló ülés, politikai fogadtatás}

1913 őszén az erdélyi függetlenségi ellenzéki erők kezdeményezőként léptek fel a politikai mozgósítás és a párt újjászervezése érdekében. Erre azért került sor, mert az 1910-es választást követően mind a képviselőház párt- és személyi összetételében, mind az ország választókerületeiben a függetlenségiek radikálisan visszaestek. 1913 nyarán, a párton kívüli függetlenségiek, a Függetlenségi és 48-as Kossuth Párt, a Függetlenségi és 48-as Justh Párt (mindkettő vezéréről, Kossuth Ferencröl, illetve Justh Gyuláról kapta nevét) újraegyesültek Egyesült 48-as és Függetlenségi Párt néven. ${ }^{302}$ Az aktivizálódás mögött két ok minden bizonnyal közrejátszott. Egyfelöl a székelyföldi törvényhatósági jogú választásokon több helyen is felülkerekedtek a munkapárti képviselőjelöltek. Csík vármegyében például a kiosztható 69 mandátumnak a háromnegyedét nyerték meg az egynegyed függetlenségivel szemben. ${ }^{303}$ Háromszék vármegyében pedig meghatározó helyi függetlenségi politikusok, például báró Apor János, dr. Király Aladár ${ }^{304}$, dr. Czeglédi Miklós, Végh Endre maradtak alul a munkapárti jelöltekkel szemben. ${ }^{305}$ Székelyfölddel ellentétben azonban fontos sikernek bizonyult, hogy Kolozsváron a függetlenségi érzelmü, Haller Gusztávot választották polgármesterré, aki 1918. december 24-ig, a román hadsereg Kolozsvárra való bevonulásáig irányította a várost.

\footnotetext{
${ }^{302}$ Az 1910-es belpolitikai változások mértéke az 1905-öshöz volt fogható, amikor a dualizmus történetében először az ellenzék szövetsége megnyerte az országgyülési képviselőválasztásokat. A Tisza-féle Nemzeti Munkapárt 1910-ben megszerezte a mandátumok 62\%-át, a valamikori Szabadelvủ Párthoz hasonlóan nagyszámú kerületben (a kerületek 77\%-ában) állított jelöltet. A megosztott függetlenségi csoport, amelynek három pártja még az országgyülés feloszlatásakor is együttesen a mandátumok 61\%-ával rendelkezett, egyenként nem sorakoztatott fel a győzelemhez elégséges politikust. A Justh-, illetve a Kossuth-párt egy sor kerületben (az összes kerület 10\%-ában) egymással is összecsapott, ahol nevető harmadikként a Munkapárt került ki győztesen. A csoport részben éppen megosztottsága miatt csak a mandátumok 26\%-át tudta megszerezni. BOROS ZsuzsannaSZABÓ Dániel: Parlamentarizmus Magyarországon (1867-1944). Parlament, pártok, választások. Budapest, ELTE Eötvös Kiadó, 2014. 61, 154.

${ }^{303}$ Törvényhatósági tagok választása. Csíki Lapok, 1913. XXV. Évf. 47. szám, november 19. 2.

${ }^{304}$ A királyi ügyészség helyi vezetője, a koalíciós kormányzat alatt alispán. Részt vesz a Magyar Szövetségben. 1917-től Háromszék főispánja. A román prefektus karhatalommal távolította el, kiutasították Erdélyből. Belügyi Szemle

${ }^{305}$ A legtöbb kistelepülésen, de Kézdivásárhelyen és Sepsiszentgyörgyön is többséget szerzett a munkapárt. A munkapárt győzelme Háromszék megyében. Kolozsvári Hirlap, 1913. XIV. évf. 283. szám, november 29. 2-3.
} 
Ekkor vált a városi közgyülés tagjává: Apáthy István egyetemi tanár, 1918-tól a Magyar Nemzeti Tanács Erdélyi Bizottságának vezetője, Janovics Jenő ${ }^{306}$ színházigazgató, 1918-ban a Magyar Nemzeti Tanács alelnöke, Kenéz Béla, Boér Elek, Pósta Béla, Somló Bódog, Szádeczky-Kardoss Lajos egyetemi tanárok, Ferencz József erdélyi unitárius püspök, akik az impériumváltás időszakában a magyarság politikai képviseletének fenntartásában, új intézmények létrehozásakor is szerepet vállaltak. ${ }^{307}$ Másfelől az 1914-es választásokra történő felkészülés (a háború kitörése miatt erre nem került sor), amelynek politikai kontextusát Tisza István második kormányának (választójogi reform, sajtótörvény, egyesülési és gyülekezési jog korlátozása, helyi közigazgatás túlkapásai stb.) és nemzetiségi politikájának ellenzése jellemezte.

Bethlent a birtokpolitikai küzdelem eredménytelensége, és Tisza „békülékeny” nemzetiségpolitikája arra sarkallta, hogy szövetségeseket keressen az erdélyi politikai céljaihoz és Tisza-ellenes támadásaihoz. Ehhez sokat nem is kellett várnia, 1913. december elején Apáthy István és báró Kemény Árpád az erdélyi magyar függetlenségi ellenzék nevében egy manifesztumot bocsátott közre „Védjük meg Erdélyt!” címmel. A kiáltvány Erdély önvédelmének megszervezését és egy erdélyi szövetség megalakítását irányozta elő. Az erdélyi kérdést országos és európai fontosságú ügyként jelölték meg, követelték annak Budapestről történő erőteljesebb támogatását. Tanácskozásra hívták össze Erdély minden ellenzéki pártszervezetét. „Tanácskozásainkra a munkapárthoz tartozó honfitársakat - sajnos - nem hívhatjuk meg, mert az ő politikai hitvallásuk a jelenlegi és mindenkori kormány cselekedeteinek birálat nélküli helyeslése és türelmes bevárása annak, amíg a kormányzati bölcsesség Erdélyt lemetszi Magyarország testéről." ${ }^{308}$ A Tisza-féle román tárgyalások és a kormánypárt ellenesség az erdélyi magyar politikai és budapesti ellenzéki körök között, az áthidalhatatlannak tűnő ellentéteket felülírva, megteremtette az együttműködés feltételeit. $\mathrm{Az}$ előkészítő-bizottság ülését 1913. december 7-ére, Kolozsvárra hirdették meg párhuzamosan az erdélyi függetlenségiek gyülésével. ${ }^{309}$

\footnotetext{
306 Janovics Jenő (1872. Ungvár-1945. Kolozsvár): színész, színházi és filmrendező, színigazgató, forgatókönyvíró, illetve a Polgári Radikális Párt kolozsvári tagozatának vezető egyénisége. A Kolozsvári Nemzeti Színház igazgatója és az erdélyi filmgyártás kezdeményezője, szervezője. 1913-ban készült el Kolozsváron az első erdélyi film, a Sárga csikó. Ugyanitt 1913-1920 között több mint 50 filmet készítettek, amelyek megvalósításában Janovics is közremüködött. Janovics Jenő müvészetéről lásd: ZAKARIÁS Erzsébet: Janovics az erdélyi Hollywood megteremtője. Editura Tractus Arte, Bukarest, 2014; BALOGH Gyöngyi-ZÁGONI Bálint (szerk.): $A$ kolozsvári filmgyártás képes története 1913-tól 1920-ig. Magyar Nemzeti Filmarchívum, 2009

${ }^{307}$ Az új polgármester. Kolozsvári Hírlap, 1913. XIV. évf. 279. szám, november 25. 2.

${ }^{308}$ Védjük meg Erdélyt! Csíki Hírlap, 1913. III. évf. 49. szám, december 6.2 ${ }^{309}$ Uo.
} 
Apponyi Albert, Justh Gyula függetlenségi képviselőket díszes lovasbandérum és fáklyás menet élén Apáthy István és Haller Gusztáv kolozsvári polgármester fogadta. A kolozsvári Vigadó termében ekkor jelent voltak: Beck Lajos országgyülési képviselő, az EMKE nevében Sándor József, báró Kemény Árpád nyugalmazott föispán, báró Wesselényi Miklós koronaőr, a Bethlen Istvánhoz közel álló Désy Zoltán, illetve Ugron Gábor volt Maros-Torda vármegye főispánja, akiket beválasztottak a vezető tanácsba. ${ }^{310}$ Továbbá a kolozsvári, a gyulafehérvári, a nagyenyedi, a székelyudvarhelyi, a marosújvári, a dévai, a gyergyószentmiklósi, a marosvásárhelyi, a tordai, a brassói stb. függetlenségi párt helyi képviselői. ${ }^{311}$

Az ülést Apáthy István nyitotta meg. A társadalmi és politikai szervezet létrehozását a belpolitikai válsággal, a kormányzati legitimitás hiányából fakadó „cselekvéstelenséggel”, illetve a román nemzeti mozgalom térnyerésével indokolt. „Nem kell-e az önvédelem gondolatának minden erdélyiben fölvetödnie akkor, midőn az erdélyi érdekek védelmében az országgyülésre nem számíthat, mert országgyülés nincs."312 Akié a föld, azé az ország politikai szlogenbe burkolva vázolta fel az erdélyi földkérdés kihívásait, a magyarság románsággal szembeni térvesztését. Egy alacsony kamattal müködő Erdélyi Magyar Bank létrehozást javasolta, amely a magyar birtokos réteg földvásárlásához nyújthatott volna megfelelő anyagi fedezetet. A munkában tanítók, papok és jegyzők segítségére számított, akik a falusi lakosságot adminisztratív úton segítették volna a föld megvásárlásakor.

\footnotetext{
${ }^{310}$ Désy Zoltán: (Nagyölyves, 1862-Zalesczyki, Galícia, 1915): függetlenségi politikus. 1892-ben nemzeti párti programmal országgyülési képviselő, 1896-ban Maros-Torda vármegye alispánja, majd Szolnok-Doboka vármegye föispánja. 1905-ben függetlenségi párti programmal lett országgyülési képviselö. 1906-ban a koalíciós kormányban pénzügyminiszteri államtitkár. 1910-ben Kossuth párti programmal nyert parlamenti mandátumot Marosvásárhely 2. választókerületében. Ö robbantotta ki a hírhedt Lukács-féle panamapert. Azzal vádolta a miniszterelnököt, hogy „Európa legnagyobb panamistája”, hogy a Munkapárt képviselői korrupció útján kerültek a parlamentbe. A bírósági eljárás során öt felmentették, mire Lukács miniszterelnök lemondott. Önkéntes jelentkezés útján került az I. világháborúban a frontra, ahol elesett.

Ugron Gábor (Marosvásárhely, 1880-Bakonybél, 1960): politikus, miniszter. 1906-tól Ugocsa, majd 1907-től Maros-Torda vármegye és Marosvásárhely főispánja. 1910-ben, a koalíció bukása után lemondott főispáni tisztségéről. Főgondnoka volt a marosvásárhelyi római katolikus egyházközségnek, igazgatótanácsosa az erdélyi római katolikus státusnak, s az udvarhelyi országos katolikus autonómia kerületnek megválasztott képviselője. 1913-ban Andrássy Gyula alkotmánypártjához csatlakozott, egy ideig a párt igazgatója. 1915-ben - Désy Zoltán halálát követően - a megüresedett marosvásárhelyi 2. választókerületben parlamenti mandátumot szerez. 1917 ben, Tisza István bukása után az Esterházy és a Wekerle-kormány belügyminisztere (1917. jún. 15.-1918. jan. 25.). 1918. március-június között Erdély királyi biztosa. A polgári demokratikus forradalom idején megszervezte a Székely Nemzeti Tanácsot, a forradalomban nem vett részt. A Tanácsköztársaság bukása után részt vett a Nemzeti Szabadelvü Párt megalakításában. A Demokrata Párttal történt egyesülés után a Nemzeti Polgári Párt elnöke lett. 1926-ban csatlakozott Bethlen István Egységes Pártjához.

Magyar országgyülési almanach, 1927-1932. http://mpgy.ogyk.hu/mpgy/alm/al927_32/296.htm (Letöltve: 2017. szeptember 5.)

311 Az Erdélyi Szövetség megalakulása. Kolozsvári Hírlap, 1913. XIV. évf. 291. szám, december 9. 3-4.

312 Az Erdélyi Szövetség alakuló ülésének iratai: 1913. december 7. Kolozsvár, Lyceum Ny. 1914. 19. [Továbbiakban: Az Erdélyi Szövetség alakuló..., 1914]
} 
(Ez az eljárás volt az, amelyet a magyarok a románokkal szemben vélelmeztek, kritizáltak.) Erdély iparosítását sürgette, amelyet véleménye szerint az állami monopólium alá rendelt erdélyi földgáz készletek nem megfelelő hasznosítása is csak hátráltatott. Erdély valós parlamenti politikai képviseletét elenyészőnek vélte, a hetvennégy erdélyi képviselőt pedig gyengének az öncélú Tisza-kormánnyal szemben. Az erdélyi választókerületek magyar képviselőinek megválasztása eszerint nem pusztán országgyülési választási eljárás, hanem Erdély és az állami egység védelmére irányuló döntés. Apáthy e ponton védelmébe vette az Apponyi-féle népoktatási törvényt és a magyar nyelv nemzetiségi területeken való tanításának kötelezővé tételét. (Apáthy ennek részleteit egy budapesti gyülésen fejtette ki 1914-ben. Erről később lesz szó.) Az Erdélyi Szövetség feladatát öt pontban vázolta fel: irányítsa az erdélyi közigazgatási intézményrendszert; hozzon létre új nemzeti intézményeket; folytasson nemzeti propaganda tevékenységet; vegyen részt a helyi társadalom mindennapjaiban; szervezzen politikai mozgalmat egy egységesen fellépő erdélyi politikus csoport megválasztásáért; az 1913. évi választójogi törvény helyett az 1912. évi ellenzéki pártok által támogatott tervezetet képviselje, és hívja életre az országos szintü Nemzeti Népszövetséget. ${ }^{313}$ (Lásd erről a 3.3. Nemzeti Népszövetség: az Erdélyi Szövetség kiterjesztett keze című alfejezetet).

Pósta Béla - egyetemi tanár, régész, Kolozsvár törvényhatósági bizottsági tagja, az Erdélyi Szövetség alapítója - Magyarország Ausztriához, illetve Erdély Magyarországhoz való kulturális és oktatási rendszerének elmaradottságát vázolta fel. ${ }^{314}$ A magyar államnyelv erőteljes kiterjesztését követelte, illetve minden községben magyar iskolát javasolt felállítani. Közvetetten felvázolta az ún. kultúrzóna tervét, amely keretén belül a magyar néptanítók magasabb fizetések és pluszjuttatások ellenében oktattak volna a nemzetiségi területeken. ${ }^{315} \mathrm{~A}$ kultúrzóna ötlete az 1916-os román betörés után reális koncepcióként jelent meg, de tényleges alkalmazására csak a román impériumváltást követően, 1924-től került sor már a román nemzeti célok érdekében. ${ }^{316}$

\footnotetext{
${ }^{313}$ Uo. $20-31$.

${ }^{314}$ Pósta Béla (Kecskemét, 1852-Kolozsvár, 1919): 1899-töl 1919-ig a kolozsvári egyetem régészeti tanszékének professzora, az Erdélyi Nemzeti Múzeum tagja, az első két nyelvủ magyarországi régészeti folyóirat megindítója, a kolozsvári régészeti iskola alapítója, 1907-1919 között a magyar múzeumok országos régészeti főfelügyelöje. Pósta Béla születésének százados ünnepe 1862-1962. Budapest, Múzeumok Rota, 1962

Pósta Béla régészeti munkásságát lásd: VINCZE Zoltán: A kolozsvári régészeti iskola a Pósta Béla-korszakban (1899-1919). Erdélyi Múzeum-Egyesület, 2014

${ }^{315}$ Uo. 41-45.

${ }^{316}$ A témában lásd részletesebben: AJTAY András: Kultúrzóna. Magyar Kisebbség. 1924. 15-16. szám, 615-19.; FRITZ László: Erdélyi román kultúrzóna ügye a Népszövetség előtt. Magyar Kisebbség. 1932. 11. évf. 11-12. szám, 348-352; 13. szám, 400-406; 14. szám, 437-444; 15-16. szám, 480-491; 17. szám, 517-524; 18. szám, 557563; BARABÁS Endre: Erdélyi magyar és román kultúrzónák. Magyar Szemle. 1928. 2. kötet, 1-4. szám, 15462.; PAPP József: Erdélyi kultúrzóna ügye a Népszövetség előtt. Magyar Szemle. 1932. 16. kötet, 9-12. szám, 28796.
} 
A felszólalók sorában Kenéz Béla - egyetemi tanár, EMKE igazgatóságának tagja, Póstával egyetemben Kolozsvár törvényhatósági bizottsági tagja és az Erdélyi Szövetség alapítója, a két világháború között magyarországi országgyülési képviselő - következett, aki Erdély iparának, iparvállalatainak, gazdaságának, vízi közlekedésének mielőbbi fejlesztését szorgalmazta. ${ }^{317} \mathrm{Az}$ ásványkincsekben gazdag Királyhágón túli területek történelmi rendeltetéséről beszélt, amelyért külső hatalmak harcolnak Kelet és Balkán kapujában, Magyarország államterületének integritása tekintetében pedig a legveszélyeztetettebb pontja. Éles kritikát fogalmazott meg kormányzó munkapárttal szemben is, amelyet felelősségre vont a Darányi-féle birtokpolitikai javaslat elfektetéséért. Kenéz a telepítési program újratervezését szorgalmazta. ${ }^{318}$ Thorma Miklós erdélyi földbirtokos előadásában a nemzetiségi kérdés megoldásának lehetséges orvoslását egy átfogó közigazgatási reform keretében vázolta fel. Kemény Árpád a megalakítást kimondó javaslatot ismertette, és minimum évi kétszeri ülés (május, október) megtartását javasolta, felváltva Kolozsváron, Marosvásárhelyen és Brassóban. ${ }^{319}$

Az országos politikusok közül Justh Gyula és Apponyi Albert kértek szót. Justh Gyula országos ügyekben foglalt állást, a demokratikus választójogi rendszer megteremtését követelte. „Meg kell védelmezni a népképviseleti rendszert, melynek Magyarországon csak roncsai állnak. A népképviseleti rendszerbe életet kell vinni, a népparlamentet kell megalkotni. Az általános, egyenlő, titkos szavazati jogot kell megteremteni." ${ }^{320}$ Apponyi Albert, Apáthy Istvánhoz hasonlóan az egy politikai közösség (magyar nemzet) és egységes állam struktúra összetartozásának vízióját manifesztálta, amelyre nézve az egyre fokozódó nemzetiségi mozgalmakat reális veszélyként értékelte. A nemzetiségi probléma számára azonban nem abból gyökerezett, hogy a „haza polgárainak egy része más anyanyelvü, [...] anyanyelvükböl kifakadó kulturális egyéniséget szeretik, hogy a határokon túl lakó vérével rokonszenvez", hanem abból, hogy „meggyengül a magyar állampolgári érzés”. 321

\footnotetext{
317 Kenéz Béla (Szolnok, 1874-Budapest, 1946): közgazdász, az MTA levelező tagja. 1917-1917 között a kolozsvári Ferenc József Tudományegyetem, 1917-től a Budapesti Tudományegyetem oktatója. Tagja a kolozsvári Patronage Egyesületnek, az Erdélyi Múzeum Egyesületnek, az Erdélyi Háziipari Szövetkezetnek, választmányi tagja a Magyar Társadalomtudományi Társaságnak, az Országos Ingatlanforgalmi Bizottság tagja. A Tanácsköztársaság alatt az egyetemi oktatástól eltiltották, de utána élete végéig tanított. 1920-ban csatlakozik az Országos Kisgazda- és Földmüves Párthoz, majd az Egységes Párt (Bethlen István) tagja. 1922-1939 között országgyűlési képviselő. Károlyi Gyula kormányában kereskedelemügyi miniszter (1931-1932). A Magyar Revíziós Liga társelnöke. Közgazdászként elsősorban statisztikai és demográfiai kutatásokkal, a munkanélküliség és a nemzeti kérdés gazdasági hatásával, iparstatisztikával és iparvédelemmel foglalkozik. Nemzetgyülési Almanach 1920-1922, 1927-1932. http://mpgy.ogyk.hu/mpgy/alm/al927_32/166.htm (Letöltve: 2018. január 21.) ${ }^{318}$ Az Erdélyi Szövetség alakuló..., 1914. 41-55.

${ }^{319}$ Az Erdélyi Szövetség megalakulása. Kolozsvári Hirlap, 1913. XIV. évf. 291. szám, december 9. 3-4.

${ }^{320}$ Az Erdélyi Szövetség alakuló..., 1914. 67.

${ }^{321}$ Uo. 71-72.
} 
Apponyi meggyőződése arra épült, ha a belpolitikai állapotok megfelelők és az állam nem elnyomóként jelenik meg a nemzetiségek szemében, akkor sem a magyar állameszme, sem a magyar állampolgári érzés nem kérdőjeleződik meg előttük. A zárszót Bíró Balázs, az Erdélyi Múzeum Egyesület (EME) Jog- és Társadalomtudományi Szakosztályának tagja mondta. A legfontosabb feladatot az erdélyi magyarság szupremáciájának biztosításában jelölte meg, amely egy sajátos, regionalista erdélyi gondolkodásban testesült meg. „Mi itt élünk Erdélyben, testvéreik [értsd: a románoké - F. N.] vagyunk jóban, rosszban, mi tehát nem az oláhok ellen szervezkedünk, hanem a közös erdélyi, egységes magyar érdekek miatt." "322 Felszólalásában továbbá cáfolta és alaptalan politikai vádaknak tulajdonította azokat a kijelentéseket, miszerint az Erdélyi Szövetség Magyarország és Erdély unióját szét akarnák szakítani. Arra a bírálatra, hogy a gyülésre a kormánypárt tagjait nem hívták meg, a következőképpen reagált. „,Munkapárt nem létezik, mert van ugyan egy kormány, amelynek társaságában van egy ilyen párt, ez azonban egyetlen programját sem tette közzé. [...] Ennek a pártnak tehát itt nem lehet szerepe." 323

A gyülésen elhangzottak szellemiségét és a célok elérésének politikai eszközeit tekintve egyszerre voltak fellelhetők a demokratizmus és a nacionalizmus elemei, amelyek az állam jogkiterjesztő magatartásában, a választójogi rendszer reformjában, illetve az erdélyi magyarság gazdasági, társadalmi dominanciájának biztosításában kereszteződtek.

Az Erdélyi Szövetség megalakításának tervével szemben több ellentétes vélemény és támadás látott napvilágot. A jövőre vonatkozóan elmondott kolozsvári programbeszédekre Jászi Oszkár, a Huszadik Században reagált röviden. A polgári radikális teoretikus elsősorban Kenéz Béla - Bethlenével megegyező - telepítési javaslatait kifogásolta. Véleményét mégis úgy összegezte, hogy az Erdélyi Szövetség alakuló gyülésén ,régi soviniszta melódiák mellett [...] egészen új, szokatlan és termékenyebb álláspont nyilvánult meg," többek között a választójogról folyó diskurzust illetően. ${ }^{324}$

A Tisza-párti Kolozsvári Hírlap az Erdélyi Szövetség hírét pusztán ellenzéki kezdeményezésként tüntette fel, amely célját tekintve az erdélyi kérdést politikai eszköznek használta. „Eszünk ágában sincs komolyan venni azt a zavaros manifesztumot, melyet Apáthy István Védjük meg Erdélyt! címen Kemény Árpád báró ellenjegyzésével bocsátott ki. [...]

\footnotetext{
322 Uo. 73.

${ }^{323}$ Uo. 75-76.

${ }^{324}$ ROMSICS, 1991. 56-57.
} 
Az erdélyi kérdést, ezt a súlyos gondokat okozó nagy válságot közönséges ellenzéki kortes fegyverré süllyessze.”325 Dr. Pordea Gyula ${ }^{326}$ magyarul kiválóan beszélő kolozsvári román ügyvéd olvasói levélében reflektált a Szövetség megalakulására. Szándékát tekintve azt úgy értékelte, hogy egyfelől egy függetlenségi párti románellenes megmozdulás, másfelől a kormány ellenében az ellenzéki politizálás kelléke. Kiemelte, hogy a manifesztum az erdélyi románság vezetőiről általánosan negatívan fogalmaz, miszerint „,nem képesek az egységes politikai nemzet feldicsőitésére közös munkát folytatni," és ezért meg kell Erdély védelmét szervezni velük szemben. Apáthyék lépését összességében úgy interpretálta, amely a szövegben álló transzilvanista szemlélet (,ki kell zárjon minden fajpolitikát, türelmetlenséget”) és bárminemü magyar-román együttmüködési szándék ellentéte. ${ }^{327}$

A szintén Kolozsváron sorra kerülő Nemzeti Munkapárt gyülésére Tisza István december 5-i román-magyar kapcsolatokat érintő parlamenti beszédét és a román nemzeti párt politikusaival lezárt tárgyalásokat követően került sor. A jövő évre tervezett választásokra való felkészülés a következő szellemben történt. „A munkapártnak három fö eszmét kell terjesztenie. Az elsö: Deák politikájának gondolata. [...] A világ helyzete ma olyan, hogy nagyhatalomnak kell maradni. [...]. A második, erös, intenzív nemzeti politikát kell hirdetnünk. [...] Végül meg kell értetni a magyar néppel, hogy a történelemellenes radikalizmus nem szolgálja a nemzet érdekeit, egy nemzet érdekeit nem szabad semmiért sem kockáztatni." ${ }^{328}$ A Kolozsvári Hírlap „Kész a magyar-román paktum. Gróf Tisza István megnyerte Erdélyt” - a valóságtól eltérö címmel tudósított a miniszterelnök román politikusokkal történő tárgyalásairól. ${ }^{329}$ A munkapárt gyülésére azért is volt szükség, mert a korábbi elnök elhunyt. A megüresedett tisztséget báró Szentkereszthy Zsigmond foglalta el.

\footnotetext{
325 „Erdélyi Szövetség”. Kolozsvári Hírlap, 1913. XIV. évf. 286. szám, december 3. 1.

${ }^{326}$ Dr. Pordea Gyula: kolozsvári román ügyvéd, az EME jogi szakosztályának tudományos előadója, a Román Nemzeti Párt tagja. Két nevezetes eseményben tünt fel Pordea neve. 1) 1914-ben 34 román vádlott védelmét látta el a kismajtényi bünperben, amelyet görög katolikus hívek és lelkészek ellen, valamint hatóság elleni eröszak büntette miatt indítottak. Jaczkovich Mihály (később a debreceni bombamerénylet egyik áldozata), Csaba Adorján főispán, Madarassy István főszolgabíró 1913. április 10-én Kismajtényban iskola és egyház látogatásán erőszakos események történtek. Védőbeszédében kiemelte, hogy „a per nem a kismajtényi harmincnégyek pere, hanem az egész magyarországi románság küzdelmének egy jelenete”. (A kismajtényi bünpör. Szatmármegyei Est, 1914. 2. Évf. 33. szám, április 25. 3.) 2) 1918. novemberben a Kolozs megyei Jósikafalván az Urmánczy birtokot kirabolták, majd a védelmére szervezett fegyveres összecsapásokban 20-30 fö románt kivégeztek (bővebben lásd később). Az eset kivizsgálására egy vegyes bizottságot állítottak fel, amelyben részt vett Pordea Gyula is.

[Kertész Jenő: A tíz év előtti Erdély napjai. Korunk, 1929. január. http://epa.oszk.hu/00400/00458/00239/1929_01_4738.html (Letöltve: 2017. szeptember 16.)

${ }^{327}$ Pordea Gyula: Az Erdélyi Szövetség. Kolozsvári Hírlap, 1913. XIV. évf. 290. szám, december 7. 1-2.

${ }^{328}$ A munkapárt feladata. Kolozsvári Hírlap, 1913. XIV. évf. 252. szám, október 25. 1-2.

${ }^{329}$ Kész a magyar-román paktum. Kolozsvári Hírlap, 1913. XIV. évf. 294. szám, december 12. 2.
} 
A nagygyülésen többek között jelen volt: dr. Kiss Mór ügyvezető elnök, gróf Bethlen Ödön kolozsvári főispán, Dózsa Endre Kolozs megye alispánja, Dr. Gidófalvy István, a teológiai intézet főgondnoka, Költő Gábor törvényszéki bíró, Dr. Réz Mihály egyetemi tanár, Ravasz László református lelkész, Dr. Szádeczky Lajos történész, egyetemi tanár. A német szellemtörténeti gondolkodás gondolataiból kölcsönözve Kiss Mór köszöntő beszédében az állam és az azt vezérlő transzcendentális szellemi áramlatokról és az emberiség civilizálásának tovább fejlődéséről szólt. „Az emberiség erkölcsi világát közös eszmék irányítják, melyek egyegy nagy gondolkodó elméjében születnek, aztán elterjednek és uralomra jutnak. A gondviselés által csoportokra, nemzetekre osztott emberiséget a civilizáció egyesiti. ${ }^{{ }^{3} 30}$ Az utolsó évtized azonban hullámvölgybe került, mert „,korcs eszmeáramlatok kerültek felül, amelyek hatása alatt a polgári jogokat a visszaélés lehetöségébe helyezik, [...] a nemzeti akarat helyett a kisebbség terrorja akar uralkodni”. ${ }^{331}$ Kiss Mór ezzel a parlamenti ellenzékre és a politikai szélsőségekre utalt, majd Tisza István támogatására szólította fel az egybegyülteket. A fiatal lelkész, Ravasz László emelkedett szólásra, aki szintén elismerő szavakkal illette a miniszterelnököt. „Egy történelmi nevezetességü nagy ember, Tisza István azon törekszik, hogy a történelembe egy új fejezetet állítson be. Születik egy nagy gondolat, melyböl nagy, nemzeti eszme lesz, mert egy nagy ember látja meg. A nagy ügy meg van, ez a nemzeti lét, meg van a nagy emberünk is, kiben szinte tragikummá vált a hazaszeretet. [...] Ne legyen Kassandra Tisza, mert ez azt jelentené, hogy minden lángba borul. Lenni kell s hogy mivé, azt Tisza mondja meg." ${ }^{332}$ A soron következő alapszervezetet megalakító politikai munkapárti gyűlésre Kolozsvárt követően Tordán került sor (1914 februárjában, 200 fővel). Az előkészületeket dr. Betegh Miklós Torda-Aranyos vármegye főispánja (1914-től Erdély kormánybiztosa) vezette. ${ }^{333}$

\footnotetext{
${ }^{330}$ Szentkereszthy Zsigmond: Kolozsvári Hirlap, 1913. XIV. évf. 293. szám, december 11. 1.

${ }^{331}$ Uo.

${ }^{332} \mathrm{Uo}$

${ }^{333}$ A választójavaslat módosítása. Kolozsvári Hirlap, 1913. XIV. évf. 43. szám, február 20. 3.
} 


\subsection{Az Erdélyi Szövetség programja, 1914}

Az Erdélyi Szövetség programtervezetének összeállítása nem ment kompromisszumok nélkül.

A 115 tagú vezetőtanácsba azért választották be a december 7-i ülésen részt nem vevő, Apáthyéknál konzervatívabb Bethlen Istvánt és társait, hogy egy valódi programkoalíciót mutathassanak fel. Bethlen és Désy Zoltán annak a bizottságnak is tagja lett, amelynek az volt a feladata, hogy a Szövetség végleges programját hivatott marosvásárhelyi nagygyülést előkészítse. Az egyeztető fórumok lehetőséget biztosítottak arra, hogy a kolozsvári nemzeti demokraták (a függetlenségi eszme elve mentén a választójog általánossá tételét összekötötték a nemzeti célokkal) és a konzervatív nacionalisták megegyezése létrejöjjön. A decemberi üléshez képest januárban megjelenő első írásos tervezet (Az erdélyi szövetség programjának tervezete. 1914) is már Apáthy, illetve Bethlen és Kenéz közeledését mutatta. A kifejezetten Tisza-ellenes él a júniusi gyülésen elfogadott szöveg elfogadásáig alább hagyott, kevésbé voltak hangsúlyosak Apáthy szociális követelései és körültekintőbben fogalmazták meg az államszervezet demokratizálásának ügyét is. Legszembetűnőbb változás a földbirtokpolitika kérdése volt, amely alapvetően Bethlen és Kenéz álláspontját tükrözte. A választójog demokratikus reformja és a népoktatás nyelvére (Lex Apponyi) vonatkozó kolozsvári gyülésen elhangzottak is ugyanebben az irányban változtak. A közös nevező a románokkal kapcsolatos pontban volt megtalálható, amely minden egyéb szakpolitikai ügyet a nemzeti céloknak rendelt alá. Az eredeti tervek közt az is szerepelt, hogy az Erdélyi Szövetség az Erdélyi Magyar Közmüvelődési Egyesület (EMKE) szerve lesz. A program azonban már csak a két intézmény, kiegészülve az Erdélyi Múzeum Egyesülettel (EME), a Nemzeti Népszövetséggel és a Katolikus Népszövetséggel való szoros kapcsolatot tartalmazta. ${ }^{334}$

Az Erdélyi Szövetség 1914. június 7-én, Marosvásárhelyt tartotta meg alakuló gyülését, amelynek szónokai Apáthy István, Thorma Miklós, Bíró Balázs, Bethlen István, Désy Zoltán és Ugron Gábor voltak. Az Erdélyi Szövetség munkatervét az erdélyi ellenzéki politikusok mellett országos jelentőségü függetlenségi képviselők, Apponyi Albert, Károlyi Mihály, Justh Gyula is üdvözölték.

\footnotetext{
${ }^{334}$ ROMSICS 1991. 57; EGRY Gábor: Regionalizmus, erdélyiség, szupremácia. Az Erdélyi Szövetség és Erdély jövője 1913-1918. Századok, 2013. 1. szám, 9. [Továbbiakban: EGRY, Századok, 2013]; Az erdélyi szövetség programjának tervezete. 1914. Összeállította: Apáthy István, Kenéz Béla, Pósta Béla, Thorma Miklós. 1-38. [Továbbiakban: Az erdélyi szövetség programjának tervezete. 1914]; Az Erdélyi Szövetségnek 1914. június 7-én Marosvásárhelyt megalapított szervezete, munkaterve és megválasztott vezetötanácsa. Kolozsvár, Lyceum, 1917. Közölte: BÁRDI, Magyar Kisebbség. 2003. 2-3. szám, 106-114. [Továbbiakban: Az Erdélyi Szövetségnek 1914. június 7-én Marosvásárhelyt megalapított szervezete, 1917]
} 
A gyülés által elfogadott 34 pontos program átfogó, regionális és magyar hangsúlyú munkaterv volt. A politikai szempontok mellett sor került közigazgatási, közgazdasági és közművelődési kérdésekre is.

A szerzők által megjelölt elsődleges probléma, szemben az országos pártok problémaérzékelésével, nem közjogi kérdés volt, hanem az Erdélyért folyó román - magyar politikai küzdelem, és az erdélyi magyarság modernizációjával kapcsolatos társadalmi feladat. A balkáni háborúk tükrében a prioritást Erdély katonai és a Keleti- és Déli-Kárpátok hágóinak megerősítése jelentette, és csak ezután következtek a társadalomszervezéssel és a választójoggal kapcsolatos kihívások. ${ }^{335}$ Megállapításuk értelmében Erdély egy katonai támadás visszaverésére nem volt képes, megfelelő létszámú hadsereg nem állt rendelkezésre. A Szövetség a katonai védelem megerősítését, új hadtestek felállítását követelte, akár a flottára szánt összegek jelentős csökkentése árán is. A nagyszebeni katonai központnak megszüntetését és annak Kolozsvárra vagy Marosvásárhelyre való áthelyezését kérték, abból az okból, mert az erdélyi tisztek és katonák többsége román nemzetiségü volt.

A munkaterv az 1913. évi választójogi törvény és a választókerületi beosztás korrekcióját sürgette, azáltal, hogy az a „magyarság érdekein esett sérelmek orvoslása” megtörténjen. Számukra a negatívum elsősorban abban jelentkezett, hogy egy-egy román választókerületben fele vagy harmada volt a választók száma, amely a románságot hozta előnybe. Például Beszterce-Naszód vármegye 13 ezer lakója egy magyar többségü kerülethez képest egy képviselőt delegált, miközben a 60 ezres Kolozsvárnak csupán két mandátum járt. Nemzeti szempontokat előtérbe helyezve titkos választójogot követeltek a törvényhatósági városokon kívül is minden városi kerületben, ahol az írni-olvasni tudók száma meghaladta a 60 százalékot. Tiltakoztak a román többségű választókerületek kikerekítése ellen és elvetették a román képviselők számának megállapítását. ${ }^{336}$ (Ez utóbbi téma volt Tisza és a román politikusok tárgyalásain is. ${ }^{337}$ ) Elfogadták az erdélyi választókerületek számának csökkentését, mert azzal a román többségü választókerületek száma mérséklődne a magyarságnak tulajdonított „értelmi és gazdasági fejlettség figyelembevételével”. Az önkormányzatokat a politikai és a társadalmi élet megszervezésében kiemelt eszközként említették, amely a városokban domináns magyarság érdekeit kifejezte. ${ }^{338}$ (Az impériumváltást követően a román kormány emiatt a potenciál miatt is korlátozta az önkormányzati rendszert, és annak vezetőit Bukarestből nevezte ki.)

\footnotetext{
335 ROMSICS, 1991. 57.; EGRY, Századok, 2013. 9.

${ }^{336}$ Az Erdélyi Szövetség programjának tervezete. 1914. 4-5.

${ }^{337}$ EGRY, Századok, 2013. 10.

${ }^{338}$ Az Erdélyi Szövetség programjának tervezete. 1914. 5-6.
} 
A nemzetiségi kérdés irányait tekintve a munkaterv előre meghatározását tekintve a francia nemzetkoncepciót képviselte, a minden állampolgárnak kijáró egyéni jogokra épülő egyenlőséget. Minden nemzetiség ezért a magyar nemzet része, külön jogok számukra nem adhatóak, ebből következően semmiféle paktum megkötése sem lehetséges, sőt az állam nem ismerheti el azokat tárgyalófélnek. Ezzel a Tisza-féle tárgyalásokra utaltak. Az egyéni sérelmeket viszont orvosolandónak tekintették, akkor, ha tömegesen, akár milliós számban fordult is elö. ${ }^{339} \mathrm{~A}$ munkatervben hangsúlyos részt ölelt fel az erdélyi magyar társadalom megszervezésének kérdése. Fel kívánták vállalni a külföldre emigrált (például a székelyföldi kivándorlók), illetve a Romániában élő magyarság képviseletét, hazatérésük ösztönzését. A társadalmi összetartozás előmozdítása érdekében és a falusi lakosság bevonásának szándékával szoros együttmüködést, „hathatós részvételt” kívántak müködtetni az erdélyi kulturális, vallásos és gazdasági szervezetekkel. Ezek célja a szociális és gazdasági problémák kezelésében való lokális részvétel, illetve a nemzeti érdekek szolgálatának felébresztése volt. A társadalmi problémák közül külön kiemelték a közegészségügy elmaradottságát, annak előmozdítását és annak e célból történő államosítását. A közigazgatásról szóló részt azzal összegezték, hogy az erdélyi államszervezet a „maga részéről is kellöképpen hozzájárulhasson a Magyar Állam hatalmának és tekintélyének növeléséhez". ${ }^{340}$ Erre akkor kerülhet sor, ha az állam mai szóval a szolgáltató közigazgatás elve mentén az állampolgárokat társadalmi különbségre, „gazdagra, szegényre, vagyonra, osztályra, felekezetre, nemzetiségre” tekintet nélkül segíti. Első lépésként a községi közigazgatást kell átalakítani, mivel az adott rendszerben a magyar államot képviselő jegyző nem segítőként, hanem adóbehajtóként, követelőként jelenik meg a nemzetiségi lakosok előtt, nyomban nemzeti ellentéteket szülve. A nemzeti egység vízió céljából a törvényhatósági és községi hivatalos teendők közül száműzni kívánták a pártpolitikai csatározásokat, mert az nemcsak a parlamentarizmust ássa alá, hanem a tisztviselők párthovatartozása lehetetlenné teszik Erdély politikailag megfogalmazott önvédelmét is.

A gazdaságpolitikai fejezetben hasonlóan keveredtek a nemzeti és a modernizációs szempontok. Elengedhetetlennek tekintették az agrárium fejlesztését, a szakemberképzést, az erdélyi környezeti viszonyoknak megfelelő nemesített vetőmagok, tenyészállatok gazdáknak való eljuttatását, a legelőterületek feljavítását.

\footnotetext{
${ }^{339}$ Uo. 7-8.; Az Erdélyi Szövetségnek 1914. június 7-én Marosvásárhelyt megalapitott szervezete, 1917. 106-107. ${ }^{340}$ Az Erdélyi Szövetségnek 1914. június 7-én Marosvásárhelyt megalapított szervezete, 1917. 108.
} 
A földbirtokpolitika egész területét átfogó törvényben kellene a program szerint a magyar birtokállomány, illetve a középbirtokos struktúrát biztosítani, telepítések révén a magyar kisbirtok számát növelni, a kisegzisztenciákat feltőkésíteni, amely fedezetét egy altruista jellegü, magyar-erdélyi bank létrehozása biztosíthatta volna. Az Erdélyi Szövetség Erdélyt Magyarország ipari központjává kívánta fejleszteni, amelynek fontosabb lépéseit a telekkönyvek rendezésében, a tagosításban, Erdély ármentesítésében és vízszabályozásában, a földgáz természeti erőforrásának felhasználásában, értékesítőipari szövetkezetek terjesztésében, az ipari létesítmények korszerüsítésében, illetve nagyfokú vasútfejlesztésében határozták meg. A földbirtokpolitika kapcsán az ellentéteket hangsúlyozták, míg az iparosodásban a nemzetiségi konfliktusok feloldásának lehetőségét látták. Úgy értékelték, hogy az iparosítás, a nemzetiségi parasztság városokba áramlása a „természeti és politikai elöfeltételek által kijelölt helyeken létesitett iparvállalatok útján részeseivé teszi az erdélyi népfajokat egy magasabb rendü gazdasági jólétnek és müveltségnek". 341

Az utolsó szakasz a közmüvelődési feladatokat taglalta. A magyar nyelv ismeretét az állampolgári egyenlőség alapvető feltételének tekintették, amely minden más polgártárssal való érintkezést biztosítja, például a közhivatalokban, a közlekedésben stb. A hazai népoktatás rendszerében elismerték a községi, a felekezeti, a társulati és a magániskolákat is, nem feltétlenül ragaszkodtak az állami oktatáshoz, de a tartalmi egységet, az államnyelv elsajátítását megkövetelték, vagyis a Lex Apponyi mellett álltak. Nemzetiségi területeken népiskolákat, kisdedóvodákat szerveztek volna, illetve nagy hangsúllyal képviselték a gyakorlati ismeretek oktatását. A falusi népnevelés területén a tanítón kívül kiemelt szerepet kapott az egyház, a lelkész, a jegyző, az orvos, valamint a földbirtokos, akik felelősek a helyi társadalom müveléséért. Az erdélyi középiskolák tantervének kívánalmait illetően, vélhetően Pósta Béla közbenjárásával a történelem és a földrajz oktatásában, összhangban a keleti területek felé irányuló gazdasági expanzió terveivel, javasolták a keleti nyelvek oktatását és a keleti kultúrák megismerését. A kolozsvári turáni társaság eszmeisége abban is megnyilvánult, hogy a felsőoktatásban egy keleti nyelvek tanszékét is fel kívántak állíttatni. ${ }^{342}$

A programnak két fó vonulata volt: a nemzeti demokratikus és a nemzeti társadalomszervező. Az előbbi az egyenlőség eszméjében, a választójogi reform követelésében, a szociális javaslatokban, az iparosodáshoz és a városiasodáshoz füződő reményekben, a müveltség és az oktatási rendszer fejlesztésében, illetve a hatékony és segítő közigazgatásban mutatkozott meg.

\footnotetext{
${ }^{341}$ Uo. 110.

${ }^{342}$ Uo. 111-114.
} 
A nemzeti alapon történő társadalomszervező koncepció alapját a nemzetállami felfogás jelentette, ahol az állam aktív szereplő a társadalmi élet formálásában. Ez egyfelől az alacsonyabb társadalmi rétegek felemelésében fogalmazódott meg, másfelől társadalmi szervezetek létrehozásában és együttmüködésében a magyar célok érdekében. Az Erdélyi Szövetség szerepfelfogásában egyszerre volt jelen a koordináló, a szervező és a nyomásgyakoroló funkció. Az erdélyi politikusokat nemcsak egy platformba kívánta terelni, hanem rajtuk keresztül Erdély regionális érdekeit akarta képviselni az országgyülésben, és a politikai küzdelmekben. Úgy vélték, hogy az erdélyiség politikája nemzeti és politikai egységet kíván meg az önálló regionális politikai, kulturális és gazdasági intézmények létrehozásával párhuzamosan. ${ }^{343}$

Bethlen István az új programmal két okból volt elégedetlen. Nem sikerült megvalósítania, hogy a Szövetség az együttmüködni kész munkapártiakat is soraiba hívja, s hogy az OMGE-hez hasonlóan egy pártérdekektől független, nagy regionális szervezetté váljon. A marosvásárhelyi gyülésen elfogadott szervezeti szabályzatba végül bekerült, hogy a tagok bármelyik párthoz tartozhatnak. A gyakorlati megvalósulását azonban jelentősen gyengítette, hogy egyes függetlenségi és alkotmánypárti képviselők továbbra is nagyon erősen hangoztatták Tisza- és Munkapárt ellenességüket. ${ }^{344}$ Apáthy István a júniusi gyülésen a következőképpen fogalmazott: „Magyarországon ma csak két párt van és a mi e két pártot elválasztja, az nem a politika. Az egyik párt a panamát és a pinkát ${ }^{345}$ félti Magyarországtól, a másik pedig Magyarországot félti a panamától és a pinkától’" ${ }^{346}$ Désy Zoltán még a gondolata ellen is tiltakozott annak, hogy munkapártiak is részt vehessenek az Erdélyi Szövetségben. „Ha az apró csirkefogókat becsukják, akkor a milliók sikkasztójának is börtönben van a helye. Nem tudna mentséget találni egy miniszterelnök számára sem, ott szeretné látni a csendörök közt, de mint vádlottat. ${ }^{" 347}$ Bethlen elégedetlenségének másik oka a választójogi program volt, amely véleménye szerint visszalépést jelentett. Bethlen ugyanis ellenezte a titkosság kiterjesztését.

\footnotetext{
${ }^{343}$ EGRY, Századok, 2013. 12-13.

344 ROMSICS, 1991. 58.

345 Pinka: a kártyázók az asztal közepére tettek egy kis tálkát az aprópénznek.

${ }^{346}$ Az Erdélyi Szövetség gyülése. 1914. XXXIV. évf. 133. szám, június 9. 3.

${ }^{347}$ Uo.
} 
Egry Gábor megvizsgálta a Szövetség politikusainak pártállását, a Szövetség társadalmi bázisát, és ebből világosan kimutatható az ellenzékiek túlsúlya. A tizennégy parlamenti képviselő közül egyedül Bethlen Sándor, a marosújvári kerület képviselője tartozott a Nemzeti Munkapárthoz, a többi tizenhárom politikus a Függetlenségi Párthoz ${ }^{348}$, az Alkotmánypárthoz (Bethlen István) $^{349}$, vagy párton kívüli 67 -es volt ${ }^{350}$. Az ellenzéki túlsúlyt a Csík vármegyei képviselők csoportos részvétele is erősítette, amely azt is mutatta, hogy a Szövetségnek Székelyföldön jelentős támogatottsága volt. A szervezethez csatlakozott régebbi országgyülési képviselők ${ }^{351}$, de a regnáló városi és vármegyei politikusok zöme is függetlenségi volt, például a helyi pártelnökök ${ }^{352}$. A Szövetség a személyi kapcsolatokon keresztül az ellenzéki sajtóval állt leginkább együttműködésben. Például Zágoni István, a Függetlenségi Párt hivatalos erdélyi orgánumának, az Újságnak, Magyar Mihály az Ellenzéknek (1919-et követően a konzervatívnak kikiáltott passzivisták lapja) volt főszerkesztője, Bölöni Zoltán a zilahi Független Újság kiadója, Ferenczy Géza (unitárius egyház főtanácsának gondnoka) az Erdővidék tulajdonosa volt, Sümeghy Vilmos pedig a Magyarország Újságkiadó Rt. igazgatójaként és a Magyar Újságkiadók Országos Szövetsége igazgatósági tagjaként müködött. A Szövetség életében a sajtón és a politikai szereplökön kívül az egyházak, különösen a katolikus felekezethez tartozó személyek vállaltak szerepet. ${ }^{353}$ Szoros kapcsolat állt fenn a Gyulafehérvári Főgimnáziummal, a Katolikus Státussal, az erdélyi Kereskedelmi és Iparkamarával $^{354}$, illetve az EME-vel és az EMKE-vel is. ${ }^{355}$ A marosvásárhelyi nagygyülés megválasztotta 115 fős vezető tanácsát, amely az évi két nagygyülés között a szervezet ügyeiben döntési joggal rendelkezett. A mindennapi ügyeket az elnöki tanács látta volna el, amelynek megválasztására az adott év októberében került volna sorra, de az első világháború kitörése miatt ez elmaradt. A Szövetség érdemi munkáját csak 1917 végén kezdte meg. ${ }^{356}$

\footnotetext{
${ }^{348}$ Barcsay Andor, Győrffy Gyula, Sümeghy Vilmos, Urmánczy Nándor, Valentsik Ferenc, Vertán Endre 349 Désy Zoltán, Gál Sándor, Kállay Ubul, Ugron Gábor

${ }^{350}$ Incze Domokos, Szereday Aladár

${ }^{351}$ Ferenczy Géza, báró Petrichevich Horváth Artúr (unitárius egyház főgondnoka), Teleki Arvéd, Thorma Miklós, Wesselényi Ferenc, Zakariás János

352 Benkő Elek, Bölöni Zoltán, Czeglédi Miklós, illetve Papp József a Függetlenségi Párt titkára

${ }^{353}$ Zlamál Ágoston szentszéki tanácsos, Bárány Lukács örmény katolikus főesperes, Fejér Gerő római katolikus státus igazgatója, Hirschler József kolozsvári egyetemi lelkész

354 B. Bürger Albert elnök, dr. Rácz Lajos titkár

355 Apáthy István, Pósta Béla, Bíró Balázs, Gáspár János, Zakariás János Wesselényi Ferenc, Sándor József. EGRY, Századok, 2013. 12-15.

${ }^{356}$ ROMSICS, 1991. 58.
} 
Megállapítható, hogy az Erdélyi Szövetség megalakulásakor kitúzött célokat, a pártokon felül álló szervezeti politikai nyomásgyakorlást csak korlátozottan volt képes megvalósítani. Hangsúlyos ellenzékisége (Függetlenségi Párt, Alkotmánypárt) hátrányt jelentett a közigazgatással való érintkezésben és a politikai hatalmat gyakorló döntéshozók befolyásolásakor. Az Erdélyi Szövetség hiába rendelkezett szélesebb társadalmi hálózattal, de ezzel együtt volt domináns az erdélyi intézményrendszerben. A szervezet pozíciójának változására 1917 őszén került sor, amikor a Szövetséget újjáalakították és több vezető tagja is országos befolyásra tett szert. ${ }^{357}$

\subsubsection{Nemzeti Népszövetség: az Erdélyi Szövetség kiterjesztett keze}

A Nemzeti Népszövetséget budapesti székhellyel (VIII. kerület, Trefort utca 2.) 1913. szeptember 14-én alapították, hogy országos nyomásgyakorló szervezetként, az Erdélyi Szövetséggel együttmüködve a nemzeti eszme jegyének érdekében a nép kulturális, társadalmi és gazdasági fejlődését propagálja. A Nemzeti Szövetség vezető tisztikara a következő volt: báró Prónay Gábor elnök ${ }^{358}$, Apáthy István és gróf Vigyázó Ferenc ${ }^{359}$ alelnökök. A tiszti karon kívül részt vett a vezetésben egy igazgatótanács, amelynek tagjai között volt báró Kemény Árpád, Sándor József, az EMKE főtitkára, Ugron Gábor ny. főispán. ${ }^{360}$ Tagjai részére ismeretterjesztő füzetek formájában havonta (1 Korona tagdíj ellenében) oktatótartalmú (gazdaság, mezőgazdaság, állam és társadalom), nemzeti célokat megjelentető kiadványt juttattak el. A szervezet jogvédő irodát is működtetett, amely tagjai részére ingyenes tanácsadást biztosított.

\footnotetext{
${ }^{357}$ EGRY, Századok, 2013. 15.

358 Prónay Gábor (Budapest, 1856.-?): jogász, politikus. 1877-ben jogtudományi államvizsgát tett. 1879-ben a lipcsei egyetemen bölcsészettudományi doktorátust szerzett (különösen a történelmet hallgatta). 1875-ben beutazta Olaszországot, 1884-ben Romániát és Bulgáriát. 1881-től 1884-ig a váci választókerületet képviselte. A cenzus alapján 1885-től a förendiház örökös tagja, ahol a förendi ellenzék aktív tagja. Lakhelyei: Budapest, VIII., Trefort utca 2., ahová a Nemzeti Népszövetséget 1913-ban bejelentették, illetve Acsakürt, Pest vármegyében található családi kastély. A Magyar Országgyülés. A förendiház és képviselőház tagjainak életrajzi adatai. Kiadja: A „Magyar tudósító” szerkesztősége. 126.

Elérhető: https://library.hungaricana.hu/hu/view/OGYK_Almanach_1906-1910_2/?pg=0\&layout=s (Letöltve: 2017. szeptember 11.)

${ }^{359}$ Gróf bojári Vigyázó Ferenc Antal József (Bécs, 1874.-Bécs, 1928.): politikus, a felsőház tagja, jogi író. 1895 ben grófi címet kapott I. Ferenc József magyar királytól. Az 1905. évi választáson az apatini kerület képviselőjévé választotta, de a következő évben nem vállalt képviselöséget. A förendiház tagja volt 1918-ig, itt több ízben viselt jegyzői tisztséget. 1928-ban öngyilkos lett. Országgyülési Almanach 1910-1915. http://mpgy.ogyk.hu/mpgy/alm/al910_15/001.htm (Letöltve: 2017. szeptember 12.)

${ }^{360}$ A tisztikar további tagjai: Baján Gyula fötitkár, a szövetség közlönyének szerkesztője, Kutkafalvy Miklós föügyész, Ágh Endre, Hucik Elemér, Katona Imre, Nádas Miklós, Salamon Rezső szervező-titkárok. Az igazgatótanács további tagjai: Battlay Dezső ügyvéd, Fothi József író, tanár, Lajos Dénes, Németh Zoltán hírlapírók, gróf Vay Gábor gróf, illetve választottak egy százötven főből álló választmányt is.

A Nemzeti Népszövetség szervezkedése Pest megyében. Ellenzéki Hirlap. Újpest. 1914. XI. évf. január 25. 1.
} 
Felekezeti és nemzetiségi különbségre való tekintet nélkül minden 16. évét betöltött állampolgár jelentkezését követően felvételt nyert. ${ }^{361}$ Országos szervezeti hálózatot igyekeztek kiépíteni, de a kezdeti lendületet a világháború kitörése megakadályozta. A vidéki szervezkedés állomásai közül kiemelkedő volt Békés vármegye, ahol Öcsödön, Kondoroson, Nagyszénáson ${ }^{362}$, Gádoroson, Csorváson, Szentetornyán ${ }^{363}$, Orosházán, illetve Békéscsabán alakultak helyi csoportok. Utóbbi helyen a tudósítás szerint ezer fös közönség előtt szónokolt Prónay Gábor. A báró népszerüségéhez minden bizonnyal az is hozzájárult, hogy nagybátyja, báró Prónay Dezső ${ }^{364}$ békéscsabai országgyülési képviselőként nyújtott segítséget a város fejlesztéséhez. ${ }^{365}$ Ezt követően Szabolcs vármegyében, Nyíregyháza központtal ${ }^{366}$ alakult helyi alapszervezet, amelyet további nyolc kisebb település ${ }^{367}$ követett.

Hogy mennyire azonosak voltak a két szervezet politikai és szellemi gyökerei, azt jól mutatja Pál Gábor Az erdélyi veszedelem cikkének hangvétele (Pál Gábor életútját lásd később). A kormánykritikus tartalmú Csíki Hírlap felelős szerkesztője a magyar-román viszonyt és a magyar belpolitikai helyzetképet a következőképpen írta le. „Ha az oláhok mozgolódnak, mozgolódunk mi is. Természetesnek találjuk, hogy immár az erdélyi kormánypárti [Nemzeti Munkapárt, Tisza István - F. N.] lapok is kezdik lassan-lassan elhinni, hogy a havasi franciáknak [értsd: franciabarát románok - F. N.] nincsenek békés szándékaik. [...] A vészharang megkondítása ellenzéki politikusok részéről történt." ${ }^{368}$ Közülük is kiemelte Apáthy István szerepvállalását a Nemzeti Népszövetségben, aki azzal került a kormánypárti sajtó célkeresztjébe, hogy pártpolitikai alapon megosztja az erdélyi magyarságot.

\footnotetext{
${ }^{361}$ Igazgatótanács tagok: Battay Dezső, báró Kemény Árpád, Sándor József, az EMKE főtitkára. OSZK Kézirattár, Quart. Hung. 2456. Apáthy István hagyatéka [Továbbiakban: OSZK Kézirattár, Quart. Hung. 2456]; A Nemzeti Népszövetség szervezkedése Pest megyében. Ellenzéki Hírlap. Újpest. 1914. XI. évf. január 25. $1-2$.

${ }^{362}$ A nemzeti népszövetség agitációja. Szarvas és Vidéke. 1913. XXIV. évf. 49. szám, november 30. 3.

${ }^{363}$ A Nemzeti Szövetség gyülései. Békésmegyei közlöny, 1913. XL. évf. 85. szám, október 26. 3-4.

364 Prónay Dezső, báró (Pest, 1848. - Acsa, 1940.): jogász, politikus. 1871-től országgyülési képviselő, pártonkívüli, ellenzéki érzelmű. Tagja a förendiháznak. 1883 - 1917 között a magyarországi evangélikus egyház egyetemes felügyelöje. http://keptar.oszk.hu/html/kepoldal/index.phtml?id=055105 (Letöltve: 2017. szeptember 11.)

365 Prónay az 1888. évi árvizet követően a várost körülvevő körgát megépítésében nyújtott segítséget, illetve a károsultak részére 40 ezer Korona alaptőkéjü pénzügyi alapot létesített. 1913-ig a település vezetése többször kérte Prónay Dezsőt, hogy az alapítvány forrásait másra is fordíthassák, amire Prónay Gábor közben járt nagybátyjánál. A Nemzeti Szövetség terjeszkedése. Nagygyülés Csabán és Orosházán. Békésmegyei közlöny, 1913. XL. évf. 94. szám, november 27. 3 .

${ }^{366}$ A Nemzeti Népszövetség Szabolcs megyei értekezlete. Nyirrvidék, 1914. XXXV. évf. 13. szám, február 12. 2.

367 Szabolcs vármegyében a Nemzeti Népszövetség a következő helyeken alakult meg: Tiszanagyfalu, helyi igazgató Bozóky Sándor református tanító; Balsa, helyi igazgató Bugyi Antal gazdálkodó; Tiszatardos, helyi igazgató Dembrovszki Lukács iparos; Gáva, helyi igazgató Kedves Gyula birtokos; Kenézlő, h. i. Rahó András nyugalmazott tanító; Tiszaladány, h. i. Sári Sándor gazdálkodó; Zalkod, h. i. Tarbaj József gazdálkodó; Vencsellő, h. i. Trembeszky József birtokos; Tímár, h. i. Vatamány Sándor gazdálkodó. A Nemzeti Népszövetség Szabolcs megyében. Nyírvidék, 1914. XXXV. évf. 40. szám, május 17.

${ }^{368}$ Az erdélyi veszedelem. Csíki Hírlap, 1914. 4. évf. 3. szám, január 17. 1.
} 
Pál nemcsak megvédte a természettudós politikust, hanem élesen támadta Tiszát, amiért tárgyalásokba bocsátkozott az RNP vezetőivel. Háromszék vármegye törvényhatóság közgyülésében is vitát és ellenállást váltott ki a románokkal való tárgyalásokról szóló hír. A közgyülés függetlenségi érzelmü többsége ezért külön határozatot fogadott el, hogy Erdély védelmének kérdését kiemelt nemzeti ügyként kezeljék. ${ }^{369}$

A Nemzeti Népszövetség politikai célja világos volt, a magyar nemzeti szempontból veszélyeztetett vidékeken a lehető legsürgősebben szervezze meg a magyarság ellenállását. Így került sor a hajdúdorogi görög katolikus egyházmegye magyar híveinek a felkeresésére az 1914 februárjában történt debreceni bombamerényletet követően. ${ }^{370} \mathrm{Az}$ igazgatótanács arra a politikai véleményre jutott, hogy a merénylet nem egyes személyek ellen irányult (Miklósy István görög katolikus püspök), hanem az egész magyar nemzet ellen. Megállapításukat arra alapozták, hogy a Magyarországon élö 304 ezer görög katolikus magyar hívő közül 120 ezer magyar felekezeti tag rutén és román nyelvű egyházmegyékhez tartozott, a hatezer románnal szemben. Azt követelték, hogy a magyar ajkú hívők kerüljenek ki a román püspökök egyházhatósága alól, mert nincsenek biztonságban. A Nemzeti Népszövetség ezért kötelességének tekintette azt, hogy a román egyházmegyékből a hajdúdorogi egyházmegyébe beosztott magyar nyelvü görög katolikus hívőket, illetve az egyéb görög katolikus egyházmegyékhez tartozókat a Szövetség keretén belül megszervezzék. ${ }^{371}$ A Népszövetség a világháború kitörését követően érdemi müködést nem tudott kifejteni.

\footnotetext{
${ }^{369}$ Uo.

${ }^{370}$ A görög katolikusok bizánci szertartású keresztények, akik a Római Apostoli Szék fennhatósága alatt állnak. Ma Magyarországon a mintegy 300 ezer görögkatolikus hívő két egyházkormányzati egységben él: a Hajdúdorogi Egyházmegyében (1912) és a Miskolci Apostoli Exarchátusban (1924). Ferenc József király, mint a magyar katolikus egyház fökegyura, 1912. május 6-án alapította meg a Hajdúdorogi Egyházmegyét a magyar ajkú és identitású görögkatolikusok számára. Az alapítást X. Szent Piusz pápa is jóváhagyta (Christifideles graeci kezdetü bulla). Első püspökévé az uralkodó Miklósy István, sátoraljaújhelyi parókust nevezte ki, aki ellen 1914 februárjában bombamerényletet követtek el. A szálak a román elkövetőkön keresztül az orosz titkosszolgálathoz vezettek. (Jaczkovics Mihály helynök, Slepkovszky János püspöki titkár, Csatth Sándor jogtanácsos vesztették életüket, Miklósy túlélte). Az első világháborút lezáró határmódosítások következtében a Hajdúdorogi Egyházmegye elveszítette parókiáinak mintegy felét. Sok tízezer magyar görögkatolikus az ország határain kívülre került.

Lásd bővebben: Hajdúdorogi Főegyházmegye hivatalos honlapját, http://hd.gorogkatolikus.hu/rolunk-ahajdudorogi-egyhazmegye-tortenete, illetve Szantner Viktor Phd disszertációját: A hajdúdorogi egyházmegye története a kezdetektöl 1920-ig. http://doktori.btk.elte.hu/hist/szantnerviktor/diss.pdf (Letöltve: 2017. szeptember 12.)

${ }^{371}$ A nemzeti népszövetség és a debreceni merénylet. Szatmármegyei Est, 1914. 2. évf. 18. szám, március 4. 2. (A Szatmármegyei Est a Szatmár vármegyei Függetlenségi és 48-as Párt hivatalos lapja volt. Felelős szerkesztő: Dr. Nagy Vince)
} 


\subsection{6-A román betörés politikai tapasztalata: az Erdélyi Szövetség „magyar terve”}

Az Erdélyi Szövetség újjászervezéséhez minden bizonnyal hozzájárult a számára kedvező belpolitikai fordulat. Egyfelől az, hogy a szabadelvü munkapárti kormány és erdélyi ellenzéke közötti ellentét a világháború alatt némileg enyhült, és ez a viszony olyan irányban módosult, hogy egyes ellenzéki vezetők (Bethlen István elsősorban) készek voltak bizonyos ügyek (például választójog) mentén Tiszához közeledni. Másfelől a kialakult kormányválság, amely az ellenzék nyomásának és az uralkodó óhajának következményeként Tisza lemondásához vezetett 1917. májusban. ${ }^{372}$

A pártérdekek alárendelése elsősorban az Alkotmánypártban helyet foglaló Bethlen István politikai magatartásában mutatkozott meg. Az 1917. március 3-án elmondott parlamenti beszédének első felében Erdély aktuális feladatait (kártalanítás, hazaárulók elítélése) és a régió rekonstrukciójával foglakozó nemzeti elvű programját (infrastruktúra, gazdasági és társadalmi modernizáció) ismertette. Második felében nemzetpolitikai víziója, ezzel összefüggésben a nemzeti önrendelkezés elvével szemben a Monarchia kiegyensúlyozó középhatalom fennmaradásának történelmi szükségszerüsége mellett sorakoztatott fel érveket. A térség stabilitása előtt álló legnagyobb kihívásnak a nemzetiségi kérdést jelölte meg. Évek óta a nemzetiségpolitika kormányzati szintre emelését követelte. Érvelésének aktualitását egyfelől Románia Magyarországgal szemben tanúsított fegyveres támadásával, másfelől az antant válaszjegyzékében megfogalmazott kis nemzetek függetlenségét elismerő állásfoglalással támasztotta alá. ${ }^{373}$ Bethlen úgy gondolta, ha a Monarchia felbomlana és létrejönne 10-12 kisállam, azok fennmaradása kétséges lenne, a két hatalmas, a német és az orosz nemzet befolyása alatt, és rövid időn belül „oroszokká, vagy németekké válnának”.

\footnotetext{
372 ROMSICS Ignác: Bethlen István. Budapest, Osiris, 1999. 92-93. [Továbbiakban: ROMSICS: Bethlen. 1999]; VERMES, 2001. 392-425.

${ }^{373}$ Az antant és a központi hatalmak között többször sor került béketapogatózásokra a háború alatt. Az USA hadba lépése előtt (1917. április) felajánlotta segítségét a békés viszonyok helyreállításában, majd 1916. december 20-án - 8 nappal azután, hogy Bécs és Berlin ajánlatot tett (Bukarest elfoglalását követően) az előzetes tárgyalások megkezdésére - felszólította a harcoló feleket, hogy hozzák nyilvánosságra háborús céljaikat. Az antant szövetségesek 1917. január 12-i válaszjegyzékükben a következőket kérték: a központi hatalmak által megszállt területek kiürítése, Lengyelország függetlensége, Elzász-Lotaringia francia kézre juttatása, illetve az Oszmán Birodalom és az Osztrák-Magyar Monarchia uralma alatt élő „kis nemzetek” felszabadítása. Utóbbi pont szolgált Woodrow Wilson 1918. januárban meghirdetett 14 pontos rendezési terve alapjául.

Lásd erre vonatkozóan: DIÓSZEGI István: Az Osztrák-Magyar Monarchia külpolitikája 1867-1918. Budapest, Vince Kiadó, 2001; GALÁNTAI József: Az I. Világháború. Budapest, Korona, 2000; LIGETI Dávid Ádám: A Monarchia béketörekvései 1917-18-ban Arz tábornok emlékiratainak tükrében. Nemzetek és birodalmak. Szerk. Háda Béla, Budapest, ELTE Új- és Jelenkori Egyetemes Történelem Tanszék, 2010. 393-405.
} 
„Ausztria és Magyarország - állapította meg - [...] nem egyéb, mint a kis nemzetek vétója a nagyokkal szemben." ${ }^{374}$ A Monarchia két legerősebb nemzetének, az osztráknak és a magyarnak ezért az a „történelmi hivatása”, hogy e „,negatív összetartozás” helyébe „erös, pozitiv lelket" öntsenek. Az orosz veszélyre való figyelmeztetés az újabb kori magyar külpolitikai gondolkodás egyik alaptétele volt. Bethlen, a kormányzati és az ellenzéki körökben egyaránt ismeretes terveket fejlesztette tovább, amikor javaslatában további (BoszniaHercegovinán túl) délszláv területek annektálása szerepelt (az önálló szerb államiság teljes felszámolása nélkül). Az ország keleti határainak biztosítása érdekében Románia és Magyarország közötti határkiigazításokat, lakosságcserét, állami birtokpolitikát (a szociális szempontokat figyelembe véve) követelt. A határ menti románság helyére megbízható magyarokat kívánt telepíteni, részben moldvai csángókat, részben a háborúban kitűnt veteránokat. $^{375}$

1917 elejétől ismét felerősödtek a választójogi problémakörrel kapcsolatos kormányellenes támadások. Ez megakadályozta a belpolitikában azt, hogy Erdély újjáépítéséhez a kívánt egység létrejöjjön. A kormányfő bár Bethlennek felkínálta egy erdélyi minisztérium vezetését, de ellenzéki társainak várható ellenállása miatt nem fogadhatta el. Így maga is hozzájárult Tisza lemondásához 1917 májusában. ${ }^{376}$ Helyére, IV. Károly az Andrássyhoz közel álló, gróf Esterházy Móricot nevezte ki kormányfővé. Ugron Gábor belügyminiszter (1917. június-1918. január), aki az Erdélyi Szövetség tagja volt, bejelentette, hogy Erdély újjáépítését az Erdélyi Szövetség 1914-es programja alapján kívánja megkezdeni. A minisztert egyúttal Erdély újjáépítését felügyelő királyi biztosnak nevezték ki, amely a Szövetséghez tartozók véleményének országos szintre történő becsatornázását is elősegítette. ${ }^{377}$ Ezt támasztja alá az a levélváltás is, amely a frissen kinevezett belügyminiszter és Apáthy között történt. Ugron elpanaszolta, hogy a román hadsereg által feldúlt keleti részek közigazgatása több mint félév alatt sem állt helyre. A probléma megoldásához erdélyi szövetségeseinek támogatását kérte, hogy a közigazgatás, a városok és a községek tisztségviselőit a kormány nevezhesse ki, és az alkalmatlanokat meneszthesse. Az önkormányzati jogköröket nem szüntette volna meg, de a helyi választójog korlátozását szükségesnek tartotta. Apáthy válaszában Ugront támogatásáról biztosította.

\footnotetext{
374 Képviselőházi napló, 1910. XXXV. kötet. 710. Országos ülés, 1917. március 3.13. http://www3.arcanum.hu/onap/a1 10616.htm?v=pdf\&a=pdfdata\&id=KN-1910_35\&pg=0\&l=hun (Letöltve: 2017. szeptember. 17.)

${ }^{375}$ Uo. 12-16.

376 K. LENGYEL Zsolt: Erdély újjáalkotásának a magyar terve 1917/1918 során. Korunk, 2017/2. 65. [Továbbiakban: K. LENGYEL, Korunk, 2017/2]

${ }^{377}$ ROMSICS, 1991. 60-64.; EGRY, Századok 2013. 15-16.
} 
Ha szükséges a kormány éljen kinevezési hatalmával, és az alkalmatlan, föként munkapárti tisztviselőket bocsássa el. A Tisza ellenes hangvételü levél a választójog korlátozásának kérdéséről nem tesz említést. ${ }^{378}$

Minden bizonnyal a belpolitikai fókusztémák alakításának szándékával készült el 1917 nyarán az a programszöveg, amely Az erdélyi kérdés címmel Apáthy István, az Erdélyi Szövetség egyik ügyvezető elnökének hagyatékában maradt fenn. Az 1917. június 14-i keltezésü névtelen irat, Bethlen márciusban elmondott parlamenti beszédéhez hasonlóan, abból a meggyőződésből indult ki, hogy a Monarchia államjogi feldarabolása „egész mai KözépEurópa végveszedelmét jelentené". ${ }^{379}$ Vélhetően a névtelenség mögött rejlő Apáthy számára a háború és különösen Románia katonai támadása azt tette nyilvánvalóvá, hogy az erdélyi kérdés, mint nemzeti és nemzetközi súllyal bíró probléma megoldatlansága magában hordozza az összeomlás eshetőségét. „Gyökeres s a jövőre is teljes biztonságot nyújtó megoldása egyedül az erdélyi magyarságnak és a vele azonos érdekü, feltétlenül államhü németségnek etnikai túlsúlyra juttatásán sarkallik." ${ }^{380}$ Erdély etnikai viszonyainak ${ }^{381}$ a magyar nemzeti állam érdekeit szolgáló megváltoztatása a „preventív honvédelem” formájában fogalmazódott meg, egy „külön erre hivatott kormányzati szerv” irányításával.

A programterv öt tárgykörben és három általánosabb zárófejezetben tárta fel az Erdélyi Szövetség két kívánságát és hat követelését. I. Közgazdasági szempontból a román kivándorlás és a magyar bevándorlás elősegítése mellett nemzeti földbirtok, kereskedelmi - és iparfejlesztő állami politikát kívánt. II. Tan- és egyházügyi vonatkozásban a görögkeleti és görögkatolikus iskolák és tanítóképzők államosítását, a román állami középiskolák, kultúregyletek állami felügyeletét, illetve a román felekezetekből való áttérések előmozdítását követelte. III. A közigazgatástól a vármegyék új területi beosztását írta elő, annak érdekében, hogy a „magyarság és szászság együttesen lehetőleg minél több vármegyében számszerü többséggel, illetve erös számszerü súllyal bírjon". ${ }^{382}$ IV. Igazságügyi téren az államellenes büntettek megtorlását és a büntetőjog megszigorítását óhajtotta.

\footnotetext{
${ }^{378}$ OSZK Kézirattár, Quart. Hung. 2456.

${ }^{379}$ OSZK, Kézirattár, Quart. Hung. 2456. (Az erdélyi kérdés nyomtatott kiadásban megtalálható, kézírásos jegyzet nélkül a budapesti Országos Széchényi Könyvtárban a 112.352 jelzet alatt is.)

${ }^{380}$ OSZK Kézirattár, Quart. Hung. 2456.

${ }^{381}$ Erre vonatkozó tervek között szerepelt: Maros-menti telepítési akció, a Székelyföldet Kolozsvár környékével és a Partiummal összekötő „,etnikai híd” kialakítása, illetve a román nemzetiségü köztisztviselők áthelyezése az Alföldre vagy a Dunántúlra.

${ }^{382}$ Uo. 5.
} 
V. Szociális vonatkozásban állami intézkedéseket javasolt a természetes népességszaporodás elősegítéséért (közegészségügy intézményes javítása, csecsemő-, gyermek- és anyavédelem, különösen a legnagyobb gyermekhalandóságú székelységnél). Az átfogó jellegű három utolsó fejezet a katonai határvédelem megfelelő szervezését (VI.), a törvényhozás förendiházában az erdélyi részek arányos képviseletét (VII.) követelte. Az emlékirat utolsó pontja (VIII.), a Bethlen és Apáthy által is támogatott „külön (rekonstrukciós) minisztérium felállitását” indítványozta, amely a felsorolt pontok végrehajtásához szükséges törvényjavaslatokat készítette volna elő. ${ }^{383}$

Esterházy kormányzása nem tartott sokáig, 1917 öszén újabb kormányfő cserére került sor, ezúttal Wekerle Sándor vette át a vezetést. Az 1917. évi belpolitikai kormányváltások összességében mégis azt eredményezték, hogy ugyan parlamenti többség nélkül, de a korábbi ellenzék került hatalomba. A közigazgatásban ez úgy tükröződött, hogy a korábbi munkapárti főispánokat a függetlenségi párthoz vagy az Alkotmánypárthoz kötődő személyekkel cseréltek le. A belpolitikai vitákban pedig úgy jelentkezett a változás, hogy ismét a választójogi kérdés került a politika középpontjába és ez a Szövetséget is megosztotta. Az erdélyi politikai erők szervezkedése két irányú volt. Míg a munkapártiak és Bethlen egy választójog-ellenes erdélyi blokk felállításán dolgozott, addig a Kolozsvári Választójogi Liga a választójog kiszélesítésének újbóli deklarálásával közös nagygyülésre hívta össze a függetlenségieket, a szociáldemokratákat, illetve a polgári radikálisokat. ${ }^{384}$ A kolozsvári Újság nem kisebb politikai élccel illette, a Bethlen István, Réz Mihály, báró Jósika Sámuel, Bernády György nevével fémjelzett választójog-ellenes mozgalmat, mint „,múmiák blokkja.” A függetlenségi párti lap a konzervatív arisztokráciát képviselő munkapártiak és a szászság közös lobbijáról írt. Az 50-60 főből álló alakuló ülés névsorából kiolvasható, hogy abban hét szász képviselő, több mint húsz magyar báró ${ }^{385}$ és gróf vett részt kezdeményezőként. Jelzés értékü a titkos tanácsosok kiemelkedő száma, a felsoroltakon kívül további tíz fő. ${ }^{386}$

\footnotetext{
${ }^{383}$ K. LENGYEL, Korunk, 2017/2. 65-66.; OSZK Kézirattár, Quart. Hung. 2456.

${ }^{384}$ 1917. június 6-án, Budapesten megalakult a Választójogi Blokk. Tagjai: Károlyi párt, Radikális Párt, Vázsonyiféle Demokrata Párt, Magyarországi Szociáldemokrata Párt. Céljuk: az általános és titkos választójog kivívása. Június 8-án, Budapesten, IV. Károly budapesti látogatásakor a Liga nagygyülést tartott.

${ }^{385}$ Bárók: Kemény Kálmán titkos tanácsos, Kemény Pál, Szentkereszthy Zsigmond titkos tanácsos. Grófok: Bethlen György, Klebelsberg Kunó titkos tanácsos stb.

${ }^{386}$ Gróf Bánffy György, Béldi Ákos, Betegh Miklós, gróf Bethlen István, gróf Bethlen Ödön, Kálmán Gusztáv, Lukács László, Mangra Vazul, Mikó Bálint, Sándor János

Érdekes eset Mangra Vazul (1852-1918) részvétele. Mangra román nemzetiségi politikus és publicista, aradi teológiai tanár. 1893-ban politikai magatartása miatt felfüggesztették állásából. 1900-ban nagyváradi gör. kel. püspöki helynök lett. 1902-ben aradi püspökké választották, de az uralkodó nem erősítette meg. Később a magyarromán együttmüködés (erről írt könyve: Magyarok és románok. Nagyszeben, 1918.) és a kormány hívévé lett, s ekkor elnyerte a gör. kel. érsekmetropolitai széket is.
} 
A választójog demokratizálását elutasítók mozgalmában olyan személyekkel találkozhatunk, akik a romániai magyar kisebbség politikai életének kialakításában majd fontos szerepet játszanak. Közülük néhány, akik a budapesti kormányhoz szorosan kötődő, 1919 elején szerveződött informális erdélyi központhoz tartoztak: Bethlen György, az Országos Magyar Párt (OMP) elnöke, Béldi Kálmán, a Magyar Szövetség (MSZ) alelnöke, báró Jósika Samu, az MSZ és az OMP első elnöke, Nagy Károly református püspök, Ravasz László egyházkerületi főjegyző (1921-ben repatriált, majd Dunamelléki református püspök), Szentkereszthy Zsigmond, a Felekezetközi Tanács tagja, Szentkereszthy Béla, a Magyar Nemzeti Párt alapítója. Ki lóg a sorból Albrecht Lajos, aki a Magyar Szövetség alelnökeként egy rövid ideig, a transzilvanista Kós-féle Erdélyi Magyar Néppárt elnöke volt, illetve Bernády György, aki 1922től országgyülési képviselő, és az elsők között szólította fel az erdélyi magyarságot a politikai cselekvésre (lesz róla szó később.) $)^{387}$

A választójog reformját ellenzőket ért kritikákra Réz Mihály reflektált, aki a román betörést követően a korábbinál is élesebben támadta a függetlenségi, a szociáldemokrata és a radikális pártot, amelyek fellépésében a korábbi állításait látta visszaigazolni. „A magyar közélet ma két táborra szakad. Az egyik oldalon állnak a régi Magyarországnak hívei. A magyar szupremáciának, a magyar intelligencia vezető szerepének a fenntartói. A másik oldalon állnak a nemzetietlen radikalizmus és a nemzetközi szocializmus régi hívei. Az elnyomott nemzetiségek felszabaditásának és népuralom szükségességének a hirdetői." ${ }^{388}$ Réz szerint az utóbbiak kezében az általános választójog csupán politikai eszköz és nem a végső cél. Egyfelől, mert a szociáldemokraták a plusz jogokkal a fennálló társadalmi és gazdasági rendet, másfelöl a nemzetiségi mozgalmak a területi integritást számolnák fel. ${ }^{389}$ Réz minden politikai engedményben a Monarchia belső válságának eszkalálódását, a nemzetiségi harcok radikalizálódását, az erdélyi románság politikai képviseletének többségbe kerülésének veszélyét, a Monarchia berendezkedésének visszafordíthatatlan átalakulását látta. ${ }^{390}$

1917. szeptember 23-án két politikai eseményre került sor Kolozsváron. Egyfelől a kolozsvári függetlenségi párt (élén Apáthy István) és a szociáldemokrata párt (Nagy Balázs) valamint a polgári radikálisok (Janovics Jenő, színházigazgató, aki 1918-ban a Magyar Nemzeti Tanács alelnöke) - által közösen szervezett Választójogi Liga nagygyülésére, annak érdekében, hogy a választójog kiszélesítését támogatókat egységes táborba szervezzék.

\footnotetext{
${ }^{387}$ OSZK Kézirattár, Quart. Hung. 2456.

${ }^{388}$ Réz Mihály: A demokrácia és a magyarság. Magyar Figyelő, 1917. VII. évf. III. kötet, 145.

${ }^{389}$ Uo. 152-153.

${ }^{390}$ Réz Mihály: A koalíció statisztikája. Magyar Figyelő, 1917. VII. évf. IV. kötet, 217-221.
} 
A Liga aktivitását abban a meggyőződésben fejtette ki, hogy a nemzetiségre és nemre való tekintet nélküli általános, egyenlő és titkos választójog az ezeréves magyar alkotmányossággal összeegyeztethető, és a különféle cenzusok csak bizonyos pártok hatalommegőrzését szolgálják. A területi integritás biztosítását ezért nem a választójog korlátozásában látták, hanem az államellenes vétségek „,büntetőjogi” úton történő szankcionálásában. ${ }^{391}$

A másik esemény az Erdélyi Szövetség Vezető Tanácsának ülése volt, amely az egy héttel később esedékes újjáalakulási gyülést készítette elő. Apáthy, ahogy 1913-ban most is föszerepet vállalt. Bethlen az Erdélyi Szövetség újra indításával egyetértett, de Apáthyval szemben eltérőek voltak a szándékai. Ugron és Apáthy az új kormány támogatására, illetve a választójog demokratizálására kívánták felhasználni a Szövetséget, míg Bethlen Apáthynak jelezte, hogy csak akkor vesz részt az tanácskozáson, ha a választójog nem kerül napirendre. Apáthy végül engedett, mert tudta, hogy Bethlen nélkül a szervezet jelentősége csökkenne. ${ }^{392}$ A tudóspolitikus a választójog kapcsán képviselt nézetéből később sem engedett, amelyet alátámaszt Vázsonyi Vilmos választójogi miniszterrel történt későbbi levélváltása (1918. június 5.). Apáthy Paálhoz hasonlóan ekkor is azt sérelmezte, hogy az erdélyi magyarság több választókerületben el van tiltva a választójog gyakorlásától. Más kontextusban, de hasonló véleménykülönbség alakult ki a brassói magyarokat tömörítő Brassói Egységes Magyar Párt 393 körül is, amikor dr. Hantz Mihály elnök szembe került Zakariás János, az Erdélyi Szövetség, illetve brassói törvényhatósági jogú bizottság tagjával 1917 decemberében. Zakariás és az őt támogatók azt kérték, hogy egy pártgyülés keretében foglaljanak állást az általános választójog mellett, amelyet az ellenkezők megpróbáltak leszavaztatni. ${ }^{394}$ Paál Árpád Udvarhely vármegye főjegyzője és az Erdélyi Szövetség Vezető Tanácsának tagja, Székelyföld magyar társadalmának politikai megerősítése céljából támogatta a választójogi reformküzdelmet. Érvelése szerint 1913-ban, Udvarhely megyében a választásra jogosultak számát feleannyira csökkentették, mint 1874-ben. Számításai alapján a Székelyföld választóinak 1874. évi, 40 év előtti számát 37-38\%-kal apasztották. Ezt a magyarság elleni lépésként értelmezte, amely végeredményben a románság politikai érdekeinek kedvezett.

\footnotetext{
${ }^{391}$ OSZK Kézirattár, Quart. Hung. 2456.

392 ROMSICS, 1991. 64-65.

${ }^{393}$ Egységes Magyar Párt (1910-1918. november): mérsékelt konzervatív, etnikai párt. A párt vezető testületeibe (24-es és 100-as bizottságok) egyenlő arányban kerültek be a korábbi koalíciós pártok politikusai és a Munkapárt helyi vezetői. Első elnökévé dr. Hantz Mihályt (Munkapárt), alelnökévé Szele Bélát (újságíró, függetlenségi párti) választották. A párt célja a kisebbségben élő magyarok egyesítése volt, tekintet nélkül az országos politikai törésvonalakra. A pártot a parlamentben a '67-es elveket valló Szterényi József képviselte (Brassó második választókerületében). A párt hivatalos lapjának a Brassói Lapok számított.

394 OSZK Kézirattár, Quart. Hung. 2456.
} 
A „választójogi kiterjesztéstől való félelmek szerintem se nem jogosak, se nem célszerüek [...] a székelyek szempontjából pedig egyenesen ártalmasak" - figyelmeztetett az állam- és jogtudományi végzettségü Paál. ${ }^{395} \mathrm{Az}$ a gondolat, amely a választójog reformját nemzetpolitikai okokkal indokolta, a világháború végéig a függetlenségi tábor elképzeléseinek egyik kulcseleme maradt. ${ }^{396}$

Az Erdélyi Szövetség másodszori megalakítására 1917. szeptember 30-án került sor Kolozsváron. A tanácskozáson több országos politikus is részt vett: Apponyi Albert vallás- és közoktatásügyi miniszter, dr. Földes Béla (Függetlenségi Párt) ideiglenes gazdasági miniszter, Ugron Gábor belügyminiszter képviseletében Velits Zoltán, Kolozs vármegye új föispánja (1917. július 25.). A Szövetség, ahogy 1913-1914-ben, úgy most is kölcsönös kompromisszumokat követően, megfelelő személyi összetétellel, de immár valóban párt- és vármegyehatárok feletti szervezetként kezdhette meg müködését. Az ülés fő feladata a korábbi program aktualizálása és a 9 tagú Elnöki Tanács megválasztása volt. Az újjáalakulás iratai ügyvezető elnökként nevezik meg Apáthy Istvánt (Kolozsvár), Bedő Sándort (Marosvásárhely) és Zakariás Jánost (aki korábban a székely akció ügyét is képviselte), helyetteseikként báró Petrichevich-Horváth Emilt (Dés), Király Aladárt (Sepsiszentgyörgy), Papp Józsefet (Kolozsvár), Pósta Bélát (Kolozsvár), Thorma Miklóst (Csicsókeresztúr) és Vertán Endrét (Torda). Az Elnöki Tanácsot három elnök vezette: két főnemes, gróf Bethlen István (Budapest és Mezősámsond) és a függetlenségpárti báró Kemény Árpád (Alsógáld), 1906-1910-ben Alsófehér vármegye főispánja, valamint utóbbi párttársa, Ugron Gábor (Marosvásárhely). A világháborút megelőző rövid epizóddal ellentétben most ténylegesen megkezdődött az Erdélyi Szövetség szervezetének kiépítése, amelyről Zakariás János egy későbbi előterjesztése alapján döntöttek november 21-én. A három fös ügyvezető elnökség ${ }^{397}$ feladata volt a területi szervezetek létrehozása vármegyei és választókerületi szinteken. Élükre egy-egy elnököt, valamint külön-külön álló tanácsokat választottak. Az elképzelt szervezeti struktúra, ha maradéktalanul nem is tudott megvalósulni, de Erdély egész területét sikerült behálózni. 1918 tavaszán számos erdélyi föispán és magas rangú közigazgatási tisztviselő csatlakozott az akkor már több mint 100 tagú Vezető Tanácshoz, amely ekkor már az erdélyi kormánybiztosság létrehozását tartotta elsőrangú feladatának.

\footnotetext{
${ }^{395}$ K. LENGYEL, Korunk, 2017/2. 67.

396 Uo.

397 (Kolozsvár: Szilágy, Kolozs, Szolnok-Doboka, Torda-Aranyos, Alsó-Fehér, Beszterce-Naszód vármegyék; Marosvásárhely: Csík, Maros-Torda, Udvarhely, Kis-Küküllő vármegyék; Brassó: Háromszék, Brassó, NagyKüküllő, Hunyad, Szeben, Fogaras vármegyék)
} 
Bethlen a román-magyar békekötésre vonatkozóan a következő javaslatot terjesztette elő: Magyarország elismeri Románia szuverenitását, az viszont elkerülendő, hogy a Monarchia és Románia szorosabbra füzze kapcsolatait. Bethlen tehát felülvizsgálta korábbi álláspontját, és nem számolt romániai területek elcsatolásának a lehetőségével. Ebből következett az a biztonságpolitikai-katonai javaslata, hogy a magyar-román határ kiigazításával egyrészt a Kárpátokon túl egy védelmi zóna felállítására, másrészt a Kárpátokon belül a székely határörség megerősítésével polgári határvédelemre van szükség. A gyülésen emellett Erdély gazdasági rekonstrukciója szempontból az első lépések egyikének a vasúthálózat fejlesztését jelölték meg, illetve a nemzeti érdekeket megjelenítő szociális birtokpolitika megvalósítását, ,, a föld nem csak az egyesé, hanem a nemzeté is". Bethlen, ahogy márciusi beszédekor hiányolta az államellenes tevékenység ellen való határozott fellépést, most a gyülés megerösítette erre irányuló törekvését és támogatták a büntetőtörvénykönyv (1915. évi XVIII. tc.) vagyonelkobzásáról szóló rendelkezésének a szigorítását.

A gyülés egyetértőleg fogadta el egyfelől Bíró Balázs indítványát, a városi fenntartású Kolozsvári Nemzeti Színház államosításáról, illetve újak alapításáról Marosvásárhelyen, Brassóban és Nagyszebenben. Másfelöl a görögkeleti és görögkatolikus tanárképzők fokozott állami ellenőrzésére vonatkozó javaslatokat. Az ülés vége felé Király Aladár volt főispán Háromszék és Csík vármegyék társadalmi feszültségeit ismertette, és külön felhívta a figyelmet a magyar katonák önkényes rekvirálása körül tapasztalt visszaélésekre. Megoldásként azt kérte, hogy a kormány és a föispánok az Erdélyi Szövetséget vonja be a lakosság ellátásának a végrehajtásába. Ez valószínüleg kulcsfontosságú lett volna, ekkoriban ez volt a legfontosabb pozíció és feladatkör, amiből politikai tőkét lehetett kovácsolni. Zakariás János előterjesztésére döntöttek egy központi iroda felállításáról Kolozsvár központtal, illetve a Vezető Tanács tagságának további 19 fővel való kibővítéséről. Ekkor vált taggá Gyárfás Elemér, aki a kisebbségi magyarság egyik meghatározó politikusa lett a két világháború között (lásd bővebben később). ${ }^{398}$

A földbirtok- és telepítési politika az Erdélyi Szövetség egyik központi ügye volt. Báró Petrichevich-Horváth Emil elnökhelyettes 1917. december végén terjesztette elő memorandumát, amelyet a nemzetiségek birtokvásárlásával és az 1916-os román betöréssel indokolt.

\footnotetext{
${ }^{398}$ Uo.; Az 1917. szeptember 30-i Erdélyi Szövetség ülésének jegyzőkönyve továbbá megtalálható még: HM HIL, M. kir. Honvédelmi Minisztérium iratai, első világháború korszaka, 4653. doboz
} 
Az emlékirat a földtulajdon megörzésének és visszaszerzésének a megkerülhetetlen intézkedéseit egyúttal társadalompolitikai eszköznek tekintette részben a magyar kisbirtokosság megerősítése érdekében, részben a magyarság kivándorlásának megfékezésére. A birtokpiac új jogi szabályozását üdvözölte, de eredményét tekintve kevésnek tartotta. A jogszabály hiába preferálta az állami elővásárlás lehetőségét, az eladásra kerülő birtokok nemzetiségi kézbe jutását nem befolyásolta. A tevőleges birtokpolitika eszközeként azt javasolta, hogy Erdély színmagyar vidékein a „kötött birtokot” 10-15 és 200-600 hold nagyságú kis-, illetve kis-középbirtokokra parcellázzák fel, amelynek a bevételei (10 Md Korona) fedezetként szolgálhatnak további föld és erdő felvásárlására. Támogatta a határőrvidékre vonatkozó elképzeléseket, amelynek társadalmi bázisát a földtulajdonnal rendelkező magyar kis- és középbirtokosság jelentette. A koncepció részét képezte a szociálisan érintett rétegeken túl a valamelyest életképes gazdaságok támogatása is, amely az „új földtehermentesités kell Erdélyben" szlogeneken fogalmazódott meg.

Az Erdélyi Szövetség Vezető Tanácsa 1918. január 28-i ülésén felkarolta PetrichevichHorváth ajánlásait. Megbízott egy hattagú munkabizottságot, hogy memorandumban szociális, kulturális és gazdasági érvekkel mutassa ki a kormány számára a földbirtok- és határvédelmi politika összefüggését. Az ülésen szóba került az erdélyi választókerületek új beosztásának a kérdésére is, majd határoztak arról, hogy román többségi arányok kialakulását elkerülve rajzolják újra a választókerületeket. A jelenlévők ezenkívül kormányzati felterjesztésre jóváhagyták a marosvásárhelyi Ipari és Kereskedelmi Kamara titkárának, Rácz Lajos Erdély vasútpolitikája címü gazdaságpolitikai tanulmányát. ${ }^{399}$ Végül szóba került egy olyan hivatal felállításának az ötlete is, amely a lassan haladó erdélyi újjá építkezést karolta volna fel. Élére Ugron belügyminisztert javasolták, akiről nemcsak elkötelezettje az erdélyi kérdésnek, de kiváló ismerője is. 1918. március 6-án Ugront kinevezték az erdélyi királyi kormánybiztosság élére, amely újabb lökést adott az Erdélyi Szövetségnek. 400

A Wekerle-kormány írásban értesült az Erdélyi Szövetség javaslatairól. Azokat megtárgyalta, és egyes pontjait kész volt támogatni, de egészében nem tette magáévá. A Szövetség munkaterve „,nem képezi még a kormány hivatalos programját”, csupán a „,szükséges teendők szerves megállapítása céljából, ezen tanulmányt fogadta el a tárgyalás alapjául”. ${ }^{401}$

\footnotetext{
${ }^{399}$ Dr. Rácz Lajos: Erdély vasút-politikája gazdaságpolitikai tanulmány. 1917. Marosvásárhely. A tanulmány 11 fejezetben tárgyalja a vasút hátrányos állapotát, illetve a fejlesztéshez legszükségesebb feladatokat és terveket (keleti körvasút, határvasút). [Továbbiakban: RÁCZ, Erdély vasútpolitikája. 1917]

${ }^{400}$ K. LENGYEL, Korunk, 2017/2. 69-71.

${ }^{401}$ HM HIL, M. kir. Honvédelmi Minisztérium iratai, első világháború korszaka, 4653. doboz. Tárgy: Erdély rekonstrukciója
} 
A honvédelmi minisztérium egy név nélküli jelentésében (1917. december) az alábbiakról tájékoztatta Wekerle Sándor miniszterelnököt a Szövetség programpontjairól. A vasútfejlesztés katonai szempontból kiemelt beruházásként kezelendő, és támogatásra érdemesnek nevezte a nemzetiségi hadiárvák magyar szellemben való gondozását, bentlakásos internátusokban való nevelését, amelyre az előzetes számítások szerint Kolozsváron és Marosvásárhelyen 2500 főig lehetőség nyílt. A határörvidék létesítésének ötletét ellenben elvetette. A hadsereg főparancsnoksága azt már 1915 novemberében (18025. sz.) felvetette, de „erre a háború alatt még amúgy sincs szükség, miután a kivételes intézkedések a kormány részére a kellö eszközöket biztositják" ${ }^{402}$ A határörvidékek felállítását továbbá időszerütlennek gondolták, és a javasolt formájában és megfelelő források hiányában megvalósíthatatlannak. „Ezen elavult intézmény immár sem a magyar közjogi viszonyokhoz, sem a mai modern védelmi berendezkedésekkel össze nem egyeztethető." 403 A jelentés ezzel szemben szellemiségében és nemzetiségpolitikai célkitüzéseiben megegyezett a Szövetségével. Egyetértettek abban, hogy a háborút követően szükséges a határ mentén egy megfelelő védelmi zóna kialakítása. Azt is megnevezték, hogy milyen szempontokat vegyenek ehhez figyelembe. Egy $25 \mathrm{~km}$ széles katonai sávon belül a hazaárulással elítéltek és az ellenséghez pártolt személyek teljes vagyonelkobzása és családjaik kitelepítése. Az így állami kézbe került földeket rokkant magyar katonák és tisztek részére utalják ki katonai szolgálataikért cserébe. Az ipari vállalatok vezető posztjait pedig kérik, hogy nemzethű személyekkel töltsék be. A helyi társadalomépítés során a magyar tannyelvü iskolák és egyházak kapjanak kiemelt állami támogatást. Az ortodox felekezeti iskolákat, papneveldéket, nemzetiségi egyesületeket pedig vonják állami kontroll alá. ${ }^{404}$

Az Erdélyi Szövetség 1918-tól fokozta intézményesülését. Áprilisban megalakult a Szilágy, júniusban pedig a Kis-Küküllő vármegyei választmánya. ${ }^{405}$ Előbbi azonos volt a helyi függetlenségi párti körrel, de ez a világnézeti kötelék nem akadályozta meg a választmány tagjait abban, hogy kijelentsék: nem pártpolitikai célokat támogatnak, hanem a „nemzeti lét teljességéért való küzdelmet”. A másik helyi választmány létrehozását, a dicsőszentmártoni alakuló ülést 1918. június 29-re hirdette meg Gyárfás Elemér, aki 1917 júliusától töltötte be Kis-Küküllő vármegye főispáni székét.

\footnotetext{
${ }^{402}$ Uo.

${ }^{403}$ Uo.

${ }^{404}$ Uo.

405 Szilágy vármegye elnök: Dr. Bölöni Zoltán, kerületi elnökök: Dinogén János polgármester (Szilágysomlyó), dr. Kósa Béla, ügyvéd (Tusnád), Benkő Elek, földbirtokos (Szilágycseh). Kis-Küküllő vármegye elnök: Gyárfás Elemér, kerületi elnökök: Pataky Sándor (Dicsőszentmárton), Pósta Bertalan (Erzsébetváros), Haller Jenő (Hosszúaszó). OSZK Kézirattár, Quart. Hung. 2456.
} 
A pártpolitikai kötetlenséget hangsúlyozva azzal a kéréssel fordultak a vármegye vezető intelligenciájához, hogy minél többen csatlakozzanak az Erdélyi Szövetséghez. Az említett két vármegyén kívül a Szövetség alapszervezete Szolnok-Doboka, Beszterce-Naszód, TordaAranyos, Alsó-Fehér és Kolozs vármegyékben alakult meg, de a vezetőség névsorán kívül források hiányában tevékenységüket nem ismerjük. ${ }^{406}$

A magyar kormány az Erdélyi Szövetség követeléseiből a világháború végéig két dolgot valósított meg, igaz az egyiket csak részlegesen. Wekerle Sándor kormánya 1917 november 1től minisztériumi utasítással megtiltotta a keleti-délkeleti államhatár mentén fekvő földbirtokok eladását és vásárlását, valamint tíz évnél hosszabb időtartamú bérbeadását, illetve kikötötte az állam elővásárlási jogát ${ }^{407}$. A birtokforgalmi ügyletek szabályozási joga az akkor létesített Erdélyi Ingatlanforgalmi Bizottság jogkörét illette meg, amely Bethlen István vezetésével müködött. A másik intézkedés Apponyi kultusz- és tanügyminiszter felügyeletével megkezdett kelet-magyarországi kultúrzóna megtervezése volt, amelyben a legtöbb román felekezeti iskolát állami tanintézményekkel váltották volna fel. 1918 júniusában 311 román egyházi iskola 477 pedagógusa elvesztette államsegélyét.

1918 utolsó hónapjaiban a világháború eseményei a Szövetség által elképzeltekkel ellentétes irányban zajlottak. 1918. szeptember 11-én az erdélyi királyi kormánybiztosság müködését felfüggesztették. A Szövetség a valóságban utolsó napjait élte, vezetősége 1918 októberében ülésezett utoljára. Az összeomlás hónapjaiban, a történeti Magyarország önmentési kísérlete között a Szövetség irányítói közül Apáthy István vállalt kitüntetett szerepet a Károlyi-kormány által támogatott Kelet-Magyarországi Főkormánybiztosság élén. ${ }^{408}$

\footnotetext{
${ }^{406}$ Szolnok-Doboka vármegye elnök: László László, kerületi elnökök: Abrudbányai Ede (Szamosújvár), Jogomán Antal (Dés), Huszár Ádám (Magyarlápos), Jimó Lajos (Nagyilonda), Torma Miklós (Bethlen). Beszterce-Naszód vármegye elnök: Ugron András. Torda-Aranyos vármegye elnök: Szenkovics Aurél. Alsó-Fehér vármegyei elnök: Fogarassy Albert. Kolozs vármegyei elnök: Ferenczy Lajos. OSZK Kézirattár, Quart. Hung. 2456.

${ }^{407}$ Lásd a teljes rendeletet: A m. kir. minisztériumnak 4000/1917. M. E. számú rendelete, az ingatlanok forgalma tárgyában. Földmivelési Értesitö, 1917. XXVIII. évf. 43. szám, 880-885.

${ }^{408}$ K. LENGYEL, Korunk, 2017/2. 72.; Erdély története, SZÁSZ, 1986. 1898.
} 


\subsection{Az Erdélyi Szövetség funkciói és tagjainak eltérö szerepfelfogása}

Az Erdélyi Szövetség tevékenységét és céljait tekintve egymással összefonódva egyszerre két fö funkciót próbált meg betölteni. Elöször, az országos politikában egyfajta regionális lobbi csoport (pressure group) kialakítására törekedett, ami sikerrel befolyásolhatja a törvényalkotókat és a kormányt a vélt vagy valós erdélyi érdekeknek megfelelő intézkedések meghozatala irányába. Tisza miniszterelnökségét követően erre azért volt esély, mert az erdélyi megyék élére a korábbi ellenzékhez közeli főispánok kerültek, részben a belügyminiszter, Ugron Gábor jóvoltából.

A szövetség vezetőiben hamar felmerült az a gondolat is, hogy az új főispánokat vonják be a szövetség vezető tanácsába. 1917-1918 fordulójától lett tag például Ugron András, báró Diószeghy Zsigmond, Gyárfás Elemér, a régi tagok közül pedig többeket föispánná nevezték ki (Papp József, Velits Zoltán stb.). Bethlen István azon törekvése, hogy a szövetség integrálja a munkapártiakat is egy nagy közös erdélyi politikai csoportba azért sem valósulhatott meg, mert a szövetség döntően a Függetlenségi Párt fennálló szervezeteire épült.

\begin{tabular}{|c|c|c|c|c|}
\hline \multicolumn{5}{|c|}{ Új főispánok kinevezése 1917. június-november között ${ }^{409}$} \\
\hline Név & Vármegye & Korábbi titulus & Előző főispán & Megjegyzés \\
\hline $\begin{array}{l}\text { br. Szentkereszthy } \\
\text { Béla } \\
\text { kormánybiztos }^{410} \\
\end{array}$ & $\begin{array}{l}\text { Temes és } \\
\text { Temesvár sz. } \\
\text { királyi város }\end{array}$ & $\begin{array}{l}\text { Háromszék } \\
\text { főispán }\end{array}$ & $\begin{array}{l}\text { Joanovich } \\
\text { Sándor }\end{array}$ & ESZ, MSZ, MNP, OMP \\
\hline dr. Steuer György & Torontál & miniszteri titkár & $\begin{array}{l}\text { Dellimanics } \\
\text { Lajos }\end{array}$ & $\begin{array}{l}\text { Steuer helyére Botka Béla } \\
\text { NMP ogy. kép. (felmentés: } \\
\text { 1918. XI. 17.) }\end{array}$ \\
\hline $\begin{array}{l}\text { dr. Eöttevényi Nagy } \\
\text { Olivér }\end{array}$ & Krassó-Szörény & $\begin{array}{l}\text { udvari tanácsos, } \\
\text { egyetemi tanár }\end{array}$ & Medve Zoltán & $\begin{array}{l}\text { Felmentés: 1918. XI. } 24 . \\
\text { Helyére: dr. Issekutz } \\
\text { Viktor kormánymegbízott } \\
\text { (MSZ, OMP) }\end{array}$ \\
\hline Purgly László & Arad & földbirtokos & & $\begin{array}{l}\text { Felmentés: 1918. XI. } 17 . \\
\text { Helyére: Varjassy Lajos } \\
\text { polgármester } \\
\text { (ellenforradalmi kormány) }\end{array}$ \\
\hline $\begin{array}{l}\text { Barabás Béla F48P } \\
\text { ogy. képviselö (1892- } \\
\text { 1918) }\end{array}$ & $\begin{array}{l}\text { Arad szabad } \\
\text { királyi város }\end{array}$ & $\begin{array}{l}\text { országgyülési } \\
\text { képviselő }\end{array}$ & Kintzig János & $\begin{array}{l}\text { Felmentés: 1918. XI. } 17 . \\
\text { Helyére: Bartha Albert; } \\
\text { MSZ, MNP }\end{array}$ \\
\hline Pogány Béla & Hunyad & alispán & Mára László & Felmentés: 1918. XII. 01 \\
\hline
\end{tabular}

${ }^{409}$ Új föispáni kinevezések 1917. július-november között Ugron Gábor belügyminiszteri kinevezését követően a Belügyi Közlöny (1917) alapján. A félkövérrel kiemelt személyek a romániai magyar kisebbségi politika kialakításában fontos szerepet vállaltak az impériumváltást követően. A megjegyzés rovatban annak a szervezetnek a rövidítése szerepel, amelyben egyesek szerepet vállaltak.

Rövidítések: Erdélyi Szövetség (ESZ, 1913-1918), Magyar Szövetség (MSZ, 1921-1922), Országos Magyar Párt (OMP, 1922-től), Magyar Nemzeti Párt (MNP, 1922), Függetlenségi és 48-as Párt (F48P); Nemzeti Munkapárt (NMP)

${ }^{410}$ A m. kir. minisztérium az 1912. LXII1. tc. 4. §-a értelmében Szentkereszthy Bélát 1917. október 28-án kormánybiztosnak kinevezik: Arad, Bács-Bodrog, Békés, Bihar, Csanád, Csongrád, Krassó-Szörény, Temes és Torontál vármegyék, valamint Arad, Baja, Debrecen, Hódmezővásárhely, Pancsova, Szabadka, Szeged, Temesvár, Újvidék, Versecz és Zombor városok területére. Belügyi Közlöny, 1917. 53. szám, 1690. https://adtplus.arcanum.hu/hu/view/BelugyiKozlony_1917/?pg=1719\&layout=s (Letöltve: 2018. január 22.) 


\begin{tabular}{|c|c|c|c|c|}
\hline Malatinszky Lajos & $\begin{array}{l}\text { Bihar és } \\
\text { Nagyvárad }\end{array}$ & $\begin{array}{l}\text { járási } \\
\text { főszolgabíró }\end{array}$ & $\begin{array}{l}\text { dr. Miskolczy } \\
\text { Ferenc (1910- } \\
\text { 1917) }\end{array}$ & $\begin{array}{l}\text { Felmentés saját kérésre: } \\
\text { 1918. XI. } 17 .\end{array}$ \\
\hline dr. Rainprecht Antal & $\begin{array}{l}\text { Nagyvárad tvh. } \\
\text { város }\end{array}$ & $\begin{array}{l}\text { törvényszéki } \\
\text { bíró }\end{array}$ & Ciffra Kálmán & $\begin{array}{l}\text { 1918. májustól } \\
\text { Malatinszky Lajos }\end{array}$ \\
\hline dr. Kaizler György & Szilágy & $\begin{array}{l}\text { földbirtokos, ny. } \\
\text { föispán }\end{array}$ & Péchy Imre & Felmentés: 1919. II. 23. \\
\hline $\begin{array}{l}\text { Jékey Sándor } \\
\text { függetlenségi párti }\end{array}$ & $\begin{array}{l}\text { Szatmár és } \\
\text { Szatmárnémeti } \\
\text { sz. királyi város } \\
\end{array}$ & $\begin{array}{l}\text { földbirtokos, } \\
\text { járási } \\
\text { föszolgabíró } \\
\end{array}$ & Csaba Adorján & Felmentés: 1918. XII. 15. \\
\hline ifj. Bolgár Ferenc & Máramaros & $\begin{array}{l}\text { udvari és } \\
\text { miniszteri titkár }\end{array}$ & Nyegre Lázsió & Felmentés: 1918. XI. 24. \\
\hline Ugron András & $\begin{array}{l}\text { Beszterce- } \\
\text { Naszód }\end{array}$ & $\begin{array}{l}\text { tiszteletbeli } \\
\text { föszolgabíró }\end{array}$ & \multirow{2}{*}{$\begin{array}{l}\text { gróf Bethlen } \\
\text { Balázs }\end{array}$} & $\begin{array}{l}\text { Károlyi-kormány } \\
\text { kormánybiztosa; ESZ }\end{array}$ \\
\hline $\begin{array}{l}\text { báró Diószeghy } \\
\text { Zsigmond }\end{array}$ & $\begin{array}{l}\text { Szolnok- } \\
\text { Doboka }\end{array}$ & $\begin{array}{l}\text { földbirtokos, } \\
\text { polgármester }\end{array}$ & & $\begin{array}{l}\text { Felmentés: 1918. XI. } 17 . \\
\text { ESZ }\end{array}$ \\
\hline Velits Zoltán & Kolozs & földbirtokos & \multirow{2}{*}{$\begin{array}{l}\text { gróf Bethlen } \\
\text { Ödön }\end{array}$} & $\begin{array}{l}\text { Felmentés: 1918. XII. } 01 . \\
\text { ESZ }\end{array}$ \\
\hline $\begin{array}{l}\text { dr. Papp József } \\
\text { F48P titkára }\end{array}$ & $\begin{array}{l}\text { Kolozsvár sz. } \\
\text { királyi város }\end{array}$ & $\begin{array}{l}\text { ügyvédi kamara } \\
\text { elnök }\end{array}$ & & $\begin{array}{l}\text { Felmentés: 1918. XII. } 01 . \\
\text { ESZ, MSZ }\end{array}$ \\
\hline $\begin{array}{l}\text { gróf Bethlen Sándor } \\
\text { Nemzeti Munkapárt }\end{array}$ & Torda-Aranyos & $\begin{array}{l}\text { vármegyei } \\
\text { másodföjegyző }\end{array}$ & $\begin{array}{l}\text { dr. Betegh } \\
\text { Miklós } \\
\text { kormánybiztos } \\
\end{array}$ & $\begin{array}{l}\text { Bethlen felmentése: } 1918 . \\
\text { XI. } 17 . \\
\text { Betegh: MSZ }\end{array}$ \\
\hline \multirow[t]{2}{*}{ br. Bánffy Kázmér } & Alsó-Fehér & alispán & Szász József & Felmentés: 1918. XII. 29. \\
\hline & Szeben & & $\begin{array}{l}\text { Waldbaum } \\
\text { Frigyes } \\
\text { szászispán }\end{array}$ & \\
\hline dr. Gyárfás Elemér & Kis-Küküllő & $\begin{array}{l}\text { ügyvéd, } \\
\text { földbirtokos }\end{array}$ & $\begin{array}{l}\text { báró Kemény } \\
\text { Ákos }\end{array}$ & $\begin{array}{l}\text { Kemény MSZ; Gyárfás: } \\
\text { ESZ, MSZ, MNP, OMP }\end{array}$ \\
\hline $\begin{array}{l}\text { báró Petrichevich } \\
\text { Horváth Emil }\end{array}$ & Nagy-Küküllö & $\begin{array}{l}\text { ügyvéd, } \\
\text { földbirtokos }\end{array}$ & Somogyi István & $\begin{array}{l}\text { ESZ, Országos } \\
\text { Menekültügyi Hivatal } \\
\text { vezetöje }\end{array}$ \\
\hline Lengyel Zoltán & Fogaras & föispán & Széll József $^{411}$ & \\
\hline \multicolumn{4}{|c|}{ gróf Mikes Zsigmond Brassó vármegye } & $\begin{array}{l}\text { Felmentés saját kérésre: } \\
\text { 1918. XI. } 17 .\end{array}$ \\
\hline \multirow{2}{*}{$\begin{array}{l}\text { Inczédy-Joksmann } \\
\text { Ödön }\end{array}$} & Maros-Torda, & & Szász József & \multirow{2}{*}{$\begin{array}{l}\text { Felmentés: 1918. XI. } 27 . \\
\text { MSZ, MNP, OMP }\end{array}$} \\
\hline & $\begin{array}{l}\text { Marosvásárhely } \\
\text { sz. királyi város }\end{array}$ & & $\begin{array}{l}\text { Bernády } \\
\text { György }\end{array}$ & \\
\hline dr. Lengyel György & Udvarhely & földbirtokos & Ugron János & $\begin{array}{l}\text { Lengyel helyére Ugron } \\
\text { Ákos (felmentése: } 1918 . \\
\text { XI. 24.) }\end{array}$ \\
\hline dr. Tolnay Lajos & Csík & ügyvéd & $\begin{array}{l}\text { Gyalókay } \\
\text { Sándor }\end{array}$ & $\begin{array}{l}\text { Felmentés: 1918. XI. } 17 . \\
\text { Helyére: Györgypál } \\
\text { Domokos föügyész }\end{array}$ \\
\hline dr. Király Aladár & Háromszék & alispán & $\begin{array}{l}\text { Szentkereszty } \\
\text { Béla }\end{array}$ & MSZ, kiutasították \\
\hline
\end{tabular}

\footnotetext{
${ }^{411}$ A m. kir. minisztérium az 1912: LXII1. tc. 4. §-a értelmében Széll József Fogaras vármegye főispánját a brassói cs. és kir. katonai parancsnokság területére és egyidejüleg az ugyanezen területen müködő legfelsőbb parancsnokság mellé kormánybiztossá kinevezte. Belügyi Közlöny, 1917. 30. szám, 948. (https://adtplus.arcanum.hu/hu/view/BelugyiKozlony_1917/?query=Fogaras\&pg=977\&layout=s) Letöltve: 2018. január 22.
} 
Másodszorra, a szövetség kísérletet tett a regionális társadalomszervező szerep betöltésére. 1916-ot követően új helyzet állt elö Erdélyben, a társadalom egyes csoportjaiban és vezetőikben nagyobb igény mutatkozott a segítség nyújtás és az új, radikálisabb típusú politikai iránt. A szövetség ebben a helyzetben sokkal inkább elfogadottnak bizonyult, mint politikai lobbicsoport és sokkal könnyebb volt számára a társadalom-szervező szerep felvállalása. A menekültek segítésében és az újjáépítésben (kezdetben Bethlen István, később Ugron Gábor kormánybiztos) aktívan szerepet vállaló erdélyi politikusok kulcsszereplőkké váltak, illetve többed magukkal szoros kapcsolatokra tettek szert, mint lobbisták (Kemény Árpád, Zakariás János, Vákár P. Arthur, Kenéz Béla) kormányzati szereplőkkel. Ezen felül megerősödött az EMKE és a szövetség kapcsolata, hiszen a vezető tanács tagjává választják Sándor Józsefet, az EMKE elnökségének főtitkárát, amelyben Apáthy, Pósta és Bíró Balázs is helyet foglaltak. A tagok nem egyszer komoly intézményes háttérrel rendelkeztek, például Barabás Samu református esperes, dr. Sebess Dénes, a budapesti ítélőtábla tanácselnöke, majd az Igazságügyi Minisztérium államtitkára, Zombori László, az erdélyi püspök udvari káplánja, az erdélyiek megsegítésére indított Pro Transsylvania segélyakció vezetője. Összességében elmondható, hogy az Erdélyi Szövetség politikai jelentősége, társadalomszervező lehetőségei és érdekkijáró szerepe megerősödött az 1917 őszi újrakezdést követő időszakban. ${ }^{412}$

Erdélyi Szövetség keretei között tevékenykedők nemcsak eltérő szerepet tulajdonítottak a szervezetnek, de az egyéni, saját szerepfelfogásuk is különbözött. A szövetség egyes reprezentáns szereplőinek életútját és politikai környezetét illetően jelentős mértékű változások következtek be a Monarchia összeomlását követően. Egry Gábor 1918-ig legalább négy, különböző személyekhez kapcsolható szerepfelfogást különített el.

A helyi politikusok kategóriájába, azok tartoztak, akik a szövetség létrejöttét, formálódó ideológiáját, közigazgatási és más intézményi kapcsolataikat a helyi politikai tér átformálására kívánták felhasználni (például a választókerületekről szóló paktum révén). A helyi szervezők legnagyobb része (Thorma Miklós Szolnok-Dobokában, Gyárfás Elemér Kis-Küküllőben stb.) többnyire szilárd közéleti pozíciókat birtokolt, az Erdélyi Szövetség kevéssé volt számukra egzisztenciális kérdés. A brassói ügyvezető elnökké választott Zakariás János ezzel szemben 1917 végére teljesen perifériára szorult a helyi politikában, őt az a Szele Béla buktatta meg egy pótválasztáson, aki 1920-at követően a passzivisták oldalán jelentős politikai szervező munkát végzett a Brassói Lapok főszerkesztőjeként. A helyi politikusok, egy-egy helyi sajátosságtól eltérően, elsősorban a Tisza-rendszer elleni küzdelem eszközét látták az Erdélyi Szövetségben.

${ }^{412}$ EGRY, Századok, 2013. 19-25. 
A transzilvanista vizionárius gondolkodású személyek Erdély kérdését próbálták egységes látószögből képviselni. Elsősorban Vákár P. Arthur ${ }^{413}$ volt az, aki egy még kiforratlan (proto)ranszilvanista eszme mentén nem csak románokkal, hanem valamilyen formában a Magyarországon belüli helyzettel is számot kívánt vetni. Említést tett egy remélt valódi erdélyi vezetőről, egy kormánybiztos eljöveteléről, ezzel bizonyosan Bethlen Istvánra utalt. Erdély nemzetiségeire úgy tekintett, mint akiket a közös múlt és erdélyi származás összeköt. Vákár követelménye az Erdélyi Szövetség programjában feltüntetett faj fogalmával összhangban állt, mert azt úgy határozták meg, mint lelki összetartozást és nem testi bélyeget. Erdély-centrikus felfogásában az Erdélyi Szövetség az egyetlen autentikus megjelenítője volt az erdélyi közvéleménynek. Kritika tárgyává tette azt is, hogy Erdély kérdése régóta inkább csak (Budapestről nézve) a Királyhágón inneni érdeket jelent. Végső konklúziója igazán meglepő volt: Erdély, „Magyarország Kaliforniája”, a „magyar Belgium” képes eltartani önmagát. Ez a következtetés egyértelműen előfutára volt egy néhány hónappal későbbi gondolatnak. Magyarország nem élhet Erdély nélkül, mert Erdély mindennek a kútforrása. Ami korábban csak a jövőre vonatkozott és inkább csak Erdély gyámkodástól való mentességét jelentette, itt már ellenkezőjére fordult. Erdély értékei jelentik Magyarország felemelkedésének a kulcsát is. ${ }^{414}$ Vákár P. Arthur rendkívül aktívnak bizonyult Erdély határőrvidék tervének képviseletében is. A történeti előzményekre támaszkodva, önálló javaslattal állt elő 1918-ban, amelyet Ugron Gábor belügyminiszter elé terjesztett. Vákár összefoglalta Székelyföld „ösi foglalás jogán" alapuló határvédelmi rendszer és a székely nemesi előjogok történetét. A modernkor viszonyainak megfelelő újragondolását a világháború kitörésével, a román betöréssel, az orosz és a román kapcsolatokkal és a „rövidlátó bécsi politikával” indokolta. „A katonailag feloszlatott határörvidékek most lehettek volna igaz oszlopai a dinasztiának s a katonailag szervezett [...] székely határörvidékek most teljesithették volna történelmi feladatukat." 415 Vákár érvrendszerében a Magyarország nem élhet Erdély nélkül gondolat itt is szerepet kapott.

\footnotetext{
${ }^{413}$ Vákár P. Arthur egyedüli politikus, aki fölszólalt az Országházban a törökországi örmény népirtás ellen. A román katonai betörés után a kelet-magyarországi fökormánybiztosság Csík vármegye kormánybiztosa. 1919-től a gyergyói medence közhatóságának vezetője, az Antant fegyverszüneti bizottságát és a velük bevonuló román csapatokat fogadta. Letartóztatták (egykori osztálytársa) Iuliu Maniu menlevele megmentette és emigrált. 1919 öszén Bethlen Istvánnal megalakította az Erdélyi Menekültek Segítő Hivatalt, 1920-tól az Országos Menekültügyi Hivatal helyettes vezetöje. http://lexikon.katolikus.hu/V/V\%C3\%A1k\%C3\%A1r.html (Letöltve: 2017. október 1.) ${ }^{414}$ EGRY, Századok, 2013. 25-27.

415 VÁKÁR P. Arthur: A határörvidékek fejlesztéséröl és újjászervezéséröl. Gyergyószentmiklós, Kossuth könyvnyomda, 1918. 4.
} 
„Erdély, gazdaságilag kelet felé Magyarország egy elöretolt állomása, amely nemcsak önmagáért, Erdély belsö értékeiért, de az egész Magyarország gazdasági akció képességéértáldozatos, gondos elbánást igényel."416 Vákár érvelésében mindvégi jelen van az a gondolat, hogy a székely határőrvidék, annak ősi jellegéből kifolyólag sajátos önállósággal bír. A dinasztia örökösödési jogával ezért nem rendelkezhetett felette, ez jog legfeljebb a magyar Szent Korona előtt nyílhat meg. A határőrvidék fejlesztésének katonai szempontú magyarázata egy történeti és jogi érvelési kontextusba került, amelyben a király és a nemzet, utóbbit az országgyülés testesített meg, volt hivatott dönteni. ${ }^{417}$

A történeti hagyományokra épülő erdélyi gondolatiság részben az 1916-os év pusztító eseményeinek hatására válhatott a korszellem egyik felkapott szellemi termékévé. Az Erdélyi Szövetségben és azon kívül, elsősorban egyes sajtóorgánumokban kapott publicitást. Az Erdélyi Szemle 1916-tól több cikkében Erdély sajátos érdekeiről, az elképzelt erős Erdélyről írt. Állandó jelleggel napirenden volt a vasúthálózat elégtelensége, a pénzügyi- és kereskedelmi viszonyok újragondolása és a földbirtokpolitika. Nemény Vilmos újságíró a nagyobb önálló kezdeményezőkészségre hívta fel a figyelmet, azzal a kritikai éllel, hogy a kormánytól nem lehet várni mindent és annak segítsége is az átmeneti pénzgyüjtésben és címek osztogatásában nyilvánul meg. ${ }^{418}$ Az időszakos pénzgyüjtésre tett kritika részben a Pro Transslyvaniára és elnökségének személyi összetételére utalhatott, amelyben 1 herceg, 27 gróf, 11 báró és mindösszesen 6 nem arisztokrata foglalt helyet, de utóbbiak közül 3 excellenciás 3 pedig mint főrendi, illetőleg méltóságos címet viselt. ${ }^{419}$ Sipos Iván a németországi bankrendszer példáján keresztül tartotta fontosnak, hogy ne legyenek elaprózva a magyarországi bankok. Míg Németországban mintegy 50 nagybank kezében összpontosult a banki tőke, addig a hazai rendszerben 2000 körüli intézményben forgácsolódott szét. A viszonyok megváltoztatása érdekében egyfelől miniszteri rendeletben korlátozták új pénzintézetek alakítását, másfelől a nagyobb bankok a kisebb, elsősorban vidéki pénzintézeteket igyekeztek magukba olvasztani. Kolozsváron is erre került sor, amikor a Pesti Magyar Kereskedelmi Bank az Erdélyi Bankot affiliálta. Az Erdélyi Szemle a lépés pozitívumát elsősorban abban látta, hogy a bank 8 millió Korona értékben vásárolt földbirtokokat Erdélyben. A vásárlás mögött két ok is húzódott, egyfelől a háborúval járó pénzromlás, másfelől a tordai földgáz területek megszerzésének a szándéka. ${ }^{420}$

\footnotetext{
416 Uo. 4-5.

${ }^{417}$ Uo. 5-7.

${ }^{418}$ Nemény Vilmos: Erős magyar Erdélyt! Erdélyi Szemle, 1917. III. évf. 6. szám, február 11. 58.

${ }^{419}$ Pro Transsylvania. Magyar Figyelö, 1917. VII. évf. I. kötet, 449.

${ }^{420}$ Sipos Iván: Az erdélyi tőke fogalma a háború előtt. Erdélyi Szemle, 1917. III. évf. 13. szám, május 20. 149.
} 
A korszak egyik legnagyobb fejlesztésének politikai és társadalmi igénye a vasúthoz kötődött, amelyet számos terv, javaslat, program támaszt alá. A kereskedelmi és a gazdasági szempontokból előnyös beruházás mélyen összefonódott a nemzetpolitikai és a nemzetiségi kérdéssel. A fejlesztések elmaradásának megindokolását Rácz Lajos és más megszólalók is politikai mulasztásokhoz kötötték, amely az említett gazdasági szempontokon túl „,katonailag is a területmegtartás vagy elvesztés egyik közvetlen alapkérdésévé nőtt”. ${ }^{421}$

A nagypolitikusok csoportjába az országos és kormányzati pozíciókat ellátó képviselöket sorolhatjuk. Az Erdélyi Szövetségen belül egyértelműen Bethlen István volt az élen járó politikus, aki túllépett a regionális vezető szerepén és pártokon felül álló kompromisszumokat (Nemzeti Munkapárt) és konfliktusokat vállalt fel. Ezzel együtt, noha Bethlen országos politikussá vált a világháború idején, az általa azonosított problémák vagy erdélyi ügyek (földbirtok-politika), vagy erdélyi magyar nézőpontból szemlélt kérdések (választójog) maradtak. Jelentősége korán megmutatkozott, például 1912-ben, amikor a kormány a Magyar Földhitelintézetek Országos Szövetségén keresztül titkos hitelprogramot indított bajba jutott erdélyi középbirtokok megmentésére a hitelekről döntő informális bizottság vezetőjévé Bethlent delegálták. 1916-ot követően pedig mind erőteljesebben bekerült a döntéshozás mechanizmusába. Bethlen mellett idesorolható továbbá Ugron Gábor, akit 1915ben választották országgyülési képviselővé (marosvásárhelyi II. körzet), előbb belügyminiszter lett Esterházy, majd Wekerle kormányában, 1918 márciusától pedig Erdély királyi biztosa volt. A negyedik kategóriát, a szövetség hálózatát és kapcsolatrendszerét müködtető közéleti figurák - ,pókok” - alkották. A szövetség egyben tartásában, regionális szervezésében és a központi kormányzatra való nyomásgyakorlásban Apáthy István vállalt kiemelkedő szerepet, aki országos politikai ambíciókra nem tört. Apáthy lett a szövetség szervezésének lelke, ami abból következett, hogy ő volt vidéki szerveztek bázisát adó Függetlenségi Párt erdélyi kulcsfigurája. Közmegbecsülését tudományos pályáján kívül minden bizonnyal az is megerősítette, hogy országos kapcsolatain túl képes volt Bethlennel kompromisszumra jutni. ${ }^{422}$

\footnotetext{
${ }^{421}$ RÁCZ, Erdély vasútpolitikája. 1917. 9-16.; Rácz Lajos: Erdély vasútpolitikájának feladatai. Erdélyi Szemle, 1917. III. évf. 22. szám, július 22. 238.;

${ }^{422}$ EGRY, Századok, 2013. 25-29.
} 


\section{ERDÉLYI SZEMMEL NEMZETRŐL, NEMZETISÉGI KÉRDÉSRŐL AZ ÖSSZEOMLÁSIG}

Bethlen István, Jancsó Benedek, Pósta Béla, Apáthy István, Kenéz Béla, Réz Mihály, Jakabffy Elemér, Pál Gábor, Gyárfás Elemér és Paál Árpád életútját korszakos átalakulások befolyásolták, amikor Magyarország még egy (gyenge) európai nagyhatalom része volt, és a magyarság egésze tartozott a szuverenitása alá, amit a kisállami lét és a magyarság negyedének kisebbségi sorba kényszerítése követett. A felsorolt személyek a téma szempontjából többek között, azért fontosak, mert érdemi befolyásuk volt az erdélyi magyar politikai élet alakítására, és az volt a szándékuk, hogy az erdélyi kérdés a regionális problémakörből országos megvilágításba kerüljön. A tíz személy gondolkodásának és politikai kezdeményező szerepvállalásának megvilágítása elősegítheti azt, hogy részletes képet kapjunk azokról az elképzelésekről, véleményekről, amelyek megfogalmazódtak a nemzet és nemzetiségi kérdés tárgyában az 1910-es években. Meg kell jegyezni, hogy a nemzetépítők rendkívül eltérő nézetkavalkádja mivel kidomborítja a magyar szupremácia biztosítására használni kívánt - nem egyszer ódon - elemeket, mint a hitbizománytól, a székely határőrség újbóli felállításától, a birtokmentéstől, a nemzeti telepítéstől, a románok kivándoroltatásáig, vagy a telepített hadirokkantak fejlesszenek nemzetivé korábbi agrárvidékeket bezáró javaslatokat. Ugyanakkora a kitűnő férfiak és tudósok, mint például a demokrata hajlandóságú Apáthy István, akit minden bizonnyal mélyen áthatott a nemzetiségi mozgalmaktól való félelem, még a racionális kompromisszum készséget (Tisza István románokkal való kiegyezési kísérleteit) is árulásnak minősítették. Azt is ki kell emelni, hogy ezek az erdélyi főszereplők voltak azok, akik a periférián fekvő Erdélyből a központ felé nyomatékosították korszakuk általánosabb gazdasági és társadalmi problémáit, ,,anyagi romlás”, a külországokból jövő fenyegetettséget, „sűrüsödő félelmek”, amelyek az erdélyi, illetve magyarországi realitásokkal való szembenézést kívánták előmozdítani.

\subsection{Bethlen István: Erdély vezetö politikusa}

Romsics Ignác gróf Bethlen Istvánt a 20. századi magyar politika egyik legjelentősebb és a konzervatív-nacionalista magyar politikai gondolkodás egyik utolsó nagy alakjaként jellemezte. Bethlen 1901-es képviselővé választásától kezdve 1918-ig sajátos erdélyi jegyekkel rendelkező regionális politikus, aki az erdélyi magyar szupremácia ügyével, főleg annak földforgalmi, választójogi és nemzetiségi aspektusain keresztül került be az országos politika fóáramába. 1921-1931 között Magyarország miniszterelnöke, lemondását követően Horthy Miklós kormányzó tanácsadója, az angolszász orientációjú külpolitika támogatója. 
1946-ban szovjet fogságban, a Szovjetunióban hunyt el. ${ }^{423}$ Politikai gondolkodásában nagymérvü változások nem következtek be, szocializációja és környezete élete végéig a liberális konzervativizmus politikai alapértékeihez kötötték (a 19. század eleji liberalizmus, illetve a 19. század közepi hazai polgári átalakulás elfogadása). Elutasított minden olyan törekvést, amely a társadalom és a politikai rendszer alapvető megváltoztatását tűzte céljául, szóljon az radikális jogkiterjesztésről vagy annak ellenkezőjéről (bolsevizmus, fasizmus). Azon a fajta népképviseleten, amely a 19. századi liberalizmus gyakorlatában elsősorban a vagyonos (magyar arisztokrácia, birtokos nemesség), müvelt rétegek politikai érdekképviseletét biztosította, lényegében nem kívánt változtatni. Bármiféle módosítást csak akkor támogatott, ha az a történelmi fejlődés során szervesen keletkezett intézmények (formák) megmaradását nem veszélyeztette. Az 1918-as összeomlás előtt Bethlen politikai gondolkodását meghatározó vonások - a konzervativizmus mellett - az agrárizmus ${ }^{424}$, illetve a kormánypolitikához képest a nemzeti érdekek erőteljes képviselete voltak, amelyek szorosan kötődtek az erdélyi arisztokrata, földbirtokos társadalmi mivoltához. ${ }^{425}$

Az 1890-es éveket megelőző két évtized tőkés fejlődése megbontotta az uralkodó osztályoknak a kiegyezés után kialakult erőegyensúlyát, amely a nemesi eredetű földbirtokos rétegek mellett jelentős pozíciókat biztosított a felemelkedett ipari, kereskedő- és pénztőkés rétegnek. A 19-20. század fordulójától továbbá társadalmi befolyást szerző városi polgárság ${ }^{426}$, munkásság és parasztság emancipálódó felső rétege a politikai érdekérvényesítés jogát kezdték követelni a történelmi elit, az arisztokrácia és a dzsentri politikai vezető szerepe mellett. ${ }^{427}$ Bethlen ebben a küzdelemben a történelmi elit pozícióinak a megörzése mellett foglalt állást, és minden progresszív irányt (demokrata, polgári radikális ideológia) és erre irányuló eszközt, például a választójog demokratizálását (kiterjesztését) elutasított. Az agrárius szociálprotekcionizmus és a történelmi elitizmus szervesen kiegészítették egymást a nemzetről és nemzetiségekről való gondolkodásában.

${ }^{423}$ ROMSICS: Bethlen, 1999. 9.; ABLONCZY Balázs: „Bethlen István erdélyisége”. Kommentár, $2013 / 5$. http://kommentar.info.hu/iras/2013_5/_bethlen_istvan_erdelyisege_\#up6

${ }^{424}$ Főbb elemei a következők voltak: az ipar mérsékeltebb és a mezőgazdaság fokozottabb állami támogatása, az agrárszektor vámvédelme, a mezőgazdasági hitelek kamatfeltételeinek fejlesztése, a hitbizományok rendszerének kiterjesztése a közép- és kisbirtokokra, a termelési, fogyasztási és értékesítési szövetkezetek országos hálózatának a létrehozása. ROMSICS Ignác: Bethlen István életpályája. Kommentár, 2013/5. http://kommentar.info.hu/iras/2013_5/bethlen_istvan_eletpalyaja (Letöltve: 2017. október 2.) [Továbbiakban: ROMSICS, Kommentár, 2013/5]

${ }^{425}$ ROMSICS: Bethlen. 1999. 66-185.; ROMSICS, Kommentár, 2013/5.

426 1901-től lépett fel Vázsonyi Vilmos Demokrata Pártja

${ }^{427}$ SZABÓ Miklós: Az újkonzervativizmus és a jobboldali radikalizmus története 1867-1918. Budapest, 2015, 142-143. 
A gróf a magyar birtokos osztály megerősítésében látta a magyarság utolsó lehetőségét, amely képes lehet védelmezni a magyar nemzet befolyásának fenntartását. Ez azt is jelentette, hogy a nemzetet a földbirtokosok reprezentálják. Az erdélyi románsággal kapcsolatos koncepciójának kiindulópontja az volt, hogy a románság politikai szándéka a Magyarországon belüli nemzetiségi jogok követelése helyett idővel Erdély és a román királyság egyesítése felé irányul. Ebből a tételből következett, hogy a magyar nemzetiségpolitika feladatát Bethlen egészen 1918ig nem a kollektív nemzetiségi jogok vagy általában az állampolgári jogok kiterjesztésében, hanem a nemzetiségi és vegyes etnikumú vidékeken élő magyarság gazdasági és kulturális pozícióinak erősítésében látta. Politikai eszközrendszerébe tartozott a románság gazdasági térnyerésének megakadályozása, politikai érdekérvényesítési és kulturális önszerveződési lehetőségeinek korlátozása. ${ }^{428}$

A nemzetiségi kérdés és Erdély Bethlen számára a világháború alatt egyszerre összmagyar és birodalmi szintű problémává vált. A radikalizálódó nemzeti mozgalmakkal szemben a térség stabilitása érdekében a Monarchia kiegyensúlyozó középhatalom (oroszokkal és németekkel szemben) támogatása mellett foglalt állást. Érvelését Románia katonai támadásával és az antantnak a kis nemzetek függetlenségét elismerő állásfoglalására való hivatkozással. Erdély kapcsán nem a sajátos kulturális és regionális eltéréseket emelte ki, hanem a magyar állam regionális politikájának hiányát (földbirtokpolitika, gazdaság- és infrastruktúrafejlesztés), illetve az erdélyi magyar nemzetépítés (szupremácia fenntartásának) erőteljes támogatásának szükségességét. Az ország keleti határainak biztosítása érdekében Románia és Magyarország közötti határkiigazításokat, lakosságcserét és telepítéseket (moldvai csángókat, veteránokat) és állami birtokpolitikát (a szociális szempontokat figyelembe véve) javasolt. ${ }^{429}$

A háború elvesztésével és a Monarchia felbomlásával Bethlennek is szembe kellett néznie, aki feladva korábbi nemzetiségpolitikai koncepcióját közeledett az autonóm vagy független Erdély gondolatához. Romsics Ignác megállapítása értelmében ez a koncepciómódosítás - szoros kapcsolatban az 1918 ősze és 1919 ősze között gyorsan változó (és magyar szempontból romló) nemzetközi körülményekkel - három szakaszban következett be.

\footnotetext{
${ }^{428}$ ROMSICS: Bethlen. 1999. 66-185.

429 Képviselőházi napló, 1910. XXXV. kötet. 710. Országos ülés, 1917. március 3., 4-16. http://www3.arcanum.hu/onap/a1 10616.htm?v=pdf\&a=pdfdata\&id=KN-1910_35\&pg=0\&l=hun (Letöltve: 2017. szeptember. 17.)
} 
Első lépésként Károlyi Mihály és Jászi Oszkár demokratikus, de az egységes magyar állam keretén belül maradó rendezési tervéhez közeledett. Elismerte, hogy a nemzetiségek javára engedményeket kell tenni (megyék kétnyelvüsége, felekezeti iskolák tanügyi szabadsága, nemzetiségi államtitkárságok felállítása. Bethlen támogatta Jászi Oszkár nemzetiségügyi miniszter kantonális tervezetét (nyelvhatárokat követő autonómiák kialakítása Erdélyben) 2018. november 11-én egy budapesti politikai megbeszélésen.

Második gondolati lépcsőnek a székely köztársaság terve, lényegében a történeti állam egységéről való kényszerü lemondás tekinthető Jászi aradi tárgyalásainak kudarca (1918. november 14.), illetve a belgrádi katonai konvenciót (1918. november 13.) követően. A független köztársaságról szóló - wilsoni elvekre hivatkozó - terv értelmében a kompakt egységben élő 600 ezres székelyföldi magyarság szuverén székely köztársaságot hozott volna létre (lásd 4.8.1. alfejezetet).

A harmadik szakasz az önálló erdélyi állam vagy a román állam keretein belüli Erdély autonómia tervet először Gyárfás Elemér vázolta fel (1919. március 24., Az erdélyi három nemzet uniójának alapelvei). Gyárfás a magyar, a román és a szász nemzetek 1526-ig visszanyúló autonóm fejlődéséből, az erdélyi önkormányzat történeti hagyományaiból indult ki. Erre hivatkozva javasolta egy, a három erdélyi nemzet képviselőiből álló kormányzótanács megalakítását és külön erdélyi országgyülés megválasztását. Gyárfás Emil Haţieganu erdélyi román miniszterhez juttatta el memorandumát, de választ sem tőle, sem a nagyszebeni román Consiliul Dirigent-től nem kapott. 1919 májusában született egy másik memorandum is, amit Rugonfalvy Kiss István debreceni egyetemi tanár készített. Gyárfástól eltérően a román és a magyar nemzetet fenyegető szláv „veszedelemböl” indult ki (ez megegyezett Bethlen korábbi helyzetértékelésével), és tett ajánlást a román-magyar perszonálunió létesítésére. Ez a gondolat Iuliu Maniu (Kormányzótanács elnöke) és Teodor Mihali (Erdélyi Román Nemzeti Tanács vezetője) nyilatkozataiban is visszhangra talált, amikor Románia és Magyarország egymásrautaltságát hangoztatták. A Tanácsköztársaság kikiáltása után Bethlen István Bécsbe menekült, és egy „új politikai irányvonalat” kezdeményezett. Ennek a lényege - Rugonfalvy gondolatmenetéhez hasonlóan - a szlávellenes magyar-román együttmúködés, végső célja pedig egy Románia és Magyarország közötti államszövetség megteremtése volt. A kérdésben tárgyalásokra is sor került 1919 augusztusában és szeptemberében, de a románok mindenekelött az 1916-os bukaresti szerződéshez közelítő határok garantálását szerették volna elérni. Bethlen Jancsó Benedekkel együttmúködve egy újabb tervezetet készített az erdélyi kérdés megoldásáról 1919 végén (ez később a magyar békedelegáció VIII. számú jegyzéke is volt). 
Az előterjesztés Gyárfás ismertetett memorandumáéhoz hasonlított, amely a történeti Erdély (15 vármegye) egységének megőrzését javasolta, illetve államjogi hovatartozását (Románia vagy Magyarország része, illetve független) egy népszavazás dönthetné el. Erdély kérdéséről Bethlen és mások által felvetett tervezetek végül semminemü eredménnyel nem jártak. Az összeomlást követően Bethlen erdélyi koncepciójának egyik lényegi eleme az volt, hogy a történeti Erdély egységét fenn kell tartani, és belső viszonyait svájci mintára, az ott élö nemzetek egyenjogúságát szem elött tartva, nyelvi-etnikai kantonok kialakításával lehet kezelni ${ }^{430}$

\subsection{Jancsó Benedek: a szakértő, a publicista és a Székely Nemzeti Tanács vezetője}

Jancsó Benedek a székelyföldi Gelencén született, a nemzetiségi kérdés egyik elismert szakértője, aki Bethlennel és Apáthyval szoros kapcsolatot ápolt. Nem tartozott az Erdélyi Szövetséghez, de termékeny íróként és befolyásos személyiségként szélesebb körben is hatottak a gondolatai. Az MTA levelező tagjává választották 1916-ban, 1917-1918-ban a bukaresti osztrák-magyar katonai parancsnokság nemzetiségügyi előadója volt, egyik kezdeményezője az 1918. november 9-én megalakult Székely Nemzeti Tanácsnak, 1922-től a szegedi Ferenc József Tudományegyetem tanára. ${ }^{431}$

Jancsó a Szabad Lyceum tudományos ismeretterjesztő társaság által szervezett előadássorozat (1917. március 6., 13., 20., 27.) keretében hosszasan elemezte a magyarországi román nemzetiségi mozgalom fejlődését. A románság történetének (dákó-román kontinuitás elmélete, Supplex libellus valachorum, Horea és Closca-féle lázadás, görög keleti felekezeti iskolák fejlődése stb.) ismertetésével Jancsó arra kívánt rámutatni, amit kezdettől fogva maga is vallott, hogy a románság célja, ,állambomlasztó politikai törekvése”, Erdély és Románia egyesítése. Jancsó a román nemzetépítést szociológiai értelemben veszi górcső alá. Azt állítja, hogy az erdélyi románság csonka társadalom, mert nincs osztályokra tagozódva. Többnyire falvakban élő földművelő paraszti rétegekből áll, nagybirtokos arisztokrata egy-két kivételtől eltekintve nincs, illetve egyetlen nagyobb román város sem alakult ki. Egynéhány városban szám szerint többséget alkotnak, de ezt a dominanciát nem városi polgárság, hanem iparos, kereskedő, földmíves, napszámos és cseléd társadalmi kategóriák jelentik. A középosztályt egy növekvő és gyarapodó értelmiség képezi, foglalkozásukat illetően papok, tanítók, tisztviselők és különböző szabad foglalkozásúak, például ügyvédek, akik a román nemzetiségi, kulturális és politikai törekvések hordozói.

${ }^{430}$ ROMSICS Ignác: Bethlen koncepciója a független vagy autonóm Erdélyről. Magyarságkutatás Évkönyve, 1987. 49-64.

${ }^{431}$ Lásd Jancsó Benedek életéhez: Jancsó Benedek Emlékkönyv. Szerk.: Asztalos Miklós. Királyi Magyar Egyetemi Nyomda, Budapest, 1931. 
Jancsó ezekből a szociológiai jellemzőkből azt a konklúziót vonta le, hogy a hazai románság „csonkasága” miatt társadalmilag és politikailag is fejletlen a magyar és szász társadalmakkal szemben. Két további következtetést is megállapított. Egyfelől „a népeknek e társadalmi különbözöségén alapuló politikai és gazdasági súlyát semmiféle demokratikus politikai szervezet vagy rendszer - talán még a szociáldemokrácia politikai elveinek diadalmaskodása sem változtathatná meg, illetöleg nem egyenlithetné ki,” másfelöl, „hogy a magyarországi románság, összehasonlítva a magyarsággal, etnikai tekintetben egyáltalán nem mondható haladó fajnak" ${ }^{432}$ Jancsó ezt egyszerü számadatokkal támasztotta alá: 1840 és 1910 között (Horvát-Szlavóniát leszámítva) a magyarság 5,5 millió fővel, míg a románság csupán 700 ezerrel gyarapodott.

Fontosabb ennél az, hogy Jancsó mit gondolt a nemzet kialakulás kérdéséről. A magyar és a román nacionalizmusról tett jellemzésében a két eltérő nemzetépítés fejlődését minőségi értelemben is elkülönítette egymástól. A román nemzeti mozgalomra, mint etnikai, nyelvi nacionalizmusra tekintett, amelynek politikai legitimitását az adta, hogy összekapcsolódott a korszak demokratikus törekvéseivel. Ezzel szembe állította az általa fejlettebbnek, magasabb rendűnek vélt történeti alapokon nyugvó magyar nemzetépítést, amely önálló államot hozott létre. A szakértő az 1916-os román betörést követően azt a nézetet képviselte, hogy ez az új, demokratikus-populáris nacionalizmus a nemzeti fejlődés, (amely alatt az államnemzet, egységes politikai közösséget kell értenünk) és az állam fennállását érintő legsúlyosabb kihívás a magyar államra nézve. Jancsó bár felismerte az új nacionalizmusok újszerü tömegerejét, de szilárdan hitte, hogy a nemzeti törekvések jogalapját elsősorban a történeti előzmények, maga az államalapítás képessége jelenti. Ha hiányzik ez a történeti előzmény „az etnikum, a faji és nemzeti törekvések igazolására és megvalósitására, nagyon gyönge erönek számított" fogalmazott Jancsó. ${ }^{433}$ Előadásaiban hosszasan ismertette a dákó-román kontinuitás elméletét, amely román nézőpontból azt volt hivatott alátámasztani, hogy a román nemzeti mozgalom rendelkezik történeti jogalappal Erdélyre vonatkozóan. Jancsó ezt a Dácia történetet kétségbe vonta és úgy foglalt állást, hogy a magyarországi román nemzeti egység eszméjének minden jogtörténeti alapja hiányzik.

\footnotetext{
${ }^{432}$ JANCSÓ Benedek: Erdély és a nagyromán aspirációk. Kiadja a Szabad Lyceum, Budapest, 1918. 1-6.

${ }^{433}$ Uo. 8.
} 
Jancsó Benedek a Székely Nemzeti Tanács megerősítése érdekében az erdélyi székely tanácsok megalakítását javasolta. Az érdekképviselet vezetésében helyet kapott Jancsó mellett Sebess Dénes, Ugron Gábor volt belügyminiszter, az erdélyi származású Urmánczy Nándor országgyűlési képviselő is. A Tanács külügyi albizottságának irányítását Bethlen István vállalta, ahol először került munkakapcsolatba Teleki Pállal. A székely érdekképviseleti Tanácsot két célkitüzéssel hoztak létre: az integer Magyarország megőrzése, illetve egy székely fegyveres erő felállítása Erdély védelmére (lásd az 1. számú mellékletet). ${ }^{434}$ A Székely Nemzeti Tanácsok müködésük során több nagygyülést is tartottak Magyarország területi integritása mellett. Az egyik legjelentősebb demonstrációra, 1918. november 17-én került sor Budapesten, ahol támogatásukról biztosították a Károlyi-kormány nemzetiségi politikáját. Javasolták, hogy amennyiben a békekonferencia nem tartja fenn a magyar állam területi egységét: 1) a magyarromán együttélés a wilsoni elvek alapján kantonális rendszerben biztosíttassék, 2) a székely összefüggő területeken a nemzetközi garanciák mellett független, szabad és szuverén köztársaságot alkothasson, 3) kérik a Magyar Népköztársaság támogatását az államalakulat létrehozásában és képviseletet a békekonferencián. A Székely Nemzeti Tanács vezetői (Jancsó Benedek, Ugron Gábor) Jászi Oszkárt is felkeresték javaslataikkal, aki támogatásáról biztosította törekvéseiket. ${ }^{435}$ A Károlyi-kormány egymillió Koronát folyósított a Tanács részére (külföldi propagandát folytatni a magyar kérdés ügyében), illetve Ugron Gábor közbenjárására 30 millió koronát a székely különítmény toborzására és felszerelésére. ${ }^{436}$ A Székely Nemzeti Tanács 1919. március 22-e után átalakult.

Jancsó a Trianoni döntést követően az Új Magyar Szemle 1920. júliusi számában összegezte a világháború Erdélyre vonatkozó következményeit. A szerző nézőpontjának egyik sajátossága, hogy a világháború hosszát öt évben állapítja meg, amelynek az 1919-es antant megszállás is része. Jancsó az új Romániával kapcsolatban két hipotetikus kérdésre keresi a választ.

\footnotetext{
${ }^{434}$ Bethlen István ösztönzésére 1918. november 19-én, Marosvásárhelyen létrejött egy előkészítő bizottság az Erdélyi Székely Nemzeti Tanács megalakítására, illetve a november 28-ra, Marosvásárhelyre hirdetett „székely nemzetgyűlés" megszervezésére. A gyűlésen erdélyi, bánáti és partiumi magyarok is részt vettek, ahol Bíró Balázs és Szádeczky Lajos kolozsvári tanárok, Ravasz László püspökhelyettes, valamint Szöts János és Csetri János szociáldemokrata vezetők szónokoltak. A nagygyülés helyeselte a kormány wilsonizmuson alapuló nemzetiségi politikáját és a területi integritáshoz való ragaszkodást. Bethlen jelen volt a gyülésen, de nem szólalt fel. A gyülést támogatta Kolozsvárról a függetlenségi párti Apáthy István és a szociáldemokrata Vincze Sándor. Marosvásárhelyen kívül Székely Nemzeti Tanács alakult Gyergyóban, Háromszéken és Udvarhelyen. ROMSICS: Bethlen. 1999. 107-110.

${ }^{435}$ BÁRDI Nándor: Impériumváltás Székelyudvarhelyen 1918-1920. Aetas, 1993. 3. sz. 76-118.

${ }^{436}$ Primipilus: A székely hadosztály és a székely nemzeti tanács. Új Magyar Szemle, 1920. 3. szám, október, 272281. (A cikk álnéven jelent meg. A latin primipilus lóföt jelent. Társadalmi rang volt a székelyek között, amely a föszékelyek (primorok) után következett a hierarchiában. Az egyes címek és rangok megszüntetéséről szóló 1947. évi IV. törvény törölte el.)
} 
Az egyik, hogy a régi román királyság képes lesz-e a területében megduplázódott és a társadalmi összetételében sokszínüvé vált Romániát integrálni? ${ }^{437}$ A másik, hogy a milyen stabil alapokra épül a román parlamentarizmus, illetve a fennálló intézményrendszer képes-e belpolitikai vitákat megfelelő keretek között tartani? Jancsó álláspontja az volt, hogy a „hódító” román királyság társadalmi, nemzeti, politikai és gazdasági fejlettsége elmaradt az újonnan elfoglalt területekétől. „Nagyrománia imperium romanum-má [Római Birodalom-F.N.] csak akkor lehetne, ha rendelkeznék egy olyan erös dinasztikus hatalmi támaszponttal, mint aminö a régi Osztrák-Magyar Monarchiában a Habsburg-dinasztia volt." ${ }^{438}$ A kultúrharcos nézőpont olvasata, hogy az új államalakulat elmaradt a német-osztrák-magyar állami fejlettség szintjétől, illetve I. Ferdinánd román király nem rendelkezett rövid történeti múltjánál fogva „fejedelmi” tekintéllyel. A szerző a román parlamentarizmusról hasonlóan értekezett: a stabil intézményes szerkezet helyett politikai hatalmi körök befolyása dominál a döntéshozatalban. Konklúziója 1920-ban a következő volt: „A románság képtelen megfelelni annak a történeti feladatnak, amely osztályrészévé lett [...]. Nincs ehhez sem politikai ereje, sem erkölcsi hivatása, sem az a tekintélye, amelyet egy hosszú, századokra visszanyúló történeti múlt képes egyedül megadni." 439

\subsection{Az Erdélyi Szövetség tudós hármasa: Apáthy István, Pósta Béla, Kenéz Béla}

Az Erdélyi Szövetség 1914-es programtervezetét a kolozsvári egyetem három oktatója, Apáthy István, Kenéz Béla és Pósta Béla (egyikük sem erdélyi származású), illetve Beszterce-Naszód vármegye főispánja, Thorma Miklós állította össze. A szervezet programjának kidolgozását segítette továbbá báró Kemény Árpád, 1906-1910 között Alsó-Fehér vármegye föispánja, később a förendiház alelnöke.

\subsubsection{Apáthy István: eugenetika és állami politika a nemzetépítés szolgálatában}

Apáthy István nemzetközileg elismert zoológus, MTA tag, kolozsvári egyetemi tanár (1890től). Sokoldalú személyiség, aki a kutatói munkáján kívül a közügyekkel is behatóan foglalkozott. A kolozsvári függetlenségi párt helyi elnöke, Károlyi Mihály erdélyi megbízottja, szövetségese.

\footnotetext{
${ }^{437}$ Románia területe az 1914-es 137.903 km2-ről 1920-ra 294.967 km2-re növekedett.

438 Jancsó Benedek: Nagyrománia. Új Magyar Szemle. 1920. 3. szám, július, 295.

${ }^{439}$ Uo. 301 .
} 
Az 1918-as októberi forradalom alatt a Magyar Nemzeti Tanács Erdélyi Bizottságának elnöke ${ }^{440}$, Jászi Oszkárral közösen részt vesz a románokkal való aradi tárgyaláson, az 1919. januári letartóztatásáig az Kelet-Magyarországi Főkormánybiztosság főkormánybiztosa. 1920 nyarán repatriál, Szegeden (a kolozsvári egyetem új otthonában) megszervezte az Állattani Intézetet, amit 1922-ben bekövetkezett haláláig vezetett.

A tudós az 1900-as évek elején zajló élénk erdélyi közéleti viták során vált politikai szereplővé. Előbb a báró Bánffy Dezső ${ }^{441}$ által alapított Újpárt tagja, majd a Függetlenségi 48as Pártba lép át. Vagyok, aki voltam személyes hangvételü politikai írásában értekezett döntése okairól. Lépése mögött egyfelől a Bánffy-párt szegedi hintapolitikája, másfelől függetlenségi politikai meggyőződése, és a szabadelvű kormányokkal szemben érzett ellenállása állt. ${ }^{442}$ Bánffy miniszterelnök munkásságát korábbról úgy ítélte meg, többek között Széll Kálmánnal és Tisza Istvánnal ellentétben, hogy ő lehetőségeihez képest megfelelően képviselte a magyar érdekeket Béccsel szemben. Tiszát különösen azért kritizálta, mert véleménye szerint megakadályozta a Darányi-féle telepítési akciótervet. Az 1905-1906-os oktrojált kormányzati politika, illetve Bánffy lépése azonban azt mutatta meg számára, hogy milyen könnyedén felrúgható Magyarországon az alkotmányosság és a törvények betarthatósága. ${ }^{443}$ Apáthyt politikai értékrendje mellett még egy fontos dolog kötötte a függetlenségi táborhoz.

\footnotetext{
${ }^{440}$ Erdélyi Nemzeti Tanács (Magyar Nemzeti Tanács Erdélyi Bizottsága): az 1918-as polgári demokratikus forradalom erdélyi hatalmi szerve, amely 1918. november 1-jén alakult Kolozsvárott. Elnöksége a függetlenségi párt tagja, Apáthy István, alelnöke a polgári radikális Janovics Jenő és a szociáldemokrata Vincze Sándor.

${ }^{441}$ Bánffy Dezső báró (Kolozsvár, 1843.-Budapest, 1911.): országgyủlési képviselő a szilágysomlyói (18921896), illetve a belső szegedi (1904-1911) választókerületekben, főispán (Belső-Szolnok, Szolnok-Doboka vármegyékben). A képviselőház elnöke (1892-1895), majd miniszterelnök (1895-1899). 1875-1904 között a Szabadelvü Párt tagja, annak feloszlatását követően megalakította az ellenzéki Új Pártot (1904-1906) és csatlakozott az ellenzéki szövetséghez. 1906. márciusában azonban kivált a koalícióból. http://mek.oszk.hu/00300/00355/html/ABC00523/00886.htm (Letöltve: 2017. szeptember 14.)

${ }^{442} \mathrm{Az}$ 1905. június 18-án kinevezett első Fejérváry-kormány ellen a választáson győztes koalíció június 21 -én nemzeti ellenállást hirdetett. Szeged függetlenségi többségü közgyülése június 28 -án helyben csatlakozott az országos akcióhoz, és határozatban tagadta meg az állami adóbeszedést. Nyártól a közgyülés korábbi egyetértése - a müködést is biztosító kieső adók miatt - az ellenállás folytatása ügyében kérdésessé vált. A Fejérváry-kormány másodszori kinevezését a közgyülés 32:17 szavazattal bár tudomásul vette, a kormány Szegeden csak hónapokkal később (1905. december 25.), jelentős helyi ellenállás mellett töltötte be a föispáni helyet (Nagy Mihály kecskeméti országgyülési képviselő). Az ügyben akkor történet fordulat, amikor 1906. március 4-én, Bánffy Dezső szegedi országgyülési képviselő nyílt levélben bejelentette szegedi választóinak, hogy a kilép a koalícióból. A helyi Szabadelvű Párt maradéka és az Új Párt elhatározta, hogy a továbbiakban biztosítani fogja a közgyűlés rendszeres müködését.

Magyarországi pártprogramok 1867-1919. Szerk.: Mérei Gyula, Pölöskei Ferenc. 2003. Budapest, ELTE-Eötvös Kiadó, 213.

${ }^{443}$ APÁTHY István: Vagyok, aki voltam. 1906.
} 
Kolozsvárra történő kinevezése óta ugyanis egy dolgot sehogy sem tudott elérni: egy jól felszerelt, korszerü állattani intézet megteremtését. Számtalan beadvánnyal fordult a minisztériumhoz, de mindhiába. Amikor aztán Apponyi Albert közoktatásügyi miniszter lett, akivel egy politikai platformon álltak, csaknem két éven belül megvalósult a vágyott intézet. ${ }^{444}$

Apáthy közéleti tevékenységében ki kell emelni azt a társadalmi szerepvállalást, amely az Erdélyi Múzeum Egyesülethez (EME), a Magyar Társadalomtudományi Egyesülethez, illetve a Magyar Társadalomtudományi Szemléhez kötötte. Ezeken a fórumokon számos előadással és publikációval képviseltette magát. Apáthy axiómája az volt, hogy a tudomány hat az életre, és az élet visszahat a tudományra, és éppen ezért a társadalmi kérdéseket is tudományos megközelítésben vizsgálta. Arra a kérdésre, hogy mi vezesse a társadalmat, az emberi egyedeket a fejlődésnek magasabb fokára, a következő választ adta az EME, nagyenyedi vándorgyülésén (1907). „Az akarat! De az akarat, mely számot vet az irányadó társadalom természetével, az élettudományi és erkölcsi törvényekkel. Ilyen akarat csak egy lehet, ilyent csak a nemzeti gondolat érlelhet. Ez az akarat, nem szállhat szembe a nemzeti sajátságokkal, nem vezethet más irányba, mint amit a nemzeti történet tanúságai kijelölnek." ${ }^{445}$ A nemzeti gondolatot a korszakot átható versenyszemlélettel állította szembe. Tudta, hogy a versengés káros következményei nem iktathatóak ki, de kereste az új erkölcsi alapokon nyugvó lehetséges utat. Úgy gondolta, ha a verseny jól irányított, az ösztönzőleg hat, mert kikeresi a jobb képességüeket, akik mindig a jobbat akarják, a haladást.

Apáthy egyik alapítója a Magyar Társadalomtudományi Egyesületnek, amely a polgári radikális Jászi Oszkár fémjelezte Magyar Társadalomtudományi Társaságból kilépett konzervatív tagjaiból szerveződött meg. Az előkészítő-bizottság 1906-ban felhívást tett közzé azzal a céllal, hogy egy nemzeti alapon fennálló társadalomtudományi egyesületet alakítsanak. „A társadalomtudományoknak magyar szellemü és történeti alapon álló, de a korral haladó és lehetőleg sokoldalú müvelésére a magyar nemzeti továbbfejlődés szolgálatára megfelelö szervezet és életmüszer létesüljön." ${ }^{446}$ Az egyesület eszmeiségének krédója a magyar nemzet aktuális, de a múltban gyökerező társadalmi, gazdasági kérdések előtérbe helyezése volt tudományos, összehasonlító alapon, pártpolitikai irányzatok befolyásától mentesen. Az egyesület tudományos vizsgálódásának egyik központi témájává a nemzet fogalmának és tartalmának a kutatása vált.

\footnotetext{
${ }^{444}$ BENEDECZKY István: Apáthy István a tudós és a hazafi. Budapest, Szenczi Molnár Társaság, 1995. 121. ${ }^{445}$ Uo. 115.

${ }^{446}$ VASVÁRI Ferenc: A Magyar Társadalomtudományi Egyesület megalakulása. Acta Sociologica, 2007. 2. évf. 1. szám, 95 .
} 
A nemzet kitüntetett szerepet töltött be, amely a tagság gondolkodásában a társadalom és az állam kategóriái felett állt és a legnemesebb egyetemes emberi szerveződést segítette elő. Dr. Gaál Jenő volt az első elnöke, az alapításban részt vett továbbá dr. Marczali Henrik történész, dr. Hornyánszky Gyula kolozsvári egyetemi tanár, gróf Bánffy Miklós, dr. Jancsó Benedek. Az egyesület szellemi vezetői, Apáthy István és Gaál Jenő a célok és a feladatok tekintetében egykét kérdéstől eltekintve közös álláspontot képviseltek. A tudományos eredményeket elsősorban a magyar nemzet és társadalom javára kell fordítani, a magyar társadalomban fennálló nemzeti értékeket és intézményeket meg kell védeni. A liberalizmusból fakadó versengést mindketten elvetették, mert az nemcsak értékromboló és kapkodó haladást próbál megvalósítani, de aláássa a nemzeti érzelmet is. Gaállal szemben Apáthy a szocializmus egyes alapelveit azonban magáénak tudta, de nem marxista értelemben, utóbbit ugyanis egyoldalú gazdasági megközelítése miatt elvetette. ${ }^{447}$ A szocializmus az emberi továbbfejlödés szempontjából címü előadásában a fejlődés és a társadalom olyan típusú együttállását vetítette előre, amely az individuális életforma helyett ,a társadalomban élő egyedek összetartozandóságának és egymásért valóságának, a közösségnek alapelvén épül föl" ${ }^{448}$ Egy fontos megkötést füzött hozzá, hogy „az embert első sorban, mint társas lényt, mint a társadalom tagját, nem az egyén, nem az alkotórész, hanem a szervezett egész, a társadalom, illetöleg a legmagasabb rendü társadalmi alakulat, a nemzet nézöpontjából" kell értelmezni. ${ }^{449}$ Egy sajátos, a magyar viszonyoknak megfelelő szocializmus kigondolását vetette fel. Figyelemre méltó tudománynak tartotta a szociológiát, de kizárólag nemzeti alapon kívánta művelni. Nem az osztályok és az uralom kategóriáival kell foglalkozni, hanem a nemzettel és annak kialakulásával. Elfogadta azt a nézetet, ami a szociológia létrejöttének időszakára volt jellemző, hogy a társadalomtudományok legyenek részei a természettudományoknak. A múltat, az emberi életet törvényszerüségek formájában dekódolta, illetve a változás hajlandóságát a legerősebb elem felől érkezőnek tulajdonította. A tudós gondolkodásában egyszerre érhetjük tetten a darwinista és a spenceri organicista-evolucionista megközelítést, amely sok tekintetben visszalépést jelentett Jászi Oszkárék újonnan adaptált durkheimi szociológiai eljárással szemben. ${ }^{450}$

\footnotetext{
447 Uo. 96.

448 APÁTHY István: A socialismus az emberi továbbfejlődés szempontjából. Budapest, 1913. 7-8.

${ }^{449}$ Uo.

${ }^{450}$ Uo. 97-101.
} 
Apáthy főszerepet vállalt a Társadalomtudományi Egyesület által kiadott Magyar Társadalomtudományi Szemle szerkesztésében is. A folyóirat első számának nyomtatására 1908-ban került sor. A lap helyet biztosított olyan tematikáknak, mint a kivándorlás, a szociális mozgalmak és sztrájkok mögött meghúzódó társadalmi és politikai folyamatok, az oktatás és a család, a szocialista irányzatok, illetve a nemzetiségi problémák elemzése. A társadalom- és természettudományos gondolkodású lap indulásakor kiemelten foglalkozott a modernitással, a haladással összefüggő társadalmi problémákkal, amiket főként német hatásra, az 1910-es évek elejétől felváltottak az eugenetikáról és a faji biológiáról szóló publicisztikák. A Magyar Társadalomtudományi Egyesület, a Budapesti Királyi Orvos- és az Országos Közegészségügyi Egyesület 1914. január 24-én közösen megalakította a ,fajegészségügyi (eugenikai) szakosztályt." Apáthy István három pontban foglalta össze a szakosztály feladatát: 1.) „odahatni, hogy [...] minél kevesebb embertársunk váljék fajegészségügyi szempontból alkalmatlanná;” 2.) ,megállapítani azokat a jeleket és körülményeket, melyek után valakinek a szaporitása nem kivánatos”. 3.) „legkevésbé kívánatos egyedek szaporodását lehetöleg gátolni" ${ }^{451}$ A zavarosnak tűnő célok elérése a magasabb erkölcsi és társas rend, a közműveltség növelésének vízióját jelentette. Visszaszorítandó társadalmi jelenségek közé tartozott a prostitúció, az alkoholizmus, a szexualitás, az ellenőrizetlen bevándorlás és kivándorlás, az etnikumok keveredése, melyek szemben álltak a család, a társas kapcsolatok, a faj kollektív egységét megtestesítő ideálképpel. A szakosztály elnökévé gróf Teleki Pált választották, tagjai között volt többek között Apáthy István, Jancsó Benedek és Gaál Jenő. A szakosztály kapcsolatot ápolt a Földrajzi, a Néprajzi, a Közgazdasági, a Genealógiai és a Turáni társaságok vezetőségeivel is. ${ }^{452}$

Az eugenetikai szakosztály társadalmi felfogása a világháború alatt megnőtt. 1917. november 24-én, az MTA kistermében tartott közgyülésen megalakították a Magyar Fajegészségtani és Népesedéspolitikai Társaságot. Az előkészítő feladatokat Hoffman Géza vállalta magára, aki felkereste több nyugat-európai ország hasonló jellegű társaságát. ${ }^{453} \mathrm{~A}$ külföldi minták alapján három csoportba rendezték a feladatokat: tudományos, népszerüsítő és gyakorlati.

\footnotetext{
${ }^{451}$ A fajegészségügyi (eugenikai) szakosztály megalakulása. Magyar Társadalomtudományi Szemle. 1914. VII. évf. 2. szám, 165-172.

452 Uo.

${ }^{453}$ USA-ban az American Breeders Association létesített eugenetikai szakosztályt, Eugenics Record Office néven. Németországban a német eugenetikai társaság, vezetője Ploetz Alfréd, az Archiv fuer Rassen und Gesellschaftsbiologie szervezettel müködött együtt. Londonban az Eugenics Education Society népszerüsítette a fejegészségügyi eszmét. Svédországban a német egyesületnek volt kihelyezett társasága. Bécsben a Soziologische Gesellschaft, Goldscheid vezetésével alakított eugenetikai szakosztályt, amelyet Franciaországban is követettek. OSZK Kézirattár, Quart. Hung. 2454.
} 
Utóbbiba a törvényhozók és a közigazgatásban dolgozók eugenetikai szemléletű befolyásolása is beletartozott. Az alapszabály értelmében a társaság célja a „magyar nép fajegészségtanának és népesedéspolitikájának tudomány müvelésére vonatkozó ismeretek népszerüsitése és a leszürt tanulságok gyakorlati megvalósitása". ${ }^{454}$ A fajegészségügy, más néven népesedés politika tárgyában kétféle csoportot különböztettek meg, egyfelől az ún. alkotó (pozitív), másfelől nemleges (negatív) fajegészségügyet. Előbbibe az értékes népelemek „embertenyésztése”, utóbbiba a „satnyák visszaszoritása” tartozott. Vizsgálataikban kiemelt tematikáknak számított: a korai házasodás szorgalmazása, egynejü házasság, emberi faj génmódosítása, irányított be- és kitelepítések, házasságon kívüli születésszabályozás büntetése, tisztviselői bérek gyermeklétszámhoz kötött programjának kidolgozása, nagycsaládosok szavazatszámának emelése, gyakorlati eugenetika, nemi betegségek terjedésének megfékezése. Továbbá olyan napjainkban is ismert szociálpolitikai policyk, mint például lakhatási támogatás, csecsemő- és anyavédelem, oktatási- és egészségügyi rendszerhez való hozzáférés támogatása, alkoholizmus csökkentése, munkásvédelem, szegényügy. Az ún. nemleges fajegészségügy tárgyában mindenek előtt a házasság előtti kötelező orvosi vizsgálatot vezették volna be és a házasság megtiltásának lehetőségét. Svájci, észak-amerikai és svéd példákra hivatkozva pedig az eutanázia és a nők terméketlenné tételét is felvetették. A társaság a háború okozta emberveszteség következményeire és az aktuálpolitika egyik kiemelt kérdésére, a telepítési akciótervekre vonatkozóan is megszólalt. Előbbi kapcsán feladatuknak tekintették, hogy a harctéren odaveszett „erös, egészséges, bátor, önfeláldozó férfiak [...] szaporodását” elősegítsék a „gyenge, beteges, gyáva és önzőekkel” szemben. ${ }^{455}$ A telepítési programok kapcsán a társaság a későbbi nemzetiszocialista Max von Gruber müncheni egyetemi tanár, a német fajegészségtani társaság elnökének programját tette magáévá, miszerint „csupán kivánatos egyén telepitendo”, aki a „magyar fajhoz testileg és lelkileg odatartozik”, kellő számú gyermekkel rendelkezik, lehetőleg katonaviselt és fiatal. ${ }^{456}$

A társaság a Huszadik Századdal szemben is megfogalmazta kritikáját, amely jól megvilágítja a két értelmiségi kör eltérő módszertan- és világszemléletét. A Jásziék által szervezett ismeretterjesztő sorozatban került megvitatásra Tomor Ernő egyik könyve, amely az angliai eugenetikai kutatás kérdésével foglalkozott.

${ }^{454}$ A fajegészségügyi (eugenikai) szakosztály megalakulása. Magyar Társadalomtudományi Szemle. 1914. VII. évf. 2. szám, 165-172.

${ }^{455}$ Uo.

${ }^{456} \mathrm{Uo}$ 
A társaság több tagja is szóvá tette, hogy az előadássorozat a figyelmet ,elterelte tisztára a szociálpolitikai és pártpolitikai mederbe” olyan módon, „,hogy az olvasóra a fajegészségtanról téves benyomást tesz". ${ }^{457}$ Meg kell jegyeznünk azonban azt, hogy a Huszadik Század hasábján is számos eugenetikával, mint társadalomról való politikai-módszertani gondolkodással, szemlélettel foglalkozó cikk kapott helyet a folyóiratban.

Az Erdélyi Szövetség szellemi vezetői közül Apáthy volt az, aki a leghangsúlyosabban képviselte azt, hogy az államnak kulcsszerepet kell vállalnia az oktatáson keresztül a nemzetépítés folyamatában. ${ }^{458}$ Első és legfontosabb lépésként a heterogén iskolarendszer reformját, majd annak teljes államosítását javasolta. Az iskola legfontosabb feladataként a nemzeti egység, a magyar nemzeti eszme és együvé tartozás fenntartását, biztosítását jelölte meg. Apáthy államosításra vonatkozó követelését azzal indokolta, hogy a nemzetiségi mozgalmak és a mögötte álló felekezeti iskolák valós veszélyt jelentenek az állami integritásra, éppen ezért, minden egyházi iskolát állami felügyelet alá kell vonni. Bár elismerte, hogy korábban volt szerepe a nemzetiségi iskoláknak a nemzeti fejlődésben, de véleménye időközben megváltozott. „A felekezeti iskoláknak volt jogosultságuk a múltban; nemzeti fejlödésünknek is tényezői voltak, elismerem. Ma akadályai ama lelki egybeforradásnak." "459 Szándéka természetesen nem a katolikus egyház ellen irányult, amely jelentős számú iskolát működtetett. Úgy gondolta, annak társadalmi befolyása akkor sem csökken, ha éppen nem ő a fenntartó. A vallásra és az erkölcsre nézve szerinte nem jelentett volna az veszélyt, ha a felekezeti iskolák helyett államiak vannak.

\footnotetext{
${ }^{457}$ OSZK Kézirattár, Quart. Hung. 2454.

${ }^{458}$ A ,népiskolai oktatásról” szóló 1868. évi XXXVIII. tc. egyik alaptétele az anyanyelven történő oktatás deklarálása: ,58. § Minden növendék anyanyelvén nyerje az oktatást, a mennyiben ez a nyelv a községben divatozó nyelvek egyike. Vegyes ajkú községben ez okból oly tanitó alkalmazandó, a ki a községben divatozó nyelveken tanitani képes. Népesebb községekben, a hol többféle nyelvü lakosok tömegesen laknak, a mennyire a községereje engedi, különbözö ajkú segédtanitók is választatnak." A másik alaptétele az állampolgári szabadság és az állami felelösség sajátos értelmezésén alapuló tankötelezettség (6. életévétöl 12, illetve 15 éves korukig terjedt), illetve a tankötelezettség kényszerét ellenpontozó tanszabadság és tanítási szabadság egysége és kölcsönössége. A tanszabadság magában foglalta a magántanulás és a különféle nyilvános intézetek közötti választás lehetőségét. A tanítás szabadságának elvéből, amit a liberális felfogás a lelkiismereti és a szólásszabadsággal egyenrangú jogként kezelt, egyenesen következett az iskolaállitás- és fenntartás ( $=$ az iskolaszervezés) szabadsága. Ez a jog, illetve az ezzel együtt járó kötelezettség - szabályozott feltételek mellett - a hitfelekezeti és polgári közösségekre (= községekre), az államra, valamint az egyes állampolgárokra, továbbá az egyének e célra létesült egyesületeire egyaránt kiterjedt. 1910-ben az elemi iskolák összlétszáma 16.455 (100\%), amelyből a felekezeti iskolák száma 12.075 (73\%), a községi 1339 (8\%), az állami 2744 (16\%), az egyéb (magán, egyesületi, társulati) 297 (2\%). NAGY Péter Tibor: Nemzetiség és oktatás a dualizmuskori Magyarországon. Educatio. 1993/II. szám, 253-269.; FAR Sándor: Román nemzetiségi oktatási törekvések a dualizmus korában. Educatio. 1993/II. szám, 271-280.; KELEMEN Elemér: A magyarországi népoktatás a dualizmus korában. Az Eötvös Loránd Tudományegyetem Tanitó- és Óvóképzö Főiskolai Karának tudományos közleményei XIX. Filozófia-müvelödés-történet. 2001. 5772.; 1868. évi XXXVIII. törvénycikk a népiskolai közoktatás tárgyában

${ }^{459}$ Dr. Apáthy István beszéde. Elöadta Budapesten, 1914. május hó 2-án az iskolák államositása és felekezettelensége érdekében tartott népgyülésen. Külön lenyomat az Új Korszak 1914. május hó 22. számából. Világosság Könyvnyomda Rt. Budapest. 14.
} 
Apáthy államosítása a gyakorlatban többek között azt jelentette volna, hogy csak az állam tarthat fenn nyilvános iskolákat, adhat ki érvényes bizonyítványokat, illetve csak azok részesülhetnek állami támogatásban. A tannyelv magyar, még a vallásóráké is, hacsak azt nem minősítik magánórává, ahol a nemzetiségi nyelv szabadon használható. Apáthy szemben állt azzal a szabadelvű nézettel, amely szerint a vallásoktatás azonos a hitélettel (amely benső, egyéni és családi ügy), és ott az államnak nincs helye. A közművelődés területén megengedőbb volt. Az iskolán kívüli kulturális életben, amely alatt a nemzeti sajátosságok megőrzését értette, szabad nyelvhasználatot engedett meg.

Apáthy az erdélyi főkormánybiztosi tevékenységéről (1918. október vége-1919. január 15.) és Magyarország összeomlásáról az Új Magyar Szemle 1920. decemberi számában közölt személyes hangvételű visszaemlékezést. ${ }^{460}$ A szerző célját tekintve az olvasó elött tisztázni kívánta a köztársaságot kikiáltó Károlyi-kormánnyal való politikai kapcsolatát, illetve személyes felelősségét Kolozsvár 1918. decemberi román megszállásának eseményeiben. Apáthy a következőket írta: a Károlyi-kormány - eltérően a Berinkey-kormánytól (1919. január 19.-március 21.) - a király felhatalmazásával legitim módon került kinevezésre, amelynek müködése elválasztandó az azt követő „nagy földfordulást” okozó kormányokétól. Apáthy saját magára vonatkozóan hangsúlyozta, hogy ő a törvényes kormány fökormánybiztosaként tárgyalt Kolozsváron a város megszállásáról az antant csapatok tábornokával, Neculceaval, valamint a szövetségesek balkáni haderejének parancsnokával, Berthelottal, „és nem a lázadóknak tekintett erdélyi és magyarországi oláh vezetökkel!" folytatott egyeztetéseket. ${ }^{461} \mathrm{Az}$ államforma megváltoztatásának és az országgyülés feloszlatásának kérdésében utólagosan nem értett egyet Károlyi lépésével. Úgy vélte, hogy a köztársaság kikiáltása és a parlament feloszlatása (amely a jogfolytonosság megszakítását jelentette) utat nyitott a nemzetiségek elszakadási törekvéseinek. Kárhoztatta továbbá a politikai közhangulatot - megítélése szerint - rossz irányba befolyásoló budapesti politikát, illetve a fóvárosi sajtóorgánumok szerepét, amely forradalmi hangulatban tüntette fel Erdélyt. „Már az összeomlás elött sokat és sok helyen hangoztattam, hogy Magyarország legnagyobb betegsége Budapest. Azért igyekeztem minden erőmmel, hogy Kolozsvár egy Budapestnél sokkal magyarabb, sokkal egészségesebb szellemi központjává legyen Erdélynek és általában a hazának." 462

\footnotetext{
460 A Kelet-magyarországi Főkormánybiztosság irattárát 1919. március elején elkobozta a román katonai ügyészség, Apáthy lakását kétszer átkutatták, ezért csak nagyon kevés dokumentum került Magyarországra 1920ban. Apáthy írása keltezése 1920. november 21. Apáthy István: Erdély az összeomlás után. Új Magyar Szemle, 1920. 3. kötet, 2-3. szám, december, 147.

461 Uo.

${ }^{462}$ Uo. 149
} 
A függetlenségi párti politikus világháború előtti kolozsvári tevékenységéről elmondta, hogy a polgári radikális gondolkodású Galilei-kör a közben járása miatt nem tudta megalakítani helyi fiókját, a Bolyai-kört. Apáthy arra is emlékeztetett, hogy a Jászi Oszkár fémjelezte Magyar Társadalomtudományi Társasággal szemben a vezetése alatt álló Magyar Társadalomtudományi Egyesület (együttmüködve az EME-vel) szervezte a munkások képzését, illetve a kolozsvári szabadkőmüves unió páholy és az Erdélyi Szövetség tagjaként mindig a nemzeti ideák és Erdély védelmének szolgálatában dolgozott. A kolozsvári szociáldemokraták többségéről (kivéve Kun Bélát és Vincze Sándort) és a polgári radikálisokról úgy foglalt állást, hogy az erdélyi gondolattól átitatva inkább a függetlenségi párttal voltak egyetértésben, mint a budapesti központi irányzatukkal. ${ }^{463}$

Apáthy írása - ellentmondásoktól nem mentesen - reflektált a trianoni Magyarország belpolitikai diskurzusára, amelyben az októberi események távolítása zajlott. Magyarország köztársasággá való kinyilvánításakor - a Károlyi-párt erre irányuló célján felül - nem hagyható figyelmen kívül az, hogy Ausztria - időben megelőzve a budapesti döntést - kikiáltotta a köztársaságot (1918. november 12-én). Ezzel Ausztria saját részéről kinyilvánította az 1867ben létrehozott Osztrák-Magyar Monarchia megszünését, amely közjogi helyzetben a Károlyikormány nem kerülhette meg az államforma kérdését. ${ }^{464}$ A kolozsvári Nemzeti Tanács Apáthy vezetésével novemberben a szociáldemokrata Vincze Sándor alelnök javaslatára esküt tett a népköztársaságra. ${ }^{465}$ A függetlenségi szellemiségü Apáthy a kolozsvári Nemzeti Tanács megalakításakor üdvözölte az Ausztriával történő közös ügyek megszünését. Az államforma megváltoztatásáról nem beszélt, helyette a nemzetiségi kérdés veszélyére hívta fel a figyelmet. ${ }^{466}$ Apáthy mielőtt nyilvánosan állásfoglalt, október közepén megbeszélést folytatott Bethlen Istvánnal és az Erdélyi Szövetség vezetőségével a leendő magyar kormány elvárható magatartásáról, amelyről (október 14-i keltezésű) levélben tájékoztatta Károlyi Mihályt. „Magyarország képviselőinek semmi körülmények között sem szabad Magyarország belső egységének földáldozásáig, még kevésbé Magyarország területének megcsonkitásáig elmenni.

\footnotetext{
463 Uo. 147-148.

464 1918. november 16-án összeült parlamentben a Nagy Nemzeti Tanács az 1. számú néphatározat 1. §-ában deklarálta Magyarország függetlenségét és az önálló népköztársasági államformát.

465 A Nemzeti Tanács felesküdött a köztársaságra. Keleti Újság, 1918. 19. évf. november 30. 1.

466 OSZK Kézirattár, Quart. Hung. 2455 (Megalakult a Nemzeti Tanács erdélyi bizottsága. Újság, 1918. október 29.)
} 
Amennyiben a béketárgyalások ilyen elhatározásokra vezetnének, a magyar kiküldötteknek a béketárgyalásokat ott kellene hagyniuk, kijelentve a magyar nemzet sem Magyarország belsö egységének megbontásába, sem pedig területeinek megcsonkításába soha beleegyezni nem fog."467 A béketárgyalásokon kellő számú szaktanácsadó jelenlétét javasolta, köztük gróf Bethlen Istvánt, illetve önmagát is. Apáthy külön kiemelte, hogy a béketárgyalásokon Magyarországnak külön kell képviselnie érdekeit Ausztriától, amely egyúttal kifejezi a dualista állam minden korábbi közös ügyeinek megszakítását. ${ }^{468}$

\subsubsection{Pósta Béla: „a magyar a turáni népekhez tartozik”}

A kecskeméti születésü kolozsvári egyetemi tanár, Pósta Béla, aki elsősorban régészként szerzett magának elévülhetetlen érdemeket, egyik szellemi előkészítője volt az Erdélyi Szövetség megszervezésének. ${ }^{469}$ Pósta Apáthy Istvánnal a Bánffy-féle Új Párt szervezése (1903) idején került szorosabb kapcsolatba. 1918-ban, a Monarchia összeomlása időszakában a 48-as Alkotmánypárt kolozsvári elnöke volt.

Pósta tagja volt annak a századelőn, Kolozsváron kialakult értelmiségi körnek, amelynek tagjai, Márki Sándor (1853-1925) és Szádeczky-Kardoss Lajos történészek, Cholnoky Jenő földrajzprofesszor vagy a háború alatt itt oktató Pröhle Vilmos a turáni gondolat képviselői lettek, illetve közreműködtek ideológiájának kidolgozásában. ${ }^{470}$ „A magyar a turáni népekhez tartozik, akár töröknek, akár finn-ugornak tekintsük a törzset, amelyröl levált." ${ }^{" 41} \mathrm{~A}$ kolozsvári értelmiség egy része aktív alakítója volt a magyar közélet azon eszmerendszerének, amely a Kelet és a magyarság keleti néprokonságának újrafelfedezését használta fel a magyar szupremácia elméleti és politikai alátámasztására. Pósta szerepét ez utóbbi szempontból is érdemes kiemelni, aki az egyetemi világban szerzett befolyásán keresztül képes volt hatni a nemzetről való gondolkodás formálására.

\footnotetext{
${ }^{467}$ OSZK Kézirattár, Quart. Hung. 2455 (Apáthy levele Károlyi Mihályhoz, 1918. október 14.)

${ }^{468}$ Uo.

${ }^{469}$ Pósta Béla (1862. Kecskemét-1919. Kolozsvár): 1899-től 1919-ig a kolozsvári egyetem régészeti tanszékének professzora, az Erdélyi Nemzeti Múzeum tagja, az első két nyelvü magyarországi régészeti folyóirat megindítója, a kolozsvári régészeti iskola alapítója, 1907-1919 között a magyar múzeumok országos régészeti főfelügyelője. Pósta Béla születésének százados ünnepe 1862-1962. 1962. Budapest, Múzeumok Rota; Kutatói munkásságát lásd bővebben: http://www.postabela.ro

${ }^{470}$ ABLONCZY Balázs: Keletre magyar! A magyar turanizmus története. Debrecen, Jaffa Kiadó, 2016. 14-16. [Továbbiakban: ABLONCZY, 2016]

471 PÓSTA Béla: A magyar nemzet és a müvészetek. A kolozsvári M. Kir. Ferencz József Tudományegyetem 1910/11. évi pályakiosztó ünnepélyén. Kolozsvár, Ajtai K. Albert Könyvnyomdája, 1911. 7. [Továbbiakban: PÓSTA, 1911]
} 
A turanizmus kifejezés alatt mást és mást értettek. Egyszerre jelenthette: 1.) a keleti magyar őshaza keresését 2.) tudományos ismeretterjesztést Ázsiáról 3.) művészeti stílust 4.) az orientalizmus hazai adaptációját 5.) eredettudatot 6.) amelyből levezethető politikai, kulturális, gazdasági befolyásszerzés, egyfajta magyar imperializmus a Balkánon, a Közel-Keleten és DélOroszországban. ${ }^{472}$ Pósta saját bevallása szerint, már pályája kezdetén felfigyelt arra a sajátos szerepre, amelyet az évezredek folyamán a Kárpát-medence, illetve a magyarság az emberiség kultúrkincseinek cseréjében „Dél és Észak, Kelet és Nyugat kultúráinak vegyülésénél” betöltött. ${ }^{473}$ A tudományosságról vallott dichotóm felfogást elvetette, helytelennek találta, hogy megkülönböztettek „nemzeties” és „nemzetközi” irányultságú iskolákat, amelybe belekényszerítik a tudóst. Nézete szerint a helyes út középen van. Nem lehet mindent pusztán magyarnak hirdetni, illetve az emberiség kultúráját, a tudományt és a művészetet „ösidőktől fogva az árja és a sémi népeknek hol baráti, hol ellenséges találkozása" alapján csoportosítani. ${ }^{474}$ A turanista gondolkodó abból vezette le korszakának magyar kultúráját, hogy a keleti, turáni eredetű magyarság ezer év alatt magába olvasztotta a vele kapcsolatba kerülő „árja elemeket”, német, francia stb., amelynek következtében „,nagyobbára árja fajjá és a turániból csak a külső formát tartotta meg nyelvében és egy pár más vonásában". ${ }^{475}$ A nemzet fejlődés kérdésének tekintetében ezért a korszakra oly jellemző faji, biológiai szemléletet sem preferálta. Előbbre tartotta a közös nyelv, földrajzi viszonyok, egységes állam, kulturális hatások, politikai viszonyok kategóriát, amelyek alapján elsődlegesen turáni népekre és nem turáni fajokra gondolt. ${ }^{476}$

Pósta érdeklődésének középpontjában Kelet története állt, melynek értékeivel vándornépek és karavánok az európai és a magyar kultúrát gazdagították. A turanizmus egyszerre szolgálta a német politikai, kulturális befolyás csökkentésének szándékát és a magyar nemzetépítést támogató szellemi, politikai ideológiák új tartalmakkal való megerősítését. A Kis-Ázsia, a Balkán, a dél-orosz sztyeppe érintésével a Kárpát-medencén át kirajzolódó szárazföldi útirány kutatását a régész a magyar tudománynak a nemzetközi munkamegosztásából fakadó speciális feladataként fogta fel. Az oroszul is jól beszélő Pósta több expedícióban vett részt (gróf Zichy Jenő kaukázusi és közép-ázsiai útjain), amelyről könyvet is írt (Régészeti tanulmányok az orosz földön, 1905.).

\footnotetext{
${ }^{472}$ ABLONCZY, 2016. 36.

${ }^{473}$ VINCZE Zoltán: A Keleti Intézet Posta Béla-i terve. In: Emlékkönyv Kiss András születésének nyolcvanadik évfordulójára. Kolozsvár. Az Erdélyi Múzeum-Egyesület kiadása, 2003. 640. [Továbbiakban: VINCZE, Emlékkönyv. 2003]

${ }^{474}$ PÓSTA, 1911. 6-7.

475 Uo. 8.

${ }^{476}$ Uo. 8-11.
} 
Azt vallotta, hogy a magyar tudós sajátos hivatása a keleti források ismerete: „régészeti emlékeink specifikusan nemzeti elemének java részét már a legkorábbi idöktöl kezdve nem magyarázhatjuk, és meg nem érthetjük a keleti világ emlékeinek tüzetes ismerete nélkül" ${ }^{477}$ Egy magyar Keleti Intézet felállításának terve is ennek a gondolatnak a részét képezte, amelyet közösen Zichy Jenővel propagáltak. Reményeiknek támogatásul szolgált, hogy gróf Teleki Pál, a Turáni Társaság elnöke ugyan távlatilag, de nem zárta ki a lehetőségét egy intézet felállításának. Pósta ez irányú tudományszervezését a háború végül megakadályozta. A vesztes világháború és a román megszálló csapatok által kénytelenül elszenvedett meghurcoltatások között a professzor szervezete megroppant és 1919. április 16-án szívinfarktusban hunyt el. ${ }^{478}$

\subsubsection{Kenéz Béla: „a nép és a föld harmóniájának megteremtése”}

A szolnoki születésü (1874), közgazdász végzettségü Kenéz Béla a kereskedelmi minisztérium titkári címét követően tíz éven keresztül volt a kolozsvári egyetem tanára (1907-1917), a régió közéletében vezető szerepet töltött be, az Erdélyi Szövetség egyik prominenseként. A Tanácsköztársaság alatt az egyetemi oktatástól eltiltották, de utána élete végéig tanított. 19201939 között Magyarországon parlamenti képviselő. Az Országos Kisgazda- és Földműves Párt tagjaként 1921-ben a nemzetgyülés alelnöke, később csatlakozik a Bethlen István vezette Egységes Párthoz. 1927-től a Magyar Revíziós Liga társelnöke, illetve a Károlyi Gyula vezette kormány kereskedelemügyi minisztere (1931-1932) volt. ${ }^{479}$

Kenéz Béla, statisztikus, egyetemi tanár a Magyar Társadalomtudományi Szemlében (1913) terjedelmes cikkben összegezte a nemzetiségi kérdésben vallott nézeteit és javaslatait. Kiindulópontja az volt, hogy a magyarországi nemzetiségek nemzetépítésének folyamata nincs olyan előre haladott állapotban, amely egyelőre képes lehet az állami egység megbontására, az „állami összetartozás kötelékének meglazitására”. Meglátását abból vezette le, hogy a nemzeti önazonosság tapasztalata döntően a nemzetiségi középosztály egy szűkebb értelemben vett csoportjánál lelhető fel, és a társadalom alsóbb rétegeit a nemzeti együvé tartozás fölismerése nem hatja át.

\footnotetext{
477 VINCZE, Emlékkönyv. 2003. 640.

${ }^{478}$ Uo. 650-653.

${ }^{479}$ Országgyülési almanach 1935-1939. Szerk.: Haeffler István. (Sturm-féle országgyülési almanach) Bp. 1940. 294-295.https://library.hungaricana.hu/hu/view/OGYK_Almanach_1935-

1940/?pg=293\&layout=s\&query=Ken\%C3\%A9z\%20B\%C3\%A9la (Letöltve: 2018. január 23.)
} 
„Egy egészen más jellegü, nem faji, hanem általános emberi szükséglet-csoport közös átérzése kapcsolja e középosztállyal egybe a nemzetiségi nép nagy tömegét, nem az együvé tartozás kollektív fölismerésével." ${ }^{480}$ A nacionalizmus kutatásokból ismerjük a nemzetépítés társadalmi folyamatának fázisait, amelyre Kenéz Béla pontosan rávilágított: a középosztály a kovásza a nacionalista mozgalomnak. Mégis, mintha ezt alábecsülte volna. „Reménytelennek kell mondanunk" az államtól való 1) nemzetiségi elszakadást, 2) a föderalizációt, illetve 3) a nemzetiségi megyék közigazgatási partikularizmusát, amelyet a nemzetiségi törekvések főtörekvéseiként csoportosított. Érvelésében természeti, földrajzi, kulturális és politikai szegmensek egyaránt megjelentek. A Kárpátok lánca által ölelt államon belül a magyarság fejlettebb kulturális élete biztosítja a politikailag gyengébb, önálló államalkotó erővel nem rendelkező románsággal szemben az egységet. Teljesen eltérő módon értékelte a nemzetiségi törekvések negyedik csoportját, a népoktatást, a saját kultúra, a közigazgatás és a bíráskodás anyanyelven történő megvalósítását, illetve a saját teljesítményre épülő nemzetiségi gazdasági élet fejlesztését. Kenéz ebben a dimenzióban történő társadalmi interakciókat írta le az „általános emberi szükséglet-csoport közös átérzés” jelentésében. Ebbe a kontextusba helyezve érthetjük meg a korábban ismertetett Apponyi és Apáthy beszédeket is, amikor az állam belpolitikai viszonyainak a javításáról beszéltek. Az állam tehát a társadalomszervezésben főszerepet tölt be, amely megfelelő gazdasági, közigazgatási és szociálpolitikai lépésekkel képes nemzetiségi hovatartozás nélkül egységben tartani az államot alkotó politikai közösséget. Kenéz tíz pontba gyüjtötte össze az állam feladatait, amiket érvényesítenie kell a nemzetiségi kérdés kezelésében. Szempontrendszerében helyet kapott a negyedik csoportban már ismertetett elemek fejlesztése (anyanyelvü oktatás, kultúra, közigazgatás, bíráskodás), a magyarság gazdasági és kulturális „felsőbbségének” növelése, illetve a nemzetiségi területeken élő magyar közösségek kiemelt támogatása. A javaslat a következő főbb pontokat tartalmazta: telepítési és kultúrzóna koncepció; önálló nemzetpolitikai ügyosztály felállítása minden minisztériumban; agrárium és iparfejlesztés; népoktatás államosítása, különös tekintettel a görög katolikus és görög keleti felekezeti iskolákra vonatkozóan. Továbbá a román és a szerb egyházak állami kontrollja; a katonaköteles nemzetiségek magyar többségű városokba történő besorozása; egy magyar pénzügyi intézet felállítása; a nemzeti érzelmü tőkés középosztály támogatása; a Magyar Társadalomtudományi Egyesület keretén belül müködő országos bizottság megalakítása politikai nyomásgyakorlás céljából. ${ }^{481}$

\footnotetext{
${ }^{480}$ KENÉZ Béla: Javaslatok a nemzetiségi kérdés megoldására. Magyar Társadalomtudományi Szemle, 1913. VI. évf. 4. szám, 250. (Külön kiadásban megjelentette ugyanezzel a címmel a Pesti Könyvnyomda Rt. 1913-ban.)

${ }^{481}$ Uo. 251-272.
} 
Kenéz Béla Nép és föld című könyve a hazai, illetve az európai társadalom és föld viszonyainak, a földbirtok megoszlásának, magyarság és nemzetiségek százalékos földtulajdon részesedésének, földhöz jutás eszközeinek, különös tekintettel a telepítés kérdéseit tárgyalta. A statisztikus az előszóban megjegyezte, hogy a könyv tartalma javarészt békés időszakban készült és békés állapotokra vonatkozó terveket ölel fel. A könyv azzal a szándékkal íródott, hogy rámutasson az agrárpolitika valós céljaira, „a nép és a föld harmóniájának megteremtése” érdekében. „Sohase szólalt meg parancsolóbban nemzeti létünk törvénye: gazdasági életünk rendjét a nemzeti élet követeléseihez kell szabni, mint ma, [...] nem volna erkölcsös, ha az annyi nemes magyar vérrel termékenyült föld másnak hozna gyümölcsöt." ${ }^{482}$ Kenéz a táblázatokkal, statisztikai adatokkal ellátott könyvében azt is kifejtette, hogy miért tartotta elengedhetetlennek az állami földbirtokpolitika újragondolását. Egy etnikailag heterogén államban a „,vezetö faj hatalmát, számbeli többsége mellett, müveltségbeli és gazdasági felsőbbségével biztosithatja”. A gazdasági erőnek legfontosabb eszköze pedig a földbirtok. Bemutatta nemzetiségenként a földbirtokosok arányát, amely szerint az összlakosságra kivetítve a magyarság 40\%-a volt főfoglalkozása szerint földbirtokos, ide értve segítő családtagjaikat is. A németek esetében ez a szám 9,9, a szlovákoknál 13,4, a románoknál 26,4, a ruszinoknál 4,1, a horvátoknál 1,6 és a szerbeknél 3\%-ban volt megállapítható. Az 1000 holdnál nagyobb birtokok kapcsán a magyar földbirtokosok dominanciája megkérdőjelezhetetlen volt, 91,4\%-uk tartozott a magyarsághoz a 8,6\% nem-magyarral szemben. Az 5-10 holdas és 5 holdnál kisebb birtokosok esetében a képlet a fordítottját mutatta, ahol a nem-magyarok aránya 63,5 és 61,7\% volt a magyar 36,5 és 38,3\%kal ellentétben. A legtöbbet adózók sorában szintén a magyarok domináltak. Ezekböl következően a nagybirtokossághoz társított képet a következőképpen foglalta össze. „A nagybirtokos osztály gazdagsága függetlenné s a tagjaiban kifejlödött kormányzóképességgel (gyors elhatározással, gyakorlati érzékkel) párosulva: a közéleti szereplésre, a nobile officiumként teljesitendö köztisztségek ellátására alkalmassá teszi." ${ }^{483}$ Kenéz a magyar tulajdonú földbirtokállomány növelésének másik eszközét az oly nagyon szorgalmazott telepítés programjában látta. A telepítés történeti előzményei (Árpádok és a Habsburgok alatt), illetve a dualizmus alatt történt telepítések (1894. évi V. tc. és annak 1911. évi módosítása) számára jogalapul szolgáltak az újabb nagy telepítési akciók kivitelezéséhez. A dualizmus alatt megvalósult 21 telep létrehozását és 2000 fö földhöz juttatását természetesen fontosnak tartotta, mert annak elve a magyar nyelvszigetek összekötését szolgálta, de magvalósítást már nem vélte megfelelőnek.

\footnotetext{
${ }^{482}$ KENÉZ Béla: Nép és föld. Budapest, Grill Károly Könyvkiadó Vállalata, 1916. VII-VIII.

${ }^{483}$ Uo. 34-43.
} 
Azt kisléptékünek ítélte és a törvényeröre nem lépett Darányi-féle javaslat (12 éven át évi 10 millió Koronával emelte volna a földalapot) megvalósítását javasolta. Tisza kormányának kritikája sem maradt el. A Bethlen-féle, az EMKE, az Erdélyi Gazdasági Egylet adatira hivatkozva azt írta, hogy az állami politika súlyosan megsértette a magyar nemzet érdekeit, amikor a románságnak nyújtott földvásárlással kapcsolatos előnyöket. 1908-tól kezdve 805 ötven holdnál nagyobb magyar birtokot játszottak át román és szász tulajdonba. ${ }^{484}$

Kenéz a magyarságra nézve statisztikailag alátámasztott objektív folyamatok mögött „láthatatlan finomságú lelki rugókat” is megállapított. A tudós úgy vélekedett, hogy a román kisebbség elnyomatott érzéséből kifolyólag sokkal törekvőbb, míg a magyarság túlsúlyából fakadóan „elbizakodva lanyhábban nézi a fajok harcát”. A nehezen mozduló magyar társadalom ezért összességében ,fatalizmusig menő egykedvüsége, állandó, összetartó és kitartó munkára kevéssé képes,” ami „keletről magával hozott turáni jellemvonás”. ${ }^{485}$ Kenéz bár nem volt tagja a kolozsvári turáni társaságnak, de mondatai alapján minden bizonnyal megállapítható Pósta Béla hatása. A jellemzést abban látta igazolni, hogy a magyar birtokos réteg egy része, akár strómanok révén a haszon érdekében jó áron képes túladni földjén a nagy veszedelem alatt. Az állam pedig vagy gyenge és eszköztelen volt vagy a változó kormányok az állam telepítő politikáját nem tartották egyformán fontosnak. Kenéz ezért mind az állam, mind a társadalom egyes szereplöit a magyar föld és a magyar nemzet egybekötésére kívánta felhasználni. „Mert a magyar faj felsőbbségének megtartása nélkül a Kárpátok koszorújában fekvő ország nem tudja megvalósítani az állami élet minden irányát egységesen átható ama különleges géniuszt, amely az önálló állami lét igazolása. Mert enélkül apróbb országocskákká szaggatódik, vagy legjobb esetben laza föderatív szervezetté mállik s képtelen lesz betölteni világtörténelmi rendeltetését, [...] hogy földrajzi fekvésével és etnikai összetételével gátat emeljen az északi és a déli szlávság két óriási áradata közé, amelynek egyesülése [...] az európai hatalmak egyensúlyát és békéjét semmisithetné meg."

\footnotetext{
${ }^{484}$ Uo. $117-125$.

485 Uo. 132.

486 Uo. 133.
} 
Kenéz a békeszerződés aláirását követően a magyarországi földkérdéshez füzött véleményében - a kor közgondolkodásához hasonlóan - a „nemzeti lét” és a gazdaság együvé tartozását hangsúlyozta. ${ }^{487}$ A kisgazda párti politikus gondolkodására vonatkozóan, amely szemben állt a Rubinek-féle nagybirtokot védő állásponttal a következő általánosságok vonhatóak le. A földpolitikát szociális kérdésként értelmezte, amellyel a háborús veszteségeket szenvedett lakosság (rokkantak, hadiözvegyek, hadiárvák, menekült közszolgálati alkalmazottak, katonák, kisiparosok), illetve cselédek, napszámosok, föld nélküli proletárok életkörülményei javíthatók, illetve elkerülhetetlen folyamat a nagybirtokrendszer mellett kialakuló kisbirtokok megerősödése, támogatása. Érvkészletében a gazdasági és társadalmi szempontok egyformán kiemelendők: a városi lakosság élelmezésében a nagybirtok hatékonyabb; a kisbirtokokra épülö szövetkezeti rendszer foglalkoztatottsága társadalompolitikailag kedvezőbb hatású; a nagybirtok gazdasági elsőbbsége (anyagbeszerzés, értékesítés, gépesítés stb.) addig áll fenn, amíg az iskolázottság tekintetében a társadalmi szakadék nem csökken, amiből a szövetkezésre való csekély hajlandóság is következik. A népsürüség egyenetlensége kapcsán - az adottságaiban eltérő - Fejér és Brassó megye példáját emelte ki: az 1000 hektár szántóföldre eső lakosok száma Fejér megyében 81 fő (ahol a nagybirtok területi aránya 63\%), míg Brassóban 247 fö (ahol a nagybirtok területi aránya 2,4\%). 1900 és 1920 között a nagybirtok jellegzetes vidékein, mint Fejér megyében az 1000 hektár szántóföldre átlag 160 fö népnövekedés esett, ellenben a kisbirtokos megyékben $240 .{ }^{488}$ Kenéz magyarázata politikai érvelésnek tekinthető, amely célját tekintve a kisgazdapárt törvényjavaslatát kívánta megerősíteni a parlamenti vitában. A kisgazdapárti politikus leegyszerüsített indoklásában nem vette figyelembe az eltérő földrajzi adottságokat és kialakult földtulajdoni viszonyokat, illetve a Dunántúl és Erdély eltérő népességalakulását befolyásoló tényezőket (etnikai viszonyok, tényleges szaporulat, nyers születési ráta, gyermeknemzés korlátozása stb.).

\footnotetext{
${ }^{487}$ Nagyatádi Szabó István kisgazdapárti politikus 1919. október 12-én újjá szervezte az Országos Kisgazdapártot és programjában az egyházi, a pénzintézeti, a városi és a községi, illetve az 500 holdnál nagyobb magánbirtok állami kisajátítását szorgalmazták. A nagybirtokosok érdekvédelmi szervezetei - az OMGE és a Gazdaszövetség valamint az Egyesült Kisgazda- és Földmívespártban szervezkedő újkonzervatív-agrárius politikai exponenseik, - mint például Rubinek Gyula - élesen támadták Szabót. Az 1920. januári választások után Nagyatádi és hívei kompromisszumokra kényszerültek. Az elfogadott új földtörvény (1920. XXIX) a nagybirtokstruktúrának kedvezett. Rubinek Gyula: Az új földbirtokpolitikai javaslatról. Új Magyar Szemle, 1920. 1. szám, május, 23-27.; SIPOS József: A földkérdés. Rubicon. http://www.rubicon.hu/magyar/oldalak/a_foldkerdes/ (Letöltve: 2018. január 26.)

${ }^{488}$ Kenéz Béla: A készülő földtörvény. Új Magyar Szemle. 1920. 3. kötet, 1. szám, november, 8-23.
} 


\subsection{Réz, Mihály: „a nép nem demokrata”}

A székelyföldi, elszegényedett, református, székely köznemesi családban született Réz Mihály a Tisza István patronálta konzervatív szellemiségü Magyar Figyelö lap belső munkatársa volt 1911-1918 között. 1918-1919-ben Erdélyben tartózkodott, de a román hatóságok zaklatása miatt el kellett hagynia Romániát. 1920-21-ben Genfben a Népszövetség magyar ügyekkel foglalkozó titkárságának vezetője volt. Súlyos betegségben hunyt el 1921-ben.

Réz Mihály annak ellenére sem sorolta magát a szabadelvű politikai gondolkodók közé, hogy Tisza István szükebb értelemben vett köréhez tartozott. Saját szóhasználatával a „,örténelmi realizmust” és a „,nemzeti haladást” tekintette világnézetének, amely szerinte leszámol a - nemzetiségi kérdés terén is uralkodó - destruktív liberális és baloldali illúziókkal. ${ }^{489}$ Társadalom- és politikai gondolkodása a nemzeti értékeket magán hordozó, ezeréves államiság diskurzusára, tradicionalista-nacionalista társadalmi közepet támogató frazeológiára épült. ${ }^{490}$

Réz politikai gondolkodására Széchenyi István és Otto von Bismarck szellemisége gyakorolta a legnagyobb hatást, akiket megfontolt, óvatos reformer konzervatívoknak, illetve mintául szolgáló államférfiakként jellemzett. Széchenyi politikai munkássága úgy jelent meg előtte, mint aki „előmozdította a jobbágyság fölszabaditását; de a vezető osztályok kezében kívánta a politikai hatalmat megtartani". ${ }^{491}$ Az 1867-es liberális állam előtti korok értékeit élesztette újjá, amely arra is alkalmasnak bizonyult, hogy új tartalommal töltse fel a konzervatív irányba forduló szabadelvü gondolkodást. Azt a következtetést vonta le, hogy a szabadelvüséget „,akár konzervativizmusnak is nevezheti," mert annak valódi tartalma a nemzeti értékeket magukon viselő aktorok megőrzése. A szabadelvü politika feladata ezért az, hogy „,haladjon a nemzet erőinek kifejtésében s konzerválja annak meglevő elemeit”. ${ }^{492}$

Réz társadalompolitikai programjának fókuszában a magyar történelmi középosztály állami támogatással történő - felemelése és megerősítése állt, akikre úgy tekintett, mint az ország vezetésére és az erdélyi magyar szupremácia megvédésére egyedül alkalmas társadalmi réteg. Ezzel szemben a társadalom többségét kitevő magyar és nemzetiségi parasztság, illetve munkásság szociális és politikai reformköveteléseit a politikai tekintély fenntartásával, felülről és csak lépésről-lépésre vélte támogathatónak.

\footnotetext{
${ }^{489}$ Réz Mihály: A magyar szabadelvüség. Magyar Figyelö, 1911. I. évf. I. kötet, 113-126.

${ }^{490}$ MOROVÁN, Valóság, 1998. 2. szám. 47-55.

${ }^{491}$ RÉZ Mihály: A magyarság uralma és a kor szelleme. Publicisztikai dolgozatok. Budapest Pallas Rt. Nyomdája, 1909. 34-35.

${ }^{492}$ Uo. 38.
} 
„Isten adott a vezéreknek tehetséget, hogy megmutassuk az utat. [...] Ha a tömeg szabja meg az irányt, egyaránt kárba vész a vezérek tehetsége s a tömeg idealizmusa, mert az utóbbi hamis útra téved." 493

A századfordulótól az első világháború végéig a választójogról és a nemzetiségi kérdésről szóló viták szorosan egymással összefüggésben tematizálták a politikai közbeszédet. Tisza tanácsadója kérlelhetetlen ellenfele volt a polgári radikális, a szociáldemokrata, illetve a túlzó függetlenségi párti nacionalista törekvéseknek. Előbbiek, míg a társadalom fejlődését gazdasági és kulturális eszközökkel vélték elösegíteni, addig Réz az alkotmányjogi és állami intézkedésektől remélte azt. Elvetette az egyenlő, titkos választójogot, a szabadgondolkodást, az internacionalizmust és a radikális haladást (modernitást) követelő politikai programokat, amit kritikusan a „kor szelleme” kifejezéssel illetett. A választójog reformját a tudatlan, vezetetlen, elöítéletes, demagóg, radikális tömegek uralmával azonosította, a haladást jelképező természettudományos világnézetet a vallás és erkölcs, illetve a nemzetköziséget a hazafias érzés meggyengítésével párosította. A jogtudós úgy érvelt, hogy a haladást nem sajátíthatja ki sem a gazdaság (ezért sem fogadta el a marxista érvelést), sem pedig a politika. Minden reform előkészítését elsődlegesen az állam feladatának tulajdonította. ${ }^{494}$

Réz reális kihívásként értékelte az 1874. évi választójog óta eltelt társadalomban bekövetkezett átalakulási folyamatokat: erős román és szlovák parasztbirtokos, iparos rétegek, „osztályok” keletkeztek, illetve a megnövekedett román és szlovák értelmiség, „intelligencia” céltudatos közgazdasági politikával szervezte és vezette ezeket a csoportokat. A nemzetiségi társadalmakkal szemben ,az ország minden részében meggyöngült a magyar középosztály s a nemzetiségek fölötti gazdasági és politikai vezetést kezéböl kiejtette". ${ }^{495}$ Erdélyi etnikai viszonyainak a megváltozásával arra kívánta felhívni a figyelmet, hogy Erdély ügye országos ügy. „Erdély ez érdekei az országnak is érdekei. Ha a magyar középosztály védelmét, ha a magyar szupremácia fönntartását követeljük: ez nemcsak Erdélynek érdeke. Ha azt mondjuk, hogy a választói jog korlátlan kiterjesztése Erdélynek pusztulás: ez a veszedelem nemcsak Erdélynek veszedelme lesz. [...] Ez nem partikularizmus, hanem nemzeti politika." 496 A megoldás kérdésében Réz egyetértett Tiszával. Mindketten úgy vélték, hogy nem egy átfogó választójogi reform biztosítja a magyarság politikai dominanciáját, hanem a nemzetiségek rovására történő választókerületek technikai kiigazítása.

\footnotetext{
${ }^{493}$ RÉZ Mihály: A magyar fajpolitika. Budapest, 1905. VIII.

${ }^{494}$ RÉZ Mihály: A választójogról. Választójog. Budapest. A Magyar Figyelő kiadása, 1913. 90-101.; RÉZ Mihály: A történelmi realizmus rendszere. A Studium kiadása, Budapest, 1924. 204-209. [Továbbiakban: RÉZ, 1924] ${ }^{495}$ RÉZ Mihály: A kor szelleme és a választói jog. Választójog. Budapest. A Magyar Figyelő kiadása, 1913. 63. ${ }^{496}$ RÉZ Mihály: Erdélyi politika. Nemzeti politika. Budapest, Pallas Rt. nyomdája, 1907. 47-48.
} 
A választójog kiterjesztésével álláspontjuk szerint a széles tömegek hajlamosak a nemzeti, „faji” és a vallási demagógiára, és különben is „a nép nem demokrata. ${ }^{~ 497}$ Réznek ez az érvelése általánosan bevett fordulatként jelent meg az általános választójogról szóló vitákban. Szerinte még a függetlenségi párti képviselők sem vették figyelembe, hogy a túlságosan demokratikus reform a közjogi küzdelmek helyébe a fajok harcát hozza. Nacionalizmus és demokrácia kéz a kézben jár. A szociális vívmányok kiterjesztésének kérdéséről hasonlóan vélekedett. Legyen szó akár a keresztény, akár a szocializmus politikai ideológiájáról, a túlzó ígéretek mind a nemzetiségi tömegmozgalmakat, nacionalista törekvéseket erősítik és abból nem a mérsékelt, de igazán vallásos, illetve a haladás valódi hívei profitálnak. Réz a demokratikus választójogtól azért intett óva mindenkit, mert azzal az egész belpolitika nemzetiségi és felekezeti izgatás alá kerülne, táptalajt adva a magyarellenességnek, az antiszemitizmusnak, a korrupciónak és a liberalizmus, „szabadelvüség” ellenességnek. A választójog kiszélesítése pedig összességében a magyar szupremáciát ásná alá. Réz álláspontja értelmében az általa vélelmezett magyar fennhatóság, „a magyarság gazdasági, politikai és kulturális fölénye”, melynek társadalmi reprezentánsa a középosztály és az intelligencia, a választójoggal járó negatív folyamatok következtében egyszer s mindenkorra elvész. „Akkor valóban csupán két lehetöség marad fönn számunkra: az erőszak vagy a pusztulás."498

\subsubsection{Két politikai gondolkodó vitája: Réz Mihály és Jászi Oszkár}

A Réz-Jászi évtizedes vita utolsó felvonására néhány héttel a Monarchia összeomlása előtt került sor a Huszadik Században. A két politikai gondolkodó nemcsak koruk két eltérő egyénisége volt, de a történeti Magyarország és a dualizmus jövőjéről két egymással összeegyeztethetetlen társadalompolitikai nézetrendszer reprezentánsai is.

Réz Mihály A nemzetiségi kérdés a politikai tudomány szempontjából címü ${ }^{499}$ írására Jászi Oszkár A nemzetiségi kérdés a társadalmi és az egyéni fejlődés szempontjából címü tanulmányában reagált. ${ }^{500}$ Réz szerint korának viszonyait a különböző erők, az egymással élethalálharcot vívó fajok küzdelme alkotta. A harc fő eszköze a nemzetállam, amely az erősebb jogán biztosítja uralmát a gyengébb, jelen esetben a nemzetiségek fölött. Markánsan kijelölte a vita további irányvonalat és fogalmi körét: faj, nemzetiség, nemzet és azok változó tartalmát.

\footnotetext{
${ }^{497}$ Uo. $48-55$.

${ }^{498}$ Uo. 78-79.

${ }^{499}$ A Huszadik Században közöl Réz Mihály cikk újbóli és szó szerinti közlésére 1923-ban került sor A történelmi realizmus rendszere munka, A fajok című alfejezetében. A disszertációban az 1923-as munkát használom.

500 JÁSZI Oszkár: A nemzetiségi kérdés a társadalmi és az egyéni fejlődés szempontjából. Huszadik Század, Tizenkilencedik évf., XXXVIII. Kötet, 1918. július-december, 97-111. [Továbbiakban: JÁSZI, Huszadik Század, 1918]
} 
„Nemzetiség: az a politikai öntudatra ébredt faj, amely államalkotó hatalommal nem bír. Nemzet az, amely bír és él ezzel a hatalommal. Mihelyt elnyeri e hatalmat valamely faj: nemzetiségböl nemzetté válhat. Mihelyt ezt elveszíti: nemzetiséggé lesz csupán. Ha pedig a faji öntudat is kivész belöle: a nemzetiségböl fajjá lesz megint. Hatalom emeli nemzetté a nemzetiséget. A fajt nemzetiséggé: az öntudat." ${ }^{501}$ Réz fogalomkészletében kulcsfontosságú értelemmel bíró tartalmak: politikai öntudat, múlt (időbeliség), uralkodó faj, bontó és kapcsoló tényezők (felekezet, osztálytagozódás, etnikai párt, területiség), élö és komplex. Hierarchikus viszonyrendszerben értelmezte a faj, a nemzetiség és a nemzet közti kapcsolatot. A szociáldarwinista fejlődéselméletnek a kor emberére gyakorolt hatását láthatjuk, amikor Réz a létért való küzdelemről beszél egyedek és nemzetek között egyaránt. A nemzetiség a fajtól abban különbözik, hogy rendelkezik közös politikai öntudattal és törekvéssel, a nemzettől, hogy nem képes államalkotásra. A nemzet az államalkotó faj, amely egymaga alkotja az államot. A nemzet áll tehát a képzeletbeli fejlődési lépcsőfok tetején, szupremáciája alatt léteznek a nemzetiségek és a fajok. A képlet ebben a tiszta formájában például Franciaországban valósult meg, ahol a francia államalkotó faj minden más faj segítsége nélkül, magában képes önálló államalkotásra. Franciaországgal ellentétben Magyarország soknemzetiségü állam, ahol a magyarság, mint uralkodó faj, gazdasági, kulturális, politikai fejlettsége alapján és mindenekelőtt múltja („elsőrendü fajképző tényező”) miatt a maga jellegét nyomja rá az államra, (amely nevét is ettől veszi) és más fajok felett szupremáciát gyakorol. Réz értelmezésében - a mai szakirodalmakkal ellentétben - nem a nyelv és a közös származás tudata, és nem is biológiai megközelítés a döntő tényező, bár nem mellékesek, hanem a múlt és a közös politikai öntudat. ,Ahol ez nincs meg, ott a faj közös nyelv, közös származás dacára sem képez önálló politikai faktort. Ahol megvan, ott a fajból politikai faktor lesz, habár tagjai tényleg nem közös származásúak." 502

A szeparatizmus, „,bontó tényezők” kérdése kapcsán meghatározó tényezőként sorolta fel, hogy az adott faj/nemzetiség az állam területén belül földrajzilag hol (határt mellett vagy középen) és milyen formában (szórvány, tömb) helyezkedik el, milyen felekezetű, társadalmi fejlettségében mennyire (osztály)tagolt, etnikai jellegü párttal és kulturális intézményrendszerrel rendelkezik-e, illetve, ha van anyaországa, az milyen hatást gyakorol rá. Réz fajképző elemeknek tekintette: osztály, vallás, párt, terület, állam, amelyek külön és komplexen is hatnak a faj nemzetiséggé, a nemzetiség nemzetté való fejlődésének folyamatában.

\footnotetext{
${ }^{501}$ RÉZ, 1924. 44.

${ }^{502}$ Uo. 46.
} 
„Cél mindig a faj további érvényesülése lesz. [...] A nemzetiségnek: a nemzeti lét. A nemzetnek: a nemzeti egység. Az egységes nemzetnek: a függetlenség. A független államnak: a más államok feletti befolyás." ${ }^{, 503}$ Réz ebböl azt a következtetést vonta le, hogy téves azt gondolni, hogy a nemzetiségeknek tett engedmények megszüntetnék a nemzetiségi törekvéseket, illetve a szabadságnak e tekintetben kohéziós hatása van. Ezen a ponton túllépett a szabadelvü politikára hatást gyakorló 19. századi irányelveken. Nem tekintette magáénak sem az Eötvös-féle liberális, sem a Rousseau-féle természetjogi gondolatot, hogy a nemzetiségi (kollektívum) kérdés az egyéni szabadság elvének eszközeivel orvosolható lenne. Elavult gondolatoknak nevezte azokat a nézeteket, amelyek csupán egyéneket vagy, ahogy a marxizmus csak osztályokat látott a társadalom tagjaiként. „Az a feltevés, hogy az osztályszempont a nemzetiségnél háttérbe szoritja a faji szempontokat, - amelyre nézve a világháború fajpszichológiai tanulságai megadták a feleletet - éppoly anakrizmus és anatopizmus, mint akár az Eötvös-féle." ${ }^{504}$ Réz minden típusú jogkiterjesztésről úgy vélekedett, hogy azok a bontó tényezőknek és a politikailag öntudatlan tömegeknek nyit utat. Az állam egységét veszélyezteti a politikai jogokban kedvezményezett öntudatlan nemzetiségi paraszti tömeg, az uralkodó faj egységét pedig osztálytudatában fejlett munkástömeg bontja meg. A nemzetiségi kérdés ezért nem izoláltan, önmagában kezelendő kihívás, hanem olyan állandó probléma, amelyet az egységes nemzeti állam struktúráján belül kell orvosolni.

Jászi az uralkodó-meghatározó állam- és nemzetközpontú felfogással, így Rézzel szemben a demokratikus, jogkiterjesztés pártján állt. Ahogy Réz az állam és a nemzet, úgy Jászi a társadalom és az egyén fogalmi kategóriáiban jelölte ki a vita menetét. Jászi tételesen cáfolta Réz nemzetiségről felállított téziseit. Jászi szerint Réz rossz úton járt, amikor azt feltételezte, hogy a nemzet és a nemzeti állam a végleges érték, illetve a nemzetiségi kérdés nem megoldandó probléma, hanem „organikus hiba”. Jászi álláspontja ezzel szemben az volt, hogy a társadalmi fejlődés menete nem a nemzetállam elérésekor ér véget, hanem amikor az egyén, a társadalom, illetve az állam életében egy együttmüködő egyensúlyállapot következik be. A Jászi-féle demokratikus gondolat építőkövei az egyén és a kooperatív társadalom, és nem a faj és a nemzeti gondolat, amely szükség esetén a fegyverekhez nyúlva harcol folyton az államiságért. A polgári radikális gondolkodó szemében a nemzetiségi kérdés nem hatalmi, uralmi kérdés, hanem demokratikus eszközökkel, jogkiterjesztéssel megoldható feladat.

\footnotetext{
503 Uo. 59.

${ }^{504}$ Uo. $43-44$.
} 
A Réz által képviselt szakadatlan harc (lehanyatlás versus fejlődés) helyett Jászi a történelmet egy szélesebb körü civilizációs, kooperatív egységek felé haladó folyamatnak látta, ahol az öntudatos egyén nem rendeli magát alá (tulajdonát, erkölcsi értékeit, életét) a faji, a nemzeti és a gazdasági imperializmus hódításának. Az egyén fejlődéséről azt feltételezte, hogy a demokrácia és a kulturális élet előrehaladásával meghaladható az öncélú állami gondolat és a túlfütött etnikai érzelem „vak zsarnoksága”, amelyek helyébe a felvilágosult egyének és a szervezett világállam lép.

A nemzetiségi kérdésben Jászi ment el a legmesszebbre, amikor elismerte, hogy egy ponton túl az adott nemzetiség az önálló állam létrehozására való törekvését nem lehet megállítani. Réz és Jászi közti döntő különbség abban volt, hogy utóbbi az egyre élesedő nemzetiségi ellentétek enyhítésének eszközét minden nemzetiség ama jogának elismerésében javasolta, hogy nyelvét, kultúráját szabadon fejlesztheti. A gyakorlatban ezt a Renner-féle tervvel azonosította, amely azt jelentette, hogy egy nemzetiség az államon belül az egyházak mintájára jogi személyként, bizonyos fokú önkormányzatiság megadása mellett anyanyelvén szervezheti társadalmát. ${ }^{505} \mathrm{Nem}$ sokkal a Jászi - Réz vitát követően, 1918 őszén és telén - Jászi rövid minisztersége idején - tudomásul kellett vennie, hogy a hazai nemzetiségek vezetöi visszautasították összes kompromisszumos javaslatát, nem fogadták el a Monarchia helyén felajánlott Dunai Egyesült Államok, sem pedig egy Keleti Svájc tervét.

\subsection{Jakabffy Elemér: „a nyelv és a vallás azonossága még nem minden "506}

Jakabffy Elemér örmény eredetü, a 18. század végén nemesi címet kapott, katolikus bánsági földbirtokos családban született 1881-ben, a román többségű Krassó-Szörény vármegyében fekvő Lugoson. ${ }^{507}$ 1908-ban ügyvédi irodát nyitott Lugoson. Első jelentősebb tanulmánya 1904-ben jelent meg Budapesten Mit kell tennünk elsősorban a gazdasági cselédkérdés megoldása érdekében? címen. A családi tradíciót ${ }^{508}$ folytatva Tisza István politikai irányvonalát képviselte.

\footnotetext{
505 JÁSZI, Huszadik Század, 1918. 97-111.

506 JAKABFFY Elemér: A románok hazánkban és a román királyságban. Budapest, Singer és Wolfner, 1918.1.

507 1881-ben Román- és Németlugos 11287 lakosából 4852 (42,99\%) volt román, 4533 (40,16\%) német és 1355 $(12,00 \%)$ magyar anyanyelvü. 4184 római katolikus, 4089 ortodox, 1253 zsidó, 1052 görög katolikus, 417 evangélikus és 286 református vallású. 1910-ben 19818 lakosából 6875 magyar (34,69\%), 6227 román (31,42\%), 6151 német (31,03\%), 221 szerb (1,14\%) és 127 szlovák (0,64\%) anyanyelvü; 9279 római katolikus, 5413 ortodox, 1878 zsidó, 1414 református, 1235 görög katolikus és 553 evangélikus vallású volt. (Az 1881. és az 1910. évi népszámlálások adatai alapján. https://library.hungaricana.hu/hu/collection/ksh_neda_nepszamlalasok/ Letöltve: 2017. október 9.)

${ }^{508}$ Apja, Jakabffy Imre az 1880-ban Lugos székhellyel egyesített Krassó és Szörény vármegyében előbb alispán, majd főispán, szabadelvü párti képviselő, később államtitkár Tisza István első kormányában. MIKÓ Imre: Jakabffy Elemér és a Magyar Kisebbség. Korunk, 1973. 32. évf. 8. szám, 1198.
} 
1910 és 1918 között nemzeti szabadelvü párti programmal a németbogsáni választókerület országgyülési képviselője. Kortesbeszédeit magyar, német és román nyelven mondta el. Tartalékos tisztként a Montenegróban állomásozó ezrednél szolgált. 1916-ban tért vissza Budapestre, részt vett I. Ferenc József temetésén, illetve IV. Károly király megkoronázásának ünnepségén. A legfiatalabb tagja volt a Monarchia hatvantagú magyar delegációja külügyi és hadügyi albizottságának (1918. januártól). Az őszirózsás forradalom Lugoson érte. ${ }^{509}$ Az új államhatalommal szemben az esküt megtagadta, ezért Lugosról Zaguzsénba költözött a birtokára. A Romániába szakadt magyar kisebbség önkéntes szervezőjévé szegődött. Eleinte álnéven, majd saját nevével közölte cikkeit a Sulyok István szerkesztette Krassó-Szörényi Lapokban, illetve a Keleti Újságban. Kiemelt témái között szerepelt a romániai agrárreform, a bánsági magyar telepesek ügye, az iskolaügy, illetve a népesség statisztikai változásai. Egyik alapítója a Magyar Kisebbség folyóiratnak ${ }^{510}$, melyet 1922-ben alapít Sulyok Istvánnal és Willer Józseffel („,lugosi triumvirátus”). Nemzetiségpolitikusként a romániai magyar kisebbség képviseletében többször részt vett a genfi nemzetközi népkisebbségi konferenciákon (elsőként Balogh Artúrral 1925-ben), illetve 1928-tól a bukaresti országgyülés tagja. Az OMP bánsági tagozatának elnöke, tagja az országos vezetőségnek is. Többek között Krenner Miklós Spectatorral, Balogh Artúrral, Szentimrei Jenővel, Paál Árpáddal az OMP reformszárnyához tartozott. $^{511} \mathrm{Az}$ OMP-re úgy tekintett, amely csak nevében politikai párt, ténylegesen „nemzetképviselet, melynek csak másodlagos célja a politikai érvényesülés, elsődleges hivatása ellenben, hogy szervezetbe tömörítse mindazokat, akik akár származásuknál, akár anyanyelvüknél, akár érzületüknél vagy müveltségüknél fogva magukat magyaroknak vallják". 512

Jakabffy országgyűlési képviselőként saját bevallása szerint Tisza lemondásáig kétszer tartott politikai tartalmú beszédet (ide nem értve az igazságügyi bizottság megbízásából történteket). Az egyikre 1914 elején került sor, amikor Tisza előterjesztette a román vezetőkkel folytatott tárgyalásairól szóló beszámolóját, és Jakabffyt bízta meg a kormánypárt részéről a határozati javaslat elkészítésével, illetve annak ismertetésével.

\footnotetext{
${ }^{509}$ Részletes naplót vezetett, amely később A magyar államhatalom utolsó hónapjai Krassó-Szörény megyében című munkája alapjául szolgált.

${ }^{510}$ Lásd bővebben: BALÁZS Sándor: Jakabffy Elemér és a Magyar Kisebbség. Kriterion Könyvkiadó, Kolozsvár, 2012

${ }^{511}$ Romániai Magyar Irodalmi Lexikon. II. G - Ke. 1991. 462-464.; SZEKERNYÉS János: „Fáradozásom eredményes volt". Európai Utas, 2008/1. 41.

512 Amire a magyar nemes testörök példája tanít. Ünneplö beszédek [1. sor. Szerzői kiad.] 1934. Lugos, Husvéth és Hoffer
} 
Ennek alapgondolata Tiszától származott ugyan, de a megfogalmazás Jakabffyé volt, amelyben a területi integritás és a társadalmi haladás szabadelvü programja mellet foglalt állást. „,A képviselöház a magyar nemzet évezredes tradicióihoz híven, az állam egységéhez és nemzeti jellegéhez tántorithatatlanul ragaszkodik. E mellett a hazának nem magyar ajkú polgárait nemcsak a jogegyenlöség jótéteményeiben részesiteni, de minden olyan óhajuk elérésében készségesen támogatni hajlandó, amely az egységes nemzeti állam alapelvével összefér."513 Jakabffy aktív politikai magatartást ellenzéki képviselőként, Tisza lemondását követően fejtett ki, amikor a volt miniszterelnök államférfiúi képességeit és kormányának politikáját emelte ki az Esterházy és a Wekerle adminisztrációkkal szemben. ${ }^{514}$ Utóbbi alkalmatlanságát próbálta bizonyítani akkor, amikor gróf Apponyi Albert közoktatási minisztert vette célba. Jakabbffy Apponyi román politikáját rótta meg, amikor azzal szembesítette a grófot, hogy a román tanítóképző intézetek bezárásáról szóló kormányzati döntést képtelen volt a kitüzött célnak megfelelően végrehajtani. Jakabffy itt visszautalt a Tisza-kormányra, és megerősítette annak elképzelését, amely „a tanitóképzők tekintetében azon az állásponton volt, hogy az állami felügyeletnek és az állam közvetlen befolyásának fokozásában kívánta a remédiumot [ellenszert - F. N.] biztositani". ${ }^{515}$ A munkapárti képviselő majd azt vetette a kabinet szemére, hogy a „létalapját” jelentő választójogi reformot, amelyet még ellenzékben a leghangosabban követeltek Tiszától, pont azt nem fogja végrehajtani. Jakabffy bár az általános választójog kérdésében a konzervatív álláspontot képviselte, azt nem tekintette a születésnél fogva mindenkit megillető jognak ${ }^{516}$, mégis megváltoztatta véleményét. A politikai viták eszkalálódásától tartva arra kérte Wekerle Sándor miniszterelnököt, hogy ,igyekezzék a kormány kebeléböl a világnézetek harcát kiszoritani, [...] a választói jog kérdésében a parlamentben képviselt világnézetek között kompromisszumot létesíteni, mert ezt kívánja a haza ügye, ezt kívánja az egységes magyar nemzeti állam fennmaradása". 517

\footnotetext{
${ }^{513}$ Képviselőházi napló, 1910. XXII. kötet. 517. országos ülés. 1914. március 5., 415. http://www3.arcanum.hu/onap/opt/a1 10616.htm?v=pdf\&q=WRD\%3D\%28Jakabffy\%20Elem\%E9r\%29\&s=SO RT\&m=256\&a=rec (Letöltve: 2017 . október 8.)

${ }^{514}$ Képviselőházi napló, 1910. XXXVI. kötet. 728. országos ülés 1917. június 23. 48.

http://www3.arcanum.hu/onap/opt/a1 10616.htm?v=pdf\&q=WRD\%3D\%28Jakabffy\%20Elem\%E9r\%29\&s=SO RT\&m=340\&a=rec (Letöltve: 2017. október 9.)

${ }^{515}$ Képviselöházi napló, 1910. XXXVII. kötet. 745. országos ülés 1917. október 20. 99. http://www3.arcanum.hu/onap/opt/a1 10616.htm?v=pdf\&q=WRD\%3D\%28Jakabffy\%20Elem\%E9r\%29\&s=SO RT\&m=359\&a=rec (Letöltve: 2017. október 9.)

516 Képviselőházi napló, 1910. XL. kötet. 82. országos ülés 1918. július 19., 626. http://www3.arcanum.hu/onap/opt/a1 10616.htm?v=pdf\&q=WRD\%3D\%28Jakabffy\%20Elem\%E9r\%29\&s=SO RT\&m=359\&a=rec (Letöltve: 2017. október 10.)

${ }^{517}$ Uo. 100.
} 
Jakabffy a román nemzeti mozgalomról vallott nézeteiről a kultúr- és szociálpolitikai tanulmánya, A románok hazánkban és a királyságban (1918) ad betekintést. Az írás nyomtatására a román katonai betörést követően, de még a Monarchia összeomlása előtt került sor. A szerző figyelmét az 1916-os román hadüzenet utolsó bekezdése keltette fel, amely szerint a háborúba lépést a nemzeti egység szándéka vezérelte. „Hogy fajérdekeiket megoltalmazza, Románia azokhoz kénytelen csatlakozni, akik inkább vannak a helyzetben, hogy nemzeti egységének megvalósitását biztositsák." ${ }^{518}$ Jakabffy állambölcseleti meglátása szerint az egységesítő román szándéknak az ideje nem érkezett el. Jancsóhoz hasonlóan abból indult ki, hogy az ezeréves történeti alapokon nyugvó magyar állam- és nemzetépítés fejlettségét tekintve előbbre tartott a románéval szemben. Úgy vélte, hogy Romániának ezért „,meg kell értenie, hogy a kultúra, politikai életfelfogás és erkölcs alacsonyabb fokán álló állam és társadalom csak nyers erövel uralkodhatnék a magasabb fokon állók felett". ${ }^{19}$ Románia alacsonyabb fejlettségéből és kisnemzeti státuszából eredően nem törekedhet arra, hogy az „évezredes történelmi államalakulatok megsemmisitésén munkáljanak”. Összefoglalva Jakabffy ragaszkodott ahhoz a 19. századi tételhez, hogy egy nemzetiséghez tartozó egyén számára a fejlettebbnek gondolt magyar kultúra, tagolt társadalom és politika berendezkedés erősebb formáló hatással bír identitás fejlődésében, mint az adott nemzetiség nyelvi, kulturális és vallási közösségi élete. Magyarországhoz képest elmaradottabb Romániára ugyanezt ez az elméletet vonatkoztatta: Bukarest elsődleges feladata csak az lehetett, hogy saját állami életét, társadalmát, kultúráját fejlessze és az egységes magyar nemzet állam határain belül létrejött és létező román társadalmat igyekezzen minőségében „,utolérni”. 520

\footnotetext{
518 JAKABFFY Elemér: A románok hazánkban és a román királyságban. Kultúr- és szociálpolitikai tanulmány. Budapest, Singer és Wolfner, 1918. 1.

519 Uo. 1.

${ }^{520}$ Uo. $1-4$.
} 


\subsection{Pál Gábor: „Erdély mostohája Magyarországnak”}

Pál Gábor ${ }^{521}$, a hetente megjelenő Csíki Hírlap felelős szerkesztője 1911. decembertől, illetve Csík vármegye törvényhatóság központi választmányának megválasztott tagja. Pál világnézetét tekintve kossuthiánus, függetlenségi párti, regionalista szemléletü, amelyet lapja is tükröz a Tisza István munkapárti Csíki Lapokkal szemben. ${ }^{522}$

Pál a lap első számában a következőképpen köszöntötte az olvasókat: „Várták eljövetelét azok, kiknek lelkük egyik legszentebb vágya hazánk független államiságának kiépitése. [...] A munkapárt céljait szolgáló hangok mellett, hadd jusson szóhoz itt a vármegye középpontjában a nem hivatalos, független felfogás is." ${ }^{523}$ Ebben a gondolkodásban egyszerre több elem is helyet kapott. Egyfelöl elvetette a dinasztia centralisztikus föderalizmus tervét, illetve a délszláv területek annektálását (Bosznia-Hercegovina, 1908). Attól félt ugyanis, ha a dualista rendszer trializmussá alakul, a bécsi politika a magyarok ellenében plusz jogokkal ruházza fel a birodalom szláv nemzeteit. ${ }^{524}$ Másfelől a Magyar Királyságon belül a magyar szupremácia biztosítását Magyarország erdélyi politikájának megújításában látta. Helyzetleírásában abból indult ki, hogy „Erdély mostohája Magyarországnak”, ahol az erdélyiek magukra maradtak hol a törökkel, hol a némettel való küzdelmükben, hol pedig az elmaradt erdélyi gazdasági, infrastrukturális fejlesztésekben. Az erdélyi lélek (gondolkodás) egyik jellemzője ezért, az „ellenzéki” attitűd, melyet az országrész zárkózottsága és különállása csak megerősített. Pál Magyarország Erdéllyel való unióját követően a korábbi külső ellenségek mellé felsorakoztatta immár a nemzetiségi mozgalmakat is, amelyek szerinte „,belsö aknamunkát" folytatnak külső támogatással Bukarestből, de még Bécsből is. A budapesti kormányok elleni kritikájában egyrészt úgy fogalmazott (összhangban a székely kongresszusokkal), hogy a nemzetiségi veszélyt maguk is előidézték a „megtévedt nemzeti politikával”.

\footnotetext{
${ }^{521}$ Pál Gábor (Csíksomlyó, 1883.-1968. Csíksomlyó). A '48-as eszméken felnőtt ifjú nagyapja 1848-as hős volt, apja, id. Pál Gábor negyven éven keresztül tanára és igazgatója a csíksomlyói, illetve a csíkszeredai gimnáziumnak, anyja polgári családból származott. Kolozsváron jogot végzett, Svájcban és Münchenben is tanult, ügyvédi vizsgát 1908-ban tett. Halála előtt rendezte feljegyzéseit és megírta a Visszaemlékezését, amelynek egy része a Hargita megyei állami levéltárba került [Fondul personal Pál Gábor (Pál Gábor iratai), 1890-1961], másik része, hagyatékával együtt, magántulajdonban található.

OLẢH-GÁL Elvira: Pál Gábor élete és munkássága (I. rész). Székelyföld, 2011. XV. évf. 1. szám, január, 89-95. [Továbbiakban: OLÁH-GÁL, Székelyföld, 2011. január]

522 A Csíki Hírlap 1911-1914 között múködött, sokszorosítása rendkívül kezdetleges volt (kézi sajtóval nyomtatták), illetve Pál az első világháború kitörését követően önkéntes katonai szolgálatra jelentkezett.

${ }^{523}$ Beköszöntö. Csíki Hírlap. 1911. 1. évf. 1. szám, december 23. 1.

${ }^{524}$ Közeledés a trializmus felé. Csíki Hirlap, 1912. 2. évf. 3. szám, január 20. 1.
} 
Ez alatt azt értette, hogy a régió társadalmi viszonyait figyelmen kívül hagyva a mindenkori magyar kormány a nemzetiségi vidékeken felállított középfokú iskolákkal ellentétest hatást ért el, mert végeredményben ,állami költségen nemzeti intelligenciát, a magyar nemzeti állam ellenségeinek vezető osztályt nevelt ki”. ${ }^{525}$ Másrészt nem érvényesítették Erdélyben a magyar nemzeti szempontokat szem előtt tartó közlekedési, ipari, kereskedelmi fejlesztéseket, beruházásokat. Erdélyen belül külön kiemelte Székelyföld periférikus helyzetét: a magas analfabétizmust, az elvándorlást, a helyi gazdaság alacsonyvolumenét, illetve a határvédelem szervezetlenségét. ${ }^{526}$

Pál vezércikkekben kommentálta a választójogi vitát, amely a nemzetiségi kérdés problémájában öltött testet. Mint, arról volt már szó a függetlenségi párt - részben a véderőtörvénnyel kapcsolatos vitákban - kettészakad (1909) Justh és Kossuth-Apponyi-féle pártokra, amely politikailag elősegítette, hogy az 1910-es választásokon a Nemzeti Munkapárt kormányt alakíthasson. A függetlenségi párti Pál nem osztotta azt a véleményt (például Apáthyval szemben), hogy az általános választójog, amelyért a Justh-párt harcolt, előmozdítaná a nemzetiségi kérdéssel kapcsolatos problémákat. Azt mondta, hogy oly országban, amelyben az államalkotó magyarság a lakosság felét alig haladja meg, az általános szavazati jog eszméje nem valósítható meg a nemzeti érdek sérelme nélkül. ${ }^{527}$ Egy demokratikus választójogi rendszer bár biztosíthatná a függetlenebb parlamentet (itt arra utalt, hogy a korábbi szabadelvü, illetve a munkapárt visszaélésekkel szerezte meg a hatalmat), de a nemzeti ügyek (például a véderőtörvény, nemzetiségi kérdés) irányában elkötelezettebb nem lenne. „Hogy magyarabb és nemzetibb legyen, ezt hinni vakmerö önámitás lenne, még abban az esetben is, ha a választójog a magyarul írni és olvasni tudáshoz köttetnék, amit pedig alig lehet remélni" - fogalmazott a szerző. Ezt azzal indokolta, hogy kellő müveltség hiányában a képviselők egy része nem a közjóért küzdene (a magyar nemzeti célok szempontjából), hanem saját szociális, nemzetiségi sérelmeiknek, pártérdekeiknek adnának hangot. ${ }^{528}$ Érvelése hasonlított Bethlen Istvánéra, aki szerint az erdélyi politikusoknak ki kell kapcsolniuk az egyéni érdekeiket a magyar nemzeti ügyek szolgálatáért, a magyar szupremácia biztosításáért. A gróffal összhangban Pál az egységes és osztatlan magyar nemzeti állam eszméjét zászlajára tüző Magyar Szövetség kolozsvári alakulását messzemenőkig támogatta, amelyben az erdélyi összmagyarság és székelység védelmét feltételezte.

\footnotetext{
525 A vasút és nemzeti ügyünk. Csíki Hírlap. 1922. 2. évf. 10. szám, március 9. 1-2.

${ }^{526}$ Van-e szükség erdélyi pártra? Csíki Hírlap, 1913. 3. évf. 51. szám, december 20. 1-2.

527 Alkudozás a választójog körül. Csíki Hírlap, 1912. 2. évf. 17. szám, április 27. 1.

${ }^{528}$ Testvérharc. Csíki Hírlap, 1912. 2. évf. 9. szám, március 2. 1-2.
} 
A szövetség országos müködését úgy képzelte el, amelyet „egységes párt” jelzővel illetett, hogy külön képviselővel a mindenkori kormányban helyet kapjon. ${ }^{529}$

Pál regionalizmusában kulcsszerepet játszott a székelység társadalmi fejlődését elősegítő politika és a magyar szupremácia fenntartásnak biztosítása. Érvelésében a magyarság Erdélyben történő „vezérszerepének biztositására, a keresztény kultúra elömozditására” felsorakoztatta a székelység szabadság- és hazaszeretetét, az erdélyi fejedelemség korát, a Bocskayak és a Rákócziak küzdelmeit, az 1848-as hagyományokat. Továbbá olyan részelemek képezték az erdélyiség gondolatát, mint az ellenzéki attitüd, a tájszeretet, az elhagyatottság érzete. ${ }^{530}$

Pál a háborúban való részvételét Emlékezéseim katonai életemből címmel jegyezte le. Bevonulásakor közlegényként szolgált, majd 1916 tavasszal hadnaggyá léptették elő. 1916 júliusában, a román hadba lépés küszöbén hazautazott szabadságra, ahonnan Brassóba vezényelték. A szervezési hiányosságokról (telefonösszeköttetés, gyalogosok számára óriási távolságok) szólva az osztrák hadvezetést bírálta, mert a székely katonákat nem rendelték haza a szülőföldjük védelmére. A brassói 2. közös gyalogezredet, melynek állományában nagy többséggel háromszékiek harcoltak, néhány nappal a román hadüzenet elött az orosz harctérről az olasz frontra vezényelték át, illetve az orosz harctéren maradtak a brassói 24 . és a marosvásárhelyi 22. gyalog honvédezredek is. ${ }^{531}$

Pál a Csík vármegyei közigazgatási bizottság tagjaként javaslataival hozzájárult a háború okozta károk elhárításához. Kifogásolta, hogy az 1916-ban elmenekült és még 1917ben is távol lévő lakosságra is földadót vetettek ki háborús időkben. Indítványára Wekerle Sándor miniszterelnökhöz feliratot küldött a bizottság, hogy a vármegye közvetlen állami segélyben részesüljön. A bekövetkezett hadikárok kifizetésére többségében nem került sor. Visszaemlékezésében jegyezte fel az október végén megalakult Csík Megyei Nemzeti Tanács kapcsán, hogy elsődleges feladata a közrend megtartására irányult, tartva a helyi lakosság, de elsősorban a hazatérő katonák fosztogatásától. 1918 őszén a Károlyi-kormány Csík vármegye főispánjává dr. Györgypál Domokost, addigi föügyészt nevezte ki, akinek helyére, szintén kinevezés útján Pál Gábor került.

\footnotetext{
${ }^{529}$ Van-e szükség erdélyi pártra? Csíki Hírlap, 1913. 3. évf. 51. szám, december 20. 1-2.

${ }^{530}$ A lejtőn lefelé. Csíki Hírlap, 1911. 1. évf. 2. szám, december 30. 1.

${ }^{531}$ A német hadsereg nyomában részt vett a romániai katonai megszállásban, amelyről negatívan megjegyezte a megszálló csapatok civilekkel szemben történt önkényeskedéseket. Bukarest, Ploieşti, Buzău voltak állomáshelyei. 1917 tavaszán súlyos sérülést szenvedett. 1918 májusában főhadnagyi rangot kapott és a kolozsvári honvédkerületi főparancsnokság megállapította, hogy polgári foglalkozásán keresetképességének 50\%-át elvesztette, amiért havi 66 Korona nyugdíjat állapítottak meg részére.

OLÁH-GÁL, Székelyföld, 2011. január, 95-101.
} 
Csíkszeredába november 26-án vonult be a román 1. számú vadászezred különítménye. ${ }^{532} 1919$ májusában Csík megye élére a román Kormányzótótanács Neamţu Valeriu-t nevezte ki, aki az osztrák-magyar közös hadseregben hadbíró örnagy volt, aki a megye tisztviselőt eskütételre szólította fel. Az esküt megtagadták, amely elbocsátással járt. Kivételt az árvaszék képezett, amelynek Pál ügyésze (jogtanácsosa) volt, és ezt az intézményt a magyar állam törvényei szerint és magyar nyelven irányították a békekötésig. Így maradt hivatalában a személyzet, de csak 1920 júniusáig. Comaniciu kinevezett főtanfelügyelő a magyar iskolákat is felszólította eskütételre, de a tanszemélyzet nagy része nem jelentkezett. 1919 júliusában Csíkszereda polgármesterévé (primar) Barbir Vasile görög-keleti lelkészt nevezték ki, aki a városi orvoson, mérnökön, számvevőn kívül minden tisztviselőt elbocsátott. Az eskütétellel kapcsolatosan Pál Gábor Kolozsvárra utazott, ahol bekapcsolódott a Paál Árpád, Grandpierre Emil vezette a tisztviselői mozgalomba. Részt vesz az 1920-1921-fordulójától formálódó Magyar Szövetség elökészítésében, jelen volt az első kolozsvári megbeszélésen. Csík vármegyében kezdeményezőként lép fel a hatóság akadályoztatása ellenére is a helyi szervezet megalakításában. A Magyar Szövetség ellehetetlenítése után (1921) segédkezett a Magyar Nemzeti Párt megszervezésében is. 1922-től az agrárreform ellen lépett fel és a borszéki forrásokat övező erdők kisajátítása miatt memorandumot szerkesztett, amelyet Sándor József háromszéki képviselő által vezetett küldöttség vitt a földművelésügyi miniszterhez. ${ }^{533}$ Pál a két világháború között aktív politikai érdekérvényesítő szerepet töltött be. Az OMP megyei szenátoraként (1928-tól), majd képviselőként (1931-től) következetesen képviselte a székelység sérelmeit, a genfi bíróság elé vitte a román állam elkobzott Csíki Magánjavak ügyét. Politikai közírói pályáját is folytatta, a kolozsvári Ellenzék vasárnapi mellékletében A magyar kisebbségi politika eredményességének akadályai sorozatával jelentkezett (1922), illetve a Magyar Kisebbségben több tanulmányt közölt. ${ }^{534}$

\footnotetext{
532 Uo. 101-104.

533 OLÁH-GÁL Elvira: Pál Gábor élete és munkássága (II. rész). Székelyföld, 2011. XV. évf. 2. szám, február. http://www.hargitakiado.ro/cikk.php?a=MTI3OA==\#_ftn3 (Letöltve: 2017. október 17.)

534 A székelyföldi közbirtok és az agrárreform (Magyar Kisebbség, 1923/2, 3); Készülödés a közbirtokosságok és úrbéri birtokosságok reformjára (Magyar Kisebbség, 1928/4, 5, 6); A kisebbségi egyezmény és a magyar kisebbség (Magyar Kisebbség, 1928/17); A konkordátum és a katolikus magyarság (Magyar Kisebbség, 1928/18)
} 


\subsection{Gyárfás Elemér: „érdekközösségen alapuló érzelmi közösség”}

Gyárfás Elemér (1884-1945) sokoldalú - bankári, politikusi, egyházi tisztviselői és publicisztikai - munkássága révén az egyik legfontosabb erdélyi magyar közéleti szereplő. A nemzetiségileg vegyes ${ }^{535}$, román többségű Kis-Küküllő vármegyében született Borzáson. Katolikus vallású, kolozsvári joghallgató korában alapító elnöke a Kolozsvári Szent Imre Körnek (1903), melynek irányításában a városból való távozása után is részt vett. Ügyvédi vizsgáját követően, 1910-től közigazgatási tisztviselő, Dicsőszentmártonban ügyvéd, szervezője az Erdélyi Szövetségnek. Az első világháborúban három évet töltött a fronton, amikor hazatért Kis-Küküllö vármegye föispánjává nevezik ki (1917-1918). Az összeomlást Erdélyben élte meg. Aktívan szerepet vállalt a romániai magyar kisebbségi élet megszervezésében (Magyar Szövetség, Magyar Nemzeti Párt, Országos Magyar Párt), a két világháború között a román szenátus tagja, illetve az erdélyi katolikus státusnak előbb alelnöke, később elnöke. ${ }^{536}$

Gyárfás utólagos megítélése sokszínű tevékenysége következtében ellentmondásoktól nem mentes, amelyet Horváth. Sz. Ferenc egy tanulmányában összegzett. ${ }^{537}$ Gyárfás politikai gondolkodását áthatotta keresztény felfogása, amely valamelyest a 19. század végi újkonzervatív mozgalomhoz, illetve a Prohászka Ottokár és Giesswein Sándor fémjelezte katolikus reformtörekvésekhez, a keresztényszocializmushoz állt közel. Politikai írásaiban található kultúrkritikus megjegyzések újkonzervatív ihletettségű aktuálpolitikai iránya abban ragadható meg, hogy például az országnak a „nagy” magyar királyok (Szent István, Mátyás), illetve erdélyi fejedelmek (Bethlen Gábor) uralkodása alatti dicsőségét szembeállítja korának állapotával. A hanyatlás okát abban látta, hogy egyfelől elmúltak azok a „boldog” idők, midőn a keresztény hit és keresztény vezetők oltalma alatt állt az állam és a társadalom.

\footnotetext{
535 Kis-Küküllő vármegyének 1880-ban 92214 lakosa volt, ebből 48\% román, 24\% magyar, 18\% német, $10 \%$ egyéb. 1910-ben 116091 lakosa volt, ebből 48\% román, 30\% magyar, 18\% német, 4\% egyéb.

${ }^{536}$ Egyházjogi, pénzügyi és történeti müveket is írt. Főbb müvei: Erdélyi problémák (Kolozsvár, 1923); Bethlen Miklós kancellár (Dicsőszentmárton, 1924); Az erdélyi románok uniója (Dicsőszentmárton, 1925); Az erdélyi szászok és a katolicizmus (Dicsőszentmárton, 1925).

http://lexikon.katolikus.hu/G/Gy\%C3\%A1rf\%C3\%A1s.html (Letöltve: 2018. április 27.)

537 Gyárfás Elemért sokféle jelzővel illették, például Ion Brătianu román miniszterelnök ,javíthatatlan” magyarnak, Alexandru Vaida-Voevod a magyarok legravaszabbikának nevezte. Banki tevékenysége miatt a korabeli magyar baloldal benne a tőkés-kapitalista kizsákmányolót látta. K. Lengyel Zsolt Gyárfást, mint az erdélyi kérdést rendezni akaró politikusok egyikét mutatja be, kiemelve a csucsai paktum létrejöttében játszott szerepét. Bárdi Nándor Gyárfás társadalmi érzékenységét, demokratizmusát a budapesti politikusi körökével hasonlította össze, amely nézetből baloldalinak tűnhetett, míg Erdélyben a konzervatív-katolikus álláspont képviselőjének tekintették. Horváth Sz. Ferenc Gyárfást politikai-ideológia síkon jobboldalra hajló konzervatív politikusként ábrázolja. HORVÁTH Sz. Ferenc: Az egyensúly embere http://adattar.vmmi.org/fejezetek/1780/08_horvath_sz_ferenc_az_egyensuly_embere.pdf (Letöltve: 2018. április 27.) [Továbbiakban: HORVÁTH Sz.: Az égyensúly]
} 
Másfelől liberalizmus megszüntette az embereket szorító évszázados korlátokat, és szabadságot adott nekik, aminek egyrészt előnyei is voltak, másrészt azonban egymástól sem védte meg őket, kiszolgáltatva a szegényt a gazdagnak. Ebből társadalom és demokrácia felfogását illetően arra következtethetünk, hogy a szociálisan érzékeny, de tekintélyelvü vezetőket preferálta. Támogatta a szociális akciókat, például a keresztény munkásegyesületek szervezését, amely összhangban állt azzal a vízióval, hogy a társadalmat keresztény alapon lehet kivezetni problémáiból. ${ }^{538}$

Gyárfás a 20. század eleji Magyarország szociális feszültségeinek okát nemcsak a keresztény eszmeiség visszaszorulásában látta, hanem nagy figyelmet szentelt a nemzetiségi kérdésnek is. Kisküküllő vármegyei tapasztalatainál fogva az erdélyi románság helyzetét és politikai nézeteit közelről ismerte. Több rövidebb cikket írt a román kérdésről azzal a szándékkal, hogy megismertesse őket közelebbről a magyar közvéleménnyel. Szerinte ugyanis a magyarok nem ismerik, vagy sztereotípiákban gondolkodnak a románságról. Gyárfás a kérdés gyökerét az erdélyi történeti fejlődés viszonyaival magyarázza. A románok Magyarországon a magyarok (a székelyek és a szászok) mögött „másodrendü szerepre szorultak”, vallásuk csak megtürt volt, társadalmi összetételükben többnyire jobbágysorban éltek, ha valaki közülük elérte a nemesi címet beolvadt a magyarságba. Ilyen körülmények között érte a románságot 1848, ahol Bécs maga mellé állítva, a magyarok ellen fordította a román nemzeti mozgalmat. A magyar kormányok a magyarosítás programjával 1867-et követően pedig végleg elszalasztották az esélyét a két nemzet közös útjának megtalálásában - fogalmazott a szerző. Gyárfás ezzel szemben kiemelte a román értelmiség felkészültségét, amely európai (francia, olasz, német) müveltségre tett szert, kulturális egyesületeket tart fenn, bankokat müködtet, saját ünnepeiket és szokásaikat sikeresen terjesztik stb., tehát elörehaladt nemzeti életet él. ${ }^{539}$

Gyárfás a korabeli magyar nemzeti állameszme kereteit nem kérdőjelezte meg, a magyar politikai szupremácia és a nemzeti egység híve volt. Erdélyi tapasztalataiból kiindulva mégis erős bírálatnak vetette alá a magyar nemzetiségpolitikát, és elutasította a nemzetiségek asszimilációjára irányuló törekvéseket, a velük szemben elkövetett erőszakosságot. Ezt arra vezette vissza, hogy a románság sem létszámából, sem politikai erejéből kifolyólag nem kerülhető meg. ${ }^{540}$

\footnotetext{
${ }^{538}$ Uo.

539 GYÁRFÁS Elemér: Erdélyi problémák 1903-1923. Cluj-Kolozsvár, Erdélyi Irodalmi Társaság, 1923, 11-18. [Továbbiakban: GYÁRFÁS, Erdélyi, 1923]

Gyárfás Elemér 1923-ban megjelent könyvében 1903-1923 közt megírt cikkeit gyüjtötte egybe. Ebben a fejezetben az 1920 előtti írásai kerülnek elemzésre.

${ }^{540}$ Uo. 57-58.
} 
Gyárfás nemzetiségpolitikai elgondolásában három fontos elem kapott helyet: érdekközösség, regionális szembenállás, egységes magyar állam. 1) Mocsáry Lajos azon gondolata, hogy a magyarok és a románok érdekközösséget alkotnak, de ennek létrejöttét a két nemzetbeli szélsőségesek agitálása meghiúsítja. ${ }^{541}$ 2) Regionális tapasztalatának és nemzetiségi elképzelésének jellegzetes összefonódásáról tanúskodik mindkét nemzethez feltett kérdése 1908 pünkösdje alkalmából: „Joga van-e egy népfajnak, mely véletlen az államhatalmat kezeli, keresztülgázolni mindenen, családi életen, szerzett jogokon, valláson, tudományon a maga uralma érdekében?" ${ }_{542}$ Az önmagában ellentmondásos megfogalmazás (ha az egyik nép csak „véletlen” uralkodik, akkor a másiknak az ,alárendeltsége” sem lehet örökös állapot) valamelyest sejteti Gyárfás regionális szembenállását mind a budapesti kormánypolitikával, mind a román nemzetiség radikális politikusaival. A kettéosztott korabeli magyar pártéletben Gyárfás a függetlenségi táborhoz állt közelebb, amely a nemzetiségi kérdésről vallott felfogásában (magyar szupremácia), és a magyaroknak a birodalmon belüli helyzetéről vallott nézeteiben is nyomon követhető. Az 1905-ös politikai válságot egybekötötte Tisza István nemzetiségpolitikai elképzeléseinek bírálatával. Gyárfás úgy vélekedett Tisza politikájáról, hogy a magyarok előbb behódolnak az osztrákok előtt, majd ők maguk is szolgaságban fognak tartani másokat. ${ }^{543} 3$ ) A helyzet egyetlen megoldása, ezért az „államiság kidomboritása” és a „magyar népfaj öntudatának, politikai meggyőződésének megváltoztatása. ${ }^{544} \mathrm{Ez}$ azt jelentette megfogalmazásában, hogy a magyarság a nemzetiségekkel fennálló (német és orosz befolyással szembeni) érdekközösségre támaszkodik egy erős és egységes magyar állam keretén belül. Ha ugyanis Budapest a magyarokat szorosan Bécshez (a birodalomhoz) köti, akkor a nemzetiségeknek semmi érdekük sem lesz abban, hogy velük közösséget keressenek. ${ }^{545}$ Németellenességében Gyárfás egészen odáig ment, hogy kijelentette: „Minden irányzat, mely ellensége a német omnipotenciának, természetes hü szövetségesre kell, hogy találjon a magyarságban." ${ }^{546}$ Potenciális szövetségesként a lengyeleket, a cseheket, a románokat, a horvátokat, a szerbeket, a bolgárokat, a törököket és a görögöket nevezte meg, akik szerinte veszítenek, ha engednek a német vagy az orosz befolyásnak. A Monarchia trializmussá alakítását többek között ezért sem támogatta. ${ }^{547}$

\footnotetext{
541 Uo. 65.

542 Uo. 84.

${ }^{543}$ HORVÁTH Sz.: Az egyensúly

${ }^{544}$ GYÁRFÁS, Erdélyi, 1923, 58-66.

${ }^{545}$ Uo. 65.

${ }^{546}$ HORVÁTH Sz.: Az egyensúly

547 Uo.
} 
Gyárfás nemzetiségpolitikai írásainak hangvétele nem türelmetlen nacionalizmusról árulkodik, hanem a magyarságért aggódó, de a nemzetiségi mozgalmak veszélyérzetétől átitatott önkritikáról. Kárhoztatta a vármegyék tisztikarának „kasztrendszerét”, a kisebbségi nyelvek nem ismerését, a magyar középosztály hanyatlását, a magyar bankrendszer gyenge erőforrását, az elmaradt infrastrukturális fejlesztéseket (vasút), illetve a takarékos, produktív gondolkodás hiányát. Az erdélyi románok gazdasági építkezését nem kívülröl irányított magyarellenes tervnek, hanem következetes, sérelmek nélküli nemzetépítő modernizációként festette le. ${ }^{548}$ A regionális szempontok képviseletének igénye és az erdélyi magyarság helyzetén való javítani akarása vezette oda Gyárfást, hogy részt vegyen a Magyar Szövetség munkájában.

\subsection{Paál Arpád: a kossuthi függetlenségi polgári-radikális}

A vármegyei főjegyzőként szolgáló Paál Árpádot ${ }^{549}$ az 1918. november 3-án megalakult Székely Nemzeti Tanács elnökévé választották Székelyudvarhelyen, majd a Károlyi-kormány Udvarhely vármegye alispánjává nevezték ki (1918. november 23.). Vármegyei főjegyzőként és a háború alatt a közélelmezés előadójaként segítette a lakosságot, illetve 1916-ban ő irányította a román betörés elöl, a vármegyei igazgatás Tiszántúlra telepítését. Naplójegyzeteiből és $A$ vármegye lapban közölt írásaiból kitünik, hogy a Nemzeti Tanács vezetőjeként egy szervezettebb, szociálisan érzékeny közigazgatás tervét vázolta fel. Reformelképzeléseit a háború, illetve a második román megszállás megakadályozta. A román hatóságok letartóztatták és hadbíróság elé állították, majd Kolozsvárra internálták. Itt az erdélyi magyarság irányítására „Szellemi Front” - más néven tisztviselők mozgalma - néven, Grandpierre Emillel és Költő Gáborral szervezkedett. (A Szellemi Front tevékenységéről lásd bővebben később.) ${ }^{550}$ Több erdélyi lapban jelentek meg cikkei, többek között az 1919. december 24-én induló polgári radikális hangvételü Keleti Újság hasábjain és a szintén progresszív hangvételü Napkeletben. Politikai gondolkodásában egyszerre érhető tetten a nemzetköziség, a szociális és a nemzeti felszabadulás ellentmondásos viszonya. Előbbi nem célként jelent meg, hanem a különböző népek, nemzetek fejlődésének teret adó széles együttmüködő keretként.

\footnotetext{
548 GYÁRFÁS, Erdélyi, 1923, 99-102.

${ }^{549}$ Paál Árpád: (Brassó, 1880-Nagyvárad, 1944) szerkesztő, közíró, a kecskeméti jogakadémián szerzett felsőfokú képesítést (1903), Kolozsvárt államtudományi (1903), illetve jogtudományi (1905) doktorátust. Közéleti pályáját 1908-1918 között Székelyudvarhelyen vármegyei föjegyzőként kezdte. Romániai Magyar Irodalmi Lexikon. http://mek.oszk.hu/03600/03628/html/p.htm\#PaálÁrpád,bethlenfalvi (Letöltve: 2017. október 17.)

550 BÁRDI, Otthon. 2013. 24-34.; Paál Árpád kézirathagyatékát Bárdi Nándor dolgozta fel: http://adatbank.transindex.ro/cedula.php?kod=172
} 
K. Lengyel Zsolt megállapítása szerint Paál Árpád a kossuthi függetlenségi eszmét polgáriradikális változatában antibolsevista elemekkel ruházta fel. ${ }^{551}$ Kós Károllyal és Zágoni Istvánnal közösen kiadta a Kiáltó szó (1921) röpiratot. A nemzetiségi életen belül a demokratikus egység híve volt. A Magyar Néppárt és a Magyar Szövetség egyesítésének folyamatában és az Országos Magyar Párt (OMP) megalakításában (1922) aktív szereplőként vett részt, fenntartva ugyanakkor a Keleti Újság radikális irányát mindaddig, amíg az új párt konzervatív-arisztokrata jobbszárnya meg nem vásárolta a lapot, ahonnan 1924-ben több társával együtt távozni kényszerült. Ekkor újult meg főszerkesztése alatt az Újság kolozsvári napilap, amely maga köré tömöríti a népi programot valló kalákásokat, a Benedek Elek szerkesztette Vasárnapi Újság gárdáját is. ${ }^{552}$

\subsubsection{A Székely Köztársaság alternatívája}

A szerb és a román csapatok, amikor megszállták a belgrádi katonai konvencióban (1918. november 13.) meghatározott demarkációs vonaltól délre eső területeket, időszerüvé vált az annexiós törekvések (wilsonizmussal összeegyeztethetetlen) igazságtalanságának propagálása és a béketárgyalásokra való felkészülés. ${ }^{553}$ A korábbi föhatalom képviselőit a keletmagyarországi megyék leendő állami hovatartozásának kérdése új stratégiák kidolgozására késztette. Az önálló államiságról szóló részletesebben kidolgozott terveket Gyárfás Elemér 1919 márciusában nyújtotta át Iuliu Maniunak. ${ }^{554}$ Az önálló Erdélyi Köztársaság eszméjét Paál Nagyszebenben a Romul Boilával (a Román Kormányzótanács minisztere) folytatott tárgyalásokon képviselte. A románok a gyulafehérvári nemzetgyülés határozata alapján utasították el a tervet. ${ }^{555}$

\footnotetext{
${ }^{551}$ K. LENGYEL: Az elnapolt alternatíva (Paál Árpád és az erdélyi autonómia 1919/1920). Korunk, 1991. 3. évf., II/10. 1265. [Továbbiakban: K. LENGYEL, Korunk, 1991]

${ }^{552}$ Romániai Magyar Irodalmi Lexikon. http://mek.oszk.hu/03600/03628/html/p.htm (Letöltve: 2017. október 12.)

553 1918. november 17-i budapesti Székely Nemzeti Tanács tiltakozó nagygyülésén biztosították Jászit, hogy támogatják az integritás megóvása mellett a Magyarország kantonális átszervezéséről szóló tervét. November 28án, Marosvásárhelyen tiltakozó székely nemzetgyülést tartottak. ROMSICS: Bethlen. 1999. 107.

${ }^{554}$ Gyárfás terve hasonló volt Bethlen azon elképzelésével, amely egy olyan önállósított erdélyi tagállamot vázolt fel, amely a bolsevista veszélyt elhárítandó, de népszavazással majdnem esetleg Magyarországhoz csatlakozó erdélyi három nemzet uniója.

GYÁRFÁS Elemér: Egy át nem adott memorandum. U. ő. Erdélyi problémák. Cluj-Kolozsvár, 1923. 143-154; K. LENGYEL, Korunk, 1991. 1265

${ }^{555}$ K. LENGYEL, Korunk, 1991. 1265; BÁRDI, Otthon, 2013. 35-36.; Az erdélyi kérdés két világháború közti rendezésére vonatkozóan lásd: Javaslatok, modellek az erdélyi kérdés kezelésére - A magyar elképzelések 19181940. In: Konfliktusok és kezelésük Közép-Európában, TLA, 2000, 137-180. Ua. Magyar Kisebbség, 2004. 1-2. sz. 329-376.
} 
Paál és környezete ezt követően a Székely Köztársaság eszméje felé fordult, amely a székelyföldi tisztviselői ellenállás során 1918 decemberében-1919 januárjában formálódott ki. Részben a századelő Székely Kongresszusainak törekvéseire támaszkodva egy semleges államalakulat tervét vázolták fel. A fegyverszüneti szerződés és a megszállás elismerése mellett kívánták kikiáltani a független székely államot, amely gazdasági szövetségre lépett volna a román és a szász nemzettel, Romániával, Magyarországgal, Szerbiával, Lengyelországgal, Oroszországgal és Ukrajnával, illetve Svájc, Anglia és az USA protektorátusát kérte volna. Amikor a népszavazás megszervezésének lehetősége felmerült, elötte egy nappal, 1919. január 9-én Paált letartóztatták. ${ }^{556}$

A köztársaság tervezete, Emlékirat a semleges, független Székely Államról magába foglalta a wilsoni önrendelkezési jog alapján Háromszék, Csík, Udvarhely és Maros-Torda vármegyéket, illetve Brassó, Kolozs és Torda-Aranyos megyék magyarok lakta területeit.

Az államalakulat létrehozását a Brassó melletti csángók, az aranyosszéki székelyek és a Kolozs megyei magyarok együtt 800 ezres egybefüggő, magyar anyanyelvü tömegén túl a székely nemzet múltbeli jogi-politikai különállásával indokolta. A székely államra fontos szerep hárult volna, a háború hatására létrejövő két gyenge állam, Magyarország és Románia között gazdasági szerződéseket köthetne. A béke feltétele a semlegesség elve, amelyet a környező államok és a nagyhatalmak garantálhatnának. „Magyarországnak is jobb lesz, ha a székely nemzet révén is a magyar fajiság számára egy szuverén területet megmenthetett. A kivitel érdekében tehát minden fokozatos alkudozás nélkül magának Magyarországnak is a világbéke tárgyalásaiba bele kell dobnia a semleges székely állam igénylését." ${ }^{557}$ A létrehozás elképzelése megegyezett Jancsó Benedek 1918. novemberi álláspontjával: ha a magyar integritás védelme nem sikerül, minden eszköz felhasználni az idegen uralommal szemben az erdélyi tömbmagyarság védelmére. ${ }^{558}$

\footnotetext{
556 Paál január 12-én házi őrizetében kapott üzenetet arról, hogy a háromszékiek (Király Aladár főispán vezetésével) a Székely Köztársaságot Budapesten tervezik kikiáltani, de ezzel addig várnak, míg véglegessé nem válik, hogy a békekonferencia Magyarország felosztása mellett dönt-e. BÁRDI, Otthon. 2013. 37.

${ }^{557}$ Uo. 38.

558 A Székely Köztársaság részletes háttereként lásd: Bárdi Nándor: Impériumváltás Székelyudvarhelyen 19181920. Aetas, 1993. 3. sz. 76-118.
} 


\section{ATALAKULÓ HATÁRHELYZETEK: HATALOMÁTVÉTEL-ELLENÁLLÁS, SZEMBENÉZÉS AZ ELCSATOLÁSSAL-KISEBBSÉGI ÚTKERESÉS KIJELÖLÉSE}

A változó körülményekkel változnak a közösségi célok is. A Max Weber-i meghatározás értelmében a modern magyar politikai közösség cselekvése arra irányult a dualizmus korában, hogy egy körülhatárolható területen a résztvevők rendezett uralmát fenntartsa, és esetleg további területeket hajtson az uralma alá, hogy az ott található emberek cselekvése fölött a vezető szerepét megőrizze. ${ }^{559} \mathrm{Az}$ adott korban ennek a felfogásnak az érvényességét az jelentette, hogy a hagyományos értelemben vett állam egyedüli alapként jelent meg a politikai közösség szemében, és politikai cselekvése elsősorban az államhoz kötődött. ${ }^{560}$

1918-1919 fordulójától a trianoni békeszerződés aláírásáig (1920. június 4.), illetve annak a magyar Nemzetgyülésben történt ratifikálásáig ${ }^{561}$ egyes erdélyi magyar politikai szereplök saját és képviselt közösségük érdekeit védve a politikai ellenállás különböző eszközeit választották (Felekezetközi Tanács, Szellemi Front-tisztviselőmozgalom, kritikus hangvételü nyilvánosság) a második román megszállás alatt. A tiltakozás egy másik módszere a sztrájk volt, amikor a gyári munkások, a vasutasok, a hivatali közalkalmazottak (postások, távirodák dolgozói stb.), illetve a kereskedők a munkabeszüntetés eszközéhez nyúltak. A motivációk ellenben sokszor eltérőek voltak. A vasutasok országos tiltakozó megmozdulása 1919. januárban egyértelmüen politikai jellegü volt, amely Petrozsényböl kiindulva terjedt ki Erdély vasútjaira. A megszálló katonai hatalom nyilatkozatot adott ki, amelyben arra kötelezték a magyar állami vasúti alkalmazottakat, hogy aláírásukkal ismerjék el a román kormányt, valamint a román államvasutakat (CFR), mint felettes hatóságot. A kolozsvári Munkástanács ezt követően csatlakozott a sztrájkhoz, és a következő követeléseket fogalmazták meg: Apáthy István és a politikai foglyok (köztük szociáldemokraták is) szabadon bocsátása, a cenzúra eltörlése, a szabad vasúti utazás biztosítása, a gyülekezési és az egyesülési jog tiszteletben tartása, a telefon és távíró rendeltetésszerü megindítása. ${ }^{562}$

\footnotetext{
559 WEBER, Max: A politikai szociológia. 2009. Helikon Kiadó, 9-10.

${ }^{560}$ Megjegyzés: A 20. század második felétől fokozatosan kitágult a politikai cselekvés, amely nem azt jelenti, hogy az államok elvesztették volna jelentőségüket, hanem maga a politikai cselekvés nem érheti be pusztán az államhatárok által meghatározott cselekvési térrel (globalizmus-antiglobalizmus stb.) A politikai cselekvés tere nem egyszerüen kiszélesedett a 20. század végétől, hanem elvesztette évezredes kötődését az államhoz. BAGI Zsolt: Politikai cselekvés és új tömegtársadalom. Magyar Filozófiai Szemle, 2016. 60. évf. 4. szám, 90-91.

561 1920. június 4-én írták alá az I. világháború győztes hatalmai Magyarország képviselőivel a versailles-i Nagy Trianon kastélyban a háborút lezáró magyar békeszerződést. A békeszerződést a magyar Nemzetgyülés 1920. november 15-én ratifikálta, és 1921. július 26-án, a XXXIII. törvénycikkel hirdette ki. https://1000ev.hu/index.php?a=3\&param=7489 (Letöltve: 2017 . október 23.)

562 Véget ért a sztrájk. Keleti Újság, 1919. 2. évf. 18. szám, január 27. 1.
} 
Marosvásárhelyen a hivatali alkalmazottak hasonló indíttatásból függesztették fel a munkát, amikor a románok átvették a közigazgatás intézményeit. ${ }^{563}$ A föhatalom-változás időszakában politikai szándéktól mentesen, a rossz és elégtelen munka- és életkörülmények következtében számos helyen került sor sztrájkra. Például a kolozsvári mészárosok tiltakoztak a hús ármaximalizálása ellen, a pénzintézeti tisztviselök az életkörülményeik javítása érdekében tett ígéreteket kérték számon, illetve a kollektív munkaszerződések be nem tartása váltott ki ellenállást. ${ }^{564}$

A ratifikációt követően a politikai cselekvés hangsúlya egyfelől a román állam keretein belül történő egyéni és kollektív politikai, kulturális és szociális jogok kivívására irányult. Másfelől az etnikai elv mentén megvalósítandó autonóm intézmények és legitim érdekképviseletek (egyesületek, pártok) megszervezésére, ezeknek a romániai magyar társadalom tagjaira történő kiterjesztésére, mindvégig remélve a határrevíziót. A kitüzött célok megvalósítása kérdésében azonban jelentős nézetkülönbségek formálták az erdélyi magyar politikai szereplők fokozatosan kibontakozó politikai cselekvését, amely a passzivista (más néven erdélyi központ) és az aktivista szimbolikus küzdelemben vált szemléletessé.

\subsection{Hatalomátvétel: a román Kormányzótanács és a magyar impérium megszünése Erdélyben}

Az 1918. november 13-án aláírt belgrádi katonai egyezmény ${ }^{565}$ értelmében a magyar kormány köteles kiüríteni a Szamos felső folyásától keletre, valamint a Maros vonaltól délre eső erdélyi és bánsági területeket, tehát a Bácskát és a Drávaközt is. Ezen kívül megszabta azt is, hogy Magyarország csak 6 gyalogos és 2 lovashadosztályból álló hadsereget tarthat fenn, és szükség esetén biztosítani kell az antanthaderő szabad átvonulását az ország területén.

\footnotetext{
563 LÁSZLÓ: Maros-Torda/Maros, AREOPOLISZ, 2015. 195-199.

${ }^{564}$ Sztrájkolnak a kolozsvári mészárosok, Keleti Újság, 1919. 2. évf. 39. szám, február 21. 5.; Sztrájkolnak a pénzintézeti tisztviselők. Kolozsvári Hírlap, 1918. 19. évf. 272. szám, december 24. 2.;

Aradon a vagongyárban az igazgatóság nem ismerte el a szakszervezeteket, illetve megszegte a kollektívszerződésben foglaltakat. Két napos sztrájk a vagongyárban. Munkás (Arad), 1922. III. 28. szám, július 9. 1-3.

565 1918. november 3-án a Padova melletti Villa Giustiban Viktor Weber tábornok az Osztrák-Magyar Monarchia nevében aláírta a fegyverszünetet. November 13-án Belgrádban az új Magyarország képviselöje, Linder Béla hadügyminiszter szignálta a katonai konvenciót. A szerződést az antant részéről Paul-Prosper Hensys francia tábornok és a szerb hadsereg föparancsnoka, Živojin Mišić vajda írták alá. ORMOS, 1983. 13.; A katonai egyezmény teljes szövegét lásd: Katonai egyezmény a szövetséges hadseregek és a magyar kormány között. Francia diplomáciai iratok a Kárpát-medence történetéröl, 1918-1919. Szerk.: ÁDÁM Magda és ORMOS Mária, Akadémiai Kiadó, 1999. 16-18.
} 
A Károlyi-kormány mindezt ideiglenes megoldásként fogta fel, és bízott benne, hogy a végleges rendezést jelentő békeszerződés biztosítja az ország szuverenitását, és a határkérdésben méltányosságra törekszik. ${ }^{566}$ A megállapodás arról is szólt, hogy a megszállt területen a polgári közigazgatás (csendőrség, rendőrség) és igazságszolgáltatás minden ágazatában, az összes állami törvényhatósági és községi hatóságok és közegek müködésüket az addigi jogszabályok szerint változatlanul folytathatják, illetve, hogy a közalkalmazottak állásaikban megmaradnak. A megszálló három román hadosztály a Keleti- és Déli-Kárpátok szorosai után 1918. december 2-12. között elérte a Marost, mint demarkációs vonalat, amelyet néhány helyen át is lépett. ${ }^{567}$ A Marosnál a magyar haderő csak pillanatnyi sikereket tudott volna elérni, ezért volt később szükség a hatékonyabb védekezés érdekében a Királyhágó környékéig visszavonulni, és ott csoportosítani a magyar csapatokat egy esetleges ellenállás esetére. ${ }^{568}$

A szövetséges hatalmak nevében a szerbek és a románok által megszállt területeken két, többségében magyar (Baranya megye és Székelyföld) és egy vegyes lakosságú tájegység (Bánát) feküdt. Az újvidéki Nagy Nemzetgyülés 1918. november 25-én deklarálta a délmagyarországi megyék csatlakozását Szerbiához, Gyulafehérváron pedig az erdélyi románok nemzeti gyülése csatlakozott Romániához (1918. december 1.). A nemzetgyülés Alexandru Vaida-Voevod javaslatára ideiglenesen egy 200 tagú Nagy Nemzeti Tanácsot választott ${ }^{569}$, amelyek többsége a Román Nemzeti Pártból került ki.

\footnotetext{
566 ROMSICS Ignác: Magyarország története a XX. században. Osiris, Budapest, 2004. 115.

${ }^{567}$ A Marosvásárhelyet megszálló 6. román hadosztály csapatai december 8-án osztagot toltak át a Maroson. Mezőbándra egy 30, Mezőmadarasra pedig egy 30 főből álló különítmény érkezett, amellyel a román haderő megszegte a belgrádi katonai konvenció demarkációs vonalra vonatkozó szabályozását. December 9-én Marosvásárhelyről kiindulva egy 1300 fős, tüzérséggel kiegészült reguláris román haderő, átkelve a Maroson, Aranyosgyéres, Torda irányába hatolt elöre. FRÁTER Olivér: Erdély mint hadszíntér 1916-1922-ben. FRÁTER, Erdélyi magyar helyzetkép, 2003. 78-80.

http://www.kre.hu/portal/doc/studia/Cikkek/2003.1_2.szam/09.Frater_Oliver.pdf (Letöltve: 2017. október 31.) [Továbbiakban: FRÁTER, Erdély, 2003]

568 A Wekerle-kormány 1918. október elején lépéseket tett Erdély katonai megvédésének feltérképezésére. Bornemissza Jánost Háromszék vármegyébe küldte, aki 1918. október 21-én Brassóból a következő távirati jelentést küldte Wekerle Sándor miniszterelnöknek: „Értesülésem szerint a határszéleken a helyzet komolyra fordult, és nyolc nap óta katonai csapatszállítások teljesen szünetelnek. Az itt lévö katonai erök az elsö nyomás fenntartására sem elégségesek, tüzérség pedig majdnem teljesen hiányzik." 1918 októberében Erdély katonai helyzete a következő volt: Goldbach altábornagy erdélyi csoportja (28 zászlóalj és 12 üteg) azokat a hágókat tartotta megszállás alatt, amelyeken a román csapatok a betörést tervezték. Erdély keleti határainak megvédésére a következő csapatok állottak rendelkezésre: 1. lovas hadosztály, 17. és 29. népfelkelő ezred, a 113., 204. és 206-os gyalogezred, a 311./I. és 316./I. hadtápzászlóalj. Ezen felül két repülős század és 10 üteg tüzérség. További két üteg odaszállítás alatt állott. E haderő ( 28 zászlóalj, 2 hadtápzászlóalj, 12 üteg tüzérség és 2 repülős század) összesen 13.662 puskát és 82 ágyút képviselt.

FRÁTER Olivér: Erdély román megszállása 1918-1919-ben. Kisebbségkutatás, 2000. 9. évf. 2. szám, $242-263$.

${ }^{569}$ Foglalkozásukat tekintve a tagok többsége ügyvéd, jogász ( 99 fö), illetve pap (39 fö) volt A román szocialistákat 17 fő képviselte, és mindösszesen egy nő volt a Tanács tagja, Eleonora Lemeny-Rozvan nagyszebeni tanár.
} 
December 2-án a Tanács kijelölte a 15 fös Kormányzótanácsot (Consiliul Dirigent), amelynek elnökévé Iuliu Maniut választották. ${ }^{570}$ Az új román politikai testület esküt tett a görög katolikus és az ortodox egyházra, amely szimbolikusan kifejezte a teljes románság nemzeti akaratát, Erdély és Románia egyesítését. A Kormányzótanács tevékenységére úgy tekinthetünk, mint a bukaresti kormány erdélyi reprezentánsa, amely az egyesítés kezdeti nehézségeit áthidalva ideiglenesen ellátta a közügyek intézését. ${ }^{571} \mathrm{~A}$ Kormányzótanács december 7-én megküldte a gyulafehérvári határozat teljes dokumentumát a magyar kormánynak, amely a gyulafehérvári román nemzetgyülés értelmében jogot formált 26 magyarországi vármegyére. Károlyi Mihály miniszterelnök a levélre azt felelte, hogy „e határozatok a fegyverszüneti megállapodásokkal, melyek szerint a közigazgatásnak továbbra is változatlanul a magyar kormány föhatósága alatt kell maradnia a legélesebb ellentétben állanak, miért is a magyar népköztársaság kormánya a határozatokat a tudomásul nem veszi és azok ellen a leghatározottabban tiltakozik." 572

A Károlyi-kormány érzékelve azt, hogy az erdélyi hadi eseményeket nem képes befolyásolni, 1918 decemberében két jelentős belpolitikai intézkedésre szánta el magát. Az első a Kelet-Magyarországi Főkormánybiztosság felállítása volt, amelynek élére Apáthy István nevezték ki (1918. december 6.). ${ }^{573}$ Ugyanakkor Budapesten a kolozsvári Erdélyi Bizottság ${ }^{574}$ (a Károlyi-párt, a Szociáldemokrata Párt és a Polgári Radikális Párt tagjai alkották) nevében Apáthy István és Vincze Sándor tárgyalást folytattak Batthyány Tivadar belügyminiszterrel és Jászi Oszkárral. A kolozsvári küldöttség azt kérte a magyar kormánytól, hogy a „kolozsvári tanácsot ruházzák fel teljes hatalommal, mert a gyulafehérvári román kormány csakhamar átveszi az ügyek vezetését." ${ }^{\circ 75}$ Apáthy István két vezérkari tiszttel utazott vissza Kolozsvárra, hogy a fökormánybiztos érintkezésbe lépjen a demarkációs vonalat megszálló román csapatokkal.

\footnotetext{
${ }^{570}$ A Consiliul Dirigent közel két éves müködése alatt a megszállt magyarországi területek felett különböző igazgatási hatásköröket gyakorolt. A következő szaktárcákat hozta létre: belügy (élén: Iuliu Maniu), kulturális és közoktatásügy, ahová a nemzetiségi ügyek is tartoztak (Vasilie Goldiş), katonai és közbiztonság (Ştefan CicioPop), külügyek (Alexandru Vaida-Voevod), alkotmányügy (Ioan Suciu), igazságügy (Aurel Lazăr), egyesítés (Emil Hațieganu), pénzügy (Aurel Vlad), agrár és kereskedelem (Victor Bontescu), közmunka, illetve posta (Romul Boilă), szociális (Ioan Flueraş szocialista), illetve iparügy (Iosif Jumanca szocialista). A gyakorlatban a Kormányzótanácsnak önálló külpolitikai, külkereskedelmi és katonai politikája nem volt, mert az szigorúan a központi kormányzat hatáskörébe tartozott.

${ }^{571}$ IANCU: The Ruling Council. 1995. 34-44.

${ }^{572}$ Károlyi Mihály levelezése I. 1905-1920. Szerk.: LITVÁN György, Akadémiai Kiadó, 1978. 333. dokumentum, 318.

${ }^{573}$ A hivatal pontos címe Jászi Oszkár javaslatára a következő volt: „A kelet-magyarországi magyarság védelmére alakitott fökormánybiztosság". FRÁTER, Erdély, 2003. 78.

574 Apáthy István kérése értelmében nem „Erdélyi Magyar Nemzeti Tanácsnak”, hanem a „Magyar Nemzeti Tanács Kelet-Magyarországi Bizottságának” vagy „Erdélyi Bizottságának” nevezte. A Bizottság 1918. november 1-jén állt fel Kolozsvár központtal. A Kelet-Magyarországi Fökormánybiztosság szervezeti és ügykezelési szabályai. Kolozsvár, 1918. december. OSZK Kézirattár, Quart. Hung. 2455/1.

575 Impériumot kap a kolozsvári Nemzeti Tanács. Kolozsvári Hírlap. 1918. 19. évf. 288. szám, december 7. 1.
} 
A belügy, a közoktatás, a forgalom és a közélelmezés felett rendelkező új szerv az erdélyi magyarság érdekképviseletét ellátó erdélyi magyar kormánynak felelt meg a Népköztársaság kormányzatának ellenőrzése alatt. ${ }^{576} \mathrm{Nem}$ erdélyi, regionális intézmény volt, hanem országos közügyek intézését, és mindenekfölött a továbbra is az államközpontból irányítandó feladatok dekoncentrálását szolgálta. ${ }^{577}$ Apáthy december 22-ére tiltakozó nagygyülést hirdetett Kolozsvárra, hogy a kelet magyarországi magyarok és németek közösen foglaljanak állást a gyulafehérvári román nemzetgyülés határozata ellen. Két nappal később, karácsonykor a román egységek bevonultak Kolozsvárra. ${ }^{578}$ A kormány másik intézkedése az öt legfiatalabb korosztály, (az 1896-1900-as évfolyamok) bevonulását elrendelő hadiparancs kiadása volt. ${ }^{579}$

\subsubsection{Tisztviselöi helyzetkép, a hüségeskü problémája}

Az 1918 októberében lezajlott forradalom és az azt követő román megszállás a magyarság hivatali közegeiben szolgálatot teljesítő köztisztviselőkre és közalkalmazottakra nézve társadalmi és egyéni élethelyzetükben is visszafordíthatatlan hatást gyakorolt. Eleinte a legveszélyeztetettebb helyzetbe az állami hatalmat helyi szinten képviselő községi jegyzők, illetve a rendvédelmi szervek tagjai kerültek, amikor - még a román csapatok lefegyverzési intézkedéseit megelőző időben - a lakosság részéről (magyarok és nemzetiségiek egyaránt) ellenük irányuló támadások hatására kénytelenek voltak több helyen is hivatali működésüket beszüntetni, és sok esetben saját életük védelmében elmenekülni. ${ }^{580} 1918$. november második felétől kezdve az ország megszállott területeiről naponta százával érkeztek a Belügyminisztériumba magyar tisztviselők kérvényei, amelyekben Budapestre vagy homogén magyar területre való áthelyezésüket kérték. 1919. januártól az Erdélyt megszálló román hatalom elérkezettnek látta az időt arra, hogy az erdélyi magyar tisztviselői réteg ellen megindítsa a harcot, és megkezdje a Főkormánybiztosi Hivatal felszámolását. Moşoiu tábornok, a Kolozsvárt megszálló román haderő parancsnoka január 8-ától a főkormánybiztossal való mindennemü hivatalos érintkezést betiltatott.

\footnotetext{
576 A kolozsvári Nemzeti Tanács Erdély főkormánybizottsága. Kolozsvári Hírlap. 1918. 19. évf. 289. szám, december 8. 2.

577 K. LENGYEL Zsolt: „Keleti Svájc” és Erdély 1918/1919 (I.). Korunk, 2004. Január. 110.

578 Tiltakozás a gyulafehérvári határozat ellen. Kolozsvári Hírlap, 1918. 19. évf. 295. szám, december 15. 1.; Nemzetgyülés a Mátyás-király téren. Kolozsvári Hírlap, 1918. 19. évf. 302. szám, december 22. 1.; Keletmagyarország tiltakozó nagygyülése. A románok nem engedték be a különvonatokat Kolozsvárra. Kolozsvári Hírlap, 1918. 19. évf. 304. szám, december 24. 2.; Huszonhat megye önrendelkező nagygyülése. Kolozsvári Hírlap 1918. 19. évf. 272. szám, december 24. 2-3.

${ }^{579}$ FRÁTER, Erdély, 2003. 79-80.

${ }^{580}$ November végén például csak Aradon 69 olyan községi jegyző tartózkodott, akik hivatali helyükről kénytelenek voltak elmenekülni. 1918. október-november hónapjaitól főleg a vidéki térségekben egyes csendőrök, sőt bizonyos esetekben egész csendőrörsök szolgálati müködése megbénult, illetve adott esetekben az állomány teljes erőszakos lefegyverzésére is sor került. Uo. 81-82.
} 
Végül január 15-én, a bolsevizmus terjesztésének vádjával, valamint a január 14-i cigányi eset miatt Apáthyt letartóztatták, és fegyveres katonai őrizet alatt Nagyszebenbe szállíttatták. ${ }^{581}$ Apáthy helyét az Erdélyi Bizottságból Grandpierre Emil törvényszéki bíró vette át. Rata J. Vasile királyi százados január 18-án egy szakasz román katona kíséretében a vármegyeházán lévő Főkormánybiztosi Hivatal müködését azonban véglegesen beszüntette, amivel gyakorlatilag megszűnt a magyar kormányzati ellenőrzés Erdély felett. Grandpierre az adminisztratív irányításban még március közepéig vett részt.

A Consiliul Dirigent (1919. január) II. számú törvényerejü rendeletének 4. §-a révén az összes törvényhatósági és községi képviseleteket feloszlatta, a megyék és a települések autonómiáját felfüggesztette. A vármegyék és a városok élére román prefektusokat neveztek ki, továbbá a magyar tisztviselőktől, az I. Ferdinánd román királyra történő hüségeskü letételét követelték. ${ }^{582}$ A magyar közigazgatás képviselői az annexiós törekvésekkel szemben a belgrádi fegyverszüneti egyezményre, a Hágai Nemzetközi Konvenció III. részének 45. cikkelyére, amely megtiltja, hogy „ellenséges hatalom a megszállott terület népességét hüségeskü letételére kötelezze", valamint arra hivatkoztak, hogy a békekonferencia nem döntött a határok kérdésében. Az erdélyi magyar tisztviselök többsége ezeken felül azért tagadta meg a román királyra teendő hűségesküt, ha az bekövetkeznék, a békekonferencián ez a szerb, illetve a román álláspontot erősítené. ${ }^{583}$ A prefektusok válaszul elbocsátással, kiutasítással fenyegetőztek. A hűségesküt megtagadó tisztviselőket hivatali működésüktől eltiltották, állásukból elbocsátották, akik ezáltal minden illetményüktől és kilátásban lévő nyugdíjigényüktől elestek. Minden fenyegető szankció ellenére az erdélyi tisztviselők többsége megtagadta a hűségeskü letételét. Azok a tisztviselők, akik kényszer vagy egzisztenciális okok miatt a hủségeskü letétele mellett döntöttek román állampolgároknak minősültek, és az elkövetkezőkben rájuk a román törvények vonatkoztak. ${ }^{584}$

\footnotetext{
${ }^{581} \mathrm{Az}$ engedély nélkül vasúton elörenyomuló 2-300 fönyi román haderőt Cigányi községnél a magyar 24. ezred (Székely főhadnagy) feltartóztatta, és a harcok során 9 román katona elesett. Az akció értelmi szerzőjének a románok Apáthy Istvánt tartották. Az esetet követően a Kolozsvári Román Nemzeti Tanács hivatalos értesítést adott ki, mely szerint a román megszálló csapatok parancsnoksága 900 ezer korona büntetést szabott ki a Kolozsvári Főkormánybiztosságra. Uo. 83.

${ }^{582}$ A következö prefektusokat nevezték ki. Fogaras vármegye: dr. Vasu Oktavian, Hunyad vármegye: dr. Vasinei Toma, Alsófehér vármegye: dr. Topu János, Torda-Aranyos vármegye: dr. Chirtop Zosin, Beszterce-Naszód vármegye: dr. Trifon Gavrilla, Szolnok-Doboka vármegye: dr. Miháli Tivadar, Szeben vármegye: dr. Comsa Nikolaus, Kisküküllő vármegye: dr. Roman Diomsie, Maros-Torda vármegye: dr. Vescen János. A románok átveszik a közigazgatást Erdélyben. Kolozsvári Hirlap, 1919. 20. évf. 5. szám, január 8. 1-2.

${ }^{583}$ BÁRDI, Otthon, 2013. 41.

${ }^{584}$ Tudomásunk van ilyenről például: Gyulafehérváron a magyar polgármester elmenekült, aki helyére dr. Velics Kamil ügyvédet ültették. Az új polgármester egybehívatta a köztisztviselőket és kijelentette, hogy eskütétel ellenében a tisztviselők helyükön maradhatnak. Az összes tisztviselő letette az esküt. Gyulafehérváron felesketik a tisztviselöket. Kolozsvári Hírlap, 1918. 19. évf. 289. szám, december 8. 1.
} 
Helyzetük azonban csak átmeneti volt, mert már 1922 folyamán tapasztalható, hogy miután beosztásukra román nemzetiségű alkalmazottat szerződtettek, sokukat állásukból elbocsátották. $^{585}$

\subsubsection{A székelyföldi vármegyék közigazgatásának román átvétele}

A román hatalomátvételről nem rendelkezünk átfogó és részletes információkkal, mert alapkutatásokra csupán egy-egy vármegye és város vonatkozásában került sor (lásd a bevezető rész erre vonatkozó historiográfia összeállítását). Nagy Botond Háromszék vármegye, illetve Sepsiszentgyörgy és Kézdivásárhely közigazgatásában beállt hatalomváltozást vizsgálta. A vármegye bizottsága (közgyülése) 1918. november 11-én tartotta utolsó közgyülését, amelyen döntöttek az országos Magyar Nemzeti Tanácshoz való csatlakozásról, illetve megtárgyalták az alispán, Dr. Török Andor javaslatát, hogy fegyveres ellenállást nem fejtenek ki. Sepsiszentgyörgy város képviselőtestülete három nappal később a Belügyminisztérium konkrét utasításait tárgyalta, amely az állami és önkormányzati hivatalok székhelyükön való békés továbbműködését irányozta elő, anélkül, hogy a tisztviselők esküt tegyenek. Tigoianu százados első rendeletében a hivatalok helyben maradásáról intézkedett. Időközben, Iuliu Maniu vezetése alatt álló nagyszebeni román Kormányzótanács (Consiliul Dirigent) a közigazgatási struktúra átvételét prioritásnak határozta meg, és új alapokra helyezését ígérte (virilizmus eltörlése, a tisztviselők román nyelvtudásának megkövetelése, a közigazgatás egésze a romániai 1886. évi 28. törvénycikk alapján való müködése stb.), illetve a budapesti kormánnyal való kapcsolatok megszakítására szólította fel a lakosságot. Az események alakulása 1919 folyamán, Háromszéken (az erdélyi törvényhatóságok centralizációja az élére kinevezett prefektusokkal, magyar tisztviselők kikényszerített lemondása, internálások, kirendelt alispán titulus, román nemzeti jelleget öltő csendőrség felállítása) azt mutatja, hogy a megnövelt katonai jelenlét a polgári berendezkedésnek volt hivatott hátteret nyújtani. Elöbb a hüségesküt le nem tett és eltávozott tisztviselők lakásait román hivatalnokok részére rekvirálták, másodjára a helyben maradt, de esküt le nem tett tisztviselők lakásait foglalták le. Jelentős fordulatot hozott, hogy a Kolozsvárra költözött Kormányzótanács 1920 áprilisában megváltoztatta titulusát Egyesités Területi Bizottságára (Comisia Regională de Unificare), amelynek szaktárcáit és személyi állományát közvetlenül a bukaresti minisztériumoknak rendelték alá. A hűségeskü kérdését is ettől kezdve közvetlenül Bukarest sürgette.

\footnotetext{
${ }^{585}$ Az erdélyi és bánsági pénzügyigazgatóságok alkalmazásában álló magyar nemzetiségủ tisztviselőket 1922 októberében tömegesen bocsátották el, azzal is súlyosbítva helyzetüket, hogy nyugdíjigényüktől megfosztották öket. FRÁTER, Erdély, 2003. 80.
} 
Nagy Botond az 1921. év eleji állapotokból azt a következtetést vonta le, hogy a legmélyrehatóbb változások ezzel szemben a vármegyei hivatalok - alispán, árvaszék és járások főszolgabírói hivatalai - keretén belül zajlottak le. Sepsiszentgyörgy esetében a régi polgármester kicserélődött (Bálint Dénes helyére Dr. Zaharia Crişan, volt közélelmezési kormánybiztos került), a tisztviselőgárda azonban csekély kivétellel azokból állt össze, akik 1918 decemberében is állásukban voltak, fogyatkozás az irodaszolgák, napidíjasok és ideiglenes alkalmazottak körében figyelhető meg. Kézdivásárhelyen is a tisztviselőgárda - a föorvos kivételével - zömében a helyén maradt, a polgármestert is beleértve. Az a tanulság vonható le Háromszék vármegyében az impériumváltásra vonatkozóan, hogy a megyeközpont alakult át leginkább a hatalmi tényező elvárásai szerint, a változás szintje vidéken jóval alacsonyabb volt. ${ }^{586}$

Maros-Torda vármegye hatalomátvétele - 1919. január 11-20. - összehangolt formában zajlott: átvették a vármegye föispáni hivatalát (Ioan Vescan tekei ügyvédet nevezték ki prefektusnak) és az állami adóhivatalt, felügyelet alá helyezték azon magánkézben lévő pénzintézeteket, amelyekben a vármegye közpénzét tartották. A marosvásárhelyi városházát január 24-én foglalta le a prefektus, az átvétel azonban nem volt akadálymentes: Halász József, a városi főispán, a belgrádi fegyverszüneti egyezményre hivatkozva megtagadta hivatala átadását. A román katonai hatóságok - talán a válaszreakciót elkerülendő - betiltottak minden köztéri rendezvényt, felszámolták a politikai szervezeteket és életbe léptették a cenzúrát. A magyar tisztviselőktől hűségesküt követeltek. A felszólításnak a vármegyei tisztviselők - a fegyveres erőn alapuló kényszerhelyzetnek engedve - többsége eleget tett, szemben a marosvásárhelyiekkel, akik halasztást nyertek, mert a megyei igazgatással ellentétben, nem álltak rendelkezésére a megfelelő szakembereket helyettesítő román alkalmazottak. A hatalomátvételre a marosvásárhelyi lakosság sztrájkkal válaszolt: január 22-én (három napon keresztül) a Magyar Államvasutak helyi egységei csatlakoztak az erdélyi vasutasok általános munkabeszüntetéshez, másnap a postások és a távíróhivatal alkalmazottai, illetve a kereskedők közös elhatározással függesztették fel a munkát. A román Kormányzótanács 1919. január 26án feloszlatta a vármegyei, a községi és más Nemzeti Tanácsokat, így a nemzetiségek gyakorlatilag politikai képviselet nélkül maradtak. ${ }^{587}$

\footnotetext{
${ }^{586}$ NAGY: Háromszék. AREOPOLISZ, 2015. 159-169.; FODOR, Múltunk, 2016/2. 168-172

${ }^{587}$ LÁSZLÓ: Maros-Torda/Maros, AREOPOLISZ, 2015. 195-199.
} 
Udvarhely vármegye és Székelyudvarhely város 1918-1920 közti közigazgatás történetére vonatkozóan Bárdi Nándor és Gidó Csaba végzett kutatásokat. 1918. október 30-án került sor Udvarhely vármegye törvényhatósági közgyülésére, amely határozatban kérte a magyar katonák hazahozatalát, a székely megyék közti kapcsolat megerősítését, ugyanakkor számoltak a román megszállással lehetőségével is. A budapesti Nemzeti Tanács felhívására Székelyudvarhelyen 1918. november 1-jén a vármegye részéről Paál Árpádot bízták meg a helyi Nemzeti Tanács szervezésével, amely elnökévé is megválasztották (Székelyudvarhelyen, november 3-án). A vármegye élére a hónap végén a Károlyi-kormány Válentsik Ferenc országgyülési képviselőt nevezte ki kormánybiztosnak, aki az alispáni teendőkkel Paál Árpádot bízta meg. Válentsik és Paál a Székelyudvarhelyre bevonuló román hadsereg tábornokával, Nicolescuval egy több pontból álló megegyezést (katonák elszállásolása, közélelmezés, közbiztonság, utazás stb. - lásd 2. számú melléklet) írtak alá a december 6-án. 1919 januárjától a román hadsereg figyelmen kívül hagyta a megállapodást. A legszembetűnőbb esetek közül ki kell emelni a következőket: Válentsiket katonai segédlettel eltávolították főispáni pozíciójából és helyére Neamţu Valert nevezte ki a Kormányzó Tanács, illetve Paált és más tisztviselöket letartóztattak, mert nem voltak hajlandóak felesküdni a román államra. A tisztviselők, a tanítók, az igazságszolgáltatás tisztikara eleinte ellenállt a hüségeskünek, de 1919-1920 fordulójától a kényszerhelyzetből következően egyre többen behódoltak a román államnak. A trianoni békeszerződés aláírása után a tisztviselők szolgálatra jelentkeztek. 1920-ban Udvarhely megyéből és Székelyudvarhely városából 104 család repatriált, többségükben tisztviselők, értelmiségiek. ${ }^{588}$

Csík vármegye közigazgatási bizottsága 1918. október 21-én ülésezett utoljára. A Csík Megyei Nemzeti Tanács november 7-én alakult meg, amely számolva az idegen katonai megszállással, a csendőrség müködési kötelességét erre az esetre is elöírta. Az első román csapatok 1918. november 12-én jelentek meg a megyében. Csíkszereda katonai megszállása 26-án vette kezdetét, amely többek között a polgári lakosság mozgásának korlátozását, a botozás bevezetését vonta maga után. Katonai közigazgatás lépett érvénybe, de 1919. április végéig amellett a magyar polgári közigazgatás még hivatalban maradt, amelyekben közremüködött Pál Gábor föügyész és Ugron András a Károlyi-kormány kormánybiztosa is. 1919 februárjában a Kormányzótanács hajlandó volt a megye élére magyar prefektust (föispán) kinevezni Gaál Endre személyében, mert ekkor még hiányoztak a román tisztviselők a megyében.

${ }^{588}$ BÁRDI, Otthon. 2013. 65-72., GIDÓ, Udvarhely, AREOPOLISZ, 2015. 225-238. 
1919. április folyamán átvételre került: az alispáni hivatal, a főszolgabíróságok, a városi tanácsok, a rendőrkapitányi hivatalok, a pénzügyigazgatóság és az állampénztárak. A magyar tisztviselőket a vármegye egész területén esküre szólították fel, amit a többség megtagadott. Csíkszereda város adminisztrációjának átvételére 1919. július 3-án került sor. Vasile Barbier felcsíki főszolgabíró, akit újonnan neveztek ki Csíkszereda polgármesterévé közölte Ujfalusi Jenő addigi polgármesterrel, hogy eskü ellenében helyettes polgármesterként tovább folytathatja munkáját. Ujfalusi arra hivatkozva, hogy hivatali és állampolgári esküje alól Budapesten nem mentették fel, a többi tisztviselővel együtt megtagadta a felszólítást. Rendszeresek voltak a letartóztatások, Csíkban például Gaált Endrét és Györgypál Domokost is (Károlyi-kormány által kinevezett föispán) internálták. A közigazgatáshoz hasonlóan mélyreható változtatások mentek végbe az igazságszolgáltatás területén is: Csík, Háromszék és Brassó megyéknek egy közös törvényszéket hoztak létre Brassó székhellyel, (ahol a régi bírók közül csak Szebeny Gerő gyergyószentmiklósi járásbíró teljesített további szolgálatot). 1919. november elején képviselö-, és szenátorválasztásokat tartottak. A Csík megyei kerületekben érdemi voksolásra nem került sor, ellenjelölt nélkül a Kormányzótanács által elfogadott jelöltek kaptak mandátumot: Aurel Esca a csíkszeredai, Emil Precup a karcfalvi, Octavian Tăslăuanu a gyergyótölgyesi, illetve a magyar közösség politikai felhatalmazása nélkül induló Ürmösi Maurer Béla a gyergyószentmiklósi kerületben (Lásd később a renegátok tárgyalásakor). ${ }^{589}$

A rendelkezésre álló kutatási eredmények fényében az adminisztratív-végrehajtói hatalmat birtokló Kormányzótanács 1919 nyarára többnyire átvette a kelet-magyarországi területek irányítását. Általánosságban elmondható, hogy az első intézkedés a megyék autonómiájának teljes vagy részleges megszüntetése volt. A megyei tisztviselök többsége kinevezéssel és nem választással töltötte be a pozícióját. A törvényhatósági bizottságokat felszámolták, helyükbe gyenge jogosítvánnyal rendelkező bizottságok léptek, tagjait a prefektusok és a kormány által kinevezett megyei tisztviselőkből verbuválták.

Az impériumváltást követően az önkormányzati szintü politikai képviselet (a kisebbségek a gyakorlatban itt enyhíthetik a többségi nemzet kizárólagosságából adódó hátrányokat) az országosnál is korlátozottabb formát öltött. A Kormányzó Tanács 1919. január 24-én kelt II. dekrétum, 4. szakasza alapján feloszlatta a törvényhatósági közgyüléseket, a városi és a községi képviselőtestületeket. Előbbi hatáskörét a felülről kinevezett prefektusokra, utóbbiakét helyi tanácsokra, illetve előljáróságokra ruházták át.

\footnotetext{
${ }^{589}$ A központi közigazgatás átvétele. Csíki Lapok. 1919. XXXI. évf. 17. szám, május 4. 1.; SZABÓ: Csík megye. Magyar Kisebbség. 2014. 3-4. szám, 209-220.
} 
Az 1926-ban életbe lépett közigazgatási törvényt követően az önkormányzati testületek lajstromos választás és „arányos" ${ }^{590}$ képviselet formájában alakultak újjá. A gyakorlatban a rendszer erősen torzított, a városi többséget adó magyar és német nemzetiségủeket diszkriminálva. Az OMP a helyben politizáló alapszervezeteknek szabad kezet biztosított a magyarság helyi képviseletének megszervezésében. ${ }^{591}$ Ez azt eredményezte városi és községi szinteken, hogy a helyi adottságoknak megfelelően igyekeztek együttműködni a román és szász vezetőkkel. 1926. évi helyhatósági választásokon OMP és liberális közös lista 30 városban győzött (12-ben elöre megegyeztek), ellenben 19-ben elbukott. ${ }^{592}$ A brassói választás volt az első helyi szintü kísérlet a kisebbségek közös indulására. A leadott 6176 szavazatból 3248 (52\%) esett a magyar-szász közös listára az összes román, valamint szociáldemokrata szavazatokkal szemben. Hét város eredményei alapján megközelítőleg rekonstruálható, hogy az 1926. évi helyhatóságon szerzett tanácstag helyek mennyiben tükrözték az adott település etnikai megoszlását. Az 1910. évi népszámlálási adatok értelmében táblázatos formában feltüntetett helységek megközelítőleg 90\%-ban magyar települések voltak. A helyek száma bár a magyarságnak kedvezett, a döntéshozatali mechanizmus a románságnak volt előnyösebb. ${ }^{593}$

\begin{tabular}{|c|c|c|c|c|c|c|}
\hline \multirow[b]{2}{*}{ Város } & \multicolumn{3}{|c|}{$\begin{array}{l}\text { Tanácstagok } \\
\text { száma }\end{array}$} & \multicolumn{3}{|c|}{ Nemzetiségek } \\
\hline & 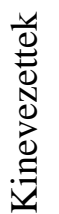 & 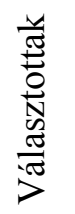 & 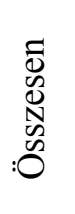 & 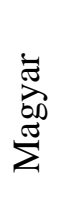 & 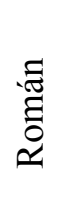 & :? \\
\hline Marosvásárhely & $\overline{16}$ & 24 & 40 & 15 & 8 & 1 \\
\hline Gyergyószentmiklós & 5 & 16 & 21 & 14 & 2 & - \\
\hline Kézdivásárhely & 8 & 12 & 20 & 10 & 2 & - \\
\hline Nagyszalonta & 7 & 15 & 22 & 12 & 3 & - \\
\hline Nagykároly & 10 & 15 & 25 & 7 & 7 & 1 \\
\hline Zilah & 10 & 16 & 26 & 10 & 5 & 1 \\
\hline Csíkszereda & 8 & 12 & 20 & 9 & 3 & - \\
\hline Összesen & 64 & 110 & 174 & 77 & 30 & 3 \\
\hline
\end{tabular}

Táblázat: Erdélyi Magyar Évkönyv 1918-1929. 1930. 24.

\footnotetext{
${ }^{590}$ Az arányosítást a törvény (190. és 191. szakaszai) jelentősen korlátozták. A számszerüleg kisebbségben maradt listák ennek értelmében csak a mandátumok 1/5-ét kaphatták meg, ezt is csak akkor, ha a leadott szavazatok 20\%át elérték. Erdélyi Magyar Évkönyv 1918-1929. 1930. 12-16.

591 A nemzetiségileg magyar többségü településeken az előljárok személyében egyeztek meg, a vegyes lakosú helyeken pedig az ügyek vitelében tudtak elönyökre szert tenni a helyi magyar politikusok. Több városban előfordult az, hogy a magyar munkásság és a zsidóság a Nemzeti Parasztpárttal szövetkezett, amely a liberálisokkal együttszavazó OMP vereségét eredményezte. Azt remélték a kormánypárttal való kooperációtól, hogy a politikai erőszak alább hagy és érdemi beleszólást kaphat a helyi magyarság az adott település közügyeibe. Uo. 15-18.

${ }^{592} \mathrm{Az}$ egyesült ellenzék, amelyet Erdélyben a magyar munkásság és a magyar zsidóság egy része is támogatott, 13 városban nyert, 15-ben vesztett. Román nemzeti lista 2, önálló szász 3, magyar-szász kisebbségi lista mindössze 1 városban szerzett többséget. 16-21.

${ }^{593}$ Uo. 16-25.
} 


\subsubsection{A Szellemi Front-tisztviselömozgalom ellenállása}

A tisztviselömozgalom megszervezésére - más néven Szellemi Front vagy erdélyi központ 1919 januárjától Kolozsváron került sor, Apáthy István kelet-magyarországi főkormánybiztos letartóztatását követően (január 18.). Ezekben a napokban Grandpierre Emil kolozsvári törvényszéki bíró vezetésével öt tagú küldöttség tárgyalt a hüségesküről Maniuval Nagyszebenben a magyar tisztviselők képviseletében. Azt kérték, hogy az ideiglenes román kormányzat elégedjen meg az ünnepélyes fogadalomtétellel és ne követeljen tőlük hűségesküt, de azt elutasította a Kormányzótanács. ${ }^{594}$ A magyar tisztviselői kar többsége az erdélyi központ közvetítésén keresztül budapesti utasításra megtagadta az eskütételt, abból kiindulva, hogy a folyamatban lévő béketárgyalásokon ezt a román kormány Magyarországgal szemben felhasználhatná, illetve az esküt megtagadó tisztviselők a román megszállást csak ideiglenesnek és nem közhatalom-változásnak tekintették. ${ }^{595}$ A Szellemi Front tagjait elsősorban azok a kérdések foglalkoztatták, hogy miként viszonyuljanak a román Kormányzótanácsokhoz, hogy a román hüségeskü letételével szembeni ellenállás koordinált legyen; miként rendeződjék a végleges békekötésig az erdélyi magyar egyházi iskolák ügye; elcsatolás esetén passzívan vagy aktívan viszonyuljanak-e a román államhoz (lásd 3. számú melléklet). ${ }^{596}$

Grandpierre Emil, Költő Gábor és Paál Árpád voltak a tisztviselői ellenállási mozgalom legfőbb vezetői. ${ }^{597}$ Feladataik közé tartozott, hogy a tisztviselőkön keresztül az állandó kapcsolat fennmaradjon Kolozsvár és a vidék között, Szeged és Budapest felől közvetítsék a tisztviselők segélyezésére kiutalt összegeket, illetve a magyar felekezeteknek a vezetőivel együtt megszervezzék a magyar felekezeti oktatást. ${ }^{598}$

\footnotetext{
594 BÁRDI, Otthon. 2013. 66.;

A delegáció tagjai: Grandpierre Emil, Jósika János, Kertész Jenő, Menyhárt Gáspár, Papp József, Ujhelyi József. Kolozsvár küldöttei Nagyszebenben. Keleti Újság, 1919. 2. évf. 11. szám január 15. 5.

595 BÁRDI, 1995. 90-91; BÁRDI, 2003. 163.

${ }^{596}$ K. LENGYEL, 2007. 100.

${ }^{597}$ Paál Árpád letartóztatásának megszünését követően, 1919. április 20-án visszatért Székelyudvarhelyre. Mivel sokan felkeresték a lakásán, és a román hatóságok a tisztviselői ellenállás helyi irányítójának tartották, a román polgármester egy elöre kiállított utazási igazolvánnyal arra kérte, hogy három hónapra hagyja el a várost. A kijelölt új tartózkodási hely 1919. május 1. és július 31. között Kolozsvár lett, ahol bekapcsolódott a Szellemi Front munkájába. Paál kolozsvári tartózkodási engedélye lejártával hazautazott Székelyudvarhelyre, de másnap rendőri felügyelet alá helyezték, majd 10-én letartóztatták, és a volt helyettes alispánnak távoznia kellett a városból és a megszállt területekről. 1919. október 10-én a fogarasi internálótáborba került, ahol erdélyi román politikai foglyokkal és bánsági magyarokkal találkozott. Október 20-án felmentették, de egyidejüleg azonban ismét Kolozsvárt jelölték ki számára kényszerlakhelyül, rendszeres jelentkezésre kötelezve őt. BÁRDI, Otthon.2013. 79-81.

${ }^{598}$ Budapesten Ugron Gábor, Jancsó Benedek, Teleki Pál, majd megalakulása után a Bethlen István vezette ún. erdélyi minisztérium szervezte a segélyakciókat. A pénz és az írásos kimutatások, elszámolások kabátbélésbe varrt vásznakban, titokban jutottak el Kolozsvárról Szegedre és Budapestre. 1919 tavaszán elsősorban mozdonyvezetőkön keresztül folyt a postázás, majd később külön megbízottak teljesítettek szolgálatot. Uo. 80.
} 
Paál tevékenységi köre elsősorban a Székelyföldre irányult. Egyfelől kézzel másolt terjesztett levelek útján propagandát folytatott a nagyszebeni Kormányzótanács ellen. Másfelöl a béketárgyalásokra készülő magyar delegáció számára gyüjtött adatokat a sérelmekröl.

Paál és az erdélyi magyar politika a román megszállás alatti hónapokban sikeres katonai és diplomáciai lépéseket remélt Magyarország területi épségének megőrzéséért. A tisztviselőmozgalom Budapesti kapcsolatain keresztül előbb a Vörös Hadseregnél, majd Horthy Miklós környezetében sürgették az erdélyi támadást. Udvarhely és Háromszék vármegyék magyar elöljárósága 1919 májusában arról döntött, hogy a román állammal szembeni magatartást a négy székely vármegye (Csík és Maros-Torda is), egyezteti a magyar kormánnyal. Elhatározták, ha a nemzetközi és a budapesti politika lehetővé teszi, hogy magyar katonaság felszabadítsa Erdélyt, a székelyek is fegyverbe állnak. Ha azonban a magyar kormány nem vállalhatna egy ilyen beavatkozást, Paál Árpádék a magyar kormány útján teljes körű jogokkal felruházott önálló területi autonómiát követelnének. Ha pedig a magyar kormányzat semmilyen formában nem avatkozna be az erdélyi ügyekbe, úgy a székely megyéknek kellene a román vezetésnél kiharcolniuk azt a jogot, hogy jövőjükről önmaguk dönthessenek - feltéve, ha Budapest erre felhatalmazná őket (lásd 4. számú melléklet). ${ }^{599}$

A nemzetközi viszonyok, és a Tanácsköztársaság, majd Horthyék tekintetében várt kedvező fordulat csupán illúzió volt, hiszen bármiféle önálló erdélyi akció elmaradt. 1920 első felétől egyre nehezebbé vált fenntartani a tisztviselői ellenállást is, mert egyre többen repatriáltak, és a magyar közalkalmazottak hűségeskü hiányában kiszorultak a közigazgatásból, az igazságszolgáltatásból, illetve illetményüknek csak kis részét kapták meg, vagy esetlegesen valamilyen budapesti kormánysegélyből részesültek. Az ellenálláson belül megváltoztak a prioritások, a külső beavatkozás helyett a társadalomszervezés feladatai váltak fontossá. 1919 szeptemberétől az egyik legnagyobb gondot a magyar nyelvủ állami iskolák tanárainak az egyházi, magyar nyelvü iskolákba történő átirányítása jelentette. Ezeknek az új intézményeknek az alapítása nagyrészt Paálék anyagi támogatásával történt, illetve az 1918. novemberben megalakult Felekezetközi Tanács közremüködésével (lásd erre vonatkozóan a következő fejezetet). ${ }^{600} \mathrm{~A}$ Kormányzótanács időszaka alatt ún. redukciós iskolapolitika érvényesült. Maniuék a felekezeti iskolák engedélyezésén keresztül képzelték el a kisebbségi oktatás biztosítását.

\footnotetext{
${ }^{599}$ K. LENGYEL, 2007. 101-102; BÁRDI, Otthon. 2013. 82-83.

${ }^{600}$ A felbomlott Székely Hadosztály vagyonából mintegy 20 millió korona került Paálékhoz, és ezt teljes egészében tisztviselők, tanítók segélyezésére és iskolaalapítások támogatására fordították. BÁRDI, Otthon. 2013. 80-81.
} 
Ebben a rövid időszakban a magyar egyházak viszonylag könnyedén, de saját erejükre támaszkodva alapítottak iskolákat. 1922-őt követően ezzel ellentétes, nyíltan diszkriminatív oktatáspolitika érvényesült Romániában (egészen 1940-ig.) ${ }^{601}$

A tisztviselőmozgalom Budapestről a békeszerződés aláírásáig a Területvédő Ligán és különböző titkos társaságokon keresztül a hüségeskü elutasítására és a passzív ellenállásra kapott utasításokat. Az erdélyi ellenállás központjában 1920 április-májusában az érkező segélyek elosztása és a román politikai erőkkel kapcsolatos stratégia kérdésében komoly vita alakult ki Paál és Grandpierre között. Paál aránytalanul kevésnek ítélte meg azt az összeget, amelyet a székelyföldi tisztviselők megsegítésére, iskolák támogatására fordítottak, és elsősorban a tisztviselők foglalkoztatását szolgáló vállalkozások beindítását szorgalmazta (részvénytársaságok, háziipari szövetkezetek stb.). Ezzel szemben Grandpierre döntően a kolozsvári érdekeket képviselte, és a kivárás, a passzív ellenállás magatartását preferálta. Paál ezzel egyet nem értve már 1920 januárjában felvetette egy Független Székely Párt létrehozásának szükségességét, amely elsősorban a Székelyföld belső társadalom- és gazdaságszervezésével foglalkozott volna. A politikai megosztottságot tovább erősítette 1920 március-áprilisában az erdélyi román vezetők részéről érkező felhívás a magyarság politikai megszervezésére és az erdélyi román-magyar tárgyalások megindítására. ${ }^{602}$

\subsection{A magyar intézményi szerkezet és lehetséges alternativák: egyház, nyilvánosság, egyesületek és a politizálás alternatívái}

Az erdélyi magyar társadalom az összeomlást követő időszakban két széles körben elismert struktúrára támaszkodhatott, egyfelől a magyar nyelvü egyházakra, másfelől az anyanyelvü sajtóra. A nemzeti tematika ezeken az utakon jutott el a szélesebb magyar közvéleményhez. A politikaformálás során az egyházi elitek és a sajtó rendelkezett a legerősebb véleményformáló szereppel.

Az impériumváltás után a legszervezettebb magyar intézményrendszer az egyházaké lett (római katolikus, református, unitárius, evangélikus). Az államhatalom-változással párhuzamosan az egyházakat súlyosan érintette az agrárreform. ${ }^{603}$

\footnotetext{
${ }^{601}$ BÁRDI Nándor: A romániai magyarság kisebbségpolitikai stratégiái a két világháború között. REGIO, 1997. 8. évf. 2. szám, 46-47. [Továbbiakban: BÁRDI, REGIO, 1997]

${ }^{602}$ BÁRDI, Otthon. 2013. 83-84.

${ }^{603}$ A román agrárreformról lásd: Az erdélyi román földbirtok törvények (A gyulafehérvári nemzetgyülés határozata. A 3911/1919. és 2478/1920. sz. rendelettörvény. A Garoflid-féle törvény.) Budapest, Népies Irodalmi Társaság, 1922; VENCZEL József: Az erdélyi román földbirtokreform. Az Erdélyi Tudományos Intézet évkönyve 1940 -1941. Erdélyi Tudományos Intézet Kiadványai, 1941.
} 
1919-től az egyházi birtokok, valamint az iskolafenntartó alapítványok birtokainak nagy részét kisajátították, ezért az iskolákat a két világháború között magyarországi támogatás nélkül nem tudták fenntartani. ${ }^{604}$ Erdélyben a római katolikus egyház sajátos egyházi jellegü intézményei (püspökség, papnevelde, főesperességek, plébániák, szerzetesrendek stb.) mellett léteztek papi, kántori, tanítói és tanári, tisztviselői nyugdíjintézetek, árvaházak, kórházak, iskolák, könyvtárak, internátusok stb. Az intézmények koordinátora és működtetője az Erdélyi Római Katolikus Státus ${ }^{605}$ volt, amelynek két jelentős kihívással kellett szembe néznie. Egyfelől, hogy a vagyona az agrártörvények után drasztikusan lecsökkent [csak az erdélyi katolikus egyházmegyék 290570 hold birtokából 277645 kat. holdat (98 \%) sajátítottak ki (a plébániák birtokai nélkül)], amely alapjaiban rázta meg az egyház kulturális és oktatási intézményeit. ${ }^{606}$ Másfelől az Osztrák-Magyar Monarchia megszünésével és a köztársaság kikiáltásával (1918. november 16.) napirendre került a főkegyúri jog (az egyházi kinevezések) kérdése. Vajon a főkegyúri jog teljes egészében a magyar állami szuverenitás körébe tartozó kormányzati jogosítvány volt-e ${ }^{607}$ Három elképzelés létezett: 1) a királyi koronához kötött főkegyúri jog a Monarchia megszünésével szintén megszünik, 2) állam és egyház viszonya érdemben nem változik $^{608}$, amíg a kormány ezen nem változtat, 3) Róma előzetes állásfoglalása szükséges. ${ }^{609}$ A katolikus püspökök az impériumváltás után az új uralkodó előtt csak azt követően tettek esküt, miután arra a Vatikán engedélyt adott (lásd a 6.1. alfejezetet). A református és az unitárius ${ }^{610}$ egyházak birtokai hasonló kisajátítás alá estek.

\footnotetext{
${ }^{604}$ Az egyházak földbirtokainak nyolcvan százalékát az agárreform során elvették. BÁRDI Nándor: Az ismeretlen vízmosás és a régi országút. Stratégiai útkeresés a romániai Országos Magyar Pártban 1923-1924. Etnopolitika. Szerk.: Bárdi Nándor-Fedinec Csilla. TLA, Budapest, 2003. 160. [Továbbiakban: BÁRDI-FEDINEC, 2003] Az agrárreformról lásd:

${ }^{605}$ Erdélyi Római Katolikus Státus: egyházmegyei intézmény, amely az erdélyi püspöki megyében történelmileg és jogilag kialakult római katolikus egyházmegyei autonómia, azaz egyfajta egyházi önkormányzat. Szervezete két részből áll: az erdélyi katolikusok egyetemét képviselő Státus-gyűlésből és az önkormányzatot adminisztráló igazgatótanácsból. Mindkét szervezetnek törvényes feje a gyulafehérvári püspök. A vagyoni ügyek intézésén kívül az iskolai és az alapítványi vagyon kezelése, a tanító- és nevelőintézetek, valamint a tanítás és nevelés ügyei feletti intézkedés és az egyháznak kifelé való képviselete teszik ki a Státus munkáit.

MARTON József: Az erdélyi római katolikus egyházmegye intézményei a két világháború között. Korunk, 2002. 13. évf. 4. szám, 17-18. [Továbbiakban: MARTON, Korunk, 2002/4]

${ }^{606}$ MARTON József: A trianoni békeszerződés hatása az erdélyi egyházmegye igazgatására. Iustum Aequum Salutare 2010. 6. évf. 1. szám, 85.

${ }^{607}$ A kérdés a két világháború közti Magyarországon is felmerült, mert voltak olyan kormányzati jogok, amelyek a király személyéhez kötöttek, s így interregnum idején nem gyakorolhatók. SZABÓ István: A királyi fökegyúri jog kérdése a két világháború közötti Magyarországon. Iustum Aequum Salutare 2010. 6. évf. 1. szám, 104.

${ }^{608}$ Ezt képviselte Persián Ádám (Budapest, 1887-Pozsony, 1934) a katolikus egyházi ügyek kormánybiztosa, majd miniszteri tanácsosa 1918 novemberében. Persián a Tanácsköztársaság kikiáltása után Bécsbe, majd Pozsonyba emigrált, 1920-ban tért haza. http://mek.oszk.hu/00300/00355/html/ABC11587/12079.htm (Letöltve: 2017. november 27.)

${ }^{609}$ ERK SIL, Kolozsvár, IV. 4. Erdélyi Katolikus Státus iratai, 355. doboz, 1918:606. 373/1918. október 22.

${ }^{610}$ Az unitárius egyház jövedelmét jelentős alapítványi birtokok képzeték, például az Augusztinovich Pál-féle ladamos-alamori birtok, a Berde Mózsa-féle búni és bányabükki birtok, a Derzsi János-féle pusztaszentmiklósi birtok stb.
} 
1922-ben az iskolák megmentésére egyházak bevezették az ún. egyetemes adót, amely azt jelentette, hogy a híveket minden lélek utáni évi 30 lei értékü egyházi adó befizetésére kötelezték. ${ }^{611}$ A négy egyház 1914-ben összesen 275 millió, 1929-ben csupán 13 millió leinek megfelelő állami segítségben részesült. Egyéb bevételeiket, illetve hadikölcsöneiket, értékpapírjaikat a koronabeváltás és a lei inflációja elemésztette. ${ }^{612}$

Magyar egyházak földbirtokvagyona (kat. hold)

\begin{tabular}{|c|c|c|c|}
\hline & reform előtt & kisajátított & reform után \\
\hline római katolikus & 290.649 & 277.645 & 13.004 \\
\hline református & 62.148 & 25.222 & 36.926 \\
\hline unitárius & 17.916 & 11.389 & 6.527 \\
\hline evangélikus (magyar) & 1.041 & 73 & 968 \\
\hline
\end{tabular}

Forrás: Sas Péter, 1987.

A Monarchia összeomlásának rendkívüli heteiben a négy egyház püspöke - Majláth Gusztáv Károly (katolikus), Nagy Károly (református), Ferencz József (unitárius), Friedrich Teutsch (evangélikus) - 1918. november 15-én, püspöki találkozót szerveztek. Történetük során elsőként, közös pásztorlevelet bocsátottak közzé. Az alakuló értekezlet elfogadta Majláth püspök következő állásfoglalását. Az erdélyi magyar és szász egyházak vezetői a „magyar népkormányt, mely [...] az ország függetlenségének kivívására, és a társadalmi megújhodás megszervezésére vállalkozott, a történelmi idökhöz mért hazafias érzésekkel üdvözli. [...] Viszont kérik a kormányhatalom letéteményeseit, hogy az egyházakat, mint a nemzeti társadalom legrégibb és legerösebb biztositékait, minden erejükkel támogassák. Különösen gondoskodjanak arról, hogy Erdélynek esetleges katasztrófaszerü átalakulása esetére a magyar és szász egyházak teljes anyagi és erkölcsi biztositékok birtokában cselekvöképesen készen álljanak, hogy mint a nemzeti élet legerősebb mentsvárai, az anyaországtól elszakadt magyarság és szászság nemzeti fennmaradását biztositsák." ${ }^{\text {"13 }}$ A püspökök egyetértőleg hívták életre a Magyar Egyházak Felekezetközi Központi Tanácsát Kolozsváron, amely a negyvenes évek közepéig összehangolta intézményrendszerük közéleti és társadalmi (iskolai, szociális) tevékenységét. A Tanács müködése rendszeressé 1919-1920 fordulójától vált. A Tanácsban meghatározó szerepet töltött be a Szellemi Front vezetői közül Grandpierre Emil és Költő Gábor.

\footnotetext{
${ }^{611}$ MOLNÁR B. Lehel: Az Erdélyi Unitárius Egyház intézményrendszere. Korunk, 2002. 13. évf. 4. szám, 36. ${ }^{612}$ SAS, 1987. 32.

${ }^{613}$ Jegyzőkönyv az erdélyi és a szász egyházak vezetőinek értekezletéröl, amelyet Kolozsváron, 1918. november 15-én az erdélyi róm. kat. státus igazgatótanácsának gyüléstermében tartottak. ERE IL 2417/1921. (A felekezetközi értekezlet jegyzökönyvei 1918. november 15. - 1922. november 15-16.)
} 
Ebben a körben találkozunk többek között Bíró Balázzsal, Ravasz Lászlóval, akkori egyházkerületi főjegyzővel (1921-ben repatriált), Boér Elek egyházkerületi főgondnokokkal, báró Kemény Árpáddal, Kolosváry Bálint volt rektorral, akik a békeszerződés aláirását követően a budapesti kormány utasításait követő konzervatív platformot alkottak a politikai aktivitást sürgető Paál Árpádot és Kós Károlyt követőkkel szemben. ${ }^{614}$

Az egyházak mellett a magyar nyelvü sajtó volt a másik szerkezet, amelyre támaszkodhatott az erdélyi magyarság. A román megszállás alá került kelet-magyarországi megyék és Budapest közötti kapcsolatok (sajtószolgálat, posta, táviroda, közlekedés, kereskedelem) a román hatóságok korlátozó intézkedése következtében megszüntek, illegálisan, illetve informálisan müködtek. ${ }^{615}$ A korábban Budapestről is támogatott erdélyi lapok tönkrementek, a hírlap és könyvbehozatali tilalom, a cenzúra és a Magyarországtól való elszakítottság kényszerhelyzete Erdélyben egy új és gyorsan kibontakozó újság- és folyóirat kultúrát teremtett meg. ${ }^{616}$ A kor viszonyai között egy napilap tartósan akkor tudott fennmaradni, ha elérte a napi tízezres példányszámot. A lapok tulajdonosi köre piaci alapon müködött, ezért függetlenek voltak az egyházaktól, pártoktól és politikai finanszírozóktól. ${ }^{617} \mathrm{Az}$ erdélyi nyomdászat 1918-at követően is fontos gazdasági és szellemi tényező maradt. Monoki István erdélyi bibliográfus az 1919-1941-es időszak romániai magyar könyv- és újságtermelést összegezte, amelyben vezető szerepet játszott a kolozsvári Minerva Irodalmi és Nyomdai Müintézet Rt. A két világháború közti magyar nyelvü könyvmennyiségnek a 22,5\%-a (a 22 év alatt kiadott 6968 könyvből 1563 mü) a Minerva mühelyeiben készült. Kolozsvár központi szerepet töltött be az összkönyvtermés közel 50\%-a (3487 mü) innen került ki. Monoki táblázata alapján 67 helységben mintegy 287 nyomda müködött, amely az elaprózottságot és a rendkívül eltérő, inkább kicsi kapacitást mutatja. ${ }^{618}$

\footnotetext{
${ }^{614}$ A Felekezetközi Központi Tanács további vezető személyisége: Dr. Jósika Gábor, Dr. Márki Sándor, Dr. Vezér László és Dr. Király Pál teológus tanárok. Merza Lajos tanácsos, Sándor József tanácsos, egyházkerületi tanácsbíró, Barabás Samu kolozsvári esperes lelkész, Dr. Boros György unitárius egyházi föjegyző, Dr. Gál Kelemen és Dr. Kovács Kálmán főgimnáziumi tanárok, Szentkereszthy Zsigmond v.b.t.t., Miklós István római katolikus egyházmegyei tanfelügyelö, Péter Károly, György Lajos. ERE IL 2417/1921.

${ }^{615} 1922$. áprilisban belügyminiszteri rendeletben tiltották meg továbbra is a magyarországi lapok romániai terjesztését. A magyarországi lapok nem terjeszthetők. Aradi Friss Újság, 1922. IV. évf. 76. szám, április 6. 2.

${ }^{616}$ 1919-1924 között 330 magyar lap jelent meg. Ebből 87 volt 1919 előtti, 243 pedig újalapítású. A kiadványok döntő részét Kolozsváron adták ki. 1923-ban Kolozsváron 113 periodika, Temesváron 42, Nagyváradon 36, Aradon 25, Marosvásárhelyen 20, Szatmárnémetiben 13 jelent meg.

GYÖRGY Lajos: Erdélyi magyar idöszaki sajtó öt esztendeje 1919-1923. Az idöszaki sajtó ötéves termése, újságiró-szervezetek. Erdélyi Almanach, 1925. 235-238. [Továbbiakban: GYÖRGY, 1925]

${ }^{617}$ BÁRDI-FEDINEC, 2003. 159.

${ }^{618}$ A következö 14 nyomda (a Brassói Lapok Könyvnyomdája, a dicsőszentmártoni Erzsébet Könyvnyomda, a kolozsvári Concordia, Deutsche Bote, Fraternitas, Graphic Record, Gutenberg, Pallas, Providentia, Schildkraut, a lugosi Husvéth és Hoffer, a szatmárnémeti Szabadsajtó, a székelyudvarhelyi Globus és Könyvnyomda Rt.) mindösszesen 103 müvet adott ki csupán, amely a 22 év alatti könyvtermés 1,48\%-a. Ezzel szemben a következö 5 helységben működő 11 nyomda (az aradi Vasárnap, a kolozsvári Corvin, Gloria, Grafica, Lapkiadó Rt. és Szent
} 
A Minerva nyomdaipari nagyvállalat a magyar nyelvü kiadványokban domináns szerepet töltött be, 1920. augusztus 16-án alakult 653 részvényes által jegyzett 1,5 millió lei alaptőkével. Az erdélyi értelmiségiek, arisztokraták és haladó polgárok összefogásával létrehozott kezdeményezés célja a Budapesttől kényszerüen elszakadt erdélyi magyarság számára szükséges tankönyveket, irodalmi, müvészeti és tudományos köteteket, folyóiratokat, heti- és napilapokat volt hivatott előállítani. Az alapító tagok (533 fö) között volt többek között gróf Bethlen György, Betegh Miklós, Gyárfás Elemér, Grandpierre Emil, Makkai Sándor író, református püspök, Pál Gábor, Sándor József. A Minerva operatív vezetése, az alapítók közé tartozó dr. Vékás Lajos $^{619}$ kezében volt a kezdetőktől egészen 1940-ig. Vékás 1919-ig kolozsvári törvényszéki bíróként dolgozott, amíg a hüségeskü megtagadását követően állását elvesztette. A müintézet alapítói, amint megvásárolták Stief Jenő nyomdáját (1920), hozzáfoghatott a közösség számára legszükségesebb kiadványok kiadásához. 1920 és 1922 között átvette az Erdélyi Orvosi Lap kiadását, és megkezdte a legszükségesebb iskolai tankönyvek megjelentetését a vallásos (pl. Heidelbergi Káté - A református keresztyének hitvallása), szépirodalmi (Reményik Sándor, Áprily Lajos stb.) és történelmi témájú művek mellett. Ekkor indult el a Pásztortüz (1921. szeptember) és a hetente megjelenő, magát politikai, gazdasági, szépirodalmi képes hetilapként meghatározó, elsősorban a vidéki, falusi magyar lakosságnak gazdasági, kulturális és politikai tájékoztatást nyújtó Magyar Nép ${ }^{620}$ címü néplap (1921. november). ${ }^{621}$

1918-1924 között a legbefolyásosabb napi lapok közé az újonnan alapított polgári radikális irányultságú Keleti Újság, a függetlenségpárti hagyományai miatt konzervatívabb, de a magukat átmenteni képes Ellenzék (alapította Bartha Miklós, 1878), illetve a Brassói Lapok számítottak, amelyek regionális befolyással és jelentős szerkesztői háttérrel bírtak.

\footnotetext{
Bonaventura, a nagyváradi Kálvin, Sonnenfeld és Szent László Nyomda, a temesvári Moravetz Testvérek Könyvnyomdája és a tordai Füsi József-nyomda) összesen 1369 művet, azaz 19,65\%-ot.

Erre vonatkozóan lásd: MONOKI István: A magyar idöszaki sajtó a román uralom alatt. 1919-1940. Budapest, Országos Széchényi Könyvtár, 1941.; MONOKI István: Magyar könyvtermelés a román uralom alatt. 19191940. II. kötet: Hirlapok és folyóiratok. Budapest, Országos Széchényi Könyvtár, 1941.

${ }^{619}$ Dr. Vékás Lajos (1885. Barátos-1962. Győr) Középiskolai tanulmányait Sepsiszentgyörgyön, a Székely Mikó Kollégiumban végezte, ügyvédi oklevelet és jogi doktorátust Kolozsváron szerzett. 1905-töl 1919-ig törvényszéki bíró. 1920-as kezdettől 1922-ig a Minerva Rt. ügyvezető igazgatója, 1923-tól 1940-ig vezérigazgatója. Tagja volt az Országos Magyar Párt Központi Intézöbizottságának. A magyar közigazgatással együtt hagyta el Erdélyt 1944 öszén. TIBORI Szabó Zoltán: Edidit et typis Minervae Claudiopolitanae. 17-18. http://minerva.org.ro/hu/aminerva-tortenete-1920-1948/ (Letöltve: 2017. november 8.)

${ }^{620}$ A lap elkészítésével Gyallay Pap Domokos (1880-1970) kolozsvári unitárius kollégiumi tanárt bízták meg. A lap 10 év alatt havi átlagban 19 ezer példányban jelent meg. Uo. 79

${ }^{621}$ Uo. 5-25.; A Minerva történetét lásd bővebben: TIBORI Szabó Zoltán-ÚJVÁRI Mária: A kolozsvári Minerva története és bibliográfíaja (1920-1948). Kolozsvár, Minerva Müvelődési Egyesület Kiadója, 2015. illetve http://minerva.org.ro/hu/
} 
A Keleti Újságot a Ferenczy Gyula elnökletével 1918-ban létrehozott Lapkiadó Részvénytársaság indította meg Kolozsvárott 1918. december 24-én. A lapkiadás terve 1917 őszére nyúlik vissza a nagyiparos Farkas Mózeshez, akit 1918-ban a kolozsvári Polgári Radikális Párt alelnökévé választottak. A többes kötődéssel bíró Farkas a Magyar Szövetség 1921-es kolozsvári alakuló ülésén a magyar zsidóság nevében a magyarság ügye mellett kötelezte el magát. ${ }^{622}$ Az újság első felelős szerkesztői a budapesti Szentmiklósi József, Zágoni István, 1922 második felében a polgári radikális Ignotus, szellemi irányítói többek között Paál Árpád, Szentimrei Jenő, Kádár Imre voltak. Megjelenésének első éveiben a lap általános irányvonala polgári radikális jellegü, a konzervatív körök politikáját bíráló, a realista és aktivista szemlélet érvényesítéséért szállt síkra, a kisebbségi, párhuzamos társadalmi életlehetőségek kimunkálásán, a román-magyar közeledés elősegítésén fáradozott, amíg az 1920-as évek második felétől az OMP hivatalos lapjává nem vált. ${ }^{623}$ A Keleti Újság vezető szerepét támasztja alá, hogy megközelítőleg naponta 20 ezres példányszámban jelent meg, de „áttörve a demarkációs vonalakat, Kassán és Debrecenben is napi 2-3000 példányban fogyott. [...] Az átmenti időkben és később is, csaknem egy évtizeden keresztül, az erdélyi sajtó jelentett úgy szólván mindent, a sajtó volt az erdélyi magyarság egyetlen megnyilatkozása, az egyetlen kopoltyú, amelyen keresztül a magyarság lélegzett."

Az erdélyiből romániaivá váló Ellenzék alcíme 1919-től „,független politikai napilap”, majd 1923-tól „magyar politikai napilap” lett, amelynek első főszerkesztői Dobó Ferenc (1919-1921) és Grois László (1921-1926) voltak. A polgári liberális, függetlenségpárti hagyományokra épülő újság eleinte kevésbé törekedett a közönség irodalmi vagy színvonalasabb publicisztikai elvárásainak kielégítésére, de aktív szerepet vállalt társadalmi téren, például segélyakciók vagy az 1920-tól, az EMKE köré szerveződő első magyar érdekvédelmi szervezet létrehozásában (lásd később). Munkatársai közé tartozott többek között a reformista, haladó eszméket valló Krenner Miklós Spectator, a tisztviselőmozgalom vezetője, Grandpierre Emil, aki az általa képviselt passzivisták, konzervatívnak tekintett csoport elképzeléseit fejtette ki, illetve a Budapestről visszatért Hunyady Sándor drámaíró és Indig Ottó színmüíró.

\footnotetext{
${ }^{622}$ Farkas Mózes (1881. Huszt-1941. Budapest): ügyvédként 1910-ben részt vett a Renner Testvérek és Társai bőrgyár megalapításában, amelynek a vezérigazgatója lett. A két világháború között a Romániai Nagyiparosok Országos Egyesülete kolozsvári igazgatóságának a vezetője. Farkas bár magyar érzelmü volt, de 1922-ben a zsidók palesztinai kitelepítéséért felelős Keren Hajeszod elnöki funkcióját is elvállalta. A két világháború közötti időszak erdélyi magyar kulturális életét jelentős anyagi támogatásban részesítette. GIDÓ, Úton. 2009. 27.

${ }^{623}$ A Lapkiadó Társaság förészvényese, Weiss Sándor ügyvéd eladta a lapot 1927-ben, amitől kezdve a Keleti Újság az OMP lapjaként jelent meg. LIGETI Lajos: Súly alatt a pálma. Egy nemzedék szellemi élete. Fraternitas Rt, Kolozsvár, 1941. 30-79. [Továbbiakban: LIGETI, 1941]

${ }^{624}$ Uo. $18-29$.
} 
Az Ellenzék elöbb a Grandpierre szervezte Magyar Nemzeti Párt (1921-1922), majd az OMP orgánuma lett. ${ }^{625}$ Székelyföldön a legelterjedtebb lap a Szele Béla szerkesztette Brassói Lapok volt. ${ }^{626}$ Lokálisan kiemelkedőnek tekinthető a Csíki Lapok, amely 1888-tól 1944-ig jelent meg Csíkszeredában. A hetente megjelenő lap Csík vármegye és a régió társadalmáról, az első világháborúról, az impériumváltás mindennapjairól is tudósított. Szerkesztői közül kiemelkedett Élthes Gyula egyetemi tanár, aki mintegy két évtizeden keresztül volt főmunkatárs, illetve Pál Gábor, aki összefoglalókkal és iránymutatásokkal látta el az olvasókat. Pál 1919. októberben két nagy publicisztikában összegezte a háborús veszteségeket, illetve irányított a helyiek figyelmét a Kolozsváron fokozatosan kibontakozó magyar politikai szervezkedésre. Sem Paál Árpád, sem Grandpierre Emil nevét nem említette, csak azt jegyezte meg, hogy a politikai passzivitást a sajtó részben feloldotta és a trianoni békeszerződés ratifikációját követően egységben, a nemzeti autonómia programja mentén kell kigondolni a politikai érdekképviselet formáját. ${ }^{627}$

A zsidóság körében a legnépszerübb lap az Új Kelet volt, amelynek első száma 1918. december 19-én jelent meg Kolozsváron. A politikai hetilap irányultságát tekintve a zsidó nemzeti eszmékhez, a cionista mozgalomhoz állt közel, akár a Temesváron kiadott Neue ZeitÚj Kor, az Erdélyi Zsidó Nemzeti Szövetség (1918-1940) és a romániai Zsidó Párt (1931-1938) erdélyi tagozatának befolyása alatt állt. Az EZSNSZ a tagjai számára az újságra való előfizetést erkölcsi kötelességgé tette. Induláskor 3500 napi példányban jelent, amely a két világháború között megközelítette a 15-20 ezret. ${ }^{628}$ Az erős cionista sajtó megteremtése a zsidó nemzeti gondolat és a cionista mozgalom fejlődése szempontjából bírt jelentőséggel.

${ }^{625}$ BÁNDI Melissa: Ellenzék repertórium 1918-1924. http://ellenzek.adatbank.transindex.ro/bibl.php (Letöltve: 2017. november 8.); LIGETI, 1941. 53.

${ }^{626}$ Marosvásárhelyen a Hajdú István vezette Székelyföld, a Partiumban a Hegedűs Nándor által írt Nagyvárad és Nagyváradi Napló, Aradon az Erdélyi Hirlap, Krenner Miklóssal a háttérben és az Arad és Vidéke, Temesváron pedig a Temesvári Hirlap látta el információkkal az olvasóközönséget. GYÖRGY, 1925. 235-238.

${ }^{627}$ Pál Gábor: A Romániához szakadt magyarság helyzete és jövője. Csíki Lapok, 1919. XXXII. évf. 41. szám, október 9. 2.

${ }^{628}$ GIDÓ, Úton. 2009. 59-80. 
Az alapító közé tartozott többek között Weissburg Chaim ügyvéd, az EZSNSZ alapítója ${ }^{629}$, Glasner Mózes kolozsvári ortodox főrabbi (1923-ban alijázott), illetve Marton Ernő cionista közíró, 1918-ig a Kis-Küküllő vármegyében főispáni titkár. ${ }^{630}$ Az újság első munkatársai főként a magyarországi fehérterror elől Bécsbe, majd Erdélybe települt újságírók voltak. ${ }^{631}$

A fontosabb folyóiratok közé a kisebbségvédelmi tematikájú Magyar Kisebbség (1922től), a Keleti Újság világnézetét képviselő irodalmi, politikai Napkelet, illetve a már említett, a Minerva körébe tartozó, konzervatívabb erdélyi irodalmat képviselő Pásztortüz voltak. ${ }^{632} \mathrm{~A}$ Magyar Kisebbség nemzetpolitikai szemle a két világháború között, 1922-1942 között havonta kétszer jelent meg a lugosi Húsvéth és Hoffer könyvnyomdájában. Alapítói a hűségesküt megtagadó „lugosi triumvirátus” volt: Jakabffy Elemér ügyvéd, a Munkapárt liberális képviselője, Sulyok István Krassó-Szörény vármegye járási szolgabírója, a Krassó-Szörény Lapok tulajdonosa, 1918 őszén a helyi radikális mozgalom vezetője ${ }^{633}$, illetve Willer József $f^{634}$ Lugos alpolgármester-helyettese (1913-1919). A folyóirat magyar, román, német és francia nyelvű cikkeiben, illetve melléklapjaiban (Glasul Minorităţilor, La Voix des Minorités stb.) szolgálta éppúgy a magyar, mint az egyetemes kisebbségi ügyet és adattára volt minden, a kisebbségekre vonatkozó megnyilatkozásoknak. ${ }^{635}$

${ }^{629}$ Weissburg Chaim (1892. Diósfalu-1959. Izrael): ügyvéd, aki Budapesten belépett az 1903-ban alapított Makkabea zsidó főiskolás szervezetbe. 1915-ben orosz fogságba esett, ahol fogolytársai körében terjesztette a cionista eszméket. 1918-as hazatérését követően Erdélyben telepedett le, aktívan részt vett az erdélyi cionista intézményrendszer kiépítésében. Főként a Palesztina-munka területén, erdélyi zsidók palesztinai letelepítésében vállalt részt. 1925-ben maga is alijázott (Palesztinába kitelepült). Uo. 505.

${ }^{630}$ Marton Ernő (1896. Dicsőszentmárton-1960. Tel Aviv): ügyvéd, politikus, cionista ideológus, az Új Kelet föszerkesztője. 1930-ban, a Zsidó Párt színeiben Kolozsvár alpolgármestere, 1931-1933 között parlamenti képviselő. 1944 márciusában közremüködött az erdélyi zsidóság mentési kísérleteiben. Tel Avivban telepedett le, ahol újraindította a még ma is múködő Új Keletet. Uo. 504.

${ }^{631}$ Kaczér Illés, Újvári Pétert (az 1929-ben Budapesten megjelent Zsidó Lexikon szerzője), Giszkalay János, Sas László, Szabó Imre, Darvas Simon, Faragó Miklós. Az 1920-as évek második felétől a Kolozsvárról fokozatosan eltávozó magyarországi származású újságírógárdát fiatal, erdélyi ifjak váltották fel, például Barzilay István, Danzig Illés, Hátszegi Ernő és Kasztner Rezső. Utóbbi Danzig Illéssel együtt jelentette meg 1924-ben A zsidóság évkönyvét. Uo. 79.

${ }^{632}$ BÁRDI, 1997. 47-50.

${ }^{633}$ Sulyok István (1891. Lugos. - 1945. Németország): 1924-től az Ellenzék szerkesztőségéhez szegődött, 1927ben az erdélyi magyarság nemzetközi jogvédelmére létrehozta a Romániai Magyar Népliga Egyesületet, 1930-tól az OMP Intézőbizottságának tagja, ennek listáján 1932-től a román parlamentben képviselö, 1939-ben áttelepült Magyarországra, ahol a jobboldali, szélsőséges nacionalista Magyarság munkatársa lett. http://lexikon.kriterion.ro/szavak/4136/ (Letöltve: 2017. november 9.)

${ }_{634}$ Willer József (Kecskemét, 1884.-Budapest, 1972.): köztisztviselő, politikus, lapszerkesztő, muzsikus. Budapesten végezte az egyetem jogi karát és a zeneiskolát. 1905-1907 között szülővárosa szolgálatában állt. 1913-19 között alpolgármester-helyettes Lugoson. A román hatalomátvétel után, mint esküt nem tett tisztviselö, elvesztette köztisztviselői állását, ezután 1925-ig zenetanítással foglalkozott. Jakabffy Elemérrel és Sulyok Istvánnal megindította Lugoson a Magyar Kisebbség c. 1925-ben a Brassói Lapok c. napilap szerkesztöje. Az 1926-os és 1927-es romániai választásokon Csík vármegyében parlamenti képviselővé választották. Bethlen György bizalmas híve és munkatársa volt. http://lexikon.kriterion.ro/szavak/5120/ (Letöltve: 2017. december 17.) ${ }^{635}$ MIKÓ Imre: Jakabffy Elemér és a Magyar Kisebbség. Korunk, 1973. 32. évf. 8. szám, 1198-1202.; 
A Napkelet története a Keleti Újságéval fonódik össze, amelyek a polgári radikális ideológiával rokonszenvező Ferenczy Gyula, Farkas Mózes és Szentmiklósi József közremüködésével jelentek meg. A Keleti Újság közönségsikere megteremtette a feltételeit annak, hogy a Lapkiadó Rt. egy további lapot, a Napkeletet megjelentesse (1920. szeptember 20-ától). A folyóirat csak két évet élt meg, de a kibontakozó erdélyi magyar kisebbségi közélet számos szereplője talált itt fórumot. Főszerkesztője Paál Árpád, társszerkesztői: Kádár Imre, Ligeti Ernő és Szentimrei Jenő - valamennyien tagjai voltak a Keleti Újság szerkesztőségének is. A főmunkatársak közé tartozott továbbá Janovics Jenő, Kós Károly, Nyírő József, Bárd Oszkár stb., akikre a törekvések sokrétűsége, interferenciája volt a jellemző. Paál És fölkél a nap címü beköszönő cikkének tanulsága szerint az induló folyóirat az erdélyi sajátosságok (közös kultúrák kifejlődése, vallásszabadság, nemzeti egyenjogúság) kidomborítására törekedett. Kós Károly az 1921 nyarán induló Erdélyi Néppártját kívánta népszerüsíteni, amit a Lapkiadó Rt. végül nem vállalt. A Napkeletben, egymással összefonódva, több irodalmi törekvés érvényesült: a transzilvanizmus (Paál, Kós, Szentimrei), az aktivista-expresszionizmus (baloldali emigránsok), illetve a Nyugat folyóirat szellemisége, amely Barta Lajos közremüködésével, némiképp az erdélyiség rovására nyert teret. ${ }^{636}$ A Napkelethez hasonló szellemiségben jelent meg Kolozsváron a Vasárnap hetilap 1921 novemberétől, amit a Kiáltó Szó Szentimrei Jenővel kiegészült szerzőhármas (Kós Károly, Zágoni István, Paál Árpád) szerkesztett. A lapot a Magyar Néppárt szócsövének szánták, amely arra bátorította a román parlamentbe bejutott magyar képviselőket, hogy „,autonóm magyarságot” szervezzenek „egy autonóm Erdély keretein belül”, elöre vetítve Románia föderális berendezkedésének kívánalmát. ${ }^{637}$

A partiumi és a bánsági lapok szerkesztőségeinél, illetve a Keleti Újságnál is jelen voltak a magyarországi emigráns újságírók, akik a városi polgárság modernista igényeit elégítették ki. A demokratikus gondolkodású magyar nyelvü sajtó összességében hozzájárult egy újfajta, a régi tematikától eltérő tartalmak mentén való politikai megközelítés kialakításához.

\footnotetext{
${ }^{636}$ A Napkelet a szük két év alatt mintegy 60 költő (Babits Mihály, Szentimrei Jenő, Bárd Oszkár), 50 prózaíró (Déry Tibor, Tabéry Géza, Nyírő József, Márai Sándor), 60 irodalomkritikus-publicista (Kádár Imre, Dienes László) és 20 müfordító (Székely Béla) írását adta közre.

Napkelet 1920-1922. Antológia. Válogatta, az elöszót írta és a függeléket összeállította MÓZES Huba. Kriterion Könyvkiadó, Kolozsvár, 2004. 5-14.

${ }^{637}$ K. LENGYEL: A kompromisszum, 2007. 132-133.; Lásd a Vasárnaphoz: Szentimrei Jenő: A nagy Napkeletről és a kicsi Vasárnapról. Igaz Szó, 1957. 5. évf. 7. szám (július), 52-70.
} 
A vezércikkek napi iránymutatást adtak (Paál Árpád, Krenner Miklós, Zágoni István, Dózsa Endre, Jakabffy Elemér, Szentimrei Jenő, Ligeti Ernő, Kádár Imre), illetve egyszerre biztosították az eltérő politikai szocializációjú nemzedékek közti átjárást, a történeti múlt és a jövő határozottabb körvonalazását, a nemzetszemlélet és a történeti gondolkodás új minőségekkel való feltöltését. ${ }^{638}$

A társadalmi egyesületek/szervezetek volt a harmadik pillér, amelyre valamelyest támaszkodhatott az erdélyi magyarság. Szervezeti hátterük 1918-at követően jelentősen csökkent, mert az uralomváltás alatt jogi személyiségük megszüntették, ingatlanjaikat elvették, illetve tagságuk létszáma megcsappant. Ha egy részük át is tudta magát menteni, de korábbi erejét és befolyását csak kisebb mértékben volt képes megőrizni. Az erdélyi magyar társadalmi egyesületeket Sulyok és Fritz öt csoportra osztotta: 1) olvasó- és társaskörök (1930-ig 195 kör müködött 16 ezer taggal), 2) dal- (130 kör, 6400 tag), 3) nö- (107 egyesület) -, 4) hitbuzgalmi, illetve 5) gazdasági (gazda- és fogyasztási) egyesületek. Kulturális téren a legfontosabb országos jellegü - közmüvelődési egyesületek közé tartozott az Erdélyi Magyar Közmüvelődési Egyesület (EMKE, alapítva 1884), az Erdélyi Múzeum-Egyesület (EME, 1859), Erdélyi Kárpát Egyesület (EKE, 1891), Dalosszövetség (1921). ${ }^{639}$

Gazdasági téren az Erdélyi Gazdasági Egyesület (1936-ig nem voltak falusi tagozatai), illetve Hangya/Kaláka szövetkezeti központba tömörült fogyasztási szövetkezetek emelkedtek ki. ${ }^{640} 1918$ elött az Országos Központi Hitelszövetkezet (OKH) 2474 hitelszövetkezetének 64,5\%-a, községeinek pedig több mint 2/3-a maradt az utódállamokban, Romániában (869 hitelszövetkezet, 277.775 tag), Jugoszláviában, Csehszlovákiában és Ausztriában.

\footnotetext{
${ }^{638}$ LIGETI, 1941. 18-29.

${ }^{639}$ Női egyesületek: az erdélyi magyar nők társadalmi és közéleti tevékenységének összefogása 1925. október havában történt meg a „Romániai Magyar Kisebbségi Nők Központi Titkárságának” megalapításával Bukarestben, ahol Gróf Bethlen Györgyné, Kovács Dezsőné és Farkas Anna 75 erdélyi magyar nőegyesületet képviselt. A magyar női egyesületek felekezetenként végezték tevékenységüket: katolikus nőmozgalom, Református Nőszövetség, Unitárius Nök Szövetsége, magyar lutheránus nömozgalom.

Hitbuzgalmi egyesületek, például: Oltáregyletek, Bibliakörök, Dávid Ferenc egyesületek stb.

Erdélyi Magyar Évkönyv 1918-1929, 1930. 121-159.

${ }^{640}$ EME: a két világháború között az EME gyüjteményeit és könyvtárát a kolozsvári tudományegyetem használta és kezelte, amelyet az állam és az EME között létrejött szerződésbe foglaltak. A megállapodás értelmében az államnak a gyüjteménye használata után, évi 10.000 aranykoronának megfelelően, mintegy 450.000 lejt kellett volna fizetni 1919 óta. Az EME tulajdonában két kolozsvári ingatlan volt. Müködését tagdíjakból és adományokból biztosította.

EMKE: ingatlanjait (iskolák, föld) elvették. 1935-ben nyerte csak vissza jogi személyiségét és ismerték el az alapszabályát.

Dalosszövetség (Romániai Magyar Dalárda): 1921 november 13-án Brassóban harminc erdélyi dalárda kiküldöttei alapították meg, amelynek élére dr. Inczédy Joksmann Ödön került.

EKE: 1929-ben nyerte vissza jogi személyiségét.

Erdélyi Magyar Évkönyv, 1937. 82-91.
} 
Az erdélyi magyar szövetkezetek 1918 előtt az OKH vagy a Hangya kötelékébe tartoztak, az új határok miatt elszakadtak egykori központjaiktól, a háborús pusztítás miatt kifosztva, egyesek szervezetlenek maradtak, mások pénzforrás hiányában megszüntek (Budapesten rekedt betétek kifizetetlensége). 1918-1920 közötti időszakban az összes erdélyi magyar hitelszövetkezet közül 42,6\%-ot, a fogyasztási szövetkezetek közül pedig 32,5\%-ot számoltak. A Hangya újraszervezésére 1920. június 3-án Nagyenyeden 433 fogyasztási szövetkezet csatlakozásával került sor. 1922-ben a Hangya központhoz 563 szövetkezet tartozott, mintegy 150 ezer taggal és 650 ezer üzletrésszel. Az áruforgalom javítása, emelése érdekében a Hangya a húszas évek folyamán áruraktárakat létesített (Nagyvárad, Arad, Sepsiszentgyörgy, Marosvásárhely, Székelyudvarhely, Szatmár és Torda városokban). Gyárfás Elemér, az OMP szenátora és a Bankszindikátus elnöke a román parlamentben és román pénzügyi körökben képviselte a magyar szövetkezetek érdekeit. ${ }^{641}$

\subsubsection{A politikai önszervezés öt eltérö alternatívája}

A politizálás módszerében 1919 tavasza és 1922. december 28. (Országos Magyar Párt megalakítása) között öt eltérő érdekérvényesítési forma fogalmazódott meg. Az öt lehetséges út: A) Az EMKE újjászervezése kulturális, politikai érdekérvényesítő szervezetként, B) egy új egységes, széleskörü szervezet (népszövetség) alakítása, amely a magyar kisebbséget közjogi személyiségként képviselte volna, a nemzeti autonómia megteremtésének első lépcsőfokaként. C) Önálló etnikai (vagy vegyes) politikai párt létrehozása és részvétel (politikai integráció) a román törvényhozásban, D) a nemzetközi „Emberi Jogok Ligájához” való kapcsolódás, E) a román pártokon belüli politizálás és részvétel a bukaresti országgyülésben.

A) $\mathrm{Az}$ EMKE köré elképzelt szervezkedést az Ellenzék napilap mellett álló (konzervatívnak mondott) kör kezdeményezte 1920 októberében. A párizsi békeszerződést követő államhatalmi változás tudomásulvétele megkövetelte a magyarság politikai életének megszervezését „társadalmi, felekezeti és osztálykülönbség nélkül egy egyesületbe tömörülve." ${ }^{642}$

\footnotetext{
${ }^{641}$ A hitelszövetkezetek képviselői 1920. augusztus 9-én, 403 hitelszövetkezet csatlakozásával, megalakították a Gazdasági és Hitelszövetkezetek Szövetséget (Kolozsvár székhely) szövetkezeti jogi formában. Jogi, pénzügyi újjászervezésben vezető szerepet töltött be dr. Valkó Gyula, a kolozsvári OKH-kirendeltség korábbi ügyvezetője, dr. Láday István miniszteri tanácsos, Bocsánczy László, a Kolozsvári Takarékpénztár és Hitelbank Rt. Igazgatója. A nagyenyedi Hangyánál pedig Rohay László igazgató, dr. Harmath József, illetve dr. Drexler Béla játszották a föszerepet. Utóbbi a Földmüvelésügyi Minisztérium Székelyföldi kirendeltség korábbi, 1918 elötti tisztviselöi tapasztalataira támaszkodva segített a szövetkezetek újjászervezésében.

HUNYADI Attila: Nemzetgazdasági önszerveződési modellek Erdélyben. Az erdélyi magyar, szász és román szövetkezetek kölcsönhatásai. In Bárdi Nándor-Simon Attila (szerk.) Integrációs stratégiák a magyar kisebbségek történetében. Fórum, Somorja, 2006. 189-217.

642 Szervezni kell a magyar társadalmat. Ellenzék, 1920. XLI. évf. 213. szám, október 13.1.
} 
Elsődleges feladatuknak azt tartották, hogy az erdélyi összmagyar társadalom képviselve legyen, a magyar nyelv, müvelődés, szellem és nemzeti érdekeinek megvédelmezésére egy társadalmi szervezet keretén belül, de nem politikai pártban. „A politikai aktivitás ideje még nem jött el. Kukorékolnak ugyan egyes kakasok, de azért a hajnalhasadás még nem pirkad."643 Az „egység” ideája, az „összetarozunk vagy elveszünk” elve lebegett szemük előtt, amelyről úgy gondolkodtak, hogy azt egy párt nem képes széthúzás nélkül megjeleníteni.

Nagy Károly református püspök, az EMKE kuratóriumának tagja az egyház közremüködésével megvalósuló kulturális kibontakozásról beszélt. „Míg a politikai szervezkedés erkölcsi alapot kap a békekötés ratifikálásának formaságai bevégzésével, magyarságunk közélete a közgazdasági és a szorosabb értelemben vett kultúrmunkásság terére van szoritva." ${ }^{644}$ A kultúrmunka a vallásos élettel szorosan együttjáró szociális tevékenységet is magába foglalta. A szervezeti keretet részben az autonóm, külső befolyástól mentes egyházak, részben pedig a magyar társadalom egyesületi alapon történő szervezetei, nevezetesen az EMKE biztosíthatták volna. Sándor József, az EMKE vezetője a magyar kultúra megtartásáért és a gazdasági élet megteremtéséért vállalt feladatokat hangsúlyozta. ${ }^{645} \mathrm{~A}$ szervezet kiterjedt infrastrukturális hálózata (iskolák, óvodák, menedékhelyek, könyvtárak, daloskörök, alapítványok, földbirtok stb.) és a kulturális életben elfoglalt pozíciója miatt a hazafiság szimbólumaként, és a „magyarság társadalmi parlamentjének szerepét” betöltve jelent meg. A parlament kifejezést nem politikai értelemben használták. Elképzelésükben a pártpolitikát kiiktatták, mert úgy vélték a fontolva haladás jegyében, hogy előbb megteremthető a magyarság társadalmi, gazdasági egysége. Minden egyes erdélyi magyarra számítottak az EMKE újjászervezésében, de legfőbb szolgálatot a magyar nyelvű sajtó csatlakozásától remélték. „Ha Erdély magyar társadalma az EMKE-ben egy egységes magyar társadalmi szervezetben lesz tömörítve ez a társadalmi szervezet - ha szükséges lesz - úgyszólván márólholnapra átalakitható politikai szervezetté." ${ }^{646}$ Ferenc József unitárius püspök elsősorban az egyetértést és a társadalmi egység fontosságát emelte ki. ${ }^{647}$ Kolosváry Bálint egyetemi tanár, a református egyházkerület tanácsosa konkrétabban nyilatkozott, amikor az aktivista kör nyílt politikai szervezkedést sürgető felhívását türelmetlennek és elhamarkodottnak ítélte meg.

\footnotetext{
${ }^{643}$ Munkába kezd az EMKE. Tömörüljön a magyarság a kulturális és társadalmi munkára. Csíki Lapok, 1920. XXXII. évf. 43. szám, október 24. 2.

${ }^{644}$ Szervezni kell a magyar társadalmat. Ellenzék, 1920. XLI. évf. 213. szám, október 13. 1.

${ }^{645}$ Uo. 2.

${ }^{646}$ Egy szervezetbe tömörül Erdély magyarsága. Ellenzék, 1920. XLI. évf. 216. szám, október 14. 1. ${ }^{647}$ Uo.
} 
„A lekapcsolt részek magyarsága a türelmetlenek által mind hangosabban sürgetett szervezkedést egyelöre kulturális és gazdasági téren hajthatja végre."648 Kolosváry a fokozatosság elve mentén úgy képzelte el az erdélyi magyarság politikai képviseletének kibontakozását, hogy előbb egy társadalmi szervezetben tömörítik a szellemi, a kulturális és a gazdasági élet minden szereplőjét, és majd csak azt követően, megfelelő erejü képviselettel lépnek be a politika nyílt küzdőtérébe. ${ }^{649} \mathrm{Az}$ Ellenzék beszámolt egy Kézdivásárhelyen megtartott tanácskozásról, ahová 85 főt hívtak meg a helyi politikai elit szereplöi közül, amelyen végül 27-en jelentek meg. (A résztvevők névsorát nem ismerjük). A tudósításból az derül ki, hogy a megjelentek nem támogatták a politikai párt létrehozásának tervét, amelyet Bernády György kezdeményezett, és helyette csak a kulturális és a gazdasági élet újjászervezése érdekében tett egyesületi alapon történő szervezkedést támogatták. Az Ellenzék szerkesztőségéhez mindeközben több székelyföldi városból azzal a kéréssel fordultak, hogy az EMKE széles körben ismertesse meg alapszabályát és tanácsokkal segítse a szervezkedés helyi szintü elindítását. ${ }^{650} \mathrm{Az}$ EMKE újjágondolásának, a kulturális és a társadalmi szervezetekre épülő szervezkedés opcióját támogatta Ugron Gábor volt belügyminiszter, Bedő Sándor a marosvásárhelyi ügyvédi kamara volt elnöke, illetve Nagy Endre a református kollégium igazgatója. ${ }^{651}$

Az ún. konzervatív passzivista kör a romániai magyarság megszervezetését egy horizontálisan és vertikálisan müködő nem pártpolitikai, hanem társadalmi alapon (egyesület, mozgalom) képzelte el. Segítséget az egyházaktól, az 1918 előtt is müködő kulturális és gazdasági egyesületektől, illetve a sajtótól reméltek. A fokozatosság elvét vallották, előbb fel kívánták mérni a rendelkezésre álló humán és szervezeti erőforrásokat, illetve a sajtó segítségével tagtoborzást indítani az az EMKE részére. A pártpolitikától több ok miatt is tartózkodtak. Minden bizonnyal nem akartak olyan helyzetet teremteni, hogy egy parlamenti választás során ne az általuk preferált személy jusson mandátumhoz. Kategorikusan elutasították a román pártok listáin való indulást, amelyet árulásnak ítéltek. A budapesti kormányzat is ellenezte a választásokon való részvételt, amely az impériumváltás elfogadását jelentette volna.

\footnotetext{
${ }^{648}$ A magyarság társadalmi szervezkedése. Ellenzék, 1920. XLI. évf. 217. szám, október 15. 1. ${ }^{649}$ Uo.

${ }^{650}$ Az EMKE újjászervezése. Ellenzék, 1920. XLI. évf. 219. szám, október 17. 3.

${ }^{651}$ Szervezkedik az erdélyi magyarság. Ellenzék, 1920. XLI. évf. 228. szám, november 3. 3.
} 
B) A magyar kisebbségi politikusok elhatározása 1920 decemberére vált egyértelmüvé arról, hogy az EMKE újjászervezése helyett (a bizonytalan jogi helyzete miatt) egy új egységes, széleskörü szervezet (népszövetség) megalakítását kezdeményezik. A szükös levéltári források hiányában a korabeli sajtóra támaszkodva az rekonstruálható, hogy november hónapban fogalmazódott meg az új kisebbségvédelmi szervezet, a Magyar Szövetség terve. (A Magyar Szövetség intézmény- és programtörténetét lásd a 6. fejezetben.) Arra vonatkozóan nem rendelkezünk részletekkel, hogy pontosan kik is kezdeményezték az első megbeszéléseket, de a konzervatív passzivista oldalt reprezentáló Ellenzék, illetve az aktivista kör sajtója, a Keleti Újság is egyformán pozitív hangnemben számolt be a szövetség ötletéröl december 25-én. Minden valószínüséggel a két fél tárgyalásokat folytatott egymással, de figyelembe véve Grandpierrék tevőleges lépéseit az EMKE újjászervezésére, a „passzivista” csoport volt a kezdeményező fél.

Az Ellenzék december 25-i számában a Magyar Szövetség megalakításának részleteiről tudósított, amelyről egy Kolozsváron tartott tanácskozáson született elhatározás. Az egybegyültek, akiknek a névsorát az újság nem közölte, döntöttek arról, hogy első lépésben a kolozsvári magyarság képviseletét szervezik meg. Az alakuló ülés feladatait is elöírták, amely között szerepelt az intézőbizottság felállítása és tagjainak megválasztása, illetve a szövetség hálózatának kiépítése egész Erdélyre nézve. Egyetértés mutatkozott abban, hogy a gazdasági, a kulturális és a társadalmi élet területein túl az állami centralizációval és a kisebbségi jogokat sértő rendelkezésekkel szemben a politikai úton való érdekérvényesítést fel kell vállalni. Az EMKE-tervhez hasonlóan a passzivista kör továbbra is elvetette a pártalakításra vonatkozó elképzeléseket és a hangsúlyt a társadalmi egységre és összetartozás fontosságára helyezte. „Az új szerv lesz hivatva minden egyes, a magyarságot érdeklö kérdésben megállapítani azt, hogy milyen magatartás felel meg legjobban a magyarság egyetemes érdekeinek. S az egyes magyar pártárnyalatoknak kötelessége lesz az általános elvek tekintetében alárendelniük magukat az összesség javának." 652

Grandpierre Emil az Ellenzékben fejtette ki álláspontját a politikai magatartás megváltoztatásának szükségességéről. A békeszerződés ratifikálását követően elérkezettnek látta az időt a politikai szervezkedés megkezdésére, amelynek központját és kiindulópontját, történelmi hagyományainál fogva Kolozsvárra helyezte.

\footnotetext{
${ }^{652}$ Megalakul az erdélyi magyarság szervezete. Ellenzék, 1920. XLI. évf. 271. szám, december 25. 4.
} 
A szövetség tagjának tekintett minden vármegye és székely szék magyar és székely lakóját, ideértve a moldvai csángó, a bukaresti és más regáti magyarokat, akikben „élénken él a magyar érzés és a magyarsághoz tartozás tudata." ${ }^{653}$ Az EMKE-tervvel ellentétben, amely csak egy minimális keretet jelölt meg a magyarság kulturális és gazdasági fejlődéséhez szükséges alapok kialakításához, addig a Magyar Szövetség elképzelésében már a nemzetiségi autonómia terve fogalmazódott meg. A szervezet politikai célt kapott, amely legfőbb jogforrását a kisebbségvédelmi egyezményből nyerte, és a belefoglalt új jogi kategóriából, a nemzeti kisebbségből. Bár a nemzetközi szerződések a nemzeti kisebbség pontos tartalmát pontosan nem határozták meg, ezzel számos értelmezési vitának táptalajt adva, mégis politikai fogódzó volt a kisebbségpolitikusok kezében saját stratégiai érdekeik kijelöléséhez. Grandpierre ebből három következtetést vont le. Egyfelől a nemzeti kisebbség fogalmával a nemzetállam koncepció az államjogi fogalmak lomtárába került. Másfelől a nemzeti kisebbségek jogalanyiságának elismerésével megnyílt az út a kollektív kisebbségi jogok, nevezetesen az etnikai alapú autonómiák megvalósítására. Harmadrészről pedig az autonomista törekvések politikai legitimitását a bekövetkezett általános demokratizálódás biztosítja, amelynek Románia sem szabhat gátat. ${ }^{654}$ Költő Gábor Grandpierrehez hasonlóan foglalt állást a politikai építkezés kérdésében. A kulturális, a társadalmi és a gazdasági kihívásokra adható válaszok mielőbbi kiérlelését szorgalmazta egy egységes szövetség létrehozásának keretén belül. A pártpolitikai úton történő aktivitást elvetette, amiben a múlt hibáinak megismétlődését és az ideológiák mentén történő konfliktusok lehetőségét látta. ${ }^{655}$

A politikai progressziót képviselő Keleti Újság a szövetség technikai részleteiről nem nyújtott információt, helyette a tiszta politikai üzeneteknek adott teret. Paál Árpád vezércikkben üdvözölte a szövetség tervét egyértelművé téve azt, hogy a parlamenti politizálás megragadását sem lehet tovább halogatni. „A megalakulandó Magyar Nemzeti Szövetségnek minden eszközt meg kell ragadnia, hogy a magyarság érvényesülését keresztül vihesse. Meg kell ragadni tehát a parlamenti aktivitást is és ezért választóinak a tömöritését, azok választójogának a kiküzdését már mindjárt kezdet óta munkába kell vennie." ${ }^{656}$ Grandpierre vezette passzivista csoport Paállal szemben a parlamenti aktivitást időszerütlennek tartotta. Ragaszkodtak az egységes szervezethez, amely egyedüliként volt hivatott dönteni az országgyülési választásokon való részvételről és a jelöltek megnevezéséről. ${ }^{657}$

\footnotetext{
${ }^{653}$ Grandpierre Emil: Magyar szervezkedés. Ellenzék, 1920. XLI. évf. 271. szám, december 25. 7.

${ }^{654} \mathrm{Uo}$.

${ }^{655}$ Helyzetünk s jövőnk. Ellenzék, 1920. XLI. évf. 271. szám, december 25. 8.

${ }^{656}$ Paál Árpád: A magyarság politikai aktivitása. Keleti Újság, 1920. 3. évf. 283. szám, december 25. 1-2.

${ }^{657}$ A szervezkedési mozgalom kinövései. Ellenzék, 1921. XLII. évf. 5. szám, január 7. 3.
} 
Kós Károly, Zágoni István és Paál Árpád, a politikai aktivistást szorgalmazók három vezető prominense minden bizonnyal tárgyaltak Grandpierrékkel a Magyar Szövetség kérdésében. Hármójuk tollából három politikai írás született, amit együtt jelentettek meg 1920 december végén - Kós írásából éve - Kiáltó Szó címmel. ${ }^{658}$ A röpirat töredékesen jelent meg, a szöveg több mint felét törölte a cenzúra és ilyen körülmények között a szélesebb rétegekhez sem tudott eljutni. A Keleti Újság a december 25-i számában egy oldalt szentelt az írás propagálására Röpirat a politikai aktivitásról címmel, ezzel segítve tartalmának megismerését. ${ }^{659}$ A Keleti Újság és a Kiáltó Szó az Ellenzékkel ellentétben az intézményes politikai építkezés technikai részleteiről hallgatott. A progresszív lap december 28 -án továbbra is a politikai iránymutatást vállalta magára, megerősítve a Kiáltó Szó főbb politikai cselekvésre vonatkozó mondanivalóját. A Magyar Szövetség pártokon, osztályokon és felekezeteken felül álló nemzeti szervezet lehetne szerintük, amelynek mindenki tagja, aki a magyarsággal sorsközösséget vállal. Célja a népi önkormányzati rendszer megteremtése, amely abban a tekintetben univerzális érdekü, hogy számít az európai nemzetiségek és vallási kisebbségek támogatására, illetve a munkásmozgalom, mint elnyomott társadalmi tömeg rokonszenvére. A magyar szervezkedés minden eszközében demokratikus, „ezért el kell vetnie magától a bolsevizmus ideáját, mert a faj diktatúrájának helyébe nem teheti az osztálydiktatúrát." Kiáltó Szó tartalmáról lesz szó.)

A romániai magyarság, illetve a szász és sváb német kisebbségi elitekben hasonlóan megfogalmazódott az egységes szervezet iránti igény, amikor Nagy-Románia területén egymástól távol élő magyarokat és németeket akarták saját intézményes kereteik között integrálni. A lényegi különbség az erdélyi magyarok és a németek között mégis az volt, hogy míg az utóbbiaknak nemzetiségi, kisebbségi státusza volt 1918-at megelőzően is, addig a magyarok egy meröben új élethelyzetet kellett megtapasztalniuk kisebbségbe kerülve.

\footnotetext{
${ }^{658}$ KÓS Károly: Kiáltó szó. ZÁGONI István: A magyarság útja. PAÁL Árpád: A politikai aktivitás rendszere. Cluj-Kolozsvár, 1921

${ }^{659}$ Röpirat a politikai aktivitásról. Keleti Újság, 1920. 3. évf. 283. szám, december 25. 5.

${ }^{660}$ A magyar szervezkedés taktikája. Keleti Újság, 1920. 3. évf. 284. sz. december 28. 1.
} 
Az összeomlást követően az erdélyi szászok legmagasabb képviseletét ellátó Erdélyi NémetSzász Néptanácsot 1919. november 6-án, Segesváron ${ }^{661}$ azzal a céllal hívták életre ${ }^{662}$, hogy az erdélyi szászok egyesülve az óromániai, a bánáti, a besszarábiai, a bukovinai valamint minden más nagyromániai némettel közösen ${ }^{663}$ belépjenek a román állam politikai életébe. A bánáti svábok 1918 után két politikai pártot (Sváb Autonómpárt, illetve Német Néppárt ${ }^{664}$ ) és egy egységes szervezetet (a pártok és az egyházfők közreműködésével), a Német-Sváb Népközösséget ${ }^{665}$ (1921. március 13.) hozták létre. Nagy-Románia német közösségeinek (erdélyi szászok, szatmári és bánáti svábok, besszarábiai, bukovinai, dobrudzsai és regáti németek) képviselöi 1921. szeptember 17-19. között Cernáutiben (Czernowitz, ma Ukrajna) megrendezett Német Napok keretében találkoztak első alkalommal. Itt alakították meg a Nagyrománia Németjeinek Szövetségét ${ }^{666}$ (Verband der Deutschen Grossrumäniens), amelynek élére Rudolf Brandschot, a német parlamenti párt elnökét választották. A Szövetség feladatának tekintette a német érdekek érvényesítését a kisebbségvédelem és a kulturális autonómia területén. A Német Párt volt a németek politikai képviselője a román parlamentben. ${ }^{667}$

\footnotetext{
${ }^{661}$ A szászok 1918 előtt háromszor tartottak gyülést (Sachsenteg), amelyet utoljára 1896-ban hívtak egybe Segesvárra. Az 1919. november 6-án megtartott (negyedik) szász gyủlésen kimondták a Nagy-Romániához való csatlakozásukat. 18 pontos határozatot fogadtak el, amelyben egyéni és kollektív kisebbségi jogok garantálását követelték a gyulafehérvári pontok németekre vonatkozó részleteinek betartásával. A szászok nemzetgyülése előtt. Keleti Újság. 1919. 2. évf. 251. szám, 5.; Qullen zur Geschichte der Sieben Jürger Sachsen 1191-1975. Köln/Wien 1975. 268-271.

${ }^{662}$ Vezetöi: Adolf, Schullerus (Fogaras, 1864-Nagyszeben, 1927): Evangélikus lelkész, nyelvész, néprajzkutató. Rudolf Brandsch (Medgyes, 1880-Börtönben Romániában, 1953): 1910-1918 között szász képviselő a magyar. 1919-1933 között a román parlamentben, 1930-1931-ben kisebbségi államtitkár-helyettes. BAUMGARTNER Bernadette: Kisebbség a kisebbségben A Szatmár megyei németek a két világháború között 1918-1940. Doktori értekezés, Pécs, 2010. 55. http://www.idi.btk.pte.hu/dokumentumok/disszertaciok/baumgartnerbernadettephd.pdf (Letöltve: 2017. november 10.) [Továbbiakban: BAUMGARTNER, 2010]

${ }^{663} 1918$ után alakult meg a Besszarábiai Német Néptanács, amely 80 ezer helyi németet képviselt, vezetöje: dr. Haas evangélikus püspök volt. 1918 után alakult meg szintén a Bukovinai Német Néptanács, amely 70 ezer helyi németet képviselt (50 ezer fö katolikus, 20 ezer evangélikus), amelynek vezetői voltak: Anton Keschman, Dr. Kohlruss (elnök 1916-1935), Dr. Lebouton (képviselő 1931-1933, szenátor 1933-1936). A Regátban mintegy 30 ezer német élt, föként Bukarestben és Turnu-Szeverin környékén. A dobrudzsai, föként szászok kicsi létszámuk miatt az erdélyi vezetést fogadták el. 1920-as népszámlálás alapján Erdélyben 224 ezer, a Bánságban és Arad megyében 268 ezer, Szatmár, Máramaros, Bihar és Szilágy megyékben 47 ezer német élt. Uo. 51-65.

${ }^{664}$ Sváb Autonómpárt vezetői: Blaskovics Ferenc (katolikus pap, szerkesztő, a Német-Sváb Népközösség egyik alapítója), Dr. Kaspar Muth és Dr. Kräuter Ferenc (1920-1938 között parlamenti képviselö). A Német Néppárt vezetöi: Dr. Josef Gabriel, Dr. Michael Kausch (1922-1938 között parlamenti képviselö, 1924-től a Nemzeti Liberális Párt listájáról), Oberst von Möller, Eschker és Röser. Uo. 60-61.

${ }^{665}$ Elnöke dr. Kaspar Muth volt 1936-ig. A temesvári nagygyülésen kb. 20 ezer bánáti német vett részt. A népközösségbe való belépés önkéntes volt, s a szervezet 1929-ben mintegy 60 ezer tagot számlált. Uo. 61.

${ }^{666}$ A Szövetség legfelsőbb szerve a Nagygyülés volt, amelyen részt vettek az egyes Néptanácsok delegáltjai, minden tízezer német után egy delegált (regáti németek 2, bánátiak 25 , besszarábiaiak 7 , bukovinaiak 8 , szatmáriak 1, szászok 25, továbbá a Német Párt parlamenti képviselöi). Uo.114.

${ }^{667}$ BAUMGARTNER, Bernadette: A szatmári svábok és a német népi mozgalom Romániában, 1918-1940. Múltunk, 2010/2. 157-158.
} 
C) A romániai döntéshozatalban önálló, etnikai (vagy vegyes) párttal való részvétel volt a harmadik alternatíva. A német párthoz hasonló magyar párt létrehozása a trianoni békeszerződés ratifikálása előtt nem merülhetett fel reális alternatívaként, amely az Erdélyről való önként történő lemondást jelentette volna. 1920-1921 fordulójától, amikor, de jure az államhatalom-változás realizálódott, mindenféle politikai szervezkedés az ostromállapot körülményei között fokozatosan, de akadályoztatva lassan kibontakozott. A passzivitástaktivitást képviselők vitájának egyik eltérő kérdése a parlamenti politizálás megindításában fogalmazható meg. Paál Árpád 1920. december 25-én, mint arról korábban volt szó, vezércikkben üdvözölte a Magyar Szövetség tervét, egyértelművé téve azt is, hogy a parlamenti politizálás megragadását sem lehet tovább halogatni. ${ }^{668}$ A konzervatívok álláspontja ezzel szemben az volt, hogy a választásokon való részvétel időszerütlen, amíg a magyarság szervezetlen. ${ }^{669}$ 1921-ben, miközben már folyamatban volt a Magyar Szövetség megszervezése, Kós Károllyal az élén, megalakult az első magyar politikai párt, az Erdélyi Magyar Néppárt (1921. június 5.). Válaszul a Grandpierre Emil vezette konzervatívok életre hívták a Magyar Nemzeti Pártot (1922. január 15.). A két szervezet 1922 végén egyesült, miután a Magyar Szövetség müködése ellehetetlenült, illetve a magyar kisebbségi elit saját jól felfogott érdekében arról döntött, hogy a romániai magyarság parlamenti képviselet nélkül tovább nem maradhat. ${ }^{670}$ (Az Erdélyi Magyar Néppárt és a Magyar Nemzeti Párt intézmény- és programtörténetét lásd továbbá a 6 . fejezetben.)

D) Egy másik elképzelés szerint a magyarságnak elsőként a nemzetközi „Emberi Jogok Ligájához" való kapcsolódás révén lehetett volna megszerezni a magyar közéletet. 1921-ben mivel még egy kialakulatlan szervezetről volt szó, és inkább nemzetközisége, mint politikai, jogvédő oldala volt domináns, ez hamar lekerült a napirendi pontról. ${ }^{671}$ Ez az elképzelés föként az aktivizmust hirdető csoport részéről fogalmazódott meg a kezdetek kezdetén. Abban a kontextusban merült fel, hogy amikor az erdélyi magyarságot önállósította a békeszerződés, a kisebbségi jogok védelmét a hazai (romániai) - gyenge - jogszabályi keretek mellett nemzetközi szintű védelemben is kellett biztosítani.

\footnotetext{
${ }^{668}$ Paál Árpád: A magyarság politikai aktivitása. Keleti Újság, 1920. 3. évf. 283. szám, december 25. 1-2.

${ }^{669}$ A szervezkedési mozgalom kinövései. Ellenzék, 1921. XLII. évf. 5. szám, január 7. 3.

${ }^{670}$ Szervezik a Magyar Pártot. Keleti Újság, 1921. 5. évf. 241. október 24. 5; A Magyar Párt országos megalakulása. Keleti Újság, 1921. 5. évf. 292. december 28. 1-2; Az egységes Magyar Párt megalakulása Kolozsváron. Keleti Újság, 1921. 5. évf. 293. december 29. 3-4;

${ }^{671}$ BÁRDI-FEDINEC, 2003. 164.
} 
„Emberi jogokat követelünk magunk számára, és azoknak a védelmét keressük. Bajtársaink pedig a kisebbségi jogok védelmére utalt többi nemzetek, [...] keresni kell a módot arra, hogy az emberi jogok védelmének erös és nagy eredményekre biztató ligája alakulhasson ki." 672

E) A politikai részvétel egyik útjának az mutatkozott, ha a magyar kisebbség képviselői közvetlenül a román politikai pártok támogatásával (akár azok választási listáin keresztül) vesznek részt a bukaresti törvényhozásban és a helyi politikában. A román elit szempontjából ez azért lett volna előnyös, mert a magyar és a román politikai szereplök közti alkufolyamaton keresztül utóbbi úgy éri el a magyar követelések mérséklődését (kontroll-kooptáció), illetve az új állam legitimációját a magyar politikai közösség előtt, hogy közben nem kell intézményesíteni az etnikai hatalommegosztást, és minimalizálja a centralizáció elvén kiépítendő román nemzetállam intézményes és jogi kereteivel szembeni ellenállást. ${ }^{673} \mathrm{~A}$ magyar politikai közösség részéről ennek az útnak három okból sem volt realitása. 1) Erdélyben a nemzetiségi alapon szerveződő politikai érdekvédelem hagyományai erősek voltak (pl. Román Nemzeti Párt, szász és sváb önkormányzatiság, 1918 előtt a magyar szupremáciát védő társadalmi szervezetek). ${ }^{674}$ 2) 1920-at követően a romániai pártoknak nem volt a kisebbségi elitek számára elfogadható kisebbségi programjuk (oktatáspolitika, autonómia, föderáció stb.). 3) Az előző kettővel összefüggésben az erdélyi magyar társadalom 1920 után, ha megtépázva is, továbbra is sürü intézményes hálóval (társadalmi pillér) rendelkezett. A magyar politikai közösség tagjai számára a választott út ezért az volt, hogy midennapi életüket a „sajátjaik” körében éljék, a más oszlopok (a többségi társadalom) létezésének figyelembevétele nélkül. Trianont követően a magyar elit politikai retorikájában és önreprezentációjában ez az intézményesített etnikai pilléresedés (vagy párhuzamos társadalomépítés) a kisebbségi társadalom fogalmában jelent meg a két világháború között. ${ }^{675}$

Az 1919 novemberi választásokon ettől függetlenül indultak magyar nemzetiségű képviselők román pártok képviseletében vagy függetlenként, de őket a magyar nyilvánosságban (sajtó és az egyházi körök) egyaránt renegátoknak tekintették.

\footnotetext{
${ }^{672}$ Jogvédelmünkért. Keleti Újság, 1920. 3. évf. 268. szám, december 7. 1.

${ }^{673}$ KISS Tamás Marginalizáció, etnikai párhuzamosság és aszimmetrikus akkomodáció. Az erdélyi magyar közösséget érintő társadalmi és politikai folyamatok. Magyar Kisebbség, 2015. 20. évf. 1-2. szám, 55. [Továbbiakban: KISS, Magyar Kisebbség, 2015]

${ }^{674}$ BÁRDI-FEDINEC, 2003. 164.

${ }^{675}$ Ez egy olyan etnikailag integrált intézményes struktúrát jelent, amely lehetővé teszi a közösség tagjai számára, hogy az életüket egy „magyar világon” belül élhessék (anélkül, hogy túlságosan tekintetbe vennék, hogy ez fizikailag Romániában történik). Ez az intézményes struktúra, illetve a párhuzamos magyar világ megléte központi jelentőséggel bír a magyar közösség etno-kulturális reprodukciója szempontjából is. KISS, Magyar Kisebbség, 2015. 43.
} 
Erdélyben a feladat lebonyolítását a Kormányzótanács vállalta magára (205 választókerületben), amelynek vezetöit a gyulafehérvári nemzetgyülést elökészítő RNP adta. A politikai szervezkedést akadályozó ostromállapot, a cenzúra, a sorozatos választási csalások, illetve a választási névjegyzék hiányos volta az RNP „győzelmét” biztosították be Erdélyben. A kisebbségi választókerületben az RNP nem mindenhol állított saját román nemzetiségü jelöltet, hanem a velük együttműködő magyar és szász indulókat íratták fel a szavazólapokra. ${ }^{676}$ 1919 elején egy magyarokból-székelyekből álló politikai csoportosulás, az Ürmösi-Maurer Béla vezetése alatt, és egy aradi ügyvéd, Lengyel Béla szerkesztésében 1919. április 27-én, Nagyszebenben Új Világ címmel napilapot indított, és főleg Székelyföldön próbált követőket toborozni magának. ${ }^{677} 1919$ szeptemberében, tekintettel a közelgő parlamenti választásokra, a csoport létrehozta a Magyar-Székely Nemzeti Demokrata Pártot (hivatalosan csak november 27-én, Bukarestben alakult meg, elnökévé vargyasi báró Dániel Lajost választották). Az RNP közvetett támogatásával 8 képviselői, illetve négy szenátori helyet szereztek meg. ${ }^{678}$ Fáy József ${ }^{679}$ Udvarhely megye képviselőjeként a bukaresti törvényhozásban elmondott bemutatkozó beszédében (1920. február 19.), amelyet az Új Világ leközölt, az infrastruktúra fejlesztésének szükségessége mellett Erdély és Románia egyesülésének elfogadásáról, a tisztviselőmozgalom vezetőinek elutasításáról, illetve az új helyzettel való szembenézésről beszélt: ,[...] a székelyek nyugalommal és bizalommal fogadták a Romániával való egyesülést [...] A magyar államnak a székelység mindig mostoha gyermeke volt. [...] Mint a román állam hüséges polgára és mint székely, aki szereti nemzetét, jöttem el ide, erre a helyre, mert nem akartam figyelembe venni annak a társaságnak féktelen terrorját, mellyel az egykori vezetök arra akarták kényszeriteni a székely népet, hogy szélmalomharcot folytasson." ${ }^{80}$

\footnotetext{
${ }^{676}$ SEBESTYÉN, Látó, 1999/1. 82-83.

677 NAGY, Korunk, 1999. X/5. május; http://epa.oszk.hu/00400/00458/00017/5k20.htm (Letöltve: 2017. november 13.)

${ }^{678}$ Képviselők: Szabó Gábor volt udvarhelyi szolgabíró, székelykeresztúri képviselő, Pető Mózes oklándi kisgazda, dr. Fekete András kézdivásárhelyi képviselő, kovásznai ügyvéd, Fáy József ügyvéd, udvarhelyi képviselő, Ürmösi-Maurer Béla, Lengyel Béla, Morvay Endre, Nesselrode Károly. Szenátorok: báró Dániel Lajos vargyasi nagybirtokos, udvarhelyi szenátor, Keresztszegy Lajos, Truppel Győző, Herepey Iván.

TÓTH, Szilárd: Hungarian Elites in the Romanian Parliament during the Interwar Period. In: Radu, Sorin-Maner, Hans-Christian (eds): Parliamentarism and Political Structures in East-Central and Southeastern Europe in the Interwar Period. Lucian Blaga University of Sibiu Publishing House, Sibiu, 191-194.

${ }^{679}$ Fáy József: a Fáyok a 12. századra visszavezethető nemesi család, amelynek tagjai közé tartozott többek között Fáy András (1786-1864) író, reformkori képviselö és a Pesti Hazai Első Takarékpénztár (a mai OTP Bank Rt. elődje) alapítója. Fáy Józsefet Ferdinánd király javaslatára a román tokiói követség élére nevezték ki.

Interviu: Stefan de Fay sau cum se vede istoria de la inaltimea unui arbore genealogic de aproape dona milenii. http://www.zf.ro/ziarul-de-duminica/interviu-stefan-de-fay-sau-cum-se-vede-istoria-de-la-inaltimea-unui-arboregenealogic-de-aproape-doua-milenii-5532206 (Letöltve: 2017. november 14.)

680 NAGY, Korunk, 1999. X/5. május; http://epa.oszk.hu/00400/00458/00017/5k20.htm (Letöltve: 2017. november 13.)
} 
Az RNP-én kívül román párthoz csatlakozott még Ébert Ernő (az Alexandru Avarescu tábornok vezette Néppárthoz), valamint a debreceni egyetem volt rektora, Kiss Géza ${ }^{681}$ és Szőts Géza, utóbbiakat a liberálisok támogatták, mint a magyarság igazi képviselöit. A román pártokban történő magyar érdekképviselet kiépítése egy elszigetelt politikai kísérlet maradt, amelyet a magyar közvélemény egyöntetüen elutasított. Akik ezt az utat választották, vagy csak megpróbálkoztak vele (lásd Bernády György esetét) mind megkapták az áruló és a renegát jelzőket. $^{682}$

\subsection{A politikai cselekvés értelmezése a „passzivisták” és az „aktivisták” konfliktusában}

Paál Árpád, Kós Károly, Zágoni István, Kádár Imre, illetve Grandpierre Emil, Költő Gábor, Kolosváry Bálint fémjelezte politikai magatartás az aktivista-passzivista ellentétként vált ismertté az erdélyi magyar politika- és eszmetörténetben. ${ }^{683} \mathrm{~A}$ háború nyomán előállt közhatalmi változásokhoz való gyakorlati-politikai viszonyulás két részre osztotta az erdélyi magyar társadalom politizáló rétegeit. A két fél közti ellentét az erdélyi magyarság helyzetértékelésében, a kisebbségi-közügyi taktika megszervezésére irányuló gyakorlati lépésekben, illetve történelemfelfogásukban és társadalmi mentalitásukban is eltért. ${ }^{684} \mathrm{~A}$ helyzetértékelést döntően meghatározták az erdélyi társadalom- és politikatörténeti adottságok. Egyrészt a romániai magyarság akkor még nem tekinthető a kifejezés mai értelmében kisebbségnek, mert az erdélyi városok döntően magyar nyelvűek voltak, a gazdasági és a kulturális életben domináns szerepben volt jelent a magyarság és a németség. ${ }^{685}$

\footnotetext{
${ }^{681}$ Kiss Géza (1882. Nagyszeben-1970. Kolozsvár): a római jog első professzora, müfordító. A nagyváradi jogakadémiáról került a debreceni egyetem dékáni pozíciójába 1915-ben, 1918-tól rektor. 1919 májusában Schneller István, a kolozsvári egyetem rektora, illetve szeptemberben Kolosváry Bálint levelet intéztek a kar tagjaihoz. A panaszukban azt állt, hogy Kiss Géza rektor a debreceni egyetem képviseletében részt vett Ferdinánd román király nagykárolyi fogadtatásán, illetve a tisztviselőmozgalom ellen tiltakozott a kolozsvári tanárok között. 1920-ban felfüggesztették debreceni állásából, majd nevének törlését is elrendelték valamennyi egyetemi kiadványból. 1932-ig romániai képviselö, illetve szenátor.

HOLLÓSI Gábor: A debreceni Jog- és Államtudományi Kar története (1914-1949). 207. Szerzői kiadás, Debrecen, 26-27.

${ }^{682}$ BÁRDI, Otthon, 2013. 66-67.

${ }^{683}$ Hasonló vita bontakozott ki a jugoszláviai magyarok politikai szervezkedésének megindulásakor 1921-ben. A „passzivisták” (főként Baranyából menekült októbristák) nem támogatták egy önálló párt létrehozását (érvelésük szerint a kulturális és a gazdasági kérdésekre kell koncentrálni), ellenben az „aktivisták” az önálló magyar párt mellett foglaltak állást. A Magyar Párt országos alakuló gyülésére a helyi szervezetek megalakulását követően, utolsóként az utódállamok magyar kisebbségi pártjai között, 1922. szeptember 17-én Zentán került sor, mintegy háromezer küldött részvételével. A. SAJTI Enikö: A jugoszláviai magyarok politikai szervezkedésének lehetőségei és korlátai (1918-1941). Regio, 1997. 8. évf. 2. szám, 3-31.

${ }^{684}$ NAGY György: Erdélyi magyar szellemi élet a két háború között I-II-III (1918-1940). Korunk. 1999. X/2. február, $\mathrm{X} / 3$. március, $\mathrm{X} / 5$. május

685 A Metamorphosys Transylvaniae címủ kötet egyes fejezetei jól rekonstruálja a városok nemzetiségi átalakulását, illetve a magyar intézményi élet hanyatlását. Metamorphosys Transylvaniae. Szerk.: Győri Illés István, Cluj, 1937.
} 
A városi polgárság a régiót és saját magát a romániai modernizáció és demokratizálás fontos szereplőjeként képzelte el. Egy másik eltérés a trianoni Magyarországhoz képest, hogy az 1918as progresszív mozgalmakban részt vett értelmiségiek nem váltak társadalmi bűnbakká. ${ }^{6} 6$

Az egyik csoportot a realitások tudomásul vételét és a cselekvés eszméjét hirdető aktivisták képezték. Úgy vélték, hogy a trianoni békeszerződést követően meg kell kezdeni a magyar kisebbség jogérvényesítő politikai tevékenységét. A legkifejezőbb címszavaik között szerepelt az aktvitás, a cselekvés és a szervezkedés, amely annak a középosztálybeli és értelmiségi körnek (jogász, tanár, író, illetve részben köztisztviselő) politikai szándékát fejezte ki, amely bár társadalmilag szük, egy részét tekintve asszimilált zsidó és emigráns volt, politikai világnézetét illetően népi demokratikus, polgári radikális, illetve liberális beállítottságú. Az aktivisták néhány újság (Keleti Újság, Napkelet) körül, főként Kolozsváron csoportosultak.

A másik politikai kör a tények provizórius jellegét valló, ezért a romániai politikai életbe való bekapcsolódást ellenzők, ún. passzivitás tábora volt. ${ }^{687}$ Reprezentánsai zömmel az 1918 előtt is vezető szerepet játszó köztisztviselői elitből (egy részük a tisztviselőmozgalmat is szervezte), a Felekezetközi Központi Tanácsban is helyet foglaló egyházi vezetőkből és a földbirtokos arisztokráciából verbuválódott. A csoporthoz tartozott többek között Grandpierre Emil, a kolozsvári Magyar Nemzeti Tanács elnöke és a Károlyi-kormány által kinevezett főispán, Kolosváry Bálint egyetemi tanár, Költő Gábor törvényszéki bíró. Továbbá 1919-től Papp Antal kolozsvári pénzügyi igazgató, 1920-tól Nagy László ügyvéd, gróf Bethlen György, az Erdélyi Gazdasági Egyesület vezetője, illetve báró Jósika Sámuel, a főrendiház utolsó elnöke, akit később a Magyar Szövetség (1921. július 6.), majd az Országos Magyar Párt (1922. december) elnökének is megválasztottak. Rövid időre Paál Árpád, Udvarhely vármegye helyettes alispánja, akit szintén Károlyi Mihály kormánya nevezett ki. A lassan kibontakozó erdélyi magyar önszerveződés során a folytonosság kérdése alapproblémaként jelentkezett, hiszen az új helyzetben egyéni és közösségi válaszokat kellett kidolgozni. A passzivista politikai tábor a kiútkeresésben elsősorban a történeti magyar intézményekre és társadalmi osztályokra támaszkodott. Kolosváry Bálint egy kolozsvári fórumon - és általában az erdélyi központ - a magyarság társadalmi és kulturális élet megszervezésének alapját az egyházi autonómia (katolikus, református, evangélikus, unitárius) megőrzésében jelölte meg. Az egyházakra úgy tekintettek, mint a magyar társadalom egyetlen megmaradt szervezetére, amely megőrizte a magyar anyanyelvet és képes működtetni a magyar oktatási intézményrendszert.

\footnotetext{
${ }^{686}$ BÁRDI, 2011. 304-306.

${ }^{687}$ Paál Árpád: A magyarság pártalakulásai. Napkelet, 1921. 2. évf. 22. szám. 1340-1343.
} 
A magyar társadalom közmüvelődési, népjóléti, gazdasági ágazatokban való építkezését ezért a felekezetek és mellettük álló arisztokrata réteg aktív részvételével látta biztosítottnak. ${ }^{688}$

A korabeli politikai diskurzust alakító szereplők a romániai magyar politikai csoportok magatartását a leegyszerüsítő aktivista-passzivista jelzőkkel tették szemléletessé, amely elsősorban a közvélemény számára szolgált eligazodási pontként a politikai közbeszédben. Az aktivista-passzivista beszédmód kibontakozását 1920 május-júniustól datálhatjuk. A figyelemre méltó esetek közé tartozik többek között Bernády György Nyillt levél röpiratának a fogadtatása 1920 májusában, amikor a marosvásárhelyi Székely Napló Bernádyt, „mint az aktivitás híve" aposztrofálja (lásd bővebben a következő fejezetet) ${ }^{689}$ A Keleti Újság főszerkesztője, Zágoni István vezércikkben tisztázta az aktivitás mibenlétét a Trianoni békeszerződést követően. „Olyan aktivitás, amelynek céltévesztő programja csak szigorúan elszigetelt szervezkedésben merülne ki, nem volna kívánatos. [...] Amikor az erdélyi magyarságot önállósítja a békeszerződés ratifikációja. ${ }^{\circ 90}$ Az erdélyi magyar közvéleménynek a valódi mérföldkövet az jelentette, amikor a magyar nemzetgyülés ratifikálta a Trianoni békeszerződést. ${ }^{691}$ Grandpierre Emil az Ellenzékben ${ }^{692}$, Paál Árpád, illetve a politikai progressziót képviselők a Keleti Újságban ${ }^{693}$, Szele Béla a Brassói Lapokban, illetve Tabéry Géza a Nagyváradban és a Szabadságban fejtette ki a politikai aktivitás fontosságát. „Ha a magyarság a politikai munka terére lép, akkor csak egy zászló és egy program köré csoportosulhat. A széthúzó elemeket, a frakciókat eleve ki kell küszöbölni, a többségi elvet érvényre kell juttatni." - fogalmazott Szele Béla. ${ }^{694}$ A konzervatívok politikai magatartásában további lökést jelentett a magyar egyházfőknek a román államra tett esküje. ${ }^{695}$

A valódi törésvonal ezzel szemben pontosabban meghatározható, ha azt a budapesti kormányzathoz való viszonyban, összességében pedig a politikai cselekvésükön keresztül értelmezzük. Az erdélyi központ tagjai jelentős politikai befolyással rendelkeztek Erdélyben és az egykori Erdélyi Szövetségen keresztül szoros kapcsolatok füzték a budapesti kormányhoz, akiket nevezhetünk lojalistáknak.

\footnotetext{
${ }^{688}$ A magyarság szervezési alapjai. Napkelet, 1920. 1. évf. 1. szám, 244-246.

${ }^{689}$ SEBESTYÉN, Látó, 1999/1. 85.

${ }^{690}$ Jogvédelmünkért. Keleti Újság, 1920. 3. évf. 268. szám, december 7. 1.

${ }^{691}$ A magyar nemzetgyülés 1920. november 15-én ratifikálta, és 1921. július 26-án, a XXXIII. törvénycikkel hirdette ki a békeszerződést.

${ }^{692}$ Grandpierre Emil: Magyar szervezkedés. Ellenzék, 1920. XLI. évf. 271. szám, december 25. 7.

${ }^{693}$ Paál Árpád: A magyarság politikai aktivitása. Keleti Újság, 1920. 3. évf. 283. szám, december 25. 1-2.

694 KUPÁN Árpád: A romániai magyarság első politikai szervezkedése. http://www.varad.ro/a-romaniaimagyarsag-elso-politikai-szervezkedese/ (Letöltve: 2017. november 16.)

${ }^{695}$ Majláth Gusztáv Károly erdélyi és Glattfelder Gyula csanádi püspökök 1921. március 19-én, Széchenyi Miklós nagyváradi püspök és Ferencz József unitárius püspök pedig április 9-én hüségesküt tett Ferdinánd román királynak. SAS, 2002. 66-70.; Keleti Újság, 1921. 4. évf. 67. szám, április 7. 6.
} 
Grandpierre Emil, Kolosváry Bálint, Költő Gábor vezette csoport tartotta a budapesti kormányzattal, közvetlenül gróf Bethlen Istvánnal és gróf Teleki Pállal a kapcsolatot. Az aktivista tábor ellentétben nem állt kapcsolatban Budapesttel, akiket illethetünk az önjáró progressziveknek. Például Kádár Imre író a kommün bukása után emigrált és Kolozsváron telepedett le, ahol a Keleti Újság fömunkatársa, a Napkelet és a Kulissza irodalmi és színházi lap szerkesztője lett. A politika gyakorlati szintjén az ellentét elsősorban abban nyilvánult meg, hogy a budapesti kormányok tulajdonképpen megválasztották mely politikai-személyi körrel kívántak szorosan együttmüködni Erdélyben. A budapesti kormány erre vonatkozó döntését a minisztertanács 1921. február 24-én tartott ülésén hozta meg, amikortól az erdélyi központ tagjait a továbbiakban a maga hivatalos megbízottainak tekintette. ${ }^{696}$ A passzivista kör a szervezkedésnek ezért olyan módját képviselte, amely Budapest orientált volt. Míg az aktivisták, tudomásul véve a párizsi békeszerződést, ideje korán megfogalmazták Románia politikai rendszerén belül a kisebbségbe került magyarság jogkiterjesztésének és a társadalom demokratizálásának programját.

Az impériumváltás időszakában született aktivista-passzivista politikai jelzőket a két világháború közti (pl. Mikó Imre) és a későbbi történetírók (pl. Nagy György, Sas Péter, György Béla) általánosan elfogadták, majd tovább örökítették. Bárdi Nándor az erdélyi magyarság intézményrendszeréről írt tanulmányában hívta fel a figyelmet az 1919 elejétől szervezetett erdélyi központ és a budapesti kormányzat közötti szoros politikai kapcsolatok intenzitására és fontosságára. A magyar kormányzat és Grandpierrék kapcsolatának értelmezése, és utóbbiak az alábbiakban kifejtett példák során - világosan látható aktív politikai szerepvállalása, érdekvédelmi tevékenysége új megközelítésbe helyezi az aktivista-passzivista leegyszerüsítő megközelítést. Az erdélyi központ tagjai egyszerre több társadalmi csoportot képviselő és értük lobbi tevékenységet folytató formális és informális szervezetben vállaltak szerepet a Magyar Szövetség létrehozásáig (1921). Ide sorolható maga az erdélyi központ (a volt Főkormánybiztosi Hivatal és magmaradt stábja), az EMKE a kulturális életben, az EGE tiltakozása a földreform ellen Bukarestben, ${ }^{697}$, a Felekezetközi Központi Tanács, a felekezeti oktatási intézményrendszer védelmében kibontakozott politikai ellenállás, az Ellenzék és más helyi lapok körül csoportosuló konzervatív gondolkodású értelmiségiek és volt tisztviselők. Cselekvésükkel a politikai folyamatokat befolyásolták, alakították és szervezték a befolyásuk alatt álló társadalmi csoportokat.

\footnotetext{
${ }^{696}$ BÁRDI, 1995. 91-92.

${ }^{697}$ Jogvédelmünkért. Keleti Újság, 1920. 3. évf. 268. szám, december 7., 1.
} 
Politikai magatartásukban az aktivistáktól leginkább abban tértek el, hogy csak azután kívántak pártot létesíteni és részt venni a parlamenti választásokon, miután az elképzelt össztársadalmi szervezetet, mozgalmat már saját vezetésük mellett megfelelően szervezettnek gondolták.

Az erdélyi központ politikai aktivitásának megértéséhez használjuk most a politikatudományban használatos politikai cselekvés fogalmát. A politikai jelzővel ellátott cselekvés lényege a cselekedtetés, vagyis a politikus vagy egy jól behatárolható kör által megadott cél elérése érdekében sok más személy által folytatott cselekvés, a maguk helyén müködve, összhangban a politikai céllal. ${ }^{698}$ Nevezetesen Grandpierrék cselekvése az a döntés volt, hogy az erdélyi magyarság ne vegyen részt az országgyülési választásokon, tartsák magukat távol az új állami intézmények kiépítésétől, hogy ezzel se legitimálják a hatalomváltást, de beadványokkal tiltakozzanak a földreform törvény és az oktatás államosítása ellen stb. Elméletben a döntés alapfeltétele a jól strukturált probléma, amelyben pontosan leírható a döntési problémát kiváltó feszültség oldás helyes útja, amitől a tévutakat remélik elkerülni.

A politikai döntés kiiktathatatlan eleme, bármennyire is álljon rendelkezésre szakirányú információ, az értékeken és hiten alapuló valamely fix ideológia, hogy melyik alternatíva kívánatos és melyik nem. Az értékítéletek relatív és a bizonytalan alternatívák volta miatt ezért nem lehetnek a problémák jól strukturáltak, ellenben a szituáció megköveteli a politikustól az azonnali döntést. Az egymással ellentétes alternatívák, például részvétel, kooperáció, tagadás, rombolás stb. ráadásul együttesen jelentkeznek és egymással versenyezve. A döntés helyességét vagy helytelenségét csak a későbbi folyamatok fogják igazolni, hogy a rendelkezésre álló opciók közül melyik rejti magában a siker valószínűségét. A politikai cselekedtetésre felhasználható eszközök legerősebbike a kimondott vagy írott szó, amely által történik a vezetés, az irányítás, a befolyásolás és a politikai szervezés. A kitűzött cél érdekében előbb azonban meg kell találnia azokat a személyeket, akik a végrehajtást biztosítják. ${ }^{699}$ Bethlen István, Jancsó Benedek és Bánffy Miklós Budapestről mielőbb igyekeztek megtalálni és kijelölni azt az erdélyi politizáló csoportot, amely politikai céljaikat iránymutatásaik alapján helyben képviselik.

\footnotetext{
${ }^{698}$ A politikai cselekvés. ELTE, Társadalomtudomány Kar, Társadalmi Konfliktusok Kutatóközpont. Kutatóközpont vezetö: Dr. Csepeli György. http://konfliktuskutato.hu/index.php?option=com_content\&view=article\&id=249:8-a-politikaicselekves\&root=239\&catid=23:fejezetek (letöltve: 2017 . április 15.) [Továbbiakban: A politikai cselekvés. http://konfliktuskutato.hu] ${ }^{699}$ A politikai cselekvés. http://konfliktuskutato.hu
} 
A velük szoros kapcsolatot ápoló erdélyi központ tagjainak pedig az állt érdekében, hogy regionális hatalmi befolyásuk biztosításáért szövetségesekre leljenek és integrálhassák a romániai magyar politikusokat szervezetileg is.

Az összeomlással járó tragédia abban áll, hogy elháríthatatlan és a közösség minden tagja számára fájdalmas, mert velejéig érinti életét. Továbbá egy-egy közösség kulturálisan meghatározott értelmezési sémájává válhat, következésképpen a kudarc (és siker) sémák identitásképző eszközök, melyeknek kivételes szerep jut a közösségi emlékezet tartalmainak müködtetésében. A háborús vereséggel való együttélés mindenkoron nehéz, legkézenfekvőbb válasz a kudarc letagadása, a politikai dimenzióban a bünbak kreálása. Wolfgang Schivelbusch (2003) írta le a háborús kudarcokra való reagálás folyamatmodelljét. ${ }^{700}$ 1) Eufória. A vereség ebben a szakaszban még nem tudatosul. A hangsúly a megpróbáltatások elmúlásán van, és a hátországban a felszabadultság-érzésben nyilvánul meg. 2) Ráébredés. A béke által hozott felszabadulást rövid idő alatt széttépi a vereséggel való szembenézés. 3) Átértékelés. Felháborodást, meglepetést és elégedetlenséget kiváltó periódus, amely előkészíti a talajt a kudarc okainak megkeresésére. Itt indul meg a vereség átértékelése, melynek perspektívájából a győztesek győzelme igazolhatatlan. A vereség érzete heroizálódik, de mielőtt az ok-keresés beindulna a kudarc okozta frusztráció általános szintre emelkedik és kommunikálhatóvá válik. A felháborodás jogcíme az igazság megsértésén alapul, amely kirótt, „diktált” büntetésként jelenik meg. 4) Oktulajdonítás periódusa, amikor beindul az okok keresése, mely a kudarc eredményeképpen bekövetkező identitás-válság feloldásának kulcsfontosságú eszköze. Az okok megfelelő differenciája teszi lehetővé a verességgel való (nem)együttélést, és a felkészülést a jövőre. A következő ok-típusok jönnek létre: külső-tartós, külsö-ideiglenes, belsö-tartós, belső-ideiglenes. ${ }^{701}$ A mai napig feldolgozatlan Trianon traumára adott véleményirányítók reakciói jól rekonstruálhatók Zeidler Miklós 2003-ban kiadott szöveggyüjteményéből. ${ }^{702}$ Szociáldemokraták, jobboldaliak és kisebbségi magyarok a külsőtartós ok sémája szerint egyformán beszéltek a hatalmi szóval diktált békéről, amely a történelmi Magyarországot kisállamokra osztotta fel. A külső-ideiglenes okra építő érvelés többek között az antant hatalmak és egyes magyar politikusok és vezetett közösségeik vélt megtévesztettségére épített.

\footnotetext{
${ }^{700}$ Eredetiben lásd: Schivelbusch, W.: The culture of defeat: on national trauma, mourning and recovery. New York, Henry Holt and Co. Metropolitan Books, 2003

${ }^{701}$ A politikai cselekvés. http://konfliktuskutato.hu

702 ZEIDLER Miklós: Trianon. Budapest, Osiris Kiadó, 2003; FEISCHMIDT-GLÓZER-ILYÉS-KASZNÁRZAKARIÁS: Nemzet a mindennapokban. Az új nacionalizmus populáris kultúrája. L'Harmattan-MTA, 2014
} 
Wlassics Gyula azt rótta fel, hogy éveken keresztül hamis és félremagyarázott propagandát folytattak a nemzetiségek Magyarország ellen, amely Trianonhoz vezetett. ${ }^{703}$ Károlyi Mihályt és Jászi Oszkárt bíráló érvek részben arra épültek, hogy az önrendelkezésre hivatkozva félremagyarázták Wilson pontjait, amely végeredményét tekintve Magyarországra pusztulást hozott. ${ }^{704}$ A párizsi békeszerződés rendszerét belső-tartós okokra vezette vissza Bethlen István a nemzetgyülésben tartott miniszterelnöki programadó beszédében (1921. április 19.). Magyarország vesztes helyzetét három tényezővel magyarázta: az ország Mohácstól számítva folyamatos külpolitikai kényszerek közé szorult, a magyar társadalmat ,fajhibák”, hamis ábrándok, könnyelmüség és a jelszavak szeretete hatotta át. Harmadrészt az első világháborúig eltelt ötven év alatt bekövetkezett középbirtokos osztályt sújtó elszegényedés (lásd előző fejezetekben Bethlen földbirtokreformra tett javaslatait), ami azzal járt, hogy a „kereskedelem, a vállalkozás, a pénzügy olyanok kezébe került, akik a nemzet érzésével nem voltak s talán ma sincsenek még úgy összeforrva, mint ahogy az helyes és kívánatos volna."705 Hogy Bethlen kimondatlanul mely társadalmi rétegre utalt az „összeforrva” kijelentésében arra a belsöideiglenes okokat felsorakoztató Bangha Béla, az Ébredő Magyarok Egyesülete (ÉME) vagy az 1919-20-as egyetemi tanévben zajlott antiszemita diákzavargások megadták a politikai választ. ${ }^{706}$ A politikai beszéd részévé váltak olyan politikai tartalommal felruházott kategóriák, mint áruló, felforgató, idegen, plutokrata stb. Bangha Béla többek között az alábbiakat írta 1920-ban: „A nemzet védtelen lett belsö árulóival, felforgatóival, a mérges miazmák terjesztőivel szemben. [...] A magyar közélet fel sem ismerte a bomlasztó kórságokat, amelyek a nemzet testén rágódtak. Belefúrta magát a liberális doktrinákba. [...] A szabadkömüvesség, mely az országok erkölcsi alapjainak aláásásával s a belsö bomlás tervszerü elökészitésével amúgy is böven rászolgált arra, hogy hazaáruló, nemzetpusztitó bünszövetkezetnek tekintessék, melyet tovább is megtürni egyértelmü volna a nemzeti öngyilkossággal."707

\footnotetext{
${ }^{703}$ Trianon, ZEIDLER, 2003. 336-340. (Wlassics Gyula: Az Antant területi szerződései. Új Magyar Szemle, 1920. június 129-135.)

${ }^{704}$ GÁLOCSY Árpád: A népek önrendelkezési joga. Budapest, Pfeifer Ferdinánd Könyvkereskedése, 1920. 3-7.

${ }^{705}$ Trianon, ZEIDLER, 2003. 350-353.

${ }^{706}$ A világháborút követő egyetemi diákság politikai mozgalmairól lásd: LADÁNYI Andor: Az egyetemi ifjúság az ellenforradalom elsö éveiben (1919-1921). Budapest, Akadémiai Kiadó, 1979; UJVÁRY Gábor: Egyetemi ifjúság a „neobarokk társadalomban”. Valóság, 1991. 5. szám; PELLE János: A Csaba Útja. Politikai antiszemitizmus és értelmiségi érdekvédelem. Múlt és Jövö, 1997/4.

707 BANGHA Béla S. J.: Magyarország újjáépitése és a kereszténység. Szent István Társaság, 1920 http://mek.oszk.hu/05300/05387/05387.htm (Letöltve: 2017. április 15.)
} 
Az első világháborút követő kirekesztő beszédmódot nem tekinthetjük előzménynélkülinek, ha csak visszatekintünk az 1910-es évek elején használatos eugenetikával kapcsolatos forrásokban feltüntetett tartalmakra vagy az 1916-os román betörést követően radikalizálódott gondolkodási sémákra. 5) A modell ötödik pontja a bosszú és visszavágás, amely a kudarc előtti helyzet visszaállítását tűzi célul. ${ }^{708}$ A revans politikájának egyik szemléletes történeti példáját dolgozta fel Bibó István Az európai egyensúlyról és békérōl írt tanulmányában az 1870-71-es németfrancia háborúról és következményeiröl. ${ }^{709}$ 6) A vereség lehetőséget is adhat a megújulásra, hogy a közösség önvizsgálatot tartson és orvosolja azokat a strukturális okokat, amelyek a veszteséget okozták. ${ }^{710}$ A kisebbségi magyar irodalom, kultúra és politikai újságírás egyik központi témája volt a megújulással járó újrakezdés megfogalmazása. „Amikor az erdélyi magyarságot önállósitja a békeszerzödés ratifikációja, abban a pillanatban a legkonzervativabb gondolkodózó elött sem lehet már kétséges, hogy ennek a leszakitott nemzetnek a sorsa szorosan egybeesik a világdemokrácia útjaival. Emberi jogokat követelünk magunk számára, azoknak a védelmét keressük."711 7) Az ideális eset a kibékülés periódusa, amikor a sorozatos konfliktusok sorozata ártalmas mind a kétfélnek. A változó körülményekkel változnak a közösségi célok is. Az új perspektívából nézve idejétmúltnak tünhet a múltban fontosnak vélt egymással összeegyeztethetetlen cél, amelyért háborúkat vállaltak. A konfliktusokat felváltja a kooperáció és a kölcsönös odafigyelés. (Az európai történelem ilyen példái közé tartozik az Európai Unió létrehozása. $)^{712}$

\subsection{A romániai magyarság nemzetkonstrukciója}

Az az erdélyi magyarság három politikai pártot (az Országos Magyar Párt az Erdélyi Magyar Néppárt és a Magyar Nemzeti Párt egyesüléséből alakult 1922. december 28-án), egy kulturális szövetséget (Magyar Szövetség, 1921. január) és egy felekezeti alapon (Felekezetközi Központi Tanács, 1918. november) szerveződött egyeztető fórumot hívott életre 1923-ig, amelyek szélesebb társadalmi csoportokat is képesek voltak elérni. A nemzet mibenlétéről szóló önazonosság viták főként ezen szervezetek vezetői között zajlottak, amelynek publicitást a sajtó biztosított.

\footnotetext{
${ }^{708}$ A politikai cselekvés. http://konfliktuskutato.hu

${ }^{709}$ BIBÓ István: Az európai egyensúlyról és békéröl. Válogatott tanulmányok 1935-1944. Magvető Könyvkiadó, 1986

${ }^{710}$ A politikai cselekvés. http://konfliktuskutato.hu

711 Jogvédelmünkért. Keleti Újság, 1920. 268. szám, december 7, 1.

712 A politikai cselekvés. http://konfliktuskutato.hu
} 
Elsősorban az aktivista csoport számára a valódi mérföldkövet az jelentette, amikor a magyar nemzetgyülés ratifikálta a Trianoni békeszerződést. ${ }^{713}$ Az erdélyi központ politikai magatartásában a magyar egyházfőknek a román államra tett esküje hozott érdemi változást, mert fontolóra kellett venniük, hogy az addig folytatott politikai módszerükön változtassanak. ${ }^{714}$

Az alábbiakban röpiratokat (Bernády György: Nyílt levél; Kós-Zágoni-Paál: Kiáltó Szó), politikai szervezetek (Magyar Szövetség, Erdélyi Magyar Néppárt, Magyar Nemzeti Párt) dokumentumait, politikai beszédeket, jelentéseket és publicisztikákat vizsgálok meg, érintve a zsidóság és a magyarság viszonyát, amely forrásokon keresztül rekonstruálni igyekszem az erdélyi magyar elitek által megfogalmazott nemzet- és társadalomkonstrukciókat.

\subsubsection{Bernády György: Budapest és Bukarest között}

Erdély Romániához való csatolását követően két fő politikai és társadalmi szintü kérdéscsoport bontakozott ki. Egyrészt a párizsi békeszerződés államhatárokat módosító, a történelmi Magyarország megszűnésének a magyar nemzetre gyakorolt lehetséges politikai következményei. Másrészt az impériumváltás mindennapokra gyakorolt konfliktusai: az eskü letételének megkövetelése a magyar tisztviselőktől, a magyar tannyelvü iskolák ellehetetlenítése, a hadikölcsön-kötvények vissza nem térítése, a lakás és egyéb ingóságok rekvirálása, az élelmiszer ellátás rendszerének összeomlása, a nagyszámú kényszer repatriálás, a birtokok királyi rendeletre történő kényszerbérletbe utalása, a százezres nagyságrendü rendezetlen állampolgársági viszonyok, illetve a jogbizonytalanság okozta irracionális politikai döntések és a vele járó elcsalt romániai politikai választások. A felsoroltak arra késztették az erdélyi szellemi és politikai elit egy részét, hogy tudomásul véve a nemzetközi szerződések kötelezőségét megkíséreljék az abban foglaltak szerint kisebbségi jogaiknak érvényesítését.

\footnotetext{
${ }^{713}$ A magyar nemzetgyülés 1920. november 15-én ratifikálta, és 1921. július 26-án, a XXXIII. törvénycikkel hirdette ki a békeszerzödést.

${ }^{714}$ Majláth Gusztáv Károly erdélyi és Glattfelder Gyula csanádi püspökök 1921. március 19-én, Széchenyi Miklós nagyváradi püspök és Ferencz József unitárius püspök pedig április 9-én hüségesküt tett Ferdinánd román királynak. SAS Péter: Az Erdélyi Római Katolikus Státus. Egyháztörténeti Szemle. 2002. 3. évf. 2. szám, 66-70.; Az erdélyi protestáns püspöki kar esküje. Keleti Újság, 1921. 4. évf. 67. szám, április 7. 6.
} 
Marosvásárhelyen, a városépítő polgármesterként ismert Bernády György, szabadelvü politikus, Tisza István feltétlen híve ${ }^{715}$ már 1919-1920 fordulójától igyekezett tábort szervezni a politikai-közügyi tisztánlátásnak. Bernády 1918-ban és az őszirózsás forradalom idejében Budapesten tartózkodott ${ }^{716}$, Marosvásárhelyre politikai hátország hiányában 1919. júliusban hazatért, ahol azonnal aktivitásba lendült. Augusztusban a város református egyházának főgondnokaként Maros-Torda vármegye román főispánjával, Ioan Vescanttal elutazott Nagyszebenbe, hogy megbeszélést folytasson a Kormányzótanács elnökével, Iuliu Maniuval a marosvásárhelyi református egyház iskolái jövő tanévének (1919-1920) biztosítása és függő kérdései (államsegélyek tisztázása, magyar nyelvü oktatás újraindítása, tanárok alkalmazása, nyilvánossági jog rendezése) tisztázásában. 1920 nyarán a város előljárója, Adrian Popescu prefektus kinevezte Bernádyt Marosvásárhely közigazgatási és pénzügyi bizottságába, amivel tulajdonképpen visszakerült a városi politikai közéletbe. ${ }^{717} \mathrm{Az}$ iskolaügyek mellett felszólalt azon magyarok védelmében, akiket azért utasítottak ki Romániából, mert 1914. augusztus 1. után települtek le Erdélyben. Ugyanez például a méltányosság jegyében nem vonatkozott azokra, akik 1918. decembertől követően érkeztek az egykori román királyság területéről. Bernády sokrétü és kiterjedt kapcsolatokkal rendelkezett, aki azon kevesek közé tartozott, akik számára volt átjárás, útlevél a szigorú katonai határvonalakon. 1919 decemberében ismét Budapesten tartózkodott, minden bizonnyal a Mikes-féle vállalkozás ügyeiben, amelyet követően azonnal Bukarestbe utazott. Az erdővállalat ugyanis nagyobb erdőségeket vásárolt Văitoianu volt miniszterelnöktől (1919), ahol az ügylet során megismerkedett - a még miniszterelnökség előtt álló - Alexandru Averescuval (1920-1921) és Take Ionescuval (19211922). Bernády életrajznak ez egy olyan epizódja, amely részben megvilágítja a későbbiekben hasznosítható bukaresti elittel való kapcsolatait, illetve a magyarság körében az impériumváltás időszakában érzett Bernády-ellenességhez is útmutatóul szolgál. ${ }^{718}$

\footnotetext{
${ }^{715}$ Miután Tisza István vezette kormány a választójogi reformok körüli parlamenti csatározásokba belebukott 1917 nyarán, az Esterházy-kormány belügyminisztere, a marosvásárhelyi születésủ ifj. Ugrón András Bernádyt leváltotta föispáni állásából. SEBESTYÉN, Látó, 1999/1. 72.

${ }^{716}$ Bernády György 1918-ban Székelyföld iparfejlesztési miniszteri biztosként Budapesten tartózkodott, továbbá ekkor ajánlották fel neki a Mikes grófok a „Gróf Mikes [Ármin] Zabolai Erdőgazdasága és Fürésztelepei Rt.” egy igazgatótanácsosi állást Budapest székhellyel. Uo. 73.

${ }^{717}$ A bizottságban Bernády mellett Bodor Pál, Bürger Albert, Bálint János, Kovácsy Albert, Tóthfalusy József, Victor Suciu alprefektus, Aurel Baciu, Russu esperes és Pedura állami gazdasági tanácsos is helyet kapott. FODOR, Múltunk, 2016/2. 183.

${ }^{718}$ SEBESTYÉN, Látó, 1999/1. 74-85.
} 
Bernády 1920 májusában jelentette meg politikai röpiratát, a Nyílt levelet. A programadó beszéd pragmatikus politikai állásfoglalás, amely egyfelől szembesítésre törekedett a forradalom következményeivel (a történelmi Magyarország szétesése, a nacionalizmus szétfeszítő erejének fellángolása, gróf Tisza István halála). Másfelől az erdélyi magyarság előtt álló lehetséges politikai alternatívákat vázolta fel. A Nyílt levél az októberi események és az arra adott magyarországi jobboldali válaszok, továbbá a Kormányzótanács kritikája (a gyulafehérvári 1918-os pontok be nem tartása) mellett vizsgálja az erdélyi magyarság aktuális helyzetét. Bernády a bünbakképzés helyett a háborús bukás következményeinek tudomásulvételére és az abból következő gyakorlati-közéleti konzekvenciák vállalására hívta fel a figyelmet még a békekötés előtt. A passzivista politikai magatartást elvetette, amely véleménye szerint ,helyrehozhatatlan károkat” okozott. Úgy vélte, hogy „, a megnehezedett viszonyban szervezkednünk, tömörülnünk kell nekünk, magyaroknak is. [Utalás a szászokra. - F. N.] Egy táborban, a Magyar Nemzeti Pártban kell egyesülnie rang, állás, foglalkozás, születés és vagyoni helyzetre való tekintet nélkül, bármelyik felekezethez tartozzék, avagy felekezeten kívül álljon, és akármilyen elveket valljon, minden magyarnak." ${ }^{19}$ Bernády ennek a pártnak a világnézetét nemzeti, liberális és demokratikus alapokra helyezte volna. A korabeli erdélyi magyarságot három általa elképzelt politikai alakulatra osztotta fel: „A maga egészében szervezetlen magyarság három pártban, az Egyesült Székely Nemzeti Pártban, a Magyar Demokrata Pártban és a Szociáldemokrata Pártban lelhetö fel." "720 A politikus úgy képzelte el ezt az egységes pártot, hogy az képes lesz kifelé megvédeni a magyarság egészét a román államhatalommal szemben, de befelé megengedi a platformszabadságot. Felismerte annak politikai szükségét, hogy el kell ismerni a munkásság szociális területen való jogkiterjesztő küzdelmét, de ezt úgy vélte megvalósíthatónak, ha a modernizációs törekvéseket összeegyezteti a nemzetépítés folyamatával. „Erre való tekintettel arra kérem munkás testvéreimet, hogy sziveskedjenek Jumanca elvtársuk által 1918. december 1-jén Gyulafehérváron megtartott román nemzetgyülésen a magyarországi román munkások nevében kifejtett azon álláspontot elfogadni, amely szerint az itteni román munkások elvtársaikkal továbbra is együtt lesznek az osztályharcban, de nemzeti tekintetben külön fognak haladni." ${ }^{21}$ Magyar-zsidó relációban mindez pedig úgy hangzott, hogy azok az izraelita vallású személyek, akik magyarnak vallják magukat, maradjanak a magyarság keretében, „,ne üljenek fel divatos jelszavaknak, ne bontsák meg rendeinket."

\footnotetext{
${ }^{719}$ BERNÁDY György: Nyilt levél. 1920. május 15. Kosmos Grafikai Műintézet Rt., Marosvásárhely 720 Uo.

721 Uo.
} 
Ellenben „Azoknak az izraelita polgártársaknak, akik már az elszakadás útján vannak, [...] menjenek Isten hírével s elmélkedjenek útközben afölött, hogy mennyi része volt hozzájuk hasonlóknak Magyarország összeomlásában." 722 Bernády György a munkásság képviselöit is óva intette, hogy ne álljanak különféle ideológiák szolgálatába, és „,ne tagadják meg még egyszer a közös édesanyát - nemzetünket, - az öseinktöl örökölt hitet, [...], mert egy újabb árulás büntetése csak a végleges megsemmisülés lehet." ${ }^{723}$

A marosvásárhelyi nemzeti liberális politikus nyílt levelének szellemisége korának politikai kérdéseit megelőzte, amelyekről érdemi vita majd csak a trianoni békeszerződés magyarországi ratifikációját követően alakult ki, elsősorban az aktivista körhöz tartozó újságírók fellépését követően. Bernády megfogalmazta azt a politikai-érzelmi törésvonalat, amely lényegét tekintve a román állam kereteibe való beilleszkedésről (politikai integráció) szólt, átvitt értelemben pedig az 1918 előtti nemzetiség- és társadalompolitika felülvizsgálatának, az azzal történő szembenézés vitájához járult hozzá.

Bernády a Nyílt levelet követően további két másik röpirattal is elöállt. Az egyik, az Emlékirat még 1920 májusában, közvetlenül az 1920. évi romániai választások, illetve a trianoni békeszerződés aláírását megelőzően jelent meg. A hatalmat megszerző Averescu erdélyi körútra indult, amelyen fogadta Bernádyt, aki a magyarságot ért sérelmeket, jogfosztottságot felsoroló memorandumot nyújtott át részére. Arra kérte az új miniszterelnököt, hogy garantálja az erdélyi magyarság részére az anyanyelvhez való jogot, szüntesse be a helyi hatóságok civilekkel, köztisztviselőkkel szemben tanúsított önkényeskedéseket, és végül, ha a trianoni békeszerződés értelmében elszakítják Erdélyt Magyarországtól, akkor a gyulafehérvári pontokban megfogalmazott nemzetiségek részére biztosítandó önkormányzati jogok, mint kisebbségi jogok teljesítendők. A másik röpirat, az Elöterjesztés a magyar tisztviselők és ügyvédek eskütétele tárgyában volt, amely a hüségesküt le nem tett tisztviselők érdekében született. Míg Bernády célja az volt, hogy ráirányítsa Bukarest figyelmét az erdélyi magyar állapotokra, addig Averescué az - és ezért felajánlott egy szenátor helyet Bernádynak - hogy megnyerje magának a volt főispánt, közvetve pedig a magyarok egy részét. A volt polgármester bár az ajánlatot nem fogadta el, mégsem kerülhette el a politikai támadásokat a románokkal való együttmüködés gyanúja miatt. A Brassói Lapok ellen Bernády sajtópert indított, mert azt írták róla, hogy Averescunak és Take Ionescunak tálcán felajánlotta az erdélyi magyarságot.

\footnotetext{
722 Uo.

723 Uo.
} 
A Zord Idő főszerkesztője, Osvát Kálmán, a Székelyföld főszerkesztője, dr. Hajdú István hasonlóan elmarasztalták Bernádyt, akik a Grandpierre Emil vezette erdélyi központ álláspontját képviselték. ${ }^{724}$

\subsubsection{A politikai-kulturális együvé tartozás igényének megfogalmazása}

A Keleti Újságban Ratifikáció után című cikkben a függetlenségi és a polgári radikális hagyományokhoz közelálló Paál Árpád a következőket írta 1920 novemberében: „A magyar kényszerbéke ratifikálása azt jelenti, hogy Magyarország a szabályokat maga akarata révén elfogadta, alkalmazkodott a világnak egy eröhatalmi tényéhez. A magyarság lelki közjogi lélek, a jogszabályozást magára nézve elismerte."725 A Keleti Újság köré szerveződött politikaiértelmiségi csoportosulás az illúziókkal való szakítást és a romániai közéletbe való mielőbbi bekapcsolódást szorgalmazta.

Fokozatosan bontakozott ki az erdélyi sajtón keresztül a kisebbségi élettel összefüggő ügyeknek, különböző önszerveződő kiutak keresése. A kisebbségi politikai és a társadalmi önszerveződésre irányuló diskurzusokban kiemelt helyet foglaltak el zsidóság-magyarság társadalmi együttélésének és vele összefüggésben a magyar nemzetfogalomról szóló viták. Szentimrei Jenő erdélyi költő, a Napkelet címü folyóiratban a következőképpen fogalmazta meg a kulturális együvé válás feltételeit. „A magyar vezetőktől Erdélyben a magyar kisebbség megszervezését várjuk egyetlen hatalmas kulturális lendületre, ahol párt és felekezeti ellentétek nélkül találkoznia kell mindenkinek, aki erdélyi és magyar, vagy a magyar kultúrával közösséget vállal. A vád, melyet egyenesen emelek és minden formában fenntartok, áll azokra a vezetö egyéniségekre, akik - repatriálnak. [...] Mégis ki kell mondanom, hogy súlyos hibát követnek el itteni fajtestvéreikkel szemben, mert kivonják magukat a kollektív felelösség alól."726 Az emigráns Kádár Imre író, a Keleti Újság szabadelvü-demokrata beállítottságú főmunkatársa tudomásul véve a nemzetközi szerződés előírásait a magyar kisebbségek politikai szerveződése kapcsán két lehetséges stratégiát vázolt fel. Az egyik egy alkalmazkodó út volt, amely az államhatalmat bíró többséggel való kooptálást jelentette. Kádár Imre ezt az irányt azért vette el, mert szerinte ez csak a kisebbségi elitek érdekeit szolgálta volna. A költő antielitista álláspontra helyezkedett, miszerint az erőforrások felett mindenkoron az elitek uralkodnak és nem a széles néptömegek érdemi boldogulása a cél.

\footnotetext{
724 SEBESTYÉN, Látó, 1999/2. 86-99.; FODOR, Múltunk, 2016/2. 183-184.

${ }^{725}$ Kádár Imre: Zsidóság és sovinizmus. Keleti Újság, 1920. 3. évf. 252. szám, november 18. 1.

${ }^{726}$ Szentimrei Jenő: Magyar kötelesség. Napkelet, 1920. 1. évf. 3. szám, 129-133.
} 
A másik út ezért nem lehetett más csak ,a nyilt és öszinte ellenzéki politika, a népkövetelések rendszeres felállitása"727 mindaddig, amíg a népkisebbségek harmonikus és egyenlőségen alapuló jogai nincsenek biztosítva a románság, a szászság és a zsidóság demokratikus rétegeinek egyetértésével. Ez tulajdonképpen egy szociális, baloldali alternatívát jelentett. Kádár Imre a nemzetiségi megbékélés egyik feltételéül a szociális igazságosság politikáját határozta meg, amelyben magyarság és románság széles rétegei egymásra találhatnak. Az erdélyi zsidó és magyar közösségek összetartozását az anyanyelv használatának (közigazgatás, igazságszolgáltatás, oktatás) biztosításában jelölte meg. „Ezen a ponton az erdélyi zsidóság csak a magyar kisebbségi szervezeteiben keresheti az érvényesülését". ${ }^{22}$

A Keleti Újság szellemiségéhez közel álló Napkeletben ${ }^{729}$ három irányzat, a transzilvanizmus (Paál Árpád, Kós Károly, Szentimrei Jenő), a társadalmi megújhodásért küzdő képzőmüvészeti és irodalmi irányzat, az avantgardizmus és a nyugatosság szellemisége egyszerre jelen voltak. Pomogáts Béla szerint a folyóirat kultúra, az erdélyi irodalomalapítás kezdeti időszakában a Napkelet mutatott rá arra, hogy a regionalista szemlélet és az emigránsok (Ignotus, a Nyugat volt föszerkesztője, Áprily Lajos költő, Kádár Imre) eszméinek, gondolkodásának szintézise megalapozta a romániai magyar kisebbségi irodalmat a két világháború között. ${ }^{730}$ A Napkelet, Paálnak, a magyarság jelentős szerepébe és más népekkel való közös munkamegosztásra épülő jövőbe vetett pozitív hangvételü cikkével jelent meg 1920 elején. „Erdélyböl nézvén a világba [...] nem hagyhatjuk feledetlenül, hogy a magunk táján [...] mély hagyományai vannak vallásszabadságnak, nemzeti egyenjogúságnak, népek világbeli egymásmellettisége megértésének, közös kultúrák kifejlödésének. Ilyen környezetböl való beidegzödésünk például az is, hogy az Ázsia keletéröl Európa közepébe sodort magyarságnak egyazon sorsnemüsége van a közötte élö zsidósággal. Mindketten hazát keresünk hol más nép szivében, hol a föld valamely pontján."731

\footnotetext{
${ }^{727}$ Kádár Imre: A kisebbségek taktikája. Keleti Újság, 1920. 3. évf. 253. szám, november 19. 1.

728 Uo.

729 Főszerkesztő: Paál Árpád. Szerkesztők: Ligeti Ernő, Kádár Imre, segédszerkesztő Szentimrei Jenő. Főmunkatársak: Bárd Oszkár, Janovics Jenő, Kós Károly, Nagy Dániel, Nyirő József, Szombati-Szabó István, Tabéry Géza, Zsolt Béla.

${ }^{730}$ Avantgárd: a 20. századi újítók művészeti csoportjainak összefoglaló elnevezése. Megértésének egyik akadálya az ellentmondásos fogalmi háló, amely a korabeli eltérő tartalmakra való reflektálásból adódik. Képviselői új formai eszközökre, új témakörökre - gyakran szociális tartalommal - kívánták megváltoztatni a polgári ideológiát kiszolgáló müvészetet. Többnyire radikális csoportok alakultak ki körülöttük írókból, muzsikusokból, rendezőkből stb., akik nemcsak a müvészeteket, hanem a társadalmat is meg akarták változtatni. Erdélyben a két világháború között hasonló szellemiségú írásokat jelentetett meg többek között a kolozsvári Napkelet, az aradi Genius (Krenner Miklós Spectator) és az Új Genius, a Periszkóp, a temesvári Holnap, illetve a Korunk. 53-102.

Az erdélyi avantgardizmus történetéhez lásd bövebben: BALÁZS Imre József: Az avantgárd az erdélyi magyar irodalomban. Mentor Kiadó, Marosvásárhely, 2006

${ }^{731}$ Paál Árpád: És fölkél a nap. Napkelet, 1920. 1. évf. 1. szám, 1-3.
} 
A demokratikus hagyományok hangsúlyozása, az elnyomás minden formájának elvetése és a nemzeti autonómiáknak elismerése olvasható ki Zágoni István írásából is. Egyfelől a román nemzetiesítő folyamatokra utalt, amelyet némi szocialista retorikával reakciósnak nevezett, másfelől kárhoztatta a magyarság nevében fellépő szélsőségesek politikáját. „Egészen világos csak az, hogy nemzeti elnyomás zónájában élünk. [...] A megfoghatatlanságig érthetetlen tehát az, ha e területen magyar nacionalisták a nemzeti elnyomás ellen reakciós eszközökkel akarnak küzdeni. [...] Amikor pedig a nemzeti sors forog kockán, akkor takargatás nélkül, nyíltan le lehet szögezni, hogy a feudalizmus hitette el sokakkal a múltban, hogy osztályuralmi makacs törekvésük magyar nemzeti politika volt." ${ }^{\text {732 }}$ A két oldalról érkezö túlzó nemzeti követelések ellen lépett fel a Jászi Oszkár és Otto Bauer szellemisége alatt álló Kádár Imre is, aki az előző írókhoz hasonlóan elvetette a bolsevista szélsőséget. „A magyarság nem fogadhatja el sem egyének, sem fajok, sem osztályok diktatúráját és az emberi jogok teljességét, a demokráciát, a szociális igazságosságot követeli a maga számára. Tanulva és tanítva fog a magyarság dolgozni és harcolni az emberi ideálért: pártokon felül, osztályokon felül, hazákon felül - a szellem uralmáért és a világállamért." ${ }^{" 733}$ A polgári radikális idea a pozitív hitnek és az értelemre támaszkodó önbizalomnak volt egyik legkifejezőbb eszmeisége. A világháborút követően az erdélyi magyar szellemi életben ez a fejlődésbe vetett hit az aktivista táboron keresztül formálódott tovább. Egyfelől arra keresték a választ, hogy miként lehet biztosítani a magyar nemzetiség részére a kollektív demokratikus jogokat. Másfelöl arra, hogy a „törzsmagyarságról” elszakadt magyar nemzeti közösségek milyen formában tudnak szerepet vállalni az új határokon átívelő együttműködések megtalálásában. Paál Árpád a magyarságnak olyan hídszerepet tulajdonított, amely képes a magyar nemzetrészek mellett a többségi nemzetekkel is „öszinte testvérséget” kialakítani. „A szétdaraboltságok (értsd: a külhoni magyarság - F. N.) az új államokba beleidegzödö lelki szervei a megmaradt törzsmagyarságnak, a népek lelke diplomáciájának az alakulatai, hogy fölkeltsék és folytonossá tegyék a mindenirányú népszövetség megvalósulását. A dunai konföderációt. Ezt kell kívánnunk, ezért kell az új államokban politikai cselekvőségbe is lépnünk.”734

\footnotetext{
732 Zágoni István: Fordított világ. Napkelet, 1920. 1. évf. 1. szám, 51-53.

${ }^{733}$ Kádár Imre: Az olaszországi szocializálás. Napkelet, 1920. 1. évf. 2. szám, 57-58.

${ }^{734}$ Paál Árpád: A magyarság világnézete. Napkelet, 1920. 1. évf. 7. szám, 385-389.
} 
A passzivista politikai kör a nyílt, napi szintü publicisztikai vitába csak fokozatosan kapcsolódott be. Érvelésük középpontjában eleinte az egyházi birtokokat és a magyar oktatást ért sérelmek felsorakoztatása állt. A nemzetről szóló vita számukra akkor vált igazán politikai kérdéssé, miután szembesültek azzal, hogy a román állam külön nemzetiségként deklarálja a székelységet és a magyarságot. A konfliktus automatikusan maga után vonta a zsidóság és a magyarság közti kapcsolatok kérdését is. A passzivista kör diskurzusának fókuszába a történelmi Erdély, a magyarság egykori kulturális domináns szerepe, a keresztény egyházaknak helyzete, illetve a magyarság egysége került. Kolosváry Bálint a Pásztortüzben a következőképpen írt Erdélyről és a nemzetiségi kérdésről. „Erdély az erdélyieké! - azt jelentette ez idötlen idökön át, hogy miénk a földnek múltja, [...] szellemi kincseinek gazdagsága, történelmileg fejlett kultúrájában és nemzedékröl nemzedékre szálló egységes érzelemvilágában." ${ }^{735}$ Kolosváry Bálint Erdélyre és annak népeire olyan kulturális közösségként tekintett, amely a régióban egy fejlett és szerves egységet alkotott évszázadokon át, de a trianoni békeszerződés rendszere a korábbi viszonyokat felforgatta, amikor külön etnikumként nevezték meg a szászokat, a székelyeket és a magyarokat. A volt egyetemi rektor szerint a megközelítőleg 2 milliós magyar közösséget „ez tovább gyengítette, hiszen székely és magyar között tényleges különbséget tenni nem lehet. A szerzödés igy jár el a zsidósággal kapcsolatban is, miszerint külön nemzetiségként tüntette fel a zsidóságot. A román politikum [értsd: osztály - F. N.] ezzel szemben még sem biztositja a szerzödésben foglaltakat, a kisebbségek részére az önálló vallási és iskolai autonómiát." ${ }^{736}$ Székelység és magyarság egy etnikumhoz való tartozásáról írt Kolosváry Bálinthoz hasonlóan Paál Árpád, amikor azzal érvelt, hogy a két etnikum megkülönbözetése lehetetlen, mert a magyarság és a székelység egy népkisebbséget alkot. (Itt fontos visszautalni Paál Székely Köztársaság programjára, amely az egység gondolattal ellentmondásosba keveredik). ${ }^{737}$ A transzilvanista hangvételü Napkeletben, Szentimrei Jenőnél is megjelent az erdélyiség, mint közös objektiváció, de Kolosváry Bálinttal ellentétben a sokszínűség mellett a közös történelmi tapasztalatokra épülő regionalizmus kapott hangsúlyt. „Erdély a keleti és nyugati kultúrák keveredő helye volt $s$ e keveredés eredményeképpen kap Erdély egészen külön egyéniséget, amely aztán kihat nyugatra és keletre egyaránt. [...] A jövő a kultúrák vérátömlesztő egymásra hatásaiból kell, hogy kialakuljon. [...] Itt nincsenek kurzusai sem a kereszténységnek, sem a zsidóságnak, itt a tordai országgyülés levegője él. [...] Ez nem Turán és nem Párizs, nem Balkán és nem Berlin, ez Erdély."’738

\footnotetext{
${ }^{735}$ Kolosváry Bálint: Kultúrpolitika. Pásztortüz, 1921. I. kötet, 5. szám, 152-155.

${ }^{736}$ Uo. 154.

${ }^{737}$ Paál Árpád: Székely és magyar. Napkelet, 1921. 2. évf. 21. szám, 1226-1232.

${ }^{738}$ Szentimrei Jenő: Erdély hivatása. Napkelet, 1921. 2. évf. 13. szám, 756-758.
} 
Az erdélyi gondolatnak társadalmasítása mellett tört lándzsát Zágoni István is szintén a Napkeletben, amikor a politikai aktivitás megindítása mellett érvelt az „Erdély az erdélyieké” narratívát alkalmazva. ${ }^{739}$ Ugyanezzel a tartalommal indult útjára a Magyar Kisebbség címü folyóirat is 1922-ben. „Nemzetünk, az erdélyi magyar nemzet nemzeti gondolatát kell újra kifejeznünk s elismertetésének eszközeit megtalálnunk." ${ }^{740}$ A többségi államalkotó nemzeti pozícióból kisebbségbe kényszerült magyarság részére megfogalmazott irányadó gondolatot Jakabffy Elemér és Sulyok István fogalmazta meg a folyóirat nyitó számában. Abból az alaptételből indultak ki, hogy az erdélyi magyarság politikai és szellemi elitje már rendelkezett bizonyos fokú és mélységü regionális és nemzeti tudattal. „Hasonló sorsra jutott többi nemzettöredékeinkkel szemben mi elönyben vagyunk: az erdélyi magyar nemzeti érzés emlékei és hagyományai még nem halványultak el egészen a lelkekben. Az újjászületés erröl a történelmi alapról indulhat korszerü teljes kifejlödése felé." ${ }^{71}$

A vitában a délvidéki svábok ügyéből kifolyólag részt vett Reményik Sándor is a Pásztortüz hasábján, amikor a magyarsághoz való kötődésben a kulturális és történelmi viszonyt hangsúlyozta az etnikaival szemben. A költő azt írta, hogy a cipszerek, a délvidéki svábok évszázadokon át tanúsítottak hüséget a magyar állam mellett. „Vegyék tudomásul: a magyarság nemcsak vérségi kötelék, nemcsak faj, nem is csak nyelv, a magyarság mindezeknél több: lélek, élet, titokzatos és gyönyörüséges történelmi közösség, múlt, tradició, világnézet, mentalitás. Aki ebbe a lélekbe bele tud illeszkedni, az magyar, aki nem tud vagy nem akar, az idegen." 742 Reményik Sándor nemzetfelfogása nem egyezett az aktivista kör felfogásával. A magyarsághoz való tartozást „,feladatként” értelmezte, ahol az egyéni értékek nagy részének elsajátítását a csoporthoz való tartozáshoz kötötte. Míg például Kádár Imre a szociális érzék alatt bizonyos fokú osztálytudatot feltételezett, addig Reményik Sándor és az erdélyi hagyományos elit többsége magasabb fokra helyezte a nemzeti öntudatot, mint politikai igazodási pontot. „A nemzeti érzés a maga ősi mélységében misztikum. [...] bonyolultabb és szubtilisebb is minden osztályöntudatnál. Az utóbbi puszta érdekszolidaritáson, tehát valami kézzelfoghatóan alapul. [...] A történelmi Magyarország összeomlása pillanatában a magyarság új forradalmi vezetöi alárendelték osztályöntudatuknak a nemzet érdekét, amivel nem akarom azt mondani, hogy a magyarság egyéb osztályainak nem voltak mulasztásai, söt vétkei.

\footnotetext{
${ }^{739}$ Mit kell tennünk erdélyieknek 1922-ben? / Zágoni István. - [Válasz a Napkelet körkérdésére. A szerző a Keleti Újság szerkesztője]. Napkelet, 1921. 2. évf. 24. szám, 1471-72.

${ }^{740}$ Sulyok István: Levelek helyett. Magyar Kisebbség, 1922. 1. évf. 1. szám, 1.

${ }^{741}$ Uo.

${ }^{742}$ Reményik Sándor: Fajmagyarság. Pásztortüz, 1922. VIII. évf. I. félév, 86-87.
} 
A döntö pillanatban a legalkalmatlanabb pillanatban a szociális átalakulás problémája volt legfontosabb nekik. [...] Mondanivalóm summája pedig az, hogy a mi számunkra a csoporthoz való tartozás nem biológiai tény, hanem feladat: tehát erkölcsi, szellemi jelentés." "743

Az októbristák elleni kritika az aktivitást sürgető Bernády Györgynél és a passzivitást támogató Reményik Sándornál is megjelent. A tartalom mégis hasonlított egymáshoz. Az erdélyi politikai közbeszédben számos olyan érvelés jelent meg, amely a nemzet fogalmának szélesítését, a kulturális és a történelmi gyökerek fontosságát helyezte előtérbe a tisztán etnikai, faji jellegű megközelítésekkel szemben. A politikai szocializáció és a sokszínű erdélyi kultúra minden bizonnyal befolyásolta az aktivista és a passzivista kör tagjainak nemzetről alkotott eltérő felfogását. Az impériumváltás pedig olyan kényszerhelyzetet szült, ahol jól felfogott érdekek miatt sem lehetett megtenni, hogy a magyarság társadalmi körét szükítsék. Láthatjuk, hogy az egyes, a kisebbséget jelentő érvelésekben nagyobb hangsúlyt kaptak a szociális és a korábban kirekesztett társadalmi csoportok nemzetbe való beillesztésének tónusai, míg a többségi érvelésben a Monarchia idején meghonosodott politikai nemzet elvárások voltak a dominánsak. A két világháború közti erdélyi politikai gondolkodásban egyszerre volt jelen egy demokratikus, jogkiterjesztő és egyenlősítő nemzetfelfogás és egy a történelmi osztályokra és közös hagyományokra épülő, de az önként vállalt kulturális hovatartozást elfogadó nézet. Fogalmazhatunk úgy is, hogy párhuzamosan bontakozott ki a politikai és a kulturális nemzet koncepciók diskurzusa.

\subsection{3. Új politikai és társadalmi kategória: nemzeti kisebbség}

A „kisebbség” vagy „nemzetiség” terminológiai probléma már a világháborút lezáró konferencián is előtérbe került. Az európai határok újrarajzolását szentesítő békeszerződések aláírását és a kisebbségi panaszos petíciók ${ }^{744}$ sorozatát követően egy új nemzetközi szervezet kezdte meg müködését 1925-ben Genfben, a balti német kezdeményezésre - és magyar kormány hátszéllel - létrejött Európai Nemzetiségi Kongresszus. A Kongresszus az első pillanattól kezdve viták kereszttüzébe került.

\footnotetext{
743 Reményik Sándor: „Biológiai tény?” Pásztortüz, 1922. VIII. évf. I. félév, 225-227.

744 A magyar kisebbségek érdekében 1920 és 1938 között összesen 90 beadvány érkezett a Népszövetséghez, 12 pedig más nemzetközi fórumokhoz. A petíciók közül 47 foglalkozott romániai, 24 csehszlovákiai és 19 jugoszláviai sérelmekkel. A magyar megkeresések jelentős részét a Tanács is megtárgyalta, ahol a panaszok kivizsgálására Hármas Bizottságok alakulhattak. A legtöbbször a bizottságok, miután véleményezésre megküldték a petíciót a bepanaszolt állam kormányának, tudomásul vették azok válaszát, s lezárták az ügyet.

EILER Ferenc: Kisebbségvédelem és revízió. Magyar törekvések az Európai Nemzetiségi Kongresszuson (19251939). 2007. Budapest, Gondolat - MTA Kisebbségkutató Intézet, 47. [Továbbiakban: EILER 2007]; Lásd továbbá: A magyar békeküldöttség naplója-Neully-Versailles-Budapest (1920). Szerk.: ZEIDLER Miklós. MTA Bölcsészettudományi Kutatóközpont, 2017
} 
Legitimitását részben az jelentette, hogy tagsága túlnyomórészt az európai államok nemzeti kisebbségeinek pártjaira épült, illetve azok konstruktivitására, mert elismerték a kisebbségvédelem terén hozott népszövetségi szerződéseket. A genfi összejövetel hírét döntően a kormányok félhivatalos lapjai kommentálták, amelyből kitapinthatóak a világháború végén kialakult nagypolitikai törésvonalak. Az egyik típusú érvrendszer jól előkészített német és magyar propagandaeszközt látott a kezdeményezésben, a másik pedig egy előremutató, állami befolyástól mentes érdekképviseleti szervezetet. A szervezet hivatalos neve az Európai Államok Szervezett Nemzeti Csoportjainak Kongresszusa volt, amelyet terjedelmi okokból nem használtak. Helyette a Nemzetiségi Kongresszus, a Kisebbségi Kongresszus és a Nemzetkisebbségi Kongresszus elnevezés terjedt el. A Kongresszus tagjai a nemzetiség és kisebbség fogalmait szinonimaként használták, harmadikként megjelent - mindenekelőtt a német irodalomban - a népcsoport kifejezés is. A kisebbség szótól azonban egyesek tartózkodtak annak esetleges negatív és alárendeltséget sugalló konnotációi miatt. Eiler Ferenc szókészletében a nemzetiség szó a közös nyelvet beszélő, ugyanazon - kulturális értelemben vett - nemzethez tartozó kisebbségek közösségét jelenti. ${ }^{745}$

A genfi konferencia összehívásául négy fó érvet hoztak fel. Az okok közül egy szólt pozitív nemzetközi eseményről: az elfogadott észt kisebbségi törvény (1925) iránt megnyilvánuló európai érdeklődésről. Három ellenben negatív nemzetközi tendenciára hívta fel a figyelmet: a győztes államok nem tartják be a kisebbségi egyezményekben vállalt kötelezettségeket (a nagyhatalmak a békés asszimilációt elfogadják - melting pot elve ${ }^{746}$ ), a rendszer hatékony müködését akadályozta, hogy a Népszövetség Titkársága ki volt szolgáltatva a tagállamok kormányainak, illetve az állami szuverenitás mindenre kiterjedő politikája teljesen kiszolgáltatja az amúgy is védtelen kisebbségeket az asszimilációs törekvéseknek. A felvázolt kisebbségi tervek általános céljukat tekintve a kisebbségi jogok tényleges általánosítását, a kulturális (és területi) autonómia kiharcolását, valamint a fenti célok megvalósításához elengedhetetlenül szükséges széleskörü kisebbségi szolidaritás megteremtését jelölték meg. ${ }^{747}$

\footnotetext{
${ }^{745}$ Uo. 9-19.

${ }^{746}$ Melting Pot: az „olvasztótégely” víziója, amely Észak-Amerikát a népek, nyelvek és kultúrák kohójaként jellemzi, ahol az asszimiláció következtében végbemenő transzformáció egy új és egységes népet eredményez. Ezt az elképzelést először 1914-ben Israel Zangwill (1864-1926), az emigrációs élményt négy felvonásos drámában feldolgozó zsidó származású író fogalmazta meg (The Melting Pot. New York. Macmillan, 1914).

BICZÓ Gábor: Asszimilációkutatás-elmélet és gyakorlat. MTA Politikai Tudományok Intézete Etnoregionális Kutatóközpont Budapest, 2004. 8.

http://www.uni-miskolc.hu/ btkvat/doc/pub/biczo/biczo_asszimilaciokutatas.pdf (Letöltve: 2018. január 24.)

${ }^{747}$ Uo. 53-54.
} 
A békekonferencia menetét meghatározó nagyhatalmak egyetértettek abban, hogy a közép-európai államrendszer stabilitása érdekében az új államok kisebbségeit valamiképpen védeni kell. A párizsi békekonferencián az új államok kisebbségi ügyeinek rendezésére (1919. május 1.) külön bizottságot állítottak fel. Ez volt a Commission des nouveux Etats (Új Államok Bizottsága). Wilson, Clemenceau és Lloyd George azzal bízta meg a testület tagjait, hogy készítsék el a kisebbségi szerződés tervezeteket. Összesen kilenc kisebbségi szerződést kötöttek: Lengyelország, Románia, Csehszlovákia, Görögország, Szerb-Horvát-Szlovén, Királyság, Magyarország, Ausztria, Törökország, Bulgária. ${ }^{748}$ A kormány delegációik a gyakorlatban megvalósítandó védelem módjáról azonban nem rendelkeztek egyeztetett koncepcióval. Két alaptételben állapodtak meg, egyfelől, hogy a kisebbségvédelmi jogszabályokat nem építik be a Nemzetek Szövetségének készülő alapokmányába, hanem az érintett államokat külön-külön kötelezik kisebbségeik jogainak tiszteletben tartására. (A győztes hatalmak nem akarták elővenni saját nemzeti, nemzetiségi problémáikat.) Másfelől a nemzetközi kisebbségvédelem lényegét a minimális jogok garantálásában határozták meg: elsősorban a kisebbséghez tartozók állampolgári jogegyenlőségének biztosítására helyezték a hangsúlyt. Részben túlmutatva ezen elismerték a kisebbségek sajátos jogát az iskoláztatás, a nyelvhasználat és a kultúra terén, de többnyire óvakodtak attól, hogy kollektív jogokat biztosítsanak számukra, mint jogi személyeknek. ${ }^{749}$

A győztes nagyhatalmak és a kisantant államok ez irányú politikai cselekvése rendkívül ellentmondásos volt a gyakorlatban. Az átmenetek vizsgálata során azt a leegyszerüsítő következtetést és közvélekedést cáfoljuk, hogy az első világháború előtt, alatt és azt követően antidemokratikus és kisebbség ellenes kormányzati politikák ne lettek volna jelen kelet és nyugat európai viszonylatban egyaránt. Nyílt és erőszakos etnikai diszkriminációval és létezésüket tagadó álláspontokkal találkozunk, legyen szó a német, majd a francia fennhatóság alatt lévő Elzász-Lotaringiáról, a magyar, majd a román államhatalom alatt álló Erdélyről stb. A megtapasztalt politikai konfliktusokat kiváltó okok között szerepeltek közösségi sérelmek, hatalmi ambíciók, ideológiai radikalizmus és terminológiai eltérésekből fakadó összeegyeztethetetlen viták.

\footnotetext{
748 BARANYAI Zoltán: A kisebbségi jogok védelmének kézikönyve. Berlin, Ludwig Voggenreiter Verlag, 1925. 215-222. [Továbbiakban: BARANYAI, 1925]

${ }^{749}$ EILER, 2007. 24-26.
} 
Balogh Artúr, aki az egyik legjelentősebb romániai kisebbségi szakértő lett a két világháború között, a kisebbség fogalmának pontatlanul történt meghatározására hívta fel a figyelmet. A kisebbségi és a békeszerződések a nemzeti kisebbség kifejezést nem használták, hanem attól eltérően az „etnikai, a vallási és a nyelvi kisebbségekhez tartozó állampolgárokról” és „eltérő nyelvü állampolgárokról” szóltak. Nem definiálták azt, hogy a faji és etnikai vonás, vagyis a leszármazás, valamint a nyelv alapján hogyan állapítható meg a nemzeti kisebbséghez való tartozás. Nem pontosították azt sem, hogy milyen személyekből állnak azok a csoportok, amelyek az etnikai, a faji és a nyelvi kisebbségeket alkotják. Balogh ebből azt a következtetést vonta le, hogy a származás és a nyelv nem képezheti a nemzeti kisebbséghez való tartozás jegyeit. A nemzetiséghez való tartozásnak a feltétele a nemzeti érzésén, az együvé tartozás tudatán alapszik, vagyis azt a szubjektív ismérvet kell elfogadni, amely a saját bevalláson alapszik „A nemzetiségnek lényege ugyanis a bizonyos népközösséghez, kultúrközösséghez való tartozásnak tudata és akarata." 750 Jakabffy Elemér nem definíciót adott a kisebbség/nemzetiség vitatott kérdésére, hanem a kisebbségi társadalom építésén dolgozók figyelmét irányította rá annak jelentéstartalom változásaira, illetve kijelölte helyét a nemzetközi térben. A feladat „az egyetemes kisebbségi gondolat kiépitése. Mert nemcsak ismernünk kell e szellemi mozgalom minden alakulását, hanem abban tevékenyen részt is kell vennünk. [...] Összhangosan bele kell helyeznünk az európai emberi közösségeknek ama képébe, amelyet a fejlödés irányai a távoljövőben már kipontoznak." 751

A kisebbségeknek és anyaországaik kormányának szembe kellett nézniük a nemzetiségi kérdést relativizáló vagy azt egyenesen tagadó politikai álláspontokkal. Az egyik ilyen esetre 1925-ben, a Nemzetek Szövetségének hatodik ülésén került sor, amikor Mello-Franco brazíliai tanácstag előterjesztette jelentését. „Kétségtelennek látszik elöttem, hogy azok, akik a védelemnek ezt a módját megalkották, nem gondoltak arra, hogy egyes államok kebelén belül a lakosoknak egy olyan tömegét teremtsék meg, mely a nemzet általános organizmusával szemben állandóan idegennek tekinti magát, hanem ellenkezöen, e tömeg tagjainak számára a jogi védelemnek olyan állapotát akarták, mely alkalmas a személyek sérthetetlenségének elismerését minden vonatkozásban biztositani és elökésziteni lassanként azokat a feltételeket, melyek a teljes nemzeti egység megvalósításához szükségesek.”752

\footnotetext{
${ }^{750}$ BALOGH Artúr: A kisebbségek nemzetközi védelme: a kisebbségi szerződések és a békeszerződések alapján. Berlin, Voggenreiter Verlag, 1928. 76-81. [Továbbiakban: BALOGH, 1928]

${ }^{751}$ Jakabffy Elemér: Az erdélyi magyarság helyzete nemzetközi vonatkozásaiban. Magyar Szemle, 1928. IV. kötet, 9-12. szám, 166.

752 BUZA László: A kisebbségek jogi helyzete a békeszerződések és más nemzetközi egyezmények értelmében. Budapest, Kiadja a Magyar Tudományos Akadémia, 1930. 200-201. [Továbbiakban: BUZA, 1930]
} 
A nagykövet kijelentése félreértésre okot adó viták sorozatát gerjesztette, amely valójában az európai államokétól merőben eltérő észak amerikai kisebbségekkel kapcsolatos tapasztalatokra épült. Az utólagos értelmezések egyöntetüen arról szóltak, hogy a kisebbségi szerződések a kisebbségekhez tartozóknak bár egyéni sérthetetlenséget biztosítanak, de végcélja ezeknek az egyezményeknek az egységes nemzetállam megteremtése és az asszimiláció elősegítése. ${ }^{753}$ Balogh Artúr a nagykövet álláspontját nemcsak a kisebbségi jogok elutasításaként, hanem nyíltan asszimiláció pártinak értékelte. ${ }^{754} \mathrm{~A}$ Mello-Franco kijelentéssel párhuzamosan jelent meg Sir Austen Chamberlain, Nagy-Britannia képviselőjének véleménye, amely szintén a beolvasztás gondolatát formulázta. „A kisebbségi szerzödések tárgya s az a cél, melyet a Tanács követ, midön e szerzödések által rábízott feladatot teljesíti, az, hogy a kisebbségeknek a védelem és igazságosság ama foka biztosittassék, mely öket fokozatosan olyan helyzetbe fogja hozni, hogy beleolvadjanak abba a nemzeti közösségbe, melyhez tartoznak."755 A francia kormány képviseletében, Henry de Jouvenel azt nyilatkozta, hogy Franciaország nem ír alá egyetlen Kisebbségi Szerződést sem, mert „,nincsenek kisebbségei.”756

A kelet és a nyugat európai etnikai diszkriminációval kapcsolatos kölcsönhatások vizsgálata elengedhetetlen az első világháború idejében bekövetkezett társadalmi, politikai változások mélyebb megértéséhez. Tara Zahra amerikai történész Franciaország (és Csehszlovákia) német kisebbségeit elemző tanulmányában kritika alá vette azt a hidegháború alatt megerősödött leegyszerüsítő nézetet, hogy a 20. század elejének kelet-közép európai multietnikus államai illiberális nacionalista és demokrácia-ellenesek voltak, míg a nyugati államberendezkedések alkotmányosan müködő demokratikus, polgári nemzetállamok. A nemzetiségek besorolására vonatkozó eljárások rendkívül eltérő és helyenként brutális eszközeit egyszerre megtaláljuk Keleten és Nyugaton. A háború és a forradalmak következményeképpen a nemzetiségi problémára adott európai válaszok egy stratégiára épültek, amely kormányzati részről megbélyegző, korlátozó különbségtételt jelentett állampolgár és külföldi, többség és kisebbség kategóriák között.

\footnotetext{
${ }^{753}$ Képviselőházi napló, 1927. XX. kötet. Az országgyülés képviselőházának 292. és 294. ülése. 1929. május 14. és 16., 277., 384. https://library.hungaricana.hu/hu/view/OGYK_KN-1927_20/?pg=286\&layout=s (Letöltve: 2017. április 15.)

${ }^{754}$ BALOGH, 1928. 60.

755 BUZA, 1930. 201.

756 ZAHRA, Tara: The Minority Problem' and National Classification in the French and Czechoslovak Borderlands. Issue: 02. May 2008. Contemporary European History. Vol. 1., 137.
} 
Elzász-Lotaringia francia annektálása 1919 februárjában vette kezdetét. A lakosságot aszerint osztályozták, hogy az érintettek, illetve a felmenőik az 1870-es francia-német háborút megelőzően melyik ország állampolgárai voltak. Négy kategóriát állítottak fel, amely célját tekintve a német nemzetiség elnyomására, mielőbbi asszimilálásukra, illetve kivándorlásuk elősegítésére irányult. ${ }^{757}$ A hatóságok közremüködésével történő diszkrimináció következtében 200 ezer németet kitelepítettek, a német valutát leértékelték, a lakosság szabad mozgását korlátoztak, sokakat állásukból eltávolítottak, különösképpen az egyetemek német nemzetiségü oktatóit. A csehszlovákiai nemzetiségeknek szigorú népszámlálást szabályozó eljárás (1921) alapján kellett nyilatkozniuk etnikai hovatartozásukról. A bejelentés valódiságát állami hivatalnokok ellenőrizték, amely során olyan extrém helyzetek sokasága állt elö, hogy a nyilatkozatott személyek részére 14 napon belül új nemzetiségi besorolást írtak elő. A vizsgálat magába foglalta, hogy az egyén milyen nyelvet használt mindennapi kapcsolatai során, milyen nemzetiségi környezetben élt, felmenői, házastársa és családtagjai milyen nyelvet beszéltek, milyen társadalmi egyesületeknek volt tagja, mi volt a politikai meggyőződése, állandó tartózkodásának helye stb. Akikről „megállapították”, hogy szándékosan rosszul vallotta be nemzetiségét, azok vagy 100 ezer Korona vagy három hónap börtönbüntetést kaptak. A beiskoláztatás terén megkövetelték, hogy német gyerekek csak német iskolába iratkozhatnak be. A szigorú nemzetiségi szempontokat figyelembe vevő iskolai beiratkozás negatív példáival fogunk találkozni a romániai szabályozásokban is, amely a magyarságot és a zsidóságot érintette a leghátrányosabban. A csehszlovák állami hivatalnoki rendszer emberek százezreinek nemzetiségi besorolását változtatta meg önkényesen, akik előzőleg magukat németnek vallották. A Habsburg államhatalom 1881. évi szabályozása értelmében állampolgáraitól csak a nemzetiségi hovatartozást kérdezte meg, hogy melyik nemzetiséghez tartozónak vallja magát. A Monarchia nemzetiségekkel kapcsolatos eljárás rendje az egyénre, míg Franciaországé és az új államoké egész csoportokra fókuszált. Franciaország mialatt szándékosan nacionalizálta, „franciásította” a maga teljes lakosságát, addig a Monarchia, ha nem szándékosan is, de multikulturálissá változtatta. ${ }^{758}$

\footnotetext{
757 „A” kártyát azok az elzásziak kaptak, akik szülei vagy nagyszülei francia állampolgárok voltak 1870 előtt (1.082.650 fö). „B” kártyát, akiknek egyik szülője vagy nagyszülője francia állampolgár volt (183.500). „C” kártyát, azok a külföldiek, akik ellenséges államból érkeztek. „D” kártyát azok, akik Németországban vagy Ausztriában, illetve felmenőik németek vagy osztrákok voltak. Uo. 138-139.

${ }^{758}$ Uo. 138-140.
} 
Megállapíthatjuk, hogy a vizsgált időszakban a keleti és a nyugati európai államok politikai gyakorlatában általánosan jelent volt az etnikai diszkrimináció gyakorlata és szándéka. Rendelkezésünkre állnak azok a források, amelyek egyszerre igazolják a németországi lengyelekkel, a németországi franciákkal, a franciaországi németekkel, a magyarországi románokkal, a romániai magyarokkal stb. szemben gyakorolt nemzetállami célokat vizionáló politikákat. A teljesség igénye nélkül egy francia forrás arról tanúskodik, hogy a német fennhatóság alatt lévő Elzász-Lotaringiában egy 1912-es törvény értelmében bárki, aki köztisztviselö vagy helyi lakos automatikusan elzász-lotaringiai állampolgár, illetve a leszármazottai is. 1915-ben a francia hangzású neveket németesítették. 1916-ban született törvény értelmében, aki német volt és 1914-ben Elzászban élt, annak kötelező jelleggel vissza kellett térnie eredeti lakhelyére, ellenben elvesztette állampolgárságát. Erre elsősorban azért került sor, hogy a német kormány az elmenekült embereket is besorozhassa. Egy 1917-es jelentés értelmében az elzászi hivatalnokok és helyi képviselők többsége francia párti, de a helyi lakosság többsége, akik franciául beszéltek elfogadták a német életmódot, illetve a helyi parasztság azt sem támogatta, hogy a háborút követően Franciaországhoz csatolják őket. Rendelkezésre állnak arra vonatkozóan is források, hogy németeket csoportosan ítéltek el franciákkal való kollaborálás vádjával. ${ }^{759}$ Erdélyre vonatkozóan a magyar politikai elit az 1916os román betörést követően csakugyan a korábbinál erőteljesebb magyarosítási politikát javasolt, illetve hasonló célok fogalmazódtak meg román részről az 1918-1919-es államfordulatot követően.

\subsubsection{A Keleti Újság szerepe a kisebbségi társadalom építésének tudatosításában}

A Keleti Újság jelentős szerepet vállalt abban, hogy bevezette a mindennapi szóhasználatba a kisebbség és a kisebbségi jogok gondolatát. Paál Árpád $A$ kisebbségek védelme című írásában az erdélyi magyarság önálló érdekérvényesítő munkájáról a következőképpen értekezett. „Sorsunk azonban még nem dölt el a ratifikálás tényével, csak államjogi helyzetünk tisztázódott és ezzel sorsunk további intézése a mi vállainkra nehezedett. A bekebelezés nem jelent beolvadást, a békeszerzödés sem követeli meg ezt, ellenkezöleg nemzetiségi kisebbség címen megkülönböztetett közösség a többségtöl. [...] Elsö tenni valónk a rendelkezésünkre álló hatalom, jog és erőforrásokat felkutatni, majd csoportositani valamennyit egy szilárd alappá, amelyröl megindulhat a teljes erővel önvédelmi akciónk $s$ teljes súlyával nyomulhat az államhatalom mérlegének serpenyöjébe. [...]

\footnotetext{
${ }^{759}$ Matter, Florent. Les alsaciens-Lorrains contre l'Allemagne: l'Alsace-Lorraine pendant la guerre / par FlorentMatter. 1918. Source gallica.bnf.fr/Bibliothèque nationale de France. 66-96.
} 
A kisebbségek hathatós védelmét csak maguk a kisebbségek tudják ellátni." ${ }^{760} \mathrm{Az}$ első világháborút lezáró párizsi békeszerződések és az Osztrák-Magyar Monarchia romjain létrejövő új államok között kötött Kisebbségi Szerződések a magyar jogi értelmezésben új közjogi személyt hívtak életre a kisebbség fogalmában. ${ }^{761}$ Románia 1919. december 9-én ${ }^{762}$ Párizsban a szövetséges és társult föhatalmakkal (antant) közösen aláírt egyezményben garantálta, hogy azok a román állampolgárok, akik etnikai, vallási vagy nyelvi kisebbségekhez tartoznak, joguk van „saját költségükön jótékonysági, vallási vagy szociális, iskolákat és más nevelöintézeteket létesiteni, igazgatni és azokra felügyelni, azzal a joggal, hogy azokban saját nyelvüket szabadon használhatják, és vallásukat szabadon gyakorolhatják.” Az erdélyi székely és szász „,közületeknek a román állam ellenörzése mellett, vallási és tanügyi kérdésekben helyi önkormányzatot" engedélyeznek. ${ }^{763}$ Az erdélyi magyarság egyéni és kollektív jogai körül kibontakozó politikai vitákban az említett két jogforrás mellett a Gyulafehérvári Határozatok (1918. december 1.) szerepeltek gyakori hivatkozásként. Bár a román parlament csak az egyesülést ratifikálta, ennek ellenére a magyar politikusok gyakorta használták hivatkozási alapként a román nemzetgyülési határozatok harmadik pontját: ,Mindenik népnek joga van a maga neveléséhez és kormányzásához saját anyanyelvén, saját közigazgatásával, saját kebeléből választott egyének által.”764 A magyarság számára 1918. december 1-jéhez egyszerre társult Erdély Magyarországtól való elszakítása, illetve a román államtól elvárt demokratikus kisebbségi jogok biztosításának igénye. „A gyulafehérvári pontok Románia alaptörvényeiül tekintendők, immár jog szerint is, amelyek szigorúan kötelezö erejüek. [...] Demokratikus kormányzatot irt elö, amely helyett szakadatlanul tart a kivételes állapot. Teljes sajtószabadságot, gyülekezési és egyesülési jogot, amelyet csak hírből ismerünk már. Radikális földbirtokreformot, amelyet a többi nemzetek ellen éleztek ki. [...] Nincs messze az idö, amikor a magyarság is felveszi a politikai küzdelmet a maga jogainak biztositása érdekében." ${ }^{765}$

A román nemzetállami törekvések és a trianoni békeszerződés ratifikációjának hatására a magyar közéletre elsőként hatást gyakorló döntően polgári és liberális demokrata író, újságíró körök következetesen a kisebbségi jogok védelmét, egyfajta morális kötelesség tudatot és a magyarság nevében fellépő politikai részvételt szorgalmazták.

\footnotetext{
${ }^{760}$ A kisebbségek védelme. Keleti Újság, 1920. 3. évf. 254. szám, november 20. 1.

${ }^{761}$ MIKÓ Imre: Huszonkét év. Az erdélyi magyarság politikai története 1918. december 1-töl 1940. augusztus 30ig. A „STUDIUM” kiadása, Budapest, 1941. 19. [Továbbiakban: MIKÓ, 1941]

${ }^{762}$ A román parlament a törvényt 1920. szeptember 4-én ratifikálta, amelynek pontos szövege igen kevés újságban jelent csak meg.

${ }^{763}$ Uo. 198.

${ }^{764}$ MIKÓ, 1941. 265. (Lásd: A gyulafehérvári egyesülési határozatok I-IX)

765 Két esztendő. Keleti Újság, 1920. 3. évf. 263. szám, december 1. 1-2.
} 
„A falvak és a vidéki magyar lakosságnak is meg kell értenie, hogy a ratifikáció után Romániához csatolt területeken meg kell kezdeni azt a munkát, amely a jogvédelem korlátai között a szabad fejlödést biztositani tudja. [...] Amikor az erdélyi magyarságot önállósítja a békeszerzödés ratifikációja, abban a pillanatban a legkonzervatívabb gondolkodózó elött sem lehet már kétséges, hogy ennek a leszakitott nemzetnek a sorsa szorosan egybeesik a világdemokrácia útjaival. Emberi jogokat követelünk magunk számára, és azoknak a védelmét keressük."’66 Wilson 14 pontja az elképzelt demokratikus világbékéről az erdélyi magyar progresszívak számára nem jelentett feltétlenül negatív tartalmat, ellenkezőleg bizonyos elemei tovább éltek a fejlődésbe vetett liberális gondolatiságban. „A létrejött békerendszer torz, mert ellentétben áll Wilson pontjaival, a népek önrendelkezésével, az annexió és büntetö bírság nélküli békével, a vámhatártalan világgazdasági rendszerrel, a népek gazdasági együttmüködésével. "’67 Paál Árpád a Kiáltó Szóban ezt a következőképpen fogalmazta meg némi keserüséggel: „A békekonferencia békealkotásai és a világ demokratikus fejlödése mindenesetre szembe kerültek egymással. Mert a békealkotásban csak a megindulás volt jó. A népek önrendelkezési joga, a gazdasági elzárkózások megszüntetése, a földek és a vizek szabadsága, az annexió és megtorlás nélküli béke: ezek voltak az alapgondolatok, amiben gyözö és legyőzött eleve megegyezett." 768 Paál Árpád ezt a folyamatot az utódállamokban és Magyarországon is azzal indokolta, hogy ,a kormányzatoknak az a hibája, hogy mindnyájan demokráciaellenes vagy áldemokratikus irányokkal dolgoznak. Sehol nincs kellő szabadság, sehol nincs a népek lelkének kellő felmagasodása és egymásra találása."769

\subsubsection{A Kiáltó Szó és a Magyar Szövetség}

A magyar nyelvü iskolahálózat volt az egyik olyan kulcsterülethez tartozó, ahol a legmélyrehatóbb sérelmek érték a kisebbségi magyarságot. A birtokreform alapjaiban rázta meg az egyházakat, amikor földjeik jelentős részét kényszerbérletbe kellett adniuk, amellyel az egyházi iskolák szinte finanszírozhatatlanná váltak. ${ }^{770}$

\footnotetext{
766 Jogvédelmünkért. Keleti Újság, 1920. 3. évf. 268. szám, december 7. 1.

${ }^{767}$ Az örökéletü békegondolat. Keleti Újság, 1920. 3. évf. 272. szám, december 12. 1-2.

${ }^{768}$ KÓS Károly-PAÁL Árpád-ZÁGONI István: Kiáltó Szó. A magyarság útja. A politikai aktivitás rendszere. Cluj-Kolozsvár, 1921. 42. (Hasonmás kiadás: Kapu könyvek, Idegennyelvü Folyóirat Kiadó Leányvállalata, 1988.) [Továbbiakban: KÓS-ZÁGONI-PAÁL, 1988]

${ }^{769}$ Paál Árpád: Népkisebbségi politika az utódállamokban. Napkelet, 1921. 2. évf. 14. szám, 769-771

770 BARABÁS Endre: A magyar iskolaügy helyzete Romániában 1918-1940. Kecskemét, Első Kecskeméti Hírlapkiadó és Nyomda Rt. 1944. 11. [Továbbiakban: BARABÁS, 1944] DIÓSZEGI, 1990. 82-84.; IANCU, 1995. 209.; Rendelet a felekezeti tanszemélyzet eskütételére. Keleti Újság 1920. 3. évf. 256. szám, november 23.; ERE IL 4950/1920. (Jegyzökönyv a felekezetközi tanács Kolozsvárt, 1920. augusztus 11-én tartott értekezletéröl); ERE IL 6775/1920. (A római katolikus esperesi hivatalnak Brassóba.)
} 
A kezdeti szabadabb iskolaalapítási hullámot ${ }^{771} 1920$ után az ún. redukciós, nyíltan diszkriminatív iskolapolitika váltotta fel. ${ }^{772} \mathrm{~A}$ nem-román származású tanköteles tanulók jelentős részét a román nyelven történő oktatásra kötelezték, amely a fokozatosan bevezetett származás, név és valláselemzés következtében számos esetben visszaéléshez vezetett. A gyakorlatban ez azt jelentette, hogy egy zsidó felekezetü gyermeknek, vagy románul, vagy héberül kellett tanulnia, akkor is, ha nem bírta egyik nyelvet sem. A Keleti Újság interjút készített Matiei András kolozsvári közoktatásügy tanácsossal, aki úgy foglalt állást, hogy ,az anyanyelv fogalmát úgy magyarázzuk, hogy ez azonos - a békeszerzödésben szerzett jog szempontjából - a nemzeti nyelvvel. Így például az elmagyarosodott román nemzetiségüek nemzeti nyelve a román. [...] A zsidóságnak, mint nemzetiségi kisebbségnek a héber, illetve a jiddis a nemzeti nyelve. Korántsem akarjuk lehetetlenné tenni ezen iskolák fennmaradását, hiszen jól tudjuk, hogy a zsidóság nagy része magyar anyanyelvü. Ha a zsidó felekezet által fenntartott iskola nem akarna nemzeti nyelvére áttérni, úgy követelni fogjuk a román nyelvre való áttérést." 773 A gyakorlatban, ebben a formában is tetten érhető volt a zsidóságnak magyarságról való leválasztása.

A politikai tájékozódás első valódi lépését az aktivista csoport tette meg. Paál Árpád, Kós Károly és Zágoni István tette közzé a Kiáltó Szó címü transzilvanista szellemiségü politikai pamfletjét, amelyben a passzivitás helyett az aktivitást, a romániai politikai életben való részvételt, saját kulturális és közigazgatási önkormányzatiságot (bele értve a területi autonómiát) és egy érdekvédő szervezetet, a Magyar Szövetségnek mielőbbi megalapítását szorgalmazták. Kós Károly bár nem Kolosváry Bálintra reflektált, de Erdélyre mindketten önálló földrajzi és kulturális régióként tekintettek. Kós Károlynál is megjelent a historizáló szemlélet, de az építész-politikus gondolkodásában Erdély regionális történelemmel rendelkező és külön politikai entitásként realizálódott. „Kétmillió magyar, ezeresztendős históriája tudatában” kész önmagát megszervezni Erdélyben, amely „,külön históriai egység ezer esztendö óta, saját, külön erdélyi öntudattal, önálló kultúrával, önérzettel."’774

\footnotetext{
771390 új iskolát alapítottak, az összmagyar nyelvű felekezeti iskolák száma 1184-re volt. Az elemi iskolákat tekintve a megmaradt 600 állami és 1068 felekezeti magyar iskola az összes erdélyi elemi iskola 31\%-át tette ki, amely megegyezett a nemzetiségi arányszámmal. DIÓSZEGI, 1990. 81-82.

7721920 második felétől a román állam megkövetelte a felekezeti iskoláktól a román állami felügyelet elismerését, az egyházi iskolák tanszemélyzetétől a hüségeskü letételét, megszüntette a felekezeti magyar iskolák államsegélyezését. A nyilvánossági jog megvonásával fenyegették azokat az iskolákat, amelyek 1922. áprilisig nem fogadták el az állami román tantervet, illetve a letett érettségi vizsgákat érvénytelenítették (utóbbi határozatot visszavonták). Erre hivatkozva később bezárták a máramarosszigeti, a nagykárolyi, a szilágysomlyói, a nagyváradi katolikus, a szászvárosi, a székelyudvarhelyi, a máramarosszigeti református főgimnáziumokat. DIÓSZEGI, 1990. 81-82.; BARABÁS, 1944. 7-11.; BÁRDI Nándor: A romániai magyarság kisebbségpolitikai stratégiái a két világháború között. REGIO, 1997. 8. évf. 2. szám, 37.42.

${ }^{773}$ A felekezeti iskolák nyelve. Keleti Újság, 1921. 4. évf. 72. szám, április 13. 3.

${ }^{774}$ KÓS-ZÁGONI-PAÁL, 1988. 4.
} 
Zágoni István ennek az erdélyi magyarságnak tagjait politikai és jogi értelemben is egyenlő felekként határozta meg, amely közösséghez való tartozás önálló választás eredménye. „Ma nemcsak a hétszilvafás tekintetes és magasabb titulusú urakból áll a nemzet, de mind egyenlö tagok vagyunk valamennyien. Egyformán tartunk igényt a nemzeti jogokra, de egyforma készséggel akarjuk meghozni áldozatainkat is érettük. [...] A magyar nemzeti autonómiának pedig tagja mindenki, aki Románia számára kijelölt határokon belül magyarnak vallja magát. Módot kell nyújtani a zsidók számára, hogy testületileg is csatlakozhassanak a magyar autonómia kereteihez."775 Paál Árpád a megalakítandó Magyar Szövetséggel szemben azt az elvárást fogalmazta meg, hogy a szervezet „az itteni minden rendü és rangú magyar lakosság” képviselője legyen. Kiemelt kérdésként kezelte a székely kérdést, mert a kisebbségi egyezmény külön egyházi és iskolai autonómiát írt elő részükre. Zágoni Istvánhoz hasonlóan Paál Árpád is, a munkássággal való szerves és állandó munkamegosztást képzelt el a magyarság gazdasági erejének erősítése érdekében. Továbbá a világnézeti különbségek meghaladását az óhajtott egységes magyar politikai közösség megteremtéséért. ${ }^{776}$ Balogh Artúr jogász, később szenátor a Pásztortüzben írt cikkében úgyszintén a kollektív demokratikus jogoknak nemzetiségekre való kiterjesztése mellett foglalt állást. A politikus a Monarchia összeomlását nem önmagában a nemzetiségi mozgalmak szétfeszítő mozgásához kötötte, hanem a déli és az északi szlávok pánszlávizmusának politikai vágyához. A nemzetiségi konfliktusoknak megnyugtató rendezését ezért a nemzetek felett álló államszövetség (föderális állam) formájában látta kivitelezhetőnek, amelyen belül minden nemzetiségnek egyenlő szabadsága és önrendelkezése van, és így nincs ok szétválási törekvésekkel az állam területi integritását veszélyeztetni. ${ }^{777}$

A Kiáltó Szó bár töredékesen jelent meg, a szöveg több mint felét törölte a cenzúra ${ }^{778}$ és ilyen körülmények között a széles rétegekhez sem tudott eljutni, de a passzivista csoportot válaszra késztette. Erdély másik tekintélyes lapja, az Ellenzék, amely az erdélyi központ véleményét képviselte, felismerte a változás szükségességét. Költő Gábor a lap karácsonyi számában úgy fogalmazott, hogy „A trianoni békének a magyar nemzetgyülés részéröl történt ratifikálása után jogi befejezettséget nyert nemzetközi jogi helyzetünk kérdése. Most már körül kell néznünk és meg kell találnunk elhelyezkedésünk feltételeit az új államkapcsolatban." 779 A Kiáltó Szóra történő első nyilvános közvetlen reagálás Grandpierre Emiltől származott.

\footnotetext{
775 Uo. 31-32.

776 Uo. 45-47.

${ }^{777}$ Balogh Arthur: Uralkodó irányok, eszmék és jelszavak a társadalmi fejlődésben: V. Nemzetiség. Pásztortüz, 1921., II. kötet, 22. sz., 75-81.

778 BÍRÓ Rózsa: Kós Károly politikai iratai a Székely Nemzeti Múzeumban. Acta Siculica 2008. (A Székely Nemzeti Múzeum évkönyve), Sepsiszentgyörgy. 401-418., 1-2.

${ }^{779}$ Költő Gábor: Helyzetünk s jövőnk. Ellenzék, 1920. XLI. évf. 271. sz. december 25. 8.
} 
Az erdélyi központ prominense, Kós Károlyék lépésében nem pozitívumot, hanem pusztán a mandátum szerzés szándékát feltételezte. ${ }^{780}$

A Kiáltó Szó megjelenését követően a sajtón keresztül vita bontakozott ki a passzivista és az aktivista körök között a Magyar Szövetség létrehozásáról, amely lényegét tekintve a képviselni szándékozott társadalmi rétegekről és a politizálás eltérő módszeréről szólt: önálló párt vagy egy egységes szövetség létrehozása. A vitában élen járt Paál Árpád, aki meghatározta, hogy a szövetség mely társadalmi csoportokra, milyen értékekre és célokra támaszkodjon. „Pártokon, osztályokon és felekezeteken felül álló nemzeti szervezeteknek a kialakitásáról van szó, amelynek mindenki tagja lehessen, aki sorsközösséget akar a magyarsággal. [...] Célja: a népi önkormányzati rendszer megteremtése. A szabadságmozgalomban számítanak a világ nemzetiségeinek támogatására, melynek immár a kisebbségi magyarság is részese lett, továbbá a munkásmozgalom rokonszenvére, mint elnyomott társadalmi tömegre. A magyar szervezkedés nem lehet antidemokratikus, és ezért el kell vetnie magától a bolsevizmus ideáját, mert a faj diktatúrájának helyébe nem teheti az osztálydiktatúrát. [...] A többi kisebbségi népek és a munkásság támogatása mellett a románság haladó elemeinek támogatását is meg kell szerezni. [...] Továbbá a zsidóságra is számítanak, akár a magyarsággal egy szervezetben, akár külön szervezetben. [...] Hogy a zsidóság most el ne távolodjon a magyarságtól, nyiltan és örökre szakítani kell az antiszemita izgatás ostoba és mindenkire káros aknamunkájával." "781 Paál Árpád a demokratikus politikai közösségalakítás programjával lépett a nyilvánosság elé, amely 1918-as alapokra helyezkedett, ahol a nemzeti érdekek összefonódtak az autonóm, demokratikus társadalom igényével. Elvetette az osztálylogikát, a rendies kiváltságokra épülő nemzetfelfogást és elítélte az antiszemitizmust. A zsidóságot izraelita magyaroknak tekintette. A nemzet kapuit szélesre nyitotta, a munkásságot, a parasztságot és a zsidóságot a magyar politikai közösség egyenlő tagjainak ismerte el.

\subsection{Magyarság és zsidóság útválasztása}

Az első világháború jelentős fordulatot hozott az erdélyi magyarság és a zsidóság azonosság és helyzettudatában egyaránt: identitásproblémák, illetve új identitásalternatívák megjelenése hatottak a magyar nemzetszemléletre, magyar és zsidó közösségekben zajló nemzetépítő folyamatokra. A megváltozott környezetben a kisebbségbe kényszerült magyarságnak egyfelől szembe kellett néznie a román nemzetépítő politikával.

\footnotetext{
${ }^{780}$ Grandpierre Emil: Magyar szövetség. Ellenzék, 1921. XLII. évf. 33. sz. február 15. 2.

${ }^{781}$ Egyedül rajtunk áll. Keleti Újság, 1920. 3. évf. 278. szám, december 19. 1.
} 
Másfelől a forradalmak bukását követő trianoni Magyarország politikai életében bekövetkezett bünbakképző magatartással és a magyarság modern történelmének első zsidóellenes, diszkriminatív célzatú törvényével (numerus clausus). Az előbbi számos értelmiségi és közéleti szereplő külföldre, illetve Erdélybe való emigrálását vonta maga után. A termékeny publicista, Kádár Imre a következőképpen fogalmazott 1920 őszén magyarság és zsidóság viszonyáról, feltételezve a felek között kialakult kultúrközösséget. „Az erdélyi zsidóság egy jelentős része nem tudja, hogy mit tegyen. Magyarnak vallania magát nem könnyü, amikor odaát Magyarországon fajtáját nem akarja magyarnak elismerni a jelenleg felszínen lévö agrárfeudális klikk s itt Erdélyben is az egyházi szervezkedésre épitök a keresztény kultúra követelésének jelszavaival ki akarják öt rekeszteni a magyar kultúrközösségböl. [...] Eröszakos románositás, magyarositás, zsidósítás egyformán bünös, mert nem a kulturális értékek kiteljesedését szolgálja. "782 A passzivista körrel szemben megfogalmazott álláspont mögött minden bizonnyal az a negatív tapasztalat húzódott meg, amely a magyarországi forradalmi és zsidóellenes eseményeknek tulajdonítható.

Kádár Imre érvelésénél nagyobb erővel bírt az a társadalomtörténeti folyamat, hogy a 20. század második évtizedére az erdélyi zsidóság többsége a magyarságba asszimilálódott, illetve az asszimiláció útjára lépett. Az erdélyi zsidók közel 80\%-a az első világháború végére már magyar anyanyelvü volt. Legfontosabb központjaiknak Máramarossziget, Szatmárnémeti, Nagyvárad, Temesvár, Arad, Gyulafehérvár, Dés, Kolozsvár és Marosvásárhely számítottak. A kelet-magyarországi területeknek Románia fennhatósága alá kerülése fordulópontnak tekinthető az erdélyi zsidó közösség életében, mivel a magyarsággal együtt kisebbségi létbe sodródott. A történelmi töréspont pedig maga után vonta, hogy felgyorsult az erdélyi zsidó társadalmon belül a szétfejlődés. Gidó Attila arra kereste a választ, hogy egy többségében magyar nyelvü, de vallásilag 783 és társadalmilag rétegzett régió zsidó közösség milyen identitásstratégiákat épített ki az első világháborút követő közhatalomváltozás és az ezzel együtt járó új politikai, kulturális hatások által teremtett kihívások megválaszolására. ${ }^{784}$

1918-at követő politikai viták egyik kulcskérdése az lett, hogy - míg a Monarchia idejében, a magyar intézményi keretek között a magyar nemzet részének tekintették a zsidóságot - az új impérium alatt az asszimiláció vagy disszimiláció volt-e erősebb hatással a zsidóságra?

\footnotetext{
782 Kádár Imre: Zsidóság és sovinizmus. Keleti Újság, 1920. 3. évf. 252. szám, november 18. 4.

${ }^{783}$ Ortodoxok, neológok, status-quo ante alapon állók és szefárdok. GIDÓ, Úton. 2009. 16.

${ }^{784}$ GIDÓ, Úton 2009. 15-17. Az erdélyi magyarság és zsidóság kapcsolatának, illetve utóbbi nemzetépítésének történetéröl részletesen tájékozódhatunk Gidó Attila: Úton. Erdélyi zsidó társadalom és nemzetépitési kísérletek (1918-1940), illetve Két évtized. Zsidók Kolozsváron a két világháború között c. munkáiból.
} 
A történelmi magyar állam megszünése az erdélyi zsidóságot is új helyzet elé állította. Gidó Attila Milton Yinger asszimilációs modellje alapján úgy véli, hogy a történeti Magyarország zsidóságának asszimilációja erősen előrehaladott volt, többnyire megvalósult. A külső politikai változások hatására a magyar társadalomba, a magyar állami keretekbe történő integráció 1918at követően azonban megtorpant és ennek a helyét egy egyénenként, és régiókként változó mélységű román állami/társadalmi integráció vette át. ${ }^{785}$

Az erdélyi zsidóság rendkívül heterogén volt és különböző szervezetek mentén tagolódott. Az asszimilánsok többsége az OMP-hez (1923-tól), egy kisebb részük a szociáldemokratákhoz, a kommunistákhoz és egyéb román pártokhoz csatlakozott. ${ }^{786} \mathrm{~A}$ nemzeti alapra helyezkedő zsidóság a magyar, a román és a szász nemzeti tanácsok mintájára alakult Erdélyi Zsidó Nemzeti Szövetséghez csatlakozott, amely Eisler Mátyás kolozsvári neológ förabbi és Glasner Mózes ortodox förabbi vezetésével alakult meg 1918 őszén, Temesváron. ${ }^{787}$ A tanács elfogadott egy deklarációt, amelyben kifejezte támogatását a tervezett palesztinai zsidó állam jövőbeni létrehozásáról, illetve a wilsoni pontok értelmében kérte a zsidó nemzetiség elismerését, mint „az egész világon szétszórt 14 milliónyi és a nyugati államok kormányai által nemzetnek elismert egyetemes nép részének". ${ }^{788}$ A kisebbségek jogaival egyenértékủ alkotmányos felruházást igényeltek az oktatás és a nemzeti kultúra ápolása terén. ${ }^{789}$ A „,nemzeti zsidóság” önálló társadalomszervező szándékának megértéséhez és az etnikai az etnikai szemlélet felértékelődésében nem hagyható figyelmen kívül a mintaként szolgáló román, a szász és a magyar nemzetépítés. Ráadásul a fokozódó antiszemitizmus, amely Erdély számos településén zsidók ellen elkövetett pogromok sorozatában nyilvánult meg, például a beszterce-naszód megyei Borgóprundon vagy Szentmihályon ${ }^{790}$ a többi etnikai-vallási csoporttól való elkülönülés érzetét erősítette. A nemzeti zsidóság mellett a már addig is létező cionista - de csekélytámogatottságú - politikai mozgalom is az önálló útkeresést szorgalmazta. ${ }^{791}$

\footnotetext{
785 Milton Yinger négy összefüggő asszimilációs alfolyamatot különböztet meg: biológiai (a csoportok keveredése), pszichológiai, (identifikáció), kulturális (akkulturáció) és strukturális (a befogadó csoport által működtetett intézményi és társadalmi struktúrákba történő integrálódás). GIDÓ Attila: Két évtized. Zsidók Kolozsváron a két világháború között. Erdélyi Múzeum-Egyesület, 2016. 4.

786 GIDÓ, Úton. 2009. 15.

787 A szövetségnek alakult helyi szervezete Nagyszebenben, Désen, Besztercén, Dicsőszentmártonban, Gyulafehérváron, Nagyenyeden. Új Kelet, 1918. 1. évf. 1. szám, december 19. 5.

${ }^{788}$ Mit akarunk? Új Kelet, 1918. 1. évf. 1. szám, december 19. 2.; Megalakult a zsidó Nemzeti Tanács. Kolozsvári Újság, 1918. 19. évf. november 21.

${ }^{789}$ Mit akar kolozsvári zsidóság? Kolozsvári Újság, 1918. 19. évf. november 23.

790 Zsidóüldözések Beszterce-Naszód megyében. Kolozsvári Újság, 1919. 19. évf. november 28.; Zavargások Szentmihályon. Kolozsvári Újság, 1919. 20. évf. január 9.

${ }^{791}$ Az 1900-as évek elején léteztek cionista csoportok Erdély néhány városában: Gyulafehérvár, Nagyszeben, Nagyenyed, Kolozsvár, Nagybánya, Beszterce. 1918 novemberében egyszerre, függetlenül egymástól, több
} 
Nem utolsó sorban pedig a román állam, eltérően az osztrák-magyar monarchiától, a zsidóságot nem vallási kisebbségként, hanem önálló nemzetiségként kezelte. A román állam ugyanis az erdélyi zsidóságnak a magyarságról való leválását, a disszimilációt szorgalmazta, ugyanis addig az erdélyi zsidóság többsége részese volt a magyar kultúrának, a magyar nemzetépítés folyamatának. ${ }^{792}$

Weiss Sándor, aki 1926-ban az OMP képviselőjeként került a román törvényhozásba a zsidóságnak önálló kisebbségként való megszervezését támogatta. A Napkelet folyóiratban Apponyi Albert egyik beszédére reflektált, amelyben a gróf kiemelte, hogy a magyarországi keresztény és zsidó társadalom szembekerült egymással, mert a zsidóságnak egy része jelentős gazdasági erőre tett szert. Weiss Sándor részben a disszimilációs folyamatok, részben az antiszemitizmus miatt úgy jellemezte az erdélyi magyar politika szándékát, hogy „Marginalizálják a zsidóság cionista csoportjait és azokkal, akik nem cionisták a magyarság számarányát növelnék. Az erdélyi politikában nem ilyen kis lépésekre van szükség, hanem arra, hogy az erdélyi zsidóság egyenjogú legyen más nemzetiségekkel." 793 Dózsa Endre, volt alispánból és akkori közíróból Weiss előbb idézett érvelése komoly kritikát váltott ki. Úgy foglalt állást magyarság és zsidóság kapcsolatáról, hogy a jogi és az erkölcsi egyenjogúság elvitathatatlan, de a „zsidóságnak természetes szövetségese az erdélyi magyarság”. ${ }^{794}$ Ezzel együtt az antiszemitizmust elítélte, mint egyes népeknek elöítéletszerü kollektív megbélyegzését, amely ellentétes a népkisebbségek demokratikus követelményével. ${ }^{795}$

Az erdélyi zsidó népességgel szemben megnyilvánuló ellenségeskedés 1922. októberben nyílt erőszakos eseményekbe csapott át. Ferdinánd király és Mária királyné gyulafehérvári koronázási ünnepségével egy időben, az ország nagyobb városaiban, köztük Kolozsváron, Nagyváradon is román diákzavargások törtek ki. A román egyetemi diákság a bizonytalan élethelyzetéből, illetve a romániai, a magyarországi és lengyelországi xenofób példákból is kifolyólag a numerus clausus romániai bevezetésében volt érdekelt. ${ }^{796}$

erdélyi nagyvárosban indult be a zsidóság szervezkedése: Temesváron, Máramarosszigeten és Nagyszebenben Zsidó Nemzeti Tanácsok alakultak, Kolozsváron pedig a Zsidó Nemzeti Szövetség bontott zászlót. GIDÓ, Úton. 2009. 53-54.

${ }^{792}$ Uo. $15-29$.

${ }^{793}$ Weiss Sándor: Igazi kereszténység, zsidóség és erdélyi magyar politika. Napkelet, 1922. 3. évf. 1. szám, 6-9.

${ }^{794}$ Dózsa Endre: Magyarság és zsidóság. Napkelet, 1922. 3. évf. 2. szám, 95-96.

${ }^{795}$ Uo.

796 A két világháború közti romániai antiszemitizmus történetéhez lásd: Gidó Attila: Úton. Erdélyi zsidó társadalom- és nemzetépitési kisérletek (1918-1940), 42-53., illetve Miskolczy Ambrus: A Vasgárda születése. Századok, 2004. 147. évf. 4. szám, 845-874.; A romániai felsőoktatásban kialakuló antiszemitizmus kérdéséhez lásd: NASTASĂ, Lucian (szerk.): Antisemitismul universitar în România (1919-1939). Mărturii documentare. 2011. Editura Institutului pentru Studierea Problemelor Minorităţilor Naţionale-Kriterion, Cluj-Napoca 
A kolozsvári erőszakos eseményeket követően báró Jósika Sámuel a Keleti Újságnak adott interjút, aki a következőképpen foglaltak állást a numerus claususról. „Ellene mond a kultúra és a tudomány haladásának, amelyböl az emberi szabadság értelmében mindenkinek egyformán joga van részesülni. A numerus clausus társadalmi visszafejlődésre vezethet.”797

A magyar zsidó közösségek szegregációja, szétfejlődése 1918 után kezdődött meg. Az erdélyi zsidóság a következő években betagozódott ugyan az új állam politikai, gazdasági és társadalmi kereteibe, de nem vette át a román kulturális mintákat. Többségük, függetlenül világnézetüktől és identitásuktól, továbbra is magyar kultúrájú maradt és a magyar, vagy a magyar nyelven müködő zsidó nemzeti intézményi struktúrák fenntartásában vett részt. Gidó Attila magyarság és zsidóság változó viszonyát a vizsgált korban az aszinkronitás, a közösségi azonosságtudat, a csoportszolidaritás, a kettős identitás, a lojalitás kulcsfogalmaival tette szemléletessé.

Romániához csatolt kelet-magyarországi területek izraelita lakossága ${ }^{798}$

\begin{tabular}{|c|c|c|c|c|c|c|}
\hline 1910 & $\begin{array}{c}\text { magyarnak } \\
\text { vallja magát }\end{array}$ & 1930 & $\begin{array}{c}\text { magyarnak } \\
\text { vallja magát }\end{array}$ & $\begin{array}{c}1941 \\
\text { É-Erdély } \\
\text { Magyaro. }\end{array}$ & $\begin{array}{c}\text { magyarnak } \\
\text { vallja } \\
\text { magát }\end{array}$ & $\begin{array}{c}1941 \\
\text { D-Erdély } \\
\text { Románia }\end{array}$ \\
\hline 182.489 & $\begin{array}{c}132.000 \\
(73 \%)\end{array}$ & 192.833 & $\begin{array}{c}178.699 \\
(93 \%)\end{array}$ & 151.125 & $\begin{array}{c}47.358 \\
31,3 \%\end{array}$ & 40.937 \\
\hline
\end{tabular}

a) Aszinkronitás, amelyet értelmezhetünk olyan helyzetváltozásként, amely a valamihez képest való kicsinységet, a többletterhek igényét jelenti külső és belső kényszerből fakadóan, amely a többségi társadalommal szembeni hátrányból való indulást, a kisebbségi lét lényegéből adódó hátrányokat próbálja kompenzálni. Az aszinkronitás ugyanúgy érvényes az asszimiláns és a cionista erdélyi zsidóságra nézve, azzal a különbséggel, hogy az előbbi csoport újra és újratermeli az aszinkronitást. Az erdélyi nemzeti alapokra helyezkedő zsidóság az impériumváltást követően, föként intézményteremtésében (hitközség, sajtónyilvánosság) komoly előrelépést mutatott fel és bármekkora volt is a különbség, de megtalálták a kapcsolódási pontot a regáti cionista szervezetekhez, illetve a könnyebb alkalmazkodás útjait a romániai viszonyok között. A zsidó nemzeti mozgalom részéről az aszinkronitás így fokozatosan eltolódott a vállalt önálló kisebbségi élet és a palesztinai zsidó államiság megteremtéséért folytatott háttérmunka irányába.

\footnotetext{
797 A magyarság a numerus clausus ellen. Keleti Újság, 1922. 5. évf. 278. december 8. 3.

${ }^{798}$ Az 1930-as és az 1941-es észak-erdélyi zsidó etnikai arányok közötti jelentős eltérés oka a népszámlálási módszerekben keresendő. 1930-ban a román hatóságok önhatalmúlag, minden izraelita személyt zsidó nemzetiségüként regisztráltak. A magas etnikai mutatókhoz a hatósági visszaélések mellett viszont több mint bizonyos, hogy az impériumváltást követően az erdélyi zsidóság identitástudatában bekövetkezett változások és a román állami lojalitás kialakulása (azaz az állami rendelkezések hűséges alattvalóként való teljesítése függetlenül az egyéni meggyőződéstől) is közrejátszottak. GIDÓ, Úton. 2009. 29-33.
} 
A magyar kisebbség kötelékében megmaradt izraelitáknál, kettős kisebbségi helyzetükből kifolyólag felerősödött ez a jelenség. Egyszerre kellett a magyar zsidóságnak magyarságát és ebből kifolyólag hiteltelennek látszó román államhűségét is bizonyítania.

b) A magyar kisebbség esetében a közösségi azonosságtudat egyszerre épült a nyelvre és a kultúrára, ellenben a zsidóságnál a közös nyelv szerepe (jiddis) kevésbé volt meghatározó. Az etnicitás újjáéledésében kulcsszerepet játszott viszont az a modernizált héber nyelv, amely a közép- és újkorban a vallási irodalom, a tudomány nyelv volt, valamint a vallási hagyományok és az ezzel összekapcsolódó egyetemes ókori történelmi tudat, a közös sors (Izrael népe) és az üldöztetés. A közös zsidó történelmi múlt feltárása, illetve az abba történő erdélyi betagozódás ideológiailag is fontosnak számított, a „népi önismeret” közös jelszóvá vált. A modern héber nyelv terjesztése az önazonosságtudatra nagy hatást gyakorolt, már 1920-tól héber nyelvkurzusokat indítottak (Szatmárnémeti, Beszterce, Marosvásárhely), illetve héber tanítási nyelvű óvodák, elemi iskolák kezdték meg működésüket.

c) Az erdélyi zsidóságot a csoportszolidaritás ugyanúgy jellemezte, mint a magyar és a szász közösségeket. A hagyományosan a hitközségek köré tömörülő zsidó belső világ a vallási funkciók mellett kiépítette saját szociális, oktatási feladatainak intézményes kereteit is. A külső kényszerekre válaszul jogvédő irodákat, gazdasági és politikai érdekérvényesítő szervezeteket alakítottak. Éles határt nehezen húzhatunk a magyar identitású és cionista zsidó magatartás közé, mert több esetben előfordult, hogy az előbbi csoporthoz tartozók adományoztak Palesztina-építésére vagy zsidó árvagondozók részére.

d) A kettős kötődés alternatívája. Az impériumváltást követően a magyarországi zsidó közösségekben az dualizmus időszaka alatti asszimilációs stratégia (Karády Viktor) válságba került és felerősödött a disszimiláció. Voltak, akik számára lehetséges alternatívaként a kettős identitás került előtérbe, mint például Farkas Mózes gyáros, aki magyar orientációjú volt az Országos Polgári Radikális Pártban (1918), részt vett a Magyar Szövetség (1921) megalakításában, majd a palesztinai telepítések megszerzésére létrehozott országos bizottság társelnöke lett. Weiss Sándor több írásában is úgy foglalt állást, hogy a kettős kötődést nem lehet elvitatni a zsidóságtól. ${ }^{799}$ Az asszimiláns és a cionizmustól elzárkózó zsidóság származása miatt nem vonhatta ki magát az őt is érintő politikai és nemzetközi események hatása alól.

\footnotetext{
${ }^{799}$ Weiss Sándor: ügyvéd, a Keleti Újság korábbi tulajdonosa, az Országos Magyar Pártnak volt a tagja (reform csoport), amelynek színeiben 1926-1927 között parlamenti mandátumot is betöltött. A Magyar Párt 1927-ben megvásárolta a Keleti Újságot Weisstől. GIDÓ, Úton. 2009. 368.
} 
e) A lojalitás értelmezési kerete az összeomlást követően kibővült: kettős/többes, magyar és román állami, illetve kulturális elköteleződésekről beszélhetünk. A zsidóság jövőképét több hatás is befolyásolta: a Magyarországra való odafigyelés, a budapesti revíziós politika, illetve a kettős kötődés és a változó mélységü román állami hűség. A Karády által leírt asszimilációs szerződés helyébe lépő disszimilációs folyamatban a kivárás, a nyelvi kötődés és magyar nyelvű kultúrafogyasztás gyengébb szintje kötötte a zsidóságot immár a magyarsághoz. Kisebbségek közötti kapcsolat oldaláról tekintve úgy is értelmezhető ez a viszony, hogy két önálló kisebbség, magyarság és zsidóság fogalmazza meg magát az állammal szemben, fenntartva egy bizonyos fokú összetartozás tudatát. A nemzeti alapon szervezkedő zsidóságot ezzel szemben az jellemezte, hogy immár elsősorban a román állam felé fejtette ki aktivitását, szorosan ideértve az állam felé tanúsított lojalitását, cserébe kollektív jogokat követelve magának. Az állami lojalitást egyszerre lehet értékelni kényszer- és konjunkturális lojalitásként. A politikai állásfoglalásoktól elzárkózó vallásos zsidóság (az ortodoxia egy része és a haszidok) állami lojalitása mindenkoron a vallási elöírásokból következett. ${ }^{800}$

1922-ben Szász Zoltán ${ }^{801}$ Az erdélyi zsidóság válaszúton címü írásában a következőképpen vázolta fel a magyar identitású zsidóság előtt álló kérdéseket. „A trianoni béke nemcsak a magyarság jelentös részét szakitotta el politikailag a nemzet zömétöl, de ezeknek a magyar határokon kívül rekedt nemzetrészeknek az emberállományát is problematikussá tette. Hogy kik tartoznak a magyarsághoz, ez a régi Magyarországon is gyakran bizonytalan volt. [...] Hisz a magyar városi polgárság legnagyobb része elmagyarosodó más nemzetiségüekböl toborzódott össze s mindig akadtak egyének, családok, söt egész községek, amelyek mintegy csak fél lábbal voltak bent a magyarságban, de ezért senki sem vonta kétségbe, hogy egészében magyarok." ${ }^{802}$ Erre példa a felvidéki szlovák kisnemesség nagy része, a pozsonyi vagy a temesvári etnikailag asszimilálódott magyar polgárság vegyes összetétele. Az impériumváltást követően nem volt egyszerü a válasz arra a kérdésre, hogy ki a magyar az utódállamokban. Alkotó elemei, ha nyelvileg össze is olvadt a magyar nyelvben, de nevükben, családi szocializációs kapcsolataikban gyakran megőrizték más nemzetiségi csoportokhoz való kötődéseiket.

\footnotetext{
${ }^{800}$ GIDÓ, Úton. 2009. 18-29.

${ }^{801}$ Szász Zoltán (Kolozsvár, 1877-Budapest, 1944): író, újságíró, jogász. Számos lapban jelentek meg írásai (Pesti Napló, Nyugat, Pesti Hírlap, Világ, Toll, Szellem, Keleti Újság). A Tanácsköztársaság, majd az ellenforradalmi terrort támadó cikkeiért mindkét rezsim börtönre ítélte. Több esszét szentelt a magyar-zsidó együttélésnek a Keleti Újságban. 1926-ban jelent meg Magyar és zsidóság címü könyve.

${ }^{802}$ Szász Zoltán: Az erdélyi zsidóság válaszúton. Keleti Újság, 1922. 5. évf. 118. szám, május 28. 1.
} 
Ha tehát egy olyan nagy változás, mint Trianon és egy új nyelvü és szellemü államhatalom, mint például Románia kérdőre vonja a nemzeti hovatartozást, akkor az egykor asszimiláns csoportok kiléphetnek a régi nemzeti közösségből, és válhatnak szlovákká, románná, szerbbé írta Szász.

A szerző szerint mindez Erdélyben úgy nézett ki, hogy az északkeleti megyékbe újonnan bevándorolt galíciai zsidóságot kivéve, teljesen magyarnak számított a zsidóság. Az új államok ebből kifolyólag olyan zsidósággal találták magukat szembe, akik a többségi nemzetekkel (román, szlovák stb.) nem álltak sem politikai, sem kulturális kapcsolatba, ellentétben a magyarsággal. Az utódállamok mindezt figyelmen kívül hagyták, és a zsidóságot a magyarságtól külön etnikumként kezelte. Romániában „egy új nemzeti kisebbség, a zsidó született, amely azonban nem egyéb, mint egy második magyarság." 803 A konfliktus elsősorban a nagy városokban volt érzékelhető, mint Aradon, Temesváron, Nagyváradon, Szatmáron. Szász Zoltán azt is megjegyezte, hogy a zsidóság önálló nemzetté válásának folyamata, illetve öntudatra ébredése nem az új hatalmak, Románia, Csehszlovákia vagy a délszláv királyság politikai hatalmára adott válasz volt elsősorban. Az önálló nemzeti öntudat, „,mely a zsidóság kebelében lappangó hajlamként él néhány évtizede, nyillt programmá lett s végül a háború utolsó éveiben a teljesülés küszöbéig jutott" a cionizmus politikai irányelvén keresztül. Szász Zoltán cikkében a cionizmust „,hervadásnak indult” politikai irányzatként ismertette, amely bár erőtlen és megvalósíthatatlan, de igazság tartalmát, a zsidó származás tudatot el kell ismerni. ${ }^{804}$

Zágoni István egy 1922-es cikkben értekezett a magyar-zsidó együvétartozásról, amely kapcsolatban a múltnak nagyszerepet tulajdonított. A történeti magyar állam liberális politikai intézményrendszere befogadta a zsidó betelepülőket és jogokat biztosított számukra. Románia ezzel szemben megkérdőjelezte az egyéni elhatározást, hogy ki mely kultúrközösséghez kíván tartozni. Zágoni ezt a liberalizmust kérte számon, majd lefektette, hogy a magyarságnak továbbra is ezt a liberális hozzáállást kell képviselnie. ${ }^{805}$

A magyar kisebbség belső intézményrendszerének kialakulásával a zsidókhoz füződő viszony is kialakult. A magyar értelmiségi és politikai elit túlnyomó része továbbra is a magyarság részének tekintette az erdélyi zsidóságot (izraeliták). Az erdélyi magyar konzervatív körökben viszont a magyarságtól való elidegenedés vádja fogalmazódott meg velük szembe, amely a Tanácsköztársaságban való részvételre vezethető vissza.

\footnotetext{
${ }^{803}$ Uo.

${ }^{804}$ Uo. 2.

${ }^{805}$ Minden zsidót reklamálnak. Keleti Újság, 1922. 5. évf. 205. szám, szeptember 13. 1-2.
} 
Mindemellett, a politikailag és társadalmilag külön utakat járó nemzeti zsidóság a magyar pozíciókat veszélyeztető konkurens nemzetépítő-, és ebből kifolyólag ellenérdekelt gazdasági csoportként jelent meg a magyar konzervatív körök szemében. ${ }^{806}$

${ }^{806}$ GIDÓ, Úton. 2009. 49. 


\section{INTÉZMÉNY- ÉS PROGRAMTÖRTÉNET, 1920-1922: Magyar Szövetség, Erdélyi} Néppárt, Magyar Nemzeti Párt és fúzió

A magyar kisebbségtörténetírás adós a Magyar Szövetség, az Erdélyi Néppárt és a Magyar Nemzeti Párt történeteinek feldolgozásával. A kisebbségbe kényszerült romániai magyarságról szóló ismereteink az átmenetre vonatkozóan töredékesek, miközben a kezdeti időszakban kialakult egyes tartalmak, formák és gondolatok a két világháború közti magyar intézményesültségre, politikai gondolkodásra és személyközi viszonyokra kihatással voltak. Ebben a fejezetben arra vállalkozom, hogy az impériumváltás időszakában egymással párhuzamosan futó politikai kezdeményezésekkel, kiútkereső stratégiákkal összefüggésben, bemutassam az első romániai magyar politikai szervezeteket: a pártok felettiséget képviselő Magyar Szövetséget, az első magyar politikai pártot, az Erdélyi Néppártot és annak ellenpárját, a Magyar Nemzeti Pártot.

\subsection{A Magyar Szövetség elökészítése és a magyar püspökök eskütétele}

1920 december utolsó hetében készítették el a Magyar Szövetséget előkészítő ülés részletes programját. A katonai parancsokság vezetöjének, Petala tábornoknak december 30-án bejelentették a tanácskozás helyszínét (kolozsvári városháza ülésterme), idejét (1921. január 9. 11h) és várható létszámát (60-80 fö). ${ }^{807}$ Az értekezlet engedélyeztetése tárgyában a következő kérvényt nyújtották át. „A trianoni béke által a Romániához átkapcsolt területek magyar nemzeti kisebbségére nézve elérkezett az idő arra, hogy az adott helyzet lojális elismerése mellett érdekeinek képviseletére a román állam keretén belül és annak szuverenitása alatt megteremtsék az ország területére nézve a maga kisebbségi szervezetét." "808 A kérelmet azzal egészítették ki, hogy hasonló ülések megtartását tervezik Kolozsváron kívül is. Az elökészületekben többségben a passzivista csoport tagjai vettek részt Grandpierre Emil vezetésével. ${ }^{809} \mathrm{Az}$ aktivista ellentáborból Paál Árpád és Zágoni István vállaltak szerepet az elökészületekben. A szervezet létrehozásának tervéről Grandpierre és Paál közösen értesítették dr. Teodor Mihali megbízott minisztert, akitől a január 9-i tanácskozás támogatását kérték. ${ }^{810}$

\footnotetext{
${ }^{807}$ MNL OL K610 56. csomó 3. dosszié. VI. 6. (Az erdélyi magyarság szervezkedésének bejelentése. Nagyváradi Napló, 1921. január 1.)

${ }^{808}$ Szervezik a magyar nemzeti kisebbséget. Ellenzék, 1921. XLII. évf. 2. szám, január 4. 2.

${ }^{809}$ A passzivista csoportból részt vett továbbá: gróf Bethlen György, Grandpierre Emil, Kolosváry Bálint, Költő Gábor, Sándor József (EMKE), Grois László volt törvényszéki bíró, 1921-től az Ellenzék főszerkesztője, Szász Endre a kolozsvári Újság szerkesztője, Haller Gusztáv volt kolozsvári polgármester, Barthos Ferenc, Lichnovszky Ferenc, Makkay József, Szele Márton és dr. Nagy János.

810 Szervezik a magyar nemzeti kisebbséget. Ellenzék, 1921. XLII. évf. 2. szám, január 4. 2.; Magyar szervezőgyülés. Keleti Újság, 1921. 4. évf. 3. szám, január 4. 3.; Az erdélyi magyarság kérvénye Petala tábornokhoz. Szabadság. 1921. 47. évf. 3. szám, január 5. 1.
} 
Az alakuló ülés mindkét politikai csoportra, az aktivista és a passzivista körökre rendkívüli erővel hatott, amelyről a két csoportot is reprezentáló, és az egymással is konkuráló újságok, az Ellenzék és a Keleti Újság rendszeresen, a saját politikai elképzeléseiknek hangsúlyt adva tudósítottak. Az Ellenzék a következőket jegyezte le a tanácskozásról: felvonult Erdély közéletének régi és minden ismert fontos alakja, akik többségében a középosztályt és az értelmiséget képviselték (Grandpierre Emil, Költő Gábor, Paál Árpád, Kós Károly, Sándor József). Helyet foglalt továbbá az arisztokrácia néhány tagja (gróf Bánffy György, gróf Béldi Ferenc), a földbirtokos gazdákat és az erdélyi zsidóságot (Rosenberg Sándor) képviselök egy szükebb csoportja is. Az erdélyi magyar munkásság nem jelent meg a meghívás ellenére sem. ${ }^{811}$

Köszöntő beszédet Grandpierre mondott, aki a szervezkedés célját abban foglalta össze, hogy a magyarságnak olyan pozíciót kell elfoglalnia az új állam keretei között, amely számának, kulturális és gazdasági érdekeinek megfelel. A Magyar Szövetséget pártok, osztályok és felekezetek felett álló szervezetként jellemezte, amely minden magyart, székelyt és csángót magába foglal. Sándor József programbeszédében arra mutatott rá, hogy az erdélyi magyar kisebbség számára „a jog az 1919. december 9-i párizsi és az 1918. december 1-i gyulafehérvári határozatokban van letéve." 812

A kisebbségi jogok gyakorlását egyfelől a készülő alkotmányrevízió vitájában betöltött aktivitástól, másfelől egy erős közjogi alapon nyugvó kisebbségi szervezet megalakításától tette függővé. Grandpierre a Szövetség müködtetésére vonatkozóan azt javasolta, hogy állítsanak fel egy központi bizottságot Kolozsváron, amely a teljes erdélyi magyarságot reprezentáló tavaszra tervezett nagygyülés programját fogja előkészíteni. ${ }^{813}$ Az alakuló ülés a szervezet helyi és országos kiépítését határozta el. A feladatok ellátásáért az ún. központi intézőbizottság (21 fö) felelt, amely a hivatalos megalakulásig a magyarság képviseletében eljárt, érdekeit védelmezte és a kisebbségi ügyekben tárgyalt. A nagygyülés delegáltjait úgy kívánták megválasztani, hogy a megyék magyar népességének számarányához viszonyítva húszezer lélek után egy képviselőt delegálnak a helyi szervezetek.

\footnotetext{
${ }^{811}$ Jelen volt továbbá: Papp József, Barcsay Tamás, Fekete-Nagy Béla volt alpolgármester, Várady Aurél, Óvári Elemér, báró Bánffy Dániel, gróf Teleki Ferenc, Farkas Mózes, Huber Imre, Vass Emil, Petres Kálmán, Kovács Dezső, Péter Károly, Székely Viktor, Parlaghy Lajos, Nemes Ferenc, gróf Teleki Árvéd, Árkossy Lajosné, Török Bálint, Hevesi József, Havas László, Sámodi István, Bartók György, Nagy János, Szele Márton, Ferenczi Lajos, Kovács András. Megmozdult Erdély magyarsága. Ellenzék, 1921. XLII. évf. 6. szám, január 11. 1-3.

${ }^{812}$ A Magyar Szövetség megalakulása. Keleti Újság, 1921. 4. évf. 6. sz. január 11. 1-3.

${ }^{813} \mathrm{Az}$ ideiglenes központi bizottság tagjai: gróf Bethlen György, Dósa Endre, Ferenc József unitárius püspök, Grandpierre Emil, Grois László, Haller Gusztáv, Hirschler József, Kolosvári Bálint, Költő Gábor, Nagy Károly református püspök, Paál Árpád, Sándor József, Kirchlenopf Gusztáv, Ferenczi Gyula, Papp József, gróf Teleki Árpád, Szász Endre, Zágoni István, Dálnoki Kovács Áron. Uo. 2.
} 
Egy sajtóosztály felállítását is kezdeményezték, amely a magyar nyelvű lapokkal való kapcsolattartásért és a minél gyorsabb információáramlásért felelt (tagjai: Balogh Arthur, Kovács János, Alajos Domokos).

Az ülésen szólásra emelkedett a kolozsvári magyar zsidóság nevében Farkas Mózes, aki a helyi izraeliták csatlakozását jelentette be. Ravasz László a közös és egységes politikai cselekvés ünnepélyes fogadalmáról értekezett, Fekete-Nagy Béla (volt kolozsvári alpolgármester és a Kelet-magyarországi Főkormánybiztosság tagja, Apáthy helyettese) pedig arról, hogy a szervezkedés már hosszabb idő óta előkészítés alatt van. A nyílt politikai cselekvést korábban csak azért nem vállalhatták fel magyarázata szerint, mert addig nem voltak meg a megfelelő vezető egyéniségek, akik mögé felsorakozhattak. Fekete-Nagy és Sándor József elismerésüket fejezték ki Grandpierre Emil iránt, akinek a politikai szervezkedés megkezdését köszönték. Az ülésen az intézményesülés első lépéseit is megtették, ahol megalakult a Magyar Szövetség kolozsvári és Kolozs megyei tagozata. ${ }^{814}$

A Csíki Lapok, amely a Grandpierre vezette konzervatív passzivista kör politikai irányelveit követte, történelmi fontosságú lépésnek tartotta a szövetség zászlóbontását. Az Ellenzékhez hasonlóan az egység szándékát, illetve a nem pártpolitikai szervezeti forma követelményét emelte ki. „Nem politikai pártalakulásról van szó, hanem a Romániához csatolt területek egész magyarságának egy táborba tömöritéséröl, egyetlen magyar szövetségröl, melynek tagja kell, hogy legyen minden magyar, bármely hitvallású legyen is." ${ }^{~} 15$

A politikai szervezkedés megindításának jelentős lökést adott, hogy az erdélyi magyar püspökök hajlandóak voltak eleget tenni a román kormány felszólításának, és esküt tenni Ferdinánd királynak. A magyar iskolák központi költségvetésből történő támogatását részben ettől tették függővé. A katolikus püspökök eleinte ragaszkodtak ahhoz, hogy fogadalmat csak azt követően tehetnek, amint a törvényhozás az állam és az egyház viszonyát tisztázandó jogszabályt megalkotta (fókegyúri jog rendezése). A katolikus püspökök saját helyzetüket tekintve azért is voltak bizonytalanok, mert iránymutatást vártak a Vatikántól. 1921 elején gróf Majláth Gusztáv erdélyi püspök Rómába utazott, ahol a pápától felmentést kapott korábbi uralkodójára tett esküje alól.

\footnotetext{
${ }^{814}$ A kolozsvári és kolozs megyei bizottság tagjai: Fekete Nagy Béla, Bartók György, Gabányi Imre, Hevesi József, Hirschfeld Károly, Nagy János, Kovács Kálmán, Nemes Ferenc, Óvári Elemér, Kovács Géza, Kós Károly, Szele Márton, Váradi Aurél, Jenei Aladár, Kisfaludi Árpád, Lichnovszky Ferenc, Bartók Ferenc, Makkai József, Huber Imre, Szabó József, Szilágyi András, Adorján Ákos, Albrecht Lajos, Bárdos Péter, Császár Gábor, Csiszár Gyula, Barcsay Tamás, Erdődy Imre, Ferenczi Lajos, Dózsa Endre, Gaál Elemér, Hankó Veress Károly, Naláczy István, Szentiványi József, Kovács András. Kolozsvár város és Kolozs-megye Magyar Szövetség alakuló közgyülésén való képviselőjéül Bartók Györgyöt, Szele Mártont, Váradi Aurélt, Silay Istvánt, Matskássy Pált és Bárdos Pétert választotta meg. Uo. 2-3.

${ }^{815}$ Magyar Szövetség. Csíki Lapok, 1921. XXXIII. évf. 3. szám, január 16. 1-2.
} 
Visszatérte után bejelentette Majláth Gusztáv erdélyi, Glattfelder Gyula csanádi és Széchenyi Miklós nagyváradi püspök, hogy hajlandóak felesküdni Romániára, amelynek időpontját és helyszínét március 19-ére tüzték ki a bukaresti királyi palotába. Teutsch szász lutheránus egyházfő is ugyanazon a napon fogadott esküt. ${ }^{816}$ Az eseményt megelőzően egy egyeztető tárgyalásra került sor a kormány és a két legnagyobb egyház képviselői között március 17-én. A felekezetek részéről jelen volt Majláth, Balázs András katolikus kanonok, illetve a református egyház képviseletében Ravasz László és Kolosváry Bálint. ${ }^{817}$ Az erdélyi római katolikus státus igazgató tanácsát Majláth eskütételénél dr. Balázs Andráson kívül Gyárfás Elemér volt főispán és státusgyülési tag képviselték. A ceremónián román részről Avarescu miniszterelnök, Octavian Goga, illetve az udvari marsall, a királyi udvar minisztere, a ceremóniamester és a király örnagyszárnysegédje voltak jelen. ${ }^{818}$ Majláth három emlékiratot nyújtott át az illetékes hatósági személyeknek az egyházi intézmények helyzetének tisztázása érdekében. Egyet Goga kultuszminiszternek - a királynak címezve -, amelyben a katolikus önkormányzat anyagi támogatását kérte a királytól. A második emlékiratot a közoktatási- és a kultuszminisztereknek nyújtotta át a státusi iskolák szabad müködtetése érdekében. A harmadik emlékirat, amelyet a református és az unitárius püspök is aláírt, a tanulmányi és nevelési célt szolgáló egyházi birtokok kisajátítás alóli mentessége érdekében érvelt. ${ }^{819} \mathrm{~A}$ protestáns egyházak saját hatáskörben döntöttek az eskütételről. A református egyház igazgatótanácsának átiratára az Unitárius Egyház Képviselő Tanácsa (E. K. Tanács) 1921. március 29-i ülésén döntött a kérdésben, és adta meg az engedélyt Ferenc József püspöknek az eskütételre. A Tanács tekintettel arra a körülményre, hogy a katolikus egyház püspöke a hüségesküt letette, illetve az erdélyi református egyházkerület a püspöknek engedélyt adott, az „E. K. Tanács az erdélyi református egyházzal szolidaritásban" cselekedett. Ferenc József az esküt április 10-én, egy nappal a református püspök eskütételét követőn - a magas életkorára tekintettel - Kolozsváron tette le. Egy emlékiratot is átnyújtott, amelyben a szabad vallásgyakorlás és oktatás biztosítását, illetve az unitárius alapítványi birtokainak visszaszolgáltatását kérte. ${ }^{820}$

\footnotetext{
${ }^{816}$ A katolikus püspökök letették az esküt. Ellenzék, 1921. XLII. évf. 58. szám, március 24. 4.; A katolikus püspökök eskütétele. Csíki Lapok, 1921. XXXIII. évf. 14. szám, április 3. 1.

${ }^{817}$ Az állam és a magyar egyházak tárgyalása. Keleti Újság, 1921. 4. évf. 51. szám, március 17. 5.

${ }^{818}$ A latin nyelven tett eskü szövege a következő volt: „A Mindenható Istenre és a szent evangéliumra hüséget esküszöm Öfelsége Románia királyának és engedelmességet, minö egy püspökhöz illik. Megtartom a királyság törvényeit és gondoskodni fogok róla, amennyire lehet, hogy alárendeltjeim is tiszteljék azokat. Az ország nyugalma és épsége ellen nem fogok semmiféle kísérletet tenni és amennyiben tölem függ, nem fogom megengedni ilyen akciókban való részvételt híveimnek. Isten és a szent evangélium engem úgy segitsen." A katolikus püspökök letették az esküt. Ellenzék, 1921. XLII. évf. 58. szám, március 24. 4.

${ }^{819}$ MARTON, Korunk, 2002/4. 21-22.

${ }^{820} \mathrm{Az}$ egyház képviseletében jelent volt: báró Petrechevich Horváth Kálmán és dr. Ferenczy Géza fögondnokok, Gálfi Lőrinc helyettes főjegyző, Kovács Kálmán helyettes egyházi és püspöki titkár. A román állam képviseletében jelen volt: dr. Meţhes Péter Kolozsvár prefektusa.
} 
A püspökök kérései nem tekinthetők előzmény nélkülieknek. A magyar püspökök megelőző év augusztusban memorandumban fordultak a kormányhoz, amelyre Prie közoktatásügyi államtitkár és Octavian Goga kultuszminiszter 1921. januárban válaszolt. Az egyházfők panaszai között szerepelt többek között: az önkényes eljárás során kisajátított ingóságok és ingatlanok kérdése, a felekezeti iskolák működtetésének akadályoztatása, illetve bezáratása, a magyar tannyelv korlátozása. Goga válaszában kijelentette, hogy Bukarestben nem vesznek figyelembe semmi olyan beadványt, amely a püspökök aláírását viseli. A miniszter arra hivatkozott, hogy a román állam gyakorolja a föfelügyelet jogát a felekezeti iskolák létrehozása felett, és központi engedély nélkül nem tür meg egyetlen egyházi iskolát sem, amely az 1868. XXXVIII. tc., 1893. XXVI., valamint az 1907. XXVI. t.c. kívánalmainak nem felel meg. A református püspök később erre úgy reagált, hogy az 1907-es Apponyi-féle rendelet elvesztette jogalapját, mert azóta a nemzetközi jogszabályokba bekerült a nemzetiségi kisebbségek közjogi státusza, amely értelmében biztosítani kell a saját anyanyelven történő oktatást. $^{821}$

\subsection{Grandpierre Emil: Románia föderalizálása helyett nemzeti autonómia}

A román politikai elit tagjai eltérően reagáltak a magyarság politikai szervezkedésének hírére. Az RNP irredenta veszélyröl beszélt, a bukaresti konzervatív körök pedig úgy vélték, hogy a magyaroknak a román pártok keretei között kellene keresniük a politikai kibontakozás útját. Brătianu, a liberálisok nevében a kisebbségi alapon történő szervezkedést kérdőjelezte meg. Azt fogalmazta meg, hogy a magyarok és a románok küzdelmének nem nemzetiségi alapon kell állnia, hanem ideológiák és ügyek mentén. Mihelyt valamely fontos kérdésben politikai döntésre kerül sor, úgy a magyarságnak meg kell haladnia az etnikai szempontokat. A magukat demokratának vallók a román demokratákkal, a konzervatívok pedig a román konzervatívokkal kell együttmüködni. Bratianu szerint ebben az esetben nincs szükség semmilyen magyar pártra. „Lehet-e ilyen alapon az ország általános érdekeivel megegyezö álláspontot kialakitani? Mi úgy véljük, hogy nem engedhetö meg a zsidó kisebbségi szervezet, épp így nem fogadható el a kisebbségi alapon történö szervezeti forma. A kisebbségi államtitkárság felállitása pedig további problémát jelent, mert arra, mint etnikai kisebbségi szervezetre tekinthetnek egyesek." 822

Erdélyi Unitárius Egyház Gyüjtőlevéltára (Arhivele Bisericii Unitariene din Transilvania). Az Unitárius Egyház Képviselö Tanácsa gyüléseiröl vezetett jegyzökönyv 1918-1925. 3-5. E. K. Tanács ülés jegyzökönyve (1921. március 29., április 8. és 10., 188-194.)

${ }^{821}$ Rendelet a magyar oktatás megfojtására. Keleti Újság, 1921. 4. évf. 15. szám, január 23. 3.

${ }^{822}$ Bratianuék és a magyar szervezkedés. Keleti Újság, 1921. 4. évf. 10. szám, január 16. 4. 
A kisebbségi államtitkárságról szóló tervezetről a képviselőház hetekig tartó vitát folytatott. Brătianu ellenezte a szerv felállítását, de 1921. február végén az Avarescu mellett álló többség elfogadta a javaslatot, amely végül nem került megszervezésre. ${ }^{823}$

Grandpierre Emil a januári előkészítő ülést követően cikksorozatban vázolta fel a szervezkedés stratégiáját, további lehetséges útját. A politikai iránymutatással felérő megnyilatkozást az Ellenzék közölte elsőként, de Grandpierrékre figyelö más újságok, például a Csíki Lapok is átvették. ${ }^{824}$ Grandpierre a romániai magyarok legideálisabb politikai elhelyezkedését Erdély autonómiájában jelölte meg, amely az új állam föderális berendezkedését vizionálta. Véleménye szerint Erdély évszázadokon át tartó - relatív önállósága, fejlett jogi, politikai, gazdasági, kereskedelmi, oktatási és egyesületi intézményrendszere, a sajátos, sokszínű kulturális viszonyai, a három nemzet és a négy vallás közjogisága erre kellő alapot adhatott volna. Grandpierre ezzel szemben egy reálisabb utat jelölt meg, mert az átmeneti állapotban elképzelhetetlennek tartotta Románia autonóm, Erdély, Dobrudzsa, Bukovina és Besszarábia közigazgatási egységekre való felosztását. Az erdélyi román politikai elittel szemben felvetette azt, hogy az Erdélyi Nemzeti Párt, nevezetesen Alexandru Vaida-Voevod, volt magyar parlamenti képviselő, illetve a megszüntetett Román Kormányzótanács semmibe vette saját korábbi követelését, a háború elött Tisza Istvánnal folytatott tárgyalásokon hangoztatott „Erdély az erdélyieké” programot. Grandpierre végül a bizonytalan kimenetelü föderális (erdélyi autonómia) út helyett, az etnikai elvet követő autonómiát nevezte meg lehetséges alternatívának. „Gondolatom szerint egyedül kielégítő megoldás a nemzeti autonómián való elhelyezkedés." 825

A nemzeti autonómia tervét a párizsi békeszerződések kisebbségekre vonatkozó pontjaiból vezette le. A nemzetközi szerződés megalkotta a kisebbség jogi kategóriáját, illetve a kisebbségi egyezmények kötelezték az új államokat a nemzetiségek jogi védelmére, és kultúrájuk, oktatásuk, gazdasági fejlődésük biztosítására. Grandpierre a nemzetközi szerződésben foglaltakra hivatkozva azt a következtetést vonta le, hogy az kellő alapot adott a kollektív jogokkal felruházott nemzeti kisebbség elismerésére. „Így történt a nemzeti kisebbség, mint közjogi tartalmi közösség megalkotása, jogainak biztositása s azok gyakorlásának nemzetközi ellenőrzése, tehát nemzetközi védelem alá helyezése."826 Az autonómia megteremtése előtt álló jogi utat tehát biztosítottnak látta.

\footnotetext{
${ }^{823}$ Megszavazták a nemzetiségi államtitkárságot. Keleti Újság, 1921. 4. évf. 39. szám, február 22. 2.

${ }^{824}$ Lásd: Csíki Lapok, 1921. XXXIII. 4. szám, január 23. 1.; 5. szám, január 30. 1.; 8. szám, február 20. 1.; 9. szám, február 27. 1.;

${ }^{825}$ Grandpierre: A magyar szervezkedés irányai II. Ellenzék, 1921. XLII. évf. 12. szám, január 19. 3.

${ }^{826}$ Grandpierre: A magyar szervezkedés irányai III. Ellenzék, 1921. XLII. évf. 13. sz. január 21. 2.
} 
Az etnikailag vegyesen lakott területeken való autonóm közizgatás kiépítését pusztán technikai kérdésnek tekintette, aminek megoldását - kissé naivan - a kölcsönös jóakarat feltételéül szabta. Karl Rennerre utalva a területi és a személyi autonómia együttes alkalmazását javasolta. Egyházi, iskolai, kulturális stb. ügyekben a személyi autonómia alkalmazását szorgalmazta. A parlamenti képviselet dolgában minden nemzeti kisebbség maga választotta volna képviselőit a népesség arányának megfelelően. Az igazgatási kérdésekben a területi elv érvényesülését proponálta. A nemzeti autonómia megteremtésének sikerességéhez két feltételt írt elö. Egyfelől a többség részéről találjon meghallgatásra a kisebbségek igénye, másfelől legyenek együttmüködő államok egy kedvező nemzetközi helyzetben. ${ }^{827}$

Grandpierre autonómia tervében benne foglaltatott az egység elve szerint az egész romániai magyarság közössége, magyarok, csángók és székelyek egyformán. A várható politikai támadásokra, irredenta vádaskodásra hívta fel a figyelmet, amelyet visszautasított. Érveit a nemzetközi békerendszer dokumentumaira alapozta, amely értelmében az új állam területi integritásának tiszteletben tartására intette a kisebbségi magyarságot, ellenben a többségtől elvárta a kisebbségi jogok tiszteletben tartását. ${ }^{828}$ A demokrácia tartalmát összekapcsolta az önrendelkezéshez való joggal, minden etnikai, felekezeti és osztálykülönbség mellőzésével. Úgy vélte, hogy miután a háborús „,kavargás elül [...] bizonyos, hogy a demokrácia lesz az uralkodó gondolat, amely végre fogja hajtani valamennyi kultúrállam közös szuverenitásba foglalását." ${ }^{\text {229 }}$ Utalt Teodor Mihali miniszter egyik kijelentésére, aki azzal üdvözölte a magyar mozgalom megindítását, hogy intézményes keretek között bonyolíthatóak le a magyar-román politikai tárgyalások. Grandpierre ezzel legitimálva érezte a Magyar Szövetség szervezeti formáját. A pártpolitikai aktivitást és a parlamenti részvételt továbbra is korai lépésnek tartotta. Kellő időben és megfelelően előkészítve a többi nemzetiségi kisebbséggel történő kooperációban ellenben hatékony eszköznek tartotta. ${ }^{830}$

Szintén 1921-ben készülhetett a Magyar Szövetség égisze alatt ismeretlen szerző átfogó javaslata A magyar autonómia vázlata címmel. A dátum ismeretlen, de a tartalma lényegében megegyezik a Grandpierre Emil által az Ellenzékben felvázoltakéval. A tervezet két fontos pontot fektet le: 1) a magyarság igényei nem szeparációs törekvések (Grandpierre elvetette Erdély autonómiáját, és a területi autonómiát preferálta).

\footnotetext{
827 Uo.

${ }^{828}$ Grandpierre: A magyar szervezkedés irányai IV. Ellenzék, 1921. XLII. évf. 14. szám, január 22. 3.; Grandpierre: Magyar Szövetség és irredenta. Ellenzék, 1921. XLII. évf. 33. szám, február 15. 2.

${ }^{829}$ Grandpierre: A magyar szervezkedés irányai V. Ellenzék, 1921. XLII. évf. 15. szám, január 23. 2. ${ }^{830}$ Uo.
} 
2) A jogfolytonosság fenntartásának igénye, amely a fejlettebb (erdélyi) közigazgatási rendszer megtartását jelentette, nem pedig a centralizáció kiterjesztését az autonómiák rovására. A Magyar Szövetség autonómia törekvésének négy fő területét nevezte meg: egyház (az állam tiszteletben tartja a felekezetek belső intézményrendszerét), közoktatás (az egyházi autonómia része), közigazgatás (megegyezik a nemzetiségi településterülettel ${ }^{831}$ ), igazságszolgáltatás (a közigazgatási beosztáshoz alkalmazkodva kettős hivatalos nyelvhasználat). A romániai magyarság először 1922-ben vett részt a romániai parlamenti választásokon, amelynek eljárásrendjét a következő két formában látták volna magukra nézve ideálisnak: a tömbmagyar területeken választási kerületeket kialakítása vagy a magyar lakosság arányában történő kisebbségi mandátum kiosztás. Az egész autonómia központi szervének a „magyar nemzeti kisebbségi tanácsát" jelöltek még, amelynek feladata a kormánnyal való kapcsolattartás és a belső ellenőrzés.

A tervezettel szemben a következő kritika fogalmazható meg: nincs szó a kataszteri összeírásról, a magyar önkormányzat belső müködési rendjéről, illetve Zágoni István javaslatához képest a belső demokratizmus már nem központi kérdésként jelenik meg. ${ }^{832}$

\subsection{Az „egy politikai közösség” igénye: magyarság, zsidóság, munkásság}

Minden történelmi korszaknak megvannak a kulcskérdései és jelképei, amelyeket maguk a szereplők teremtik meg, amiképpen tartalmat is tőlük, a sajátos társadalmi törekvéseiktől, közösségi magatartásuktól és szellemi habitusuktól kapnak. A magyarság történetében az első világháborút követő korszak egyik kulcskérdései közé tartozott a magyarság-munkásságzsidóság együttállásának ügye, hogy a munkásság és a zsidóság miként és milyen célok mentén vonható be (bevonható-e?) a kisebbségi társadalom (magyar politikai közösség) kereteibe.

A Magyar Szövetség januári alakuló ülése időszakában is élénk vita folyt az „,egy politikai közösség” kérdéséről.

\footnotetext{
${ }^{831}$ Az autonóm terület meghatározásakor három típust különítenének el: 1. Az összefüggő egységes nyelvü nagyobb területeket, amiböl kettő is van: a) Maros, Csík, Udvarhely, Háromszék megyék, Brassó, Kis- és NagyKüküllő megyék Székelyföldhöz csatlakozó területei, a Maros-völgyén, Aranyosgyéresen át Aranyosszékkel, Kolozsvárral, Kalotaszeggel összekapcsolva; b) Ugocsa, Szatmár, Szilágy, Bihar, Arad és Csanád megyék határszéli területei, a városokkal együtt. 2. Kisebb nyelvszigeteket. 3. Beékelt egyes községeket. A tervezet közigazgatási modelljének sajátossága, hogy a nem belügyi közigazgatás kinevezett tisztviselőire is a nemzeti kisebbség központi képviselete tehet javaslatot és ezek tevékenységét a képviselötestületek és törvényhatóságok ellenörizhetik.

${ }^{832}$ BÁRDI: Javaslatok, modellek, 2000. 362-363.
} 
A Keleti Újság a felmerült kérdésre a következőt felelte: „A magyarság pártformációkba tömörül, ezek a pártok azonban a munkásság pártjával szövetkezni tud. A koalíciós alapot kölcsönösen megkapják abban, hogy mindketten a népjogokért küzdenek."833 A Magyar Szövetség előkészítő ülésén a 21 fős intézőbizottságában két külön helyet fenntartottak az erdélyi zsidó szervezetek képviselői részére. Egyetlen politikai kikötést fogalmaztak meg, hogy a két státuszra a nem-cionista zsidóság képviselőit várták, vagyis a magyar kultúrához elkötelezetteket láttás szívesen a soraikban. Mint arról korábban volt szó, a zsidó közösségeken belüli politikai különbség részben abban mutatkozott meg, hogy míg a nemzeti zsidók és a cionisták a zsidó nemzetépítésben és a Palesztina-munkában látták a lehetséges fejlődésüket garantálni, addig az asszimilált zsidóság döntő része a magyar nemzetépítés keretein belül történő szabad politikai cselekvésben, kultúrában, anyanyelv és gazdaság területeiben való kiegyenlítődésben fogalmazta meg célját. ${ }^{834}$ Az együvé tartozás érzetének fenntartása morális kötelesség is volt. A Napkeletben Paál Árpád erről a következőképpen írt: „Vallásszabadságnak, nemzeti egyenjogúságnak, népek világbeli egymásmellettisége megértésének, közös kultúrák kifejlödésének ösi talaja volt a mi környezetünk. Ilyen környezetböl való beidegzödésünk például az is, hogy az Ázsia keletéröl Európa közepébe sodort magyarságnak egyazon sors nemüsége van a közöttünk élö zsidósággal. Mindketten hazát keresünk hol más nép szivében, hol a föld valamely pontján."835

A Keleti Újság a Szövetség alakuló ülését követően felkereste a kolozsvári zsidóság vezetőit, hogy csatlakoznak-e az új formációhoz. A kolozsvári zsidóság egyik vezetője (nevet nem közölt az újság) a következőket nyilatkozta: „Mi, erdélyi magyar kultúrájú haladó zsidók úgy érezzük, hogy [...] a haladó zsidóság nem mehet együtt ezzel [értsd: cionista - F. N.] a zsidósággal. [...] Fajiság tényénél sokkal dominálóbbnak tartja politikai cselekvésében kultúrájának, anyanyelvének, a védelmét és a gazdasági kiegyenlitödésre való törekvést. A magyarsággal minden tekintetben azonos jogokra van szükségünk, nemcsak hasonlókra, hanem ugyanazokra. [...] Mi túl vagyunk a fajiság dogmatikus értelmezésén s egyedül a kultúránk az, amelyért küzdeni akarunk minden támadással szemben. [...] Mi a magyar szövetségen belül akarjuk megszervezni a zsidóságot. A magyar szövetség címéböl éppen azért maradt ki a nemzeti szó, hogy a más fajhoz tartozó, de magyar kultúrájú tömegek számára is módot adjanak a csatlakozásra." 836

\footnotetext{
${ }^{833}$ Az aktivitás és a munkásság. Keleti Újság, 1921. 4. évf. 4. szám, január 6. 1-2.

${ }^{834}$ A nem-cionista zsidóság szervezkedése. Keleti Újság, 1921. 4. évf. 7. szám, január 12. 4.

${ }^{835}$ Paál Árpád: És fölkél a nap. Napkelet, 1920. I. évf. 1. szám, 3.

${ }^{836}$ A nem-cionista zsidóság szervezkedése. Keleti Újság, 1921. 4. évf. 7. szám, január 12. 4.
} 
A zsidóság mellett a munkásosztály tagjainak megszólítása is megfogalmazódott a kisebbségi vezetők céljai között. $\mathrm{E}$ szándékukban több ok játszhatott szerepet: a századfordulótó óta napirenden lévő szociális követelések és munkavállalói jogok megoldatlansága; a világháborús tapasztalat és a fronton radikalizálódott munkás hátterü katonák életkörülményeinek javítása; a forradalmak követelései a nagyobb társadalmi egyenlőség jegyében (a Szövetség progresszív, baloldali gondolkodású tagjai), vagy ezzel ellentétben az antikommunizmus. Nyilván a szociáldemokraták politikai befolyása is szerepet kapott, amely akár megnyerhette magának a városok magyar munkás választóit. A Magyar Szövetség gyülésein és a sajtóban több helyen is elhangzott, hogy az erdélyi magyar munkásság csatlakozására számít a Szövetség. Grandpierre Emil reményének adott hangot, hogy a „kivívni kivvánt cél teljes együttmüködésre fogja bírni a munkásságot is." ${ }^{~} 837$ A munkásság végül szervezetileg nem csatlakozott a kezdeményezéshez. Az Újság a következőképpen kommentálta a munkásság eltérő álláspontját. A munkásság többször kifejezte, hogy nem veszt részt a szerintük nacionalista Magyar Szövetség szervezkedésében. A munkásság az elutasítást azzal indokolta, hogy nem szüntek meg a feudális viszonyok a magyar társadalmon belül. Az Újság a következő ellenérvet sorakoztatta fel. A magyar kisebbség a politikai rendszer és a társadalom demokratizálásáért küzd az állampolgári egyenlőség és a széles körü szociális jogok kiterjesztése érdekében. A magyarság nem a nacionalizmus talaján áll, hanem egy kisebbségi alapon, illetve, hogy az erdélyi munkásság nem a magyarországi polgári pártokkal szemben küzd, mert ott szinte eltűntek az egykori pártok mentén létrejött törésvonalak. ${ }^{838}$

\subsection{A Magyar Szövetség megindítása}

A Magyar Szövetség januári felhívása a korábbi aktivitást sürgető hangokkal ellentétben hitelt érdemlő kezdeményezésnek bizonyult az erdélyi magyarság szélesebb körében, amit nem magán akciónak, hanem országos jelentőségü lépésnek ítéltek meg. A szövetség előkészítő munkálatai minden előzetes várakozás ellenére csak lassan indulhatott meg a kiforratlan politikai stratégia és a hatósági korlátozások következtében. Petala tábornok hetekig nem engedélyezte a Magyar Szövetség ideiglenes központi bizottságának ülését, illetve nem adott engedélyt a vidéki ülések megtartására sem a hadiállapotra és a kivételes rendszabályokra hivatkozva. ${ }^{839}$

\footnotetext{
${ }^{837}$ A Magyar Szövetség megalakulása. Keleti Újság, 1921. 4. évf. 6. szám, január 11. 1-3.

${ }^{838}$ MNL OL K610 56. csomó 3. dosszié. VI. 6. (A magyarság kisebbségi harcában a munkásságnak részt kell venni. Újság, 1921. január 21.)

${ }^{839}$ MNL OL K610 56. csomó 3. dosszié. VI. 6. (Elnémítás. Keleti Újság, 1921. február 12.)
} 
Elsőként a temesvári magyarság csatlakozott a Magyar Szövetséghez. A szervezet megalapításában az 1918 előttről is ismert helyi politikai és szellemi vezetők tagjai mellett a temesvári nem-cionista közösség is részt vett. A szövetség általános céljainak elfogadását követően megválasztották a helyi elnökséget és a kolozsvári nagygyülésre küldendő delegáltakat. ${ }^{840}$ Elnök Szabolcska Mihály lett, aki 1898 és 1928 között szolgálta a temesvári magyar református eklézsiát. ${ }^{841}$ A századforduló konzervatív irodalmának népszerű egyénisége volt, akit elsősorban, mint Ady Endre ellenfele tartották számon. ${ }^{842}$ Szabolcska az elnöki posztot nem sokáig töltötte be, részben betegsége, részben a Jósika ügy miatt, amelyben kritizálta a báró lépését és novemberben kilépett a Szövetségből. ${ }^{843}$ (Jósika ügyét lásd később.)

Háromszék vármegyében, Sepsiszentgyörgyön, 1921. február 23-án került sor a Magyar Szövetség helyi alakuló ülésére. A gyülés jegyzőkönyvében nagy gondossággal részletezték az egybegyülteket. Háromszék megye valamennyi települése egy-egy föt delegált az ülésre. A helyi újság tudósítása szerint 400 fő vett részt az alakuló ülésen. ${ }^{844}$ Báró Szentkereszthy Béla nyugalmazott föispán megnyitó beszédében a meghívottak figyelmét arra hívta fel, hogy a kétmilliós magyar kisebbség akkor érhet el eredményeket, ha párt és felekezeti ellentéteket félretéve egyesül a magyarság kulturális, gazdasági és szociális érdekeinek védelmére. Török Andor volt alispán ismertetette a Magyar Szövetség programját.

\footnotetext{
${ }^{840}$ Alelnök: Fülöp Béla, titkárok: Ujvári és Kubán Endre. A kolozsvári nagygyülésre temesvári küldöttként Szabolcska Mihályt, Fülöp Bélát és két további személyt, Pogány Mihályt és Székely Lászlót választották meg. Temesvár magyarsága csatlakozott a Magyar Szövetséghez. Keleti Újság, 1921. 4. évf. 39. szám, február 22. 3.

${ }^{841}$ Szabolcska Mihály (186. Tiszakürt - 1930. Temesvár): 1899 - 1928 közt temesvári ref. lelkész. 1899-töl a Kisfaludy Társaság tagja. 1928-tól Budapesten élt, mint az MTA tisztviselője és a Kisfaludy Társaság titkára. A népi-nemzeti költészet utánzóinak, a Petőfi-epigonok úgynevezett hazafias költészetének egyik legismertebb képviselöje. http://mek.oszk.hu/00300/00355/html/ABC14240/14384.htm (Letöltve: 2017. április 28.)

${ }^{842}$ POMOGÁTS Béla: Temesvár a magyar irodalomban. Forrás, 2016. 48. évf. 4. szám, Forrás, 2016. 48. évf. 4. szám, 53.

${ }^{843}$ MNL OL K610 56. csomó 3. dosszié. VI. 6. (Szabolcska Mihály kilépett a Magyar Szövetségböl. Nagyváradi Napló, 1921. november 6.)

${ }^{844}$ A sepsi járásból 34, kézdi járásból 22, az orbai járásból 10, a miklósvári járásból 11 fö jelent meg. Foglalkozásukat illetően többségében voltak a birtokos gazdák és a földmüvesek, de az érdeklődők között voltak lelkészek, kereskedők, iparosok, orvosok, tanítók, állásukat vesztett tisztviselők és bírók is. Továbbá Felsőcsernátonból az elemi iskola igazgatója, Orbán Balázs nyugalmazott államvasúti fökalauz, Barótról a helyi kereskedők, iparosok, szeszfinomítók, olvasókör egy-egy képviselöje, illetve a helyi takarékpénztár vezetője foglalt helyet. Elöpatak gyógyfürdő birtokosság egy küldöttje, a najtai olvasóegylet, kereskedő és iparosok képviselői, illetve az ott székelő Erdővidéki Takarékpénztár Rt. vezérigazgatója, Bedő József, a nagybaconi kereskedök, a helyi Hangya Szövetkezet, hitelszövetkezet és takarékpénztár vezetői vettek részt a szövetség megalakításában Ferenczy Géza szervezésének hatására. Sepsiszentgyörgy város lakosai, intézetei, egyesületei és testületei nevében közel 100-an aktivizálták magukat, többek között Bálint Dénes volt polgármester, a Székely Mikó kollégium elöljárói, a Székely Nemzeti Múzeum vezetői, a kaszinó igazgatója, illetve a szeretetház, a gazdakör, az erdőbirtokosság, a vasutasok, a kereskedök, az iparosok, a pénztári intézetek, a vadászok stb. egyegy reprezentánsa. Kézdivásárhely 30 föt delegált a helyi társadalom képviseletében, amelynek vezetöje dr. Török Andor volt háromszéki alispán, Szőcs Károly birtokos és Oláh Dániel föesperes voltak.

MNL OL K610 56. csomó 3. dosszié. VI. 6. (Magyar Szövetség Háromszék vármegyei értekezletének jegyzökönyve. Sepsiszentgyörgy, 1921. február 23.)
} 
Elfogadtak egy határozatot, amelyben kimondták, hogy Háromszék vármegye székelysége önmagát „Románia területén élő egész magyarsággal elválaszthatatlanul azonosnak és egynek tudja és vallja." ${ }^{845}$ Döntés született a Szövetséghez való csatlakozásról, a vármegyei szervezet 100 fős megyei bizottságáról és elnökének, báró Szentkereszthy Bélának a megválasztásáról, illetve megalakulásra váró Magyar Szövetség központi állandó választmány megyei delegáltjairól ${ }^{846}$, továbbá a kolozsvári nagygyülés szavazati joggal bíró megyei megbízottakról ${ }^{847}$. A megyei szervezet központját Sepsiszentgyörgyön jelölték ki. ${ }^{848}$ Az ülés alatt Szentkereszthy Bélához levél érkezett Sepsiszentgyörgy szociáldemokrata pártja nevében Ehrich Sándor jegyzőtől, Székely Géza ideiglenes párttitkártól és Fekécs Tivadar szervező bizottsági elnöktől. Kijelentették, hogy az összmunkásság a nemzetköziség és az osztályharc alapján áll, ezért tiltakozik minden olyan szervezkedés ellen, amely a munkásság között faji és nemzetiségi gyülöletre adhat okot. A Magyar Szövetséghez a helyi munkásság szervezetileg nem csatlakozott. ${ }^{849}$

A Magyar Szövetség kibontakozásának megtorpanásában minden bizonnyal közre játszott IV. Károly magyarországi visszatérésének kísérlete 1921 áprilisában, amely belpolitikai konfliktust okozott Romániában. A kisantant államok kormányain a félelem légköre uralkodott el, akik a párizsi békerendszer megingásától tartottak. A román politikai elit élesen támadta a kisebbségi magyarságot a bizalmatlanságuknak hangot adva. A bánsági származású román újságíró és parlamenti képviselő, C. Savu interpellálta a kormányt. Elmondta, hogy Magyarország határrevízióra készül, amelynek érdekében revíziós propaganda irodákat müködtet Belgrádban, és ilyet készül felállítani Bukarestben is. A képviselő a budapesti revíziós politika és az erdélyi magyarság szervezkedése között vont párhuzamot, amikor Kós-ZágoniPaál röpiratából idézett. Az autonómiáról szóló célkitűzést államellenes magatartásnak ítélte meg, amely elérése érdekében a magyarok erőszakos merényleteket követhetnek el a román lakosság ellen.

\footnotetext{
${ }^{845}$ Megalakult a Magyar Szövetség Háromszék megyei csoportja. Ellenzék, 1921. XLII. évf. 45. sz. március 1. 2. ${ }^{846}$ Ferenczy Géza ügyvéd, unitárius fögondnok, dr. Török Andor volt alispán, birtokos, vásárhelyi lakos, dr. Hindléder Jenő volt vármegyei föügyész, sepsiszentgyörgyi lakos.

${ }^{847}$ Szentkereszthy Béla, a Magyar Szövetség Háromszék vármegyei tagozatának elnöke, dr. Ferenczy Géza, dr. Török Andor, dr. Hindléder Jenő, Csutak Vilmos, a sepsiszentgyörgyi Székely Mikó Kollégium igazgatója, a Székely Nemzeti Múzeum igazgató-választmány tagja, Bogdán Artur a Háromszéki Takarékpénztár Rt. vezérigazgató, Kováts Kálmán volt járásbíró.

${ }^{848}$ Uo.

${ }^{849}$ MNL OL K610 56. csomó 3. dosszié. VI. 6. (Magyar Szövetség Háromszék vármegyei értekezletének jegyzőkönyve. Sepsiszentgyörgy, 1921. február 23.)
} 
Goga Octavian kultuszminiszter válaszolt az interpellációra. Kijelentette, hogy az „Erdélyben tapasztalható összes mesterkedések a magyarok túlzó természetének tulajdonithatók, amely különben még a progresszivebb magyarok ellen is üldözésben nyilvánul. Bizonyiték erre, az ismert szociológusnak, Jászi Oszkár esete, aki azért, mert baráti érzéseinek adott kifejezést a Magyarországgal ellenséges állapotban volt népek iránt, ma kénytelen idegen országban bolyongani. A magyar püspökök, akik megtagadták a hüségesküt Románia iránt, még ma is püspöki székükben ülnek." ${ }^{850}$ A Román Nemzeti Párt néhány képviselője, Tivadar Mihali, Iuliu Maniu és Emil Hatiegan ebben az időszakban megpróbálták egyesíteni az erdélyi román ellenzéki pártokat a földreform vitája és az erdélyi román igények Bukaresttel szemben történő érdekérvényesítése ügyében. A belpolitikai harcokban a magyarországi eseményekröl is szót esett. Kormányellenes politikájuk egyik kiemelt tartalma volt, hogy a magyar kisebbség veszélyezteti Románia területi integritását. Az RNP a kormányt többször felszólította, hogy kötelessége gondoskodni az állam biztonságáról. ${ }^{851}$

A magyarság politikai szervezkedését negatívan érintő királypuccs politikai hatása mellett a hadiállapot jelentette a következő akadályt. Románia hivatalosan 1921. április 1-jétől lépett a béke állapotába. A rendkívüli intézkedések ennek ellenére nem szüntek meg a Magyarországgal határos megyékben. A cenzúra intézménye továbbra is lehetőséget nyújtott a nemzetiségi sajtó korlátozására, az újságírók megfélemlítésére és a Budapestről érkező információk szelektálására. A hadiállapottal együttjáró szabályok érvényesítése a politikai gyülekezéshez való szabadságjogok gyakorlását is rendkívül szűkre szabta. A kivételes szabályok érvényben maradtak a román-magyar határ mentén fekvő megyék teljes területén az eredetileg ötven kilométeres zóna helyett. Nevezetesen Máramaros, Szatmár, Szilágy, Bihar és Arad megyékben, továbbá az egész Bánátban, ahol jelentős magyar lakosság élt. Minden politikai gyülést előzetesen be kellett jelenteni a rendőrségnek, amelynek megtartását minden indoklás nélkül megtagadhatták. ${ }^{852}$

Pál Gábor Csík megye volt föügyésze és Nagy Jenő ügyvéd a csíki magyarság megszervezésében kiemelt szerepet vállaltak. Nagy Jenő Kötelességünk és jövőnk címü írásában hívta fel a helyi magyarságot érintő szorongató politikai és társadalmi kihívásokra. Az érdekképviseleti munka mielőbbi megkezdését két pontban indokolta. A magyarság megélhetési nehézségek között tömegesen hagyta el az országot, illetve a januári kolozsvári felhívásra adható politikai válasz.

\footnotetext{
${ }^{850}$ Erdélyi blokk. Keleti Újság, 1921. 4. évf. 66. szám, április 6. 2.

${ }^{851}$ Uo.

${ }^{852}$ A hadiállapot megszüntetése. Keleti Újság, 1921. 4. évf. 72. szám, április 13. 4.
} 
Nagy Jenő politikai és erkölcsi kötelességnek tartotta az „ősi földhöz való ragaszkodást”, a „türést” és a „kitartást” az erdélyi magyarság elött ,újult erővel meginduló kulturális és gazdasági harcban." 853 Nagy és Pál márciusban nyílt levélben arra kérték a magyar egyesületek, intézmények, testületek, közbirtokosságok vezetöit, hogy a Magyar Szövetség megyei alakuló gyülésére küldötteik megválasztásáról és megbízóleveleik kiállításáról gondoskodjanak. Felszólították a helyi magyarságot, hogy egységes szervezett alakítsanak. „Ez az egységes szervezet csak úgy létesithetö, ha megváltoztathatatlan akarattal kifejezésre juttatjuk, hogy Székelyföldön kívül élö magyarságtól különválni soha nem szándékozunk, hanem a Romániához csatolt magyarság összességéhez tartozunk." 854 Nagy és Pál a Magyar Szövetséget tekintették egyedül legitim szervezetnek, amely a magyarságot képviselni hivatott, minden más politikai aktivitást (Fáy-Maurer politikai csoportosulás) elfogadhatatlannak ítéltek. A gyülést engedélyező kérvényt harminchatan jegyezték. ${ }^{855}$ Az alakuló ülést eredetileg március 16-ra tüzték ki, de a hatóságok a szükséges engedélyeket sem akkora, sem egy későbbi időpontra (május 18.) nem adták meg. ${ }^{856}$ A Csík megyei szervezet jóval később, csak július 3án, közvetlenül a kolozsvári nagygyülés előtt alakulhatott meg.

1921. júniusban Petru Groza Erdély-ügyi miniszter látogatást tett több székelyföldi városba, hogy a közigazgatási rendszer átalakításáról folyó törvénytervezethez közvetlen információkat gyűjtsön. ${ }^{857}$ Marosvásárhelyre és Szovátára vezetett az első útja, ahol Ioan Harşia marosvásárhelyi polgármesterrel, Suciu Valér Maros vármegye alispánnal, Bernády Györggyel, Bodor László bankigazgatóval, Kovácsy Albert körjegyzővel, Tóthfalussy József református esperessel és Hajdu István lapszerkesztővel folytatott megbeszélést. (A Keleti Újság a részleteket nem ismertette. $)^{858}$ Groza Szovátáról Csíkszeredába utazott.

\footnotetext{
${ }^{853}$ Nagy Jenő: Kötelességünk és jövőnk. Csíki Lapok, 1921. XXXIII. évf. 7. szám, február 13. 1.

${ }^{854}$ Csík vármegye lakosságához. Csíki Lapok, 1921. XXXIII. évf. 10. szám, március 6. 1.

${ }^{855}$ Benke Antal ügyvéd, Hörög Joachim kanonok, Kiss Ágoston ügyvéd, Szabó György föesperes, Gáspár Máté ipartestületi elnök. Kugler Vilmos ügyvéd, László István kalapos, László Dezső ügyvéd, György Fazakas András birtokos, Blénessy Dénes birtokos, Merza Vilmos kereskedő. Élthes Gyula a Csíki Lapok főszerkesztője, Dávid Ignác birtokos, Kovács András tanár, Bíró Benedek Szent Ferencrendi szerzetes, Dr. Pál ügyvéd, Dávid Péter cipész, Dr. Györgypál Domokos nyugalmazott főispán, Szabó Ferenc birtokos. Takács Károly református lelkész, Dr. Kovács Gyárfás ügyvéd, Dr. Erőss Péter ügyvédjelölt, Szopos Domokos vendéglős. Bíró József ipartestületi elnök, Dr. Élthes Zoltán ügyvéd, Dr. Szántó Samu ügyvéd, Dr. Tauber József ügyvéd, Adorján Imre Gazdasági Egylet titkára, Wagner Sándor tanár, Szász Gyula kereskedő, Dávid János birtokos. Bíró Mihály birtokos, Dr. Szekeres János plébános, Szopos József birtokos, Szilassy László pékmester, Gáspár József birtokos, Hajnod L. Ferenc birtokos, Dr. Nagy Jenő ügyvéd, Bartha Ferenc plébános. Uo. 1.

${ }^{856}$ A Magyar Szövetség szervezkedő gyülése Csíkban. Csíki Lapok, 1921. XXXIII. évf. 12. szám, március 20. 2 .; Elmarad a Magyar Szövetség alakuló közgyülése. Csíki Lapok, 1921. XXXIII. évf. 19. szám, május 8. 2.

${ }^{857}$ Groza a Maniu vezette Román Nemzeti Párt tagja volt, majd belépett a Román Néppártba és erdélyi ügyekért felelös miniszter és közmunkaügyi miniszter lett az Averescu-kormányban.

${ }^{858}$ Az alakuló nagygyülés. Keleti Újság, 1921. 4. évf. 115. szám, június 7. 5.
} 
A fiatal (38 éves), dévai miniszter programbeszédében elismerte a kisebbségek által igényelt, az állam előtt mindenkire egyenlően vonatkozó joggyakorlatot. Feladatának tartotta, hogy mielőbb orvosolja az esküt nem tett magyar tisztviselők helyzetét, munkához való juttatását. A beszédet követően egyenként fogadta a különböző delegációkat. A csíkszeredai közkórház képviseletében dr. Veress Sándor igazgató, dr. Hirsch Hugó sebész föorvos és dr. Balássy belgyógyászati főorvos jelentek meg a miniszter előtt. A közkórház és annak fejlesztésének szükségességéről volt szó. A miniszter ezután dr. Pál Gábor ügyvédet fogadta, akitől a csíkmegyei magyarság helyzetéről, sérelmeiről kért tájékoztatást. A közlegelök ügyében tizenhárom felcsíki község küldöttsége jelent meg a miniszter elött. Elpanaszolták, hogy a közbirtokosság havasi legelőit az agrárreform címén elvették, amely a környék állattenyésztését ellehetetleníti. Az ügyvédek delegációját dr. Bocskor Béla vezette, aki Grozától azt kérte, hogy Csíkszereda kapja vissza törvényszékét és Csíkszentmárton a járásbíróságát. A miniszter a közigazgatás hatékony müködése érdekében arra kérte a tisztviselőket, hogy mielőbb sajátítsák el a román nyelvet. A Magyar Szövetség Csík megyei tagozatának megalakításáról szóló panaszokat dr. Nagy Jenő és dr. Élthes Gyula ismertették. A miniszter érkezése előtt Kolozsváron tájékozódott, hogy az alakuló Magyar Szövetség gyülését két esetben sem engedélyezték, ezért a beadott harmadik kérelmet Kolozsváron magához vette. Azt állította, hogy a helyi hatóság akadályozta meg a szervezkedést, amely a kormány intenciója ellenére járt el. Bukarest ugyanis szükségesnek és az új állam érdekének tartotta a magyarság intézményesülését. A küldöttségtől azzal búcsúzott el, hogy a kérésüket még az útközben kedvezően elintézi, amelyről a Csík megyei előkészítő bizottságot táviratilag értesíti. ${ }^{859}$

A miniszteri látogatás Sepsiszentgyörgyön folytatódott. Groza tárgyalt a Magyar Szövetség háromszéki képviselőivel ${ }^{860}$, akik a szövetség nevében reményüket fejezték ki, hogy a román hatóságok nem állítanak akadályt a magyar szervezkedés elé. Továbbá elpanaszolták, hogy a háromszéki prefektus nem vette figyelembe a helyi szokásokat és önhatalmúlag 25\%os megyei pótadót vetett ki. Követelték azt is, hogy a helyi igazságszolgáltatásban magyarul beszélő bírákat nevezzenek ki. Az agrárreform törvénnyel szemben is kifejezték aggályukat, mert a tervek szerint a román állam elvenné Sepsiszentgyörgy és Árkos község között elterülő négy-hat millió lei értéket képviselő erdőséget egy katonai lőtér létesítésére. ${ }^{861}$

\footnotetext{
${ }^{859}$ Groza erdélyi minisztérium Csíkszeredán. Csíki Lapok, 1921. XXXIII. évf. 24. szám, június 12. 1-2. ${ }^{860}$ Szentkereszthy Béla, Kovács Kálmán, Csutak Vilmos, József Lajos, Keresztes István, Béldi László

${ }^{861}$ Miniszteri járás Háromszéken. Keleti Újság, 1921. 4. évf. 119. szám, június 12. 4.
} 
1921 nyarától lendületet kapott a Magyar Szövetség vidéki kiépítése. Két előzmény közvetlenül hozzájárult az aktivitás megindításához. Egyfelől, hogy a hatóságok engedélyezték a már januárban elhatározott Magyar Szövetség alakuló nagygyülésének megtartását július 6ára, Kolozsvárra. Másfelől Grandpierrékkel szemben, akik nagyobb befolyással bírtak Erdélyben, Kós Károlyék megalakították a parlamenti részvételt is felvállalni kész Erdélyi Néppártot június 5-én, Bánffyhunyadon (lásd később).

A székelyudvarhelyi magyarság június 21-én csatlakozott a Szövetséghez. A gyülés elnökévé Pál István apátkanonokot választották meg, aki a helyi közösség gondoskodásának szükségességét vázolta fel. A megjelentek között volt Pál Gábor Csík megyéből. A Magyar Szövetség feladatait és a szervezés módozatait Lőrinczy István székelykeresztúri esperes és az Unitárius Egyház újság volt szerkesztője ismertette. „A székelységnek a többi elszakadt magyarsággal egy úton kell haladnia, mert csak a faji egység keretében tud fennmaradásának és fejlödésének védelmet biztositani az egységes Magyar Szövetség által."862 A Csík megyei szervezőkhöz hasonlóan, a gyülés közönsége állást foglalt a Székelyudvarhely címü újság irányzata ellen, amely véleményük szerint a székelységet a magyarság más részeitől elválasztani törekedett. Sebesi János volt alispán terjesztette elő a Magyar Szövetséghez való csatlakozás nyilatkozatot. ${ }^{863}$ Megválasztották a kolozsvári nagygyülés megyei küldötteit ${ }^{864}$, továbbá a kolozsvári központi állandó választmányba delegálandó tagokat. ${ }^{865} \mathrm{~A}$ szövetség képviseletét ideiglenes elnökként Szakáts Péter földbirtokos látta el, aki később a Magyar Nemzeti Párt helyi elnöke lett. ${ }^{866}$

Székelyudvarhelyt követően a Magyar Szövetség újabb megyei tagozata Kis-Küküllő megyében, Dicsőszentmártonban alakult meg. A gyülést Pekry Sándor dicsőszentmártoni birtokos vezette fel. A szervezet elnökévé Gvidó Béla unitárius esperest választották meg, aki a nemzetiségi alapon történő szervezkedés fontosságát hangsúlyozta. Surinya Balázs építőmester, az ipartestület alelnöke az iparosok nevében beszélt, aki nem zárta ki a különböző világnézeti alapon létrejövő magyar politikai pártok megalakulásának lehetőségét, de a magyarság egységének fenntartását ezek fölé helyezte.

\footnotetext{
${ }^{862}$ Felhívás Csík vármegye lakosságához! Csíki Lapok, 1921. XXXIII. évf. 26. szám, június 26. 2.

${ }^{863}$ Uo.

${ }^{864}$ Frölich Ottó tanár, státusgyülési képviselő, Gál Imre Udvarhely vármegye Méhészegyesület titkára, Gyárfás Pál székelykeresztúri földbirtokos, dr. Lörinczi István, Máthé István, Nagy János, Sebesi János

${ }^{865}$ Frölich Ottó, Lőrinczi István, Sebesi János.

${ }^{866}$ Udvarhelyi szervezkedés. Keleti Újság, 1921. 4. évf. 129. szám, június 25. 5.
} 
Miklós Béla küküllődombi kisgazda a helyi gazdák csatlakozását jelentette be. Hegyi Károly református esperes javaslatára megválasztották a kolozsvári központi állandó választmány tagjait. $^{867}$

A Bihar megyei magyarság szervezkedését a hadizóna korlátozó előírásai eleve, illetve külön politikai úton is megakadályozták. A ratifikációt követően, Kolozsvárhoz hasonlóan Nagyváradon is a sajtó segítette elő a politikai tájékozódást. A Nagyvárad 1920 októberében az EMKE, illetve Grandpierre Emil köré kezdeményezett önszerveződésről számolt be. A névtelen vezércikkben ezt így értékelték: „Megmozdulása a párciumbeli (sic!) magyarság széles rétegének egy politikai táborba való tömörülését jelenti, amire ma már elkerülhetetlenül szükség van, s ami nélkül az erdélyi magyarság mint oldott kéve hull szét." 868 A Szabadság 1920. karácsonyi számában, Tabéry Géza az „erdélyi magyar belpolitika” alapgondolatait propagálta, hogy „,bekapcsolódjunk a romániai emberközösség problémái megfejtésébe." ${ }^{869} \mathrm{~A}$ nagyváradi vezető lapok, a Szabadság, a Nagyvárad és a Nagyváradi Napló elkötelezett hívei voltak a magyarság politikai aktivitásának. Az első lépéseket Tabéry Géza (Szabadság) és Perédy György (Nagyvárad) újságírók tették meg. Aláírásgyüjtésbe kezdtek a Magyar Szövetség megalakításának érdekében 1921 júniusában. ${ }^{870}$ A Szabadság úgy kommentálta a hírt, hogy aktivitásra a bihari magyarság saját lelkiismeretével szemben csak a békeszerződések magyarországi ratifikálását követően szánhatta el magát. ${ }^{871}$ A szervezkedést a bihari prefektus (Jacob József) és a szigurancia vezetője (Jon Boncilla) előbb engedélyezték, az állam egységét hangsúlyozva, végül mégsem támogatták. A prefektus azzal indokolta tiltó rendelkezését (Nr. 2240-1921.), hogy a „beadvány aláirói között sok a zsidó” felekezetü személy, például a két hitközség rabbija, a neológ Kecskeméti Lipót és az ortodox Fachs Benjámin, akik a trianoni békeszerződés (43. szakasz) és a gyulafehérvári határozatok (5. szakasz) értelmében nem magyar nemzetiségüek, hanem önálló kisebbségek, ezért önálló intézményes kereteiken belül szervezkedhetnek csak. ${ }^{872}$

\footnotetext{
${ }^{867}$ Kispál László, Gyárfás Elemér volt föispán, Isekutz Viktor volt országgyűlési képviselő. Magyar szervezkedés Kik-Küküllőben. Keleti Újság, 1921. 4. évf. 131. szám, június 28. 3.

${ }^{868}$ KUPÁN Árpád, 2011. A romániai magyarság első politikai szervezkedése. http://www.varad.ro/a-romaniaimagyarsag-elso-politikai-szervezkedese/ (Letöltve: 2017. november 16.) [Továbbiakban: KUPÁN, varad.ro, 2011]

869 Uo.

${ }^{870}$ Az aláirók között szerepeltek például: Karácsony János és Lányi József katolikus püspökök, Kecskeméthy Lipót neológ förabbi, Sulyok István református püspökhelyettes, Matterni Imre evangélikus lelkész, Fuchs Benjámin ortodox förabbi, illetve az egykori függetlenségpárti politikusok közül Czeglédi Jeremiás, Dr. Adorján Emil, Stocker József, Olasz Béla. Nagyváradon szervezkednek. Keleti Újság, 1921. 4. évf. 132. szám, június 29. 4.

${ }^{871}$ Szervezkedik Nagyvárad magyarsága is. Szabadság, 1921. 48. évf. 140. szám, június 28. 1.

${ }^{872}$ Elmarad a nagyváradi magyar szervezkedés. Szabadság, 1921. 48. évf. 144. szám, július 2. 1.
} 
A román megosztó politika sikeresnek bizonyult. A Nagyvárad július 3-án A zsidó nemzeti program és a magyarság szervezkedése címmel interjút készített a nagyváradi ortodox zsidóság vezetőjével. A magyar szervezkedést korábban aláírásával támogató ortodox főrabbi ezúttal az alábbi kijelentést tette: „Az ortodox zsidóság politikailag nemzeti alapon állt, [...] a zsidóság, mint politikai minoritás egy zsidó egységet képez." ${ }^{~} 73$ Silbermann Jenő, a nagyváradi cionista mozgalom hasonlóan a zsidóság nemzeti elhatárolódását hangsúlyozta: „Zsidó politikai értelemben csak egyféle van. Az a kis töredék, amely lerohadt a zsidóság fájáról, nem zsidó többé, hanem zsidó vallású magyar vagy német. Viszont Mózes vallású magyar a zsidó nemzeti minoritást nem képviselheti." ${ }^{874}$ Velük szemben dr. Kecskeméti Lipót neológ förabbi továbbra is az együttmüködés, a magyarsággal való összefogás híve maradt. ${ }^{875}$

Nagyváradon az újabb próbálkozásra októberben került sor. Morvay Zsigmond ügyvéd, a Munkapárt volt képviselöje a prefektusoz két kérvényt nyújtott be a Magyar Szövetség megyei alakuló gyülésének megtartására, illetve az EMKE tagtoborzására. A prefektus a kérést ismét elutasította, részben a Magyar Szövetség hiányos alapszabálya miatt (ősszel a Szövetség müködését erre hivatkozva felfüggesztették), részben azt oktalannak és céltalannak minősítve. Magyarázata az volt, hogy „itt a határ mentén hadizóna van, itt már volt kommunizmus is” és mindenféle politikai akció tiltott, kivéve a parlamenti választásokon való részvételt. Szerinte mivel Nagyvárad lakossága többségségben magyar volt, és azzal nem állt arányban a románság voksa, a magyaroknak így lehetősége nyílt a képviselőválasztáson keresztül kifejezni politikai akaratát és magyar jelöltet küldeni Bukarestbe. ${ }^{876}$

Az Alsófehér megyei Magyar Szövetség megalakítására 1921. június 30-án került sor. Az előkészítő bizottság elnökévé dr. Jeney Endre árvaszéki ügyvédet, alelnökeivé Bala Béla mészáros mestert, dr. Asztalos Kálmán ügyvédet, dr. Jancsó Ödön marosújvári orvost és dr. Takos Géza volt megyei főjegyzőt választották meg, továbbá egy 100 tagú választmányt. ${ }^{877}$

A Szilágy megyei magyarság július 3-án, a tudósítások szerint mintegy 1500 fős gyülésen fejezte ki csatlakozási szándékát a Magyar Szövetséghez. Bölöni Zoltán ismertette a politikai célokat: „a Magyar Szövetség munkájából ki kell vennie mindenkinek a részét, aki érzésében magyarnak vallja magát [...] mert ha nem így lesz, azt a gyanút ébreszti föl maga iránt, hogy lélekben sohasem volt együtt a magyarsággal."

\footnotetext{
${ }^{873}$ KUPÁN, varad.ro, 2011.

${ }^{874} \mathrm{Uo}$

875 Uo.

${ }^{876}$ Megint szervezkedés? Nagyváradi Hétföi Lap, 1921. II. évf. 41. (67.) szám, október 10. 1.

877 Jegyzők: dr. Szabó András ügyvédet, Solymosi Bálintot, dr. Uray Lászlót és Wolhfárt Lörincet. Az Alsófehér megyei magyarság szervezkedése. Keleti Úság, 1921. 4. évf. 136. szám, július 3. 3.

${ }^{878}$ A Szilág megyei határozat. Szabadság, 1921. 48. évf. 147. szám, július 6. 1.
} 
Személyi kérdésekben is döntöttek: a megyei szervezet élére gróf Béldi Kálmánt, az Ellenzék Rt. Igazgatótanácsának elnökét választották meg, küldötteket delegáltak a kolozsvári nagygyülésre, illetve elhatározták a járási szintü építkezést. ${ }^{879}$ A hónap végén, Szilágysomlyón külön tagozatot állítottak fel, amelynek vezetésével dr. Somogyi Kálmánt bízták meg. A megyei szervezet 100 tagú választmánnyal működött és a 14 járásban élő magyarságot képviselte. ${ }^{880}$

Kevés információ áll rendelkezésre, de alakuló ülést tartottak Hunyad megyében, Déván június 29-én, illetve Fehér megyében, Nagyenyeden július 3-án. A hadizónában lévő Arad megyében is meg volt a szándék a szövetség alakuló ülésének összehívására, de erre engedélyt nem kaptak. Beles Jenő volt alispán kezdte el a helyi szervezést. A kolozsvári júliusi nagygyülésen Arad város és megye magyarságát a hatósági korlátozások miatt senki sem képviselhette. Barabás Béla, Arad város volt főispánját ennek ellenére beválasztották a Szövetség vezetőségébe. ${ }^{881}$

Féléves akadályoztatást követően, július 3-án, Csíkszeredán került sor a Csík megyei Magyar Szövetség alakuló ülésére. A Csíki Lapok a következőképpen vezette fel a gyülést. „Semmi mást nem akar a magyarság, csupán azt, hogy mint a szászok, svábok, zsidók stb. megalkossa a maga képviseletét, részt vegyen a közügyekben és mikor állampolgári kötelességeit teljesiti, ugyanakkor részesüljön az állampolgári jogok teljességében és mindazon kisebbségi jogokban, melyeket részére a trianoni békeszerzödés, a párizsi külön egyezmény és a gyulafehérvári határozatok biztositanak." ${ }^{82}$ A közgyülés elnökévé Görög Joachim gyergyószentmiklósi kanonokat választották meg. Köszöntő beszédében a magyar-román és az erdélyi nemzetiségek együttéléséhez, illetve a magyarság boldogulásához vezető út megtalálásának szükségét, intézményes kereteinek megteremtését emelte ki. A jog és a törvényesség betartatását kérte számon az új állammal szemben. „Nincs háború, nincs forradalom s mégis kivételes törvények rendelkeznek felettünk. Az élet és vagyon ezernyi bonyodalma, mely régen az itélöbíróság pártatlan igazságossága döntött el, ma a csendör, rendör detektív hatalmának van kiszolgáltatva. Bírói végzés nélkül besúgások alapján hatolnak be lakásainkba, motoznak, nyomoznak, letartóztatnak, internálnak.

\footnotetext{
${ }^{879}$ A megyei tisztikar vezetösége: alelnökök Péchy Imre, ügyvezető alelnök dr. Bölöni Zoltán. A kolozsvári gyülésre és a központi szervezet tagjai közé az elnökség tagjain túl dr. Both Istvánt, dr. Gazda Endrét, illetve Kádár Imrét, a Keleti Újság és a Napkelet újságíróját delegálták. A zilahi járás élére Kiss Ernőt, a somlyóiba dr. Somogyi Kálmánt, a tasnádiba dr. Kósa Bélát, a krasznaiba Kádár Imrét, a zsibóiba Péchy Imrét, a szilágycsehibe báró Bomberg Frigyest választották meg. A szilágy megyei szervezkedés. Keleti Újság, 1921. 4. évf. 137. szám, július 5. 4.

${ }^{880}$ MNL OL K610 56. csomó 3. dosszié. VI. 6. (Magyar Szövetség szilágysomlyói tagozata. Ellenzék, 1921. július 31.)

${ }^{881}$ MNL OL K610 56. csomó 3. dosszié. VI. 6. (A magyarság szervezkedése. Brassói Lapok, 1921. június 21.; A nagyenyedi szervezkedő gyülés. Ellenzék, 1921. július 2.)

${ }^{882}$ A csík megyei magyarság egysége. Csíki Lapok, 1921. XXXIII. évf. 27. szám, július 3. 1.
} 
A nyílt egyenes lelkü magatartás közönséges bünnek vétetik. A Siguranta hatalma belenyúl életünk minden mozzanatába. [...] Sajtónk panasza fehér folttá változik át. Egyesülési jog illuzórikus, gyülekezés ma két és fél év óta vált lehetségessé - félévi tartó kérelmezés után. [...] Törvényszékünk száz kilométerre van, iskoláink jó része bezárva, a többi ezernyi akadály között vergödik, hogy a hatóságok különbözö intézkedéseinek eleget tehessen." 883 A beszédeket követően került sor a határozati javaslat elfogadására. 1) Kijelentették, hogy Csík megye székelysége a Romániához csatolt magyarság összességének elválaszthatatlan részét képezi és elítél minden ezzel ellentétes törekvést (utalás a Fáy-Maurer csoportra). Támogatták a magyarság egységes szervezeteként a Magyar Szövetség megszervezését. 2) Megnevezték a kolozsvári nagygyülés küldöttségét ${ }^{884}$, illetve a központi választmány megyei képviselőit ${ }^{885}$. A megyei szövetség elnökének dr. Pál Gábort, jegyzőnek Adorján Imrét választották, illetve egy 177 főből álló bizottságot állítottak fel (lásd az 5. számú mellékletet). ${ }^{886}$

\subsubsection{A Magyar Szövetség alakuló nagygyülése, 1921. július 6.}

A magyarság önszerveződő útkeresésében az EMKE átszervezése mutatkozott az egyik lehetséges alternatívának. Az érintettek bár más intézményes utat választottak, 1921-től párhuzamosan a Magyar Szövetséggel megindult a kulturális egyesület újjáélesztése. Mindkét építkezésben a kezdeményezők egy része ugyanazok voltak. Egy nappal a Magyar Szövetség nagygyülését megelőzően az EMKE Kolozsváron, többek között báró Jósika Sámuel, Ferenc József unitárius püspök, Ugron István és Nagy Károly református püspök részvételével tisztújítóülést tartott. Az EMKE megválasztott hat alelnöke közül hárman, Kemény Ákos (Maros), Szentkereszthy Béla (Háromszék) és Szabolcska Mihály (Temesvár) egyúttal a Magyar Szövetség helyei szervezeteinek elnöki posztját is betöltötték. ${ }^{887}$ Az EMKE politikai funkciót nem vállalt magára, de amint azt láthatjuk, a kezdetekben egyesek lehetséges szervezeti alternatívaként tekintettek rá, amit a nagyváradii ${ }^{888}$, a kis-küküllőii ${ }^{889}$ újjáalakuló ülések is mutatják.,A mi vállainkról súlyos, felelösséggel teljes terhet vettek le mai napok.

\footnotetext{
${ }^{883}$ Uo. 2.

${ }^{884}$ Görög Joachim, dr. Benke Antal, dr. László Dezső, dr. Nagy Jenő, dr. Pál Gábor, P. Bíró Benedek, Koródi János

${ }^{885}$ dr. Pál Gábor, dr. Nagy Jenő, Görög Joachim

${ }^{886}$ Uo. 2

${ }^{887}$ Elnök: gróf Béldi Ákos, volt Kolozs vármegye föispánja, tanácsos, förendiházi tag. Alelnökök továbbá: Sárkány Lajos, báró Jósika Gábor, Benedek Elek. Főpénztáros: Bocsánczy László, ellenőr: Ferenczy Gyula. Az EMKE nagygyülése. Az EMKE első nagygyülése. Szabadság, 1921. 48. évf. 147. szám, július 6. 1.

${ }^{888}$ Megint szervezkedés? Nagyváradi Hétföi Lap, 1921. II. évf. 41. (67.) szám, október 10. 1.

${ }^{889}$ Az elökészületeket Gvidó Béla unitárius esperes, egyúttal a Kis-Küküllő megyei Magyar Szövetség elnöke tette meg, aki a magyar nép érdekében kifejtett kulturális szervezőmunkát emelte ki. Új EMKE alakulása KisKüküllőben. Újság, 1922. XXIV. évf. 152. szám, július 13. 1.
} 
Két és fél esztendő alatt a magyar sajtó tudott - a lehetöségekhez mérten - hangot adni egyedül az itt élö magyar nép vágyainak, szenvedéseinek, sérelmeinek. [...] És nem roskadt össze az erdélyi sajtó a hirtelen vállára zuhant feladatok súlya alatt. Ez a megerösödött sajtó állotta az ört a szervezkedés nagy munkája mellett is, ez dobott bele gondolatokat, ez követelte a legszélesebb demokráciát s emellett a legösszehangzóbb teljességet egy Magyar Szövetség keretein belül." ${ }^{~} 90$ A Keleti Újság ezekkel a gondolatokkal értékelte önmaga és a teljes magyar nyelvü sajtó szerepét az impériumváltás korlátozott politikai nyilvánosságában. Ligeti Ernő, húsz évvel később a Súly alatt a pálma (1941) címü összefoglalójában ugyanezt a gondolatot ismételte meg az újságírás szervező funkciójáról, amely szerves részét képezte a kisebbségi magyar társadalom építkezésében. „Az átmenti időkben és később is, csaknem egy évtizeden keresztül, az erdélyi sajtó jelentett úgy szólván mindent, a sajtó volt az erdélyi magyarság egyetlen megnyilatkozása, az egyetlen kopoltyú, amelyen keresztül a magyarság lélegzett. Tényleges politikai szervezkedésröl nem volt szó, a szervezkedésnek is az elsö formáit a sajtó, különösen a Keleti Újság kényszerítette ki." 891

A valóság minden bizonnyal árnyaltabb volt Ligeti interpretációjánál. Az Ellenzék nemcsak hasonló feladatot látott el, mint a Keleti Újság, de befolyása is növekedett 1921-töl. Az erdélyi magyar elit konzervatív szárnyat képviselő lapot a budapesti kormány is támogatta. Grandpierrék Hory András bukaresti ügyvivőn ${ }^{892}$ keresztül arra kérték Bánffy Miklós külügyminisztert, hogy a lap nagyobbik tulajdonrészét, 400 ezer lei támogatás ellenében vegyék meg a többségi tulajdonos és főszerkesztő Dobó Ferenctől. A kérelmezett összeg elszámolását azzal a müvelettel írták volna le, mint „tekintélyes erdélyi urak által befizetett részesedés.” Hory azzal indokolta a megvétel szükségét, hogy az Ellenzék az egyetlen olyan újság, amely „megbízható irányú erdélyi lap s a Magyar Szövetség szócsöve is. [...] A laptulajdonosától zsidó származására való tekintettel nem is várható, hogy az Ellenzék fejlesztése érdekében nagyobb anyagi áldozatokat hozzon s azt abban a szellemben vezesse, amely egyébként kívánatos volna." $" 893$

\footnotetext{
${ }^{890}$ A Magyar Szövetség megalakult. Keleti Újság, 1921. 4. évf. 139. szám, július 7. 1.

${ }^{891}$ LIGETI, 1941.

${ }^{892}$ 1920-ban Bukarestben még nem müködött magyar követség, 1921-ben került oda Hory András ügyvivőként és szervezte meg a bukaresti magyar képviseletet, majd Rubido-Zichy Iván lett a magyar követ. MARCHUT Réka: A román konkordátum a magyar diplomáciában (1920-1929). Pro Minoritate, 2014/Tél. 8.

${ }^{893}$ MNL OL K64 3. csomó 41. tétel. (Az Ellenzék c. lap megváltása - 1921. május 7.)
} 
Grandpierre Emil az alakuló ülés elött közvetlenül egy nappal terjedelmes publicisztikában fejtette ki elvárásait a Magyar Szövetség megalakításától az Ellenzékben. Megismételte korábbi gondolatát, hogy a magyarság első politikai megmozdulása nem pártot vagy politikai pártokat egyesítő szervezetet alakít, hanem a békeszerződések értelmében nemzetiségi alapú együttmüködésnek a kereteit alakítja ki. „Meddő” és „időelőtti” vitának tartotta a magyarság parlamenti részvételéről folyó diskurzust és elhibázott lépésnek Kósék júniusi kalotaszegi pártalapítását. A szövetség létrehozását nemzetközi fontosságú lépésként értékelte, amely a romániai magyarság hazai és külföldi képviseletére alakult meg. A kezdeményezés jelentőségét szerinte az sem kisebbítette, hogy a kolozsvári gyülésen a hatóságok akadályoztatása miatt nem lehetett szabályszerüen képviselve minden romániai megye magyar lakosa. ${ }^{894}$

A Magyar Szövetség nagygyülésén 1921. július 6-án a kolozsvári református teológia nagyterme zsúfolásig megtelt. A nyitóbeszédet Grandpierre Emil tartotta. A Magyar Szövetséget a Magyarországtól Romániához elcsatolt területek magyarsága számára „életszükségletének” nevezte, amely a magyarság egyetemességét jelképezte pártállásra, vallásra, osztályokra való különbségek nélkül. A szövetséget, mint szervezeti formát azzal magyarázta, hogy a „pártok érvényesülésének lehetősége nagyon korlátolt és korlátolt fennmaradásuk ideje is. [...] Pártok keletkezhetnek, pártok elmúlhatnak, de elmúlásuknak nem szabad kihatnia a magyarság egyetemes érdekeire." 895 A szervezkedés megindításáról szóló viták kapcsán megjegyezte, hogy az csak a békeszerződés magyar parlament által történő ratifikálását követően indulhatott meg. „Mi egy nagy történelmi múltú, magas kultúrájú, ösi államnak voltunk polgárai, amelyhez [...] ragaszkodtunk is kellett mindaddig, amíg hitelesen meg nem gyözödtünk arról, hogy odatartozásunk a mi elhatározásunktól független körülmény folytán megszünt." ${ }^{996}$ A Magyar Szövetség célját tekintve arra törekedett, hogy a „magyar nemzetiségi kisebbség megnyugtató elhelyezkedésének biztositása az új államkeretek között, az állam szuverenitása érdekében" megvalósuljon. ${ }^{897}$ Grandpierre báró Jósika Sámuelt kérte fel a gyülés elnöklésére. Jósika a magyar kisebbség kereteiben való összetartozást, a nemzeti kultúra fejlesztését és modernizációját, a kisebbségi jogok érvényesítését emelte ki. Javasolta, hogy a szövetség küldjön üdvözlő táviratot Ferdinánd királynak, és abban kérjék a Romániában élő nemzetiségi kisebbségek jogainak támogatását.

\footnotetext{
${ }^{894}$ Grandpierre Emil: Magyar Szövetség. Ellenzék, 1921. XLII. évf. 140. sz. július 6. 2.

${ }^{895}$ A Magyar Szövetség megalakult. Keleti Újság, 1921. 4. évf. 139. szám, július 7. 1.

${ }^{896}$ A Magyar Szövetség alakuló nagygyülése. Ellenzék, 1921. XLII. évf. 141. sz. július 7. 1. ${ }^{897}$ Uo.
} 
Zágoni István ismertette a Magyar Szövetség politikai programját, amely a romániai magyarság kulturális, gazdaság, szociális, közigazgatás és igazságszolgáltatás társadalmi alrendszerekre vonatkozó autonóm intézményes keretek biztosításának szükségét jelölte meg. Követelte a vallásszabadság tiszteletben tartását, a magyar egyházak történelmi autonómiájának elismerését, a magyar nyelvü oktatás támogatását, a helyi és törvényhatósági autonómia és az állampolgárságtól megfosztott személyek jogainak helyreállítását. Az általános, egyenlő, titkos és a nőkre kiterjedő választójogi törvény megalkotását, a választókerületek beosztásának korrigálását az etnikai határok figyelembe vételével, az összeférhetetlenségi törvény elkészítését, a választási visszaélések kivizsgálását, a politika perek és a politikai rendőrség megszüntetését. Az egyházak és az oktatás finanszírozása szempontjából a földbirtokok, az erdők és a közlegelők felosztásának tilalmát. A kereskedelem és az ipari termelés szabadságának biztosítását, a progresszív adórendszer és a közszükségleti cikkek adójának eltörlését. A kivételes hadiállapot és a cenzúra eltörlését. A hivatalokból eltávolított magyar köztisztviselők újbóli hivatalba állítását, a társadalmi egyesületektől és egyházaktól elvett ingatlanak, ingóságok visszaszolgáltatását, a magántulajdon tiszteletben tartását. A munkásszervezetek szabad szervezkedését, a sztrájkjog helyreállítását. ${ }^{898}$

Az ülés egyik legfontosabb döntése arra vonatkozott, hogy a Magyar Szövetség késznek nyilvánította magát a romániai választásokon való részvételre. Határozatot hoztak arról, hogy minden magyar nemzetiségü román állampolgárt felvetessenek a választási névjegyzékbe, amelyben több tízezer magyar neve nem szerepelt. Gyárfás Elemér zárta a felszólalók sorát. A román parlament abban az időben tárgyalta az adó-, a földbirtok- és a közigazgatási rendszerre vonatkozó reformjavaslatokat. Erre utalva Gyárfás úgy fogalmazott az új megválasztott vezetőségnek minden magyar érdekét figyelembe véve ,gondoskodnia kell arról, hogy ezután rólunk nélkülünk senki sem intézkedjék." 899

A küldöttek a gyülésen deklarálták, hogy „a romániai magyarság, mint egységes, és azonos nemzeti kisebbség egy összefoglaló, általános politikai szervezetben egyesül."900 Kifejezték az irányú igényüket, hogy 2.042.400 főnyi magyart kívánnak képviselni, beleértve a 180 ezer főnyi magyar zsidóságot is. A Keleti Újság egy érdekes, név nélküli felszólaló véleményét külön kiemelte tudósításában, amely a zsidóság magyarsághoz való lojalitását tükrözte. „Az erdélyi magyar zsidók nagy része a honfoglaló magyarokkal jött be az országba." ${ }^{901}$ A gyülésen elfogadták a szervezeti és működési szabályzatot.

\footnotetext{
${ }^{898}$ Uo. 3.

${ }^{899}$ A Magyar Szövetség megalakult. Keleti Újság, 1921. 4. évf. 139. szám, július 7. 2.

${ }^{900}$ Uo. 2.

${ }^{901}$ Uo. 2.
} 
A szövetséghez minden huszadik évét betöltött férfi és nő csatlakozhatott. A szövetség szervezeti felépítése a következő volt: nagygyülés, központi választmány ${ }^{902}$, megyei, járási és települési választmányok, illetve a központi tisztikar (elnök, ügyvezető alelnök, öt alelnök, titkár, pénztáros, ellenőr). A nagygyülés tagjai a központi, a megyei, a járási és a városi választmányok tagjaiból, továbbá a járásokból és a városokból minden ötezer tag után kiküldött két-két képviselőből állt. A központi választmány a központi tisztikar tagjaival, továbbá 60 választott rendes és 10 póttaggal müködött. A megyei választmányokat 7-7 föben határozták meg, akiket a járási és a városi választmányok választottak négy évre. A járási és a városi választmányok 15-15 tagúak voltak. Minden pozíciót nemre való különbség nélkül töltöttek be. Két nagygyülés között a központi választmány felelt a müködésért. Tagdíjról nem döntöttek, azt a központi választmány hatáskörébe utalták.

A központi tisztikar (elnökség) a következő személyekből állt: elnök báró Jósika Sámuel volt förendiház elnök, ügyvezető alelnök: dr. Haller Gusztáv volt kolozsvári polgármester, alelnökök: Ugron István volt nagykövet, dr. Grandpierre Emil volt kormánybiztos, gróf Béldi Kálmán nagybirtokos, Ferenczy Géza volt unitárius egyházi fögondnok, Albrecht Lajos bánffyhunyadi ügyvéd. Titkár: Kós Károly az Erdélyi Néppárt alapítója (egy évre vállalta a megbízást ${ }^{903}$ ), pénztáros: Ferenczy Gyula bankigazgató, ellenőr: Bányay Károly bankigazgató. (A megválasztott vezetők névsorát lásd az 6. számú mellékletben). ${ }^{904}$ A nagygyülést követően a központi választmány megtartotta első rendes ülését, ahol a szövetség építkezésének előmozdítása érdekében ún. intézőbizottságot állítottak fel. ${ }^{905}$

\footnotetext{
902 A központi választmány 70 fővel alakult meg, amely 1922 augusztusára, a vidéki szervezetek bővülésével párhuzamosan 150-re emelkedett. A Magyar Szövetség demokratizálása. Újság, 1922. XXIV. évf. 183. szám, augusztus 19. 2-3.

${ }^{903}$ Kós Károly egy évre vállalta a megbízást a következő feltételekkel, amelyet egy magánlevélben ismertetett: feleségével és négy gyermekével lakást kell bérelnie Kolozsváron, fizetési igénye 4-4500 Lei. (Egy ügyvéd átlagosan 2-2500, a Keleti Újság föszerkesztője 4000 Lei-nek megfelelő összeget keresett.) A Szövetség munkaprogramján belül önálló és független munkalehetőség biztosítását kérte. Amennyiben a Szövetség az év vége előtt megszünne, a teljes év fizetését is kérte. A személyzetét maga kívánta összeállítani.

Arhivele Naţionale Secţia Judeţeană Cluj. Fond: Familia Ugron, Nr. actului: 319. (Kós Károly levele, Kolozsvár, 1921. július 15.)

${ }^{904}$ A Magyar Szövetség megalakult. Keleti Újság, 1921. 4. évf. 139. szám, július 7. 2.

${ }^{905}$ Vezetői: Desbordes Ernő, dr. Gyárfás Elemér, dr. Inczédy-Joksmann Ödön, dr. Pál Gábor, dr. Szele Béla, Péchy Imre, dr. Sebesi János, dr. Török Sándor, gróf Bethlen György, dr. Róth Hugó, Sándor József, Szele Márton. Ellenzék, 1921. XLII. évf. 141. sz. július 7. 3.; Megalakult a Magyar Szövetség Kolozsvárott. Szabadság, 1921. 48. évf. 148. szám, július 7. 1-2.
} 
Haller a maga részéről az ülést követően a legelső feladatnak a Szövetség központi irodájának szegszervezését tekintette. A helyiség igénylésében a lakáshivataltól kellett engedélyt kérnie. Az iroda müködésében állandó személyzetre volt szükség, amelyen keresztül kolozsvári központ és a vidéki szervezetek érintkezni tudtak. Emellett müködött volna az ingyenesen igénybe vehető ún. népirodai hálózat, amely szakemberek (jogászok, hivatalnokok stb.) bevonásával a magyar lakosság jogsérelmeit gyűjtötte, majd képviselte volna. Az irodák müködését önkéntes hozzájárulásokkal kívánták finanszírozni. ${ }^{906}$

\subsubsection{Vidéki építkezés, Központi Népiroda felállítása és a Szövetség elsö memoranduma}

A nagygyülést követően folytatódott a vidéki építkezés. A Maros megyei Magyar Szövetség július 10-én, az újságok beszámolói szerint mintegy 1000 fö jelenlétében alakult meg Marosvásárhelyen. Az előkészület nem volt zökkenő mentes, mert Bernády György személye miatt politikai, legitimációs vita alakult ki. Bernády 1920-as nyílt levele az aktivitásról, a párt alakítási kísérlete és a bukaresti politikai kapcsolatai miatt a kolozsvári központ hazaárulónak, a közvélemény renegátnak tekintette. ${ }^{907} \mathrm{Az}$ Udvarhely és a Csík megyei konzervatív passzivista helyi körök és több olvasói levél írója határolódott el nyíltan Bernádytól, mert véleményük szerint nem képviselte az erdélyi magyarság többségének álláspontját a románokkal szembeni ellenállásban a békeszerződés aláírásig. ${ }^{908}$ A Keleti Újság tudósításából derült ki, hogy az ülést megelőző napon Bernády György jelölése körül vita alakult ki. Radó Sándor városi tanácsos Bernádyt ajánlotta a szövetség megyei elnökének, de az ülést előkészítő értekezlet báró Kemény Ákost támogatta. A nagygyülést Szabó György főgimnáziumi tanár nyitotta meg. Az első felszólaló dr. Hajdu István ügyvéd, a Székelyföld főszerkesztője volt. Beszédét Petru Groza székelyföldi látogatásakor tett kijelentésére való reagálással kezdte, amikor a miniszter az átmeneti időszakot leszámolási processzusnak nevezte.

\footnotetext{
${ }^{906}$ A Magyar Szövetség kiépítése felé. Szabadság, 1921. 48. évf. 150. szám, július 9. 1.

${ }^{907}$ Három politikai csoport körvonalazódott 1920-ban Marosvásárhelyen. A magyar szociáldemokraták bukaresti párttársaikkal tartották a kapcsolatot és 1920-ban már indultak volna a parlamenti választásokon, ám a román hatóságok ezt nem tették lehetővé. A másik kezdeményezés Kovács Elek lapszerkesztőhöz kötődött, aki az Építöiparosok Szövetségével karöltve a Polgári Párt felélesztését tervezte el. Megkezdte szervezkedését Bernády irányításával a sajtóban csak „húszas bizottságként” emlegetett politikai szándékú tömörülés is, amely megyei és regionális elképzeléseket tüzött maga elé. A későbbiekben ez a tömörülés alkotta a helyi Magyar Szövetség, illetve 1922-től az Országos Magyar Párt helyi szervezetének magját. FODOR, Múltunk, 2016. 2. szám, 185.

${ }^{908}$ MNL OL K610 56. csomó 3. dosszié VI. 6. (Háromszéki levél a Bernády szervezkedésről, Árkos, Háromszék megye. Brassói Lapok, 1920. október 6., Székelyföld, 1920. október 12.)
} 
„A trianoni békeszerződés jogszerüségének bekövetkeztével megszünt az átmeneti állapot, és ma a jelen sürgös követelményeként emelt homlokkal kérjük a román államtól, azoknak a jogoknak a teljességét, mely az állam polgárait megilletik, valamint azon kollektív jogokat, melyeket nekünk a román nép spontán megnyilatkozása, a gyulafehérvári határozatban elkötelezett, és amelyeket a kisebbségi jogok intézményében, a győzö hatalmak, gyözelmük erkölcsi konzekvenciájaként világszerzödésbe foglaltak." ${ }^{909}$ Grandpierre Emil a magyarság és a székelység közti egységet, a közös történelmi kapcsolatokat hangsúlyozta. Visszautasított minden irredenta vádat, amellyel a Szövetséget igyekeztek befeketíteni.

A gyülésen a helyi társadalom különböző csoportjait képviselő küldöttek is szót kaptak. Kovács Elek lapszerkesztő bejelentette, hogy a Bernády György nevéhez köthető marosvásárhelyi polgári párt testületileg belép a Magyar Szövetségbe és elfogadja annak irányelveit. A marostordai székhelyü megyei földművesek érdekképviseleti szervezete, a Székely Gazdaszövetség nevében Orbán Balázs beszélt, aki szintén csatlakozási szándékukat jelentette be. Sebestyén Balázs a helyi magyar zsidóság nevében kért szót. „A zsidó vallású magyarokról, akikhez tartozom, kívánok szólani és hitvallomást akarok tenni a magam és azon hittestvéreim nevében, akik velem egy gondolat- és érzelemvilágban élnek. Magyaroknak valljuk magunkat, mert úgy tarjuk, hogy ezt a karakter indelibilist nem a leszármazás vagy a modern szociológia nyelvén szólva, a fajiság, de legalább nem is kizáróan a fajiság adja meg az egyénnek. De ha a fajiság nem lehet megkülönböztetési alap, még kevésbé lehet az a vallás, amely az embernek az Istenhez való viszonyát, míg a nemzetfogalom az embernek embertársával való szorosabb együtt tartozását fejezi ki. [...] Lelki megnyilvánulás mindkettö, és mindkettö csupán metafizikai törvényeknek alárendelt. És amint semmi sem parancsolja rám azt, hogy milyen hitem legyen a mindenség legföbb uráról, úgy senki sem oktrojálhatja rám azt sem, hogy távol idegenben milyen nyelven elejtett szóra dobbanjon a szívem, hogy milyen nemzet fájdalmára gyüljön hamarabb könny a szemembe. [...] Szeretet, emlékezés és kegyelet az a hármas kapocs, amely minket elszakithatatlanul a magyarsághoz füz. Magyarok vagyunk, mert mások nem lehetünk és minden magyar ügynek becsületes hüséges katonái. (Percekig zúgó taps a tudósítás szerint. $)^{910}$ A szövetség megyei tisztikaráról ${ }^{911}$ a gyülés végén hoztak döntést. A megyei tagozat elnökének báró Kemény Ákost választották.

\footnotetext{
${ }^{909}$ Megalakult a marosvásárhelyi Magyar Szövetség. Keleti Újság, 1921. évf. 143. szám, július 12. 5. ${ }^{910}$ Uo. 6

911 Alelnökök: dr. Hajdu János ügyvéd, dr. Szoboszlay László nyárádszeredai ügyvéd, Kovács Elek marosvásárhelyi lapszerkesztő. A kolozsvári központi választmány tagjának választották: a teljes elnökséget, továbbá Inczédy-Joksmann Ödön, Orbán Balázs, dr. Fekete Andor, Kacsó Lajos, báró Apor József, dr. Szabó György.
} 
Ha nem is közvetlenül a Bernády-féle vitára reagált Gyárfás Elemér, minden esetre a szervezkedés során időről-időre felmerültek az egymással szemben álló felek közti sérelmekkel, ellentétes politikai pártállásokkal és világnézetekkel összefüggő politika vádaskodások. Erdélyben a magyarországi belpolitikai közbeszéddel ellentétben a bünbak keresés nem vált szerves részévé a politikai kibontakozásnak. Gyárfás Gyakorlati programmal cikkében pragmatikus hozzáállást várt el az erdélyi magyar politikai szereplőktől. Véleménye szerint a magyarság akkor lehet erős, ha nem a múltba tekint vissza, nem keres bünbakokat, nem bélyegez meg soraiban senkit sem, mert egyesek a munkapárthoz, mások a Károlyi vonalhoz vagy eltérő társadalmi réteghez tartoztak. „Kizárjuk-e azt a mágnást, aki a hadbavonult zsellér feleségét zsandárokkal hajtatta ki krumplit kapálni? Vagy bélyegezzük meg azt a hazatérő katonát, aki lerongyolódott háztáját, megbecstelenített asszonyt és éhes porontyokat találva itthon, feldúlta az első házat, melynek falai között jómódot talált? Kiknek kiáltsunk vétót?" 912

A Magyar Szövetség első politikai akciójára 1921 augusztusában került sor. Jósika Sámuel elnök, Haller Gusztáv ügyvezető alelnök és Kós Károly titkár a szövetség nevében a politikai foglyok, az internáltak szabadon bocsátása, illetve a testi bántalmazás megtiltása érdekében memorandumban fordultak a miniszterelnökhöz, az igazságügy- és a belügyminiszterhez, illetve Erdély miniszteréhez. „Legsúlyosabb sérelmünk az, amely a magyarságra alaptalan, de mindenesetre szorosan túlzott jelentöségü politikai perekkel kapcsolatosan érte és éri most is állandóan a magyarságot. Egész sereg magyar ember, férfi és nö, agg és gyermek szenved politikai bünök gyanújával terhelten a börtönben. [...] Ezenkívül nagy a száma azoknak, akiket polgári és emberi szabadságuktól internálás címén fosztottak meg a különbözö hatóságok. Sokan vannak ma is állandóan jelentkezésre kötelezve, holott az ostromállapot megszüntetése után erre a személyes szabadságot korlátozó intézkedésre több szükség nincs." 913

A Kolozs megyei politikai élet augusztusban megpezsdült. Ekkor az Erdélyi Néppárt kolozsvári gyülésének volt nagy szerepe. (Kósék pártja, Kecskeméthy István volt országgyülési képviselő vezetésével helyi pártszervezetet hozott létre.) Grandpierrék válasza sem maradt el. Felgyorsították a szervezeti építkezést. Megalakították a Magyar Szövetség Kolozs vidéki tagozatát, amely Kalotaszeg és Mócs között elterülő községeket foglalta magába.

\footnotetext{
912 MNL OL K610 56. csomó 3. dosszié. VI. 6. (Ne keressünk bünbakokat! Újság, 1921. július 22.)

913 A politikai foglyok szabadon bocsátását kéri a Magyar Szövetség. Keleti Újság, 1921. 4. évf. 167. szám, augusztus 9.3.
} 
A tudósítás szerint a 4-4500 főre becsült gyülésen többségében gazdák jelentek meg, akik között számos nagybirtokos képviseltette magát ${ }^{914}$. Györgyfalváról 200-250-en látogattak el az eseményre. Elfogadtak egy programot, amely a helyi problémák orvoslását irányozta elő: az agrárreform károsultjainak anyagi és jogi téren történő megsegítése, a vasúti szállítás fejlesztése, a szarvasmarha export megszervezése, illetve az állás nélkül maradt tisztviselők foglalkoztatása.

A felszólalók között szerepelt Grandpierre Emil, Kiss Sándor unitárius lelkész, illetve Bárdos Péter a magyarfenesi kisgazdák nevében. Bárdos lényegében Kósék néppárti programját ismételte meg, aki arról beszél, hogy a közös egységbe immár a korábban képviselet nélküli kis- és középbirtokosok is beletartoznak. A magyar társadalom fejlődése feltételéül kiemelte a fiatal nemzedékek képzését, „,hogy a bennünket itt hagyott, megapadt középosztály helyett, egy új, erös és egészséges középosztály tudjunk gyermekeinkböl nevelni."915 Lőrincz Sándor szászfenesi római katolikus esperes az egységről és a szövetség ideálisnak vélt vezetéséröl beszélt. A Szövetségről egyfelől azt gondolta, hogy rajta keresztül feloldódik az osztály és a vallási ellentét. Másfelől vezetésében akkor lehet sikeres, ha nagy tudású, becsületes vezetők kapnak helyet, mint például Grandpierre Emil. A gyűlés a helyi vezetőség ${ }^{916}$ megválasztásával ért véget.

Egy érdekes esetre is sor került a gyülésen. Kide község delegáltjai, akik alapítói voltak az Erdélyi Néppártnak nemcsak bejelentették a szövetséghez való csatlakozási szándékukat, de azt is indítványozták, hogy a Kolozs vidéki tagozat csatlakozzon Kós pártjához és a meglévő magyar szervezetek keressék az együttmüködés útját. A kidei néppártiak nevében a javaslatot Nyírő József író és Fülöp Mózes unitárius lelkész terjesztette elő. Második pontban azt kérték, hogy a Magyar Szövetség vezetői készítsenek tervezetet a területi és a nemzeti autonómia megvalósíthatóságáról. Ajánlásaikat megküldték a szövetség elnökségének, de az arra történő reakciókról nem rendelkezünk információkkal. ${ }^{917}$

\footnotetext{
${ }^{914}$ Például Zeyk Károly, volt Kolozs képviselője, báró Bánffy Albert, gróf Teleki Géza, gróf Béldy Ferenc, Gaál Elemér, Gaál Péter, Gaál Jenő, gróf Wass György, Sipos Aladár, Mélik Jeromos.

${ }_{915}$ MNL OL K610 56. csomó 3. dosszié. VI. 6. (A kolozs vidéki magyar szervezkedés. Keleti Újság, 1921. augusztus 23.)

${ }^{916}$ A Kolozs vidéki tisztikar tagjai: elnök Ferenczy Lajos birtokos, elnökhelyettesek Zeyk Károly, illetve HankóVeres Károly volt föszolgabíró.

${ }^{917}$ Uo.
} 
Kolozs vármegye a Magyar Szövetség és a magyar politikai szervezkedés szempontjából az egyik leglefedettebb terület volt. Kolozsvár központi jellegéből fakadóan ide koncentrálódott a legtöbb szellemi és infrastrukturális erőforrás. A vármegye területén belül zajló politikai küzdelmekből pontosan rekonstruálható a két magyar politikai csoport egymáshoz való viszonya. Kós júniusi pártalakítását követően a konzervatívok azonnal intenzív építkezésbe kezdtek. Az augusztusi kolozsvári néppárti rendezvényeket követően hasonlóan reagált a passzivista kör, miközben tudták, hogy Kósék nem rendelkeztek érdemi befolyással és anyagi tartalékokkal egy szélesebb körü pártpolitikai kibontakozáshoz. A Kolozs vidéki tagozat létrejöttét követően a vármegye három keleti járásában is megszervezték a Szövetséget. Teke, Sármás és Örményes járások szórvány magyarságának szervezete októberben kezdte meg müködését. Előbb külön-külön alakítottak járási szintü választmányokat, de egy közös megyei választmányt is felállítottak, amelynek elnöké Dózsa Endre nyugalmazott alispánt tették meg. 918

Torda-Aranyos megyében és Torda városban a szövetség szeptemberben bontott zászlót. $^{919}$ A szervezkedésben a helyi egyházi személyek jártak az élen. A gyülésen a vezérszónokok, Lőrinczi Dénes unitárius esperes és Dóczy Endre római katolikus esperes, a szabadságjogok érvényesüléséért vállalt politikai aktivitás fontosságáról beszéltek. Bartha Lajos református lelkész a Szövetséget a magyarság egyetemességével hozta párhuzamba, amely minden romániai magyart képvisel. „Mi, a Magyar Szövetség annak a nyíltszívü, őszinte lelkü elszakitott magyarságnak összege akarunk lenni, kiknek igaz voltáról 1000 éves diploma beszél, [...] bár el vagyunk szakitva, de itt is, ezen impérium alatt is, egy egészet képezünk."920

A Szövetség bővülésével és a vele járó megnövekedett feladatok, illetve költségek miatt a kolozsvári központ egyre inkább rászorult a budapesti kormány támogatására. Rudibo-Zichy Bukarestből azzal fordult Khuen-Héderváry Sándorhoz, hogy Budapesten irányozzanak elő plusz forrást a Kolozsvári Ellenállási Központ Vezetőség (más néven erdélyi központ) tagjai részére. A drágaság és a Magyar Szövetség szervezkedése által megemelkedett kiadások miatt tiszteletdíjukat 5000 leire emelték meg, amelyet a Bocskay Szövetség is jóváhagyott. ${ }^{921}$

\footnotetext{
${ }^{918}$ Magyar szervező gyülés Tekében. Keleti Újság, 1921. 4. évf. 218. szám, október 7. 4.

919 A megválasztott tisztikar a következőképpen állt fel. Elnök Lőrinczi Dénes unitárius esperes, alelnökök dr. Gaál Miklós, Dóczy Endre római katolikus főesperes, Bartha Lajos aranyosgyéresi református lelkész, illetve egy ügyész, egy pénztárnok és egy ellenőr. A kolozsvári központi választmányába Nagy Mózest és dr. Szenkovics Aurélt delegálták. 100 tagú választmányt alakítottak, illetve 23 fős intézőbizottságot.

${ }^{920}$ MNL OL K610 56. csomó 3. dosszié. VI. 6. (A tordai nagygyülés. Ellenzék, 1921. szeptember 1.)

${ }^{921}$ MNL OL K64 3. csomó, 41. tétel (Kolozsvári Ellenállási Központ Vezetőség tagjainak tiszteletdíja - 320.Res. 1921. augusztus 19.)
} 
Az alakuló ülés döntése értelmében a Magyar Szövetség ún. Központi Népirodája Kolozsváron, a Farkas utca 2. szám alatt csak szeptemberben tudott megnyílni. Az iroda egy éves költségvetési előirányzatát összesen 426 ezer leiben határozták meg, amely személyi, szervezeti és propaganda célú kiadásokat foglalt magába. ${ }^{922}$ A kolozsvári iroda felállítása mellett arról is döntöttek, hogy a helyi szervezetek hatékony működtetése érdekében az országban népiroda hálózatot alakítanak ki (erre vonatkozóan külön költségvetés nem készült). A központi választmány az irodákra vonatkozó ügyrendet 1921. szeptember 18-án fogadta el. Az ügyrendben foglaltak szerint a Magyar Szövetség saját funkcióját társadalomszervező és társadalomépítő szervezetként fogalmazta meg, amely a magyarság mindennapjainak ügyesbajos dolgaival és nem pusztán politikai képviseletével kívánt foglalkozni. Az ügyrend a helyi irodák feladatát a következőkben állapította meg. Alulról és felülről érkező lakossági és politikai feladatokat lát el, ahol az adott megyék és járások lakossági ügyeit feldolgozzák. A népirodák a Magyar Szövetség szellemében az „általános népjóléti érdekek” elve mentén a Szövetség minden tagjának magán és közügyekben díjtalan segítséget nyújt. Az irodák figyelmét arra is felhívták, hogy az ügyfelet tájékoztassák, ha a vélelmezett jogsérelem a bírósági eljárás keretében bizonytalan kimenetelü. Az irodák munkatársai felkért és önkéntes szaktanácsadókból és szakelőadókból állt, akik között ügyvédek, közigazgatási tisztviselők, lelkészek, tanítók és tanárok voltak többségében. A megbízatás 1-2 éves szerződésre szólt, amiért általában díjazás nem járt. Az ügyrend részletezte az ügyintézés menetét, a panaszos adatainak pontos és biztonságos kezelési módját, az ügy képviseletét az arra kijelölt törvényes fórumokon. ${ }^{923}$ De 1921-ben nem került sor a vidéki irodák felállítására a korlátozott lehetőségek és a Szövetség őszi felfüggesztése miatt.

A központi választmány szeptemberi ülésén napirendre került a júliusi program első pontja, az autonómia kérdése. Tárgyalását azért kezdeményezték, mert egyfelől kidolgozatlan volt, másfelől Paál Árpád külön, a korábbi székelyföldi autonómia tervével állt elő ismét. Paál a javaslatát Szentkereszty Béla vezette delegáció nyomására végül visszavonta, de kérte a szövetséget, hogy az autonómia tervezetben a székelység kérdése külön pontban kerüljön kifejtésre. $^{924}$

922 A Magyar Szövetség Központi Irodájának egy éves költségvetési elöirányzata. Személyi kiadások: 129.200 Lei, ebből a titkár 48.000 lei és további 5 fö. Dologi kiadások: 37.200 Lei (helységbérlet, fütés, világítás, irodaszerek, nyomtatványok), szervezeti is propaganda kiadások: 16.000 Lei (utazási költség, napidíjak, nyomtatványok), elöre nem látható kiadások: 100.000 Lei, középtávon: népirodák elöirányzata: 0, amely összesen: 426.400 Lei. Fond: Familia Ugron, Nr. actului: 319. Román Állami Levéltár, Kolozsvár

${ }_{923}$ MNL OL K63 229. csomó 27. tétel 27/4. Kisebbségi ügyek I. rész. 1922. 1922-27/4. A Magyar Szövetség Központi Irodája Cluj-Kolozsvár Farkas utca 2.; Ügyrend a Magyar Szövetség Vármegyei Népirodái részére

${ }^{924} \mathrm{Az}$ ülésen többek között megjelent egy székelyföldi küldöttség, amelyet báró Szentkereszthy Béla vezetett. A küldöttség tagjai között volt: dr. Pál Gábor, dr. Sebesi János, Szini Lajos, Csantak Vilmos, Görög Ferenc, Fröhlich 
Az égetően fontos kérdések közé tartozott az agrártörvény, amelynek kritikáját Pál Gábor vezetette fel (csíki magán javak elvétele). Azt javasolta a vezetőségnek, hogy az agrártörvény elleni küzdelem során a Szövetség partnerségre lépve az erdélyi szászokkal és a bánáti svábokkal közösen forduljon kiáltványban a királyhoz. Balázs András kanonok a készülő félben lévő oktatási törvényről beszélt, kiemelve a magyar felekezeti iskolák ellehetetlenítését (müködési hiányosságok, nyilvánossági jog megvonása, iskolabezárások). Az ülés végén a titkár egy rövid tájékoztatót tartott, ahol bejelentette, hogy szeptemberig 11 szövetségi tagozat alakult meg. ${ }^{925}$

A Hunyad megyei aktivitásról csak szalagcímben számolt be az Ellenzék. Szászváros központtal a Szövetség járási tagozatot alakított, amelyben Lózsád, Kudzsír, Algyógy, Tordos, Sebeshely és Rápost községek szórvány magyarjai vállaltak szerepet. ${ }^{926}$

A szövetség őszi felfüggesztéséig Krassó-Szörény megye Béga völgyi magyarsága kapott engedélyt a helyi szervezőgyülés megtartására. Nem megyei alakulásról volt szó, hanem egy tagozat létrehozásáról. A központi választmány képviseletében Sulyok István ismertette a szövetség célkitüzésit. Az újság tudósítása szerint az egybegyültek többségében a kis- és közepes gazda és iparos rétegekhez tartoztak. A gyülésen jelen volt Jakabffy Elemér, a Magyar Kisebbség folyóirat egyik alapítója is. Elnöknek Bakos János bodófalvi kisgazdát, helyettesének Kozka Jánost választották. A tagdíj mértékét a jövedelemmel arányos módon állapították meg. A gazdák holdanként 1 leit tartoztak fizetni, a zsellérek és a munkások évi 6 lei-t. ${ }^{927}$ Krassó-Szörény megyében, Facsád községben még egy tagozat alakult. ${ }^{928}$ A gyülést annak ellenére engedélyezték, hogy már megjelent a Szövetség felfüggesztését kimondó rendelet. A szervezésben Bakos János és Sulyok István segítettek. ${ }^{929}$

Ottó, Cs. Lázár László, dr. Nagy Jenő, illetve Marosvásárhelyről dr. Hajdú István, dr. Szoboszlay Gábor, Kovács Elek, Fekete Andor. A szövetség megyei szervezeteit képviselte: Szilágy megyéből gróf Béldy Kálmán, Péchy Imre, Brassóból dr. Szele Béla, Fogarasból Ignátz László ref. esperes, Alsófehér megyéből dr. Asztalos Kálmán, dr. Inczédy-Joksmann Ödön, Szolnok-Doboka megyéből dr. Bene Ferenc, Kis-Küküllő megyéből Kispán László, dr. Gyárfás Elemér, Issekutz Viktor. Ellenzék, 1921. XLII. évf. 205. sz. szeptember 20. 5.

${ }^{925}$ Dolgozik a Magyar Szövetség. Ellenzék, 1921. XLII. évf. 205. sz. szeptember 20. 5.

${ }^{926}$ MNL OL K610 56. csomó 3. dosszié. VI. 6. (Magyar Szövetség Hunyad megyében. Ellenzék, 1921. október 18.)

${ }^{927}$ MNL OL K610 56. csomó 3. dosszié. VI. 6. (A magyarság szervezkedés Krassó-Szörény megyében. Brassói Lapok, 1921. 204. szám, szeptember 25.)

${ }^{928}$ A tagozat élére Nemes Elemér református lelkészt, alelnököknek dr. Szabó Márton római katolikus esperesplébános és Őz Lajos kisgazdát választották meg.

${ }_{929}$ MNL OL K610 56. csomó 3. dosszié. VI. 6. (Szervezkedik Krassó-Szörény magyarsága. Ellenzék, 1921. november 5.) 


\subsection{Az Erdélyi Néppárt megalakítása és hatása a két magyar politikai csoport viszonyában}

Az aktivista és a passzivista kör között a vita nem csillapodott azt követően sem, ahogy kimondták a szervezkedés megindítását 1920-1921 fordulóján. A Keleti Újság a gyorsabb és a pártszerü építkezést sürgette. Újvárosi Miklós, volt ítélőtábla bíró véleménye szerint semmi sem támasztotta alá azokat az érveket, hogy a politikai passzivitás magatartása a román hatalom centralizációját megakadályozná, illetve az aktivitás jogfeladással párosulna. A konzervatívokat óva intette, hogy politikai elzárkózásuk tévedésben tart sokakat, mert nem a valóságnak megfelelő politikai erőt sugároz, túlbecsüli az elérhető eredményeket. A politikai aktivitás minimális előfeltételeit is meghatározta. Mielőbb szükségesnek tartotta az egyéni választó kerületi beosztás reformját, egy új és demokratikus választójogi törvényt, illetve az összeférhetetlenség szabályozását. ${ }^{930}$ Paál Árpád a helyi önkormányzatiság visszaállításával kapcsolatos feladatokat jelölte meg. Az alkotmányozás vitájában fogalmazta meg azt a demokratikus elvet, hogy az új állam kiépítésének nem felülről, hanem alulról kell történnie, tiszteletben tartva az önkormányzatiság hagyományait. Egy központosító hivatalnokrendszer ugyanis elnyomja az önkormányzat valódi önálló jogosultságát a helyi társadalom, az oktatás, az igazgatás és a gazdaság alrendszereiben. A függetlenségi hagyományokat felidőző cikk kifogással élt a megyerendszer átszervezésére vonatkozó román tervek ellen. „Történelmi, társadalmi és gazdasági összefüggéseket akarnak szétszakitani, holott ezek mind bizonyos kipróbált fejlödéseknek a színvonala. [...] Az új megyei kikerekitések nem az országrészek összeszoktatását szolgálnák, hanem fokozatosan és idö haladtával mind veszedelmesebb akadályai lesznek az állami konszolidációnak." 931

Kós Károly író, építész, Bokor Márton bánffyhunyadi református lelkész, dr. Bod László, dr. Kapdebó Szilárd és dr. Nagy Miklós ügyvédek vezette csoport 1921 májusában a román belpolitikai vitákban való teljes részvételt és a parlamenti aktivitást szorgalmazók nevében elszánták magukat a pártalapításra. A Keleti Újság beharangozójában Egy lépéssel elöbbre című cikk a döntést közvetlen kiváltó okot a földreformmal indokolta. „Föerénye a leendö pártalakulásnak, hogy van maga elé kitüzött, sem jobbra, sem balra nem kacsingató erdélyi programja. [...] Az Erdélyi Néppárt egyik lényegbevágó program pontja a földkérdés rendezése." $932 \mathrm{Az}$ alapvetően progresszív szemléletű kisgazda programmal előálló párt az erdélyi magyar kis- és közepes gazdákat, a városi kisebb egzisztenciával rendelkezőket, illetve a munkásságot kívánta megszólítani az erdélyi gondolat ideológiája mentén.

930 Újvárosi Miklós: Hozzászólás a politikai aktivitás kérdéshez. Keleti Újság, 1921. 4. évf. 103. szám, május 22. 4. ${ }^{931}$ Gyönge falak. Keleti Újság, 1921. 4. évf. 108. szám, május 29. 1. 932 Uo. 
A pártot nem feltétlenül etnikai alapon kívánták megszervezni. „A kalotaszegiek pártja nem kizárólagosan magyar párt. Olyan programot ad, amelyet maga elé tüzhet bármilyen fajú, felekezetü erdélyi nép." 933 A magát demokratikus néppártként aposztrofáló kezdeményezés elutasította a cárizmust és a kommunizmust, ellenben programelvének az egyéni és a kollektív szabadságjogokat tüzte zászlajára. Az előkészítő bizottság 9 pontban foglalta össze a népgyülés programtervezetét. 1) Erdély az erdélyi nemzeteké. 2) A gyulafehérvári határozatok III. 1.2 pontjának sürgős végrehajtása (minden nemzet önmagát kormányozza, amely a közigazgatási, a bíráskodási és az önkormányzati autonómiában testesül meg.) 3) Az alkotmányos közszabadságok helyreállítása. 4) Leszerelés. 5) Munkaszabadság és munkásvédelem. 6) A birtokminimum és a maximum megállapítása, ezen belül a tulajdonjog egysége, az összes nemzetekre nézve egyenlően igazságos földreform. 7) Progresszív adózás, a monopóliumok megszüntetése. 8) Az ipar és kereskedelem szabadsága. 9) Általános, titkos szavazójog a nemzetek szerinti kerületekkel és lajstromokkal. ${ }^{934}$

Az Erdélyi Néppárt alakuló nagygyülésére 1921. június 5-én, Bánffyhunyadon került sor. A gyülésen megjelent Sándor József, az EMKE képviseletében, Josip Pop főszolgabíró és a rendőrség fönöke is. ${ }^{935}$ Megnyitóbeszédet Bokor Márton mondott. Kifejezte, hogy a békeszerződés tudomásul vételét követően a magyarság kész részt venni a közügyek intézésében, az állami konszolidáció politikai munkájában. „Nekünk, erdélyi magyaroknak el kell helyezkednünk az új állam keretei között. [...] Első feltételünk nemzeti kisebbségi jogainknak teljes elismerése és biztositása. Ennek a céljából olyan szervre van szükségünk, mely politikai tárgyalásokat kezdhet és folytathat. Ezért midön a Magyar Szövetség kalotaszegi tagozatát megalakitjuk, politikai párttá és meg kell alakulnunk, hogy megbizottaink a néptöl nyert politikai megbizást is kezdeményezhessenek."936 Ezt követően Kós Károly a háború tapasztalatából és nem a békeszerződésből kiindulva ismertette a szervezkedés célját és indokát. A háború gazdasági romlást hozott magával, ahol az árak az égbe szöktek, az infláció és a spekuláció aláásta a munkabecsületét, a munkabérek nem elégítették ki a dolgozó kezeket, sem a munkásét, sem a tisztviselőét.

\footnotetext{
933 Uo.

934 Kalotaszeg megmozdult. Keleti Újság, 1921. 4. évf. 109. szám, május 31. 4.

${ }^{935}$ Kalotaszeg falvaiból az érdeklődők tömegesen érkeztek szekereken, vonaton és gyalogosan. A távolabb eső közösségek négy-öt küldöttel, a közelebbiek akár ötven-kétszáz fővel is képviseltették magukat. Magyarvista, Türe, Makófalva, Darócz, Bojértelke, Egeres, Kis- és Nagypetri, Zsobok, Váralmás, Kelecel, Bikal, Körösfö, Gyerővásárhely, Inaktelke, Kis- és Nagykapus, Nyárszó, Magyarókerék, Bábony, Farnos, Sárvásár, Magyarvalkó, Jakótelke, Kalotaszentkirály, Zentelke, Sztána, Hídalmás, Középlak, Magyargyerőmonostor, Dormos, Bánffyhunyadról stb. településekről számolt be a sajtó. Zászlóbontás Kalotaszegen. Keleti Újság, 1921. 4. évf. 115. szám, június 7. 1.

${ }^{936}$ Uo. 2.
} 
A vámok és a nyersanyag magas ára nyomorba döntötte a vállalkozásokat. A földreform mielőbbi megalkotását az emberi igazságok egyikének nevezte, amely a „régi, feudális igazságtalanságok végleges temetője kellene, hogy legyen.” Az önkormányzati rendszer visszaállítását követelte, amelyet az új hatalom hónapok alatt felszámolt. Megszünt a régi közigazgatási rendszer, benne a vármegyével, a városi törvényhatósági bizottságokkal, a bíró, a jegyző, a szolgabíró, az alispán és a polgármester intézményeivel egyetemben. Kárhoztatta a cenzúrát és azt, hogy megakadályozzák a gyülekezési és az egyesülési jog szabad gyakorlását. A gyülés utolsó felszólalója Major József kereskedő, baptista elöljáró volt, aki egy heti politikai néplap elindítását, illetve egy népiroda és ingyenes jogsegélyszolgálat felállítását szorgalmazta. A gyülés záró aktusaként elfogadták az előzetesen meghirdetett kilenc pontos javaslatot, illetve felállítottak egy szervező bizottságot a párt kiépítésére. ${ }^{937}$

A kalotaszegi kezdeményezés a két magyar politikai tömörülés között tovább mélyítette a feszültséget. Az Ellenzék éles kritikával illette Kósékat. Nemcsak a parlamenti részvételre irányuló felhívásukat utasították el, hanem magát a pártalapítást is. A konzervatívok szerint a Néppárt nem a 60 ezer kalotaszegi magyar érdekét, hanem egy szűk csoport célját szolgálta. A pártalapítás ugyanis a két csoport között megkötött Magyar Szövetségre vonatkozó januári paktum felrúgásával volt egyenértékü. Kósékkal szemben azt is felrótták, hogy társadalmi feszültséget generálnak a magyarságon belül. A passzivista csoport tagadta ugyanis azt a néppárti állítást, hogy Erdélyben erősen jelen lett volna a feudalizmus intézményrendszere. „Erdélyben sohasem volt erös feudalizmus, agrárfeudalizmusról pedig a birtokreform és a kényszerbérletek után szó sem lehet, a magyar társadalom egyes osztályai között tehát nincsenek olyan súlyos érdekellentétek, amelyek lehetetlenné tennék egy egységes magyar program megalkotását." 938 A Keleti Újság ezzel az érveléssel szemben egy teljesen más álláspontot képviselt. Paál Árpád vezércikke a következőképpen üdvözölte a pártalakítás hírét: „a Magyar Szövetségnek is helyi tagozata, de azonkivül mélységes forrása Erdély népei céltudatosságának és önálló irányának.

\footnotetext{
${ }^{937}$ A szervező bizottság tagjai. Elnök: Albrecht Lajos ügyvéd, ügyvezető alelnök: Bokor Márton ref. lelkész, ügyvezető jegyző: Tolcsvai Lajos ügyvéd. Tagok: Pócs Márton, Lakatos András, Varga Márton, Makfalvi János, Csöregi András tanító, Tordai József, Bokor Márton mészáros, Nagy Ferenc, Budai János, Majos József, Csoma Sándor, dr. Bod László, dr. Kapdepó Szilárd, Nagy Miklós, Tóth Ferenc, Pap András bíró, Vincze Ferenc, Kudor Márton, Betlendi Márton, Buzás Pál Bunffyhunyadról. Kalotaszeg többi községeiből Ágoston Palkó János, Tulogdi János, Ábrahám János, Jakab Gazsi János, Fekete Bíró Ferenc, Kós Károly, Imre József, Bányai László, Gelli Gyula, Császár Gábor, Hatfaludi Ferenc, Korpos B. János, Varga Gáspár, Káló Bandi János, Kolcsár Márton, Vince Pál István, Pitroff József, dr. Szentiványi József. Zászlóbontás Kalotaszegen. Keleti Újság, 1921. 4. évf. 115. szám, június 7. 1.

${ }^{938}$ Kalotaszegi pártalakítás. Ellenzék, 1921. XLII. évf. 113. szám, június 2. 2.
} 
Nemcsak helyi jelentöségü mozgalom, hanem az egész romániai magyarság számára is lenditö erő, Erdély minden népei számára is útmutatás, az államalakulás számára is a népakarat teremtö közbelépése." 939

A Magyar Szövetség júliusi megalakításában a néppártiak közvetlenül részt vettek, illetve pozíciókat kaptak a felek között fennálló viták ellenére is. A Kiáltó Szó megfogalmazói, Kós Károly a szövetség titkára, Zágoni István és Paál Árpád a központi választmány tagjai lettek.

Az Erdélyi Néppárt tovább folytatta építkezését és augusztusban megtartotta kolozsvári előkészítő ülését. Kecskeméthy István volt függetlenségi párti országgyülési képviselő, teológia professzor és Szathmáry Ákos kollégiumi tanár nyílt levélben jelentették be, hogy Kolozsváron egy demokratikus polgári pártot kívánnak alakítani, amely a kalotaszegi Erdélyi Néppárthoz csatlakozik, azzal a feltétellel, hogy a „közös nemzeti céljaink kiküzdése céljából feltétlenül alávetjük magunkat a Magyar Szövetség pártokon felül álló politikai vezetésének."940

A párt előkészítő ülésére Kolozsváron, a Honvéd utca 53. szám alatt, Gombos Mihály udvarában került sor, ahol a Keleti Újság beszámolója szerint közel 250 fő vett részt. A közönségben kisgazdák, iparosok, kereskedők voltak többségében. Köszöntő beszédet Szathmáry Ákos mondott, aki kijelentette, hogy „kötelezönek fogadják el a Magyar Szövetség programját és szabályait, de szükséges a szövetség keretein belül egy mozgékonyabb, demokratikus alapon álló pártot is alakitani." ${ }^{\text {"41 }}$ Kecskeméthy vette át a szót, aki úgy fogalmazott a Magyar Szövetségröl, hogy „ebben a pillanatban csak egy ékes tetőszerkezet, amelynek tartó falakra, bástyákra, a népre szüksége van, e nélkül hiába a csillogó érckakas a vártorony tetején. Várharcot nem lehet megvívni mozgékony védőcsapatok nélkül." "942 Külön kitért az aktivitás és passzivitás vitájára, amire azt felelte, hogy az erdélyi magyarságnak fel kell készülnie a román országgyülési választásokon való részvételre, amelyhez az Erdélyi Néppárt segítséget nyújt.

Ütő Sándor igazgató-tanító ismertette a határozati tervezetet a Magyar Szövetséghez való csatlakozásról. Döntöttek arról, hogy továbbítsák politikai követeléseiket a Szövetség központi választmányához: állampolgári jogok érdekérvényesítése, a városi önkormányzat újjászervezése, a gazdasági és a kulturális életben való képviselet biztosítása. Határoztak a kolozsvári párt létrehozásának szándékáról is.

\footnotetext{
${ }^{939}$ Az alakuló nagygyülés. Keleti Újság, 1921. 4. évf. 115. szám, június 7. 1.

${ }^{940}$ Kolozsvár polgársága szervezkedik. Keleti Újság, 1921. 4. évf. 170. szám, augusztus 12. 5.

${ }^{941}$ Szervezkedik Kolozsvár magyarsága. Keleti Újság, 1921. 4. évf. 173. szám, augusztus 16. 2.

${ }^{942}$ Uo.
} 
„A szervezkedés a népjólét és népjövö kívánságai szerint a valódi demokrácia tiszta alapjaira helyezkedik, s ez alapon szükségesnek tartja, hogy érdekképviseleti tevékenység szempontjából magát politikai pártnak és nyilvánitsa s pártkört alakitson. Új pártot a szövetség keretében nem akar csinálni, mert a kalotaszegi magyarság szervezetében megtalálja az azonosan demokratikus politikai alapelveket." "943 Zágoni programbeszédével ért véget a gyülés. A centralizáció leállítását, az egyéni jogok alkotmányos és az általános választójog biztosítását, az önkormányzati testületek autonómiájának helyreállítását, a cenzus eltörlését, illetve az erdélyi nemzetek részére önkormányzati jogokat követelt. Együttmüködést kért a gazdasági és a politikai élet szereplőitől a kereskedelem, a szabad áru- és vasúti forgalom szabadságának helyreállítása érdekében. A gazdasági élet fellendítése kérdésében a banki kamatok nagyságának csökkentését, a kereskedelmi és a gazdasági egyesületek, társaságok autonómiájának tiszteletben tartását, a munkás szakszervezetek szabad szervezkedéshez való jogát kérte. Az állami redisztribúció progresszív és arányos elosztása mellet foglalt állást. A magyarság közteherviseléséböl befizetett adók kapcsán megjegyezte, hogy azok kerüljenek vissza a magyar oktatási, kulturális és gazdasági életbe vérkeringésébe. Tiltakozott a lakosságot negatívan érintő lakás rekvirálások ellen. A választói névjegyzék azonnali kiigazítását kérvényezte, hogy minden magyar nemzetiségü román állampolgár élhessen szavazati jogával, mert a választói névjegyzékből a magyar választók 70-80\%-át kihagyták. ${ }^{944}$

Néhány héttel később újabb néppárti gyülést szerveztek Kolozsváron, a Kétvízköz városrészben. Barthos Sándor gazda, volt törvényhatósági képviselő szervezte meg a találkozót, ahol részben gazdák, kereskedők, iparosok és munkások is elmentek. A felszólalók között volt Szathmáry Ákos, Zágoni István, illetve Kecskeméthy István. Mindhárman a szövetség lokális, alsó szinten történő építését tartották fontosnak. Kecskeméthy nem hagyta szó nélkül a pártjukat ért támadásokat. Leszögezte ismét, hogy a Néppárt tagja a Magyar Szövetségnek, amelyet elismertek a magyarság legfőbb képviseleti szervének. A Néppárt szerepét azzal jellemezte, hogy a magyar társadalom korábban nem képviselt rétegeit integrálja a szövetséggel való együttműködésben. „A Magyar Szövetség, mint elmélet nem képvisel erőt, az erőt, a súlyt és a hatékonyságot a nép tudja adni neki."

\footnotetext{
${ }^{943}$ Uo.

${ }^{944}$ Uo. 3.

${ }^{945}$ MNL OL K610 56. csomó 3, dosszié. VI. 6. (Kolozsvár szervezkedik. Tizedgyülés a Kétvízköz városrészben. Keleti Újság, 1921. augusztus 23.)
} 
Arra a kritikára, hogy a pártpolitikai szervezkedések károsak úgy felelt: „amennyiben elfogadják a szövetségnek az alapelveit, azok érlelik ki az igazi politikai programot." "446 (A sajtóban a párt neve négy féleképpen olvasható: Erdélyi Néppárt, Magyar Néppárt, Erdélyi Magyar Néppárt, illetve Néppárt.)

A konzervatív passzivista kör Kósék kolozsvári lépését a magyarság politikai egységének megbontásaként értékelte. Az Ellenzék több cikkben foglalt állást a pártalakítás ellen, illetve az egységes vezetés kívánalma mellett. Érvelésük arra vonatkozott, hogy a Magyar Szövetség megalakításával a többség elfogadta a pártokon felüli szervezkedés irányelvét. „S $a$ bánffyhunyadi pártalakitással kapcsolatosan tiltakozott az ellen, hogy egy agresszív kisebbség, kizárólag saját pártérdekei szolgálatában, pártokra szaggassa szét az egységes magyarságot és meggátolja a nemzeti kisebbség pártokon felül álló egységes kisebbségi szervének megalkotását." 947 A hírlapi cikk Kósékat „radikális, progresszív csoportként” aposztrofálva azzal kritizálta, hogy osztályérdeket képviselnek. Továbbá azt kifogásolta, hogy nem fogadták el azt az irányelvet, hogy a pártalakítás kérdésében a szövetség jogosult dönteni, ha és amennyiben időszerünek látják a parlamenti részvételt. „Románia mai alkotmányos élete semmi esetre sem alkalmas arra, hogy a nemzeti kisebbségek a siker kilátásával vehessenek részt abban." 948

Kós az Ellenzéknek adott interjúban elmondta, hogy a szövetség direktóriumának ülésén előzetesen bejelentette, hogy az Erdélyi Néppárt a Magyar Szövetség keretein belül politizál. Jósika az ominózus ülésen azt felelte Kósnak, hogy tudomásul veszi a kezdeményezést, mert a párt a megszabott kereteket nem lépte túl. A vezetőség többsége ellenben nem fogadta el ezt az érvelést és az Ellenzéket már arról tájékoztatta, hogy a titkár kivételével a pártalakítás ellen foglaltak állást. ${ }^{949}$ A konzervatívok azzal érveltek, hogy a pártalakításnak nem jött el az ideje és megbontja a magyarság egységét, mert minden osztály, érdekcsoport saját pártot kíván majd alakítani. A szövetségen belül ezért sem támogatták azt, hogy egy párt többlet lehetőségekkel és szervezetileg helyet kapjon a szövetségen belül. Visszautasították azt a vádat, ami arról szólt, hogy azért nem támogatták az Erdélyi Néppártot, mert a demokratikus értékek ellenségei lennének. „Szabad lesz talán a gyanúsitók szives figyelmébe ajánlani azt, hogy mi a konzervatív vagy bármely más párt megalakitását épp úgy elitéljük, mint a Néppártét.

\footnotetext{
946 Uo.

${ }^{947}$ Késik a kolozsvári szervezkedés. Ellenzék, 1921. XLII. évf. 173. szám, augusztus 13. 2.

${ }^{948}$ Uo.

${ }^{949}$ A Magyar Szövetség nem akar pártot. Ellenzék, 1921. XLII. évf. 177. szám, augusztus 18. 2.
} 
Mi egyelöre a Magyar Szövetséget akarjuk a legdemokratikusabb alapon kiépiteni. [...] Gondosan kerülni akarjuk, hogy a Szövetséges politikai küzdelmekbe sodorjuk."950

A konzervatívok a parlamenti aktivitás ellen két fó érvet hoztak fel. Egyrészt, hogy amíg nem volt Romániának elfogadott alkotmánya és választójogi törvénye, amelyek tisztázták és garanciákat biztosítottak a kisebbségek jogi helyzetére vonatkozóan, addig lehetetlen a parlamenti többséggel szemben bármilyen ellenőrző és érdekérvényesítő politikai munkát végezni. ${ }^{951}$ Másrészt a szervezettség alacsony foka és a fokozatosság elve jelent meg. „A magyarság ma még teljesen szervezetlenül áll, mert hiszen azelött társadalmi szervezkedését teljesen elhanyagolta, minden életmegnyilvánulása az állami közösség keretében folyt le. Elsö feladatuk társadalmi úton tömörülni, a magyar nyelv, müvelödés, szellem és faji érdekeink megvédelmezésére." 952

Az Erdélyi Néppárt soron következő gyülésére 1922. január 15-án került sor Kolozsváron, miután a Magyar Szövetség müködését 1921 őszén felfüggesztették, illetve a román kormány lemondott, és 1922. márciusára parlamenti választásokat írtak ki. A néppárti gyülés célja a magyarság egy pártban történő összefogására és a parlamenti választásokra való felkészülésre irányult. A megnyitó beszédet Szathmáry Ákos tanár mondta, aki a megváltozott belpolitikai viszonyokkal és a politikai képviselet megteremtésével indokolta a politikai szervezőgyűlést. Paál Árpád programbeszédében a magyar nemzeti közösség saját erejéből történő építkezés fontosságára és az állami életben való részvételre hívta fel a figyelmet. „Nemcsak az államtól, nemcsak a kormányzó, a többségi nemzettöl kell várni a kezdeményezést, hanem a magunk részéröl is bele kell szólanunk, hogy ez a kialakulás [román állam - F. N.] ne ellenünk, ne a haladás ellen való legyen." ${ }^{953}$ A részvétel formája körül kialakult konfliktusról azt mondta, hogy nem lehet fennakadni akkor sem, ha a Magyar Szövetség müködését felfüggesztették. Véleménye szerint, ha a szövetség müködött volna is, képletesen az mozgó karok és lábak nélkül életképtelen. A szövetség akadályoztatása miatt ezért pártot kellett létesíteni, amely tartalmát tekintve politikai eszköz és nem cél. A passzivista és az aktivista politikai csoportok közti különbségeket is megemlítette, de a közös célt, a nemzeti egység vízióját nem vitatta el. „Lehetnek eltérések a módszerekben, de a célban mindig egyek vagyunk. Vannak, akik felülröl gondolnak kiterjeszkedni a néprétegek felett, ezek az arisztokraták. A mi eszközeink azonban teljesen mások.

\footnotetext{
${ }^{950}$ Nincs szükség pártokra. Ellenzék, 1921. XLII. évf. 179. szám, augusztus 20. 3.

${ }^{951}$ A politikai aktivitás. Ellenzék, 1921. XLII. évf. 182. szám, augusztus 24.1.

952 Szervezni kell a magyar társadalmat. Ellenzék, 1920. XLI. évf. 213. szám, október 13. 1.

${ }^{953}$ Megalakult az Erdélyi Magyar Néppárt. Keleti Újság, 1922. 5. évf. 11. szám, január 17. 1.
} 
Mi a földböl, a népböl meritjük erőinket, demokratizmust akarunk nemcsak a magyar nép, de a románok, szászok, zsidók részére is. " ${ }^{54}$ A pártprogramot Kós Károly ismertette. 1) Románia decentralizációjának igényét az „Erdély az erdélyi nemzeteké” jelszóval világította meg. 2) A gyulafehérvári határozatok végrehajtását és a vallásszabadság gyakorlását, 3) A közoktatás és a kulturális élet intézményeinek a nemzeti autonómia jogkörébe való besorolását, 4) A nemzetközi szerződések értelmében a politikai és az állampolgári egyenlőség és szabadságjogok tiszteletben tartását, 5) Az erőszakos katonai besorozás megszüntetését, illetve a magyar katonák Erdélyben történő állományba vételét követelte. 6) A szabad kereskedelem és az ipar helyreállításával oldotta volna meg a leromlott gazdasági életet. 7) A földbirtokreform igazságos végrehajtását, illetve a magyar telepesek és a csíki magánjavak visszaszolgáltatását igényelte. 8) Munkások szociális és jogi védelmének kiterjesztését, illetve a szakszervezeti jogok biztosítását óhajtotta. Kós Károly: „Kívánjuk, hogy a munka és tőke örök harcába a hatalom ne avatkozzon bele." ${ }^{55}$ 9) Progresszív alapú adótörvény mellett foglalt állást. A magasabb adókulcs kivetését a nagy vagyonokra és nagyjövedelmekre elvét támogatta, illetve a hadinyereség útján és a törvénytelenül megszerzett javak elkobozhatóságát. Alapszükségletnek számító árucikkek fogyasztási adójának és minden kereskedelmi monopólium eltörlését pártfogolta. A gyülés végén elfogadták a pártprogramot, illetve megválasztották a párt új elnökét, az egykori függetlenségi (Kossuth-) párti képviselőt, Kecskeméthy Istvánt és az elnökséget ${ }^{956}$ A pártiroda helyiségét dr. Nagy János kolozsvári ügyvéd ajánlotta fel a Mátyás király tér 19. szám alatt. ${ }^{957}$

Az ülésen nagy feltűnést keltett jelenlétével báró Jósika Samu és Sándor József. Az Ellenzék interjút kért Jósikától, hogy miért volt jelent a gyülésen és mi a véleménye a pártalakításról. A báró korábbi véleményét fenntartva nemcsak nem ítélte el az Erdélyi Néppártot, hanem Paál által felvázolt egységes fellépéssel is egyetértett. A magyarság egységét hangsúlyozta, illetve, hogy az Erdélyi Néppártnak „,bele kell olvadnia - annak megalakulása után - az egységes magyar nemzeti pártba." 958 Jósika itt minden bizonnyal az 1922. január végén megalakult Magyar Nemzeti Pártra utalt Grandpierre vezetésével, amely akkor már szervezés alatt állt.

\footnotetext{
954 Uo.

955 Uo. 2.

${ }^{956}$ Elnök: dr. Kecskeméthy István, alelnökök: Szathmáry Ákos, dr. Paál Árpád, Ferenczy Gyula, Mestitz Ferenc, Hevesi József, Szilágyi András, Ráthy Károly, titkárok: dr. Zágoni István és Kós Károly. Uo. 3.

957 A Magyar Néppárt. Keleti Újság, 1922. 5. évf. 147. szám, július 5. 5.

${ }^{958}$ Megalakult a Magyar Néppárt. Ellenzék, 1922. 43. évf. 12. szám, január 17. 1.
} 


\subsection{A Magyar Szövetség müködésének elsö felfüggesztése, 1921 ösz}

A Szövetség politikai tevékenységének felfüggesztését kimondó novemberi határozatot közvetlenül megelőzte a Jósika-ügy. Mária román királyné kolozsvári látogatása tiszteletére színházi estélyt szerveztek októberben, ahová meghívást kapott báró Jósika Sámuel is. A báró az invitálásnak nem tett eleget arra hivatkozva, hogy egészségi állapota megromlott és nem kapott hivatalos formában értesítőt. ${ }^{959} \mathrm{Az}$ etikett kérdéséből politikai botrány kerekedett, amely a szövetségen belül és a román-magyar viszonyban is konfliktusokat eredményezett.

A szövetség vezető tagjai megosztottak voltak az ügyben, amely a fennálló két politikai tábor szembenállását csak tovább mélyítette. Kós Károly reakciója volt a legélesebb, amikor titkári megbízatásáról lemondott. Indoklásában azt állt, hogy a bizalom és az együttmüködés légköre nem volt meg a Magyar Szövetség elnökségében. ${ }^{960}$ A központi választmány többsége, a konzervatív szárny közleményben reagált, amelyben tudomásul vették Meţhes prefektusnak írt Jósika levél tartalmát. A báró úgy értelmezte a meghívást, hogy azt magánszemélyként és nem elnökként kapta, ezért azt nem továbbította a szövetség felé sem. ${ }^{961}$ Egy későbbi Jósika interjúból tudjuk azt, hogy a báró politikai szempontból mérlegelte a látogatás kérdését. A Keleti Újság kérdésére, hogy miért nem ment el a színházi estére, a báró azt válaszolta: „Nem is kell mondanom, hogy egész életétemben monarchisztikus érzelmü voltam és tudom, hogy mivel tartozom a királyi ház iránt. Éppen ezért irtam abban az ominózus magánlevélben, hogy egyelöre nem látom elérkezettnek az időt a megjelenésre, mert tudom, hogy akár elmegyek, akár nem, egy vagy más oldalról nyilvános megvitatás tárgya lesz."962

A román politikai reakciók rendkívül ellenségesek voltak a Jósika-ügyben, amely politikai tartalmát tekintve valójában a Magyar Szövetség ellen irányult. A Keleti Újság interjút kért Meţhestől, aki a következőképpen fogalmazott: „A magam részéről azt hiszem, hogy Kós Károly és a balszárny visszavonulásával a szövetség a mai összetételében nem prosperálhat. Mi nem ismerhetjük el, hogy a szövetség jelenlegi vezetösége képviselné azt az erdélyi magyarságot, amely alaptermészeténél fogva a demokratikus irány felé hajlik. [...] Jósika azt mondja, hogy beteg és ezért nem jár színházba, de a politikai helyzetet sem tartja alkalmasnak, hogy megjelenjen a királyné elött. A Jósikának bizalmat szavazók pedig kijelentik, hogy Jósika, mint magánember írta a levelet. Nyíltan megmondom: én ebben provokálást látok."963

\footnotetext{
${ }^{959}$ A Magyar Szövetség válsága. Keleti Újság, 1921. 4. évf. 218. szám, október 18. 1.

${ }^{960}$ Kós Károly lemondott. Keleti Újság, 1921. 4. évf. 231. szám, október 22. 4.

${ }^{961}$ Bizalmi nyilatkozatok. Keleti Újság, 1921. 4. évf. 231. szám, október 22. 1-2.; A királyné látogatás epilógusa. Ellenzék, 1921. XLII. évf. 229. szám, október 18. 4.

962 Interjú Jósika báróval. Keleti Újság, 1921. 4. évf. 245. szám, november 8. 4.

963 Román sajtótámadások a Jósika-ügy miatt. Keleti Újság, 1921. 4. évf. 228. szám, október 19. 2.
} 
A Román Nemzeti Parasztpárt lapja a Patria a Magyar Szövetség feloszlatását követelte a kormánytól. Voinţa: „A kormány tehát jónak látja a kisebbségek képviselöit meghívni, de a szövetségük elnöke, a budapesti förendiház nyakas mágnása, elutasítja a meghívást. Azaz mi vagyunk, akik közelednek és ök azok, akik elutasitanak. Az ügy távolról sem csupán Jósika báróé. Nem magánügye, mert nem, mint magánember kapott meghívást és nem, mint ilyen utasitotta azt vissza." ${ }^{964}$ Octavian Goga miniszter is megszólalt, aki azt mondta, hogy „A királyné kolozsvári látogatásának nem volt politika jellege. Meghívtuk Jósikát, mint a Magyar Szövetség elnökét, de ö nem jött el. [...] Én mindig védelmezöje voltam a kisebbségek ügyének, de Jósika báró elrontotta egy kissé a dolgot." $" 965$

Meţhes prefektus 1921. október 31-én kiadott rendeletében felfüggesztette a Magyar Szövetség müködését. A rendőrség a kolozsvári központi iroda helyiségeit lezárta és lepecsételte, illetve az irattárát lefoglalta. A Szövetség felfüggesztését a Szigurancia és Kolozsvár polgármesterének jelentéseivel indokolták. A Magyar Szövetség alakuló ülését megelözően az alapszabály-tervezetét nem nyújtotta be a kormánynak a belügyminiszter 1873/1394., az 1875/1508 és az 18981136. évi rendeletek elöírásainak megfelelően, ellenkező esetben tilos egyesületnek minősíteni. A rendőrség kihallgatásra beidézte Jósika Sámuelt, Grandpierre Emilt, Szele Márton, Ugron Istvánt, Sándor Józsefet, Róth Hugót és Tóth Györgyöt. Meţhes a döntését a következőkben részletezte, aki elmondta, hogy a Jósika-ügy és a vezetőség nyilatkozatai vezették ahhoz az elhatározásához, hogy a Szövetség ügyeibe betekintsen. A polgármesteri hivatalhoz, a Sziguranciához és egyéb hivatalokhoz fordult azzal a kérdéssel, hogy a szabályoknak megfelelően müködik-e a szervezet, amire azt a választ kapta, hogy az alapszabály másolatait egyetlen hivatal sem látta. Előzetesen pedig csak gyülések engedélyéhez járult hozzá, ami nem azt jelentette, hogy a Magyar Szövetség bejelentett egyesületként müködhetett. ${ }^{966}$ Ez a szituáció abból a joghézagból fakadt, hogy a Szövetség nem párt volt (nem kellett engedély, mert a magyar szabályok voltak még érvényben), de egyesületként a szabályok előírták az alapszabály engedélyeztetését. Jósika az eset után felkereste Tanasescu államtitkárt, aki megerősítette Meţhes állítását, hogy a szövetség a belügyminiszterhez elmulasztotta jóváhagyásra benyújtani alapszabályát és programját. ${ }^{967}$

\footnotetext{
${ }^{964}$ Uo.

965 Goga miniszter a Jósika ügyröl. Keleti Újság, 1921. 4. évf. 235. szám, október 27. 5.

966 Felfüggesztették a Magyar Szövetség müködését. Ellenzék, 1921. XLII. évf. 242. szám, november 2. 1.; A Magyar Szövetség müködését betiltották. Keleti Újság, 1921. 4. évf. 239. szám, november 1. 3. ${ }^{967}$ Uo. 7.
} 
A rendőrségi eljárás során azt hozták fel vádként, hogy minden jóváhagyás nélkül pénzt kezelt, határozatokat hozott, irodákat müködtetett, amely abban a formában ellenőrizhetetlen volt az állam részéről. Jósika elmondta, hogy a fennálló törvények értelmében a Szövetség jogosan müködött, a müködéshez szükség engedélyt a belügyminisztertől megkapták, amit a hadiállapot miatt Petala tábornok is megerősített. A szövetségnek alapszabálya nem volt, csak szervezeti szabályzata, amelyet az irattárban tartottak. Pénzgyüjtő akciókat nem indítottak, mert az arra vonatkozó engedélyt nem kapták meg. Jósika írásos deklarációt is átadott Filipescu rendőrkapitánynak. A beadvány tartalma Grandpierrék és Kósék szervezeti formára vonatkozó vitájában érdekes fordulatot hozott. A báró a szervezeti szabályzatra, de a gyakorlatra és a nyilatkozataira hivatkozva azt mondta, hogy a szövetség ,nem egyesület, hanem a romániai különbözö magyar politikai pártok egyesítö szerve, a pártok országos pártja. Mint ilyen nem is készithetünk alapszabályokat, mert erre a pártok, sem a magyar, sem a regáti törvények által nem köteleztetnek. Alapszabályok nélkül, csupán saját használatra szánt házi szervezeti szabályok szerint müködtek kivétel nélkül az összes országos pártok," mint például az 1918 előtti magyarországi pártok, beleértve a németekét és a románokét is. ${ }^{968}$ Érvelésében hangsúlyt kapott az 1919. évi kisebbségi egyezmény. Jósika azt úgy értelmezte, hogy minden korábbi törvénnyel szemben a nemzetközi szerződés az elsődleges irányadó jogszabály, amely szerint a volt magyar belügyminiszteri rendelet hatályát vesztette. ${ }^{969}$

A prefektus a nyomozás eredményét decemberben közölte, és a Szövetség betiltását kérte a belügyminisztertől. Az ügyben Meţhes járt el, aki szerint a betiltást „az állam törvényei által elöirt formák be nem tartása idézte elö. [...] Kétségbe vonhatatlan, hogy a romániai magyarságnak nemzetiségi jogai vannak és követelési vannak. [...] De a politikai küzdelem az államban csak a pártok útján nyilvánulhat meg. A Magyar Szövetség, mint egyesület végzett funkciókat." 970 A szövetségi formával szembeni kifogása az volt, hogy egyszerre látott el gazdasági, jótékonysági és kulturális, tehát egyesületi és pártpolitikai jellegü feladatokat, amelyek nem váltak el egymástól. A Magyar Szövetség „müködése szerint egy államot megilletö hatáskört jelent, ez pedig a román állam felsőségével, amely a nemzetiségi autonómiát nem ismeri el, nem egyeztethetö össze. [...] Az állam szuverenitását nem lehet megosztani." 971

\footnotetext{
${ }^{968}$ A Magyar Szövetség végrehajtó bizottságának tagjai a rendőrségen. Ellenzék, 1921. XLII. évf. 248. szám, november 10. 6 .

${ }^{969}$ Uo. 6.; A Magyar Szövetség pere. Keleti Újság, 1921. 4. évf. 246. szám, november 10. 4.

${ }^{970}$ MNL OL K610 56. csomó 3, dosszié. VI. 6. (Elkészült a prefektus jelentése a Magyar Szövetség ellen. Ellenzék, 1921. december 3.)

${ }^{971}$ Uo.
} 
A nyomozati anyagot megküldte a belügyminiszternek, és kérte, hogy véglegesen is szüntessék be a Szövetséget. ${ }^{972}$ A kérelem mögött kétségtelenül politikai szándék is meghúzódott. Meţhes a következő véleményt fogalmazta meg a Szövetséggel szemben egy későbbi interjúban: „a mi magyarjaink több szabadságot élveznek, mint amazok [magyarországi románok - F. N.]. Bizonyságul ennek hozom fel, hogy nálunk nagyon sok nemzeti és soviniszta jellegü egyesület és klub van, mint pl. az EMKE, EKE, ÉME gróf Bethlen Istvánnal, a Vöröskereszt gróf Bánffy Miklóssal, a Gazdasági Egylet Bethlen gróffal az élükön és a szinészek egyesülete," illetve a római katolikus és református egyházak. ${ }^{973}$

A Szövetség végleges betiltására végül nem került sor, amely nagy valószínüséggel az 1921 decemberében bekövetkezett kormányváltásokkal állt összefüggésben. Avarescu miniszterelnök lemondását követően a kormányrudat néhány hét erejéig Take Ionescu, majd Bratianu vette át. ${ }^{974}$ A parlament elött a legfontosabb feladat az 1919. évi választójogi törvény módosítása, illetve annak alapján az 1922. évi parlamenti választások lebonyolítása volt. ${ }^{975} \mathrm{Az}$ új kormány Erdély ügyeiért felelős minisztere, Caius Brediceanu ${ }^{976}$ a kormány nemzetiségi politikájáról nyilatkozott a Keleti Újságnak. Kiemelte, hogy az ideiglenes kormány tiszteletben tartja az egyházak függetlenségét és autonómiáját az oktatás területén és elismeri a kisebbségi szervezkedés feltételeit. ${ }^{977}$ A bizonytalan belpolitikai helyzetben az engedékeny hangnemnek meg lett az eredménye, mert a belügyminiszter nem a Magyar Szövetség megszüntetéséről, hanem ellenkezőleg, müködésének engedélyezéséről döntött. ${ }^{978}$ Bár a müködést engedélyezték, a román politika kifogással élt az ellen, hogy az erdélyi magyarság, a Magyar Szövetségen keresztül sérelmeinek ügyében nemzetközi fórumhoz, a Népszövetséghez forduljon. Az alapszabályról szóló engedélyt végül Take Ionescu államtitkára, Hortopan írta alá. A Keleti Újság értesülései szerint személyesen Ugron István járt el az ügyben, Bukarestben. ${ }^{979}$

\footnotetext{
972 A Magyar Szövetség betiltásának okai a kormány elött. Ellenzék, 1921. XLII. évf. 277. sz. december 15. 1. ${ }^{973}$ MNL OL K63 230. csomó 27. tétel. 27/4. II. (Mi a Magyar Szövetség? Izbanda, 1922. január 18.)

${ }^{974}$ A Magyar Szövetség betiltásának okai a kormány előtt. Ellenzék, 1921. XLII. évf. 277. szám, december 15. 1.; Bratianu letette az esküt. Keleti Újság, 1922. 5. évf. 15. szám, január 21. 1-2.

975 A király megnyitotta a parlamentet. Keleti Újság, 1921. 4. évf. 262. szám, november 29. 2.

976 Caius Brediceanu Lugoson végezte az elemi iskolát, 1918 előtt Budapesten és nyugati országokban végezte el felsőfokú tanulmányait. A háború alatt az Osztrák-Magyar Monarchia tisztje, diplomáciai pályára lépett. Tagja a román párizsi békedelegációnak, illetve a Román Nemzeti Pártnak. Az új kormány és a magyarság. Keleti Újság, 1921. 4. évf. 283. szám, december 25. 2.

977 Uo.

978 Megjelent a kormány kiáltványa. Keleti Újság, 1921. 4. évf. 283. szám, december 25. 3.

${ }^{979}$ Engedélyezték a Magyar Szövetséget. Keleti Újság, 1922. 5. évf. 19. szám, január 26. 4.
} 


\subsection{1. Értelmezési viták a Magyar Szövetségröl, a politikai egységről és a pártalakításról}

A Magyar Szövetség felfüggesztése újabb értelmezési vitát indított el. A Keleti Újság vezércikkében arra a következtetésre jutott, hogy a Szövetség összetételében nem fejezte ki a „nemzetegyéniséget.” „Az egység rosszul értelmezett jelszavának a nevében a szövetség jelenlegi vezetösége elnyomott és klikkszerü módszerekkel ledorongolni igyekezett mindazokat a megnyilatkozásokat, amelyek a szélesen rétegezett magyar tömegek igazi kívánságait és szándékait kifejezhették volna. [...] Nem kellenek pártok! - hirdette olyan képpel, mintha a magyar nemzet legéletbevágóbb közös érdekét védelmezte volna ezzel a jelszavával. Ám a nép tudta, hogy a szövetség mai vezetöségének azért nem kellenek pártok, mert ök maguk is egy párt, az egyetlen párt, a felsö osztályok konzervatívabb táborainak pártja. [...] Legyen meg minden ellentétes véleménynek a maga képviselete, a maga külön szervezete és ezek a politikai pártok azután küldjék ki maguk képviselöit a szövetség vezetésére."980

Dózsa Endre a magyarság újjászervezését az alapoktól gondolta újraépíteni. Véleménye szerint a halogató politikai magatartásnak az lett az eredménye, hogy a többségi románság a magyarságot „quantetia negligeabile”, elhanyagolható közösségnek tekintette, amely nem volt hajlandó részt vállalni sem a gazdasági, sem a társadalmi élet újjászervezésében. ${ }^{981}$ Sulyok István a legfőbb célt a „nemzeti önkormányzat” kivívásában jelölte meg. Az volt az álláspontja, hogy az általános választójog korában a kisebbségi önkormányzat minden korábbi állapottól eltérő, mint amiben a magyar nemzet valaha is élt. Az adott kontextusban a felkészültség fokát úgy jellemezte, hogy ez az önkormányzat „,holnap tökéletesen készületlenül érné az erdélyi magyar népet". ${ }^{982}$ Az önrendelkezésért folyó küzdelmet két irányúnak írta le, amiért kifelé és befelé is folyik a harc. Egyrészt a román nemzetállam centralizációs lépései ellen, másrészt a magyar társadalmon belül „a történelmi elöitéletek, a könnyed nemtörődömség, a megérteni nem tudás, a gyengeség és a gyávaság ellen." Pártolta a Magyar Szövetség megerősítését, de elfogadta, hogy az „erdélyi magyar társadalom sokkal tagoltabb - úgy a világnézetek, mint a gyakorlati megoldások akarása dolgában és a változatos élethelyzetek folyományaképp semhogy akárcsak a Magyar Szövetség felfogásában is egy meggyözödést vallhasson."983 Sulyok álláspontja az volt, hogy a sorra kerülő parlamenti választásokon (1922 tavaszán) a magyarságnak egy pártlistát kell indítania, és az induló magyar jelölteknek a Magyar Szövetség keretén belül meg kell állapodniuk. ${ }^{984}$

\footnotetext{
${ }^{980}$ Az erdélyi magyarság útja. Keleti Újság, 1921. 4. évf. 244.szám, november 6. 1.

${ }^{981}$ Dózsa Endre: A magyarság problémája. Keleti Újság, 1921. 4. évf. 246. szám, november 10. 1-2.

${ }^{982}$ Sulyok István: Magyar Szövetség és a pártok. Keleti Újság, 1921. 4. évf. 253. szám, november 18. 1.

${ }^{983} \mathrm{Uo}$

${ }^{984}$ Uo.
} 
Az Ellenzék vezércikkben reagált a Keleti Újságban megjelentekre. Elsőként tiltakoztak az ellen, hogy a progresszív oldal kisajátítsa magának a demokratikus értékeket, illetve visszautasították a megbélyegző antidemokratikus jelzőket. Egyetértés mutatkozott abban, hogy mielőbb újra kell indítani a Szövetség müködését. „Ez a megindulás és az egész további haladás nem állhat semmiféle külön érdek szolgálatában, hanem csak az összmagyarság demokratikusan, legszabadelvübben felfogott érdekeinek lehet erös eszköze. [...] A demokratikus haladást nem adjuk oda senkinek privilégiumként"985 A parlamenti aktivitást megfelelően kell előkészíteni, mert egy-két képviselővel az erdélyi magyarság nem jelenhet meg a parlamentben. A Magyar Szövetség hivatott arra, hogy kifejezze a romániai magyarság egységét és intézményes keretet biztosítson a tovább lépésre. ${ }^{986}$ Mi a Magyar Szövetség? címü vezércikkben az Ellenzék megismételte Jósika azon gondolatát, hogy a Szövetség a romániai különböző magyar politikai pártok egyesítő szerve. A magyar nemzeti kisebbség minden irányú politikai képviselete és kisebbségi jogainak érvényesítése céljából alakult egyetemes szervezet, amely minden párt- és osztályérdeken felül állva képviseli Románia területén élő magyarokat. ${ }^{987}$ Albrecht Lajos A Magyar Szövetség hivatása címmel terjedelmes cikkben jellemezte a román belpolitikai viszonyokat, beleértve a magyarság politikai lehetőségeit. Aggodalommal írta, hogy a román állam megakadályozta a népkisebbségek szervezkedését adminisztratív és erőszakos úton. Ide tartozott a nemzetiségi sajtót ellehetetlenítő cenzúra intézménye, a politikai alapon történő letartóztatások stb. Az írás nagyobb része a személyes szempontokat is megjelenítő aktivista-passzivista politikai ellentét tapasztalatát fejtette ki. A Keleti Újságról azt írta, hogy tulajdonképpen nem a Szövetséget támadta, hanem azon keresztül a nagybirtokos osztályt, amely reakciós és antidemokratikus. Két ellentétpár köré csoportosította a politikai diskurzust uraló vitát: demokrácia és reakció, parlamenti aktivitás és passzivitás. Kiúttalannak nevezte ezt a típusú közéleti gondolkodást. Albrecht is azt gondolta, ebben lényegében közmegegyezés volt, hogy a párizsi békeszerződés rendszere - a nemzeti kisebbségek nemzetközi oltalomba vétele - az 1918 előtti gyakorlathoz képest valós közjogi státuszt, garanciális jogokat nyújt. Az új társadalompolitikai helyzet ezért szükségszerüen felülírja a régi politikai kategóriákra épülő vitákat a magyar kisebbségi társadalmon belül, mint például a demokratikus-antidemokratikus vagy osztályalapú megközelítéseket.

\footnotetext{
985 Pártok és a magyarság egysége. Ellenzék, 1921. XLII. évf. 258. szám, november 22.1.

${ }^{986}$ Uo.

${ }^{987}$ Mi a Magyar Szövetség? Ellenzék, 1921. XLII. évf. 260. szám, november 24. 1.
} 
A Magyar Szövetséggel kapcsolatos elvárás a romániai magyarság nemzeti egységét volt hivatott kifejezni, amely a világnézeti és a felekezeti különbségeket, ha eltörölni nem is, de integrálni képes. „Az egységes képviselet megalakulása után sem az egyik, sem a másik világnézet, sem az egyik, sem a másik politikai párt, sem az egyik, sem a másik társadalmi osztály szolgálatában nem állhat, hanem az egységes egész magyar kisebbség érdekeit kell szolgálnia." 988 Visszautasította a szövetség vezetőségének arisztokrata származású tagjait ért reakciós vádakat, ugyanis „, a demokrácia alatt sem a társadalmi osztályok egymásra uszitását, nem az érdekellentétek kiélesitését, hanem kiegyenlitését s a politikai és polgári jogok teljes egyenlöségét értjük." 989

Paál Árpád, az Erdélyi Néppárt kolozsvári szervezetének megalakítása előtt Jöjjön el a te országod címmel vezércikkben vázolta fel, hogy a magyarság nem maradhat ki az új román állam kiépítésének folyamatából. A romániai magyaroknak, önmaguk érdekében ki kell küzdeni a kisebbségi jogokat, meg kellet találni a megfelelő gazdasági és társadalmi kereteket a többségi román társadalommal való együttélésben. Paál úgy fogalmazott, hogy az első lépéseket nem az államtól kell várni, hanem meg kell találni az utat az államalkotóvá váláshoz. A haladáshoz vezető utat a kisebbségi társadalom jelöli ki maga elött, amelyben a vezető személyiségek felelősséggel tartoznak közösségükért. ${ }^{990}$

\subsubsection{Diplomáciai jelentések a budapesti kormány részére}

A magyar kormány részben a kolozsvári központtal való összeköttetésein keresztül, részben különböző jelentések formájában értesült a romániai magyarság politikai szervezkedéséről.

A feljegyzések objektívnek nem tekinthető adatgyüjtési eljárással készültek, illetve hangvételük személyes és politikailag elfogultak. A folyamatokról, a kihívásokról, a politikai gondolkodásról és a politikai beszédmódról ennek ellenére egy adott szemszögből részletes betekintést kaphatunk a magyar-magyar politikai viszonyrendszerbe.

Az egyik ilyen beszámolót Endes Miklós készítette a Bocskay Szövetség részére 1921es kiküldetése során. Politikai, egyházi, oktatási, közművelődési, társadalmi és gazdasági kérdésekben szerzett tapasztalatokat osztott meg. A budapesti kormánnyal szorosan együttműködő kolozsvári központ Románián belüli összeköttetéseinek elégtelenségét állapította meg. „Kolozsvári vezetőség még olyan nagy magyar központjaival is, mint Arad, Nagyvárad, Szatmárnémeti, csak laza érintkezésben van.

\footnotetext{
${ }^{988}$ Albrecht Lajos: A Magyar Szövetség hivatása. Ellenzék, 1922. 43. évf. 1. szám, január 1. 4. 989 Uo.

${ }^{990}$ Paál Árpád: Jöjjön el a te országod. Keleti Újság, 1922. 5. évf. 1. szám, január 1. 1.
} 
Nem fejlödhetik ki közöttük olyan érintkezés, amely a kerületek vezető értelmiségét kellöen bekapcsolta volna a kolozsvári központi vezetőség akcióiba."991 A tájékoztató továbbá két városról (Brassó, Kolozsvár) és három megyéről (Csík, Udvarhely, Háromszék, Maros-Torda) nyújtott információkat, a politikailag megbízhatónak tartott személyeket is megjelölve.

Kolozsvár az összmagyarság és a két magyar csoport részére is a politikai központot szimbolizálta. Endes a konzervatívok szemszögéből a politikai helyzetet ellentétesnek, az óhajtott egységre tekintve aggályosnak ítélte. Problémának látta, hogy Kolozsváron a polgári radikális szellemiség a világháborút követően is erősen hatott. „Halovány nemzeti érzésü radikális gondolkodás, amely a munkásságnál és a zsidóság egy részénél - magyartalan internacionalizmusság fajul [...] ennek a radikális iránynak szelídebb, söt magyar érzésü képviselője Paál Árpád, a radikális szinezetü Keleti Újság egyik politikai vezércikk írója."992 Endes jellemzésében Paál mérséklően hatott környezetére és közvetítő szerepet töltött be a kolozsvári központ, illetve a munkásság és a zsidóság egy része között. Brassó város politikailag aktív közösségét összességében lojálisnak írta le Kolozsvár irányába. A Magyar Szövetség elökészületeihez való informális kereteket az EMKE adta, a Brassói Lapok, illetve a helyi Erdélyi Lapok, Rombauer ügyvéd szerkesztésében és a katolikus Erdélyi Tudósitó politikai irányvonalát megfelelőnek ítélte. Szele Béla vezéregyéniségére hívta fel a figyelmet, aki Brassói Lapok szerkesztőjeként politikailag egyetértésben állt Grandpierrékkel. A világnézeti különbségekkel kapcsolatosan kiemelte, hogy „Brassóban a magyar munkásság és kisiparosság, sőt még a magyar zsidóság között sincsen a radikális és szociáldemokrata törekvések annyira elterjedve, mint például Kolozsvárt. Egyik fö oka ennek az, hogy Brassót nem özönlötték el úgy, mint Kolozsvárt a Budapeströl kivonuló román hadsereggel Erdélybe menekült radikális, szociál-kommunista emigránsok. Brassó nekik messze esö pont volt ahhoz, hogy a régi hazájukkal való bomlasztó érintkezést fenntarthassák."993 Ebböl következően is „Brassóra, mint az új román állam alakulatban folytonosan növekedö erdélyi központra, az eddiginél politikai tekintetben is nagyobb súlyt kellene helyezni."994

\footnotetext{
${ }^{991}$ MNL OL K64 3. csomó. 41. tétel. Endes Miklós: Jelentés az erdélyi magyarság jelenlegi politikai, egyházi, iskolai, közmüvelödési, társadalmi, gazdasági helyzetéröl

${ }^{992}$ Uo.

${ }^{993}$ Uo.

${ }^{994}$ Uo.
} 
Endes a székelyföldi politikai szervezkedést Háromszék és Csík megyék vonatkozásában megfelelőnek értékelt, amelyek információi szerint szoros összeköttetésben álltak Grandpierrékkel. Háromszék megyében a Magyar Szövetség kiépítéséhez az első lépéseket az EMKE keretén belül Szentkereszthy Béla volt föispán és Török Andor volt alispán tették meg. Elítélte azonban azt a két magyar képviselőt, akik 1919-ben román listáról szereztek mandátumot (Morvay volt kovásznai föszolgabíró, Fekete kézdivásárhelyi ügyvéd). Csík megyében a politikai szervezkedés élén a már említett Pál Gábor csíkszeredai ügyvéd állt.

Udvarhely és Maros-Torda megyék ezzel ellentétben komoly fejtörést okoztak a konzervatív passzivista csoportnak. „A magyar érdek szempontjából legaggályosabb a helyzet Udvarhely vármegyében. Itt történt mindjárt kezdetben az oláh politikai irányzathoz való csatlakozás az erdélyi magyarság részéről a legnagyobb mértékben. Ez irány vezetői Fay Dániel Lajos, Szabó Gábor, Ebert voltak, kik a Vajda-kormány idején lefolyt első választásnál mandátumokat vállaltak." 995 Ketten közülük hírlapírók, Ebert a Székelyudvarhely címü lapot szerkesztette, Szabó Gábor pedig kiadója volt a Bukaresti Magyar Újságnak. Endes a problémát abban látta, hogy nem mutatkozott vezetésre alkalmas egyéniség. A néhai Gyárfás Endre fiáról, Gyárfás Pálról azt beszélték, hogy alkalmas lenne politikai szervezői feladatot végezni. „Az aktivitás és passzivitás kérdése a székely népet magát egyáltalán nem érdekli. Az értelmiség túlnyomó része abban a nézetben van, hogy az aktivitás kizárólagosan román érdek." 996 MarosTorda megye, Marosvásárhely központtal rendkívül erős elrománosító eljárásnak volt kitéve a leírtak szerint. A magyarság politikai magatartásában két irányzat volt a meghatározó. „Egyik a Bernády vezetése alatt álló románbarát párt. Ehhez tartozik Breschler is. Ez utóbbi az általa kiadott Új Barázda címü néplap útján igyekezik a székely kisgazdákra hatást gyakorolni a falusi gazdasági szervezetek propagálása révén. Ez irány müködése tisztán magyar szempontból nem látszik kifogástalannak."997 A másik irányzatot Bedő vezetésével az az értelmiségi csoport képviselte, amely a kolozsvári Magyar Szövetség programja alapján, illetve az EMKE keretében fejtette ki tevékenységét. 998 
Gagyhy Dénes 1921 második feléből származó adatgyüjtése szintén a Bocskay Szövetség részére készült, amely részben a sajtóviszonyokat jellemezte. Gagyhy három újságot emelt ki, amely széles körben eljutott az erdélyi magyar olvasókhoz: Ellenzék, Keleti Újság, Brassói Lapok. Véleménye „közöttük magyar szempontból a legkiválóbb a Brassói Hírlap. Bátor, szókimondó, föltétlen képviselöje a magyar nemzeti törekvéseknek." "999 Az Ellenzékről árnyaltabb képet írt le, amely „hazafias hangokat penget, azonban nincs népszerüsége és nem biznak öszinteségében.” A Keleti Újsággal szemben egyenesen ellenséges volt: „az oláh politikai törekvéseknek nyílt képviselöje, munkatársai között emigráns kommunista zsidók vannak, és elöl járnak a csonka magyarországi belpolitikai viszonyok leleplezésében és célzatos ferditésében."1000 Említést tett csak, véleményt nem mondott a marosvásárhelyi kisgazdák körében kedvelt Erdélyi Barázda, Udvarhely megyében a Székely Közélet (szerkesztö: Tompa László) és a Székelyudvarhely (szerkesztő: Ébert András) lapokról. A két legjelentősebb folyóiratot mellett, a Napkelet (szerkesztő: Paál Árpád) és a Pásztortüz (szerkesztő: Reményik Sándor) mellett már nem ment el szó nélkül. „A Napkelet is annyira keleti, mint inkább nyugati újság. A Nyugat édes gyermeke, ugyanazon destruktív szellemmel és majdnem ugyanazon irodalmi destruktorokkal, akik Budapesten garázdálkodtak."1001 Általánosságban jegyezte meg az erdélyi magyar sajtóval kapcsolatban, hogy a legközvetlenebb és hatásában a legmesszemenőbb politikai és kulturális eszköze a romániai magyarságnak. Konkrétan azonban emiatt „,nem lehet közömbös, hogy kik és milyen lelki rugókkal irányított emberek szerkesztik az erdélyi magyar lapokat. Azonban nemcsak megbizhatóságra van szükség, hanem tehetségre is. Ha azt akarjuk, hogy az erdélyi magyar sajtó komolyan és eredményesen szolgálja a nemzeti ügyet, akkor úgy formájában, mint tartalmában legyözhetetlen fölénnyel kell birnia az összes ellenséges orgánumokkal szemben és olyan fegyverekkel rendelkeznie, amelyek hódítani képesek és hódítani is. Hogy e cél elérhető legyen és a politikai irányítás a centrumból történjen, nézetem szerint egy erdélyi sajtóiroda szervezése volna kívánatos."1002

A harmadik tájékoztató Balássy Dénes tollából készült 1922-ben, amelyet a Bocskay Szövetség utód szervezetének, a Népies Irodalmi Társaságnak címeztek. Balássy vizsgálatában a székelyföldi szervezkedés állt, amelyet a következőképpen jellemzett. „Udvarhely megyében a Földmíves Szövetség az egyetlen kristálypont, amely köré elöbb a lakosságot, majd gazdaságilag és kulturálisan, azután politikailag is csoportositani lehetne. [...]

\footnotetext{
${ }^{999}$ MNL OL K64 3. csomó. 41. tétel. Gagyhy Dénes jelentése: Bocskay Szövetség jelentése az erdélyi politikai, gazdasági, társadalmi helyzetröl

${ }^{1000} \mathrm{Uo}$

${ }^{1001}$ Uo.

${ }^{1002} \mathrm{Uo}$
} 
A román kormány a gazdasági formán kívül csupán vallási cégér alatt engedi meg a közönségnek a csoportosulást, állhatatosan követve mindenütt a divide empira elvét. A megyében például nagyon kevés zsidó van, de azért áprilisban nagy jövedelmi [adománygyüjtés - F. N.] cionista koncertet tartottak, amelyen a birtokosság és az intelligencia egy része is felülfizetésekkel vett részt. S a zsidók Romániában kezdenek felül kerekedni, mindenütt ott van a kezük. A zsidókkal össze kell tartanunk - mondja Ugron volt föispán, ök kitudnak nekünkjárni hol mit. [...] Központi vagy politikai tekintély szemmel láthatólag nincs a megyében. A kolozsvári szellemi front vezetői: Grandpierre, Kolozsvári és Költő mellett és között a legnépszerübb Paál Árpád, de az igazi autoritást úgy a megyében és Székelyföldön Majláth püspök képviseli. Mert a kolozsváriak a kapott pénz kiosztásában önzően jártak el, lokálpatriotizmust üztek. Ebböl elhidegülés, súrlódás származott. Ezt fokozta az ügy érdekében Paál Árpádnak a zsidókkal való szimpatizálása, úgy, hogy autonómia és kapcsolódás tekintetében a Magyar Szövetség fennáll most Kolozsvár és Temesvár között, de nincs meg az egyetértés Kolozsvár, Csík és Udvarhely között. Ezt a gyenge viszonyt az április végén tartott EMKE közgyülésen való részvétlenség bizonyitja. [...] általában véve csíki köd, a fatális letargia és kultúrközöny a jellemző." ${ }^{1003}$ A jelentés formáját, stílusát és tartalmát tekintve tagolatlan, inkább úti, de egyértelmủen politikai beszámoló. A szerző - politikai elfogultságból - bizalmatlansággal vádolja az erdélyi magyar zsidóságot, miközben nem tesz említést az őket érő állami diszkriminációról (oktatás, ingatlanok elvétele stb.) vagy a Magyar Szövetségben való részvételükről. Grandpierre, Ugron, Paál és Majláth szerepét eltérően ítéli meg. Míg a progresszívabb Paált a zsidóság irányába elfogultsággal vádolja, addig Majláth püspököt az egyetlen szövetségesnek tünteti fel. A Magyar Szövetségről is kevés információt közöl, többek között arról, hogy szervezetet többször is felfüggesztették.

${ }^{1003}$ MNL OL K64 3. csomó. 41. tétel. Balássy Dénes jelentése a Népies Irodalmi Társaságnak, 1922. 


\subsection{Részvétel az 1922. évi választásokon és a Magyar Nemzeti Párt megalakítása}

A kormányválságok következtében 1922. januárban a törvényhozást feloszlatták és parlamenti választásokat írtak ki márciusra. ${ }^{1004} 1921-1922$ fordulóján a magyar politikai szervezkedés a teljes bizonytalanság, illetve a párhuzamosság képét mutatta. A Magyar Szövetséget váratlanul érte a választásokról szóló hír. Bethlen György az Universul lapnak adott interjúban beszélt a választások kihívásairól. Személyes példáját említette a választói névjegyzék hiányosságáról, amelyben helyi birtokos lakosként sem szerepeltették a nevét. A választásokon való részvétel lehetőségét részben ezért elvetette. „A magyarság hivatalosan nem vesz részt a választásokon, de lehet, izoláltan némely körök képviselöket fognak küldeni a parlamentbe. [...] Minket teljesen készületlen találtak a közeli választások."1005

Míg az erdélyi román pártok az egymással való együttmüködést mérlegelték, addig a magyarok szempontjából a részvételről való döntés volt a legnagyobb kihívás. A Magyar Szövetség felfüggesztésével és az Erdélyi Néppárttal összefüggő belső konfliktusok, a megalakuló félben lévő Magyar Nemzeti Párt, az előző két választáson elkövetett visszaélések megismétlődésétől való félelem, a választási névjegyzékből kihagyott több tízezer magyar kihagyása, vagyis a bizonytalan lábakon álló magyar érdekképviselet a magyar politikai vezetőket rendkívül nehéz helyzet elé állította. A kétkedő vélemények felerősödtek arról, hogy a két magyar politikai csoport nem képes megegyezni. Egyesek szerint a Magyar Szövetség és az Erdélyi Néppárt programja mivel nem fedték egymást, alááshatta volna az egységes fellépést. ${ }^{1006}$

A választási részvételről a Magyar Szövetség szervezeti szabályzata értelmében a nagygyülésnek volt joga dönteni. Egy további ügyben is összekellett hívni a nagygyülést, mert a kormány az alapszabály módosítását kérte, amikor a Szövetséget felfüggesztette. A nagygyülés meghirdetése az idő rövidsége és a müködésképtelen vezetői testületek miatt nem valósulhatott meg a választások előtt. ${ }^{1007}$ A Magyar Szövetség és az Erdélyi Néppárt vezetősége - Bernády György javaslatára - a problémát ún. vezérlő-bizottság felállításával hidalta át januárban. Itt született meg az elhatározás, hogy a magyarság egységesen és közös jelölteket állítva részt vesz a választásokon. ${ }^{1008}$

\footnotetext{
1004 Szenátorválasztás: ókirályságban, Bukovinában, Besszarábiában március 1-2., Erdélyben, Bánátban, a Körös völgyében és Máramaros megyében március 9-10. Képviselőházi választások: ókirályságban, Bukovinában, Besszarábiában március 5-7., Erdélyben, Bánátban, a Körös völgyében és Máramaros megyében 6-7. Megjelent a kormány kiáltványa. Keleti Újság, 1922. 5. évf. 18. szám, január 25.2

${ }^{1005}$ MNL OL K63 230. csomó 27. tétel. 27/4. II.

1006 G.L.: Választanunk kell. Ellenzék. 1922. 43. évf. 23. szám, január 31. 1.

1007 Össze kell hívni a Magyar Szövetség nagygyülését. Ellenzék, 1922. 43. évf. 24. szám, február 1. 3.

${ }^{1008}$ A magyarság egységesen jár el a választásokon. Ellenzék, 1922. 43. évf. 23. szám, január 31. 1.; Készülődés a választásokra. Keleti Újság, 1922. 5. évf. 23. szám, január 31. 4.
} 
Az első és legfontosabb feladat az volt, hogy a választói névjegyzékbe felvegyék a romániai magyar állampolgárokat. A kormánytól ígértet is kaptak, hogy rendeletben szabályozza a névjegyzék kibővítését. A Szövetség ezt követően kampányt indított arra kérve minden választásra jogosult személyt, hogy jelentkezzen az illetékes városi és községi tanácsnál. ${ }^{1009}$

A választási esélyekről szóló vélemények egybehangzóan arról szóltak, hogy a végleges eredmény nem fogja tükrözni a valós társadalmi támogatottságot. A részvételt és az eredményt négy tényező befolyásolta. Az egyik az volt, hogy a választási kerületeket manipulálták és a többségi elvet alkalmazták a mandátumkiosztáskor. A román etnikai szempontokat előtérbe helyezve az összefüggő magyar körzeteket megbontották (Gerrymandering). Például a tölgyesi kerületet kibővítették a szomszédos Maros-Torda megyében fekvő három teljesen román lakosságú községgel, de ez történt a Brassó megyei hétfalusi választókörzettel is. ${ }^{1010}$ A Keleti Újság publicistája szerint a „kitüzött választások vonalvezetés módja nem felel meg a modern demokrácia alapfeltételeinek. A választójog ott, ahol heterogén népek összetételéröl van szó, csak proporcionális [arányos - F. N.] lehet, mert csak a proporcionális választójog alkalmas arra, hogy a kisebbségek az őket megillető képviselethez hozzájuthassanak". ${ }^{1011}$ A második akadályt a névjegyzék hiányossága jelentette. A kormányzat hiába adta utasításba a hivatalok részére annak kiegészítéséről szóló rendeletét, egy hónappal a választások előtt a névjegyzékekről még sem rendelkeztek. A román állam müködésének ellentmondásosságát jól példázta az az eset, amikor a belügyminiszter, az előzetes ígéretek ellenére, azzal indokolta a hivatalok lépését, hogy csak a képviselőház jóváhagyása alapján bocsáthatott volna ki a választói névjegyzékre vonatkozóan módosító rendeletet. Sándor József azzal tiltakozott ez ellen, hogy ezt az 1919. évi román választójogi törvény lehetővé tette. ${ }^{1012}$ A harmadik tényező az volt, hogy a liberális párt, amely a választásokat végül megnyerte, saját listáján nagyszámban indít magyar jelölteket. Ez azért merült fel, mert a liberális párt utasította vidéki szervezeteit, hogy lépjenek érintkezésbe a magyarság és a szászság vezetőivel. Bratianu célja valójában a Maniu vezette Román Nemzeti Párt gyengítése volt.

\footnotetext{
${ }^{1009}$ Választásra jogosultnak minősült 1910. évi 3621. sz. rendelet értelmében: a) minden 21. évét betöltött férfi, akinek előzőleg meg volt a magyar állampolgársága és azóta nem folyamodott más, például magyar állampolgárságért, b) a csatolt területeken született, c) 1914. január 1-ig a csatolt területeken illetőséget szerzett vagy 1914. január 1-jén a csatolt területeken rendelkezett lakhellyel a választói névjegyzék összeállításáig román állampolgárságért folyamodott. A névjegyzékbe való felvétel kérelmét a választásokat megelőző minimum húsz nappal előtte kellett benyújtani.

Kinek van választói jogosultsága? Ellenzék, 1922. 43. évf. 26. sz. február 4. 2.; Minden magyar követelje fölvételét. Ellenzék, 1922. 43. évf. 25. szám, február 2. 1.; A Magyar Szövetség felhívása a magyar választókhoz. Ellenzék, 1922. 43. évf. 26. szám, február 3. 5.; Választunk. Keleti Újság, 1922. 5. évf. 22. szám, január 29.

${ }^{1010}$ Választási esélyek. Ellenzék, 1922. 43. évf. 39. szám, február 19. 1.

${ }^{1011}$ Kitagadva. Keleti Újság, 1922. 5. évf. 25. szám, február 2. 1.

1012 A névjegyzék miatt. Keleti Újság, 1922. 5. évf. 25. szám, február 2. 1-4.
} 
A liberális listán való indulásokra végül nem került sor. ${ }^{1013}$ Negyedik körülményként az erőszak légköre jelentett visszatartó erőt. Az Ellenzék kolozsvári szerkesztőségét a választások előtt feldúlták egy román diákok szervezte tömeggyülést követően. ${ }^{1014}$

A mandátumbecslés kalkulációjában a Magyar Szövetség legalább 20-30 parlamenti és 15 szenátori helyre számított. A választási magatartásról a választókat igyekeztek instrukciókkal ellátni. A Magyar Szövetség jelöltjei esetében természetesen nem merült fel, hogy kit javasolt támogatni. Elsődlegesen ott merült fel ez a kérdés, ahol nem volt magyar jelölt és a román pártok között kellett választani. Két eltérő vélemény versengett egymással.

Egyfelől az, hogy a román pártokra ne szavazzanak, mert a nemzetiségi programjaik egyformán antidemokratikusak. Másfelől az, hogy az 1918 előttről ismert román képviselök közül, akik megértést mutattak a kisebbségek ügyében, azok támogathatók. ${ }^{1015}$

A román választási rendszer írott és szokásjogokra épülő eszközeitől függött a magyar politikusok beválasztása a kétkamarás román parlamentbe. A visszaélésektől nem mentes eljárás során - a hatalmi ágak elkülönítésének demokratikus elvét felrúgva - a végrehajtó jogosítvánnyal rendelkező kormány, közvetlenül beleavatkozott a következő törvényhozó testület megválasztásába. A választások előtt szokássá vált, hogy a király kinevezett egy kormányt, s ez bonyolította le a választásokat, s a rendelkezésére álló eszközök felhasználásával manipulálta a folyamatot. Azt a pártot hozta ki győztesnek, amelyet a kormányalakítással és a választások lebonyolításával megbíztak. Így könnyen kiszámítható volt melyik párt nyeri el a legtöbb mandátumot. ${ }^{1016}$ 1918-1922 közti időszak Románia politikatörténetének - nem egyedülálló módon - kormányváltásokkal teli periódusa. A bukaresti egyezményt aláíró németbarát Marghiloman-kormány ${ }^{1017}$ bukását követően rövid életű kabinetek követték egymást.

\footnotetext{
${ }^{1013}$ Megalakul a háromszéki Magyar Nemzeti Párt. Ellenzék, 1922. 43. évf. 39. szám, február 19. 1.; A választási harc. Keleti Újság, 1922. 24. szám, február 1. 2.

${ }^{1014}$ A beszámoló szerint az egyik szónok az Ellenzéket a nemzetközi reakció szolgálatában álló sajtóorgánumnak nevezete. Az irattárat feldúlták, az asztalokat, az írógépeket széttörték és kidobták az utcára. Egy másik csoport ez idő alatt a lap Státus palotában lévő szerkesztőség épületét is feldúlta. Számos kéziratot, kiadványt és az Ellenzék újságjait a főtéren felgyújtották. Megtámadták az „Ellenzék” helyiségeit. Keleti Újság, 1922. 5. évf. 25. szám, február 8. 3.

1015 Arad volt az egyik olyan város, ahol azzal számoltak, hogy nem lesz magyar jelölt. Ott például Bratianu Vintilla liberális jelölttel szemben dr. Lupu parasztpárti volt belügyminisztert javasolták támogatni felvilágosult gondolkodására hivatkozva. Milyen magatartást foglaljon el a magyarság a román pártok jelöltjeivel szemben? Ellenzék, 1922. 43. évf. 42. szám, február 23. 2.

1016 BALÁZS, 2010. 29.

1017 Bukaresti különbéke: 1918. május 7-én írták alá a központi hatalmak (Osztrák-Magyar Monarchia, Németország, Törökország, Bulgária) képviselői Alexandru Marghiloman román miniszterelnökkel (1918. március-1918. november), amely lezárta a román vereséggel végződő 1916-17-es, Magyarország ellen indított háborút. Románia lemondott Dobrudzsa egy részéről Bulgária javára, az Osztrák-Magyar Monarchiával közös határa pedig a Kárpátok déli és keleti lábaihoz került.
} 
Ebben az időszakban kétszer tartottak választást (1919. november és 1920. március), de a kormányfök ennél többször cserélödtek. A Constantin Coandă-kormány csupán technikai feladatot látott el, beiktatását követően a kormányrudat azonnal átadta a liberális I. C. Bratianunak, akit a párizsi békekonferenciára kiutazó román békedelegáció vezetésével is megbíztak. ${ }^{1018}$ A háborút követő első általános választásokra 1919. november 8-án került sor és Alexandru Vaida-Voevod alakíthatott kormányt. ${ }^{1019}$ A decentralizációt hangsúlyozó és a kisparaszti birtokra épülő földreformot támogató miniszterelnöktől Ferdinánd király, minden bizonnyal liberális és konzervatív párti nyomásra, hamarosan megvonta a müködés jogát.

Az újabb választás során a kormányfői posztot, a király bizalmát élvező Alexandru Avarescu tábornok foglalta el, akit másfél múlva a konzervatív Take Ionescu követett. ${ }^{1020}$ 1922-ben ismét választásokra került sor, amelyen a megnagyobbodott Romániába szakadt magyar nemzetrész intézményesen először vett részt. Az érvényben lévő választási törvény a korábbi évekhez képest magasabb kvótát írt elő, közel ötvenezer állampolgárra jutott egy képviselő és százezerre egy szenátor. A képviselőház 367, a szenátus 168 fős volt. Az 1919. évi 3632. számú és az 1920. évi 1539. számú rendeletek értelmében Erdélyből 121 képviselőt és 53 szenátort delegáltak a bukaresti parlamentbe. 1922-ben négy évre a képviselöházi székek közül 227-t (61\%) a liberálisok szereztek meg, a felsőházban 112-őt (66\%). A kényelmes többséggel megnyílt a lehetőség a kormány előtt az alkotmányozásra és a kétharmados törvények megalkotására. ${ }^{1021}$

\begin{tabular}{|l|l|l|}
\hline \multicolumn{3}{|c|}{ Románia miniszterelnökei 1918-1926 között } \\
\hline kormányfö & pártállás & kinevezés-megszúnés \\
\hline Coandă, C. tábornok & Néppárt & $1918.10 .24 .-1918.11 .29$. \\
\hline Brătianu, I. C. & Nemzeti Liberális Párt & $1918.11 .29 .-1919.09 .27$. \\
\hline Văitoianu, A. tábornok & Nemzeti Liberális Párt & $1919.09 .27 .-1919.12 .01$. \\
\hline Vaida-Voevod, A. & Román Nemzeti Párt & $1919.12 .01 .-1919.12 .13$. \\
\hline Avarescu, A. tábornok & Néppárt & $1919.12 .13 .-1921.12 .17$. \\
\hline Take, Ionescu & Konzervatív Párt & $1921.12 .17 .-1922.01 .19$. \\
\hline Brătianu, I. C. & Nemzeti Liberális Párt & $1922.01 .19 .-1926.03 .30$. \\
\hline
\end{tabular}

\footnotetext{
1018 Bratianu öt alkalommal volt Románia miniszterelnöke: 1909. január 9.-1910. december 28., 1914. január 4.1918. január 28., 1918. november 29.-1919. szeptember 26., 1922. január 17.-1926. március 29., 1927. június 21.-1927. november 24. IANCU, 1990. 42-48. 1019 TILEA, 1926. 15-23.; IANCU, 1995. 49-51.

1020 Alexandru Avarescu tábornok kormánya: 1920. március 13.-1921. december 16. Take Ionescu kormány: 1921. december 16.-1922. január 17. LIPCSEY, 2006. 28-30. ${ }^{1021}$ LIPCSEY, 2006. 30-35.; BALÁZS, 2008. 3. 29-45.
} 
A romániai magyarság kialakulatlan, mondhatni szervezetlen körülmények között vett részt a választásokon. Balázs Sándor ezt a rövid intervallumot a „magyar párt-előtti időszaknak” nevezte, amikor az egyesületként nyilvántartott Magyar Szövetség töltötte be azt a szerepet, amelyet később másfél évtizedre az Országos Magyar Párt örökölt meg. ${ }^{1022}$ A magyar jelölések körül szinte mindenhol rendkívüli visszaélések történtek. A kormányon lévő Nemzeti Liberális Párt és a hozzá lojális közigazgatási vezetők, választási bizottságok a magyar, illetve a román ellenzéki pártok jelöléseinek többségét adminisztratív okokkal megakadályozták. ${ }^{1023}$ Képviselőjelöltnek nevezték meg többek között Marosvásárhelyen Bernády Györgyöt, Szatmár megyében a néppárti Kós Károlyt, Aradon Zima Tibort, Nagyváradon Willer József újságírót. Székelyföldön a Magyar Szövetség képviselőjelöltjei voltak például Gyárfás Elemér (Csíkszereda), Görög Joachim (Gyergyószentmiklós), illetve szenátorjelölt Jósika Sámuel. ${ }^{1024}$

Előfordult olyan eset, amikor a magyar pártok valamelyike a jelölőgyüléseket arra használta fel, hogy saját helyi szervezetét létrehozza. Nyárádszeredán a Néppárt előbb megalakította a helyi szervezetét, majd megválasztotta a választókerület jelöltjét (Árkosi Jenő református lelkész), és a Nyárád mentén tagtoborzást indított a székely falvakban. A szociáldemokrata, illetve az Erdélyi Zsidó Néppárt szereplése azt a kérdést veti fel, hogy a többnyire magyar nemzetiségű városi munkásság, illetve a zsidóság amennyiben részt tudtak és részt is vettek a választásokon, milyen volt a választói magatartásuk. (A kérdés megválaszolása e dolgozat kereteit meghaladja.) Maros megyében a szociáldemokrata párt saját képviselő- és szenátorjelölteket állított, a román és a Magyar Szövetség jelöltjeivel szemben. ${ }^{1025}$ Kolozsváron bontott zászlót az Erdélyi Zsidó Néppárt, amely Székely Bélát, az 5 órai Újság szerkesztőjét nevezte meg képviselöjelöltjének. ${ }^{1026}$

\footnotetext{
1022 BALÁZS, 2010. 29.

${ }^{1023}$ Biharban a következő okkal utasították el Willer jelölését: a jelölés során a jelölő okmányon a dátum nem felül volt, hanem alul, a „dr.” nem szerepelt az aláíráskor. Kolozs megyében minden magyar jelöltet visszautasítottak, pl. Bánffyhunyadon Sándor Józsefet, mert az aláírásokat nem találták helyesnek. Előfordult olyan összeférhetetlenség, hogy Nagy Endrét tudta nélkül kinevezték választási felügyelönek Kolozson, miközben ő képviselőjelölt volt. Visszautasítják a magyar jelölteket. Keleti Újság, 1922. 5. évf. 45. szám, február 26. 2-3.; Megbuktak a választások. Keleti Újság, 1922. 5. évf. 46. szám, február 28. 1.; A nagyváradi kifogások. Nagyváradi Esti Lap, 1922. 47. szám, február 28. 3.

${ }^{1024}$ A magyarság a választásokon. Keleti Újság, 1922. 5. évf. 39. szám, február 19. 2.; A magyar pártok mozgalmai. Keleti Újság, 1922. 5. évf. 25. szám, február 8. 2-3.; A választási küzdelem. Keleti Újság, 1922. 5. évf. 34. szám, február 4. 2. Magyar szervezkedés Szatmáron. Keleti Újság, 1922. 5. évf. 43. szám, február 24. 2.

1025 Marosvásárhelyen a képviselőjelölt Bíró Géza, író, tanár, szenátorjelölt Hámor Ferenc voltak, de jelöltek állítottak Szászrégenben, Nyárádszeredán, Mezőbándon, Ákosfalván és Toplicán is. Kolozsváron dr. Kertész Jenőt nevezték meg képviselőjelöltnek, aki 15 éve volt a helyi szociáldemokrata párt befolyásos tagja. A jelölését visszautasították. A magyar pártok mozgalmai. Keleti Újság, 1922. 5. évf. 25. szám, február 8. 2-3.

${ }^{1026}$ A választási küzdelem. Keleti Újság, 1922. 5. évf. 33. szám, február 12. 2.
} 
A képviselőválasztásokon egy magyar jelölt, Bernády György Nyárádszeredán szerzett mandátumot, a szenátorválasztásokon pedig két induló, Pál István apátplébános Udvarhelyről és Fülöp Béla Temesvárról. Pótválasztásokon még két képviselővel, Sepsiszentgyörgyről Sándor Józseffel és Aradról Zima Tiborral, illetve egy szenátorral, Jósika Sámuellel bővült a magyar parlamenti képviselet, amely a magyar lakosság arányát a népességen belül $(8,6 \%)$ nem tükrözte. A korabeli számítások szerint a magyarok 20-30 képviselői helyre számítottak, ehelyett bejutott három fö, és a hivatalból berekült magyar püspököket leszámítva továbbá három szenátor. ${ }^{1027}$ A 235 ezer fős erdélyi szászok a magyarokkal szemben hat parlamenti képviselővel és három szenátorral voltak jelen a törvényhozásban. Hans Otto Roth képviselő a politikai sikerüket két dologban jelölte meg. Egyrészt, hogy mind végig aktív politikát folytatottak. A magyarok politikai passzivitását úgy értékelte, hogy egy nemzeti kisebbségnek mivel nincs esélye a belpolitikát irányítania, nincs értelme, hogy passzivitással akarjon a belpolitikai alakulásokra hatást gyakorolni. Másrészt, legyen földrajzilag bármennyire is elszórt egy közösség, például a romániai németek (szászok, svábok, bukovinai és besszarábiai németek), elengedhetetlen a közös szervezeti háttér. ${ }^{1028}$

\subsubsection{Két pártban a magyarság: a Magyar Nemzeti Párt és az eltérö programok}

A kolozsvári konzervatívok támogatásával a Magyar Szövetség székelyudvarhelyi szervezete 1922. január 31-én megalakította a Magyar Nemzeti Pártot. Grandpierre nyíltan nem vállalt pozíciót a pártalakításban, de minden bizonnyal a háttérből koordinálta a folyamatokat. A stratégiájuk arra épült, hogy a Magyar Szövetség helyi szervezeteire támaszkodva szervezik meg saját pártjukat. Döntésük hátterében a Magyar Szövetség ellehetetlenítése, a belső konfliktusok, az Erdélyi Néppárt kolozsvári januári gyülése, a választásokra való felkészülés, illetve a határozottabb politikai érdekérvényesítés igénye játszotta a szerepet.

A zászlóbontás föpróbája, a Magyar Szövetség konzervatív csoportjának vidéki bázisát is jelentő Székelyudvarhely volt, 1922. január 31-én. Az Ellenzék a pártalakítás szükségét a következőkkel indokolta: „A magyarságot érintő hivatalos felfogás és a politikai helyzet alakulásainak megfelelöen itteni [székelyudvarhelyi] irányadó körök megalakítják a Magyar Nemzeti Pártot azzal a célzattal, hogy az, mint politikai szerv hathatós védelemben részesithesse a Románia területén élö magyarság érdekeit."1029 A magyar politikai szervezkedést alakító két markáns csoport nézetkülönbsége még ennél is fontosabbnak tünt.

${ }^{1027}$ BALÁZS, 2010. 29-31.; Erdélyi Magyar Évkönyv 1918-1929. 1930. 12-25.

1028 Akik beleszülettek a kisebbségi politikába. Keleti Újság, 1922. 5. évf. 130. június 13. 3-4.

1029 Zászlót bont az Udvarhely megyei magyarság. Ellenzék, 1922. 43. évf. 18. szám, január 25.5. 
A politikai diskurzus az egység szimbóluma köré épült, de folyamatosan jelen volt az arról szóló vita, hogy mely csoport határozza meg a magyarság politikai szervezkedésének valódi irányát. „Kétségtelen ugyan, hogy az erdélyi magyarság körében világnézeti, elvi különbségek vannak, különösen azóta, amióta Budapeströl, Bécsböl sok olyan ember szivárgott be, akinek az erdélyitöl elütő ideológiája, felfogása van." ${ }^{1030}$ A konzervatívok válasza egyértelmű volt. Saját pártot hoztak létre a Magyar Szövetség programjának égisze alatt, hogy kijelölhessék vezető pozíciójukat a magyar politikai építkezés folyamatában, mert „képtelen dolog, hogy legyen Kolozsvár környékén egy párt, amelynek [...] semmi talaj nincs Erdély távolabbi részében, de már magyar párt éppen a magyarság nagy többsége részére ne legyen."1031

Az udvarhelyi alakuló gyülést Szakáts Péter, a Magyar Szövetség udvarhelyi tagozatának elnöke nyitotta meg. Az egybegyültek között volt Pál Gábor és Élthes Gyula a Csík megyei Magyar Szövetség nevében. ${ }^{1032}$ Embery Árpád főgimnáziumi tanár, volt országgyülési képviselő az önkormányzati jogok helyreállítását, a felekezeti autonómia tiszteletben tartását követelte. A gyülés két fontos döntést hozott. Elhatározták, hogy megalakítják a Magyar Nemzeti Párt Udvarhely megyei szervezetét, amellyel deklarálták, hogy a Kolozsváron megalakítandó országos Magyar Nemzeti Párt helyi szervezetéként kívánnak müködni. ${ }^{1033}$ Amellett döntöttek, hogy részt vesznek az 1922. évi parlamenti választásokon. Szenátornak Ugron Istvánt jelölték, a képviselőjelölteket csak később nevezték meg, amit a párt helyi szervezeteire bíztak. Mindezeken túl megalakították a Magyar Nemzeti Párt Székelyudvarhely és Vidéke Kerülete tagozatát is. ${ }^{1034}$

A pártalakítás fogadtatása a román politikai vezetők többsége részéről, hasonlóan a Magyar Szövetség megindulásához negatív visszhangot váltott ki. Az Epoca ellenséges fellépése szerint „a Magyar Szövetség nem egyéb, mint a volt monarchia dualisztikus despotizmusából egyenesen eredő mágnások eltitkolt szövetsége, akik a mostani helyzetben is azt szeretnék, hogy megmaradjanak az erdélyi magyarság ugyanilyen diktátorainak. [...] A választásokban a Jósika báró mágnásai magukra maradtak. [...]

\footnotetext{
${ }^{1030}$ A Magyar Nemzeti Párt zászlóbontása. Ellenzék, 1922. 43. évf. 24. szám, február 1. 5.

${ }^{1031}$ Uo.

1032 A felszólalók a következők voltak: Kovács Lázár a helyi polgárság, Sárossy Károly nyomdász a munkásság, Papp Lőrinc gazda a székely birtokosok, Ugron Zoltán az értelmiség és Pál Gábor a Csík megyei Magyar Szövetség nevében fejezte ki támogatását a csatlakozásról. Hogyan folyt le a Magyar Nemzeti Párt udvarhelyi zászlóbontása. Ellenzék, 1922. 43. évf. 27. szám, február 4. 4.

1033 Vezetőség: Szakáts Péter elnök, Vajda Ferenc református esperes, Pál Ferenc oklándi unitárius esperes, dr. Viola Sándor székelyudvarhelyi ügyvéd, Hadnagy Mihály plébános alelnökök, Bíró Sándor kollégiumi és Fazakas Gáspár fögimnáziumi tanárok jegyzők, Varró Elek Földmüvelési Szövetség titkára pénztáros, illetve Kovács Lázár ellenőr. Továbbá a Megyei Intézőbizottságba 32 tagot és a Nagybizottságba minden községből 1-2 tagot választottak.

${ }^{1034}$ Elnök: Vajda Ferenc református esperes, alelnökök: Bartók István iparos, Szabó Dénes zetelaki földbirtokos, titkár: ifj. Szakáts Zoltán bikafalvi földbirtokos és Kovács Lázár. Uo.
} 
A Magyar Szövetség nem képes megérteni fajtestvéreinek demokratikus akcióját. Most egy új Magyar Nemzeti Pártot alakitottak, hogy amennyire lehet, a néppárt sorait megzavarjáks mindazokat, akik nem iratkoznak a pártjukba, hazaárulással vádolják."1035

A Magyar Nemzeti Párt a programját az udvarhelyi gyülést követően a sajtón keresztül tette nyilvánossá, amely alapjaiban azonos volt a Magyar Szövetségével. A kisebbségi élet szabad fejlődéséért az alábbiakat követelték: 1) Állampolgársági jogegyenlőség, vallásszabadság, magyar egyházak történelmi autonómiájának elismerése, magyar oktatási rendszer önállóságának elismerése, magyar egyházi és kulturális intézmények megfelelő állami segélyezése. 2) Általános, titkos, egyenlő, a kisebbségek képviseletét biztosító választójog, független választási bíróság felállítása, rendeletekkel történő kormányzás megszüntetése. 3) Községi és törvényhatósági jogú városok önkormányzati jogának helyreállítása, bírói jogkörbe való beavatkozás és a politikai rendőrség megszüntetése, közigazgatási rendszer helyreállítása. 4) Magyar nemzeti autonómia a gyulafehérvári határozat 3. pontjának értelmében, amely szerint minden nemzet önmagát kormányozza saját nyelvén, saját közigazgatással és igazságszolgáltatással, amelynek hivatalnokait maga választja ki. 5) A szórvány magyarság részére nyelvhasználati jogok biztosítása. 6) Földbirtokreform igazságos, kisebbségekre nézve retorziók nélküli végrehajtása. ${ }^{1036}$

Székelyföldet követően a Magyar Szövetség Kis-Küküllő megyei tagozata kezdeményezte a Magyar Nemzeti Párt megalakítását 1922. februárban. Elfogadták a parlamenti választásokon való részvételt és kijelentették, hogy a Magyar Szövetség keretében müködnek. A dicsőszentmártoni központtal létre hozott párt elnöke Pekry Sándor, titkára Pokorny Lőrinc lett. Alelnököknek három lelkészt, két ügyvédet és két iparost választottak. ${ }^{1037}$

A Nemzeti Párt kolozsvári alakuló gyülésére 1922. február 12-én került sor. Jósika Sámuel a januári vezérlő-bizottság ülését követően újabb egyeztetésre hívta a politikai vezetőket. A kolozsvári Magyar Nemzeti Párt alapítóit arra kérte, hogy működjenek együtt az Erdélyi Néppárttal a Szövetség keretén belül, és annak egységét őrizzék meg. ${ }^{1038}$ A Magyar Szövetség működtetése, a politikai egység kívánalma és a közelgő választások egymásra utalták a két csoportot. Ismét megegyeztek arról, hogy a két párt a Magyar Szövetség irányelvét elfogadva fejti ki politikai tevékenységét. ${ }^{1039}$

\footnotetext{
1035 MNL OL K63 230. csomó 27. tétel. 27/4. II. (A Magyar Szövetség csődje. Epoca, 1922. február 4.)

${ }^{1036}$ A Magyar Nemzeti Párt programja. Ellenzék, 1922. 43. évf. 28. szám, február 5. 1.

${ }_{1037}$ A Magyar Nemzeti Párt megalakítása Kisküküllő megyében. Ellenzék, 1922. 43. évf. 35. szám, február 15. 2.

${ }^{1038}$ Fordulat az erdélyi magyar politikában. Ellenzék, 1922. 43. évf. 29. szám, február 8. 2.;

${ }^{1039}$ A megbeszélésen a Magyar Szövetséget az elnökön kívül Grandpierre Emil, Ugron István, Inczédy-Joksmann Ödön, Gyárfás Elemér, Hajdu István, Nagy Károly püspök, Balázs András kanonok, Sándor József, Török Andor, Sebesi János, Pál Gábor, Ferencz József püspök, Haller Gusztáv képviselte. Az Erdélyi Néppárt nevében
} 
Továbbá, hogy a választási egyezségük keretén belül közös listát állítanak, azzal a kikötéssel, hogy a székelyföldi kerületeket egymás között megosztják. (A Néppárt Kecskeméthy Istvánt valamelyik székelyföldi kerületben kívánta indítani). ${ }^{1040}$

A közös pontok kialakítása ellenére a Nemzeti Párt gyülésén a felszólalók nem hagyták érintetlenül a két magyar párt között feszülő ellentéteket. Óvári Kázmér, Gabányi Imre és Seprődi János mondtak beszédet. Mindhárom szónok eltérő hangsúllyal, de tartalmát tekintve az Erdélyi Néppárt és a Magyar Nemzeti Párt között meghúzódó különbségekre fókuszált. Óvári az oktatás kérdésében megállapította, hogy Kósék a felekezeti iskolákkal ellentétben az autonóm, világi jellegủ oktatást preferálják. Gabányi szerint a Néppárt nem a teljes magyarságot képviselte, hanem csak egyes csoportokat. A Magyar Nemzeti Párt létrehozását többek között azzal indokolta, hogy Kecskeméthyékkel ellentétben a nemzeti egységet képviselik. Seprödi két pontban jelölte meg az eltéréseket. Egyfelől világnézeti szempontból a Néppárt osztályharcos alapon áll, másfelől a nemzetiségi kérdés nem magyar kérdésként nyer értelmet. A kritikákra a kolozsvári Néppárt nevében Nyírő József válaszolt, aki a Magyar Szövetség programjával összhangban lévőnek minősítette a Néppárt politikai céljait. Jósika zárta a felszólalók sorát, aki a Magyar Szövetség nevében üdvözölte a pártalakítást és annak irányelveit. A párt élére Ferenc József unitárius püspököt választották. ${ }^{1041}$

Háromszék megyében a kis-küküllői pártalakuláshoz hasonlóan a helyi Magyar Szövetség tagjaira épült az új párt szervezete. Szentkereszthy Béla, a Magyar Szövetség helyi elnöke a belpolitikai eseményekre hivatkozva tartotta szükségesnek a Magyar Nemzeti Párt létrehozását. Megválasztották a párt megyei vezetőségét, amely a megyei Szövetségével volt megegyező. Így lett a párt helyi elnöke is Szentkereszthy Béla. ${ }^{1042}$ A megyei szervezet belső tagozatait a járási szinthez igazították, amelyeket egy külön vezetőség koordinált. ${ }^{1043}$

A két magyar párt között a választásokat megelőzően két kérdésben bontakozott ki politikai vita. A Magyar Nemzeti Párt Grandpierre irányelveivel összhangban a nemzeti autonómia részletes kidolgozását támogatta. Az Erdélyi Néppárt ezzel szemben Erdély autonómiáját, összességében Románia föderalizációját tekintette kívánatosnak.

Kecskeméthy István, Hubay Károly, Zágoni István, Szász Endre, Csízhegyi Sándor, Cseh József, Nagy János és Balázs István voltak jelen. Elejtették az egységes párt tervét. Ellenzék, 1922. 43. évf. 30. szám, február 9. 5.

${ }^{1040}$ A magyar pártok választási egyezsége. Keleti Újság, 1922. 5. évf. 25. szám, február 11. 2-3.

${ }^{1041}$ A központi intézőbizottság (elnökség) tagjai. Titkár: dr. Székely Endre. Elnökség: dr. Abrudbányai Ede, dr. Gabányi Imre, Hevesi József, Fekete-Nagy Béla, dr. Jelen Gyula, báró Kemény Ákos, Kovács Kálmán, Reiter József, gyalui Rosenberger Sándor, dr. Seprődi János, Szabó József, Székely Viktor. Magyar Nemzeti Párt impozáns zászlóbontása. Ellenzék, 1922. 43. évf. 34. szám, február 14. 5.

1042 Alelnökök Ferenczy Géza, Török Andor, Bogdán Arthur, Csutak Vilmos, Hinléder Fels Jenő, Havadtőy Sándor, titkár Kovács Kálmán.

${ }^{1043}$ Elnök József Lajos, alelnökök Jakits István, Óváry Károly, Kónya Kálmán, Böjthe Ferenc. Megalakul a háromszéki Magyar Nemzeti Párt. Ellenzék, 1922. 43. évf. 39. sz. február 19. 1. 
A koncepcionálisan eltérő két program egyikét sem dolgozták ki, csupán a szélesebb kereteket adták meg. Kósék Erdély soknemzetiségü etnikai történetére építve, a régión belül önállóan müködő nemzeti autonómiákat magukba foglaló regionális közigazgatásban gondolkodtak. Grandpierre a magyar etnikai elveket hangsúlyozta. A másik eltérés az oktatáspolitikában jelentkezett. A konzervatív oldal az egyház iskolafenntartó szerepét emelte ki, a felekezeti oktatásra helyezve a hangsúlyt. A néppártiak elfogadták a felekezetek részvételét az oktatásban, de mellette a világi, az önkormányzatokat is magába foglaló vegyes rendszert képzeltek el. Az egységes nemzeti iskolarendszer a szemükben a felekezetek és az önkormányzatok közremüködésével valósulhatott volna meg. ${ }^{1044}$ Paál Árpád a progresszív és a konzervatív elképzelések közti vitát a következőképpen jellemezte: „Van a magyarságnak egy csoportja, amelyik erdélyi és népi alapon egyelöre nem találja meg a maga közéleti elhelyezkedésének a kilátásait, tehát kilép külön, hogy magának fórumot és megnyilatkozási módokat szerezzen. Kimutatja, hogy ö elszigeteltebb keretekben csakis a magyar népkisebbségi nemzet önkormányzatáért kíván küzdeni s hogy a közmüvelödési életben is bizonyos konzervatizmusokra törekszik, például az egész magyarságot összesitö nemzeti iskolarendszert nem akarja. Ezzel szemben áll az erdélyi és csatoltsági részek regionalizmusának az a követelése, hogy az új terület minden nemzete kapja meg a maga önkormányzatát, s hogy azoknak a kölcsönössége védje egymás fönnmaradását, mert csak ezen a módon oldhatók meg teljes megnyugvással az új területek nemzeti különbségei."1045

\subsubsection{A progresszív Keleti Újság és a Napkelet magyarországi recepciója, 1919-1922}

Az erdélyi magyar progresszívek a világháború utáni első években polgári radikális módon fogalmazták meg társadalompolitikai elvárásaikat. A Keleti Újság és a Napkelet az 1848-1849es és az 1918-as polgári forradalmak hagyományába (szabadságeszmény, pacifizmus, társadalmi megújulás, önkormányzatiság, függetlenség) foglalták a demokratikus szellemiségü erdélyi magyar politikát, a kisebbségjogi küzdelem harcát, illetve a román-magyar közeledés gondolatát. A világnézeti és a nemzeti szempontok egybefonódtak a magyar modernizációs követelményekkel, az államjogi elcsatolás kényszerében a világháború előtt is mérlegelt regionális önállósulás és a kelet-európai népek kultúrnemzeti munkamegosztásának programjával. ${ }^{1046}$

\footnotetext{
${ }^{1044}$ Az Erdélyi Magyar Néppárt az iskola kérdéséről. Keleti Újság, 1922. 5. évf. 25. szám, február 11. 3. 1045 Paál Árpád: Új magyar pártalakulás. Keleti Újság, 1922. 5. évf. 33. szám, február 12. 1.

${ }^{1046}$ K. LENGYEL: A kompromisszum, 2007. 229-231.
} 
A Budapesttől elforduló decentralizációs mozgalom - folytatva az 1918 előtti küzdelmét szembe találta magát a budapesti nemzeti-keresztény kormánykörök felé lojális erdélyi konzervatívakkal. A két tábor közti vita legélénkebb periódusa a világháborút követő korai évekre tehető, amelyben egyrészt még élénken jelen voltak a régi magyarországi belpolitikai ellentétek. Másrészt Magyarország bel- és külpolitikája hatással volt az utódállamokba szakadt magyarság helyzetére és többség-kisebbség rendezetlen viszonyára. ${ }^{1047}$ A romániai magyar nemzeti érdeket a vita ennek ellenére nem osztotta meg, mert a progresszívek fokozatosan felhagytak a világnézeti elkülönüléssel, a konzervatívak pedig alkalmazkodtak az államjogi feldaraboltsághoz (integrációs stratégiák kidolgozása), amelyet a bukaresti kormányok kisebbségellenes politikájukkal akaratlanul is erősítettek. Ebben a kényszerhelyzetben az egységgondolat jegyében - az eltérő módszerek ellenére is - a két tábor 1922-ben megalakította az Országos Magyar Pártot.

A Keleti Újság és a Napkelet hasábjain 1919-1922 között megjelent közéleti írások három - egymással összefüggő - téma körül bontakoztak ki: 1) Az 1918-as októberi forradalom demokratikus társadalomszervező szellemiségének védelme a magyarországi antiliberális ellenforradalmi kurzussal szemben, 2) A romániai magyarság kisebbségi társadalomként való értelmezése (párhuzamos nemzetépítés) 3) A független magyar köztársaság program szembeállítása a Habsburg monarchiával. A (romániai) magyarság progresszív politikai és társadalmi iránya az egyetemes emberi méltóság jegyében saját nemzeti közösségének demokratikus átformálására, a kiváltságrendszereken alapuló elnyomó uralom megszüntetésére irányult. A romániai magyar progresszív gondolkodásban „1918” egyszerre jelentette a régi Magyarország és az új román politikai rendszer kritikáját. Az erdélyi polgári radikálisok az októberi forradalom társadalomban bekövetkezett „kitörését” - minden utólagos tiltakozás ellenére is - elkerülhetetlen eseménynek tekintették. A Keleti Újság főszerkesztője, Zágoni István szerint a forradalom a korábbi fennálló társadalmi, politikai és háborús viszonyok ellen irányuló természetes következmény volt. „A nagy háborúk a forradalmi kitörések vágyát keltik a lelkeken. A meginditott nagy háborúk felhasogatják és felháborgatják a tömeglélek nyugalmát."1048 A magyarországi politikai viszonyok 1919 öszére megváltoztak. A Tanácsköztársaság bukását követően erőteljes jobbratolódás következett be, a közvéleményt az ellenforradalmi erők által képviselt keresztény-nemzeti eszmekör dominálta, amely Károlyi Mihályt, Jászi Oszkárt, Kun Bélát és követőiket a magyar állam összeomlásának felelőseiként állították be.

${ }^{1047}$ Zágoni István: Október 31-ére. Keleti Újság, 1922. 5. évf. 246. szám, október 31. 1. 1048 Uo. 
A Magyar Szemle - és sok más budapesti újság - a következő hangnemben fogalmazott: „Áll ez az 1918. október 31-iki forradalomra, mely nyitánya és megindítója volt a magyar történelem legszomorúbb és legsilányabb korszakának, mely Károlyi Mihály, majd Kun Béla nevéhez füzödik." ${ }^{1049}$ A Keleti Újság és a Napkelet mindkettőjüket védelmébe vette a Károlyi-kormány demokratikus vívmányainak hangsúlyozva. Történelmi fontosságú lépésnek tekintették az 1919. évi köztársaságról szóló néptörvényt, illetve a földreformot, amelyben Károlyi államférfi szerepét - 1919 februárjában saját birtokán kezdte el a földosztást - méltatták. ${ }^{1050}$ A két újság „október programját” - demokratikus politikai választójog, földosztás, progresszív adórendszer, békés külpolitikai orientáció- Románia és Magyarország kormányai számára követendő irányelvként fogalmazták meg. A mindenkori magyar kormánytól körültekintő külés belpolitikát vártak el, amely hatással van a kisebbségi magyarságra. „Senki nem veheti zokon az erdélyi magyarságtól, hogy különös érdeklödéssel figyeli a magyarországi eseményeket. [...] Magyarország bel- és külpolitikája mindenesetre hatással van az utódállamokba szakadt magyar nemzeti kisebbségek sorsára." ${ }^{1051}$ A polgári radikális értékekkel rokonszenvezők (Kós Károly, Zágoni István, Paál Árpád) számára a földreform - általános problémaként jelentkezett az első világháborút átélt Európában -kulcskérdés volt, amely eltérő módon, de egyformán érintette a romániai és a magyarországi paraszti rétegeket. A földpolitika (nagybirtokrendszer felszámolásának) tematizálása a két lap hasábján a demokrácia fokmérőjeként volt jelen. „A földreform kérdése az, amellyel a demokrácia áll és bukik." ${ }^{1052} \mathrm{Ez}$ az érvelés megegyezett Jászi Oszkár Az archimedesi pont címü 1919-es írásával, amely a forradalmi változások széles körü társadalmi elfogadtatását egy radikális földbirtokreform megvalósításában látta. ${ }^{1053} \mathrm{~A}$ kisebbségi magyar progresszió Budapestet érintő fölreformról szóló kritikája, átvitt értelemben a bukaresti kormány 1919-ben megindított, a magyar kisebbség földmagántulajdonát súlyosan sértő nézőpontként is értelmezhető.

1049 Túri Béla: A forradalmi felelösségről. Új Magyar Szemle, 1920. 3. szám, 295.

Továbbá lásd: JÁSZI Oszkár: Az októberi forradalom (1920). In: Jászi Oszkár publicisztikája. Magvető Könyvkiadó, Budapest, 1982. 301 (289-310) [Továbbiakban: Jászi Oszkár publicisztikája, 1982]

1050 A köztársaság védelme. (1919. évi XI. néptörvény). Keleti Újság, 1919. II. évf. 32. szám, február 5.; Károlyi Mihály saját birtokán megkezdte a földosztást. Keleti Újság, 1919. II. évf. 46. szám, február 28. 1.

1051 (Zágoni István) A rehabilitált október. Keleti Újság, 1921. 4. évf. 132. szám, június 29. 1. 1052 Uo.

${ }^{1053}$ Jászi Oszkár publicisztikája, 1982. 286.;

A „,f̈ldművelő nép földhöz juttatásáról” szóló, XVIII. néptörvényt a kormány 1919. február 2.-án fogadta el. Ez minden 500 holdon felüli világi (ez Jászi Oszkár javaslata volt) és 200 holdon felüli egyházi birtok kártalanítás ellenében történő kisajátítását lehetővé tette. Az igényjogosultak között első helyen a hadirokkantak álltak, majd a hadiözvegyek, a katonai szolgálatot teljesítő nincstelenek és szegényparasztok. SIPOS József: A földkérdés. Rubicon. http://www.rubicon.hu/magyar/oldalak/a_foldkerdes/ (Letöltve: 2018. január 26.) 
A Jászit és Károlyit, illetve az októberi forradalom híveit (újságírókat, értelmiségieket stb.) ért támadások a trianoni Magyarországon változatos formát öltöttek a két világháború között (internálás, kiutasítás, fizikai erőszak, korrupciós vádak, bűnbakképzés,). ${ }^{1054}$ A közös ellenségkép és sztereotípiák megteremtésében fontos szerepet játszott a sajtó, amely az októbristákat és a velük szimpatizálókat a nemzet ellenségének, a társadalom destruktív elemeinek bélyegzett meg. Erre példa a budapesti Szózat című napilapban Károlyival és Jászival, illetve a róluk pozitívan író Keleti Újsággal és a Napkelettel szembeni lejárató kampány. ${ }^{1055}$ A Szózat Károlyiról azt terjesztette, hogy Erdélyben a Keleti Újságot és a Napkeletet felhasználva szovjet pénzen aknamunkát végez a „Csonkamagyaroszág” és az erdélyi magyarság ellen. Ezt Károlyi úgy teszi - írja a Szózat - hogy a Keleti Újságot „,részben hazafias, erdélyi szellemben derék irókkal íratják hatalmas honoráriumok fejében”, míg a Napkeletet „a nemzetközi zsidóság és Jászi silány söpredéke.”1056 A jobboldali támadásokra az ellenválasz nem maradt el a két kolozsvári magyar lapban, amelyek a budapesti kormánypolitika antidemokratikus lépéseit kifogásolták. A cenzúra intézménye, a sajtószabadságot és az újságírókat ért korlátozások, illetve atrocitások kiemelt hangsúllyal szerepeltek a magyarországi belpolitikáról szóló tudósításokban. Az erdélyi magyar újságírók körében az egyik legnagyobb tiltakozást kiváltó eseményre akkor került sor, amikor 1921 júliusában Budapesten letartóztatták a polgári radikális párt egykori vezetőtagját, Szász Zoltán újságírót. ${ }^{1057}$ Az Erdélyi és Bánáti Újságíró Egyesület tiltakozó levelet küldött a frissen felállt Bethlen-kormánynak (1921. április), amelyben azt írták, hogy „A magyar szellem szabadságérdekeinek súlyos megsértését érezzük ebben a tényben." 1058

\footnotetext{
${ }^{1054}$ A két világháború közti bünbakképzésröl számos írást közöltek. A teljesség igénye nélkül: Major Róbert: 25 év ellenforradalmi sajtó 1919-1944. Budapest, Cserépfalvi, 1945; Zinner Tibor: Az ébredök fénykora 1919-1923. Budapest, Akadémiai Kiadó, 1989; Pelle János: A gyülölet vetése. A zsidó-törvények és a magyar közvélemény 1938-1944. Európa Könyvkiadó, 2001; Gyurgyák János: Ezzé lett magyar hazátok. A magyar nemzeteszme és nacionalizmus története. Bp., 2007

${ }^{1055}$ 1919. szeptember 28-án jelent meg a TEVÉL (Magyarország Területi Épsége Védelmi Ligája; Területvédelmi Liga) támogatását élvező Szózat első száma. A „nemzeti, keresztény, agrár, pártonkívüli” lapot kormánytámogató célzattal hozták létre, ahogy azonban mélyült az ellentét Bethlen és az Egységes Párt fajvédő frakciója között, a lap jellegében változás következett be. A Szózat a kormányt jobbról támadó (fajvédő, területvédő nacionalista, zsidóellenes) ellenzéki lappá alakult. A lapot az Etelközi Szövetség egyik vezetöje, Ulain Ferenc indította s volt első föszerkesztője, tőle Bajcsy-Zsilinszky Endre vette át 1922-ben. A Szózat a fajvédők legföbb propaganda eszköze lett. (https://adtplus.arcanum.hu/hu/collection/Szozat/, Letöltve: 2018. január 28.)

1056 Kádár Imre: „Károlyi Mihályék Erdélyben”. Napkelet, 1922. 3. évfolyam, (március 1.) 4. szám, 207-208.; Weiss Sándor: A Világ, a Szózat és egy kis relativitás. Napkelet, 1922. május 15. 3. évf. 9. szám, 7.

${ }^{1057}$ Szász Zoltán (Kolozsvár, 1877-Budapest, 1940): a Nyugat, a Pesti Hírlap munkatársa, a Polgári Radikális Párt egyik vezető tagja. A Tanácsköztársaság alatt letartóztatják, mert bírálja a szabadságjogok megsértéséért. A bécsi emigráns Jövő című lapban (szerkesztői: Garami Ernő, Lovászy Márton) megjelent ellenforradalmat bíráló cikkeiért letartóztatták 1921 kora nyarán „Az állami és társadalmi rend hatályosabb védelméről” szóló 1921. évi III. tc. értelmében. 6 hónapnyi vizsgálati fogság után a kúria egyévi fogházra ítélte.

Társadalmi Lexikon. Szerk.: Madzsar József. Budapest, Népszava-könyvkereskedés (Szász Zoltán szócikk), 632.; Vámbéry Rusztem védőbeszéde a Kúrián Szász Zoltán ügyében. Világ, 1924. 15. évf. november 6. 7.

${ }^{1058}$ Erdélyi tiltakozás a budapesti újságírók letartóztatása ellen. Keleti Újság, 1921. 4. évf. 154. szám, július 24. 3.
} 
A Keleti Újság vezércikkben állt ki Szász, illetve a gondolat- és véleményszabadság mellett. Egy névtelen cikk írója (vélhetőleg Zágoni István, aki egy korábbi írásában) arra hívta fel a magyar kormány figyelmét, hogy a népkisebbségi szabadságjogokért küzdő (romániai, csehszlovákiai stb.) magyar sajtó az utódállamok öncélú kormánypolitikákban még kiszolgáltatottabbá válhatnak, ha Budapest rossz mintát követve letér a szabadság útjáról. ${ }^{1059}$

Hasonlóan kritikus hangnemet ütött meg a Keleti Újság, amikor többek között gróf Bethlen István kormányát (1921. április) és Ravasz László református püspök repatriálását bírálta. A napilap az erdélyi gróf politikai gondolkodásáról azt a véleményt fogalmazta meg, hogy a társadalom többségét kitevő kispolgárság, parasztság és munkásság demokratikus érdekei helyett az arisztokráciát, a nagybirtokosokat képviseli. „Bethlen erös konzervatív tradiciói mellett demokrata szellemet hirdet. Ez a demokrácia azonban nem lesz túltengöbb a többi grófi demokráciáknál [...] Tartani fogja a keresztény-agrár kurzust, de nem olyan szük látókörrel, mint Teleki Pál."1060 A miniszterelnök Bethlentől, elismerve 1918 előtti erdélyi meghatározó szerepét azt várták, hogy Bukarest és Budapest között megfelelő partneri kapcsolatokat alakítson ki. ${ }^{1061}$ Ravasz Lászlóról a Keleti Újság kifejezetten támadólag írt, aki miután 1921-ben elhagyta Erdélyt, megválasztották a Dunamelléki Egyházkerület püspökévé. Ravasz repatriálását két okból kifogásolták, egyfelől hamis képet sugall az erdélyi magyarok körében, hogy a háború pusztította Magyarországon egy jobbélet várhat rájuk. Másfelől morálisan megkérdőjelezhető a repatriálás, amikor a legnagyobb hiányt szenvedik a kisebbségbe került magyarok. „Most te is elmégy Ravasz Laci és neked is kell mondanunk egyetmást. Te nem nyomorúságra mégy, téged nem riaszthatunk a nyomor képeivel. Te díszes polcról még díszesebb polcra hágsz [...]. Én azért csak annyit mondok, hogy manapság szívesebben maradnék éhezö káplán egy eldugott, havasközi faluban."

Az erdélyi progresszívak a romániai magyarságra - amelyről már volt szó - mint önálló társadalom tekintettek. A romániai magyarság társadalomszervezésében az egyik kulcskérdés az volt, hogy magyarság-munkásság-zsidóság együttállásában a munkásság és a zsidóság miként és milyen célok mentén vonható be a kisebbségi társadalom (magyar politikai közösség) kereteibe.

\footnotetext{
1059 Szász Zoltán. Keleti Újság, 1921. 4. évf. 153. szám, július 23. 1-2.

${ }^{1060}$ Bethlen István programja. Keleti Újság, 1921. 4. évf. 75. szám, április 16. 4.

1061 Bethlen István kormánya. Keleti Újság, 1921. 4. évf. 76. szám, április 17. 1.; Magyar kormányválság készül? Keleti Újság, 1921. 4. évf. 135. szám, július 2. 4.; Baranyában. Keleti Újság, 1921. 4. évf. 175. szám, augusztus 18. 1.

1062 Ravasz Lászlóhoz. Keleti Újság, 1921. 4. évf. 133. szám, június 30. 1-2.
} 
A másik kérdés, hogy a romániai magyarok - a lehető legszélesebb jogok birtokában - hogyan tudnak integrálódni a romániai politikai rendszerbe anélkül, hogy az irredentizmus vádja miatt a többségi társalom politikai jogaiktól megfossza. Ebből a nézőpontból tekintve nemcsak az erdélyi polgári radikális irányzat, de a konzervatívak (Grandpierre Emil, báró Jósika Sámuel) is elítélően nyilvánultak meg a megerősödő (romániai és magyarországi) antiszemita mozgalmakkal szemben. ${ }^{1063}$ A Keleti Újság a legélesebb hangnemben tiltakozott a szélsőjobboldali csoportok - például az Ébredő Magyarok Egyesülete, tiszti különítmények erőszakos magatartása ellen, és üdvözölte azokat a kormányzati lépéseket, amelyek visszaszorításukra irányultak 1921-1922-ben. ${ }^{1064}$ Az alkotmányos élet álláspontjuk szerint nem türhet meg más hatalmat az államban, mint a népképviseleten alapuló parlamentáris kormányzás. ${ }^{1065}$ A kirekesztés minden fajtáját elítélték, amikor a numerus clausus ellen tiltakoztak, ami a zsidó származású diákok számának korlátozására irányult. ${ }^{1066}$ A romániai magyarságra nézve ez két okból is negatívan hatott. Egyfelől azok a román politikai pártok és ifjúsági mozgalmak, amelyek a nemzetiségek, illetve a zsidó vallású állampolgárok ellen fordultak (nagyváradi, kolozsvári egyetemi antiszemita erőszakhullám) bátorítást kaptak, másfelől további lökést adott az erdélyi magyar zsidóság disszimilációs folyamatában. ${ }^{1067} \mathrm{~A}$ Keleti Újság és a Napkelet 1919-1922 között a demokratikus politikai közösségalakítás programnak nyújtott nyilvánosságot, ahol a nemzeti érdekek összefonódtak az autonóm, saját intézményekre épülő társadalom igényével. Elvetették az osztálylogikát, a rendies kiváltságokat és elítélték az antiszemitizmust, a zsidóságot izraelita magyaroknak tekintették. A nemzet kapuit szélesre tárták, a munkásságot, a parasztságot és a zsidóságot a magyar politikai közösség egyenlő tagjaiként ismerték el.

${ }^{1063}$ Dózsa Endre: Magyarság és zsidóság. Napkelet, 1922. 3. évf. 2. szám, 95-96.; A magyarság a numerus clausus ellen. Keleti Újság, 1922. 5. évf. 278. december 8. 3.; Grandpierre Emil: Magyar Szövetség. Ellenzék, 1921. XLII. évf. 140. szám, július 6. 2.; A Magyar Szövetség alakuló nagygyülése. Ellenzék, 1921. XLII. évf. 141. szám, július 7. 1-3.

1064 A belső konszolidáció érdekében a Nemzetgyülés elfogadta az ,állami és társadalmi rend hatékonyabb védelméröl” szóló 1921. III. törvénycikket, illetve átalakításra került a rendvédelem szervezete, amely lehetőséget nyújtott a különböző fegyveres különítmények felszámolására, visszaszorítására (például: Ébredő Magyarok Egyesülete, Prónay-, Héjjas-, Ostenburg-különítmények stb.). SUBA János: Karhatalmi formációk Magyarországon 1918-1920. Rendvédelmi-történeti Füzetek, 2008. 15. évf. 18. szám, 1-12.

1065 Ébredő magyarok farsangi körmenete. Keleti Újság. 1919. 16. szám, január 21. 4.; Budapesti hangulat. Keleti Újság, 1920. 3. évf. 249. szám, november 14. 1-2.

1066 Numerus clausus (zárt szám): a magyarországi felsőoktatásban ezzel az intézkedéssel kívánták visszaszorítani a zsidó diákok arányát. Az 1920. évi XXV. törvényt a Teleki-kormány 1920. szeptember 28-án léptette életbe.

${ }^{1067}$ Nagyvárad védekezik az antiszemiták ellen. Keleti Újság, 1922. 278. szám, december 8. 4.; Erdély a numerus clausus ellen. Keleti Újság, 1922. 5. évf. 154. szám, július 13. 7.; A magyarság a numerus clausus ellen. Keleti Újság, 1922. 5. évf. 278. szám, december 8. 3. 
A köztársaság program szembeállítása a dinasztikus politikával a harmadik nagyobb témakör, amely meghatározta az (erdélyi) progresszív irányzat világnézetét. Az első világháború egyik fontos következménye a közép- és kelet európai nagy monarchiák (Hohenzollern, Habsburg) bukása, akiknek a visszatérését az antant hatalmak megtiltották. A tilalom nem vonatkozott a királyságra, mint államformára. 1918 őszén, Magyarországon hasonlóan a legtöbb új államhoz (Finnország, Csehszlovákia, Ausztria stb.) - kikiáltották a köztársaságot. Horthy Miklós vezetésével az ellenforradalmi erők 1920-ban visszaállították a monarchia államformát (1920-1946). A köztársaságpárti (erdélyi) progresszív irányzat nem támogatta a királyság intézményét. Álláspontjukban egyszerre fellelhető a kossuthiánus, Habsburg ellenes hagyomány (az 1849-es detronizáció emléke), az Függetlenségi és 48-as Párthoz való elvi kötődés, az ellenforradalmi erőszak élő tapasztalata, illetve a román pártok politikai támadásától való reális félelem. ${ }^{1068}$ A Keleti Újság és a Napkelet nagy figyelmet fordított a Habsburgok magyarországi visszatérési kísérletére.

A két progresszív lap kampányt folytatott a Habsburg restaurációs kísérlet ellen. Szó szerint közölték Habsburg-ház trónfosztását kimondó 1849. április 19-én jóváhagyott Függetlenségi Nyilatkozatot. ${ }^{1069}$ Idézték a Károlyi-kormány volt belügyminiszterét, gróf Batthyány Tivadart, aki az egyetlen lehetséges politikai útnak a Kossuth-i programot jelölte meg. ${ }^{1070}$ A dinasztiát, IV. Károlyt és az őt követő magyarországi politikusokat a legkülönfélébb negatív jelzőkkel illették: „két fejü sas”, „karmos ragadozó”, „lakájpolitikusok”, „csaló exkirály”. A progresszívak a Habsburgokat és a velük szövetséges gazdasági és politikai elitet tartották a vesztett háborút követő összeomlás legfőbb okozóinak. „Az országot ők kormányozták bele a katasztrófába, a népet ők vezényelték a széditö szakadék mélységes örvényébe." ${ }^{1071}$ Ez az álláspontot megegyezett a Jászi-féle érveléssel, amelyet Paál Árpád is képviselt, amikor Monarchia összeomlásáért a Habsburg elitet okolta. „Ez a rendszer ahogyan nem tudott igazat adni a magyarság márciusi [1848-F.N.] szabadságvágyának, úgy nem tudott igazat adni a többi nemzetek szabadságvágyának sem."1072

\footnotetext{
1068 Miért kell a Habsburgokat detronizálni? Keleti Újság, 1921. 4. évf. 243.szám, november 5. 1.; Támadás a kisebbségek ellen. Goga és Take Ionescu az izgatókról. Keleti Újság, 1921. 4. évf. 66. szám, április 6. 1-2.;

${ }^{1069}$ Miért kell a Habsburgokat detronizálni? Keleti Újság, 1921. 4. évf. 243.szám, november 5. 1

1070 A kizárólagosság átka. Keleti Újság, 1920. 3. évf. 44. szám, november 9. 1.

1071 Két fejü sas. Keleti Újság, 1921. 4. évf. 64. szám, április 2. 1.; Habsburg Károly megkísérli az államcsínyt. Keleti Újság, 1921. 4. évf. 65. szám, április 3. 1-4.; A rab király. Keleti Újság, 1921. 4. évf. 234. szám, október 26. 1.

1072 Paál Árpád: Márciustól októberig. Napkelet, 1922. 3. évfolyam, (március 15.) 5. szám 257-261.
} 
Paál az 1918 előtti bécsi politikával szemben azt rótta fel, hogy a Monarchia népeit egymás ellen fordították, akik „egymás börtönőrei lettek”, a társadalmi különbségeket nem enyhítették, ami a militarizmust és az egymás közti gyanakvást a végletekig fokozták. A közép-európai államhatalmi rendszerek a belső konfliktusok következtében felbomlottak, ahol a népek (román, szlovák, szerb stb.) - Paál értelmezésében kivéve a magyarokat - teljes önrendelkezést nyertek. A magyarok a teljes szabadságot nem kapták meg, mert az utódállamokban a magyar közösség elnyomás alatt él. ${ }^{1073}$

\subsection{Az irracionalitás politikai világa: a Magyar Szövetség másodszori felfüggesztése}

A magyar politikai elit döntése, hogy a magyarság önállóan részt vesz a romániai választásokon az 1921-ben megkezdett, de a Szövetség felfüggesztésével megtorpant szervezkedést újból lendületbe hozta. A belső viták ellenére közös feladatként hárult Kósékra és Grandpierrékre a mozgósítás feladata. Mint volt arról szó, a Néppárt 1922-ben Kolozsváron és környékén, illetve a Székelyföldön próbálkozott a jelöltállítással párhuzamosan alapszervezeteket kiépíteni. Januárjától indították útjára a Magyar Nemzeti Pártot, amely részben a Magyar Szövetségre támaszkodva vett részt a választási toborzásban.

A Szövetség a bizonytalan helyzete ellenére folytatta vidéki terjeszkedését, Szatmár megye esetében az Erdélyi Néppárt közremüködésével. Február 20-án, közvetlenül a válaszátok előtt Szatmár megyében, a hadizóna területén engedélyt adtak a magyarság politikai gyülésének megtartására. Bélteky Lajos, a Nemzeti Tanács volt elnöke ${ }^{1074}$ nyitóbeszédében kijelentette, hogy a helyi magyarság körében megszületett egyezséget követően pártot nem kívánnak alakítani, helyette a Magyar Szövetség tagozatát hozzák létre. A gyülés fővendégei a néppárti Kós Károly, Zágoni István és Paál Árpád voltak, de a Magyar Szövetség képviseletében szólaltak fel. A szatmári magyarságnak arról kellett dönteni, hogy részt kíván-e venni a választásokon és kit jelölnének. Lénárt István, volt polgármester Kós Károlyt kérte fel képviselőjelöltnek, szenátornak pedig Harcsák Géza ügyvédet. Kós és Paál egy demokratikus állam jövőképéről beszéltek, ahol érvényt kell szerezni az önkormányzati, a nemzeti, a nyelvi, a vallási és az oktatási jogoknak a parlamenti részvétel kiharcolásával. A gyülés végén megválasztották a szatmári Szövetség helyi elnökét, Bélteky Lajost, valamint tíz alelnököt, az ötven tagú intézőbizottságot és a kétszáz fős megyei választmányt. ${ }^{1075}$

\footnotetext{
1073 Uo.

1074 Bélteky Lajos: Károlyi-párt tagja, a Nemzeti Tanács szatmári szervezetének elnökeként 1918-ban esküt tett a Károlyi-kormányra. Szatmárnémeti ünnepe. Szamos, 1919. 51. évf. 54. szám, március 4. 1-2.

1075 A választási küzdelem. Keleti Újság, 1922. 5. évf. 43. szám, február 24. 2.
} 
Aradon a Szövetség megalakulására csak a választásokat követőn kerülhetett sor, párhuzamosan a pótválasztásokkal, ahol Zima Tibornak sikerült elnyernie a mandátumot. Az aradi magyarságnak ez volt az első gyülése a háború befejezése óta a hadizóna viszonyai között. Barabás Béla, volt függetlenségi országgyülési képviselő és főispán ${ }^{1076}$ nyitotta meg a tanácskozást a Fehér Kereszt szálloda nagytermében. A politikus a mellözöttségröl és a szervezetlenségröl beszélt, amely a nyelvhasználat korlátozásában és az esküt nem tett tisztviselők kiszolgáltatottságában vált mindennapos tapasztalattá. ${ }^{1077} \mathrm{Az}$ aradiak a pótválasztásokon való részvételről is döntöttek, amire azért került sor, mert aradi mandátumáról Vintilla Brătianu pénzügyminiszter áprilisban lemondott. A választásokon, mint már volt róla szó Zima Tibor, az aradi Kereskedelmi és Iparkamara főtitkára képviselte az aradi magyarságot. ${ }^{1078}$

A Magyar Szövetség másféléves müködése elé folyamatos korlátokat gördített a mindenkori román kormány. 1922 nyarán belügyminiszteri rendeletre (40.229. sz.) másodszor is beszüntették a müködését. Popescu kolozsvári rendőr prefektus, Fileriu kihágási rendőrkapitány, illetve Siguranţia kiküldöttei Meţhes prefektus utasítására a Magyar Szövetség iratait és irodáit lefoglalták (július 7.). Jósika Sámuel elnök Haller alelnök és Naláczy titkár előtte eleget tett a miniszteri felszólításnak, és tudomásul vette a Szövetséget ért tiltó rendeletet. Az indok ismételten az volt, hogy a szervezet alapszabály nélkül működik. Jósika egy tiltakozó záradékot adott át Meţhesnek, amiben leírta, hogy miután az első alkalommal betiltották a Szövetséget a belügyminiszterhez azonnal beterjesztették az alapszabályt, illetve a soron következő (1922. augusztus) nagygyülésen az alapszabály módosítása elő van készítve. Meţhes a következőket válaszolta Jósikának.

\footnotetext{
1076 Barabás Béla (Arad, 1855.-Arad, 1934.: Aradon a Függetlenségi és 48-as Párt vezetője, 1892-től huszonhat éven át magyar országgyülési képviselő. 1914-ben Károlyi Mihály kísérője amerikai útján. 1917-ben Arad megye főispánja, 1922-től az OMP egyik vezetője, 1926-tól a bukaresti parlament szenátora. Jelentős publicisztikai tevékenységet fejtett ki országos és helyi lapokban. Egy ideig szerkesztője volt az Arad és Vidéke politikai napilapnak, főszerkesztője az Aradi Magyar Újságnak (1926-27). Főbb munkái: Amikor Kossuth Lajost hazahívták (Cegléd 1923); Emlékirataim (Arad 1929). http:/lexikon.kriterion.ro/szavak/246/ (Letöltve: 2017. november 18.)

1077 Aradon a lakáshivatal saját hatáskörében elrendelte, hogy csak román nyelven adható be kérvény. Ellenpélda is mutatkozott, amikor az adózáshoz szükséges iratok magyar nyelven is kitölthetőek voltak. Megalakult a Magyar Szövetség aradi szervezete. Aradi Friss Újság, 1922. IV. évf. 86. szám, április 19. 1.

1078 Zima Tibort egyhangúlag képviselőnek jelölték. Aradi Friss Újság, 1922. 1922. IV. évf. 86. szám, április 19. 1-2.; Mozgalom az aradi magyarság szervezkedésért. Aradi Friss Újság, 1922. IV. évf. 77. szám, április 7. 2.
} 
A Szövetség túlterjeszkedett a határain, mert utasításokat adott a felekezeti iskoláknak, az országgyülési választásokon politikai pártként vett részt, a tisztviselők ügyében deputációt küldött, Petőfi-ünnepségek szervezett ${ }^{1079}$, az agrárreform ellen agitációt fejtett ki Karácsonyfalván, ahol a lelkészekkel együtt arra buzdították a gazdákat, hogy ne fogadják el a nekik kiosztandó földeket stb. ${ }^{1080}$

Az irracionalitás, a szubjektív és politikai alapú szabályértelmezés, az erőszak a mindennapok szerves részévé vált. Szász Endre a Szövetség vezetőségének tagja, az Újság szerkesztője a teljes értetlenség hangján azt vetette fel, hogy miként fordulhat elö, hogy Meţhes prefektus ,a vidéki kiskirály jogot formált magának arra, hogy az egész romániai magyarságot képviselö hatalmas szervezet életét megbénitotta.” A választ is megadta: „meginogni készülö pozícióját a soviniszták előtt kétségkívül szimpatikus gesztusával megszilárdítsa."1081 Barabás Béla hasonlóan nyilatkozott, amikor az ország legtekintélyesebb kisebbségének egyesülését mindenáron igyekeztek ellehetetleníteni. ${ }^{1082}$ A belügyminiszter, Vaitoianu a lugosi Luptának adott interjúban beszélt a Szövetség betiltásáról. Véleménye szerint a „Szövetség ki akarta sajátítani a magyarság minden mozgalmát s így még azokét is, akik nem tartoztak a Szövetség zászlaja alá. [...] Megállapítottuk továbbá, hogy a Szövetség titkára olyan értesitést adott ki, amely szerint a magyarországi hatóságok csak olyan igazolványokat fogadnak el érvényesnek, amelyeket a Szövetség vezetősége állit ki." Az alapszabállyal kapcsolatosan megjegyezte, hogy amennyiben a szervezet, mint kulturális egyesület módosítja a szabályait, és az megfelel az előírásoknak, megkapja a müködési engedélyt. ${ }^{1083}$

\footnotetext{
${ }^{1079}$ Az első Petőfi-ünnepet, a Segesvár mellett fekvő fehéregyházi mezőn 1899. július 31-én tartották. (Az ünnepi ódát Jókai Mór írta, amit E. Kovács Gyula, a kolozsvári Nemzeti Színház müvésze adott elő. E. Kovács az előadás közben agyvérzést kapott.) Az első Petőfi-ünnep. Ellenzék, 1922. 43. évf. 169. szám, július 30. 2.;

A Romániába szakadt magyarság 1922-ben ünnepelhette újból a Petőfi-ünnepet, amelyre a tudósítások szerint ötezren gyültek össze. A hatóságok engedélyezték a nemzeti zászló használatát. Ünnepi beszédet mondott a Magyar Szövetségben is szerepet vállaló Dózsa Endre, volt alispán, az Erdélyi Irodalmi Társaság elnöke, Sándor József országgyülési képviselő, az EMKE fötitkára, illetve Szabolcska Mihály (aradi író). Zarándoklás a fehéregyházi sírhoz. Ellenzék, 1922. 43. évf. 170. szám, augusztus. 1. 1.

${ }^{1080}$ Ismét beszüntették a Magyar Szövetség müködését. Arad és Vidéke. 1922. XLII. évf. 144. szám, július 8. 1.

${ }^{1081}$ Szász Endre: A Magyar Szövetség föloszlatásának rejtélye. Újság, 1922. XXIV. évf. 150. szám, július 10. 1.

${ }^{1082}$ Barabás Béla a Magyar Szövetség betiltásáról. Arad is Vidéke. 1922. XLII. évf. 145. szám, július 9. 1.

${ }^{1083}$ Vaitoianu belügyminiszter indokolja a Magyar Szövetség betiltását. Arad is Vidéke. 1922. XLII. évf. 148. szám, július 14. 2.
} 
Az újabb felfüggesztő határozat kihatott az esküre jelentkezett magyar tisztviselök ügyének további intézésére is. A Magyar Szövetség keretein belül működött az ún. „Alkalmi Bizottság”, amely a trianoni békeszerződést követően esküre jelentkezett, de állást nem kapott tisztviselők képviseletét látta el. ${ }^{1084}$ A Bizottságot az egykori tábla bíró, dr. Tóth György és Naláczi István alakították és vezették, akik azzal a kéréssel fordultak Meţheshez, hogy a tisztviselőkre vonatkozó lefoglalt iratokat adja ki, mert anélkül nem tudják megtartani a tisztviselők tanácskozását. Az engedélyt megkapták. Tóth a nagygyülésen összefoglalta a kialakult helyzetet, és ráutalt arra, hogy a tisztviselök érdekében kifejtett érdekérvényesítés a kormánnyal szemben a Magyar Szövetség keretén belül 1921 öszétől vált rendszeressé. A legnagyobb eredménynek azt tartotta, hogy a nyugdíjazandó tisztviselők számára Temesváron, Kolozsváron és Marosvásárhelyen engedéllyel müködő Nyugdíjasok Szervezte működik. A Bizottság számára a legnagyobb kihívás az volt, hogy a magyar tisztviselők a Magyar Szövetség felfüggesztésével eszköztelenné válhatnak az érdekérvényesítés során. A bizonytalan helyzetre válaszul megalakították az Állásnélküli Magyar Tisztviselők Egyesületét, és memorandumban kérték a királyt a tisztviselők állásukba való visszahelyezésére. ${ }^{1085}$ A választávirat arról szólt, hogy az alsó- és a középfizetési kategóriába tartozó állami tisztviselők fizetésének sürgős elintézését kilátásba helyezték Bukarestben, de a főtisztviselőkét megtagadták. ${ }^{1086}$

\subsection{A Magyar Szövetség politikai „örököse” a Magyar Nemzeti Párt. A fúzió útján}

A Magyar Szövetség a belügyminiszter engedélyével a betiltási rendelettöl függetlenül megtarthatta nagygyülését 1922. augusztus 6-án, Kolozsváron. Két kérdés szerepelt a tervezett napirendben: az egy évre megválasztott vezetőség tisztújítása, illetve az alapszabály módosítása, amely ellen a kormány többször is kifogást emelt. ${ }^{1087}$ A nagygyülést megelőzően élénk vita folyt a két magyar párt, illetve a Magyar Szövetség közti viszonyrendszerről, és általában a politikai képviselet módjáról. Két alternatíva kínálkozott: deklarálják, hogy a Magyar Szövetség a magyar pártokat képviselő közös pártszövetség, vagy a napi pártpolitikától független, kulturális, gazdasági és kisebbségjogi szervezet.

\footnotetext{
1084 Tóth György kimutatása 1922. áprilisban: 1600 esküt tett tisztviselő, akik nem kaptak nyugdíjazást. 1600 olyan tisztviselőt írt össze, akik semmiféle gondoskodást nem kaptak. Nem tartozik e szám közé: vasutas, postás, tanító, tanár, akik nem az államnál kaptak munkát, hanem pl. utóbbiak az egyházi iskolákban. 150-160 pénzügyi és tisztviselö, akik kaptak munkát. A bíróságoktól 440 tisztviselö van alkalmazás nélkül, köztük bírók, ügyészek. A tanügyi alkalmazottak: 71 óvónő, 193 tanító, 56 tanár, 7 tanfelügyelő nem volt állásban. Akik még itthon maradtak. Keleti Újság, 1922. 5. évf. 90. szám, 21. 4.

${ }^{1085}$ Megalakult az Állásnélküli Magyar Tisztviselök Egyesülete. Újság, 1922. XXIV. évf. 150. szám, július 10. 3. 1086 Távirati választ küldött a király. Újság, 1922. XXIV. évf. 157. szám, július 16. 3.

1087 Összehívták a Magyar Szövetség nagygyülését. Keleti Újság, 1922. 5. évf. 139. szám, június 24. 2-3.
} 
Az eltérő álláspontok ellenére a vita konstruktív volt, mert ekkor körvonalazódott az egységes pártalakítás terve (fúzió). A két párt között fennálló ellentét legitimációs vitaként értelmezhető.

Az Erdélyi Néppárt, amely magát a „demokratikus magyarság egyetlen politikai szervének" tekintette, a Szövetség nagygyülésére készülve pártgyülést tartott július 15-én, Kolozsváron. A helyi magyar zsidóságot Gombos Benő képviselte. ${ }^{1088}$ Kecskeméthy István vezetésével a néppártiak egy indítványt készítettek elő, amely a Magyar Szövetség demokratikus átszervezését, az egység és a müködés garanciáit kívánta előirányozni. Attól tartottak ugyanis, hogy harmadszor is betilthatják a Szövetséget, amennyiben annak alapszabálya nem felel meg a békeszerződés alapelveinek, illetve az egyesületekről szóló elöírásoknak, amelyekre a román politika többször is hivatkozott. Meţhes legutóbb azért függesztette fel a Szövetséget, mert az pártpolitikai tevékenységet fejtett ki. ${ }^{1089}$ Fábián László és Szász Endre rámutatott arra, hogy a Magyar Szövetség nem emelkedett felül a pártkereteken, és a választásokon, mint pártpolitikai szervezet folytatott aktivitást a Magyar Nemzeti Párton keresztül, amit ő maga alakított. Kecskeméthy és Zágoni is, amellett érveltek, hogy olyan átszervezésre van szükség, amely nem pártpolitikai alapú. A gyülés az alábbi határozatot fogadta el: „a Magyar Szövetségnek ki kell kapcsolni müködési köréből a politikát s egyedüli célja a kisebbségi jogok védelme s az e körüli sérelmek elleni állásfoglalás lenne."1090 Románia magyar anyanyelvü és kultúrájú állampolgárai, mint egységes magyar nemzeti kisebbség egy szervezetben egyesüljön. A Szövetség célja ebböl kifolyólag a kisebbségi jogok maradéktalan gyakorlása. ${ }^{1091}$ Ugyanerről a kérdésről Bernády György egészen más álláspontot képviselt, amelyet a renegátnak tartott Székelyföld címü lapban közölt július végén. „A Magyar Szövetség, mint kulturális vagy más egyesület nem kell’, helyette a magyar kisebbség minden irányú kérdését felölelő egységes politikai szervezet tervét támogatta. Az erdélyi magyarságnak pártokra való szakadását végzetes veszedelemnek látta. A politikai egység útját kereste, amelyet a Magyar Nemzeti Pártban jelölt meg. Kikötötte, hogy a párt legyen demokratikus, szabadelvü és nemzeti. Ez a terve alapvetően megegyezett az 1920-as Nyilt levélben kifejtettekkel. ${ }^{1092}$

\footnotetext{
1088 Gombos Benő: a világháború előtt banktisztviselő, kolozsvári közíró, több lapban jelentek meg írásai (Ellenzék, Magyar Kisebbség). Az Erdélyi Néppárt tagja, majd belépett az OMP-be, 1924-től annak központi ellenőre. A zsidóságon belül az asszimiláns irányzathoz tartozott. GYÖRGY, 2006.19 .; http://mek.oszk.hu/03600/03628/html/g.htm\#GombosBenő (Letöltve: 2017. november 19.)

${ }^{1089}$ A Magyar Néppárt a Szövetség demokratizálásáért. Újság, 1922.XXIV. évf. 154. szám, július 13. 4.; A Magyar Néppárt a Magyar Szövetség újjászervezéséért. Újság, 1922. XXIV. évf. 157. szám, július 16. 4.

1090 A Néppárt ki akarja zárni a politikát a Magyar Szövetségből. 1922. Újság, XXIV. 158. szám, július 18. 1-2.

${ }^{1091}$ A Magyar Néppárt értekezlete. Keleti Újság, 1922. 5. évf. 157. szám, július 16. 2-3.

1092 Bernády György az erdélyi magyar egységért. Ellenzék, 1992. 43. évf. 166. szám, július 27.1.
} 
Grandpierre Emil már az Ellenzékben kifogásolta Bernády véleményét, és a Magyar Szövetség pártérdekeken felülálló egyetemességét hangsúlyozta. ${ }^{1093}$ Pontosabban az volt az álláspontja, hogy a magyarság parlamenti képviseletét ellátó párt, egy egységes magyar nemzeti párt a Magyar Szövetségnek alárendelve müködjön. A Szövetség ilyen típusú fenntartásához azért ragaszkodott, mert tartott a pártpolitikai konfliktusoktól, amelyben a magyar politikai közösség szétforgácsolódását látta. ${ }^{1094}$ Jakabffy Elemér és Willer József általánosságban fogalmazták meg álláspontjukat, konkrét javaslatot nem tettek. A két bánsági a történeti Erdély és minden azon kívül élő romániai magyar egysége és a demokratikus jogok kívánalma mellett szólt. ${ }^{1095}$

A néppárti gyülés második kérdése az alapszabály-tervezettel függött össze. Azt az igényt fogalmazták meg, hogy előbb a vidéki alakulatok vezetőségét válasszák meg, és ezek alakítsák meg a központi vezetést, hogy alulról felfelé, valóban demokratikusan épüljön fel a Szövetség. A harmadik pontban a vita a Néppárt politikai építkezéséről és útkereséséről folyt. Paál Árpád szerint a Nemzeti Párt a „,múltnak elszakadt szálait keresgéli”, de „Néppárt a reális államjogi viszonyokat veszi alapul az itteni magyarság boldogulásához." 1096 A Néppárt célja ezért - a világnézeti különbségek elfogadásával - a széles értelemben vett erdélyi magyar társadalom képviselete, amely keresi az együttélés lehetőségeit a többi erdélyi népcsoporttal. „Ennek egyedüli útja a becsületes értelemben vett regionalizmus, ami csak látszólag állambontó tendenciájú, mert [...] végeredményben a konszolidációt segíti elö."1097 Felszólalását azzal zárta, hogy a demokrácia és a föderalizmus programjával mielőbb szükséges a Néppártot országos párttá szervezni. A gyülésen megfogalmazott irányelveket megküldték a Magyar Szövetség elnökségének. ${ }^{1098}$

A Magyar Szövetség vezetősége mindeközben az augusztusi nagygyülés megszervezésén dolgozott. Jósika Sámuel és Sándor József személyesen utaztak Bukarestbe, hogy megbizonyosodjanak a nagygyülés engedélyezéséről. A kolozsvári gyülésre megkapták az engedélyt, de minden vidéki szövetségi rendezvényt betiltottak. ${ }^{1099}$ Az előkészületek politikai tétjét egy bukaresti hír is megemelte. A belügyminisztériumból (Franascovici államtitkár) Paál Árpádot a fővárosba kérették, hogy tárgyalásokat folytassanak az erdélyi nemzetiségi ügyekröl.

\footnotetext{
${ }^{1093}$ Grandpierre Emil: Magyar Szövetség és politika (1). Ellenzék, 1922. 43. évf. 163. szám, július 23.1.

1094 Grandpierre Emil: Magyar Szövetség és politika (1). Ellenzék, 1922. 43. évf. 167. szám, július 28.1.

1095 Milyen lesz a Magyar Szövetség. Keleti Újság, 1922. 5. évf. 174. szám, augusztus 5. 3.

1096 Uo. 2.

1097 Uo. 2.

1098 Uo. 2.

1099 Jósika báró a Magyar Szövetség ügyében Bukarestbe utazik. Újság, 1922. XXIV. évf. 159. szám, július 20. 3.; A kormány engedélyezte a Magyar Szövetség nagygyülését. Újság, 1922. XXIV. évf. 162. szám, július 22. 1.; A magyar Szövetség vezetői Bukarestbe utaztak. Ellenzék, 1922. 43. év. 166. szám, július 27. 2.
} 
A román kormány csehszlovákiai mintára eltervezte, hogy a belügyminisztériumban az erdélyi ügyek számára külön ügyosztályt létesít. Az élén, három erdélyi miniszteri tanács állna: egy román, egy szász és egy magyar, nevezetesen Paál Árpád. Paál a kérést visszautasította, politikai függetlenségére és újságírói munkájára hivatkozva, azzal a kiegészítéssel, hogy nyitott bárminemű magyar kérdésben konzultálni a kormánnyal. ${ }^{1100}$

A nagygyülést megelőző napon (augusztus 5-én) került sor a Szövetség központi választmány ülésére, ahol a politikai célok felvállalása vagy annak elhagyása állt a vita középpontjában. Az intézőbizottság - eleget téve a kormány kérésének - a politikai cél elhagyását javasolta előterjeszteni. Paál Árpád eltért pártja álláspontjától, amikor a néppárti határozattal ellentétben a politikai célok felvállalása mellett foglalt állást. Sándor József parlamenti képviselő előbb azt a személyes véleményét fejtette ki, hogy korábban sem akart semmiféle egyesületet vagy hasonló szervezetet, hanem csak egyetlen magyar nemzeti pártot. Szerinte ugyanis várható volt, hogy az egyesületek szigorú ellenőrzése nem teszi lehetővé, hogy egyszerre több területet (közmủvelődés, közgazdaság, politika, jótékonyság stb.) magára vállaljon a Szövetség. Majd arról a konzervatív körökben elfogadott véleményről beszélt, hogy a kormány tudatosan felhasználta az Erdélyi Néppártot a Szövetség sorainak megbontására. A román politika szerette úgy tálalni az aktivista-passzivista ellentétet, hogy a Kós és Kecskeméthy vezette demokratikus, progresszív csoportot a Grandpierre és Jósika irányítása alatt álló arisztokrata, irredenta irányvonal kirekeszti. Sándor a politikai egység biztosításának igényével ezért azt javasolta, hogy a Szövetség önként ne mondjon le programjában a politika célokról. A központi választmány bár megszavazta ezt a programpontot, ebben formában nem került bele az alapszabály-tervezetbe. ${ }^{1101}$

A Magyar Szövetség tagjai, akik a Magyar Nemzeti Pártot támogatták ${ }^{1102}$, a központi választmány ülését követően a kolozsvári Központi-szállóban ugyanaznap este 19h-órától országos pártalakuló gyűlést tartottak. A szervezet alapszabályáról és elnökségéről is döntő tanácskozás köszöntőjében Fekete-Nagy Béla a magyar kisebbség képviseletének bizonytalan intézményes helyzetéröl beszélt.

\footnotetext{
${ }^{1100}$ Paál Árpádot megkínálták a magyar kisebbségi ügyek képviseletével. Újság, 1922. XXIV. évf. 163. szám, július 23. 1.

${ }_{1101}$ A Magyar Szövetség nem mondhat le a politikáról. Ellenzék, 1922. 43. évf. 176. szám, augusztus 8. 1.

1102 Többek között: Grandpierre Emil (Kolozsvár), Gabányi Imre (Kolozsvár), Albrecht Lajos (Bánffyhunyad), gróf Bethlen György (Kolozsvár), gróf Béldi Kálmán (Zsibó), Barabás Béla (Arad), Cziffra Kálmán (Nagyvárad), dr. Haller Gusztáv (Kolozsvár), dr. Morvav Zsigmond (Nagyvárad), Orbán Balázs (Marosvásárhely), dr. Pál Gábor (Csíkszereda), báró Szentkereszthy Béla (Sepsiszentgyörgy), dr. Szele Béla (Brassó), Szabolcska Mihály (Temesvár), akiket a párt 100-as bizottságába is beválasztottak. A Magyar Nemzeti Párt nagygyülése. Ellenzék, 1922. 43. évf. 176. szám, augusztus 8. 3.
} 
„Ezért kell a magyarságnak gondoskodni egy olyan szervröl, mely a román állam mai törvényei védelme alatt is, minden körülmények között müködhetik és küzdhet a Magyar Szövetség programjáért [...] Ilyen szerve a magyarságnak a Szövetség programja alapján álló politikai párt lehet."1103 Grandpierre Emil lényegében megismételte az Ellenzékben leírtakat: olyan politikai szervezet létrehozása van szükség, amely a Magyar Szövetség programját felvállalva a magyar nemzeti kisebbséget összefogja. Grandpierre erre a feladatra a Magyar Nemzeti Pártot nevezte meg egyedülinek. Székely Endre párttitkár felolvasta szervezeti szabályzatot (lásd 7. számú melléklet), amely szerint a párt tagja minden 20. évét betöltött férfi és nő, aki a párt programjával egyetért. A párt választókerületenként alakítja meg helyi tagozatait, ha legalább 300 taggal rendelkeznek. A tisztviselőket négy évi időtartamra választják (lásd a 8 . számú mellékletet). ${ }^{104}$ Gabányi Imre a párt alakítását a külső (a román kormányok magyarellenes politikája) és belső („,be akarunk illeszkedni az állam keretébe”) kényszer hatásának tulajdonította. Magyar egységet vizionált, illetve állampolgári egyenlőséget követelt. Az utolsó felszólaló Sándor József volt, aki a következőket mondta: „Azok, akik a magyar nemzeti kisebbség aktivitását megindítottuk, az elején csak öten voltunk: Grandpierre Emil, Paál Árpád, Zágoni, Róth Hugó és csekélységem. [...] A munkát, amelyet a Magyar Szövetség tavalyi nagygyülése elfogadott Paál és Zágoni világnézetét és meggyözödését fejezik ki. [...] A tavalyi nagygyülés kimondotta, hogy ez a program kötelezö lesz az alakulandó pártra nézve. Ez nem pártokat (sic! - F. N.), hanem csakis pártot határozott el, de a balszárnyon, [...] a Néppárt, az ő vezérei által készitett programtól eltért. Ezért kérem kimondani, hogy mi vagyunk a Magyar Szövetség egész politikai irányának örökösei." 1105 A Magyar Nemzeti Párt ezután Sándor József határozati javaslatát magáévá tette, és két párt egyesülését kezdeményezte: „a fúzió, illetve egyesülés érdekében érintkezésbe lép (a Magyar Nemzeti Párt - F. N.) a Magyar Néppárttal s e célból egy 5 tagú bizottságot küld ki."1106

\footnotetext{
${ }^{1103}$ Uo. 1.

${ }^{1104}$ A Magyar Nemzeti Párt nagygyülése. Újság, 1922. XXIV. évf. 176. szám, augusztus 8. 2.

${ }^{1105}$ Uo. 3.

1106 Uo. 3.
} 


\subsubsection{Az utolsó felvonás: politikamentes Magyar Szövetség?}

A nagygyülést a kolozsvári református teológia nagytermében, augusztus 6-án, du. 15h-órakor nyitották meg. Az elnöki emelvényen Ugron István ügyvezető elnök, Grandpierre Emil, Haller Gusztáv, Albrecht Lajos alelnökök, Naláczy István és Deák Gyula titkárok foglaltak helyet. Naláczy István felolvasta az alapszabály-tervezetet (lásd a 9. számú mellékletet), amely magába foglalta a szervezeti struktúrát, a tagok jogait, a tisztségviselők feladatait, illetve, hogy feloszlatás esetén a Szövetség vagyona az EMKE-re, annak esetleges megszüntetésekor az EME-re száll. A Szövetség célját, belefoglalva a politika felvállalását is, Románia magyarságának kulturális, gazdasági és jogi érdekeinek biztosításában fogalmazták meg. Grandpierre a választmányi ülésen ez ellen érvelt, minden bizonnyal azért, mert a Magyar Nemzeti Párt, egy egységben a Néppárttal, kész volt magára vállalni a politikai feladatokat. A nagygyülés a politikai célokkal módosított alapszabályt véglegesítette. Egy ponton heves vita bontakozott ki. Az 1921-es felálláshoz képest a legnagyobb változást az jelentette, hogy a központi választmányt megszüntették, az intézőbizottságot kibővítették, illetve a nagygyülés hatáskörét szükítették. ${ }^{1107}$ Gombos Benő indítványt nyújtott be arra vonatkozólag, hogy az intézőbizottságba delegált megyei választmányok 1-1 küldöttjei a tanácskozási jog mellett szavazati jogot is kapjanak. ${ }^{108}$ Hinléder Jenő helyesebbnek gondolta azt, hogy az intézőbizottság csak 30 főből álljon. A Gombos-féle indítványt Zágoni, Paál, Inczédy-Joksman, Issekutz Viktor és Jakabffy Elemér támogatták. Utóbbi szerint ezzel is elősegíthető, hogy „a krassó-szörényiek és a bánságiak erdélyi magyar mentalitást akarnak szerezni." "1109 Ellene Sebesi János, Pál Gábor érveltek, illetve Gyárfás Elemér, aki a székelyföldi megyei szervezetek túlsúlyától tartott (a 120 ezres Háromszék 12-szer annyi képviselőt küldhet a nagygyűlésbe, mint a 10 ezer magyart számláló Fogaras megye). A nagygyülés Hinléder javaslatát fogadta el (76 igen, 38 nem ellenében). ${ }^{110}$

\footnotetext{
${ }^{1107}$ Az 1921. évi alapszabály szerint a Magyar Szövetség szervezeti felépítése a következő volt: nagygyülés, központi választmány (70 fö, amely 1922. augusztusára 150-re emelkedett), megyei, járási és települési választmányok, a központi tisztikar (elnök, ügyvezető alelnök, öt alelnök, titkár, pénztáros, ellenör), illetve az intézöbizottság (21 fö, amely a központi tisztikar és a nagygyülés maga által választott 10 tagjából állt).

Az 1922-es tervezet szerint az intézöbizottság felépítése: a nagygyülés által saját tagjaiból választott 30 fö, az elnök és alelnökök, a két titkár, illetve a tanácskozó joggal bíró megyei választmányok 1-1 küldöttje és a központi tisztikar többi tagja (pénztáros, ellenőr, ügyész). A Magyar Szövetség új szervezeti szabályainak tervezete. Ellenzék, 1922. 43. évf. 175. szám, augusztus 6.1-2.

${ }^{1108}$ A Magyar Szövetség demokratizálása. Újság, 1922. XXIV. évf. 183. szám, augusztus 19. 2-3.

${ }^{1109}$ Gyülésezik a Magyar Szövetség. Ellenzék, 1922. 43. évf. 176. szám, augusztus 8. 3.

${ }^{1110}$ Uo. 3.
} 
Ugron ezt követően ismertette, hogy az elnökség mandátuma lejárt és a szabályzat új választásokat ír elő. Domahidy Elemér Hajdú vármegye volt főispánja a választásokat nem tartotta időszerűnek, és arra kérte az egybegyülteket, hogy a jelenlegi elnökség folytathassa munkáját. Paál Árpád egyetértett a főispánnal, ami szerinte a belső konfliktusok konszolidációját jelentheti a Néppárt, illetve a Szövetség és a Nemzeti Párt közti ellentétek orvoslásában. Majd az új román alkotmányról folyó parlamenti vitára hívta fel a figyelmet: a magyarság érdemben bár abban nem tud részt venni a választási eredmények tükrében, de azt megteheti, hogy a Magyar Szövetség világossá teszi a magyar nemzet alkotmányos elismerésének igényét. „Követeli [...] a többi nemzetiség mellett szintén egyik államalkotó tényezöként való elfogadását. A Magyar Szövetséget a kormány, mint a magyar nemzet összességének képviseletét engedélyezze." ${ }^{1111}$ Az alkotmányozásban való részvétel érdekében egy tárgyaló bizottság felállítását kezdeményezte a Szövetség a korábbi elnök, Jósika Sámuel vezetésével. Pál Gábor, Zágoni István és Sándor József egyetértőleg erősítette meg Paál javaslatát.

A Szövetség vezetősége a nagygyülést követően egy memorandumot juttatott el a román kormánynak. Kifejtették, hogy a béke-, és a kisebbségi szerződések (1919. december 9.) értelmében a romániai magyarság a „nemzeti kisebbség új közjogi fogalma” alapján kezdte meg a szervezkedését, pártok felett álló szervezeti formában az egyes román politikai körök jóváhagyásával. Célja az, hogy magyar nemzetiségű népcsoportként Románia teljes jogú kulturális, politikai, gazdasági, önkormányzati jogokkal bíró közösségének elismerjék. Felsorolták azt a hét ügyet, amelyekben a Szövetség a kormányhoz előterjesztést tett, anélkül, hogy azok megoldást nyertek volna: telepesek ügye, esküt nem tett tisztviselök visszavétele/nyugdíjaztatása, székelyföldi törvényszékek, illetve bíróságok visszaállítása, csík megyei magánjavak visszaadása, aradi nőegylet engedélyeztetése, a Magyar Szövetségnek szociálisan rászorultak részére gyüjtés engedélyezése, az Ellenzék szerkesztőségét ért támadás kivizsgálása. $^{1112}$

Az alapszabály módosítása és a memorandum érdemi változást nem jelentett a Szövetséggel szemben tanúsított kormányzati magatartásban. A bánáti szervezkedés elé továbbra is korlátokat állítottak.

${ }^{1111}$ A Magyar Szövetség követeli nemzeti egyéniségének államalkotó tényezőként való elismerését. Újság, 1922. XXIV. évf. 176. szám, augusztus 8. 1-2.; Gyülésezik a Magyar Szövetség. Ellenzék, 1922. 43. évf. 176. szám, augusztus 8. 3-4.

1112 A Magyar Szövetség memoranduma. Ellenzék, 1992. 43. évf. 192. szám, augusztus 27. 1-3.; A Magyar Szövetség a kormányhoz. Keleti Újság, 1922. 5. évf. 176. szám, augusztus 8. 3-4. 
Azt a megtévesztő információt közvetítették a bánáti magyarok felé, hogy a Magyar Szövetség a müködését csak a Királyhágón túli, tehát a történeti Erdély területén belül fejtheti ki. Jósika Sámuel és Ugron István személyesen keresték fel Bukarestben a belügyminisztérium illetékes szervét, hogy engedélyezzék az Erdélyen kívüli szervezkedést. Az engedélyt nem kapták meg, sőt, megerősítették azt, hogy a Magyar Szövetség csak Erdélyben müködhet. A Temesvári Hírlap vezércikkírója, Barabás Béla azt vetette fel, ha valóban nem szervezhető meg a Magyar Szövetség, akkor Bánáti Magyar Szövetség néven szervezzék meg magukat. A megalakítását követően pedig vegye fel a kapcsolatot Kolozsvárral és lépjenek egymással szövetségre. ${ }^{1113}$ Erre végül nem került sor, mert 1922 őszén ismét kifogással éltek a Magyar Szövetség alapszabálya ellen, amely végérvényesen hozzájárult szervezet megszünéséhez. A belügyminisztérium egyfelől homályosnak ítélte a lefektetett irányelveket. Másfelől továbbra is fenntartotta korábbi álláspontját, hogy a Szövetség hatósági jogköröket vindikál magának. Valójában arról volt szó, ahogy Brătianu nem volt hajlandó aláírni a kisebbségi szerződést a párizsi béketárgyalásokon ${ }^{1114}$, úgy 1922-ben kormányra kerülve sem kívánta azt végrehajtani, illetve kockáztatni a parlamenti többségét az alkotmányozás során a nemzetiségek irányába tett esetleges engedményekkel. ${ }^{1115}$

1113 A Bánáti magyarság. Temesvári Hírlap. 1922. 20. évf. 172. szám, augusztus 2. 1-2.

1114 I. C. Brătianu a román békedelegáció vezetője volt a párizsi békekonferencián. Mellette foglalt helyet Alexandru Vaida-Voevod, az erdélyi Kormányzótanács tagja, illetve Viorel Virgil Tilea előbb Maniu, majd VaidaVoevod személyi titkára. Nagy sajtó figyelmet kapott Bratianu ellenállásra és zsarolásra épített taktikai magatartása, amikor otthagyta a konferenciát, válaszul arra, hogy az antant hatalmak az 1916. évi titkos bukaresti szerződést semmisnek nyilvánították, illetve az új államokkal kisebbségi egyezményeket kívántak aláíratni. A román politika célja egyértelmü volt, a titkos szerződéseknek érvényt szerezve a területszerzés maximumát elérni. Bratianuval szemben Vaida-Voevod mögött álló politikai erők, Nicolae Iorga és az ún. caranisták Erdélyből, Besszarábiából és Bukovinából, hajlottak a párizsi békeszerződés mielőbbi aláírására. A román kormány előtt két út állt: vagy elfogadja a konferencia legfelsőbb tanácsának feltételeit, vagy veszélyezteti nyugat felé az országhatárt és Besszarábia csatlakozásának elismerését. Bratianu miniszterelnök a megszorított helyzetben beadta lemondását, és székét átmeneti jelleggel Artur Văitoianuk adta át. TILEA, 1926. 15-23.; IANCU, 1995. 49-51. 1115 A Magyar Szövetség. Ellenzék, 1922. 43. évf. 247. szám, november 1. 1. 


\subsubsection{A Magyar Nemzeti Párt: az alkotmányreform vitája és részvétel a koronázáson}

A Magyar Nemzeti Párt országos tanácskozást tartott szeptember 4-én, hogy megválassza a párt tisztikarát $^{1116}$, megbeszélje a vidéki szervezkedés megindítását, illetve a Brătianu-kormány őszre tervezett alkotmányreformjáról állást foglaljon. Ugron Zoltán rámutatott arra, hogy 1918 előtt a szászoknál és a románoknál milyen nagy szerepet játszottak a pártok vidéki szervezetei, amelyeknek tagjai az altruisztikus bankok és birtokos szervezetek vezetői voltak. Hangsúlyozta azt is, hogy a Nemzeti Párt vidéki szervezeteit a birtokos osztályra kell építeni, amely a gerincét alkotja a romániai magyarságnak. Az újonnan megválasztott pártelnök, Grandpierre reflektált Ugronra, és kijelentette: „a párt a széles magyar rétegeken osztálykülönbség nélkül épüljön fel, mert a tapasztalat azt bizonyítja, hogy a nemzeti érzés ezek egyikében sem gyengült meg."1117

A gyülés politikailag legfontosabb napirendi pontja az alkotmányreformról szólt, amelynek Balogh Artúr volt az előadója. Tiltakozott a parlamenti eljárással szemben, mert a tervezet előkészítésébe a magyar nemzeti kisebbség megválasztott képviselőit nem vonták be. Másfelől a tervezetbe nem kívánják beépíteni a kisebbségi jogokat, miközben azt a kisebbségi szerződés elöírta a törvényhozás részére. Követelte az egyéni, az egyesülési (párt, szakszervezet stb.), a gazdasági és a politikai szabadságjogok, a vallás és a felekezetek egyenjogúságának tiszteletben tartását; az állam felügyeleti jogának fenntartása mellett a felekezetek szabadoktatáshoz való jogát; a politikai perek és a politikai rendőrség megszüntetését; a szabad anyanyelv használatát (bíróság, sajtó, gazdaság, közigazgatás stb.); a progresszív adórendszert; a nőkre is kiterjedő egyenlő, szabad, titkos választójogot; az önkormányzatok visszaállítását. A nemzetiségi kérdésben az erdélyi nemzetek autonómiáját (nemzeti nyelven saját önkormányzatiság, közigazgatás, igazságszolgáltatás, saját hivatalnoki kar). A gyülés a tiltakozó beszéd pontjait határozatba foglalta és megküldte (román és francia nyelven) a parlament képviselőinek. ${ }^{1118}$

Az alkotmánytervezetbe kollektív jogok nem kerültek beépítésre, az csak egyéni szabadságjogokat (lelkiismereti, tanítási, gyülekezési, sajtószabadság) biztosított volna Románia minden állampolgára számára, legyen akár német, magyar, orosz stb. nemzetiségü. Hans Ottó Roth szász képviselő is kifogásolta a tervezetet.

\footnotetext{
${ }^{1116}$ A párt országos vezetősége: elnök dr. Grandpierre Emil, társelnökök gróf Béldi Kálmán, Hevesi József, Sándor József, alelnökök Andrásovszky Danó, Pekry Sándor, dr. Hajdú Frigyes, Pál Gábor, Szakács Péter, báró Szentkereszthy Béla, titkár Székely Endre, pénztárnok Székely Viktor, ellenőr dr. Óvári Elemér, jegyzők dr. Kovács András, dr. Szeghő Imre és dr. Peielle Ernő. Az országos intézőbizottságnak négy kolozsvári tagja dr. Várady Aurél, Gabányi Imre, gróf Bethlen György és dr. Róth Hugó, vidéki tagok dr. Gyárfás Elemér, dr. Szele Béla, dr. Sebessy János és Korosy György. A Magyar Nemzeti Párt állásfoglalt az alkotmányreformmal szemben. Ellenzék, 1922. 43. évf. 199. szám, szeptember 5. 1.

1117 Uo.

1118 Uo. 2.
} 
Kifejtette, hogy a kisebbségek nem akarnak államot az államban, de az alkotmányban rögzíteni kell a nemzetiségek külön jogait. Kiss Géza, aki liberális listán nyert mandátumot Baloghgal és Rothtal szemben, akik a kisebbségi szerződést kérték számon elégségesnek tartotta belső egyezmény útján rendezni a kisebbségi kérdést. Külön jogokat nem kért, csak azt, hogy szövegezzék le: minden nem román állampolgárnak a románokkal egyenlő jogai vannak, vagyis az egyéni jogokért szállt síkra. ${ }^{119}$ Grandpierre Emil elhatárolta magát Kiss Géza felszólalásától, azt nem tekintete a magyarság legitim álláspontjának, mert az a liberálisok egységes nemzetállam koncepcióját támasztotta alá. ${ }^{1120}$

Ferdinánd király koronázásán ${ }^{1121}$ való részvétel nemcsak szimbolikus, de a politikai legitimáció szempontjából kardinális kérdésként merült fel. A Román Nemzeti Párt 1922 szeptemberében bejelentette, hogy nem vesz részt a koronázási ceremónián, mert szerintük: a liberális kormány erőszakkal szerezte meg a hatalmat 1922-ben, a Nemzeti Párt jelöltjeit csalással likvidálták, illetve a liberális kormány nem képviseli az erdélyi románság érdekeit a parlamentben. Maniuék saját érdekükben arra akarták felhasználni a politikai konfliktust, hogy a gyulafehérvári egyesülési nemzetgyülés évfordulóján nagygyülést hívnak össze. Bratianu ezt nem engedélyezte. ${ }^{1122}$

A magyar politikai elit választás elé került: ha a koronázáson való részvételt elutasítják az elszigetelődést választják. Ha részt vesznek, szimbolikusan kifejezik, hogy a magyar kisebbség részt kíván magának az állami életből. Grandpierre reálisan közelítette meg a kérdést: „mi kormányzópártot alkotni soha nem fogunk, konkrét politikai célok előmozditására a koronázás alkalmát fel nem használhatjuk." ${ }^{1123}$ A személyes hódolat kifejezése mellett a másik indok a dinasztikus hagyomány mutatkozott. „Jelenlétünk a magyar nép hagyományos hódolatának kifejezése a koronás király iránt, [...] hogy a király személye minden politikai küzdelem felett áll."1124

\footnotetext{
${ }^{1119}$ Hans Otto Roth a kisebbségek jogaiért. Ellenzék. 1922. 43. évf. 284. szám, december 16. 1.

${ }^{1120}$ Grandpierre Emil: A kisebbségek az alkotmányban. Ellenzék, 1922. 43. évf. 285. szám, december 17. 1.

${ }^{1121}$ A koronázási ünnepség több helyszínen és több napon keresztül zajlott 1922. szeptember és október fordulóján. Ferdinánd és felesége, Mária vonaton érkezett Gyulafehérvárra, előtte Kolozsváron tettek látogatást. Az október 15-17-én, Gyulafehérváron megtartott ünnepségre 10-15 ezer látogató gyűlt össze. A ceremónia utolsó felvonására októberben elején, Bukarestben került sor. Ferdinánd ünnepélyes bevonulása Bukarestbe. Ellenzék, 1922. 43. évf. 235. szám, október 18. 1.

1122 A nemzeti párt óvást emel a koronázás mostani megtartása ellen. Ellenzék, 1922. 43. évf. 203. szám, szeptember 10. 2.; Az RNP aradi tagozata részt vett az ünnepségen. Ellenzék, 1922. 43. évf. 234. szám, október 17. 3 .

${ }^{1123}$ Grandpierre Emil: Koronázás. Ellenzék, 1922. 43. évf. 233. szám, október 15. 1.

${ }^{1124}$ Uo.
} 
A Magyar Nemzeti Párt nevében Jósika Sámuel szenátor és Sándor József képviselő egy memorandumot juttatott el az uralkodónak, aki a koronázási proklamációjában (lásd a 10. számú mellékletet) kijelentette, hogy az ország összes polgára vallási és nemzetiségi különbség nélkül egyenlő jogokat élvez az összes románnal. Az emlékiratba belefoglalták: a gyulafehérvári határozat és a kisebbségi szerződés végrehajtását, a Magyar Szövetség müködésének engedélyezését. Kifejtették továbbá, hogy a Magyar Nemzeti Párt az egyedüli szervezet, amely a magyar kisebbség reprezentánsa, és képviselői „nem tartoznak az egyik román vagy más nem magyar nemzeti párthoz sem és nem számithatják maguk közé azt a pár magyar, vagy magyar eredetü szenátort, illetve képviselöt sem, akik [...] a kormány által önkényesen kineveztettek." (Utalás Kiss Géza képviselöre.) ${ }^{1125}$ A gyulafehérvári ceremónián a magyarság nevében a Magyar Szövetség képviselői, illetve a magyar egyházfők vettek részt. ${ }^{1126}$

\subsection{A két magyar párt egyesülése: az Országos Magyar Párt}

1922 őszére a két magyar párt fúziójáról szóló publicisztikák megsokszorozódtak. Barabás Béla terjedelmes cikkében arról írt, hogy a „hadizónás, ostromállapotos” Aradról nézve nem érti, miért van két magyar párt a megváltozott Erdélyben. Barabás a különállás helyett az egységet kereste. 1920-at követően a történeti Erdély a hozzákapcsolt új területekkel, új emberekkel és új városokkal, Arad, Temesvár, Nagyvárad, Szatmár, Nagykároly népességével egy közösséget alkot, és ügyeibe a korábbiakkal ellentétben joga van beleszólni. A megváltozott helyzetre tekintettel, ezért egy magyar pártra van szükség - írta Barabás. ${ }^{1127}$ Grandpierre Emil jelentős szerepet vállalt abban, hogy tudatosítsa a magyar közösség előtt a helyzettudat változást, amit a magyar kisebbség közjogi alanyiságának elismerésében fogalmazott meg. „Ma már helyzetünkkel tisztában vagyunk. Mindnyájan hirdetjük és valljuk, hogy magyar nemzeti kisebbség vagyunk Romániában, közjogi alanyisággal bíró része az államnak. [...] Tisztában vagyunk azzal, hogy jogainkat egyedül magunknak kell kivívnunk, hogy ebben a küzdelmünkben semmi segitségre nem számíthatunk."1128

\footnotetext{
${ }^{1125}$ A Magyar Nemzeti Párt memorandumot intézett Ferdinánd királyhoz a koronázás alkalmából. Ellenzék, 1922. 43. évf. 233. szám, október 15. 3.

${ }_{1126}$ Politikusok: báró Jósika Sámuel, Fülöp Béla szenátorok, Sándor József, Zima Tibor, Kiss Géza képviselők, illetve Jakabffy Elemér, Gyárfás Elemér, Betegh Miklós. Egyházi személyek: Majláth Gusztáv, Glattfelder Gyula, Bjelik katolikus püspökök, Nagy Károly református püspök, illetve Páll István, Láng és Hámon Róbert kanonokok. Uo.

${ }^{1127}$ Barabás Béla: Az egységes magyarság. Ellenzék, 1922. 43. évf. 222. szám, október 3. 1.

${ }^{1128}$ Grandpierre Emil: Egységes párt. Ellenzék, 1922. 43. évf. 245. szám, október 20. 1.
} 
A Magyar Nemzeti Párt augusztusi gyülésén arról döntött, hogy öt tagú bizottságot küld az Erdélyi Néppárthoz, hogy fúzióra lépjenek egymással. A tárgyalások sikerrel jártak. A két szervezet 1922. október végére megegyezett, hogy feloszlatják magukat, és egy új pártban, a Magyar Pártban egyesülnek. ${ }^{1129}$ A döntést előmozdította, hogy a Szövetség müködésében ellehetetlenült, mert október végén ismét betiltották. Vaitoianu belügyminiszter nem hagyta jóvá az augusztusi alapszabály módosítást, mert azt jogszabályba ütközőnek talált. A belügyminiszter úgy értelmezte a Szövetség alapszabályát, hogy annak tagja más nemzetiséghez tartozó állampolgár nem lehet, illetve aktív politikai szerepvállalásra törekszik. ${ }^{1130}$

Az egyesülés eljárását a következőképpen képzelték el: minden választókerületben a 20 éven felüli magyarokat összehívják, maguk közül küldötteket választanak, és a Kolozsvárt tartartandó alakuló nagygyülésen (1922. december 28.) megalakítják az egységes pártot. ${ }^{1131} \mathrm{~A}$ két párt elnöke, Grandpierre Emil és Kecskeméthy István egy kiáltványt fogalmaztak meg, amelyben a két párt tagságát az egyesülésre kérték fel és a magyarság csatlakozását az új párthoz. Számot vetettek a belső ellentétekkel, illetve azzal, hogy a megpróbáltatások sorozata nemzedékük vezetőitől a közös gondolkodást követeli meg. ,Mi, ez a mai nemzedék vagyunk hivatva, hogy sorsunk fonalát nagy megrázkódtatások viharán túl is tovább fonjuk és tovább vezessük."1132 A kisebbségi magyarság első generációjának vezetői a saját erőből történő küzdelmet, a pártellentétek meghaladását és az összefogást emelték ki. ${ }^{1133}$

Az első delegált választógyülést Sepsiszentgyörgyön, 1922. november 21-én tartották. A Magyar Nemzeti Pártot feloszlatták, amelyet Magyar Párt néven újjáalakították, és gyülés keretében a decemberi gyülésre megválasztották a három választókerület küldötteit. ${ }^{1134} \mathrm{~A}$ soron következő gyülésre Kolozsváron került sor (november 26-án), ahol a két párt kimondta a fúziót. Kecskeméthy István az egyesülést történelmi pillanatnak nevezte, amikor csak az egységes fellépés vezethet sikerre.

\footnotetext{
${ }^{1129}$ A Néppárt részéről Kecskeméthy István, Szathmáry Ákos, Zágoni István, Berkes Salamon, Nagy János és Gombos Benő, míg a Nemzeti Párt részéről Sándor József, Óvári Elemér, Várady Aurél, Hevesi József, Kovács Kálmán és Guráth Béla vettek részt a tárgyalásokon. GYÖRGY, 2007. 18-19.; A magyar pártok kimondták a fúziót. Keleti Újság, 1922. 5. évf. 240. szám, október 22. 3.

${ }^{1130}$ A Magyar Szövetségről döntött a kormány. Keleti Újság, 1922. 5. évf. 246. szám, október 31. 4.

${ }^{1131}$ Megegyezés a Magyar Nemzeti Párt és a Magyar Néppárt között. Ellenzék, 1922. 43. évf. 240. szám, október 24. 2.

${ }^{1132}$ Egy táborban. Ellenzék, 1922. 43. évf. 258. szám, november 15. 1.

1133 Uo.

1134 Máthé István, Kelemen István, Pál Ferenc, Gyárfás Pál, Lőrinczi István, Nagy János, Lázár Ferenc, Osváth Árpád, Viola Sándor, Szakáts Péter, Sebesi János, Nagy Lajos, Forró Géza, Frölich Ottó, Ugron Zoltán, Ferenczi Gyula, Hubay Károly, Guráth Béla, Reményik Sándor költő, Kovács Áron, Vásárhelyi János, Benedek Elek író, Kirchknopf Gusztáv és Hirschler József.

Székelyföld magyarsága a Magyar Pártban. Ellenzék, 1922. 43. évf. 263. szám, november 21. 2.
} 
Grandpierre Emil felidézte a belső ellentéteket, amelyet nem ideológiai, hanem eltérő módszertani különbségekre vezetett vissza. Korábbi mondatait megismételve a saját belső eröre hívta fel a figyelmet. Taktikusan megemlítette, de valójában azt jelölte meg, hogy mely politikai csoportokra nem számít: „nem várunk segítséget sem Budapestről, sem Bécsből, sem az emigránsoktól."1135 Sándor József a magyarság társadalmi és politikai szerveződéséről (autonómia, választási rendszer demokratizálása, felekezeti iskolák szabad működése) beszélt. Berkes Salamon a magyar anyanyelvű zsidóság nyelvi jogsérelmeit (a zsidó gyermekek nem iratkozhattak be magyar osztályokba), illetve Kirchknopf Gusztáv a magyar lutheránusok felekezeti autonómiájának megsértését tematizálta. Zágoni a politizálás gyakorlati tennivalóiról szólt (városi autonómia visszaállítása, a kereskedők, iparosok, szellemi és fizikai munkások érdekeinek felkarolása). A beszédek után a jelölőbizottság előterjesztésére megválasztották a helyi vezetőséget, amelynek többségét a volt nemzeti pártiak adták, kivéve Berkes Salamont, illetve a delegáltak közül Kecskeméthyt, Hevesyt és Mestitzet. ${ }^{1136}$

A bánsági magyarok elé állított politikai akadályok fokozatos elhárulását a temesvári és a temes-torontáli pártalakulás jelezte. Szabolcska Mihály megnyitó beszédében a gyulafehérvári határozatokat kérte számon, Veterány Viktor a helyei előkészítő-bizottság nevében a kétmillió magyar valós parlamenti képviseletéről beszélt. Egyhangúlag megválasztották a vezetőséget, elnökének dr. Fülöpp Bélát (1922-től szenátor is), a 19 fős Intézőbizottságot, az 50 tagú választmányt, illetve a kolozsvári országos nagygyülés küldöttségét. Ambrózy Andor az OMP országos vezetőségébe, Zágoni István pedig a központi választmányba is bekerült. ${ }^{1137}$

\footnotetext{
${ }^{1135}$ Egy táborba tömörül a csatolt részek magyarsága. Ellenzék, 1922. 43. évf. 268. szám, november 28. 1.

${ }^{1136}$ A kolozsvári Magyar Párt elnöke: Hevesy József. Alelnökök: Dr. Berkes Salamon, gróf Bethlen György, Ferenczy Gyula (a Magyar Szövetség és az EMKE ellenőre), dr. Várady Aurél. Titkárok: Dr. Nagy János, dr. Naláczy István, pénztáros Kapcza Imre, ellenőr Deák Ferenc, jegyzők: Nagy Kálmán, Szabó Géza, Szilágyi Márton, Ütő Lajos. A december 28-i országos nagygyülésre Kolozsvárról a következő tagokat delegálták: Balázs István, dr. Balogh Arthur, Cseh József, dr. Fehér Dezső, Fekete-Nagy Béla, dr. Gabányi Imre, dr. Grandpierre Emil, György Dénes, dr. Hevesy József, dr. Kecskeméthy István, Mestitz Ferenc, dr. Róth Hugó. Uo. 3.

1137 Társelnökök: báró Ambrózy Andor, Gyertyánffy László dr., (Gyér), Kabos Ármin, Mágori Lajos (Újszentes), Nemes József, Szabolcska Mihály, Székely László, Tornya Gyula dr., (Csák). Ügyvezető elnök: Veterány Viktor dr., főtitkár: Osztie Andor, titkárok: Kovács Béla dr., Uhlyárik Béla dr., pénztáros: Csongor Árpád, ügyészek: Aczél Oszkár dr., Feld Kálmán dr. Ellenőrök: Horváth Antal, Ivánovits Lajos, Tedeschi Jenő.

A december 28-i gyülés küldöttjei: dr. Fülöpp Béla, Zágoni István, báró Ambrózy Andor, Gyertyánffy László dr., Veterányi Viktor dr., Mágori Lajos, Osztie Andor, Várnay Elemér dr., Kabos Ármin. SZEKERNYÉS János: Temesvár kövei 565. A magyarság legfontosabb intézménye. http://hetiujszo.ro/szekernyes-janos-temesvar-kovei565/ (Letöltve: 2017. november 25.)
} 
A Magyar Párt Nagyenyeden december 17-én alakult meg a városháza nagytermében. Megválasztották a helyi vezetőséget, elnöknek Fogarasi Albert nyugalmazott rektort. ${ }^{1138}$ A Csík megyei magyarság december 19-én bontott zászlót, az elökészületeket a Magyar Szövetség vállalta magára. Nagy Jenő indítványára a „magyar kultúra végvárainak a felekezeti iskoláknak megmentése érdekében" kötelezettséget vállalt a megyei Magyar Párt. ${ }^{1139}$ A gyűlés elhatározta, hogy a sérelmes választói jegyzékek kiigazítása céljából a kolozsvári Magyar Párthoz fordulnak, mert a hiányos névjegyzékek miatt a magyar választók száma a kerület összes választóinak csupán egyharmadát teszi ki. Gyulafehérvárt december 20-án került sorra az alakuló ülés, ahol helyi elnöknek Balázs Ferenc prelátus-kanonokot és Rass Károly főgimnáziumi tanárt, írót választották. ${ }^{1140}$ A Magyar Párt marosvásárhelyi és Maros-Torda megyei szervezete Bernády György kezdeményezésével alakult meg közvetlenül Karácsony elött. ${ }^{1141}$

Balogh Artúr a nagygyülés előtti karácsonyi cikkében az erdélyi fejedelemség kora és a trianoni idők között vont párhuzamot. Erdély (Báthory István, Bethlen Gábor és a Rákócziak, mint történeti példaképek) a bécsi önkényuralommal (átvitt értelemben a bukaresti kormányokkal) szemben az alkotmány, a nemzeti- és a vallásszabadság védelmezői voltak mindenidőkben. A kisebbségi magyarság politikai célja ezért a párizsi békeszerződésekben lefektetett jogok kiharcolása - fogalmazott Balogh. ${ }^{1142}$ Fekete-Nagy Béla az alkotmánytervezethez írt véleményt. Véleménye szerint a nemzetiségi kérdésről a magyar és a román elit háromféleképpen gondolkodott: a gyulafehérvári határozat, a párizsi különegyezmény (kisebbségi szerződés), illetve a fegyveres megszállás oldalairól. A legfőbb különbség az első kettő között az, hogy a gyulafehérvári pontok a wilsoni elvekkel, a nemzetek egyenjogúságának elismerésével áll összhangban, de csak regionálisan, Erdélyre értelmezve. Az Erdély meghódítását hangsúlyozó álláspont szerint, a győztes egyoldalúan állapítja meg annak mértékét, amit a nemzeti kisebbségeknek ad.

\footnotetext{
1138 Alelnökök dr. Asztalos Kálmán, Bulla Béla, Papp János, titkár dr. Szabó András, Winkler Gyula, ellenőr Szigethi Béla, jegyzők dr. Uray László, Solymossy Bálint, Benkő Gyula, Wohlfarth Lőrinc. 100 tagú választmányt állítottak fel. Megalakult a nagyenyedi Magyar Párt. Ellenzék, 1922. 43. évf. 288. szám, december 21. 5.

${ }^{1139}$ Az elnökségi tisztséget ideiglenesen Incze Domokos főesperes vállalta. Titkárok Kovács Károly, Imre Gábor, Makkay Domokos, jegyző Adorján Imre. A december 28-i országos nagygyülésre a vármegyei Magyar Párt részéröl 22 kiküldöttet választottak. A Csík megyei magyarság. Ellenzék, 1922. 43. évf. 288. szám, december 21. 5.

1140 Alelnökök: Régen István, Risznei Ödön. A decemberi nagygyülésen Rass Károly és Király Géza képviselték a helyi magyarságot. A Magyar Párt Gyulafehérvárt. Ellenzék, 1922. 43. évf. 292. szám, december 28. 5.

${ }^{1141}$ Az elnöki tisztséget Bernády György töltötte be. Alelnökök: dr. Hajdú István, Bustya Lajos, dr. Sebestyén Miklós. A vidéki kerületek vezetői: dr. Szoboszlay László (Nyárádszereda), Orbán Károly (Mezőmadaras) K. Nagy Árpád (Székelyhál), Kiss Lajos református lelkész (Magyaró.) Megalakult az Egységes Magyar Párt marosvásárhelyi és Maros-Torda megyei szervezete. Ellenzék, 1922. 43. évf. 291. szám, december 24. 5.

${ }^{1142}$ Balogh Arthur: Erdély lelke. Ellenzék, 1922. 43. évf. 291. szám, december 24. 1.
} 
A különegyezmény nézőpontjából a kisebbségi jogok kérdése két táborra oszlik. Egyfelöl vannak azok, akik Romániára nézve kötelezö érvényünek tekintik a végrehajtását (magyar álláspont), illetve, akik szerint ez Románia szuverenitását sérti (román álláspont). Fekete-Nagy Béla - természetesen - az 1918. decemberi pontokat és a kisebbségi szerződés maradéktalan végrehajtását követelte. ${ }^{1143}$ Rass Károly író, szerkesztő ${ }^{1144}$ a Magyar Párt megalakítását az egység és a nemzeti elv követelményével állította párhuzamba. „Mi nekünk csak egy politikai hitvallásunk van, ez az egy szó: magyar. [...] A nyugati kultúra távoli sugarat mi fogtukfel itt reflektorainkkal s hintettük áldásait. Azt akarjuk, hogy ez a magyar kultúra a mienk legyen a jövőben is. [...] Ennek a politikai programnak lesz képviselöje a Magyar Párt."1145

A kolozsvári alakuló nagygyülés 231 küldött jelenlétében nyílt meg december 28-án. Kecskeméthy és Grandpierre megnyitója után Hajdú István marosvásárhelyi küldött foglalta össze a kisebbségek együttes jogait, és kiemelte, hogy kisebbségi politikájukat a kisebbségi egyezmény és a gyulafehérvári határozatok alapján akarják kiépíteni. Ugyanő javasolta Jósika Sámuelt a pártelnöki tisztségbe. A báró székfoglalójában kifejtette, hogy az új párt a volt Magyar Szövetség programja alapján áll. ${ }^{1146}$ A megalakuló Országos Magyar Párt (OMP) 8 pontos programját, amelyet az alkotmányreform vitájával kapcsolatban tettek közzé az Ellenzékben (lásd 11. számú melléklet), Várady Aurél olvasta fel. Ezek a következők voltak: 1) A magyar nemzeti kisebbség közjogi alanyiságának alkotmányos elismerése, a nemzeti autonómia és a demokratikus választójog biztosítása. 2) A törvényhatósági és községi autonómia (önkormányzat) visszaállítása, a közigazgatás decentralizálása. 3) törvényhozói, bírói- és közigazgatási hatáskörök szigorú elhatárolása, a rendeleti kormányzás megszüntetése. 4) Vallás- és lelkiismereti szabadság, rekvirált ingóságok és ingatlanak visszaadása. Az egyházakat az állam felügyeleti joga mellett minden fokon (elemi iskoláktól az egyetemig) megillető iskolafenntartó és alapítójog védelme, a tanítási és tanulási szabadság fokozott biztosítása. 5) A magán- és a közösségi tulajdon védelme, a lakásrekvirálás, illetve a földreform felülvizsgálata. 6) Sztrájkjog, munkásvédelem, progresszív adórendszer, létminimum bevezetése. 7) A hadseregben az anyanyelv szolgálati nyelvként való engedélyezése.

\footnotetext{
${ }^{1143}$ Fekete-Nagy Béla: Gondolatok egy törvénytervezetröl. Ellenzék, 1922. 43. évf. 291. szám, december 24. 2.

1144 Rass Károly (Aranyosgyéres, 1872.- 1962. Kolozsvár) irodalomtörténész, író. 1896-tól Gyulafehérvárt a Római Katolikus Főgimnázium magyar-német szakos paptanára. 1916-tól az Erdélyi Római Katolikus Irodalmi Társaság elnöke, 1922-töl az Erdélyi Irodalmi Társaság tagja és az OMP tagja. Föszerkesztöje volt a Gyulafehérvárt megjelent Közmüvelödésnek (1916-19), társszerkesztője (1925-28) a Minerva Könyvtárnak. Novelláit, irodalmi kritikáit 1918 után az Erdélyi Szemle, az Ellenzék, a Magyar Nép, a Pásztortüz közölte. Az elsők között rajzolta meg Reményik Sándor költői pályájának 1926-ig terjedő szakaszát, kimutatva transzilvanizmusának mély humánumát és a természeti képekből kibomló sajátos szimbolikáját. http://mek.oszk.hu/03600/03628/html/r.htm\#RassKároly (Letöltve: 2017. november 24.)

${ }^{1145}$ Rass Károly: Magyar Párt. Ellenzék, 1922. 43. évf. 292. szám, december 28. 2.

${ }^{1146}$ GYÖRGY, 2006. 21.
} 
8) Bírói végzés nélkül senki meg nem fosztható a személyes szabadságától (utalás a politikai internálásokra). Az egyesülési, a gyülekezési- és a sajtószabadság biztosítása. ${ }^{114}$ A hozzászólók lényegében megerősítették a programot. Sándor József a választói névjegyzék kiegészítéséről, Kovács Kálmán (unitárius egyház főtanácsának tikára) a felekezeti iskolákkal szembeni törvénytelenségekről, Zágoni István a személyes szabadság védelméről (internálások, kiutasítások), illetve a köztisztviselők ügyének felkarolásáról, Fekete-Nagy Béla a magyar tőkéjü gazdasági társaságok védelméről, Jakabffy Elemér Kiss Géza parlamenti magatartásáról beszélt. $^{1148}$

A jelölőbizottság tette meg javaslatait a vezetőség megválasztására: száztagú választmányt, annak tagjaiból 36 tagú Intézőbizottságot választottak (lásd 12. számú melléklet), majd a Szervezeti Szabályzat elfogadására került sor. Az elnök a folytonosság jegyében a magyarság körében köztiszteletnek örvendő báró Jósika Sámuel lett. A budapesti förendiház utolsó elnöke, a konzervatív gondolkodású politikus a Magyar Szövetség elnöki posztját követően került az OMP élére. Tizenkét alelnök került megválasztásra. 1918 előtt ketten Monarchia szintü funkciókkal bírtak: Barabás Béla a magyar-osztrák delegáció elnöke, illetve Ugron István követ volt. Barabáson kívül még ketten voltak Budapesten parlamenti képviselők, Sándor József és Jakabffy Elemér, ketten polgármesterek Haller István (Kolozsvár) és Bernády György (Marosvásárhely). Grandpierre 1918 előtt törvényszéki bíró volt, majd a Szellemi Front (a Magyarországhoz lojális, köztisztviselő-ellenállás) vezetője. Megyevezető politikusnak hárman számítottak, id. Szentkereszty Béla nyugalmazott föispán Sepsiszentgyörgyön, Turi Kálmán Nagyváradon és báró Ambrózy Andor volt amerikai konzulátusi munkatárs, az evangélikus egyház elöljárója Temesváron. Ketten a kulturális elithez sorolhatók, Szabolcska Mihály lelkész, költő és Kecskeméthy István református teológiai tanár. Az elnökség döntő többsége - Kecskeméthytől, Paál Árpádtól, illetve Bernádytól eltekintve - az OMP konzervatív oldalát erősítette.

Maga az OMP a Függetlenségi Párt utódjának tekintette magát. A vezetői összetétel azzal járt, hogy a falusi mezőgazdasági népesség és a munkásság a pártban - minden politikai kinyilatkoztatás ellenére is - képviselet nélkül maradt. Az irányítás a „régi vezetők”, a konzervatívok kezébe került. A politikai megosztottság megmaradt az új pártban, amely a jobb(Magyar Nemzeti Párt) és baloldal (Erdélyi Magyar Néppárt) jelenlétében élt tovább. A vezetésen belül a baloldal a jobboldali túlsúlyt a sajtóban elfoglalt pozíciójával ellensúlyozta.

\footnotetext{
${ }^{1147}$ Megalakult az egységes Magyar Párt. Ellenzék, 1922. 43. évf. 293. szám, december 28. 3. 1148 Uo. 1-3.
} 
Az OMP közvetlen elödjének tekintett Magyar Szövetség vezetése inkább az egyház-sajtórégi vezetők viszonyrendszert tükrözte.

A pártegységet a politikai szükségszerüségen túl a két csoport kisebbségpolitikai felfogása biztosította. Az Országos Magyar Pártra úgy tekintettek, amely a magyar kisebbség közös és egyetlen politikai eszköze a kisebbségjogi jogok érdekképviseletében. A másik összekötő elem az volt, hogy konzervatív oldalról indult meg a romániai politikai életbe való integrálódás a csucsai paktummal ${ }^{1149}$, amely a Paál képviselte baloldalnak is elsőszámú követelése volt. 1923-1924-ben a politikai stratégia közössége, a kisebbségpolitika erösebb volt, mint az önszerveződés prioritásaira vonatkozó elképzelések (egyházi, illetve társadalmi tömegszervezetek, azaz a folytonosság vagy új önszerveződési formák intézményesítése). Grandpierre visszatekintésében a két csoport között a különbséget a nemzeti autonómista szervezkedés (Grandpierre) vagy a pártszervezkedés és Erdély autonómiájának (Paál, Kós) célkitüzésében látta. A diplomáciai jelentések ezzel szemben inkább a generációs és társadalmi különbségeket hangsúlyozták. A Keleti Újság publicistái a különbséget a magyar munkás- és paraszti rétegek nyelvi alapon történő társadalmi (világi) megszervezésében, a népkisebbségi eszmének az egyetemes szabadságjogokkal való összekapcsolásában, valamint a magyarországi Bethlen-kormányzat kritikus megítélésében érzékeltették (a húszas évek magyarországi zsidópolitikája hatással volt az erdélyi közvéleményre). A belső törésvonalakat az első világháború előtti politikai és társadalmi adottságokból kiindulva a belső integrációhoz, a Magyarországhoz és az új államhatalomhoz való eltérő viszonyulások határozták meg. ${ }^{1150}$

\footnotetext{
${ }^{1149}$ A román pártokkal való érintkezés felvételéröl párthatározatban döntöttek 1923. február 12-én. Az első közös megállapodásra 1923. októberben került sor, az ún. csucsai paktumban. Az 1922 előtt már kormányon lévő Avarescu-féle Néppártnak, az erdélyi szavazatok hiányában, Brătianu és Maniu között lavírozva szüksége volt az OMP támogatására. A két párt elhatározta, hogy parlamenti egységet képeznek, és segítik egymás politikai törekvéseit a soron következő választásokon. Az OMP a parlamenti erejének növelését (választói névjegyzék kiegészítése) és a kisebbségi jogok garantálását, a Néppárt a kormányra kerülését próbálta elősegíteni (Averescu nem került kormányra). BÂRDI, REGIO, 1997. 33-36.; GYÖRGY, 2006. 21-23.
}

${ }^{1150}$ BÁRDI, Otthon. 2013. 107-114. 


\section{7. ÖSSZEGZÉS: FOLYTONOSSÁG ÉS ÚJPOLITIKÁK}

Erdély 20. század elejének interetnikus társadalmi és politikai viszonyait egyszerre több, egymással összefonódó folyamat határozta meg. A korszak általános jellemzője, hogy a nemzetiségi mozgalmak látványosan megerösödnek, illetve a kapitalista gazdaságszerkezet irányába történő átalakulás intenzív hatást gyakorol Erdélyben is. A nemzetiség, a társadalom és a politikum kategóriái sajátos fúzióra léptek, ami idegen korábbi koroktól. ${ }^{1151}$ Az erdélyi nemzetek (román, magyar, szász) egymáshoz való viszonyát történetileg két tényező határozta meg: 1) az egymás mellett párhuzamosan végbemenő nemzet, illetve államépítési folyamat, 2) a nemzetépítő elitek (az erdélyi magyar, román, német) a nemzetállami centrumaiktól részben eltérő, saját stratégiákkal bíró regionális csoportok. Az erdélyi-kérdés elemzésekor, figyelembe véve az előző tényezőket is, javasolt összességében a következő három, egymást is átfedő problémakörre koncentrálni. 1) Erdély állami hovatartozásának kérdése: Románia vagy Magyarország része, esetleg önálló. 2) Erdély, mint régió közigazgatási, gazdaságpolitikai helyzete egy-egy adott államalakulaton belül. 3) Az Erdélyben élő etnikai csoportok egymás közti viszonyai, a nemzetiségi problémák kezelése.

Ezen dolgozatban a téma megközelítésekor a hangsúly egyszerre a nemzetépitésre és a nemzetépitôkre, illetve a regionális nézőpontokra helyeződik. A nemzetépítés modellje felülről elemzi a kérdést, célja a nemzetállam kiépítése, megszilárdítása. ${ }^{1152}$ A regionalizmus egy szűkebb közösség tapasztalataira és törekvéseire (például nemzeti kultúra, gazdaság megerősítése) épülő, alulról kibontakozó politikai mozgalom az adott földrajzi térségen belül. ${ }^{1153}$ Erdélyben a nemzetépítés és a regionalizmus nem csupán elválaszthatatlanok, hanem egybe is tartozók, ha módszereikben, problémalátásukban mutatkozik eltérés is. Felülről az egységesnek vélt és láttatott nemzeten belül ugyanis lehettek különbözö, akár szembenálló identitásképzetek is. ${ }^{1154}$

\footnotetext{
${ }^{1151}$ GYÁNI: A nemzeti történetírás, Limes, 2012. 5.

1152 KÁNTOR, REGIO, 2000. 220-225.

${ }^{1153}$ ÉGER György-LANGER, Josef: Határ, régió, etnikumok Közép-Európában. Osiris-MTA Kisebbségkutató Intézet, Budapest 2001. 19-23.

${ }^{1154}$ EGRY, Etnicitás, 2015.
} 
A magyar történetírásban a diszkrimináció- és hanyatlástörténeti megközelítést meghaladni szándékozó munkákban fokozatosan jelen van a helyi/regionális politikai- és társadalomtörténeti viszonyokra irányuló szemléletmód. A közösségépitő történetíró szemléletmódban a társadalomszervezés (közösségi intézmények, hálózatok építése, müködtetése), illetve a különböző regionális és etnikai csoportok fejlődéstörténete (például az elitreprodukciója) áll a figyelem középpontjában. ${ }^{1155}$

A századfordulótól kezdve a nemzetről, az államról, az erdélyi régióról és a nemzetiségi kérdésről szóló viták a leghangsúlyosabban a birtokviszonyok, a választójogi reform, illetve magában a nemzetiségi kérdés megoldatlanságában bontakozott ki. Az erdélyi nemzetépítő aktivisták a nemzetépítés programjával a regionális társadalom és térszervezés közötti kapcsolatrendszer fejlesztésével, megújításával léptek fel a századfordulót követően. Erdélyben erre láthattuk példaként a székelyföldi regionális, illetve országos javaslattevő és nyomásgyakoroló szervezeteket (Székely Társaság, Székely Társaságok Szövetsége), az autonomikus politikákkal kezelhetőnek vélt döntően helyi kulturális jellegü társadalmi, értelmiségi törekvéseket és folyóirat kultúrát (Erdélyi Szemle, A Szemle, Új Erdély, Kalotaszeg), a birtokpolitikai és telepítési elképzeléseket (Bethlen István, Darányi Ignác), illetve a Tisza István ellenzékének tekintett Erdélyi Szövetség létrehozását (1913). Az olykor egymással is konkuráló erdélyi magyar politikai csoportok, ha más és más eszközöket is javasoltak (például a választójog kérdésében), lényegében az ezeréves államiság és a magyar állam története köré szerveződő identitáspolitikából kiindulva egy célt tüztek maguk elé: az erdélyi magyar dominancia megőrzését. Társadalmi mozgalmat indítottak, részt kívántak venni lokálisan és regionálisan a mindennapokban, az erdélyi kérdést átpolitizálták egy önvédelmi stratégiává, illetve kívülről és alulról támadták a kormányzó párt által müködtetett közigazgatási rendszert és azok képviselöit. A különböző javaslatcsomagjaikban egyszerre kaptak helyet, az egymást erősíteni kívánó gazdasági, társadalmi (bank-, ipar- és kereskedelem fejlesztése, elvándorlás megfékezése, birtokpolitika) és a tisztán nemzeti célzatú tartalmak. Utóbbi kapcsán külön ki kell emelni a nem magyar nemzetiségi társadalmak és mozgalmaik mozgásterét szükíteni kívánó megfontolásokat. Ide tartozik például a kultúrzóna tervezete, amely bumerángként fog visszaütni a romániai magyar kisebbség ellen a két világháború között, a románok kivándoroltatásának, vagy egynyelvüsítésének a szándéka. Az erős állami jelenlét mellett foglaltak állást, azon az áron is, hogy például az állam csökkentse a városi magyar lakosság pénzügyi terheit, ebből kihagyva a román és német lakosságot.

${ }^{1155}$ BÍRÓ Sándor: Többségben és kisebbségben. Az előszót írta Bárdi Nándor. Pro-Print Könyvkiadó, Csíkszereda, 2002.9. 
A helyi társadalmi, politikai viszonyokat befolyásolni kívánó „változatos” eszközökben nem volt hiány, amit számos nyugat-európai példa csak felerősített (a németek kivándoroltatása Elzász-Lotaringiából, a lengyel parasztság elnémetesítése stb.).

A vita során az erdélyi magyar vezető rétegek hatalmi befolyásuk rovására kollektív engedményeket nem tettek a nemzetiségek felé. Éles kritikával bírálták ugyanakkor a Magyar Királyság Budapestre központosított, szerintük az erdélyi magyarság kulturális és gazdasági fejlődését gátló rendszerét. A magyar-magyar, Erdély és Budapest, kormánypárt és ellenzékiek közti ellentétek enyhítésének olyan változatait mérlegelték, amelyek fenntartják az osztrákmagyar közjogi kiegyezést és biztosítható vele az erdélyi magyar szupremácia. Eltérő alternatívákat vázoltak fel. Régiójuk bizonyos fokú önállóságára, Budapesttől nagyobb autonóm mozgásra törekedtek, anélkül, hogy kétségbe vonták volna az oszthatatlan nemzeti egység dogmáját. ${ }^{1156}$ Az egyik legkiemelkedőbb személy gróf Bethlen István volt, aki 1918 előtt a magyar nemzetiségpolitika mindenféle demokratizálásával szembefordult. Szervezőkészségét és befolyását többek között az bizonyította, hogy a választójog demokratikus változatát támogató erdélyi függetlenségi politikusokat (Apáthy, Kenéz, Zágoni, Paál stb.) maga mellé tudta állítani, miközben, ha erős megkötésekkel is, de hajlott a Tiszával való együttműködésre. A progresszív politikai elemek (szociális kérdések, választójog stb.) nem tüntek el, de követeléseikben mérséklődtek, amit bizonyosan a világháborúval járó politikai radikalizálódás és az 1916-os román katonai betörés befolyásolt.

Az 1918-as összeomlás és az erdélyi impériumváltás történetének elbeszélhetősége szempontjából nem hagyható figyelmen kívül 1916 jelentősége. Az 1916-os román-magyar háború azért fordulópont, mert nemcsak mély nyomot hagytak a magyar politikai osztályban és a lokális hétköznapi viszonyokban, hanem mert Erdély katonailag is hadszíntérré vált, és maradt a háború végéig. A román határ menti megyékben nem, vagy csak alig müködtek az állami funkciók, a gazdaság összeomlott, illetve a román-magyar politikai viszony töréspontra jutott, a végletekig radikalizálva a magyar szupremácia védelmébe állított nemzetiség ellenes programokat.

${ }^{1156}$ K. LENGYEL, 2007. 5-6. 
Az első világháború minden korábbi állapotot megváltoztatott, mert a történelminek nevezett ország összezsugorodása a nemzeti identitás-diskurzus szinte minden elemét megkérdőjelezte: a történelmi hivatástól a kizárólagos államalkotó képességen át a magyarság befogadó jellegéig (utóbbi elsősorban Magyarországra volt jellemző). A változások jórészt azért vezethettek el új identitáspolitikai törekvésekhez, mert alapjaiban megváltozott az intézményes és a kulturális tér, amelyben korábban a nemzeti identitás kifejezésre jutott. ${ }^{157}$

Az impériumváltást követően a kényszerhelyzethez igazodva a folytonosság igénye (a gazdasági, a kulturális és a politikai életben való pozícióőrzés) mellett új elemek kerültek előtérbe: a megszakitottságból fakadó kihívásokra adható alkalmazkodás válasza egy eltérő és többségi román kultúrával szemben (egyben a másság kifejezése); önszervezödés egy kisebbségi társadalom megszervezéséért (intézményesülés); a politikai-kulturális integráció, amely magába foglalja a magyar zsidóság és a munkásság százezreit.

A folytonosság a romániai magyar politikai gondolkodás fontos részévé vált. $\mathrm{Az}$ erdélyi magyarság egyik politikai követelése arra irányult, hogy Románián belül elismerjék államalkotó nemzetnek (egyenjogúság). A kisebbségi magyar elit ezt azzal magyarázta, hogy a trianoni békeszerződés ratifikálását követően a romániai magyarság, tehát a magyarul beszélő, magyar nemzetiségü, fejlett nemzeti önazonosságtudattal és intézményesültséggel, illetve 1000 éves múlttal rendelkező csoport politikai kényszer hatására vált ki Magyarországból. A háborús összeomlás az élet számos területén megszakitotta a korábbi életformát. Az egyéni sorsok alakulásában kiemelendő a családi kapcsolatok szétszakadása (Magyarországra repatriálók tízezrei stb.) és a személyes magántulajdon megsértése (ingó és ingatlan rekvirálása stb.). Az impériumváltással a köztisztviselök ezreit bocsátották el állásukból, a korábbi közigazgatási és helyi döntéshozatali rendszer (önkormányzatok korlátozása) nyelvében (magyar helyett román) és müködésében (centralizált) is megváltozott. A romániai földreform rendkívül kedvezőtlenül érintette a fölbirtokos arisztokráciát, a közbirtokosságot, az alapítványi javakat, illetve a társadalmi szervezeteket és a felekezeteket. A magyar nyelvü oktatás területén hasonlóan radikális és a magyarokra nézve negatív változások álltak be a román állami oktatás kiterjesztésével.

${ }^{1157}$ EGRY, Etnicitás, 2015. 109. 
Az önszervezödéssel és mássággal összefüggő kérdések szerteágazók. A domináns pozícióból kisebbségbe került magyarságnak új és saját közösségében érvényes modernizációs válaszokat kellett megfogalmaznia az új állam keretein belül. Az új helyzettel való szembenézés, a kisebbségi életformából következően maga után vonta a kiszolgáltatottság fenyegetettségét, illetve a szolidaritás és a demokratikus értékek fokozott követelését és számonkérését. Az erdélyi magyar politikai közösségen belül, a trianoni Magyarország radikalizálódásával ellentétben a nyilvános bünbakképzés nem tudott teret nyerni 1919-et követően. A vélt magyar nemzeti egység megteremtése érdekében a zsidóság és a munkásság nemzetbe történő integrálásának programja értékelődött fel (elutasítva a numerus clausust és az antiszemitizmust). A kisebbségi kontextus az alkalmazkodási stratégiák területén sokszínüséget követelt meg, amely a Bukarest-Budapest-nemzetközi dimenzió (Nemzetek Szövetsége, más nemzeti kisebbségekkel való együttmüködés) hármasában írható le.

A magyar-magyar kapcsolatok kezdeti fázisában az egyik legélesebb vita akkor bontakozott ki, amikor a budapesti kormányzati körök (Bethlen István irányításával) kijelölték, hogy kik lesznek azok az erdélyi magyar politikusok, akikre támaszkodni kívánnak. Ez a konfliktus a magyar kisebbség-történetírásban passzivista-aktivista ellentétként maradt fenn, azzal a tartalommal, hogy előbbi csoport hosszú ideig nem kívánt a politikai szervezkedés útjára lépni (demonstráció Erdély Romániához való csatolása ellen). A regionalizmus egy következő tájékozódási pont, amely hatással volt a többség-kisebbség elhelyezkedésének viszonyában. Az erdélyi magyar politikai program egyik központi eleme Románia decentralizálása, amelyben a történeti Erdély és belső régiója, a Székelyföld, mint autonóm közigazgatási terület jelenik meg. Kétféle elképzelés fogalmazódott meg. Az egyik a Románia föderalizálását, Erdély sajátos nemzetiségi viszonyait szem előtt tartó opció, amely elemeiben hasonlított a Jászi-féle kantonális tervezethez. A másik a nemzeti intézményépítést, a saját etnokulturális közösség építését preferáló nemzeti autonómia terv. Ez a kollektív jogokat elismerő kisebbségi törekvés több pontban is megegyezett az 1918 előtti regionális román elit céljaival (például az autonóm felekezeti oktatás biztosítása, az anyanyelvi jogok széles körű garanciája az oktatásban, a közigazgatásban, a bíróságokon stb.). A decentralizációs küzdelem összefonódott a romániai politikai rendszer demokratikusságának kérdésével is. A századforduló óta - a függetlenségi pártiak és a progresszívek által - követelt demokratikus választójog 1920-at követően is napirenden maradt. Az új román állam bár lehetővé tette az általános választójogot, de számos akadályt gördített annak gyakorlása elé (választási korrupció, állampolgárság megvonása stb.). 
A progresszívak és konzervatívak immár közösen követelték a romániai magyarság etnikai számarányának megfelelő demokratikus parlamenti részvétel biztosítását, a szabad politikai szervezkedés és érdekérvényesítés (sztrájkjog stb.) tiszteletben tartását.

A magyar kisebbségtörténetben az első meghatározó nemzedéket elszakadt magyarságnak nevezték. Kós Károly, Zágoni István, Paál Árpád, Bernády György, Bethlen György, Pál Gábor Jakabffy Elemér, Balogh Artúr és sok más társuk az 1918 előtti, otthon maradt regionális politikai és szellemi elithez tartoztak, illetve egy részük az annak keretet adó Erdélyi Szövetséghez. Az első nemzedék a világháború előtti Magyarországon szocializálódott, és az új viszonyok között többségiböl kisebbségivé válva vett részt a közéletben. ${ }^{158}, A$ történelem sorshelyzeteket hoz létre, s ezekben a tudatosság különbözö szintjén magatartásformákat alakit ki az ember." ${ }^{1159}$ Ezek az eltérő világnézetű nemzetépítő aktivisták közösen hozták létre az első romániai magyar szervezetet, a Magyar Szövetséget (1921. januártól), majd a magyar politikai közösség belső politikai törésvonala mentén pártjaikat, előbb az Erdélyi Néppártot és ellentétpárját, a Magyar Nemzeti Pártot. A Magyar Szövetség a nemzeti egység jelszavával lépett fel, az Erdélyi Néppárt a progressziót és Románia föderalizálását, míg a Magyar Nemzeti Párt a nemzeti autonómia programját képviselte. A két csoportnak megvolt a maga nyilvános fóruma, a forradalmi hagyományokat is képviselő Keleti Újság/Napkelet, illetve a konzervatívabb Ellenzék/Pásztortüz. Ezek a lapok, ha időnként egymás konkurenseként is, de együtt reprezentálták a másságot és a folytonosságot, illetve az önszerveződést és integrációt. Zima Tibor parlamenti képviselő 1922. júliusban a következő kérdést tette fel: „ez a generáció már nehezen fogja emancipálhatni magát világot rengető események hatása alatt beidegzett felfogásoktól, amelyek a múltban osztályhelyzetét, pártállását, gondolkodását egész szellemi lényét determinálták. Képes lesz-e pl. ez a generációt egységesen és feltétel nélkül ráhelyezkedni a tiszta demokrácia platformjára, amelyre kisebbségi helyzete szükségszerüen utalja Románia magyarságát? ". ${ }^{1160}$ Paál Árpád a nem költőinek szánt kérdésre azt felelte, hogy az erdélyi (regionális) és az itt élő nemzetek érdekeihez illeszkedő államberendezkedést kell megtalálni, amely lényegében Románia föderális berendezkedését irányozta elő. Paál a Kós-féle Néppárt programjával megegyező gondolatot a következőképpen fogalmazta meg: „mi erdélyi népkisebbségek a regionalizmust szülőföldünk és az állam közötti legszervesebb összefüggés megteremtőjének és fenntartójának tudjuk felismerni.

\footnotetext{
1158 BÁRDI, Otthon. 2013. 481.

${ }^{1159}$ BENKÖ Samu: A helyzettudat változásai. 1977. Bukarest, Kriterion Könyvkiadó, 8. [Továbbiakban: BENKÖ, 1977]

${ }^{1160}$ Az erdélyi néppárt nagygyülése és a magyar képviselők. Keleti Újság, 1922. 5. évf. 154. július 13. 2.
} 
Erdélyi népkisebbségi tagoltságainak, tehát egész országra nézve a legnehezebb népkisebbségi kérdéseknek a megoldására függ attól, hogy regionalista alkotmányrendszer érvényesüljön Erdélyben és a többi csatolt területeken. Nem elkülönülés ez, hanem a különös részleteknek országos szervezetbe való belevitele." 1161

A tudás, az elvek, a rátermettség és az erkölcsi normák egyénenként ugyan váltakozó kontextusban befolyásolják az életpályák irányát, de a megörökölt történelmi helyzet határolja körül a cselekvés lehetőségeit. Nem eleve elrendelésről vagy belenyugvásról van szó, hanem arról, hogy az egyén számol vele, illetve az értelmiségi tudatnak rendelt hivatása alapján pedig az „objektív szituáció” megváltoztatására vállalkozik. A változás szándékával születnek új eszmék, fejlődik a tudomány, müvészet, változik a politikai magatartás. Kelet-Közép-Európa térségében a társadalom létezési formáit az elmerevedettség jellemezte, semmint az ígéretesen dinamikus mozgások. A változások mögött mindenekelőtt nagyhatalmi konfliktusok álltak, amely egyéni és közösségi szinten helyzettudat változásokat kényszerítettek ki. A pusztítástól való félelem mellett egyszerre voltak jelen a követendő példák is, amely felkészülési lehetőséget biztosított a differenciálódó és számbelileg gyarapodó erdélyi értelmiségnek, vezető réteg egyes tagjainak. Benkő Samu szerint ez az értelmiségi tudat együtt járt azzal, hogy önmagát egyetemesen elfogadott mércével mérje, az egyéni célt, közösségi feladatvállalást, az alkotásban elért eredményt aszerint értékelje, hogy az mennyiben van összefüggésben az európai szellemi élet vonulataival. ${ }^{1162}$

Az államhatalom-változás időszakában, amíg a magyarországi belpolitikai életben minden, ami a wilsonizmushoz, az emberi jogokhoz, a demokráciához, a politikai kollektív jogokhoz, az asszimilációhoz, a fejlődéshez stb. kötődött negatív jelentést kapott, addig Erdélyben ezek, ha jelentésükben módosultak is, továbbra is értékként voltak jelen a politikai diskurzusban. Magyarország szétesése megkövetelte a kisebbségi magyarság helyzettudat változásából fakadó számvetést, amely olyan politikai és társadalmi tartalmak újragondolását követelte meg, mint államhatalom, demokrácia, elnemzetietlenítés, autonómia, függetlenség, kultúra, hagyomány, szolidaritás, stb. Új alternatívák elé került a magyar vezető réteg, amelyek közt maga is a felszabadulás lehetőségeit kereste, igyekezett megszabadulni a ránehezedő elnyomás és centralizáció alól.

\footnotetext{
1161 Paál Árpád: A Magyar Párt történelmi hivatása. Keleti Újság, 1922. 5. évf. 268. szám, november 26. 1-2.
} 1162 BENKÖ, 1977. 8-9. 
Az értelmiségi élet, ha rossz közérzet légkörébe is került és az alkotó munka elé akadályok gördültek, a kisebbségi élet erkölcsi normái akkor is megkövetelik legalább kognitív szinten azt, hogy az önérdek és a közérdek összehangolása, a közösségi felelösségtudatból fakadó nagyobb szolidaritás, a nép érdekeinek felismerése és a vele való azonosulás megvalósuljon. 


\section{MELLÉKLET}

1. számú melléklet: Székely Nemzeti Tanács kiáltványa, 1918.

\section{Székely Katonák!}

Magyarország népei otthagyták a háborut. A háborut megszuntette a forradalom. Ti hazajöttetek, de idehaza nem vár a béke nyugaima rátok! A békének uj ellen. sége támadt: A románok, csehek és egyéb kis népek jogtalansága és erōszaka! A románok kimondottak, hogy elszakadnak Magyarországtól. Huszonhat vármegyêt akarnak elszakitani tôlïnk, ebben a huszonhat vármegyében van egész Erdély és Székely. ország, a Ti hazatok is! Ne hagyjátok ezt a hazá! nyomorultul elpusztulnil Tarisatok ossze édes véreink, ugyis kevesen vagyunk. Tartsatok össze, ahogy ossze. tartottunk törhetetlen hûséggel négyévi dicsösẻoben és szenvedésben, Maradjunk egymás oldalán, vallvefve. mig az igazságos béke szamunkra is megterem. Ti fudjátok, hogyha szétzulitik a csapai, ha felbornlik a rend akkor minden rongy uir lesz rajtunk, mert az eró a kơzòsségben van! A volt 2 . sz, huszárezred uj ezreddé alakul, a Székely nẹp ezredévé! Ez az ezred a Székely nemzetél Székely katonák I A Ti ezredetek tulajdonosa a mai naptól kezdve a Székely fŏld! Testvéreitek, szülöitek, feleségetek, gyer. mekeitek katonái vagytok, a Székely nép katonái. A legszentebb esku a vêr, ami obblólûk tibennetek folyiki Az árva székely nép élete, szerelme, remé. nye vagytok Ti. Oérfók éltek és Ok Tiértetekl Marad. jatok egyiltt! Egymás mellett! Alljatok össze! Jelentkezzetek! Nem mer az erószak jogtalanságokra vetemedni, ha Ti egyek vagytok!

Székely katonák! Testvéreitek, vezetōitek várnak Titeket, a Székely nép ezredét! Ne hagyjátok el egymást! Isten áldása legyen rajtatok!

A Székely Nemzeti Tanács.

Jelentkezési hely: A Székely huszárezred (régi z-es huszárok) póttestének székhelye, mely az erdélyi katonaparancsnokságnál megtudható.

2. számú melléket: Paál Árpád és a Székelyudvarhelyre bevonuló román hadsereg megállapodása

A román csapatok (egy vadászezred) Csíkszereda irányából 1918. december 6-án vonultak be Székelyudvarhelyre. Délután kettőkor érkezett meg Nicoleşcu tábornok, akit Paál Árpád, Soó Domokos helyettes polgármester, Szakács Zoltán rendőr-főkapitány és mások vártak a városi vámnál. Paál fogadó beszédében hangsúlyozta, hogy mint megszálló csapatokat fogadják a románokat, és nyugalommal várják a békekonferencia döntését. Felhívta a figyelmet arra, hogy a közigazgatást kormánybiztos vezeti, aki a közbiztonság fenntartása érdekében számít a román katonaság segítségére. Végezetül részletes megállapodás megkötését kérte a tábornoktól. Ezután a kormánybiztoshoz mentek, ahol két órás tárgyalás során - Paál előzetes javaslatai nyomán - a következőkben állapodtak meg.

„1. A katonák elhelyezése dolgában a tábornok tudomásul vette, hogy a volt reáliskolában és a kaszárnyában lesznek elszállásolva. A csendőrség tagjai közül 15 fegyverben maradhat, ellenben a polgárőrség tagjai fegyvertelenül, mint bizalmi férfiak fognak szolgálatot végezni a közbiztonság és a közrend fenntartása végett kiküldött román járörök mellett.

2. Közbiztonság dolgában a tábornok kikötötte, hogy fegyveres karhatalom általában csak a román hadseregnél lehet. 
3. Élelmezés dolgában közvetlen nem rekvirálnak. Az általunk adható készleteket 2-3 napon belül nem is kívánják. Ezentúl a közigazgatás útján veszik igénybe. Miután pedig a vármegye lisztbehozatalra van utalva, készséges támogatásra talált a vezető férfiak ama kívánsága, hogy e lisztszállítmányok behozatalát (különösen Aradról) a tábornok úr elösegítse.

4. A kaszárnyában lévő zabot és burgonyát átveszik és megőrzik és megígérték, hogy minden igénybe vett áruért az itt megállapított maximális árat fogják fizetni.

5. A kaszárnyában levő töltényekre való figyelmeztetést köszönettel tudomásul vették.

6. A barakkba lévő fölszereléseket, különösen a fürdő berendezést városi tulajdonnak elismerték, védelmét elvállalták s a berendezések leszerelésével megbízott szakiparosokat munkájukban háborgatni nem fogják.

7. A szénakérdést illetőleg, miután kevés a szénánk, kijelentették, hogy ezt jóakarattal oldják meg a lehetőség határai között.

8. A szegényügyi akció zavartalan folytatását semmiben se fogják akadályozni, az avégböl rendelkezésünkre álló 600 pokrócot és a kaszárnyában, meg a reáliskolában raktározott fehérnemüt további rendelkezésünk alatt meghagyják.

9. Az iskolák, templomok, kórházak, pénzintézetek, az adóhivatal és a hivatali épületek biztonságára felügyelnek, a hivatali müködések zavartalanságát biztosítják.

10. A piaci rend megtartásában a polgárőröknek segítségére lesznek; a rendőrök kötelességüket oldalfegyverrel tovább teljesítik.

11. Koronánk értékét, tekintettel világpiaci valutánk helyzetére 60 baniban szabja meg.

12. A szesztilalom továbbra is fennmarad, annyi módosítással, hogy étkező helyeken (csak is itt) 3 deci bor fejenként adható (csak az ebédlőben). Sört kiárusíthatnak. Más kocsmákban azonban teljesen tilos. Záróra fél kilenckor; ezentúl csak egyházi tisztükben eljáró papok, orvosok, közhivatalokba eljáró tisztviselők (permanens szolgálat megyeházán stb.) és a karhatalom segédletére beosztott polgárok tartózkodhatnak az utcán.

13. A posta és a távírda, magán és hivatali ügyben szabad.

14. A fővárosi lapok és a helybeli lap csak előzetes cenzúra után jelenhetik meg. A román nemzetet és népet gyalázó cikkek és kiáltványok kiadása tilos.

15. Ugyancsak tilos politikai jellegű gyülekezetek megtartása. Ellenben társadalmi, jótékonysági, tudományos, ismeretterjesztő gyülekezések meg vannak engedve.

A Nemzeti Tanács hetente egyszer ülésezhetik, de politikával nem foglalkozhatik. Szegényügyi, népjóléti, közélelmezési, közegészségügyi dolgokkal és kulturális kérdésekkel foglalkozhatik esetleg román tiszt ellenőrzése mellett.

A törvény által alkotott testületek (törvényhatósági, közigazgatási bizottság, képviselőtestület), a tárgysorozat előzetes bemutatása mellett, üléseit megtarthatják.

16. A fegyvereket (mindenfélét) közeli falvak két nap alatt, távoliak öt nap alatt, különben szigorú büntetés terhe mellett beszolgáltatni kötelesek. A vadászfegyvert és revolvert szintén, de az illető névre szóló elismervényt kap s a megszállás után visszakapja.

Ezzel kapcsolatban a büncselekmények elkövetőinek üldözésére és elfogására szükséges karhatalmat rendelkezésre bocsátják. Természetes, hogy a fogva tartás és az ítélkezés a bíróságok hatáskörében megmarad.

17. A városról 18-45 éves férfinak engedély nélkül elutaznia nem szabad. Ezen a koron alul, felül lehet, nők korra való tekintet nélkül utazhatnak. Közhivatalnokok egyszersmindenkorra szóló utazási igazolványt kapnak a vármegyében szabad utazásra.

Hozzájárul, hogy záróra alól kivetessék a vármegyei permanens szolgálat. Ha mozi van, este fél kilencig müködhetik.

18. Dr. Paál Árpád alispán annak tisztázására kért felvilágosítást a tábornok úrtól, vajon serege I. Ferdinánd román király impériumának a kiterjesztése jelentőségével jött-e ide, vagy csak megszállás jellegével, mely utóbbi esetben az eddigi államalakulatok megmaradnak és sorsukról a béketárgyalás fog dönteni. Az alispán jelezte, hogy ennek tisztázása a közhivatalok müködése szempontjából fontos. A tábornok úr kijelentette, hogy I. Ferdinánd parancsából az antant hozzájárulásával jönek, idejövetelük csak a megszállás jelentőségével bír, s az államalakulások dolgát nem kívánják érinteni, erről majd az érdekelt kormányok döntenek.

A megszállás ideje alatt kormányzati, közigazgatási és bírói teendők végzése az illető hivatalnoki kar kezében marad. 
Közigazgatási hatóságainkkal való érintkezésben akként járnak el, hogy megkereséseiket a kormánybiztos útján fogják megtenni.

19. Kérdésre parancsnokló tábornok úr kijelentette, hogy a román hadseregbe való sorozásról vagy internálásról szó sem lehet. Egyúttal fölkérte a kormánybiztost, hogy a fegyverek beszolgáltatására vonatkozó rendeletet haladéktalanul adja ki, úgyszintén arra is kérve figyelmeztesse a katonatiszti és katona ruhában járó egyéneket, hogy katonai ruháikat hordhatják ugyan de a román tisztekkel való érintkezésben az udvariassági formákat megtartani s a magasabb rangúakat köszönteni kötelesek.

20. A tábornok úr kifejezte azt a kívánatát, hogy a volt osztrák-magyar sereg katonái által a falukban eladott és visszahagyott tárgyakat a közigazgatás szedesse össze és a román hadseregnek adja át, mert e tárgyakra tulajdonjogot formál. A kormánybiztos és a h. alispán erre kijelentette, hogy a román hadseregnek ilyen tulajdonjogáról nincs szó a fegyverszüneti szerződésben $\mathrm{s}$ így a tárgyak összeszedésére és átadására felhívást ki nem adhatnak."

(Közli: BÁRDI: Otthon és haza, 2013. 48-50.)

\section{3. számú melléklet: Szellemi Front feladatai}

Paál Árpád 1919 májusából fennmaradt röpiratában a következőképpen fogalmazta meg a Szellemi Front feladatait:

„1. A néphangulat megőrzése, felajzása és teljes szívósságúvá kiképzése abban a hitben, hogy lesz még magyar világ.

2. Minden behódolási irányzatnak a letörése. Az ilyen irányzatok által kínált anyagi érvényesülések helyébe önnön erőnkből való érvényesülések, munkaalkalmak, vállalatkomplexumok, fejmunkáskiképzések szervezése.

3. A magyar egyházak és iskolák szellemének a magyar jövőről való hitben és hit fejlesztésében való kitartása; az egyházak és iskolák anyagi feltételeinek társadalmi megszervezése.

4. A gazdasági vállalatoknak a szociális és magyar erő építésére irányuló átszervezése, a behódoló és megegyezéses alkuktól és önzésektől való visszatartása, altruista és magyar fajszaporitó bankpolitika behozatala.

5. Sajtó és irodalom teremtése a mondott irányok ápolására és terjesztésére.

6. A magyar és székely vidékek szoros összeköttetésének megteremtése. Ez összeköttetés céljaira bizonyos jeleket és írásmódokat itt átadunk, s akinek jelen iratunkat küldtük, azt a legsürgösebb átvételre fölkérjük. Találkozásunkkor az eddigi összeköttetések ismeretét is feltárjuk.

7. Olyan önvédelmi szervezet teremtése tornaklubok, olvasókörök, dalos egyesületek és munkás szakegyletek útján, mely a magyar világ pontos rendfenntartó karhatalmaként azonnal fel tudjon lépni, s a szükséghez képest megfelelő néperőt is tudjon mozgósítani." (Közli: BÁRDI: Otthon és haza, 2013. 79-80.)

\section{4. számú melléklet: Az Udvarhely vármegye Intézőbizottsága által 1919. május 26-án kiadott megegyezéses határozat}

A székelyudvarhelyi tisztviselői ellenállás utolsó általunk ismert dokumentuma 1920 májusából származik. Az Udvarhely vármegye Intézőbizottsága által 1919. május 26-án kiadott megegyezéses határozat, amelyet a háromszéki hasonló alakulattal egyeztettek, egyrészt a magyar kormány álláspontját szeretné tisztán látni (ide vonatkozó utalásaik némileg ingerült tónusúak), másrészt a Románián belüli elhelyezkedés, önszerveződés módjára tesz javaslatot:

„1. Mindenesetre legelső feladatunk - aminek a legsürgősebben elég is lesz téve -, miszerint a magyar kormány megkérdeztessék, hogy Magyarországnak a változott állítólagos helyzetben van-é, $\mathrm{s}$ ha igen, mi a célja velünk, illetve felkérendő a magyar kormány, ejtse módját a lehető legsürgősebben annak, hogy egy futár, vagy egy salvus conductussal ellátott megbízottja útján hitelesen értesítsen, vajon a székelység (értve Udvarhelyszék, Csíkszék, Háromszék, Marosszék székelységét összességében) s illetve a székelység gerincét képező intelligens középosztály: a tisztviselői kar a továbbiakban mire számíthat s ennélfogva mihez tartsa magát, történik-e gondoskodás róluk vagy nem? 
2. Ha nevezett négy székely vármegye lakossága és tisztviselői karára nézve az elhatározás az, hogy rólunk államilag több gondoskodás történni nem fog, s így magunkra maradnánk, akkor határozottan követeljük a magyar kormány útján a teljes jogokkal felruházott önálló municipiális autonómiát, értve ezt úgy, hogy csupán a föispán képviselné a román kormányt - egyebeket, az alispántól kezdve a közigazgatás minden ágában magyar tisztviselők vennék át a szolgálatot, mert csak így biztosítható a székely-magyarság kompakt egysége. Másképp, ha ti[.] az összes tisztviselői állások fölött a román kormány diszponálhatna, az elmozdíthatóság, nyelvi kötelezettségek $\mathrm{s}$ más eszközök és módok alkalmazásával előreláthatólag rövid idő alatt román tisztviselőkkel töltetnének be az összes állások s ekkor egy-két évtized a székelységet teljesen beolvasztja a románságba, s a magyar fajnak nyoma vesz. 3. Megkérdezendő teljes határozottsággal a magyar kormány, hogy szándékozik-e a fegyveres eröt alkalmazni Erdélyért, illetve az átadásra állítólag kijelölt területekért vagy nem? Mert ha szándékozik, ezt csak úgy teheti, ha teljes tudatában és ismeretében van Európa nagyhatalmainak ez esetbeni állásfoglalásával s illetve ez esetben további erejének és esetleges szándékának mivoltával. Mert ha ezt feltétlen és teljes bizonyossággal tudja s indít háborút az ország, a székelység szervezett teljes erejére számíthat, amely csak intésre vár; ellenesetben egy kockázatos háborús akció sikertelensége biztosan maga után vonja nem csak a legkegyetlenebb retorziót ti[.] a székelység teljes kiirtását, de a végtelen bosszú eredményeképp a székelység helyén még kö kövön se maradna.

4. Feltéve, de nem remélve azon legkegyetlenebb eljárást, hogy Magyarország minket teljesen magunkra hagyna, akkor csak azon legvégső eset állhat rendelkezésünkre: kieszközölni a román vezetőségtől, adjon módot és lehetőséget arra, hogy a négy székely vármegye vezető megbízottjai a további magatartásuk érdekében összejöhessenek és sorsuk felöl szabad megbeszélést, illetve tárgyalást folytassanak.[...]" (Közli: BÁRDI: Otthon és haza, 2013. 82-83.)

\section{5. számú melléklet: Magyar Szövetség Csík vármegye 177-ős bizottsága, 1921.}

Dr. Györgypál Domokos, Antal Áron, Holló Gábor, dr. Élthes Gyula, Zimmerman Adolf, Rudics István, dr. Szekeres József, Szilassy László, Takács Károly, Kalmár Ignác, Szász Gyula, Bíró József, dr. Bocskor Béla, Fried Samu, Imre Ignác, Solymossy Károly, Pallós János, Gáspár József, Szvoboda Miklós, Dávid János, Vákár Lajos, Gyönös Gyula, Balogh Géza, Dájbukát Jakab, T. Nagy Imre, Domokos Jakab Csíkszereda. Peter Ferenc, Salló Domokos, báró Rudnyánszky Sándor. Zsögöd; Dr. Czikó István Mindszent; Lacz János Szentlélek; id. Pál Gábor, P. Bíró Benedek, Ferencz Imre Várdotfalva. Gál József Pálfalva; Ferencz Lajos, Györgypál Károly Csomortán; Balázs Tamás, Mihály Albert, Lázár Miklós, Boncz Antal Taplocza; Bartalis János, Pálosi Géza Csobotfalva; Kovács Péter Delne; Szabó Károly, Lakatos Ferenc, Péter József Csicsó; Keserü András Lázár Pál Csíkszentmiklós; Bíró Ferenc, Olti Lajos Madéfalva; Dobos Árpád Rákos; Bíró Kálmán Vacsárcsi; Kovács Boldizsár Göröcsfalva. Balog József Borzsova; Kósa Tamás, Gábosi Dénes, Búzás Albert, Tatár András Szentmihály, Kacsó Boldizsár, Antal Ferenc, Péterffy L. Madaras; Szőcs Béla, Zsok József Dánfalva. Gidró Márton, dr. Kászoni Alajos, Gidró Alajos Karczfalva; Mózes Tamás Jenőfalva; Balog Ignác, ifj. Bara János Szenttamás, Böjte Lajos, Boga István, Karda Mihály Szentdomokos. Gábor István volt bíró, Mihók Imre Gyimesközéplok; Élthes János, Ugron György Gyimesbükk; Antal József Gyimesfelsőlok. Kovács Mihály, Zakariás Andor; Antal Károly Ignácé, Péter Béla Szépvíz; Csedó Gábor Menaság; Orbai Endre, Marton Bálint Bánkfalva; Tompos János, Incze Domokos Szentgyörgy; Szőcs Sándor, dr. Botár Adolf Szentmárton. Orbán Ferenc, Kajcsa József volt bíró Kozmás; Bartha Ferenc, Csoboth István, Illyés Dénes Kászonújfalu; Szőcs Albert Kászonaltíz; Pataky Antal Kászonfeltíz; Csutak Albert Kászonjakabfalva. Albert Zsigmond Kászonjakabfalva; Virág János volt helyettes bíró, Ábrahám János volt bíró Lázárfalva; Kedves Peter, Darvas volt bíró Tusnád; Kovács Gergely, Kovács Ignác Verebes; Málnás Ferenc és Koncsag Lajos Csekefalva; Tódor István, Koródi János templomalji Csatószeg, lncze Imre, Fazakas Lajos Szentsimon. Endes Antal, Szőke József, Demes Elek Szentimre; id. Csiszér Ábel, Szabó Elek, György János Szentkirály; Bács András Balánbánya; Bartalis János, Szabó Sándor Boresék; Nagy Gyula Békás; Dobribán Péter, Blénessy József, ifj. Tódor Antal Tölgyes; id. Horváth Miklós, Smilovits Hermáim Holló. Bencze József Holló; dr. Benke Antal, Szabó György, dr. László Dezső, Gáspár Máté, Lázár János, László István, Strasser József, dr. Kugler Vilmos, György F. András, Jánossy György, Blénessy Dénes, Szini Lajos, ifj. Melles Ferenc, György Sándor, Szász István, dr. Tódor Béla Gyergyószentmiklós. Pál Antal Ignácné, Angi István, Ferenc Kálmán, Oláh Alajos, Keresztes Sándor, Mardirosz Gyula, Gáspár Péter Szárhegy, dr. Puskás Levente, Gál Imre, Kovács Antal, Mezey Ferenc, Ávéd Joachim, Liebl Ede Ditró; Szabó János Imréé, Balázs Fülöp Ferenc; Balázs bécsi József, 
Borbély Bartis Albert, Rákos Antal Remete, dr. Áved János, Kiss Antal Györgyé, Balázs J. Márton, Fehér Mihály, Kassay János Alfáin; dr. Péterffy Lőrinc, Küllő Ignác, Rokaly Dénes, Ágoston Ágoston Csomafalva; Elekes Józsa Márton, Nagy Ágoston Újfalu; Balázs Ferenc, Bálint Pétéin, Pál Dénes Kilyénfalva; Pál Lajos, Bálint Ferenc, Bencze Ágoston Tekerőpatak; továbbá a megyei bizottságnak tagja még a kolozsvári központi igazgatóságba kijelölt két rendes tag. (Közli: Csíki Lapok, 1921. XXXIII. évf. 27. szám, július 3. 1.)

\section{6. számú melléklet: A Magyar Szövetség alakuló ülésén (1921. július 6-án) megválasztott vezetők}

A szövetség vezetősége: elnök báró Jósika Sámuel, a fơrendiház volt elnöke, ügyvezető alelnök: dr. Haller Gusztáv, alelnökök: Ugron István, dr. Grandpierre Emil, gróf Béldi Kálmán, Ferenczy Géza, Albrecht Lajos, titkár: Koós Károly, pénztáros Ferenczy Gyula, ellenőr: Bányay Károly. A központi választmány tagjai: Adorján János, dr. Apáthy Árpád, Asztalos Kálmán, Balázs András, Balázs István, Barabás Béla (Arad), Bárdos Péter,Bene Ferenc, Benedek Aladár, gróf Bethlen György, Bélteky Lajos, dr. Bernády György, Bikali Márton, Bod László, Bokor Márton, Csulay Lajos, Csutak Vilmos, Desbordes Ernő, Fejes Áron, Ferencz József, Frölich Ottó, Gaál Imre, Glattfelder Gyula, Garda Kálmán, Görög Ferenc, Görög Joachim, Grois László, dr. Gyárfás Elemér, Harcsár Géza, Hinléder F. Jenő, Hintz György, Hirschler József, Ignátz László, Inczédy-Joksmann Ödön, Issekutz Viktor, Kádár Géza, Kovács Áron, Kecskeméthy Lipót, Keresztes István, Kirchknopf Gusztáv, Kispál László, Kolosváry Bálint, Lázár László, Kislörinczy István, gróf Majláth Gusztáv Károly, Nagy Jenő, Nagy Károly, Óváry Elemér, Pál Gábor, dr. Paál Árpád, Papp Endre, Peéchy Imre, Puskás Béla, Róth Hugó, Sándor József, Sárkány Lajos, Sebesi János, Szabolcska Mihály, Szász Endre, Szele Béla, Szele Márton, Szentiványi József, Szentkereszty Béla, Szigyártó Gábor, Szini Lajos, Szórády Lajos, Torma Miklós, Török Andor, Turner Albert, Willer József, dr. Zágoni István, illetve a megyei választmányoktól bejelentett tagok. (Közli: Ellenzék, 1921. XLII. évf. 141. sz. július 7. 2-3.)

\section{7. számú melléklet: A Magyar Szövetség szervezeti szabályzatának tervezete, 1922. augusztus 6-i nagygyülésre}

1. Románia magyarsága, mint nemzeti kisebbség egy szervezetbe egyesül.

2. A szervezet címe: Magyar Szövetség. Központja: Kolozsvár. Nyelve: magyar. Pecsétje: „Magyar Szövetség Kolozsvár 1921".

3. Célja: Romania magyarsága kulturális, közgazdasági es jogi érdekeinek biztosítása.

4. A Magyar Szövetség tagjának tekintetik minden 20. évet betöltött, magát magyarnak valló férfi és nő. 5. Minden tag indítványozó, tanácskozó és szavazó joggal bír a megfelelő üléseken, választó és választható, köteles azonban a Magyar Szövetség érvényben levő rendelkezéseit, valamint a szervezeti és más szabályokat híven és becsületesen megtartani az elöirt erkölcsi es anyagi kötelezettségeket pontosan teljesíteni.

6. A Magyar Szövetség szervezete: a) községi választmány; b) megyei választmány (városi választmány); c) szövetségi közgyülés valamint az ezek által alkotott bizottságok, szakosztályok.

7. A község; választmány áll: minden megkezdett 100 magyar lakos után választott 1-1, de legalább 3, legfeljebb 60 tagból.

8. A megyei választmányt alkotja: a községi választmányok által minden megkezdett 10 tag után, lakhelyre való tekintet nélkül választott 1-1 tag. Városi választmányok létesülhetnek a megyei választmányok mintájára törvényhatósági joggal felruházott városokban a szövetségi közgyülés előzetes hozzájárulása mellett, melyekben a magyar lakosság száma a 10.000-et

meghaladja. Ily varosokban a községi választmányt a varos kerületei (tized, városnegyed) szerint alkotandó kerületi választmányok helyettesítik.

9. A községi, megyei es városi választmányok szervezetei és ügyrendjét a szövetségi közgyülés utasítása alapján a választmányok önmaguk készítik el.

10. A szövetségi közgyülés áll: a megyei és városi választmányok által minden megkezdett 100 számú tag után az M Sz. tagjai közül, lakhelyre való tekintet nélkül, választott 1-1 tagból. A szövetségi közgyülés a Magyar Szövetség hivatalos képviselete, magának elnököt, alelnököt és Intéző Bizottságot választ. Évente legalább egyszer közgyülést tart a múlt év erkölcsi eredményének elöterjesztése és a jövő évi program és költségvetés megállapítása végett. 
Minden harmadik évben a tisztújítás is megtartandó, melyen a központi tisztikar és az Intéző Bizottság tagjai választatnak meg. Ügyrendjét önmaga állapítja meg.

11. A szövetségi közgyülés előkészítő és végrehajtó szervei az Intéző Bizottság és a központi tisztikar, melyek a szövetségi programjainak megfelelően az állandó ügyvitelt is végzik.

12. Az Intéző Bizottság tagjai: a szövetségi közgyülés által saját kebeléből választott 30 tag, az M. Sz. elnökei és két titkára, ezeken kívül tanácskozó joggal bír a megyei választmányok 1-1 kiküldöttje és a Központi tisztikar többi tagjai.

Az Int. Biz. tagjai 6 évre választatnak olyképpen, hogy a tagok fele a megválasztást követő 3-ik év elteltével első ízben sorshúzás útján később pedig mandátuma lejártakor kilép, azonban újra választható. Az Int. Biz. müködési körét külön ügyrend szabályozza, melyet önmaga állapít meg.

A központi tisztikar tagjai: Elnök, alelnökök, titkárok, kik közül egyet az elnök nevez ki, pénztáros-, ellenőr és ügyész. A 10-ik §-ban fel nem soroltakat az Int. Biz. választja meg.

Az elnök képviseli a Szövetséget hatóságokkal, magánosokkal és a nyilvánossággal szemben összehívja a szövetségi közgyülést, az Int. Bizottságot és azok ülésein elnököl; őrködik a szervezeti és más szabályok megtartása, valamint a határozatok végrehajtása és az ügyvitel felett. Aláír a titkárral minden kiadványt, utalványt és jegyzőkönyvet; 1000 lej erejéig utalványozhat a költségvetés keretén túl is, utólagos jóváhagyás fenntartásával; véletlen pénztárvizsgálatot rendelhet el, vagy foganatosíthat, mindennemü bizottságnak hivatalból tagja.

Az alelnökök az elnök akadályoztatása esetén megválasztásuk sorrendjében helyettesítik az elnököt. Számukat a szövetségi közgyülés esetről esetre határozza meg, 2 alelnöknek feltétlenül Kolozsvárt kell laknia. Egyikük ügyvezető alelnök címet és jelleget visel. Az elnököt az alelnökök akadályoztatása esetén az Int. Biz. tagjai közül a korra nézve legidősebb helyettesíti. $A$ titkárok az elnök irányítása szerint intézik a Szövetség adminisztratív ügyeit, előadói a Szövetség ügyeinek az Int. Biz. ülésein és a szövetségi közgyülésen. Készítik és az elnökkel együtt aláírják a Szövetség kiadványait és az utalványokat. Minden bizottságnak 1-1 titkár hivatalból tanácskozó tagja. A pénztáros az Int. Biz. által megállapítandó pénztárkezelési szabályok szerint vagyoni felelőssággel kezeli a Szövetség vagyonát. Az ellenőrrel együtt készíti a zárszámadási és költségvetést, pénzügyekben előadó. Az ellenőr vagyoni felelösséggel ellenörzi a pénztáros müködését. Helyettesítéséröl ideiglenesen az elnökség gondoskodik.

Az ügyész a Szöv. jogügyeinek intézője; szakkérdésekben előadó. A titkárok, a pénztárosok és az ügyész az Intézö Bizottság által meghatározott tiszteletdíjban, vagy javadalmazásban részesülhet.

$A z$ esetlegesen szükséges más tisztviselőket az Intézö Bizottság választja, az alkalmazottakat pedig az elnök nevezi ki.

13. A községi választmányok határozata a megyei választmányhoz, a megyei választmányok határozata a központi Intéző Bizottsághoz megfellebbezhető az illető választmányok tagjai által.

14. Az M. Sz. müködésének közvetlen megismertetése és a magyarság kulturális, szociális és közgazdasági ismereteinek fejlesztése érdekében az Int. Biz. alkalmas időben évenként más-más helyen „Magyar Szövetségi Napot” rendez. Ennek irányelveit és programját az Int. Biz. határozza meg.

15. Az M. Sz. költségvetésében megállapított szükségleteinek fedezésére az int. Biz. által megállapított és a megyei (városi) választmányokra kirótt évi járulékok, valamint önkéntes adományok szolgálnak.

16. A Szövetség feloszlása egy hónappal előbb összehívott Szövetségi közgyülésen a jogosított tagok kétharmadának jelenlétében 8-4 szótöbbséggel történhetik. Határozatképtelenség esetében egy hónapi határidővel új szövetségi közgyülés hívandó össze, mely a megjelentek számára való tekintet nélkül a fenti szótöbbséggel határoz. A feloszlást kimondó határozat alapján, vagy ha a szövetségi közgyülés bármi okból már megtartható nem volna, a Szövetség vagyona az EMKE-re, illetve ennek feloszlása, vagy nemléte esetén az Erdélyi Múzeum Egyesületre száll; ha ez sem léteznék, akkor a szövetségi közgyưlés által meghatározott célra fordítandó úgy azonban, hogy a tőke érintetlenül marad, és ha 10 év alatt a Szövetség újra alakul, a tőke visszatérítendő. (Ellenzék, 1922. 43. évf. 175. szám, augusztus 6. 12.) 
8. számú melléklet: A Magyar Nemzeti Párt alapszabálya (1922. augusztus 7.)

A Magyar Nemzeti Párt szervezeti szabályai szerint a párt tagja minden 20 életévét betöltött férfi és nö, aki a párt programjával egyetért, és csatlakozását aláírásával tanúsítja. A párt müködése egész Romániára kiterjed, vezetőségének székhelye Kolozsvár. A párt tagjai választókerületenként a párt tagozatait alkotják, amennyiben legalább 300 tagot számlálnak. A párt évenként országos pártgyülést tart a székhelyen, vagy az országos pártgyülés által kijelölt helyen. 20 kiküldött kérésére az elnök az országos pártgyúlést összehívni tartozik. Az országos pártgyuulésen szavazati joga a párttagozatok kiküldötteinek és a párt országos vezetősége tagjainak van. A tagozatok minden 300 tagjuk után kiküldöttet jelölnek az országos pártgyülésbe, 4 évi időtartamra; kiküldötteiknek száma a hármat meg nem haladhatja. Az országos pártgyülés alelnökét és 2 jegyzőjét 4 évre választja; a pártvezetőség elnöke egyúttal az országos pártgyülés elnöke. Érvényes határozathozatalhoz az országos pártgyülés tagjai egyharmadának jelenléte szükséges, a szervezeti szabályok kétharmad szótöbbséggel változtathatók meg. A szavazás közfelkiáltással történik, 20 kiküldött (országos vezetőség tagja) kívánatára az elnök titkos szavazást rendel. A párt országos vezetősége áll: a párt programjával megválasztott szenátor és képviselőkböl, a tagozatok kiküldöttei és az országos gyülésen 4 évre megválasztott 100 párttagból, ügy a tagozatok, mint a vezetőség ügyrendjét maga állapítja meg, elnökségét és tisztikarát 4 évi időtartamra maga választja. Az országos pártgyülés tagdíjakat állapíthat meg. (Közli: Ellenzék, 1922. 43. évf. 176. szám, augusztus 8.)

\section{9. számú melléklet: A Magyar Nemzeti Párt 100-as bizottsága}

Andrásovszky Danó Kolozsvár, dr. Albrecht Lajos Bánffyhunyad, Apáthy Árpád Székelyudvarhely, dr. Asztalos Kálmán Nagyenyed, dr. Abrudbányai Ede Tötőr, Andrási József Pitesti, Ballá Béla Nagyenyed, gróf Bethlen György Kolozsvár, dr. Balogh Elek, dr. Balogh György Torda, Bálint Dénes, Bogdán Arthur, ifj. Böjthe Ferenc Sepsiszentgyörgy, gróf Béldi Kálmán Zsibó, dr. Bene Ferenc Dés, Bocsánczy László Kolozsvár, Bede László Máramarossziget, dr. Barabás Béla Arad, dr. Benedek Aladár Beszterce, Bálint Dániel, Bodor Boldizsár Székelykeresztúr, Cziffra Kálmán Nagyvárad, Csulay Lajos Déva, Dánér Lajos Brassó, Deé György Marosvásárhely, Fekete-Nagy Béla Kolozsvár, Ferenczy Lajos Kolozsborsa, dr. Ferenczy Géza Nagyajta, dr. Fülöp Béla Temesvár, dr. Grandpierre Emil, dr. Grois László, dr. Gabányi Imre Kolozsvár, Gaál Péter Korpádi, Gagyi Lajos Etéd, dr. Gyárfás Pál Székelykeresztur, dr. Hinléder Ernő Sepsiszentgyörgy, Hollaky Imre Déva, dr. Harcsár Géza Szatmár, Hankó Veress Károly Kolozs; dr. Haller Gusztáv Kolozsvár, Havadtői Sándor Kovászna, Hevessy József Kolozsvár, dr. Helmeczy József Szatmár, Huber Imre Kolozsvár, dr. Issekutz Erzsébetváros, Inczédy-Joksmann Ödön Nagyenyed, Bodroghy János Nagyenyed, báró Jósika Gábor Várfalva, Jakócs István Sepsiszentgyörgy, Jancsó Gábor Nagyenyed, Kerekes József Torda, Kónya Kálmán Nagyborosnyó, Kovács Kálmán, dr. Koleszár László Kolozsvár, Kacsóh István Nyárádszereda, Kuthy Károly Szentgericze, Kovács Károly Nyárádszereda, Kovács Kálmán Sepsiszentgyörgy, Kispál László Dicsőszentmárton, Király Lajos Brassó, Köpe.F. István, Kövér György Bukarest, Kovács Zsigmond, Kovács József Ploesti, dr. Kónya György Jassy, Kövér Sándor Pitesti, Lázár László Lapusnyak, Lőrincz Sándor Szászfenes, Lónyai Sándor Bukarest, Mikó László Marostorda, dr. Morvav Zsigmond Nagyvárad, Miske László Sepsiszentgyörgy, Mezey Mihály Türe, dr. Nagy Jenő Csíkszereda, Nagy János Székelyudvarhely, dr. Nagy László Kolozsvár, Nagy Béla Segesvár, Némethy József Ploesti, Nagy Sándor Zilah, dr. Óváry Elemér Kolozsvár, Oláh Dániel Kézdiszentlélek, Orbán Balázs Marosvásárhely, Orbán Ferenc Karcfalva, Osváth Károly Székelykeresztur, Orbán Lajos Bukarest, dr. Pál Gábor Csíkszereda, Petry Zsigmond Marosvásárhely, Paál Ferenc Homoród-Oklánd, Péchy Imre Zsibó, Pröhle Gusztáv Zágon, Pekry Sándor Dicsőszentmárton, Rácz Mihály, Róth Hugó dr. Kolozsvár, Rass Károly Gyulafehérvár, Szabó Béni Brassó, Seprődi János Kolozsvár, Sebessy János dr. Székelyudvarhely, Strasniszky Schultz József, Szőcs Bálint, Szabó István Bukarest, Somay Domokos Braila, dr. Szoboszlay László Nyárádszereda, báró Szentkereszthy Béla Sepsiszentgyörgy, dr. Szele Béla Brassó, Szabolcska Mihály Temesvár, Szakács Péter Székelyudvarhely, dr. Török Bálint Kolozsvár, Török Andor Kézdivásárhely, Tótfalussy József Marosvásárhely, dr. Tóth Lajos Segesvár, Tőkés Ernő Bukarest, Tellmann Béla Brassó, Torró Miklós Braila,- Ugrón Zoltán Fiatfalva, Ugrón István Kolozsvár, Ürmössy József Homoródszentpál, dr. Várady Aurél Kolozsvár, dr. Ver- zár Ferenc Nagyszeben, Viola Sándor Székelykeresztur. (Közli: Ellenzék, 1922. 43. évf. 176. szám, augusztus 8.) 


\section{0. számú melléklet: Ferdinánd király proklamációja, 1922. október}

Isten kegyelméből és a nemzet akaratából örököltem Románia koronáját elődöm dicsőséges uralkodása után. Amikor a trónra léptem, kértem az eget, adja meg a munka gyümölcsét, amelyre elszántam magamat szeretett hazám érdekében, mint jó román, és mint király.

Az isteni gondviselés meghallgatta imánkat és népünk kitartása s höseink vitézsége által terjeszthettük á régi királyság határait és megvalósíthattuk nemzetünk ősi vágyát. Ma idejöttem a királynéval, aki a szomorúságban és örömben rendíthetetlen hittel állott mellettem, hogy ezen ünnepséggel szentesítsük az Úr előtt és drága népünk elött azt a kapcsolatot, amely mindörökké egyesítve lett. Amikor a római Dacia ezen Ösi várában fejemre teszem a plevnai acélkoronát, amelyet új és dicsőséges harcok tettek Nagyrománia régi koronájává, áhítattal fordulok mindazok emlékéhez, akik minden időben és mindenütt, hitükkel, munkájukkal és áldozataikkal biztosították a nemzeti egységet és szeretette! üdvözlöm azokat, akik egyhangúlag és egységes érzéssel proklamálták Nagyromániát a Tiszától a Dnyeszterig és a tengerig.

Ebben a pillanatban gondolatom hálával fordul vitéz és szeretett hadseregem felé. Kérem az eget, hogy a múlt szenvedéseinek jutalmául adja meg, hogy népünk békében szedje le munkájának gyümölcsét és nyugalomban, testvériségben, szorgalmas munkában fejlődjék. Szeretettel és hittel telt szívvel adok kifejezést legfőbb vágyamnak: azt akarom, hogy a parasztság a verejtékével megdolgozott ősi földön ne legyen és így váljék saját és a köz hasznára. Azt akarom, hogy a hazához hü munkásság sorsa javuljon a harmonikus élet és szociális igazság révén. Azt akarom, hogy Nagyrománia határain belül az ország összes jó fiai a vallásra és nemzetiségi tekintet nélkül egyenlő jogokat élvezzenek az összes románokkal, hogy minden erejükkel segítsék az államot, amelyben a magasabb gondviselés rendezése folytán együtt kell élniük velünk. Azt akarom, hogy a románok az összes társadalmi osztályokból a teljes nemzeti testvériség vágyától legyenek áthatva, hogy így az állam igaz üdvére váljanak mindnyájan. Azt akarom, hogy uralkodásom idején a kultúra széleskörü fejlesztésével hazánk teljesítse a civilizáció által rábízott azt a feladatot, amely Kelet-Európa újjászületése körül annyi rettenetes rázkódtatás után reá vár. Biztos vagyok abban, hogy nagy feladatunk megvalósításában a haza összes fiainak támogatását bírni fogom, akik gondolatban és tényleg a trón körül fognak csoportosulni. E szent misszió teljesítésére rendíthetetlen egységben népemmel fogom minden emberi és királyi erőmet fordítani és erre a mai magasztos ünnepnapon a Mindenható áldását kérem. (Közli: Ellenzék, 1922. 43. évf. 234. szám, október 17. )

\section{1. számú melléklet: Az Országos Magyar Párt alkotmányreformmal megvalósító követelései} (1922. december 28.)

1. A magyar anyanyelvű román állampolgárokból alakult nemzeti kisebbség, mint közjogi alany elismerése a gyulafehérvári határozatokban lefektetve lévén és a nemzetközi békeszerződésekben biztosíttatván, ezek alapján követeljük a magyar nemzeti kisebbség közjogi alanyiságának az alkotmányban való elismerését és az elismerés szükségképpeni következményeként: a nemzeti autonómiát. Ugyancsak az alkotmányban biztosítani kívánjuk a romániai összes nemzeti kisebbségek autonómiáját, mely szerint mindenik nemzet önmagát saját nyelvén saját fiai által kormányozza, saját közigazgatással és igazságszolgáltatással. Követelünk általános egyenlő, nőkre is kiterjedő választójogi, titkos szavazással és választókerületenkénti arányos képviselettel. Emellett követeljük a választókerületek törvény utján leendő arányos beosztását a választások tisztaságának a büntetőjogi védelem szigorítása melletti kellő biztosítását a parlament visszautasítási jogának, mint a népakarat kigúnyolásának, eltörlése melletti, a mandátumok érvénye felett független választási bíróság Ítélkezését és megfelelő összeférhetetlenségi törvény alkotását. Követeljük a választói névjegyzékeknek az önkormányzati szervek utján való összeállítását, a kiigazítási eljárás félremagyarázását nem türő szabályozását és a visszaélések ellen bái mikor igénybe vehető bírósági jogvédelmet.

2. Követeljük a törvényhatósági és községi autonómia (önkormányzat) visszaállítását, a közigazgatás decentralizálását, a tisztviselők szolgálati pragmatikáját, a közigazgatási bíráskodás hatáskörének széles kiterjesztését, a közhivatalnokok jogellenes hivatali ténykedéseiért az államkincstár anyagi felelősségének megállapítását $\mathrm{s}$ általában a jogrendnek és jogbiztonságnak a közigazgatás egész menetén való helyreállítását. 
3. A jogszolgáltatás egyenletességének és nyugodt menetének biztosítására kívánjuk a jogállam attribútumainak is elsősorban a bírói függetlenségnek teljes és hatékony biztosítását, továbbá a törvényhozói, bírói- és közigazgatási hatáskörök szigorú elhatárolását és különösen annak kimondását, hogy általános állampolgári kötelezettségek megállapítására nézve a törvényhozást illető jogok a kormány vagy egyes közigazgatási hatóságok által rendeleti utón egy úgynevezett Decret lege utján ki nem sajátíthatók. Kívánjuk emellett az esküdtszéki bíráskodás visszaállítását a jogbiztonság védelmére a titkos rendőrség és kivételes (katonai) bíráskodás megszüntetését.

4. A vallás- és közoktatásügy terén a jogfolytonosság alapján kívánjuk a vallás- és lelkiismereti szabadság teljes biztosítását, a törvényesen bevett és elismert vallásfelekezetek jogainak a meglevő önkormányzati szervekkel együtt alkotmányos elismerését azzal, hogy az állami ünnepeken és a törvényes munkaszüneteken kívül más napokon munkaszünetek ne legyenek elrendelhetők és senki se kényszeríttethessék ünnepein kívül más egyház ünnepeit megtartani. Kívánjuk továbbá a vallásfelekezeteket, illetve az egyházakat az állam felügyeleti jogának biztosítása mellett minden fokon, - tehát az elemi iskoláktól az egyetemig - megillető iskolafenntartó és alapító jog védelmét, a tanítási és tanulási szabadság fokozott biztosítását és pedig kapcsolatban a magyar egyházak, testületek és egyletek által annak idején a magyar államnak szerződésileg biztosított iskolaépületeknek az illető egyházak, társulatok s egyletek részére való visszabocsátásával. Az iskolák oktatási nyelve tekintetében kívánjuk az iskolákat fenntartó egyházak és társulatok elhatározásának megfelelő szabadságát. Kívánjuk az egyes egyházak, illetve vallásfelekezetek között az egyenlőség és viszonosság biztosítását és ehhez képest a régebbi törvények, különösen az 1848 évi XX. t.c.-nek megfelelő állami támogatás törvényes biztosítását.

5. Kívánjuk a tulajdonjognak teljes védelmét és törvényes biztosítását az ezeket korlátozó rendelkezések fokozatos hatályon kívül helyezését, különösen a házjog védelmét és a lakásrekvirálások záros határidőn belül való fokozatos megszüntetését. A földmíves- és földbirtokos osztály jogos érdekének kielégítésére a törvény én az eddigi eljárás revíziója mellett olyan birtokreformot kívánunk, mely a termelés fokozását is biztosítja és a tulajdonjog szentségét csak a legszükségesebb mértékig érinti, kívánjuk tehát az egyházi és iskolai célokra rendelt, általában az alapítványi birtokoknak a földreform aluli mentesítését. A kisajátítást szenvedö részére kívánjuk annak elismerését s törvényben valóbiztosítását, hogy a kisajátítás csak teljes kártérítés mellett történhetik meg, tehát kártérítésül a kisajátítás időpontjában fennálló forgalmi árat, vagy hozadék értéket kell venni és annak legalább felét készpénzben kell nyújtani.

6. A munkaszabadság teljes biztosítása végett kívánjuk a sztrájkjog teljes elismerését, a munkabiztosításnak és munkásvédelemnek az önkormányzat elvén való kiépítését. Kívánjuk az ipar és kereskedelmi tevékenység szabadságát s az ezeket korlátozó rendelkezések hatályon kívül helyezését. Kívánjuk az igazságos progresszív adó bevezetését, az adózás szempontjából egy adómentes létminimum igazságos megállapítását, az egyes foglalkozási ágak üzéséhez nélkülözhetetlenül szükséges eszközök és házi berendezkedések mind magán, mind közvégrehajtás alól való mentesítését, illetőleg a törvényekben biztosított mentesség respektálását, az adókezelés egyszerüsítését és áttekinthetőségét.

7. Kívánjuk a katonai szolgálatnak militiarendszer alapján való rendeleteit, legfeljebb három havi tényleges szolgálattal és a saját hadkiegészítő területén való szolgálatteljesítéssel $\mathrm{s}$ az anyanyelvnek szolgálati nyelvként való biztosításával.

8. A személyes szabadság védelmére kívánjuk az ezt korlátozó egyes kivételes rendszabályok hatályon kívül helyezése mellett annak az elvnek szigorú érvényre juttatását, hogy bírói intézkedés nélkül, senki személyes szabadságától meg nem fosztható és abban meg nem szorítható. Kívánjuk az egyesülési és gyülekezési jog és a sajtószabadság törvényes biztosítását. (Közli: Ellenzék, 1922. 43. évf. 292. december 28. 2.)

\section{2. számú melléklet: Az Országos Magyar Párt Intézőbizottsága, 1922. december 28.}

György Béla az OMP történetét feldolgozó doktori disszertációjában a névsorról a következőket írta. A névsor azért is fontos, mert mindeddig nem volt egyértelmű az Intézőbizottság összetétele. A Szervezeti szabályzat szerint 36 tagot választottak, a Keleti Újság 34 tagot említ. Mikó Imre a korszakról írt alapmúvében 23 nevet említ (Mikó 1941, 41-42.) A tagok száma továbbra is vitára adott okot, ugyanis az alakuló közgyülés jegyzőkönyvéből az Intézőbizottság tagjai kimaradtak. A vita továbbra is fennállhatott, annál is inkább, mert az alakuló ülés jegyzőkönyve is (sok egyéb iratanyaggal) eltünt, mindeddig ismeretlen. 
Az Intézőbizottság tagjai: dr. Apáthy Árpád (Dés), dr. Asztalos Kálmán (Nagyenyed), dr. Albrecht Lajos (Bánffyhunyad), gróf Béldy Kálmán (Zsibó), dr. gróf Bethlen György (Kv.), dr. Bene Ferenc (Dés), dr. Berkes Salamon (Kv.), Bélteki Lajos (Szatmár), dr. Cziffra Kálmán (Nagyvárad), Fekete Nagy Béla (Kv.), dr. Ferenczy Géza (Nagyajta), Ferenczy Gyula (Kv.), dr. Gabányi Imre (Kv.), dr. Gyárfás Elemér (Dicsőszentmárton), dr. Hajdú István (Marosvásárhely), Incédy-Joksmann Ödön (Nagyenyed), dr. Issekutz Viktor (Erzsébetváros), Ignácz László (Fogaras), Lőrinczy Dénes (Torda), dr. Morvay Zsigmond (Nagyvárad), dr. Nagy János (Kv.), dr. Nagy Jenő (Csíkszereda), dr. Pál Gábor (Csíkszereda), Péchy Imre (Zsibó), dr. Róth Hugó (Kv.), dr. Sebessy János (Székelyudvarhely), Szakács Péter (Székelyudvarhely), Szathmáry Ákos (Kv.), dr. Szele Béla (Brassó), Székely László (Temes-Torontál), dr. Szoboszlay László (Nyárádszereda), dr. Török Andor (Kézdivásárhely), dr. Várady Aurel (Kv.), gr. Wass Béla (Mezőzáh), dr. Veterány Viktor (Temesvár), dr. Zágoni István (Kv.) 


\section{KRONOLÓGIA: 1916-1922}

\section{Erdély kronológia: 1916. július-1922. december 28.}

\section{Július 17.}

1916. év

Károlyi Mihály gróf lemond a Függetlenségi Párt elnökségéről, 25 társával kilép a pártból és megalakítja a Függetlenségi és 48-as Pártot, amelyhez csatlakozott Apáthy István kolozsvári professzor is.

\section{Augusztus 16.}

A Brătianu-kormány titkos szerződésben csatlakozik az antant hatalmakhoz. Vállalja, hogy Románia támadást indít az Osztrák-Magyar Monarchia ellen, illetve nem köt különbékét. A nyugati szövetségesek megígérik, hogy a szaloniki fronton és a galíciai hadszíntéren indítandó támadásokkal segítséget nyújtanak Romániának és a hadba lépésért cserébe területi engedményeket ígérnek (Bukovina, Bánság, a történeti Erdély, és az attól nyugatabbra fekvő területek).

\section{Augusztus 17-18.}

A Brassói Lapok az Opinia (Iasi) és az Adevarul román lapokra hivatkozva Románia semlegességéről ír. A román kormány kereskedelmi egyezményt ír alá Németországgal és Berlinből 11 vagon mennyiségü gyógyszerszállítmány érkezik Bukarestbe. (Brassói Lapok)

\section{Augusztus 27.}

A román koronatanács az antanttal megkötött bukaresti titkos egyezmény értelmében hadat üzen korábbi szövetségesének az Osztrák-Magyar Monarchiának.

\section{Augusztus 29.}

Kézdivásárhely román megszállása, Ioanescu Györgyöt kinevezik polgármesterré. A lakosság jelentős része 28-án elmenekül. A Brassói Lapok augusztus 28-szeptember 10 között nem jelenik meg, mert a szerkesztőség elmenekült a városból. (Brassói Lapok)

\section{Augusztus 30.}

A román csapatok bevonulnak Brassóba.

\section{Szeptember 2-5.}

A magyar országgyülés mindkét háza elítéli Románia hadba lépését. A magyarországi román képviselők császárhü nyilatkozattal felérő módon tiltakoznak a két volt szövetséges háborúja ellen. Ștefan Cicio-Pop (RNP) képviselő: „A magyarországi román nemzetiségi párt mély megdöbbenéssel vette a hirt, hogy a velünk szomszédos Románia hazánk ellenségei sorába lépett és monarchiánknak hadat üzent. [...] Magyarország román népének a trón és haza iránti hüsége törhetetlen”. Radu Demeter nagyváradi görögkatolikus püspök, förendiház tagja: „saját, valamint papságom és hiveim nevében igaz hazafias érzelmeinkhez képest a magas trónhoz, a dicsö uralkodóházhoz és a magyar szent koronához való tántorithatatlan hüségünknek és ragaszkodásunknak kifejezést adhassak”. (Képviselöházi napló, 1910. XXXI. kötet. 656. Országos ülés) 


\section{Szeptember}

A román támadás a Parajd-Székelyudvarhely-Nagyszeben-Orsova vonalig húzódik. Székelyföld nagy része és több fontos város, például Brassó és Fogaras is, ideiglenesen román megszállás alá kerül.

A magyar kormány Kolozsvár központtal külön erdélyi kormánybiztosságot szervez. Bethlen István Pro Transsylvania néven segélyakciót indít a menekültek megsegítésére.

\section{Szeptember 17-18.}

A román hadsereg megszállja Székelyudvarhelyt, amelyet október 7-ig tartanak megszállás alatt. (Brassói Lapok)

\section{Szeptember 26-29., illetve október 7-9.}

A Falkenhayn német tábornok vezetése alatt egyesített osztrák-magyar és német birodalmi haderő meghátrálásra kényszeríti a nagyszebeni, majd a brassói ütközetben a román csapatokat. E két győzelem után indult meg a központi hatalmak erdélyi ellentámadása.

\section{Október 2.}

A kormány - elkerülendő az augusztus végi, szeptember eleji tumultusokat - október 2-án kiadja a visszatelepítési rendeletet. Meghatározta a hazatelepítés menetét: először a köztisztviselök, azt követően a mezőgazdasági, illetve az ipari munkások térhetnek haza.

\section{Október 12.}

Schnell Károly Ernő polgármester és Betegh Miklós kormánybiztos táviratban felszólítja Brassó és Brassó vármegye tisztviselőit, hogy térjenek vissza és vegyék fel a munkát. (Brassói Lapok)

\section{Október 15.}

A német-osztrák-magyar csapatok visszafoglalják Kézdivásárhelyt és Sepsiszentgyörgyöt. (Brassói Lapok)

\section{Október 26.}

Tisza István miniszterelnök és Sándor János belügyminiszter az erdélyi visszatelepítés személyes ellenőrzése céljából erdélyi körútra indul. Csíkszeredát és Sepsiszentgyörgyöt követően Brassóba látogatnak. (Brassói Lapok)

\section{November}

November első felében Károly trónörökös ünnepélyes látogatást tesz Erdélyben.

\section{November 5.}

A szépirodalmi Szemle (1913) folyóirat Erdélyi Szemle címre változik. A lap 1918. december1919. március között a román megszállás miatt nem jelenik meg. 1920-ban a Minerva Irodalmi és Nyomdai Műintézet Rt. megveszi az újságot, amellyel együtt a lap szellemi részének vezetése (Reményik Sándor, Grandpierre Emil) és a neve is megváltozott, a Toldi előszavából vett Pásztortüzre. (Irodalomtörténeti Közlemények, 1971.)

\section{November 21.}

I. Ferenc József osztrák császár és magyar király halála. Erdély szerte gyászszertartásokat tartanak. (Brassói Lapok) 


\section{December 6.}

A német-osztrák-magyar sereg August von Mackensen tábornagy vezetésével, a szeptember elején megindított ellentámadásban elfoglalja Bukarestet.

\section{December 9.}

A román kormány képviselői Foksányban fegyverszünetet kötnek a Központi Hatalmakkal.

\section{December 30.}

Károly koronázási ünnepsége Budapesten. Kós Károly építészt, írót a királyi koronázási domb megtervezésével bízzák meg, amelyhez a földet többek között Radnótról (II. Rákóczi Ferenc), Kökösről (Gábor Áron), a maros megyei magyarósi csatatérről (1916), illetve Brassó vármegyéböl szállítják.

\section{Január}

\section{7. év}

A kelet-magyarországi vármegyéket belső és külső hadmüveleti területekre osztják, amelyekre vonatkozóan az utazási szabályokat a belügyminiszter állapítja meg. A belső hadmúveleti terület határvonalát csak speciális engedéllyel lehet átlépni. (Magyarországi Rendeletek Tára 1867-1945.)

\section{Február 20.}

A sepsiszentgyörgyi Székely Mikó Kollégium a román betörés miatt féléves kihagyást követően megkezdi az 1916-1917. évi tanévet.

\section{Március 3.}

Bethlen István parlamenti beszédében Erdély aktuális feladatait (kártalanítás, hazaárulók elítélése) és a régió rekonstrukciójával foglakozó nemzeti elvű programját (infrastruktúra, gazdasági és társadalmi modernizáció) ismerteti. A térség stabilitása előtt álló legnagyobb kihívásnak a nemzetiségi kérdést jelöli meg. (Képviselőházi napló, 1910. XXXV. kötet, 710. Országos ülés)

\section{Március 24.}

IV. Károly osztrák császár és magyar király különbéke-kísérlettel fordul a francia kormányhoz (Sixtus-levél: Elzász-Lotharingia francia igényének elismerése, illetve szükséges Belgium függetlenségének helyreállítását).

\section{Április 25.}

10-10 évi szigorított börtönre ítélik Sánta Illés madéfalvi és Imre Mihály göröcsfalvi román lakosokat. A vád mindkét esetben az állam ellen elkövetett büntett. A román megszállás alatt önként községi bírói tisztséget vállaltak és a helyiek állatállományát elrekvirálták a román hadsereg részére. (Csíki Lapok)

\section{Május 23.}

Tisza István gróf miniszterelnök és kormánya - az uralkodóval kialakult konfliktus miatt (népjóléti intézkedések és választójogi reform tárgyában) - benyújtja lemondását.

\section{Június 6.}

Megalakul a Választójogi Blokk. Tagjai: Függetlenségi és 48-as Párt, Országos Polgári Radikális Párt, Vázsonyi-féle Demokrata Párt, Magyarországi Szociáldemokrata Párt. Célja: az általános és titkos választójog kivívása. 


\section{Június 14.}

Ha szükkörben is, de megjelenik Az erdélyi kérdés programszöveg, amely Bethlen István márciusi parlamenti beszédéhez hasonlóan Erdélyt és társadalmi, politikai viszonyait nemzeti és nemzetközi kérdésként értelmezi. Az Erdélyi Szövetség újjáalakítása irányadó dokumentumként szolgál a vélhetőleg Apáthy István által megfogalmazott program. (OSZK Kézirattár, Quart. Hung. 2456.)

\section{Június 15.}

Esterházy Móric gróf kormányt alakít. Ugron Gábor belügyminiszter (1917. június-1918. január), az Erdélyi Szövetség (1913) tagja, bejelentette, hogy Erdély újjáépítését az Erdélyi Szövetség 1914-es programja alapján kívánja megkezdeni. (OSZK Kézirattár, Quart. Hung. 2456.)

\section{Július 5.}

Megszűnik az Erdélyrészi Visszatelepítő Bizottság. A Bizottság ügykörét az Erdélyben müködő hadsereg-parancsnokság mellé kinevezett kormánybiztos látje el. (Magyarországi Rendeletek Tára 1867-1945.)

\section{Augusztus 23.}

Az Esterházy-kormány lemondása után az uralkodó - harmadszor is (1892-1895, 1906-1910)

- Wekerle Sándort neveze ki miniszterelnökké (1917. augusztus 23.-1918. október 30.). Ugron Gábor továbbra is belügyminiszter.

\section{Szeptember 23.}

A kolozsvári Függetlenségi és 48-as Párt (élén Apáthy István), a Szociáldemokrata Párt (Nagy Balázs) és a Polgári Radikális Párt (Janovics Jenő, színházigazgató) közös Választójogi Liga nagygyülést tart a választójog demokratizálásáért.

Az Erdélyi Szövetség Vezető Tanácsa Kolozsváron ülésezik, hogy a Szövetség újjáalakulási gyülését előkészítse. Az ülésen jelen volt többek között Apáthy István, Ugron Gábor, Bethlen István, Paál Árpád. (OSZK Kézirattár, Quart. Hung. 2456.)

\section{Szeptember 30.}

Az Erdélyi Szövetség újjáalakuló gyülése Kolozsváron. (OSZK Kézirattár, Quart. Hung. 2456.)

\section{November 1.}

Wekerle Sándor kormánya 1917. november 1-től minisztériumi utasítással (4000/1917. M. E. rendelet) megtiltja a keleti-délkeleti államhatár mentén fekvő földbirtokok eladását és vásárlását, valamint tíz évnél hosszabb időtartamú bérbeadását, illetve kikötötte az állam elővásárlási jogát. A birtokforgalmi ügyletek szabályozási joga az akkor létesített Erdélyi Ingatlanforgalmi Bizottság jogkörét illette meg, amely Bethlen István vezetésével müködik. (Földmívelési Értesitö, 1917.)

\section{December 21.}

Vázsonyi Vilmos választójogért felelős miniszter beterjeszti a választójogi törvényjavaslatot az 1913:XIV. tc. alapján. A választásra jogosultak számát 1,8 millióról felemelte volna 3,5 millióra, azzal hogy csökkenti az értelmi cenzust és a választójogot kiterjeszti az ipari és a mezőgazdasági munkásokra. 


\section{7 folyamán}

Erdélyben 19 új részvénytársaság alakul 15 millió korona alaptőkével, az össztőkeemelés közel 33 millió koronát tesz ki. 1911 óta nem volt ekkor pénzbőség. Új iparágak bontakoztak ki, mint a gázfelhasználás, a dicsőszentmártoni vegyikombinát, Biharban az alumínium alapanyagát képező bauxit termelése, amit azonban csak Németországban tudnak feldolgozni. (Erdély története III.)

\section{8. év}

\section{Január 8.}

Woodrow Wilson amerikai elnök a kongresszushoz intézett üzenetében meghirdeti a háború utáni békeszerződésre vonatkozó 14 pontos programját.

\section{Január 28.}

Az Erdélyi Szövetség Vezető Tanácsa támogatja báró Petrichevich-Horváth Emil ajánlásait a földkérdésben. Szigorítanák a földeladást és újak vásárlását irányozták elő részben a magyar kisbirtokosság megerösítésének, részben a magyarság kivándorlásának megfékezése szándékával. Az ülésen arról is döntönek, hogy a kormánynak javasolják egyfelől Erdélyben újrarajzolni a választókerületeket, másfelöl a Romániával határos megyékben ún. határőrvidéket alakítsanak ki. (OSZK Kézirattár, Quart. Hung. 2456.)

\section{Március 3.}

Aláírják a breszt-litovszki békét a központi hatalmak és Szovjet-Oroszország között.

\section{Április}

Az Erdélyi Szövetség megalakul Szilágy vármegyében. Elnök: Bölöni Zoltán. (OSZK Kézirattár, Quart. Hung. 2456.)

\section{Április 8.}

Az Osztrák-Magyar Monarchia nemzetiségei kimondják római kongresszusukon, hogy céljuk az állami önállóság megteremtése.

\section{Május 7.}

Bukaresti különbéke: a központi hatalmak (Osztrák-Magyar Monarchia, Németország, Törökország, Bulgária) és Alexandru Marghiloman román miniszterelnök (1918. március1918. november) egyezménye, amely lezárja a román vereséggel végződő 1916-17-es, Magyarország ellen indított háborút. Románia lemondt Dobrudzsa egy részéről Bulgária javára.

\section{Május 28.}

A Polgári Radikális Párt és a Függetlenségi és 48-as Párt közös nagyváradi nagygyülése. Károlyi Mihály és Jászi Oszkár közös függetlenségi-radikális népgyülésen pecsételte meg elvi alapokon történő összefogásukat. (Világ, 1918.)

\section{Május 29.}

Az USA kormánya helyeslöleg tudomásul veszi az április 8-i római nemzetiségi kongresszus határozatait.

Június 29.

Az Erdélyi Szövetség megalakul Kis-Küküllő vármegyében. Elnök: Gyárfás Elemér. (OSZK Kézirattár, Quart. Hung. 2456.) 


\section{Június}

A vallás- és közoktatásügyi minisztérium (Apponyi Albert) megszüntet a Romániával határos ún. kultúrzóna területén 311 román felekezeti iskola 477 tanítójának mindennemü államsegélyét. Az év folyamán a román tanítóképző intézetek ellenőrzése céljából miniszteri biztosokat neveznek ki. (Erdély története III.)

\section{Július-december}

A Huszadik Század a magyarországi zsidósággal kapcsolatos körkérdésben fordul a magyar tudomány és közélet szereplői felé. A válaszadók között volt többek között Ravasz László református lelkész, Cholnoky Jenő kolozsvári egyetemi tanár, akik az Erdélyi Szövetség tagjai voltak. (Huszadik Század)

\section{Szeptember 11.}

Az erdélyi királyi kormánybiztosság müködését felfüggesztik.

\section{Október}

Az Erdélyi Szövetség októberig a következő megyékben alakította meg alapszervezetét: Szolnok-Doboka vármegye elnök: László László, kerületi elnökök: Abrudbányai Ede (Szamosújvár), Jogomán Antal (Dés), Huszár Ádám (Magyarlápos), Jimó Lajos (Nagyilonda), Torma Miklós (Bethlen). Beszterce-Naszód vármegye elnök: Ugron András. Torda-Aranyos vármegye elnök: Szenkovics Aurél. Alsó-Fehér vármegyei elnök: Fogarassy Albert. Kolozs vármegyei elnök: Ferenczy Lajos. (OSZK Kézirattár, Quart. Hung. 2456.)

\section{Október 12.}

A francia kormány elismeri a románok emigráns szervezetét, a Take Ionescu vezette Román Egység Nemzeti Tanácsot (október 6.). Ehhez kapcsolódva Anglia külügyminisztere, Balfour november 11-én egy szívélyes levélben üdvözölte Take Ionescut és a román nemzeti törekvéseket. Olaszország mindezt november 22-én tette meg és végül Lessing amerikai külügyminiszter is kifejtette, hogy az „Egyesült Államok kormánya nem közönyös a román nép aspirációival szemben”. (OSZK Kézirattár, Fond 625.)

\section{Október 16.}

Károly osztrák császár bejelenti Ausztria föderatív átalakulását.

\section{Október 17.}

Tisza István gróf a képviselőházban elismeri a háború elvesztését.

\section{Október 18.}

Alexandru Vaida-Voevod a magyarországi és erdélyi román nemzet nevében a nemzeti önrendelkezéshez való jog elismerését követelte. (Kolozsvári Hírlap)

\section{Október 23-24.}

A Magyar Nemzeti Tanács megalakulása Budapesten. Elnök Károlyi Mihály, programíró Jászi Oszkár. 


\section{Október 28.}

A kolozsvári Károlyi-, Polgári Radikális- és Szociáldemokrata Párt állásfoglal az Ausztriától való elszakadásról és Magyarország függetlenségéről. Megalakítják budapesti mintára az Erdélyi Magyar Nemzeti Tanácsot Kolozsvár székhellyel, amelyhez a nemzetiségek csatlakozását kérik. A Károlyi-pártot Apáthy István, a Polgári Radikális Pártot dr. Janovics Jenő, a szociáldemokratákat Vince Sándor és Szentmiklósi József képviselte. (Kolozsvári Hírlap)

\section{Október 29.}

A Szászok Központi Tanácsának kibővített nagyválasztmánya Nagyszebenben Magyarország mellett foglal állást, amelyet 1919. január 8-án, a medgyesi gyülésen megváltoztat és elismeri Nagy-Romániát. A Tanács elnöke: Adolf Schullerus nagyszebeni evangélikus lelkész. (Kolozsvári Hírlap)

\section{Október 30.}

Kolozsvár törvényhatósági bizottsága csatlakozik az Erdélyi Nemzeti Tanácshoz. Kolozsvár föterén nagygyülést tartanak. A Tanács elnöke Apáthy István, alelnökök Vince Sándor és Janovics Jenő, titkárok: Seprődi János (függetlenségi párt), Stotter Aladár (polgári radikálisok), dr. Kertész Jenő (szociáldemokrata párt). (Kolozsvári Hírlap)

Temesváron megalakul a Bánáti Nemzeti Néptanács, amely a Bánát jövőjét önálló államként képzeli el. Élére ún. polgári népbiztosnak dr. Róth Ottót, katonai népbiztosnak Bartha Albert vezérkari alezredest választják. (Geml József: Emlékiratok. 1924.)

\section{Október 31.}

A Budapesten és a nagyvárosokban kitört tüntetések és sztrájkok hatására József föherceg kinevezi Károlyi Mihály vezette koalíciós kormányt. Budapesten megalakul a magyarországi és erdélyi Román Nemzeti Tanács, amely központját november 2-tól Aradra helyezi át.

Kolozsvárt kitör a forradalom. A foglyokat kiengedik a börtönökből. A katonák szét szélednek a kaszárnyákból. (EMÉ) ${ }^{1163}$

\section{November 1.}

A Román Nemzeti Tanács (Teodor Mihali), a Magyar Nemzeti Tanács (Hock János) és a szász országgyülési képviselő, Wilhelm Melzer közös proklamációban együttes fellépésre szólítják fel Erdély nemzetiségeit a belső rend, a személy- és vagyonbiztonság közös védelmének biztosítására. (Kolozsvári Hirlap)

A Nemzeti Tanács megalakul Lugoson. Elnök: Fényes József. (Jakabffy Elemér: A magyar államhatalom utolsó hónapjai Krassó-Szörény vármegyében. é. n.)

\section{November 2.}

Aradon megalakul a Román Nemzeti Tanács. A népek önrendelkezése értelmében a románok saját nemzeti tanácsokat alakítanak. Elhatározzák, hogy román katona csak a román tanácsra esküszik. (Kolozsvári Hírlap)

\section{November 3.}

Az Osztrák-Magyar Monarchia és az antant hatalmak fegyverszünete a Padova mellett fekvő Guisti Villában. A delegáció egyetlen magyar tagja vitéz Nyékhegyi Ferenc ezredes. Megalakul a Szász Nemzeti Tanács, elnöke Paál Árpád. (Kolozsvári Hirrlap)

${ }^{1163}$ Erdélyi Magyar Évkönyv, 1918-1929. Szerk.: Sulyok István, Fritz László. „Juventus” kiadás, Kolozsvár, 1930 


\section{November 5.}

A magyar és a román nemzeti tanács öt pontos megegyezése a fegyveres erő kérdésében. 1) A román ajkú katonák román ajkú tisztek alá helyezendők el és fordítva. 2) A román, a magyar és a német nemzeti tanácsok egyöntetüen elismerik Siegler Konrád tábornokot az erdélyi haderők főparancsnokául, akit a hadügyminiszter nevezett ki. 3) A föparancsnok mellé mindhárom nemzeti tanácsból 2-2 katonai népbiztost állítanak. 4) Az állandó kapcsolattartás érdekében a föparancsnok mellé egy román, egy magyar és egy német szárnysegédet osztanak be. 5) Az összes napiparancs a három nyelven közlik, amelyet a népbiztosok aláírásukkal ellenjegyeznek. (Kolozsvári Hírlap)

\section{November 8.}

A Kolozsvári Újság több erdélyi településen történt fosztogatásról és halálesetröl számol be. Drágon gróf Bethlen Ödön birtokát, Aranyosgerenden Hirsch Lajos és Zichy Vladimir kastélyát kirabolják, Csongván Búza Benedek földbirtokost elüzik birtokáról, Marosújváron feldúlják a Teleky kastélyt. Jósikafalván az Urmánczy kastélynál több mint 30 halálos áldozatot követelnek a vérengzések. Váralmáson Vásárhelyi Dezső földbirtokost megkárosítják. Mezőzáh, Mezőszopor, Magyarfráta és több mezőségi településről elmenekülnek a tulajdonnal rendelkezők. Feldúlják a marosveresmarti uradalmat, Kolozsborsán és Válaszutón gyújtogatnak. Kifosztotják gróf Haller Jenő küküllői, Széll József buni birtokát, Mezőszengyelen pedig halálra verik Betegh Sándor földbirtokost. Magyarnagyzsomboron Brunner Jakab szeszgyárát kirabolják. A fosztogatások során élelmiszert, ruhát, alkoholt és fegyvereket rabolnak. (Kolozsvári Hírlap)

\section{November 9.}

A Román Nemzeti Tanács memorandumot juttat el a magyar kormányhoz, és huszonhat vármegye területén követeli „a teljes kormányzóhatalmat”. (Kolozsvári Hírlap)

A belügyminiszter elrendelte az állami, a városi és a pénzintézeti értékek Budapestre szállítását, Temesvárról kb. 30 millió Korona értéket szállítottak a fővárosba. (Geml József: Emlékiratok. 1924.)

\section{November 10.}

Az Erdélyi Magyar Nemzeti Tanács Grandpierre Emil törvényszéki bírót megbízza, hogy a falvakban történő fosztogatások lecsillapításának programját kidolgozza. (Kolozsvári Hírlap) Románia az antant oldalán 1916-ot követően ismét háborúba lép a központi hatalmakkal szemben. Ferdinánd román királyi dekrétuma: „[...] Királyotok újra harcba hív benneteket, hogy évszázados álmunkat, minden román egyesülését, amiért 1916-17-ben oly vitézül harcoltatok - megvalósítsuk. Bukovinai és erdélyi testvéreink hívnak benneteket e végső harcra, hogy lelkesültségetekkel megvigyétek nekik az idegen járom alóli felszabadulást." (OSZK Kézirattár, Fond 625.)

\section{November 12-14.}

A Magyar Nemzeti Tanács küldöttsége Aradon tárgyalásokat folytatott az erdélyi Román Nemzeti Tanács vezetőivel. A Jászi Oszkár vezette küldöttség (Bokányi Dezső, P. Ábrahám Dezső) nemzeti autonómiát kínál, de a Iuliu Maniu vezette román tárgyaló csoport (Vasilie Goldiş) a teljes önállósághoz ragaszkodva elutasítotja azt. 


\section{November 13.}

A Károlyi-kormány és az antant aláírta a belgrádi konvenciót. A 18 pontos katonai egyezmény kijelölte Magyarország számára a demarkációs vonalat (Dráva-Pécs-Baja-Maros-Beszterce szakasz). Linder Béla, a Károlyi-kormány tárca nélküli minisztere és Franchet d'Esperey balkáni antant-föparancsnok két megbízottja, Henrys tábornok és Misic vajda jegyezték az egyezményt.

IV. Károly király eckartsaui nyilatkozatában kijelenti: „Ennélfogva minden részvételről az államügyek vitelében lemondok és már eleve elismerem azt a döntést, mellyel Magyarország jövendö államformáját megállapitja."

\section{November 13-14.}

A román reguláris csapatok a békási, az ojtozi, a gyimesi és a tölgyesi szorosnál magyar területre vonulnak. (Kolozsvári Hírlap)

Lugos szerb megszállása. A városba bevonuló szerb csapatokat Baltescu János polgármester fogadja. (Jakabffy Elemér: A magyar államhatalom utolsó hónapjai Krassó-Szörény vármegyében. é. n.)

\section{November 15.}

A szerb csapatok megszállják Buziást és Fehértemplomot. Habsburg Károly lemondó levele a magyar nemzethez. (Kolozsvári Hírlap)

Majláth Gusztáv Károly (katolikus), Nagy Károly (református), Ferencz József (unitárius), Theodor Teutsch (evangélikus) püspökök egyetértésével megalakul a Felekezetközi Központi Tanács Kolozsváron, amely a negyvenes évek közepéig összehangolja intézményrendszerük közéleti és társadalmi (iskolai, szociális) tevékenységét.

\section{November 16.}

Gyimesbükk, Csíkszentmárton, Bélbokor, Csíkszereda román megszállásának kezdete. (Kolozsvári Hírlap)

Kikiáltják a Magyar Népköztársaságot.

\section{November 19.}

A hadügyminiszter elrendeli a legfiatalabb öt korosztály behívását. A kihirdetett rendelet értelmében az 1896 és 1900 között született férfiak kötelesek bevonulni. (Kolozsvári Hirlap)

\section{November 20.}

A Román Nemzeti Tanács deklarálja Kelet-Magyarország Nagy-Romániához való csatolását (Erdély, Bánát, továbbá Arad, Bihar, Szatmár és Szilágy vármegye, valamint Békés, Csanád és Ugocsa megye részben).

\section{November 21.}

Megalakul az Erdélyi Zsidó Nemzeti Tanács. Vezetői között találjuk dr. Eisler Mátyás és Glasner Mózes rabbikat. Elfogadják, hogy az egyetemes zsidóság a palesztinai zsidó állam létrehozásáért küzd. A szövetség az erdélyi zsidóság részére határozatba foglalja, hogy az erdélyi román, a magyar és a szász nemzetek ismerjék el a zsidó nemzet létét és ebből kifolyólag önrendelkezési jogát.

A Károlyi-kormány Somló Bódogot Erdélyért felelős nemzetiségi államtitkárnak nevezi ki Kolozsvár székhellyel. (Kolozsvári Hirlap) 


\section{November 22.}

Az Erdélyi Székely Nemzeti Tanács megalakul Kolozsvárt Sándor József elnöklete alatt. (EMÉ)

\section{November 23.}

Paál Árpád, a Székely Nemzeti Tanács elnöke (november 3.) a Károlyi-kormány megbízásából Udvarhely vármegye alispánja.

\section{November 25.}

Újvidéken a dél-magyarországi megyék szerb képviselői kimondják Bácska, Bánát és Baranya Magyarországtól történő elszakadását és a Szerb Királysághoz történő csatlakozását.

\section{November 26.}

Kézdivásárhelyi székely nagygyülés, ahol a székelyek Magyarország területi integritása mellett foglalnak állást. (Kolozsvári Hírlap)

A Kolozsvári Katonai Kerület parancsnokágát, Siegler Konrád altábornagy nyugdíjazását követően Kratochvil Károly ezredes veszi át.

\section{November 27.}

Csíkszereda, Maroshévíz, Fogaras vármegye román megszállása. A román csapatok elérik Marosvásárhelyt. (Kolozsvári Hirlap)

\section{November 28.}

A román Nemzeti Tanács megbízásából Hidu ezredes bejelenti a rendfenntartás érdekében, hogy hat kerületre osztja Kolozs vármegyét és a stratégiai pontokat e célból megszállja. (Kolozsvári Hírlap)

\section{November 29.}

A Székely Nemzeti Tanács és az Magyar Nemzeti Tanács Marosvásárhelyen mintegy 5000 fös demonstrációt tart. Magyarország területi integritását és a nemzetiségek önrendelkezéséhez való jog biztosítását követelik a wilsoni elvekre hivatkozva. A felszólalók között van többek között dr. Szádeczky Lajos kolozsvári egyetemi tanár, dr. Bíró Balázs kolozsvári ügyvéd és egyetemi tanár, Ravasz László püspök helyettes, illetve a Szociáldemokrata Párt nevében Szőts János. (Kolozsvári Hírlap)

\section{November 30.}

Két székely újoncokból álló csapattest a rend fenntartására Kolozsvárra érkezik. (EMÉ)

\section{December 1.}

Szászrégen román megszállása, amelyben részt vesznek az erdélyi román tisztek is. Elfoglalják a postát, a városházát, az állomást és letiltotják a telefonvonalakat. A román hadsereg lefegyverzi a magyar csendőrséget. (Kolozsvári Hírlap)

A gyulafehérvári román nemzetgyülés. Az erdélyi románok kifejezik akaratukat, hogy Romániához kívánnak tartozni. Másnap megalakul a Román Kormányzótanács. A nemzetgyülésen közlik, hogy két héten belül megszállja a román hadsereg a követelt 26 keletmagyarországi vármegyét. (Kolozsvári Hírlap)

Kolozsvárt megalakul a Székely Hadosztály. (EMÉ) 


\section{December 2.}

A Román Nagy Nemzeti Tanács Gyulafehérvárt megtartja első ülését, amelyen a hatalom átvételére Kormányzó Tanács (Consiliul Dirigent) néven Maniu Gyula elnöklete alatt 15 tagú bizottságot alakít. (EMÉ)

\section{December 3.}

Marosvásárhely román megszállása. Kolozsvár és Marosvásárhely között megszünik az összeköttetés. Désről jelentik, hogy román reguláris csapatok vonulnak Beszterce felé, és napokon belül megszállás alá kerül a város. (Kolozsvári Hírlap, Székely Napló)

A Román Nagy Nemzeti Tanács első ülése Gyulafehérvárt, ahol a hatalom átvételére Kormányzó Tanács (Consiliul Dirigent) néven Maniu Gyula elnöklete alatt 15 tagú bizottságot alakítanak. (EMÉ)

\section{December 4.}

A román nemzetőrök elfoglalják a besztercei állomást, a vasúti irodákat lefoglalják, a személyzetet elzavarják. Beszterce, illetve Bethlen-Óradna közötti forgalmat beszüntetik.

A román hadsereg Marosvásárhelynél átlépi a demarkációs vonalat. Bartha Albert hadügyminiszter tiltakozását fejezi ki a Budapesten székelő Vix francia vezérkari ezredesnél, hogy a románok a fegyverszüneti egyezmény értelmében nem léphetik át a demarkációs vonalat. (Kolozsvári Hírlap)

\section{December 5.}

Beszterce román megszállása, a megszállók létszáma 500 fő. (Kolozsvári Hírlap)

\section{December 6.}

Székelyudvarhely román megszállása befejeződik. Összeütközésekre kerül sor a románok és magyarok között Szolnok-Doboka vármegyében. A magyar kincstári bányáknál, Erzsébetbányánál és Oláhláposbányánál a helyi lakosok ellen, mintegy 300 fegyveres román támad a környékbeli Alsó- és Felsőszőcs és Libas községekből. A bányaőrség és a Nagybányáról küldött 39. ezred kis osztagával várják a román támadást. Magyarláposon is összetüzések történnek, ahol 10 fö meghalt, 15-en megsebesültek. (Kolozsvári Hírlap)

\section{December elsö hete}

Kolozsváron antiszemita politikai röplapok jelennek meg. A röpcédulákon a következő szerepelt: „Katonák! Székely fiúk! Négy és fél évig harcoltunk [...]. Most letörve állunk itt, hazátlanul és szegényen. Földönfutók vagyunk a zsidók kapzsisága miatt. Ök vertek le minket, ök fosztottak meg édes otthonunktól, nem a külsö ellenség. [...] Vegyétek el pénzüket, raboljátok ki házaikat ezen gaz és elbizakodott zsidóknak." Hasonló tartalmú röpcédulák jelennek meg „Fekete kéz” aláírással Besztercén, Naszódon, Borgóprundon és több más erdélyi településen. (Kolozsvári Hírlap) 


\section{December 8.}

Megalakul a Károlyi-kormány jóváhagyásával az Erdélyi Magyar Nemzeti Tanács helyébe lépő Kelet-Magyarországi Főkormánybiztosság. Vezetője Apáthy István főkormánybiztos. (Kolozsvári Hírlap)

Brassó román megszállásának kezdete. Délután félötkor két román zászlóalj és egy ezredes vezetésével bevonulnak a román katonák Brassóba. (Kolozsvári Hírlap)

A Székely Nemzeti Tanács kérvényben fordul Bartha Alberthez egy székely huszárezred felállítása ügyében, amit a hadügyminiszter engedélyez. A brassói 2. közös huszárezredből megalakul az 1. székely huszárezred, amelyhez besorolják a 9-es honvéd huszárezred legénységének nagy részét is. Az ezred parancsnoksága Zsibón állomásozik. (Kolozsvári Hirlap)

Sváb népgyülés Temesvárt, melyen megalakítják a sváb-német népközösséget. (EMÉ)

\section{December 9.}

A román Kormányzótanács megkezdi müködését Nagyszebenben. (EMÉ)

\section{December 10.}

A románok Kis-Küküllő megyében átveszik az impériumot. Új főispánt, alispánt neveznek ki és az egyes hivatalokba ún. komisszárokat helyeznek. Lefegyverezték a magyar nemzetőröket. Küküllőszögön a román gárda vonatokat rekvirál, illetve megakadályozzák a magyar katonák sorozását. (Kolozsvári Hírlap)

\section{December 11.}

I. Ferdinánd király proklamálja Erdély egyesülését a román királysággal (3632. sz. törvényrendelet), és a Romániával egyesített magyar területek kormányzását és egyes közügyeit a Román Kormányzótanácsra bízza (kivétel: külügy, hadsereg, közlekedés, vámügy, bankjegykibocsájtás, állami kölcsönök, szigurancia). (EMÉ)

\section{December 16.}

Apáthy István főkormánybiztos rendeletben felfüggeszti a törvényhatóságokat és a városi képviselőtestületeket. Indoklása szerint a régi választás alapján létrejött ezen testületek nem reprezentatívak a továbbiakban, mivel az új választójogi törvény az általános, titkos és nőkre is kiterjedő választójogot írja elő. Rendelkezése végrehajtását a kormánybiztosokra bízza. A kormány egy későbbi rendeletben kívánta részletezni a helyi testületek hatáskörét. (Kolozsvári Hirlap)

\section{December 17.}

Megalakul az Erdélyi Magyar-Székely Nemzeti Tanács végrehajtó bizottsága. Az ülésen Budapestről jelen van Fényes László és Rónai Zoltán. A román csapatok előnyomulása következtében Tövisen túl megszakad a vasúti forgalom. (EMÉ)

\section{December 18.}

Aradról jelentik, hogy Kolozsvárt és Nagyváradot megszállják a román katonák. A román haderők vezére, Berceceanu altábornagy táviratban közli az összes román katonai parancsnoknak, hogy megkezdik a demarkációs vonalak átlépését. Az első megszállandó település Székelykocsárd, amely vasúti csomópont. (Kolozsvári Hírlap)

Neculcea tábornok megüzeni Apáthynak: az antant fölhatalmazása folytán megszállja Kolozsvárt. Ha ellenállás lesz, löveti a várost. Apáthy válasza: Kolozsvár nem áll ellen. (EMÉ) 


\section{December 19.}

Megjelenik az Új Kelet zsidó lap Kolozsváron. Szerkeszti: Székely Béla és Marton Ernő. (Kolozsvári Hírlap)

Kolozs vármegye utolsó, egyben tisztújító közgyülése, ahol alispánná dr. Hankó Elemért választják. (EMÉ)

\section{December 22.}

A magyar és a székely nemzeti tanácsok a gyulafehérvárival szemben önrendelkező nemzetgyülést tartanak Kolozsváron. A tömeget 40.000 före becsülték.

Dés, Torda román megszállása. (Kolozsvári Hírlap)

\section{December 23.}

Gherescu tábornok és Haller Gusztáv kolozsvári polgármester megbeszéléseket folytat Apahidán Kolozsvár katonai megszállásáról. A tábornok kijelenti, hogy parancsa van a bevonulásra és minden ellenállást rögtönítélő bíráskodás után halállal büntet. 4000 román katona érkezését jelenti be, a közigazgatás zavartalan folytatását ígéri. (Kolozsvári Hírlap)

\section{December 24.}

Délelőtt 10-11 órakor Gherescu tábornok, a román katonai parancsnok bevonul csapati élén Kolozsvárra. (Kolozsvári Hírlap)

Megjelenik a Keleti Újság, amely a két világháború közötti időszak egyik leghosszabb életű romániai magyar napilapja. A Ferenczy Gyula elnökletével létrehozott Lapkiadó Részvénytársaság tulajdonában van a lap.

\section{December 25.}

Neculcea és Gherescu tábornokok, a kolozsvári román Nemzeti Tanács tagjai, a román nemzetőrség tisztjei, illetve Apáthy István és Haller Gusztáv polgármester Kolozsvár megszállásáról tárgyalnak. Apáthy a magyar kormány nevében kifejti, hogy a fegyverszüneti egyezmény II. és III. pontja értelmében történik a román megszállás, így a csendőrséggel és rendörséggel közösen fegyverben marad a nemzetőrség, illetve a 8. hadosztályból a magyar hadsereg. A román katonai parancsnokság bevezeti a cenzúrát, a rendőrséget ellenőrzése alá vonja és lefoglalja a katonai raktárakat. (Kolozsvári Hírlap)

\section{December 26.}

Neculcea tábornok Kolozsvárt 19 pontból álló rendeletet tesz közzé. A megszállást követően ostromállapot lép életbe. A rendzavarást internálással büntetik. A közigazgatás és egyéb hivatalok mellé a román katonai hatóságok részéről összekötő tisztet küldenek ellenőrzés céljából. A gyülekezési szabadságot felfüggesztik. Korlátozzák az alkoholárusítást. Az osztrákmagyar hadsereg visszamaradt eszközeit (fegyverek, állatállomány, katonai felszerelések stb.) rekvirálják. A megszállt területekről Budapest irányába csak a katonai hatóság engedélyével utazhatnak. Mindenki, aki nem volt kolozsvári lakos három napon belül el kell hagynia a várost. Mosoiu tábornokkal az élen a román csapatok bevonulnak Nagyszebenbe. (Kolozsvári Hírlap)

\section{December 29.}

A Román Kormányzótanács vallás és közoktatásügyi reszort vezetője, Vasilie Goldiş körrendeletében tudatja a magyar egyházak konzisztóriumaival, hogy „az immár Romániával egyesült területek hatóságainak miden nemü egyházi, iskolai és kulturális ügyében való kapcsolata megszünik a budapesti magyar köztársasági kormánnyal és a magyarországi hatóságokkal." (Barabás Endre: A romániai magyar nyelvü oktatás első tíz éve 1918-1928. 1929) 


\section{December 30.}

A december 1-jei döntés értelmében Romániához csatolt területeket a királyi kormányban tárca nélküli miniszterek képviselik a jövőben. (Kolozsvári Hírlap)

\section{December 31.}

Román-magyar (Berthelot-Apáthy) megállapodás Kolozsvárott a hadseregeket elválasztó semleges övezetről $(15 \mathrm{~km})$.

\section{December-január}

Paál Árpád kidolgozza a Székely Köztárság programját, amely részben a századelő Székely Kongresszusainak törekvéseire támaszkodva egy semleges államalakulat tervét vázolja fel. A fegyverszüneti szerződés és a megszállás elismerése mellett kívánják kikiáltani a független székely államot.

\section{Január 8.}

1919. év

Rudolf Brandsch tárgyalásokat folytat Iuliu Maniuval, a Román Kormányzótanács vezetőjével, és ennek eredményeként a Szász Nemzeti Tanács és a központi választmány medgyesi gyülésén az erdélyi szászság állást foglal Erdély és Románia egyesülése mellett, cserébe a szász önkormányzatiság garantálását kérve. (Erdély története, III.)

Az erdélyi vármegyék élére a nagyszebeni Román Kormányzótanács prefektusokat nevez ki. Első körben tíz vármegye élére került román prefektus. A következő prefektusokat nevezték ki: Fogaras megye: dr. Vasu Oktavian, Hunyad megye: dr. Vasinei Toma, Alsófehér megye: dr. Topu János, Tordaaranyos megye: dr. Chirtop Zosin, Beszterce-Naszód megye: dr. Trifon Gavrilla, Szolnok-Doboka megye: dr. Miháli Tivadar, Szeben megye: dr. Comsa Nikolaus, KisKüküllő megye: dr. Roman Diomsie, Maros-Torda megye: dr. Ioan Vescan. (Kolozsvári Hírlap; Csíki Lapok, január 19.)

\section{Január 9.}

Nagybánya román megszállása. (Kolozsvári Hírlap)

Paál Árpád udvarhelymegyei alispánt és további 35 Udvarhely megyei tisztviselőt letartóztatnak, mert feleskette a helyi tisztviselöket a Székely Köztársaságra, illetve kijelentették, hogy a magyar államon kívül idegen hatalomnak nem szolgálnak. (EMÉ; Csíki Lapok)

\section{Január 10.}

Lupu őrnagy beidézi Kolozsvár magyar vezető embereit és felelőssé teszi őket a még meg nem szállott területek magyar lakosságának románellenes magatartásáért. (EMÉ)

\section{Január 11.}

Arad, Békés, Nagyvárad, Szatmárnémeti az új demarkációs vonal. Torda-Aranyos, Alsófehér és Kis-Kisküküllő vármegyékben a románok átvették a közigazgatást. A magyar tisztviselök nem tesznek esküt, arra hivatkozva, hogy Erdély kérdésében a párizsi békeszerződés még nem döntött. (Kolozsvári Hírlap)

A gyülekezési szabadságot rendeletben felfüggesztik. (EMÉ) 


\section{Január 12.}

Lupu őrnagy, a 7. román hadosztály parancsnokságán fogadja Apáthy Istvánt, akit kommunista izgatással vádolnak. (Keleti Újság)

A Károlyi-kormány Ugron Andrást Beszterce-Naszód, Szenner Józsefet Maros-Torda és dr. Gyárfás Elemért Kis-Küküllő vármegyék főispáni teendőkkel megbízott kormánybiztosaivá nevezte ki. (Csíki Lapok)

\section{Január 15.}

A Grandpierre Emil vezette bizottság (báró Jósika János nagybirtokos, dr. Kertész Jenő ügyvéd, dr. Menyhárt Gáspár egyetemi tanár, dr. Papp József az ügyvédi kamara elnöke, Ujhelyi József) tárgyalást folytat Maniuval Nagyszebenben. A magyar álláspont: a közigazgatás Erdély magyar lakta területein legyen magyar, a románokon román, a vegyeseken vegyes. A tisztviselöktől ne követeljenek esküt, hanem elégedjenek meg fogadalommal. Másnap értesítést kaptnak arról, hogy a Román Kormányzótanács a javaslatot nem fogadja el. (Keleti Újság)

\section{Január 16.}

Apáthy István fơkormánybiztost letartóztatják és Nagyszebenbe internálják. A vád ellene: bolsevizmus hirdetése, a Cigányiban történt 9 román katona halála (január 13), illetve utasítására rongálták meg Csucsánál a síneket. (Kolozsvári Hírlap)

\section{Január 18.}

Nagybánya román megszállása. A tisztviselőktől hűségesküt nem követelnek. (Keleti Újság) Megnyitják az első világháborút lezáró párizsi békekonferenciát, ahová a vesztes államok nem kapnak meghívást.

\section{Január 19.}

Kolozsvár tisztviselői megtagadják Porutiu Bálint prefektus esküre való felszólítását. Haller Gusztáv polgármester nem ismeri el a nagyszebeni Kormányzótanács jogosultságát, mert Erdély hovatartozásáról a békeszerződés jogosult dönteni. (Kolozsvári Hírlap, Keleti Újság) Román prefektust neveznek ki Marosvásárhely elére. Vescán János tekei ügyvéd, Maros-Torda vármegye prefektusa átveszi a főispáni hivatalt, és eskütételre szólítja fel a tisztviselőket. Az esküt a magyar hivatalnoki réteg megtagadja. (Csíki Lapok)

\section{Január 20.}

A máramarosi Kőrösmezőn megalakul a Hucul Köztársaság, a helyi születésű Sztepan Klocsurak volt osztrák-magyar katonatiszt vezetésével.

\section{Január 22.}

A román királyi hadsereg eléri a Máramarossziget-Csúcsa-Zám vonalat. (EMÉ)

\section{Január 24.}

A Román Kormányzótanács I. sz. dekrétuma értelmében a hivatalos nyelv Erdélyben a román (Gazeta Oficiala). A községi, a felekezeti, az alapítványi és a magán iskolákban a tannyelvet az iskolafenntartó állapítja meg. (Barabás Endre: A romániai magyar nyelvü oktatás elsö tíz éve 1918-1928. 1929.; Kolozsvári Hírlap; Keleti Újság)

A Román Kormányzótanács II. sz. rendeletével feloszlatja a vármegyei, községi és más Nemzeti Tanácsokat. (MOL K67-73-3, Székely Napló) 


\section{Január 27.}

Lugoson a szerb megszállást a francia váltja fel Lemoigne ezredes parancsnoksága alatt. (EMÉ; Jakabffy Elemér: A magyar államhatalom utolsó hónapjai Krassó-Szörény vármegyében) A nagyszebeni Román Kormányzótanács kinevezi Ioan Vescant Maros-Torda vármegye és Marosvásárhely vármegyei jogú város prefektusává. (Székely Napló)

\section{Január 28.}

A ruténok deklarálják különválásukat. 420 rutén küldött kimondja a 420.000 ruszin képviseletében, hogy Ukrajnához kívánnak tartozni. A döntés a következő megyékre vonatkozik: Ugocsa, Máramaros, Ung, Szepes vármegyék. (Keleti Újság)

A román hatóságok felszámolják a Kelet-magyarországi Főkormánybiztosságot.

\section{Január 29.}

Arad francia megszállása. (EMÉ)

\section{Január}

A tisztviselőmozgalom megszervezése - más néven Szellemi Front vagy erdélyi központ Kolozsváron Apáthy István kelet-magyarországi fökormánybiztos letartóztatását követően (január 18.). Vezető: Grandpierre Emil kolozsvári törvényszéki bíró. Vasutas sztrájk Erdélyben. (Kolozsvári Hírlap, Keleti Újság)

\section{Február 4.}

Bratianu és Mişu az egész Bánátot Romániának követeli a párizsi békekonferencián az 1915ös titkos szerződésre hivatkozva. Vesnic szerb képviselő Bánátnak azt a részét követeli Szerbiának, ahol a szerbek többségben vannak. (Kolozsvári Hírlap)

\section{Február 8.}

A Párizs környéki béketárgyalásokon megkezdi müködését a román és jugoszláv ügyek bizottsága. Fő feladata a két állam Magyarországgal közös határainak a megállapítása. Bratianu miniszterelnök jegyzéke Clemenceauhoz a fegyverszüneti feltételek módosítása ügyében: engedélyezzék a román hadsereg számára, hogy elfoglalhassa Dobrudzsát, valamint a Magyarországtól követelt területeket. (OSZK Kézirattár fond 625)

\section{Február 9.}

Bukarest bejelenti, hogy a megszálló román csapatok Erdélyben az alábbi vonal mentén állnak: Máramarossziget, Nagybánya, Erdőtelek, Zilah, Csucsa, Nagysebes, Beszterce, Abrudbánya, Lupény. (Keleti Újság)

\section{Február 11.}

A kultuszminiszter rendelete alapján Nagy-Romániában az elemi iskolákban román történelmet, földrajzot és alkotmánytant kell tanítani. (Keleti Újság)

\section{Február 14.}

Megjelenik Nagyszebenben az Erdélyi Kormányzótanács hivatalos lapja, a Pátria. Igazgatója Agărbiceanu. (OSZK Kézirattár, fond 625.) 


\section{Február 16.}

Vasilie Goldiş vallás- és közoktatásügyi reszortfelelős 931. számú körrendelete (Gazeta Oficiala 1919. II. 6/19. No. 11.) a „volt magyar állami iskolák tanszemélyzetéhez hüségeskü letételére." Az eskütétel határidejét 1919. február 15-28. közötti időszakra tűzte ki. (Barabás Endre: A romániai magyar nyelvü oktatás első tíz éve 1918-1928. 1929.)

A románok Szolnok-Doboka megyében átveszik a közigazgatást. A nagyszebeni Román Kormányzótanács dr. Teodor Mihalit jelölte ki prefektusnak. (Csíki Lapok)

\section{Február 19.}

Kolozs vármegye területén megszünik a magyar közigazgatás. Erdélyben eltörlik a virilizmus intézményét. (Keleti Újság)

\section{Február 20-21.}

Szerb impérium Temes vármegyében és Temesváron. A belgrádi kormány Filipon Márton alibunári ügyvédet nevezi ki Temes megye, illetve Heegn Reinhold verseci mérnököt Temesvár föispánjának. (Geml József: Emlékiratok. 1924.)

Temesváron a magyar vasutasok sztrájkba lépnek, Lugoson két napos munkaszünetet hirdetnek a munkások, a tisztviselők és a kereskedők is (Jakabffy Elemér: A magyar államhatalom utolsó hónapjai Krassó-Szörény vármegyében)

Sepsiszentgyörgyön a Székely Nép és Független Székelység lapokat a román katonai parancsnokság megszünteti. (Keleti Újság, Csíki Lapok)

\section{Február 22.}

2000 zsidó vándorol ki Romániából Palesztinába. (Keleti Újság)

\section{Február 26.}

A kolozsvári Nemzeti Színház román cenzúra alákerül. A próbákra is eljárnak a cenzorok. Janovics Jenő színházigazgató véleménye szerint az éved megtartása lehetetlenné vált. (Keleti Újság)

\section{Március 1. szombat}

A CFR újabb felhívása: a magyar államvasút alkalmazottaitól ismét nyilatkozatot kér a román igazgatóság. A nyilatkozatot március 11-ig kell aláírni. (Keleti Újság)

\section{Március 2.}

A Kormányzó Tanács a magyar népköztársaság kormányával megszakítja a diplomáciai érintkezést, amelyet Erdélyi János ügyvéd tartott fenn. A magyar vasutasok gyülést tartanak és elhatározzák, hogy nem irják alá azt a nyilatkozatot, melyet a Kormányzó Tanács követel. (EMÉ)

\section{Március 5. szerda}

Átveszik a románok az állami adóhivatalt, a pénztárakat, az adóbefizetések és az adóbehajtások rendszerét. Betiltják a nyilvános futballmérkőzéseket. (Keleti Újság)

\section{Március 11.}

A Szerb-Horvát-Szlovén (SZHSZ) Királyi Államon belül megszüntetik a Bánát, Bácska, Baranya Nemzeti Igazgatóságot.

Elveszik az EMKE algyógyi földmíves iskoláját és összes népiskoláit. (EMÉ) 


\section{Március 21.}

Kikiáltják a Magyar Tanácsköztársaságot Budapesten.

A Kormányzó Tanács a magyar Tanácsköztársaság ellen újabb mozgósítást rendel el. (EMÉ)

\section{Március 23.}

Apáthy István szabadon bocsátása. A dési román haditörvényszék több heti tárgyalást követően szabadlábra helyezi Apáthy István fökormánybiztost, akire nem sikerül rábizonyítani a bolsevista vádakat. (Csíki Lapok)

\section{Március 24.}

Bánság francia megszállás alá kerül. A Bánság területén a francia megszálló csapatok külön zónát alkotnak, amelynek neve Lugos vármegye. A parancsnokságot Farret Leon tábornok, a francia 11. számú gyarmati hadosztály parancsnoka gyakorolja. (Jakabffy Elemér: A magyar államhatalom utolsó hónapjai Krassó-Szörény vármegyében)

\section{Április 4.}

Issekutz Aurél lugosi alispán Farret Leon tábornok engedélyével rendeletet ad ki, amely értelmében a párisi békekonferencia döntéséig Bánát továbbra is Magyarországhoz tartozik. A helyi közigazgatást azok a polgári hivatalnokok látják el, akik a magyar kormány képviseletében állnak. A közrendet a csendőrség és a rendőrség tartja fenn. Bármilyen kokárda, nemzeti zászló viselete és kitüzése tilos. Gyülések megtartása tilos. A lapok cenzúra alá esnek. (Csíki Lapok)

\section{Április 16.}

Általános román támadás Magyarország ellen.

Posta Béla kolozsvári egyetemi tanár, kutató, a Magyar Szövetség programalkotójának halála.

\section{Április 20.}

Nagyvárad román megszállása.

\section{Április 23.}

A románok bevonulnak Debrecenbe.

\section{Április 26.}

Győrtelek, Kocsord, Mátészalka térségében a románokkal szemben megvívott ütközet után a székely hadosztály Nyírbaktán kapitulál, a fegyverletételre Demecserben került sor.

\section{Árpilis 27.}

Egy magyarokból és székelyekből álló politikai csoportosulás, Ürmösi-Maurer Béla igazgatása alatt, és egy aradi ügyvéd, Lengyel Béla szerkesztésében 1919. április 27-én, Nagyszebenben Uj Világ címmel napilapot indított, és föleg Székelyföldön próbált követőket toborozni magának.

A román Kormányzótanács földmüvelésügyi osztálya a megszállt területek erdészeteit ún. erdészeti kerületi fönökségekre osztja (segesvári, brassói, marosvásárhelyi). A végleges rendezésig ideiglenes vezető hivatalnokokat neveztek ki. Az erdészeti hivatalok tisztviselöi megtarthatják állásukat, ha az esküt leteszik. (Csíki Lapok)

\section{Április 30.}

A román csapatok elérik a Tisza vonalát. 


\section{Május 5.}

Gróf Károlyi Gyula erdélyi származású arisztokrata, a főrendiház és a Magyar Tudományos Akadémia egykori tagja megalapítja az aradi ellenkormányt. Károlyi maga mellé veszi Barabás Béla Arad vármegye főispánját és Varjassy Lajos alispánt.

\section{Május 10.}

Aradon a budapesti tanácsköztársasággal szemben francia védnökség mellett polgári ellenkormány alakul gróf Károlyi Gyula elnöklete alatt. Az ellenkormányt Szeged felé utaztában Mezőhegyesen kormányának rendeletére Radulescu ezredes letartóztatja. (EMÉ)

\section{Május 11.}

A román Kormányzótanács által a kolozsvári egyetem átvételére delegált 12 tagú bizottság ultimátumot intéz az egyetem magyar rektorához. E szerint az egyetem tanári testülete és adminisztratív személyzete csak akkor müködhet tovább, ha a hüségesküt leteszi és beleegyezik abba, hogy a rektor és a dékánok mellett a román állami hatóságok delegátusai müködhessenek. A válasz május 12 . 10 óráig volt esedékes. A magyar egyetem egész személyzete az esküt megtagadja. (EMÉ)

\section{Május 14.}

A román Kormányzótanács megbízásából Onisifor Ghibu 16 órakor birtokba veszi a kolozsvári Nemzeti Színházat. Este a bukaresti Teatrul Naţional már megtartja első előadását. A színház mellé kormánybiztost neveznek ki. (EMÉ)

\section{Május 25.}

Magyar részről Temesvárt emlékiratot nyújtanak át a belgrádi francia föparancsnoksághoz a bánsági köztársaság tervéről. (EMÉ)

\section{Május 27.}

A román királyi pár először tesz látogatást Kolozsvárt. (EMÉ)

\section{Június 13.}

A Clemenceau-jegyzék rögzítette a párizsi békekonferencia döntését Magyarország határairól.

\section{Június 10.-augusztus 10.}

A Kormányzótanács döntése értelmében az Osztrák-Magyar Monarchiában használt papírpénzeket - az egy és kétkoronásokat kivéve - az e célra kijelölt hivatalok lebélyegezik. (Csiki Lapok)

\section{Julius 20.}

Franchet D'Esperey tábornagy megjelenik Aradon és a közhatalmat átadja Marşieu prefektusnak. (EMÉ)

\section{Július vége}

A francia megszálló csapatok Krassó-Szörény vármegye területéről elvonulnak. Issekutz Aurél volt kormánybiztos-alispán, a francia parancsnokság kérésére szintén távozik. E csapatok és a magyar államhatalom utolsó képviselőjének távozása után a románok megszállják KrassóSzörény vármegyét. (Geml József: Emlékiratok) 


\section{Július vége - augusztus eleje}

Nagyszebenből útnak indítják az első vonatot az Erdélyből kivándorlókkal. A 45 teli vagon Nagyszeben-Arad-Temesvár-Szeged-Szabadka-Zágráb-Bécs vonalon halad. A szegény sorsúak ingyen utazhatnak. A kivándorlók közül mintegy 300-an Palesztinába szándékoznak menni. (Csíki Lapok)

\section{Augusztus 1.}

Lemond a magyar tanácskormány, megbukik a Magyar Tanácsköztársaság.

\section{Augusztus 4.}

A román hadsereg bevonul Budapestre.

\section{Augusztus 10.}

Román impérium Gyergyószentmiklóson. A vasút, a posta, a föszolgabíróság és a polgármesteri hivatal átvétele után a román hatóságok a járásbíróságot, a rendőrséget és az állami fögimnáziumot is átvették. A személyzet eltávozott. (Csíki Lapok)

Bánsági sváb nagygyülésen kimondják, hogy a svábok Romániához kívánnak tartozni. (EMÉ)

\section{Augusztus 24.}

A 3621. sz. rendelettörvény új választójogot léptet életbe, mely az esküt nem tett magyar tisztviselőket és ügyvédeket megfosztja választói jogosultságuktól. (EMÉ)

\section{Szeptember 6.}

Az összes romániai német törzsek képviselői Temesvárt egységes választási programban állapodnak meg. (EMÉ)

\section{Szeptember 10.}

A 3911. sz. rendelettörvénnyel életbe lép az erdélyi agrárreform. (EMÉ)

\section{Szeptember 11.}

A Brătianu-kormány lemond a Bánság megosztása és a kisebbségi szerződés miatt. Vaitoianu tábornok kap megbízást kormányalakításra. (EMÉ)

\section{Szeptember 12.}

Megszüntetik a kézdivásárhelyi, a csíkszeredai és a székelyudvarhelyi törvényszékeket. (EMÉ)

\section{Október 10.}

A román Kormányzótanács Kolozsvárra teszi át székhelyét. (EMÉ)

\section{November 2-8.}

Az első általános parlamenti választások Nagyromániában, amelyen a magyarság nem vesz részt. A választói névjegyzékeket a magyarság mellőzésével állították össze. Miniszterelnök: Alexandru Vaida-Voevod. (Keleti Újság)

\section{November 5.}

Rendelet jelenik meg, mely szerint az esküt nem tett magyar ügyvédek és jelöltek 5 nap alatt kötelesek elhagyni Kolozsvár területét. (EMÉ) 


\section{November 6.}

A szász nemzetgyülés (Sachsentag) jóváhagyja a medgyesi határozatot és felállítja 20 pontban az új szász nemzeti programot. (EMÉ)

\section{November 27.}

Az Új Világ és Ürmösi-Maurer Béla közremüködésével megalakult a Magyar-Székely Nemzeti Demokrata Párt Bukarestben. Elnökévé vargyasi báró Dániel Lajost választják. A magyar politikai elit renegátoknak tartotta Maureréket, mert a román pártok segítségével nyertek el parlamenti mandátumot.

\section{Szeptember 12.}

Közzé teszik az Erdélyre, a Bánságra és a többi volt magyar területre vonatkozó földbirtokreformról szóló királyi rendeletet (3911. sz.). Elrendelik a kisajátítandó ingatlanokat, amely érint minden jogi személyt, testületet, alapítványt és egyházat. (Monitorul Oficial)

\section{November 14-16.}

A román csapatok kivonulnak Budapestről.

\section{December 1.}

A magyar kormány meghívást kapott a békekonferenciára.

\section{December 9.}

Románia a szövetséges és társult főhatalmakkal (antant) közösen aláírt egyezményben garantálja, hogy azok a román állampolgárok, akik etnikai, vallási vagy nyelvi kisebbségekhez tartoznak, joguk van „saját költségükön jótékonysági, vallási vagy szociális, iskolákat és más nevelöintézeteket létesiteni, igazgatni és azokra felügyelni, azzal a joggal, hogy azokban saját nyelvüket szabadon használhatják, és vallásukat szabadon gyakorolhatják." Az erdélyi székely és szász ,közületeknek a román állam ellenőrzése mellett, vallási és tanügyi kérdésekben helyi önkormányzatot" engedélyeznek. (BARANYAI Zoltán: A kisebbségi jogok védelmének kézikönyve. 1925.)

\section{0. év}

\section{Január 5.}

A magyar békedelegáció elutazik Párizsba.

\section{Február 1.}

A királyi pár jelenlétében felavatják a kolozsvári román egyetemet. (EMÉ)

\section{Április 2.}

A román Kormányzó Tanács az 1462. sz. rendelettörvény értelmében megszünik. A központi hivatalok, az egységesítő bizottság alatt, mint államtitkárságok, utóbb, mint vezérigazgatóságok viszik tovább az ügyeket. (EMÉ, Ellenzék)

\section{Május}

Bernády György volt marosvásárhelyi polgármester megjelenteti három röpiratát. A Nyílt levél a politikai aktivitás megkezdését és egy magyar politikai párt megalakítását kezdeményezi. A másik kettő egyfelől a magyarságot ért sérelmeket foglalja össze (Emlékirat), másfelől a magyar tisztviselők élethelyzetét kívánja orvosolni (Elöterjesztés a magyar tisztviselök és ügyvédek eskütétele). 


\section{Május 15.}

Az Erdélyi Gazdasági Egylet deklarációban tiltakozik a földreform és végrehajtásának módja ellen. (EMÉ)

\section{Május 25-30.}

A második általános parlamenti választás, melyen Averescu tábornok pártja kap többséget. A magyarság nem vesz részt. (EMÉ)

\section{Június 4.}

Aláírják az I. világháború győztes hatalmai Magyarország képviselőivel a versailles-i Nagy Trianon kastélyban a háborút lezáró magyar békeszerződést. Romániához kerül Erdély, Máramaros, az Alföld keleti szegélye (Partium) és a Bánság egy része.

\section{Augusztus 7.}

Apáthy István, miután a fogságban szerzett súlyos betegségéből felépült, elhagyja Erdélyt. (EMÉ)

\section{Augusztus 12.}

Az erdélyi magyar egyházfök memorandumot küldenek a román kormánynak. A felekezeti autonómia tiszteletben tartását kérik a román államtól. (ERE IL 4064/1920.)

\section{Augusztus 16.}

Megalakul a Minerva nyomdaipari vállalat 653 részvényes által jegyzett 1,5 millió lei alaptőkével. A vállalat a két világháború között a romániai magyarság számára szükséges tankönyveket, irodalmi, müvészeti és tudományos köteteket, folyóiratokat, heti- és napilapokat (Pásztortüz, Magyar Nép stb.) állított elö. (TIBORI-ÚJVÁRI: A kolozsvári Minerva története és bibliográfiája (1920-1948). 2015)

\section{Augusztus 29.}

A magyar unitárius egyház főtanácsa megtarthatja első ülését.

\section{Szeptember 3.}

Magyar Egyházak Felekezetközi Központi Tanácsa határozatot hoz egy önálló magyar egyetem létesítéséről, illetve annak egyik tagozatát, a tanárképző intézetet ideiglenes jelleggel a református teológia fakultással párhuzamosan elindítja 1920. október 1-től. A pontos név: Erdélyi Református Teológia Tanárképző Intézet, elnöke: dr. Márki Sándor egyetemi tanár. (ERE IL 4950/1920)

\section{Szeptember 15.}

Temes-Torontál és Krassó-Szörény megyék közigazgatását közvetlenül Bukarest alá rendelik.

\section{Szeptember 29.}

Az Erdélyi Római Katolikus Státus megtartja első ülését. (EMÉ)

\section{Szeptember 20.}

A Lapkiadó Rt. a Keleti Újság mellett megjelenteti a Napkelet címü folyóiratot. Főszerkesztője Paál Árpád, társszerkesztői: Kádár Imre, Ligeti Ernő és Szentimrei Jenő - valamennyien tagjai voltak a Keleti Újság szerkesztőségének is. (Keleti Újság) 


\section{Október 1.}

Majláth püspök bejelenti, hogy Brassóban a római katolikus egyházközösség leány középiskolát indít, illetve Gyulafehérváron kereskedelmi iskolát. (ERE IL 4950/1920.)

\section{Október 13.}

A konzervatív ideológiájú passzivista kör (kolozsvári központ) az Ellenzékben felhívást tesz közzé, hogy a romániai magyarságot az EMKE köré kell szervezni. Elsődleges feladatuknak azt tartjá, hogy az erdélyi összmagyar társadalom képviselve legyen, a magyar nyelv, müvelődés, szellem és nemzeti érdekeinek megvédelmezésére egy társadalmi szervezet keretén belül, de nem politikai pártban. (Ellenzék)

\section{November 3.}

Engedélyezik a magán beszélgetéseket az új határokon belül. Magyarországgal való telefon összeköttetés ekkor még nem állt helyre. (Keleti Újság)

\section{November 5.}

A belügyminiszteri rendeletben (3469. szám) szabályozzák az emigrációt, amely külön nemzetiségként kezelte a magyarokat, a székelyeket, illetve a zsidókat. A rendelet 4 fejezetből állt. 1. fejezet: „Megengedik a Magyarországra való repatriálást mindazon erdélyi magyar és székely ifjaknak, valamint az Amerikába való repatriálást Románia egész területéröl azoknak a zsidó ifjaknak, akik már fel vannak véve a sorozási lajstromokban, vagy pedig fegyverben vannak." A 2. fejezetben meghatározták, hogy a magyarokon, a székelyeken és a zsidókon túl kikre vonatkozik a rendelet. Ezek szerint az 1874-1896, illetve 1898-1917 között született „idegen nemzetiségü erdélyi polgárokra is, továbbá a volt osztrák-magyar hadsereg tényleges és aktív tisztjeire." A 3. fejezet értelmében, aki emigrálni kívánt, azt önkéntesen tette és végleg elhagyja Romániát, vissza nem térhet. A 4. fejezet a kiskorúakra vonatkozott, akiknek szüleiktől írásos igazolást kellett kéri, amelynek értelmében elhagyhatták az országot. (Keleti Újság)

\section{November 14.}

Statisztika a kolozsvári egyetem hallgatóiról. 1920-21. tanévre beiratkozott hallgatók száma és nemzetiségi megoszlása: 1317 fő joghallgató, amelyből 140 zsidó, 67 magyar, a többi román. Orvosi karra beiratkozott 1007 fö, amelyben belül a zsidók aránya megegyezik a románokéval. A tanári fakultásra 138, matematikusnak 105 fö jelentkezett. A bölcsészkaron 56 román, 33 zsidó és 10 magyar tanult. A gyógyszerészeti karra 83 diákot vettek fel, akik közül 31 volt zsidó. Az összes zsidó tanuló száma 689 fő volt, a magyaroké az előző évihez képest valamivel nőtt, de alig haladta meg a 150 föt. A hallgatók közül 2257 volt erdélyi és bánáti születésü, 147 óromániai és 74 magyarországi. (Új Kelet)

\section{November 15.}

A magyar nemzetgyülés 1920. november 15-én ratifikálja, és 1921. július 26-án, a XXXIII. törvénycikkel kihirdeti az első világháborút lezáró trianoni békeszerződést.

\section{November 16.}

Az Erdélyi Irodalmi Társaság két évi szünetet követően megtartja első ülését, ahol Márki Sándor elnököl. Részt vesz továbbá Reményik Sándor, Szabolcska Mihály. (Keleti Újság)

\section{November 21-24.}

Erdélyi cionista konferencia. Témája: kulturális élet, sajtó, gazdasági élet, Palesztinával kapcsolatos kérdések. (Keleti Újság) 


\section{November 25.}

Gyerkes Mihály a magyar felekezeti tanítók nevében Székelyudvarhelyröl kérelmet továbbít Nagy Károly püspöknek, azzal a kéréssel, hogy a felekezetközi tanács engedélyezze a magyar anyanyelvü tanároknak állami iskolákban való munkavállalását. Indoklásul az állt, hogy a trianoni békeszerződés ratifikációját megelőzően a magyar oktatók esküt nem tettek, a román hatóságoknak ellenálltak, és a magyar felekezeti iskolák szervezése érdekében jóformán díjtalanul látták el a magyar tannyelvủ oktatás biztosítását.

\section{November 30.}

A felekezeti iskolák tanárait arra kötelezték, hogy vizsgát tegyenek földrajzból, alkotmánytanból és román nyelvből. A teológia tanárokat nem érintette a vizsgakötelezettség. Akik nem jelennek meg a vizsgán fegyelmi eljárásban részesülnek. A vizsgák határideje: 1921. április 1 - május 31 . között.

Rendelet a címerfeliratokról és a cégtáblákról. A 2420/1920. számú rendelet alapján kötelezik a kereskedőket, a bankokat, a vállalatokat és az összes lakost, hogy a címerfeliratokat, cégtáblákat 30 napon belül román nyelven tüntessék fel. Aki nem tartja be a rendeletet 1005000 lei bírságra ítélhető. (Keleti Újság)

\section{November 30.}

A forradalom után Erdélyt megszálló román csapatok a zsilvölgyi bányavidéken ellenállásba ütköznek. A bányavidék munkásai általános sztrájkot indítanak a bevonuló hadsereg hírére, néhol összetüzésre is sor kerül. 49 bányász fölött hozott ítéletet a bíróság. A 39 főt öt évre, 1 föt életfogytiglanra, 8 főt 10 évre, 2 föt 20 évre ítélnek. (Keleti Újság)

\section{December 5.}

Az Erdélyi Gazdasági Egyesület Kolozsvárt az agrárreform ellen nagy tiltakozó gyűlést rendez, melyen a szászok is részt vesznek. Küldöttség megy a királyhoz. (EMÉ)

\section{December 9.}

A közoktatásügyi minisztérium kolozsvári államtitkárság 19938/1920. számú határozata értelmében az összes 1919/20. évi tanévben a felekezeti intézmények által, illetve a kormánybiztos aláírásával el nem látott tanítói és tanítónői okleveleket érvénytelenítik. Az érintettek nem vállalhatnak munkát oktatói állásban. (ERE IL 600/1921.)

\section{December 11.}

Marosvásárhelyen a zsidó hitközség három imaházát, a rabbinátus hivatalos helyiségét, a Palesztina Hivatalt és a zsidó szövetség helyiségét elrekvirálta a helyi lakásügyi kormánybiztos, Seibringer. (Keleti Újság)

A református tanárok Nagyenyeden egyesületet alakítanak, melyet nem engedélyeznek. (EMÉ)

\section{December 12.}

Az erdélyi magyar egyházfők memoranduma Octavian Goga kulturális- és oktatási miniszterhez. Tiltakoztak a nyelvhasználatot és az egyházi autonómiát sértő rendeletek ellen. A felekezetek vezetői a békeszerződés tudomásul vétele kérdésében elismerikk önmagukra nézve, hogy az állam nyelve a román, de a magyar közösségek vezetői öt év haladékot kérnek az államnyelv megfelelő szintü elsajátításához. (ERE IL 6154/1920.)

\section{December 15.}

A Magyar Szövetség előkészítő ülésére ötös bizottság alakul, melynek tagjai: dr. Grandpierre Emil, dr. Paál Árpád, dr. Róth Hugó, Sándor József és dr. Zágoni István. (EMÉ) 


\section{December 24.}

Az aradi Rendkívüli Újságot a hatóság 3 hónapra betiltja. (EMÉ)

\section{December 25.}

Kós Károly, Zágoni István és Paál Árpád megjelenteti a Kiáltó Szó programszöveget. Síkra szállnak a romániai magyarság politikai aktivitása érdekében és kezdeményezik a Magyar Szövetség létrehozását. (Keleti Újság)

\section{December 29.}

A hatóság betiltja a Nagyváradi Naplót. (EMÉ)

\section{December}

Népszámlás Romániában.

\section{Január 5.}

1921. év

Balázs András római katolikus státus referens bejelenti, hogy a „felekezeti tanítók fizetésének valamely csekély részben való utalására a Kolozsvári Takarékpénztár és Hitelbanktól 6\% kamat mellett 100 ezer lei kölcsönt vett fel a római katolikus egyház.” Kirchknopf Gusztáv kolozsvári ev. lelkész, a szász nemzeti egyház nevében ugyanerre a célra 20 ezer lei kölcsönt vesz fel. Hirschler József a kolozsvári római katolikus egyházközösség nevében további 16 ezer lei kölcsönt vesz fel a polgári tanító képző intézet részére. (ERE IL 600/1921.)

\section{Január 9.}

A Magyar Szövetség elökészítő ülése Kolozsváron, ahol többek között részt vesz Grandpierre Emil, Paál Árpád, Zágoni István, Költő Gábor stb. A Magyar Szövetséget pártok, osztályok és felekezetek felett álló szervezetként kívánják megalakítani, amely minden magyart, székelyt és csángót magába foglal. A feladatok ellátásáért az ún. központi intézőbizottság (21 fö) felel, amely a hivatalos megalakulásig (július 6.) a magyarság képviseletében eljár, érdekeit védelmezi és a kisebbségi ügyekben tárgyal. (Keleti Ujság, Ellenzék)

\section{Január 11.}

Az igazságügyi minisztérium kolozsvári föigazgatósága 28.819. sz. körrendeletével valamennyi erdélyi bíróságot arra kötelezi, hogy mind szóban, mind írásban kizárólag a román nyelvet használják. (EMÉ)

\section{Január 15.}

A Brassói Lapoktól megvonják a postai szállítás jogát. (EMÉ)

\section{Január 19.}

Címtábla perek Kolozsváron. Százhét büntetés, akik között orvosok, ügyvédek, kereskedők is vannak. Szász és magyar városokban csak román nyelvü táblákat engedélyezn, és akik az elöírásokat nem tartják be büntetésre számíthattak. (Keleti Újság)

\section{Január 21.}

A román közoktatásügyi államtitkárság (31774/920. számú irat) tájékoztatja a felekezetközi tanácsot, hogy az 1918. december 1. után megnyílt iskolák esetében csak azoknak adja meg a müködési engedélyt, amelyek közvetlenül az államtitkárságtól kértek kérelmet. Továbbá az állami iskolák infrastruktúráját nem adja bérbe a felekezeti iskolák részére, illetve a felekezeti iskolákban fenntartják a román nyelv oktatásának kötelezettségét a 76000/920. számú utasítás értelmében. (ERE IL 600/1921.) 


\section{Január-február}

Grandpierre Emil cikksorozatban kifejti a magyar autonómia tervét az Ellenzékben. Románia föderalizálása helyett a nemzeti elvre helyezi a hangsúlyt.

\section{Február 19.}

Megkezdődik a koronabeváltásnál adott 40 százalékos lejbonok beváltása, mely egy hónapon keresztül folyik. (EMÉ)

\section{Február 21.}

Letartóztatják dr. Költő Gábort, az unitárius egyház főtanács előadóját, az egyházi irodákat pedig a rendőrség zár alá helyezi. (EMÉ)

\section{Február 22.}

Temesvár magyarsága csatlakozik a Magyar Szövetséghez. Az egybegyültek elfogadják a szövetség ideiglenes programját és egy ideiglenes bizottságot választanak. Elnök: Szabolcska Mihály. (Keleti Újság)

\section{Február 23.}

Háromszék vármegyében, Sepsiszentgyörgyön megalakul a Magyar Szövetség helyi szervezete, elnök báró Szentkereszthy Béla. (Ellenzék)

\section{Február 24.}

A budapesti kormány döntése arról, hogy az erdélyi központ tagjait, Grandpierre Emil vezetéséven a maga hivatalos megbízottainak tekinti.

\section{Március 1.}

Mátyás király szülőházáról Kolozsvár tanácsa leveteti a megjelölő magyar feliratot. (EMÉ)

\section{Március 5.}

Meţhes prefektus az összes kolozsvári magyar lapokat további intézkedésig betiltja azzal az indokolással, hogy bírálták a román hatóságok intézkedéseit. A betiltás 10 napig - március 16ig - volt érvényben. (EMÉ)

Március 11. - Kolozsvár magyarsága díszelőadással ünnepli az erdélyi Magyar Színház centenáriumát. (EMÉ)

\section{Március 17.}

Székely küldöttség Bukarestben, ahol a földreform ellen tiltakoznak a közbirtokosság vagyona védelmében. A memorandumot Goga Oktavian miniszter veszi át. (Keleti Újság)

\section{Március 19.}

Majláth Gusztáv erdélyi, Glattfelder Gyula csanádi és Széchenyi Miklós nagyváradi katolikus püspökök, illetve Teutsch szász lutheránus egyházfö leteszi az esküt Romániára Bukarestben. (Keleti Újság, Ellenzék)

\section{Március 27. -április 5.}

IV. Károly első visszatérési kísérlete Magyarországra, amely komoly belpolitikai vitát generál Romániában is. 


\title{
Április 9-10.
}

Az erdélyi protestáns püspöki kar esküje. Ferencz József református püspök eskütételére április 9-én, az unitáriusokéra 10-én került sor. (Keleti Újság, Ellenzék)

\section{Április 15.}

Arad, Szeben, Fogaras és Brassó megyék közigazgatását közvetlenül Bukarest alá rendelik. (EMÉ)

\author{
Április \\ Április 1-jétől a regáti és az új területek köztisztviselői egységes fizetést kapnak. Megszüntek \\ a korábbi fizetési osztályok és megváltoztak az illetmények, amely az erdélyieket negatívan \\ érintette. \\ Április 1-jével a román hadsereg teljes békeállapotba lépett és ezzel megszűntek a rendkívüli \\ intézkedések Romániában azzal a kivétellel, hogy a cenzúra, illetve a magyar határral \\ szomszédos területeken a hadiállapot fennmarad (Máramaros, Szatmár, Szilágy, Bihar és Arad \\ megyékben, továbbá az egész Bánátban). A politikai gyülések megtartását a rendőrségnek előre \\ be kellett nyújtani, amelyet szükség esetén a rendőrség megtilthatott. (Keleti Újság)
}

\section{Május 4.}

A belföldre és külföldre szóló leveleket cenzúrázás nélkül továbbítják. A levél cenzúrahivatalokat feloszlatják. (Keleti Újság)

\section{Május 7.}

Megnyílt a temesvári tôzsde (Keleti Újság)

\section{Május 10.}

Az Erdélyi Gyáriparosok Szövetsége (Dr. Czell Vilmos elnök) brassói éves közgyülésén elhatározta: a szövetség eddigi erdélyi müködési körét az egész országra kiterjeszti, a munkáspénztárak autonómiájának visszaállítását kezdeményezi a kormánynál. (Keleti Újság)

\section{Május 19.}

A közlekedési minisztérium februári rendelete értelmében májustól bezáratta a magánvasutakat, amelyeknek az igazgatóságai 10 kivételével többségében Magyarországon voltak. (Keleti Újság)

\section{Május 31.}

Réz Mihály 43 évesen, gerincvelő gyulladásban, Genfben elhunyt. A magyar kormány megbízottjaként dolgozott, miután elhagyta Erdélyt. (Keleti Újság)

\section{Június 5.}

Megalakul az Erdélyi Néppárt Bánffyhunyadon. Az első magyar párt kész volt felvállalni a parlamenti részvételt. A szervezkedés megindítására Bokor Márton bánffyhunyadi református lelkész, dr. Bod Péter és dr. Kabdebó Szilárd ügyvédek, Kós Károly építész és Nagy Miklós vállalkoztak. (Keleti Újság, Ellenzék)

\section{Június 7.}

A Királyhágóntúli református egyházak képviselői értekezletén elhatározzák, hogy az új egyházkerület megalakítása tárgyában egyházmegyéiket állásfoglalásra hívják fel. (EMÉ) 


\section{Június 21.}

Székelyudvarhelyen az Udvarhely megyei magyarság csatlakozik a Magyar Szövetséghez. Helyi elnöknek megválasztják Szakáts Péter földbirtokost. (Ellenzék)

\section{Június 26.}

Kis-Küküllő vármegyében, Dicsőszentmártonban megalakul a Magyar Szövetség, elnöke Gvidó Béla unitárius esperes. (Keleti Újság)

\section{Június 29.}

Nagyváradon Tabéry Géza (Szabadság) és Perédy György (Nagyvárad) újságírók aláírásgyüjtésbe kezdenek a Magyar Szövetség megalakításának igényével, de a gyülés megtartását a hatóságok megtagadják. (Keleti Újság, Szabadság)

Hunyad vármegyében megalakul a Magyar Szövetség. (Ellenzék)

Június 30.

Alsófehér megyei Magyar Szövetség megalakítása. Elnök dr. Jeney Endre árvaszéki ügyvéd. (Keleti Újság)

\section{Július 2-5.}

Az erdélyi reformátusok parlamentje. Az erdélyi református egyházkerület három év után ismét ülésezik. Napirendi témák között szerepel: a fópásztor és főhatóság nélkül maradt csonkaegyházmegyék problémája, hogy ezek kerüljenek az erdélyi egyházkerület alá, illetve az iskolák helyzete. Az elhunyt Lészai Ferenc helyére gr. Bethlen Ödönt fögondnokká választják. (Keleti Újság, EMÉ)

\section{Július 3.}

Féléves akadályoztatást követően Csík megyében Pál Gábor kezdeményezésével megalakul a Magyar Szövegség. Szilág megyében is megalakítják a Szövetséget. Elnöke gróf Béldi Kálmán. (Szabadság)

Fehér vármegyében, Nagyenyeden megalakul a Magyar Szövetség. (Ellenzék)

Az EMKE megtartja első közgyülését, melyen módosítja az alapszabályát. Elnök gr. Béldi Ákos maradt. (EMÉ)

\section{Július 6.}

A Magyar Szövetség nagygyülése Kolozsváron. A központi tisztikar (elnökség) a következő személyekből állt: elnök báró Jósika Sámuel volt förendiház elnök, ügyvezető alelnök: dr. Haller Gusztáv volt kolozsvári polgármester, alelnökök: Ugron István volt nagykövet, dr. Grandpierre Emil volt kormánybiztos, gróf Béldi Kálmán nagybirtokos, Ferenczy Géza volt unitárius egyházi fögondnok, Albrecht Lajos bánffyhunyadi ügyvéd. Titkár: Kós Károly az Erdélyi Néppárt alapítója. (Keleti Újság, Ellenzék)

\section{Július 10.}

Megalakul a marosvásárhelyi Magyar Szövetség. Elnök: báró Kemény Ákos. (Keleti Újság) A magyar kormány jegyzéke Bukarestbe: „A trianoni békeszerzödésre tekintettel, hogy Magyarország az összes szomszédos államokkal barátságban kíván élni, a mai napon az összes területvédö szervezeteket és alakulatokat feloszlatta. A magyar kormány öszintén kívánja a békét és legfontosabb feladatának tartja azt, hogy a trianoni békeszerzódést végre hajtsa, illetöleg tiszteletben tartsa." (Keleti Újság) 


\section{Július 20.}

Budapesten Starcea ezredes megbeszélést folytat gróf Bánffy Miklós külügyminiszterrel. Bánffy javasolja, hogy Kolozsváron egy repatriáló irodát állítsanak fel, amely Erdély és Bánát lakosainak az ügyét kezelné. A magyar kormány ehhez az irodához egy bizottságot állítana fel, amely eldöntené, hogy a kérelmező Magyarország befogadja-e vagy sem. A tárgyalások ezt követően Kolozsváron folytatódnak, ahol Tanasescu Constantin belügyi államtitkár a javaslatot továbbítja a bukaresti kormánynak, amelyet előzetesen támogatásáról biztosított. A tervek szerint az iroda rendezte volna az útlevelek érvényesítését is. (Keleti Újság)

\section{Július 23.}

Kihirdetik a földreformtörvényt, amely 1917-ben indult el, és négy királyi rendelet (Ókirályság, Besszarábia, Bukovina, Erdély) végrehajtását követően született meg. (Monitorul Oficial)

A nagyváradi, a gyulafehérvári, a temesvári és a szatmári püspökség birtokainak $95 \%$-át, az erdélyi és a királyhágó melléki református püspökséges birtokainak $45 \%$-át sajátították ki. A romániai magyar egyházak 371.614 hold birtokából összesen 314.199 holdat $(84,5 \%)$ vettek el. (Mikó Imre: Huszonkét év, 1941.)

\section{Július 24.}

Az Erdélyi és Bánáti Újságíró Egyesület kolozsvári központi szervezetének egyhangú határozata alapján a választmány tiltakozó levelet küld a budapesti kormánynak, Száz Zoltán letartóztatása ügyében. „A magyar szellem szabadságérdekeinek súlyos megsértését érezzük ebben a tényben." (Keleti Újság)

\section{Augusztus 9.}

A politikai foglyok szabadon bocsátását kéri a Magyar Szövetség. A memorandumot báró Jósika Sámuel, Haller Gusztáv és Kós Károly írták alá. (Keleti Újság)

\section{Augusztus 20.}

Temesvárt betiltják a Szent István napi nagymisét, melyet Glattfelder püspök celebrált volna. (EMÉ)

\section{Augusztus 23.}

Megalakítjták a Magyar Szövetség Kolozs vidéki tagozatát, amely Kalotaszeg és Mócs között elterülő községeket foglalta magába. (Keleti Újság)

\section{Augusztus}

Kecskeméthy István és Szathmáry Ákos vezetésével Kolozsvár több kerületében politikai gyüléseket tartanak, ahol megalakítják az Erdélyi Magyar Néppártot, amely csatlakozik a kalotaszegi Erdélyi Néppárthoz, és elfogadja a Magyar Szövetség programját. (Keleti Újság)

\section{Szeptember}

A Magyar Szövetség megalakulása Torda-Aranyos és Krassó-Szörény megyékben. (Ellenzék)

\section{Szeptember 4.}

Ravasz László elhagyja Erdélyt, mert Dunamelléki ref. püspökké választották. (EMÉ)

\section{Szeptember 14.}

Országos Dante-ünnepség a kolozsvári Magyar Színházban. (EMÉ) 


\section{Október 6.}

A Magyar Szövetség benyújtja első emlékiratát Brătianu Ionel miniszterelnökhöz a magyar egyházak és iskolák üldöztetése tárgyában. (EMÉ)

\section{Október 18.}

Hunyad megyében, Szászváros központtal megalakul a Magyar Szövetség. (Ellenzék)

\section{Október}

Jósika-ügy. Mária román királyné kolozsvári látogatása tiszteletére színházi estélyt szerveztek októberben, ahová meghívást kapott báró Jósika Sámuel is. A báró az invitálásnak nem tett eleget arra hivatkozva, hogy egészségi állapota megromlott és nem kapott hivatalos formában értesítőt. Az etikett kérdéséböl politikai botrány kerekedett, amely a szövetségen belül és a román-magyar viszonyban is konfliktusokat eredményezett. (Keleti Újság, Ellenzék)

\section{Október 31.}

Meţhes prefektus rendeletben felfüggeszti a Magyar Szövetség müködését. A hivatalos indok az volt, hogy a Magyar Szövetség előzetesen nem nyújtotta be az alapszabály-tervezetét a kormánynak. A rendőrség a kolozsvári központi iroda helyiségeit lezárta és lepecsételte, illetve az irattárát lefoglalta. (Keleti Újság, Ellenzék)

\section{November 4.}

A CFR vezérigazgatósága rendeletet ad ki, mely szerint az állomásokon árusításra kerülő sajtótermékek 60 százaléka román kell, hogy legyen. (EMÉ)

\section{November 9.}

A Magyar Szövetség vezetőségét, Jósika Sámuel báróval az élén engedély nélküli működés vádja alapján a rendőrségre idézik, s eljárást indítanak ellenük. A róm. kath. státus közgyülés előkészítő értekezletének összes résztvevőit titkos rendőrök leigazoltatják. (EMÉ)

\section{November 10.}

Az Erdélyi Róm. Kath. Státus rendes évi ülése. (EMÉ)

\section{November 18.}

A bánsági magyar telepesek dr. Sulyok István felhívására Lugoson tiltakoznak a földreformtörvény ellen. (EMÉ)

\section{November 19.}

Az Averescu-kormány 3.5 millió lej államsegélyt utal ki az összes erdélyi kisebbségi középiskolák részére. (EMÉ)

\section{December 14.}

A tiszántúli ref. egyházkerület Romániához csatolt egyházmegyéi Nagyváradon önálló Királyhágóntúli Egyházkerületté alakult. (EMÉ)

\section{December 17.}

Take Ionescu kormányt alakít. (EMÉ)

\section{December 28.}

A Magyar Szövetség helyiségeit visszaadják, és müködését ismét engedélyezik. (Keleti Újság, Ellenzék) 


\section{2.}

Január 15.

A Magyar Néppárt, melynek szervezését az 1921. június 5-i bánffyhunyadi gyülés kezdeményezte, Kolozsvárt országos gyülést tart, ahol megjelenik Jósika Sámuel báró is (Keleti Újság)

\section{Január 31.}

A kolozsvári konzervatívok támogatásával a Magyar Szövetség székelyudvarhelyi szervezete megalakítjta a Magyar Nemzeti Pártot. Döntés születik arról, hogy részt vesznek a soron következő parlamenti választásokon. (Ellenzék)

\section{Február 8.}

Román szélsőséges csoportok feldúlják Kolozsváron az Ellenzék irodáját. (Keleti Újság)

\section{Február 11.}

Az Erdélyi Néppárt és a választásokig megalakuló Magyar Nemzeti Párt a választási egyezségük keretén belül közös listát állít, azzal a kikötéssel, hogy a székelyföldi kerületeket egymás között megosztják. (Keleti Újság)

Az Erdélyi Zsidó Néppárt megalakítása Kolozsváron, amely Székely Bélát, az 5 órai Újság szerkesztőjét nevezte meg képviselőjelöltjének a márciusi választásokra. (Jelölését visszautasították.) (Keleti Újság)

\section{Február 12.}

Kolozsváron megalakul a Magyar Nemzeti Párt. Elnök: Ferencz József unit. püspök. Titkár: dr. Székely Endre.

Magyar könyvek kitiltása Erdélyből. A szigurancia bukaresti vezetősége rendeletet adott ki, amely minden magyar nyelvü nyomtatván Erdélybe való behozatalát megtiltja. Az indok, hogy irredenta tartalmú kiadványokat terjeszt a magyarországi ÉME, MOVE, Területvédő Liga. (Keleti Újság)

\section{Február 15.}

A Magyar Szövetség Kis-Küküllő megyei tagozata kezdeményezi a Magyar Nemzeti Párt megalakítását. Elfogadják a parlamenti választásokon való részvételt. (Ellenzék)

\section{Február 18.}

Háromszék megyében a helyi Magyar Szövetség tagjai megalakítják a Magyar Nemzeti Pártot. Elnök: Szentkereszthy Béla. (Ellenzék)

\section{Február 20.}

Szatmár megyében az Erdélyi Néppárt közremüködésével megalakul a Magyar Szövetség. Megválasztják Kós Károlyt képviselőjelöltnek, szenátorjelöltnek Harcsák Géza ügyvédet. (Keleti Újság)

\section{Február 26.}

A magyarok jelöléseit a legtörvénytelenebb kifogásokkal csaknem mindenütt visszautasítják. (EMÉ)

\section{Március 1.}

Indokolás nélkül megvonják az Ellenzék postai szállítási jogát hat hónapra. (EMÉ) 
Március 6-10.

Szenátorválasztás: ókirályságban, Bukovinában, Besszarábiában március 1-2., Erdélyben, Bánátban, a Körös völgyében és Máramaros megyében március 9-10. Képviselőházi választások: ókirályságban, Bukovinában, Besszarábiában március 5-7., Erdélyben, Bánátban, a Körös völgyében és Máramaros megyében 6-7.

A képviselőválasztásokon egy magyar jelölt, Bernády György Nyárádszeredán szerzett mandátumot, a szenátorválasztásokon pedig két induló, Pál István apátplébános Udvarhelyről és Fülöp Béla Temesvárról. Pótválasztásokon még két képviselővel, Sepsiszentgyörgyröl Sándor Józseffel és Aradról Zima Tiborral, illetve egy szenátorral, Jósika Sámuellel bővült a magyar parlamenti képviselet, amely a magyar lakosság arányát a népességen belül $(8,6 \%)$ nem tükrözte. A korabeli számítások szerint a magyarok 20-30 képviselöi helyre számítottak, ehelyett bejutott három fö, és a hivatalból berekült magyar püspököket leszámítva továbbá három szenátor. (Keleti Újság, EMÉ)

\section{Április 7.}

A Magyar Szövetség megalakulása Aradon. (Friss Újság)

\section{Május 5.}

Újjá alakul a Tanítóegyesület, amely az erdélyi és a bánsági magyar nyelvü iskolák tanítókat tömörítette. Székelyudvarhelyen 300 tanító csatlakozott Gyerkes Mihály vezetésével. (Keleti Újság)

\section{Május 6.}

A Keleti Újság 4 a központi repatriáló hivatal vezetőjére, Puticiu rendőrprefektusra hivatkozva 18 hónap statisztikája alapján 42.368 fỏ repatriálásról számol be. (Keleti Újság)

\section{Május 16.}

Az erdélyi magyar zsidóság tiltakozását fejezi ki az ellen a rendelet ellen, amely meg akarta tiltani, hogy zsidó iskolákban magyarul tanítsanak. Az előírás arról szólt, hogy a kormány a zsidó egyházat egységesíteni kívánja. A kolozsvári neológ hitközség vasárnap tárgyalt ezekről a rendelet tervezetekről, és elutasították a tervet, kifejezve, hogy a Zsidó Nemzeti Szövetséghez nem csatlakoznak. (Keleti Újság)

Erdélyi Gazdasági Egyesület küldöttséget (gróf Bethlen György) meneszt Bukarestbe, amely memorandumot nyújt át a földtörvény revíziója, az adóreform és a munkásbiztosítás sérelmes pontjai kérdéseiben. Az agrárreform törvény: antiszociális, mert a kisajátítás mértékék önkényesen állapították meg, a székely határőrezred ingatlanainak kisajátítása, a telepeseket érintő szakasz, stb. Az adóreform kapcsán azt javasolták, hogy vegyék figyelembe a föld és jövedelmének megadóztatásánál a katasztert. A munkásbiztosításnál azt követelték, hogy a gazdasági cselédek és munkások biztosítását vagy vegyék ki a kerületi munkásbiztosító pénztárak hatásköréből vagy külön elvek alapján kezeljék. (Keleti Újság)

\section{Június 25.}

Megalakul a Romániai Magyar Dalosszövetség. (EMÉ)

\section{Július 7.}

A Magyar Szövetség müködését másodszor is felfüggesztik, iratait és irodáit lefoglalják. Jósika egy tiltakozó záradékot adott át Meţhesnek (Arad és Vidéke, Ellenzék, EMÉ) 


\section{Július 10.}

A Magyar Szövetség felfüggesztését követően a magyar tisztviselök megalakítják az Állásnélküli Magyar Tisztviselők Egyesületét, és memorandumban kérték a királyt a tisztviselők állásukba való visszahelyezésére. (Keleti Újság)

\section{Július 15.}

Az Erdélyi Magyar Néppárt kolozsvári gyülése. Azt kezdeményezik, hogy a Magyar Szövetség alapszabályában fektesse le a napi pártpolitikától független, kulturális, gazdasági és kisebbségjogi szervezetként müködjön tovább. (Keleti Újság)

\section{Július 31.}

A magyarság Segesvárt országos emlékünnep keretében üli meg Petőfi Sándor születésének centenáriumát. (EMÉ)

\section{Augusztus 5.}

A Magyar Nemzeti Párt a kolozsvári Központi Szálloda nagytermében országos alakuló nagygyülést tart. Elnökké dr. Grandpierre Emilt választották meg. A nagygyülés Sándor József indítványára kimondja, hogy az erdélyi magyarság egysége érdekében fúzióra kíván lépni a Magyar Néppárttal. (Ellenzék, Keleti Újság, EMÉ)

\section{Augusztus 6.}

A Magyar Szövetség erre az alkalomra adott külön engedély alapján megtartja második nagygyülését, melyen a kormány követelésére alapszabályát módosítja. (EMÉ)

\section{Augusztus 10.}

Az Erdélyi Róm. Kath. Státus rendes évi közgyülése. (EMÉ)

\section{Augusztus 15.}

A Magyar Nemzeti Párt alakuló nagygyülése Kolozsváron. Sándor József a két magyar párt egyesülését kezdeményezte. (Újság)

\section{Augusztus 16.}

A Magyar Szövetség a belügyminiszter engedélyével a betiltási rendelettöl függetlenül megtarthatja nagygyülését, ahol az egy évre megválasztott vezetőség tisztújítására, illetve az alapszabály módosítására került sor. (Újság, Ellenzék)

\section{Szeptember 4.}

Megválasztják a Magyar Nemzeti Párt elnökségét. Elnök: dr. Grandpierre Emil, társelnökök gróf Béldi Kálmán, Hevesi József, Sándor József. (Ellenzék)

\section{Szeptember 17.}

Erdély minden magyar templomában - felekezeti különbség nélkül - kihirdetik az egyetemes egyházi adót, melyet valamennyi magyar felekezet egységesen fejenként 30 lejben állapított meg. (EMÉ)

\section{Szeptember 27.}

Apáthy István Szegeden meghalt. (EMÉ, Keleti Újság) 


\section{Október 1.}

A szatmári Petőfi-ünnepségről a rendőrségre vezették Tessitori Nórát Petőfi Sándor Pacsirta c. költeményének elszavalása miatt. Nyolcezer ünneplő részvételével ülték meg Nagyenyeden a Bethlen kollégium 300 éves fennállását. Nagy Károly ref. püspököt és Sándor Józsefet az ünnepségen elmondott beszédeikért vád alá helyezik. (EMÉ)

\section{Október 8.}

Kovács Kálmánt, a háromszéki Magyar Nemzeti Párt titkárát, Novák János szolgálattevő telekkönyvvezetőt és dr. Hinléder Fels Jenő ügyvédet, mint nem kívánatos elemeket kiutasították. 24 óra alatt el kellett hagyniuk az országot. (EMÉ)

\section{Október 15.}

Ferdinándot Gyulafehérváron Románia királyává koronázzák. A Magyar Szövetség és a magyar egyházfők részt vesznek a koronázási ceremónián. A Magyar Nemzeti Párt nevében Jósika Sámuel szenátor és Sándor József képviselő egy memorandumot juttatott el az uralkodónak, kérve a kisebbségi jogok érvényesítését. (Ellenzék)

\section{Október 28.}

A kormány módosított alapszabályokkal sem engedélyezi a Magyar Szövetség müködését. A Magyar Nemzeti Párt és a Magyar Néppárt között létrejön az elvi megegyezés az egyesülés tárgyában. (EMÉ)

\section{Október 29.}

Az unitárius egyházi főtanács ülése. (EMÉ)

\section{November 15.}

A két magyar párt elnöke, Grandpierre Emil és Kecskeméthy István egy kiáltványt fogalmaztak meg, amelyben a két párt tagságát az egyesülésre kérték fel és a magyarság csatlakozását az új párthoz. (Ellenzék)

\section{November 21.}

Sepsiszentgyörgyön a Magyar Nemzeti Párt feloszlatja magát, majd újjá alakul Magyar Pártként. (Ellenzék)

\section{November 25.}

Temesváron megalakul a Magyar Párt. (Ellenzék)

\section{November 26.}

Kolozsváron a Magyar Nemzeti Párt és az Erdélyi Magyar Néppárt fúziója Magyar Pártként. A kolozsvári Magyar Párt elnöke: Hevesy József. Alelnökök: Dr. Berkes Salamon, gróf Bethlen György, Ferenczy Gyula (a Magyar Szövetség és az EMKE ellenőre), dr. Várady Aurél. (Ellenzék)

\section{November 30.}

Sándor József a kamarában sürgős intézkedéseket kér a kolozsvári zsidóüldözések ellen. (EMÉ)

\section{December 17.}

A Magyar Párt megalakul Nagyenyeden. Elnök: Fogarasi Albert nyugalmazott rektor. (Ellenzék) 


\section{December 19.}

A Csík megyei magyarság csatlakozik a Magyar Párhoz, az előkészületeket a Magyar Szövetség vállalta magára. (Ellenzék)

\section{December 20.}

A Magyar Párt megalakul Gyulafehérváron. Elnök Balázs Ferenc prelátus-kanonok és Rass Károly főgimnáziumi tanár. (Ellenzék)

\section{December 21.}

Sándor József a kamarában beszédet mond a válaszfelirathoz és visszautasítja Brătianu Ionel állítását, hogy Romániában nincsenek kisebbségek. (EMÉ)

\section{December 23.}

A Magyar Párt marosvásárhelyi és Maros-Torda megyei szervezete Bernády György kezdeményezésével megalakul. (Ellenzék)

\section{December 28.}

A Magyar Párt kolozsvári alakuló nagygyülés 231 küldött jelenlétében. Elnök: báró Jósika Sámuel. Ügyvezető alelnök: Dr. Haller Gusztáv. Titkár: dr. Naláczy István. (Ellenzék, Keleti Újság)

\section{2 folyamán}

Magyar Kisebbség - nemzetpolitikai szemle. 1922 és 1942 között havonta kétszer megjelenő folyóirat Lugoson. Szerkesztette Jakabffy Elemér, Sulyok István és Willer József. Felelős szerkesztője 1924-ig Sulyok István, 1924-től Jakabffy Elemér, aki 1938-tól megszünéséig a lap igazgatója is. 


\section{FORRÁSOK, IRODALOM}

\section{Szakirodalom}

A. SAJTI Enikő: A jugoszláviai magyarok politikai szervezkedésének lehetőségei és korlátai (1918-1941). Regio, 1997. 8. évf. 2. szám, 3-31.

ABLONCZY Balázs-RICHLY Gábor: Jászi Oszkár. Szerk.: Romsics Ignác: Trianon és a magyar politikai gondolkodás 1920-1953. Budapest, Osiris, 1998, 134-155.

ABLONCZY Balázs: Keletre magyar! A magyar turanizmus története. Debrecen, Jaffa Kiadó 2016

ABLONCZY Balázs: „Bethlen István erdélyisége”. Kommentár, 2013/5.

BAGI Zsolt: Politikai cselekvés és új tömegtársadalom. Magyar Filozófiai Szemle, 2016. 60. évf. 4. szám, 89-103

BALATON Petra: A székely akció elözménye és története. http://adatbank.transindex.ro/html/cim_pdf1855.pdf

BALÁZS Imre József: Az avantgárd az erdélyi magyar irodalomban. Mentor Kiadó, Marosvásárhely, 2006

BALOGH Artúr: Jogállam és kisebbség. Az előszót írta Fábián Ernő. Kolozsvár, Kriterion Könyvkiadó, 1999

BÁRDI Nándor: A Keleti Akció. A romániai magyar intézmények magyarországi támogatása az 1920-as években. REGIO, 1995. 6. évf. 3. szám, 89-134.

BÁRDI Nándor: A romániai magyarság kisebbségpolitikai stratégiái a két világháború között. REGIO, 1997. 8. évf. 2. szám, 32-68.

BÁRDI: Javaslatok, modellek az erdélyi kérdés kezelésére. (A magyar elképzelések 19181940). In: Konfliktusok és kezelésük Közép-Európában. Szerk.: BÁRDI Nándor, Budapest, TLA. 2000, 137-180.

BÁRDI Nándor: Az értelmezés kereteinek keresése. REGIO, 2000. 11. évf. 2. szám, 281-286. BÁRDI Nándor: Az erdélyi magyar (és regionális) érdekek megjelenítése az 1910-es években. Az Erdélyi Szövetség programváltozata. Magyar Kisebbség, 2003. VIII. évf. 2-3. szám, 93105.

BÁRDI Nándor: Az ismeretlen vízmosás és a régi országút. Stratégiai útkeresés a romániai Országos Magyar Pártban 1923-1924. Etnopolitika. Szerk.: Bárdi Nándor-Fedinec Csilla. TLA, Budapest, 2003, 153-195.

BÁRDI Nándor: Összezárkózás és szétfejlődés. Kísérlet a magyar kisebbségek történetének periodizációjára. Nemzet a társadalomban. Szerk. Fedinec Csilla, TLA, Budapest, 2004, 251274. 
BÁRDI Nándor: A budapesti kormányzatok magyarságpolitikai intézményrendszere és stratégiája 1918-1938. Kisebbségkutatás, 2007. 16. évf. 1. szám, 7-18.

BÁRDI Nándor: Társadalomkonstrukciók a magyar kisebbségek két világháború közti történetében. Asszimiláció, integráció, szegregáció. Szerk.: Bárdi Nándor-Tóth Ágnes. Argumentum Kiadó, Budapest, 2011, 303-326.

BÁRDI Nándor: Otthon és haza. Tanulmányok a romániai magyar kisebbség történetéröl. 2013. Pro-Print, Csíkszereda, Magyar Kisebbség Könyvtára

BÁRDI Nándor: Impériumváltás Székelyudvarhelyen 1918-1920. Aetas, 1993. 3. sz. 76-118.

BAUMGARTNER Bernadette: Kisebbség a kisebbségben A Szatmár megyei németek a két világháború között 1918-1940. Doktori értekezés, 2010, Pécs

BAUMGARTNER, Bernadette: A szatmári svábok és a német népi mozgalom Romániában, 1918-1940. Múltunk, 2010. 2. szám, 152-186.

BENEDECZKY István: Apáthy István a tudós és a hazafi. Budapest, Szenczi Molnár Társaság 1995

BENKÖ Samu: A helyzettudat változásai. Bukarest, Kriterion Könyvkiadó, 1977

BERGER, Stefan-MILLER, Alexei: Building Nations In and With Empires-A Reassessment.

In: Berger, Stefan-Miller, Alexei (eds): Nationalizing Empires. Central European University Press, Budapest, 2015, 1-30.

BICZÓ Gábor: Asszimilációkutatás - elmélet és gyakorlat. MTA Politikai Tudományok Intézete Etnoregionális Kutatóközpont Budapest, 2004

BOURDIEAU, Pierre: Az identitás és a reprezentáció. Szociológiai Figyelő, 1985. 1. évf. 1. szám, 7-23.

BOROS Zsuzsanna-Szabó Dániel: Parlamentarizmus Magyarországon (1867-1944). Parlament, pártok, választások. Budapest, ELTE Eötvös Kiadó, 2014

BÖLÖNY József-Hubai László: Magyarország kormányai 1848-2004. Budapest, Akadémiai Kiadó, 2004

BRUBAKER, Rogers: Csoportok nélküli etnicitás. Ford. Neményi László. Beszélő, 2001/7-8. 60-66.

Erdély története. Harmadik kötet. 1830-tól napjainkig. Szerk.: SZÁSZ Zoltán. Budapest, Akadémiai kiadó, 1986

DIÓSZEGI István: A hatalmi politika másfél évszázada. História Könyvtár, Budapest, 1997

EGRY Gábor: Egy önlegitimáló politikai és történeti narratíva kérdőjelei (1861-2003). Nemzetiségi bankok, nemzetiségi mozgalmak a századforduló Erdélyében. Múltunk 2006. 3. szám, 4-34. 
EGRY Gábor: Regionalizmus, erdélyiség, szupremácia. Az Erdélyi Szövetség és Erdély jövője 1913-1918. Századok, 2013. 1. szám, 3-31.

EGRY Gábor: Etnicitás, identitás, politika. Magyar kisebbségek nacionalizmus és regionalizmus között Romániában és Csehszlovákiában 1918-1944. 2015. Budapest, Napvilág Kiadó

ÉGER György-LANGER, Josef: Határ, régió, etnikumok Közép-Európában. Osiris-MTA Kisebbségkutató Intézet, Budapest, 2001

FARKAS Zoltán: A hatalom és az uralom fogalma. Politikatudományi Szemle, 2011. 20. évf. 2. szám, 31-49.

FODOR János: Impériumváltás Marosvásárhelyen 1918-1922. Múltunk, 2016. 2. szám, 148186.

Francia diplomáciai iratok a Kárpát-medence történetéröl, 1918-1919. Szerk.: ÁDÁM Magda és ORMOS Mária. Akadémiai Kiadó, Budapest, 1999

FRÁTER Olivér: Erdély román megszállása 1918-1919-ben. Kisebbségkutatás, 2000. 9. évf. 2. szám, 242-263.

FRÁTER Olivér: Erdélyi magyar helyzetkép 1916-1919-ben. Budapest, Hamvas Intézet, 2003 FRÁTER Olivér: Erdély mint hadszíntér 1916-1922-ben. FRÁTER, Erdélyi magyar helyzetkép, 2003, 78-80.

http://www.kre.hu/portal/doc/studia/Cikkek/2003.1_2.szam/09.Frater_Oliver.pdf

GIDÓ Attila: Úton. Erdélyi zsidó társadalom- és nemzetépítési kísérletek (1918-1940). Csíkszereda, Pro-Print Könyvkiadó, 2009

GIDÓ Attila: Két évtized. Zsidók Kolozsváron a két világháború között. Erdélyi MúzeumEgyesület, 2016.

GIDÓ Csaba: Udvarhely megye közigazgatás-története impériumváltástól impériumváltásig (1918-1940). AREOPOLISZ Történelmi és társadalomtudományi tanulmányok XIV. Szerk.: Kolumbán Zsuzsánna, Róth András Lajos. Székelyudvarhely, Areopolisz Egyesület, 2015

GYÁNI Gábor: A nemzeti történetírás válaszúton. Limes, 2012. 25. évf. 4. szám, I. kötet, 5-18. GYÁNI Gábor: Polgárosodás mint zsidó identitás (Karády Viktor: Zsidóság, polgárosodás, asszimiláció). BUKSZ, 1997. 9. évf. 3. szám, 266-276.

GYÖRGY Béla: A romániai Magyar Országos Párt története (1922-1938.) Doktori disszertáció, 2006. (Elérhető: http://doktori.btk.elte.hu/hist/gyorgybela/diss.pdf)

HAJDU Tibor-POLLMANN Ferenc: A régi Magyarország utolsó háborúja 1914-1918. Osiris Kiadó, Budapest, 2014. 
HOLLÓSI Gábor: A debreceni Jog- és Államtudományi Kar története (1914-1949). 2007. Szerzői kiadás, Debrecen

HORVÁTH Sz. Ferenc: Az egyensúly embere

http://adattar.vmmi.org/fejezetek/1780/08_horvath_sz_ferenc_az_egyensuly_embere.pdf

HROCH, Miroslav: A nemzeti mozgalomtól a nemzet teljes kifejlődéséig: a nemzetépítés folyamata Európában. REGIO, 2000. 11. évf. 3. szám, 3-27.

HUNYADI Attila: Nemzetgazdasági önszerveződési modellek Erdélyben. Az erdélyi magyar, szász és román szövetkezetek kölcsönhatásai. In Bárdi Nándor-Simon Attila (szerk.) Integrációs stratégiák a magyar kisebbségek történetében. Fórum, Somorja, 2006. 189-217.

ILLÉS, Választójogi viták 1905 után Tisza István és Jászi Oszkár között. Kommentár, 2012/6.

K. LENGYEL: Az elnapolt alternatíva (Paál Árpád és az erdélyi autonómia 1919/1920). Korunk, 1991. 2. évf. 10. szám, 1265-1269.

K. LENGYEL Zsolt: A kompromisszum keresése. Tanulmányok a 20. századi transzilvanizmus korai történetéhez. Csíkszereda, Pro-Print Könyvkiadó, 2007

K. LENGYEL Zsolt: Erdély újjáalkotásának a magyar terve 1917/1918 során. Korunk, 2017/2. 64-75.

K. LENGYEL: Hanyatlástól összeomlásig. A nagymagyar nemzettudat válsága az ótranszilvanizmus idején. In: Testimonio litterarum. Tanulmányok Jakó Zsigmond tiszteletére. Szerk.: Herausgegeben von Veronka Dáné, Mária Makó Lupescuné, Gábor Sipos. Kolozsvár, 2016. 211-232.

KATONA Csaba: „Háború van-e már Romániával?” Pro Minoritate, 2016. Tél. 37-49.

Katonai értelmezö szótár. Budapest, Zrínyi Kiadó, 1976

KATUS László: A Lex Apponyi. RUBICON. 2015. 26. évf. 2. szám. http://www.rubicon.hu/magyar/oldalak/a_lex_apponyi/

KÁNTOR Zoltán: Kisebbségi nemzetépítés. REGIO, 2000. 11. évf. 3. szám, 219-241.

KEMÉGY G. Gábor: Iratok a nemzetiségi kérdés történetéhez Magyarországon a dualizmus korában, VI. kötet, 1913-1914. Budapest, Tankönyvkiadó, VII. 1985

KEMÉGY G. Gábor: Iratok a nemzetiségi kérdés történetéhez Magyarországon a dualizmus korában, VII. kötet, 1914-1916. Budapest, MTA Történettudományi Intézet, VI.. 1999

KISS Tamás Marginalizáció, etnikai párhuzamosság és aszimmetrikus akkomodáció. Az erdélyi magyar közösséget érintő társadalmi és politikai folyamatok. Magyar Kisebbség, 2015. 20. évf. 1-2. szám, 30-64.

KISS Tamás: Támpontok az erdélyi etnikai rétegződési rendszer vizsgálatához I. Pro Minoritate, 2010. Nyár, 3-28. 
KISS Tamás-BARNA Gergő-SZÉKELY István Gergő: A társadalomépítéstől a klientúraépítésig. Az RMDSZ és a magyar választók közötti kapcsolódás átalakulása. Magyar Kisebbség, 2013. 68. évf. 2. szám, 7-40.

KÓS Károly Életrajz. Sajtó alárendezte és utószó Benkő Samu. Helikon, Budapest, 2014

KÖPECZI Béla: Egy kitagadott: Moldován Gergely (1845-1930). Kisebbségkutatás, 2000. 9. évf. 2. szám, 275-286.

KÖPECZI Béla: Moldován Gergely, a lapszerkesztő. Kisebbségkutatás, 2001. 10. évf. 1. szám, 85-94.

KUPÁN Árpád: A romániai magyarság első politikai szervezkedése. http://www.varad.ro/aromaniai-magyarsag-elso-politikai-szervezkedese/

Jászi Oszkár publicisztikája. Magvető Könyvkiadó, Budapest, 1982

LÁSZLÓ Márton: Maros-Torda/Maros megye közigazgatása 1919-1938 között. AREOPOLISZ Történelmi és társadalomtudományi tanulmányok XIV. Szerk.: Kolumbán Zsuzsánna, Róth András Lajos. Székelyudvarhely, Areopolisz Egyesület, 2015

L. BALOGH Béni: 1916 - A fordulat éve. Románia hadba lépése és az erdélyi románság. Pro Minoritate, 2016. Tél, 18-25.

LITVÁN György: Jászi Oszkár. Budapest, Osiris, 2003

Magyarország társadalomtörténete. A reformkortól az elsö világháborúig 2. kötet. Szerk.: KÖVÉR György. Budapest, Nemzeti Tankönyvkiadó, 1997

LÖRINCZ D. József: Székelyföld liminális helyzetei. Pro Minoritate, 2009. Ösz, 198-205.

Magyarországi pártprogramok 1867-1919. Szerk.: Mérei Gyula, Pölöskei Ferenc. Budapest, ELTE-Eötvös Kiadó, 2003

Magyarországi pártprogramok 1867-1919. Szerk.: Mérei Gyula, Pölöskei Ferenc. Budapest, ELTE-Eötvös Kiadó, 2003

MARCHUT Réka: A román konkordátum a magyar diplomáciában (1920-1929). Pro Minoritate, 2014/Tél. 3-22.

Magyarországi pártprogramok 1867-1919. Szerk.: Mérei Gyula, Pölöskei Ferenc. Budapest, ELTE-Eötvös Kiadó, 2003

MISKOLCZY Ambrus: Románok története Magyarországon. Budapest, Kisebbségkutatás Könyvek, 2005

MOLNÁR B. Lehel: Az Erdélyi Unitárius Egyház intézményrendszere. Korunk, 2002. 13. évf. 4. szám, 31-39.

MARTON József: Az erdélyi római katolikus egyházmegye intézményei a két világháború között. Korunk, 2002. 13. évf. 4. szám, 17-27. 
MARTON József: A trianoni békeszerződés hatása az erdélyi egyházmegye igazgatására. Iustum Aequum Salutare 2010. 6. évf. 1. szám, 79-89.

MOROVÁN Zsolt: Réz Mihály. Valóság, 1998. 2. szám, 47-70.

NAGY Botond: Háromszék közigazgatása 1918-1940 között. AREOPOLISZ Történelmi és társadalomtudományi tanulmányok XIV. Szerk.: Kolumbán Zsuzsánna, Róth András Lajos. Székelyudvarhely, Areopolisz Egyesület, 2015

NAGY József: Hol voltak a székelyek, amikor Románia megtámadta Erdélyt? http://itthon.transindex.ro/?cikk=26158

NAGY György: Erdélyi magyar szellemi élet a két háború között I-II-III (1918-1940). Korunk. 1999. X/2. február, X/3. március, X/5. május

NAGY Szabolcs: A román hadsereg 1916. évi erdélyi betörése. http://itthon.transindex.ro/?cikk=16670.

Napkelet 1920-1922. Antológia. Válogatta, az előszót írta és a függeléket összeállította MÓZES Huba. Kriterion Könyvkiadó, Kolozsvár, 2004

ORMOS Mária: Politikai eszmék, politikai gyakorlatok a 20-21. században. Budapest, Napvilág Kiadó, 2009

OLÁH-GÁL Elvira: Pál Gábor élete és munkássága (I. rész). Székelyföld, 2011. XV. évf. 1-2. szám, január-február

PALOTAI Mária: A Pásztortüz elődje: az Erdélyi Szemle. Kisebbségkutatás, 2003. 12. évf. 1. szám, 182-185.

PINTÉR Csaba: „Azt hiszem, háborúba megyünk...” Kókay László brassói naplója a román hadba lépés idejéböl.http://nagyhaboru.blog.hu/2016/08/27/_azt_hiszem_haboruba_megyunk POMOGÁTS Béla: A magyar irodalom köztársasága. Irodalomtörténeti tanulmányok. Budapest, Nap Kiadó, 2014

POMOGÁTS Béla: Temesvár a magyar irodalomban. Forrás, 2016. 48. évf. 4. szám, 48-60.

POMOGÁTS Béla: A kulturális regionalizmus. REGIO, 1991. 2. évf. 2. szám, 89-97.

Pósta Béla születésének százados ünnepe 1862-1962. Budapest, Múzeumok Rota, 1962

PÖLÖSKEI Ferenc: Birtokviszonyok és viták a századfordulón (Tisza István, Darányi Ignác, gróf Károlyi Sándor, Rubinek Gyula). Agrártörténeti Szemle. 2007. XLVIII. évf. 1-4. szám, 145-169.

PÖLÖSKEI Ferenc: Tisza István nemzetiségi politikája az első világháború előestéjén. Századok, 1970/1. 3-34. 
ROMSICS Ignác: Bethlen István. Politikai életrajz. Második, átdolgozott kiadás, Osiris, Budapest, 1999. (Első kiadás: Bethlen István. Politikai életrajz. 1991. Magyarságkutató Intézet, Budapest)

ROMSICS Ignác: Bethlen István életpályája. Kommentár, 2013/5.

ROMSICS Ignác: Magyarország története a XX. században. Osiris, Budapest, 2004

ROMSICS Ignác: Bethlen koncepciója a független vagy autonóm Erdélyről. Magyarságkutatás Évkönyve, 1987. 49-64.

SAS Péter: Az Erdélyi Római Katolikus Státus. Egyháztörténeti Szemle. 2002. 3. évf. 2. szám 66-73.

SEBESTYÉN Mihály: Másnap. Adalékok Bernády György 1919-1920-as pályaképéhez, I-II. rész. Látó Szépirodalomi folyóirat. 1999. 10. évf. 1. szám, 71-95. és 2. szám, 86-108.

SIGMIREAN, Cornel: Átalakuló identitások a monarchia iránti hüségtől a nemzeti identitásig. Pro Minoritate, 2016. Tél, 26-36

STEHLER György: Karl Renner elképzelései a Habsburg monarchia nemzetiségi problémájának megoldásáról. Szerk.: Ormos, Harsányi. Kutatási Füzetek XIII., Ünnepi szám Ormos Mária 75. születésnapjára. Pécs, Pécsi Tudományegyetem, 2005

SUBA János: Karhatalmi formációk Magyarországon 1918-1920. Rendvédelmi-történeti Füzetek, 2008. 15. évf. 18. szám, 1-12.

SÜTÖ-NAGY László: Az Erdélyi Szemle történetéböl. Irodalomtörténeti Közlemények, 1971. 75. évf. 41. szám, 503-512.

SZABÓ Csongor: Csík megye közigazgatása, 1918-1940. Magyar Kisebbség. 2014. XIX. évf. 3-4. szám, 209-231.

SZABÓ István: A királyi főkegyúri jog kérdése a két világháború közötti Magyarországon. Iustum Aequum Salutare 2010. 6. évf. 1. szám, 103-117.

SZABÓ Miklós: Az újkonzervativizmus és a jobboldali radikalizmus története 1867-1918. Budapest, 2015

SZARKA László: Kényszerközösségek és védtelen védhatalom. Magyarország és a magyar kisebbségek. Szerk.: Szarka László. MTA, Budapest, 2002, 17-30.

SZARKA László: A nemzetiségi kérdés alakváltozatai a Nagy Háború éveiben. Adalékok a magyar kormányok erdélyi politikájának történetéhez. Pro Minoritate, 2016. Tél, 3-17.

SZEKERNYÉS János: „,Fáradozásom eredményes volt”. Európai Utas, 2008/1. 41-46.

SZEKERNYÉS János: Temesvár kövei 565. A magyarság legfontosabb intézménye. http://hetiujszo.ro/szekernyes-janos-temesvar-kovei-565/ 
Székelyföld története III. kötet, 1867-1990. Szerk.: BÁRDI Nándor-PÁL Judit. MTA BTKEME-HRM, Székelyudvarhely, 2016.

TIBORI Szabó Zoltán: Edidit et typis Minervae Claudiopolitanae. http://minerva.org.ro/hu/aminerva-tortenete-1920-1948/

TÓTH, Szilárd: Hungarian Elites in the Romanian Parliament during the Interwar Period. In: Radu, Sorin-Maner, Hans-Christian (eds): Parliamentarism and Political Structures in EastCentral and Southeastern Europe in the Interwar Period. Lucian Blaga University of Sibiu Publishing House, Sibiu, 2012

VINCZE Zoltán: A Keleti Intézet Posta Béla-i terve. Emlékkönyv Kiss András születésének nyolcvanadik évfordulójára. Kolozsvár. Az Erdélyi Múzeum-Egyesület kiadása, 2003, 640653.

VAJNÁGI Márta: Az osztrák örökös tartományok. Szerk.: Poór János: A kora újkor története, Budapest, Osiris Kiadó, 2009.

VASVÁRI Ferenc: A Magyar Társadalomtudományi Egyesület Megalakulása. Acta Sociologica, 2007. 2. évf. 1. szám, 90-105.

VERMES Gábor: Tisza István. Budapest, Osiris Kiadó, 2001

WEBER, Max: A politikai szociológia. Budapest, Helikon Kiadó, 2009

ZAHRA, Tara: The Minority Problem' and National Classification in the French and Czechoslovak Borderlands. Issue: 02. May 2008. Contemporary European History. Vol. 1.

\section{Levéltári források}

Arhivele Naţionale Secţia Judeţeană Cluj. Fond: Familia Ugron, Nr. actului: 319.

Erdélyi Református Egyházkerület Igazgatótanácsának Levéltára (ERE IL), Kolozsvár

A felekezetközi értekezlet jegyzőkönyvei 1918-1922. 600/1921., 2417/1921., 4950/1920., 6775/1920., 4064/1920., 4950/1920, 6154/1920.

Erdélyi Unitárius Egyház Gyüjtőlevéltára. (Az Unitárius Egyház Képviselő Tanácsa gyűléseiről vezetett jegyzőkönyv 1918-1925. 3-5. E. K. Tanácsülés jegyzőkönyve, 1921. március-április)

Honvédelmi Minisztérium Hadtörténelmi Intézet és Múzeum, Hadtörténelmi Levéltár (HM HIL). M. kir. Honvédelmi Minisztérium iratai, első világháború korszaka, 4653. doboz

Erdélyi Római Katolikus Státus Igazgatótanácsa Levéltár (ERK SIL), Kolozsvár. IV. 4. Erdélyi Katolikus Státus iratai, 355. doboz 
Magyar Nemzeti Levéltár Országos Levéltár (MNL OL)

Politikai osztály-külpolitika, K63 229. csomó 27. tétel 27/4. Kisebbségi ügyek I. rész, illetve 230. csomó 27. tétel. 27/4. Kisebbségi ügyek II. rész

Külügyminisztérium, Politikai Osztály rezervált iratai, K64 3. csomó 41. tétel

Erdélyi sajtógyüjtemény, K610 56. csomó 3. dosszié. VI. 6.

Országos Széchenyi Könyvtár Kézirattár

Apáthya István hagyatéka, Erdélyi Szövetség iratai, Quart. Hung. 2452-2., 2454., 2455., 2456.

599/1987. SAS Péter: Az erdélyi magyarság politikai szervezkedése. A politikai passzivitástól az Országos Magyar Pártig

Qullen zur Geschichte der Sieben Jürger Sachsen 1191-1975. Köln/Wien 1975 268-271. (A segesvári 4. szász gyülés 18 pontja.)

\section{Korabeli sajtó}

Arad és Vidéke, 1922.

Aradi Friss Újság, 1922.

Békésmegyei közlöny, 1913.

Budapesti Hirlap, 1911., 1913-1914.

Brassói Lapok, 1916.

Csíki Lapok, 1913., 1914., 1917., 1921.

Csíki Hirlap, 1911-1914

Ellenzék, 1920-1922.

Ellenzéki Hírlap, 1914

Erdélyi Szemle, 1917

Huszadik Század, 1913, 1918.

Keleti Újság, 1919-1922.

Kolozsvári Hírlap, 1913, 1918.

Kolozsvári Újság, 1913., 1918-1919.

Korunk, 1929.

Közgazdasági Szemle, 1904., 1909.

Magyar Figyelö, 1911-1912., 1916-1918.

Magyar Kisebbség, 1922.

Magyar Szemle, 1928.

Magyar Társadalomtudományi Szemle, 1908., 1909., 1913., 1914. 
Munkás, 1922.

Nagybánya, 1916.

Nagyváradi Esti Lap, 1922.

Nagyváradi Hétfói Lap, 1921.

Napkelet, 1920-1922.

Nyírvidék, 1914.

Pásztortüz, 1921-1922.

Szabadság, 1921.

Szamos, 1916., 1919.

Szatmármegyei Est, 1914.

Szarvas és Vidéke, 1913.

Ujság, 1922.

Új Kelet, 1918.

Új Magyar Szemle, 1920.

Temesvári Hírlap, 1922.

Világ, 1924.

\section{Elsödleges dokumentumok}

A magyar szent korona országainak 1910. évi népszámlálása. Első rész. Magyar statisztikai közlemények. 1912. 42. kötet

A kolozsvári református kollégium értesitöje az 1916-1917. iskolai évröl. Kiadja: Az elöljáróság. 1917. Kolozsvár, Gombos Ferenc „Lyceum” könyvnyomda

A marosvásárhelyi ref. kollégium államilag segélyezett fögimnáziumának értesitője az 19161917-ik iskolai évről. Kiadja: Paál Gusztáv kollégiumi igazgató. 1917. Marosvásárhely, Benkó László Kollégiumi könyvnyomda A sepsiszentgyörgyi Református Székely Mikó-Kollégium ötvennyolcadik értesítöje. 1916-1917. Szerkesztette: Csutak Vilmos igazgató. 1917. Sepsiszentgyörgy, Jókai-Nyomda Rt. könyvnyomda

A szamosújvári M. Kir. Állami Fögimnáziumának 23-ik évi értesitője az 1916-1917. évröl. Közli: Dömötör János igazgató. 1917. Szamosújvár, Todorán Endre „AURORA” Könyvnyomdája

A székelyudvarhelyi Református Kollégium értesitöje az 1916-1917-ik iskolaévröl. Szerkesztette: Bíró Sándor helyettes-igazgató. 1917. Székelyudvarhely, Becsek D. fia könyvnyomda 
Az erdélyi róm. kath. státus kegyesrendiek vezetése alatt álló kolozsvári fögimnáziumának értesitöje az 1916-1917. évi tanévröl. Közzé teszi: Rietly Károly igazgató. 1917. Kolozsvár, Szent Bonaventura Könyvnyomda

Az Erdélyi Szövetség alakuló ülésének iratai: 1913. december 7. 1914. Kolozsvár, Lyceum Ny. Az erdélyi szövetség programjának tervezete. 1914. Összeállította: Apáthy István, Kenéz Béla, Pósta Béla, Thorma Miklós. 1-38.; Az Erdélyi Szövetségnek 1914. június 7-én Marosvásárhelyt megalapitott szervezete, munkaterve és megválasztott vezetőtanácsa. Kolozsvár, Lyceum, 1917. (Újonnan közölte: BÁRDI, Magyar Kisebbség. 2003. 2-3. szám, 106-114.)

Amire a magyar nemes testőrök példája tanít. Ünneplö beszédek [1. sor. Szerzői kiad.] 1934. Lugos, Husvéth és Hoffer

APÁTHY István: Vagyok, aki voltam. 1906.

APÁTHY István: A fejlödés törvényei és a társadalom. 1912. Budapest

APÁTHY István: A socialismus az emberi továbbfejlődés szempontjából. 1913. Budapest

Apáthy István beszéde. Előadta Budapesten, 1914. május hó 2-án az iskolák államositása és felekezettelensége érdekében tartott népgyülésen. Külön lenyomat az Új Korszak 1914. május hó 22. számából. Világosság Könyvnyomda Rt. Budapest. 14.

BANGHA Béla S. J.: Magyarország újjáépitése és a kereszténység. 1920. Szent István Társaság.

BALOGH Artúr: A kisebbségek nemzetközi védelme: a kisebbségi szerződések és a békeszerződések alapján. 1928. Berlin, Voggenreiter Verl.

BARABÁS Endre: A magyar iskolaügy helyzete Romániában 1918-1940. 1944. Kecskemét, Első Kecskeméti Hírlapkiadó és Nyomda Rt.

BARANYAI Zoltán: A kisebbségi jogok védelmének kézikönyve. 1925. Berlin, Ludwig Voggenreiter Verlag

BERNÁDY György: Nyílt levél. 1920. május 15. Kosmos Grafikai Műintézet Rt., Marosvásárhely, BETHLEN István: Az oláhok birtokvásárlásai Magyarországon az utolsó 5 évben. 1912. Budapest, Pátria Irodalmi Vállalat és Nyomdai Rt.

BETHLEN István: Magyar birtokpolitika. Szerk.: BIZONY László: A keleti határról: a magyar szupremáció veszedelme Erdélyben. 1912. A szerző saját kiadása. 77.

BETHLEN István: A magyar birtokpolitika feladatai Erdélyben. 1913. Budapest, Pátria Irodalmi és Nyomdai Rt.

BUZA László: A kisebbségek jogi helyzete a békeszerződések és más nemzetközi egyezmények értelmében. 1930. Budapest, Kiadja a Magyar Tudományos Akadémia 
GÁLOCSY Árpád: A népek önrendelkezési joga. 1920. Budapest, Pfeifer Ferdinánd Könyvkereskedése

GÁLFFY Ignác: Az Országos Székely Szövetség és a Székely Nemzeti Alap. 1913. Miskolc, Klein és Ludvig Nyomda

GYÁRFÁS Elemér: Erdélyi problémák. Erdélyi Irodalmi Társaság, Cluj-Kolozsvár, 1923

GYÖRGY Lajos: Erdélyi magyar időszaki sajtó öt esztendeje 1919-1923 Az időszaki sajtó ötéves termése, újságíró-szervezetek. Erdélyi Almanach 1925.

HORVÁTH Emil báró: Erdély és az oláh kérdés. 1912. Dés, Horgos és Medgyesi Könyvnyomdája

HORVÁTH Emil báró: A választójogi reform és Erdély. 1913. Dés, Horgos és Medgyesi Könyvnyomdája

JAKABFFY Elemér: A románok hazánkban és a román királyságban. Kultúr- és szociálpolitikai tanulmány. 1918. Budapest, Singer és Wolfner

JÁSZI Oszkár: A nemzeti államok kialakulása és a nemzetiségi kérdés. 1912. Budapest

Jegyzőkönyv a Székely Társaságok Szövetségének 1911. évi VI. rendes közgyüléséröl. 1912. Jegyzőkönyv a Székely Társaságok Szövetségének 1913. évi VIII. rendes közgyüléséről. 1913. JANCSÓ Benedek: Erdély és a nagyromán aspirációk. 1918. Kiadja a Szabad Lyceum, Budapest

KENÉZ Béla: Nép és föld. 1916. Budapest, Grill Károly Könyvkiadó Vállalata

KENÉZ Béla: Javaslatok a nemzetiségi kérdés megoldására. Pesti Könyvnyomda Rt. 1913.

KÓS Károly-PAÁL Árpád-ZÁGONI István: Kiáltó Szó. A magyarság útja. A politikai aktivitás rendszere. Cluj-Kolozsvár, 1921. (Hasonmás kiadás: Kapu könyvek, Idegennyelvü Folyóirat Kiadó Leányvállalata, 1988.)

LIGETI Ernő: Súly alatt a pálma. Egy nemzedék szellemi élete. 1941. Fraternitas Rt, Kolozsvár Metamorphosys Transylvaniae. Szerk: GYÖRI Illés István, Transzilvánia, Cluj, 1937.

MONOKI István: A magyar időszaki sajtó a román uralom alatt. 1919_1940. Budapest, 1941. Országos Széchényi Könyvtár

MONOKI István: Magyar könyvtermelés a román uralom alatt. 1919-1940. II. kötet: Hirlapok és folyóiratok. Budapest, 1941. Országos Széchényi Könyvtár MOLDOVÁN Gergely: A magyarországi románok története. 1913. Budapest, Nemzetiségi Ismertető Könyvtár

NAGY Miklós: Erdély jövője. Budapesti Szemle, szerk.: Voinovich Géza. 1926. 204. kötet, 339-359. 
PÓSTA Béla: A magyar nemzet és a müvészetek. A kolozsvári M. Kir. Ferencz József Tudományegyetem 1910/11. évi pályakiosztó ünnepélyén. 1911. Kolozsvár, Ajtai K. Albert Könyvnyomdája

RÁCZ Lajos: Erdély vasút-politikája gazdaságpolitikai tanulmány. 1917. Marosvásárhely Tájékoztató az Országos Magyar Szövetség céljairól, feladatairól és eszközeiről. Szerk.: Jancsó Benedek. 1903. Budapest, Pátria Irod. Vállalat és Nyomdai R.-társ Nyomása

RÉZ Mihály: A magyar fajpolitika. 1905. Budapest

RÉZ Mihály: Erdélyi politika. Magyarság és demokrácia. Hírlapi cikkek. 1906. Budapest RÉZ Mihály: Erdélyi politika. In: Nemzeti politika. 1907. Budapest, Pallas Rt. nyomdája RÉZ Mihály: A magyarság uralma és a kor szelleme. Publicisztikai dolgozatok. 1909. Budapest Pallas Rt. Nyomdája.

RÉZ Mihály: A kor szelleme és a választói jog. Választójog. 1913. Budapest. A Magyar Figyelő kiadása

RÉZ Mihály: A választójogról. Választójog. 1913. Budapest. A Magyar Figyelő kiadása RÉZ Mihály: A történelmi realizmus rendszere. 1924. A Studium kiadása, Budapest Gróf Tisza István összes munkái. 4. sorozat, ötödik kötet. 1933. Budapest, Franklin-társulat TOKAJI László: Eladó ország. Az erdélyrészi földbirtokforgalom utóbbi 10 évi adati. Az erdélyrészi földbirtok-politika feladatai és az állam és a társadalom teendői. 1913. Kolozsvár, a szerző kiadása

ZÁGONI István: A választójog Erdélyben. Kenéz Béla egyetemi professzor nyilatkozatával. 1913. Kolozsvár, Gombos Ferencz könyvnyomdájában

VÁKÁR P. Arthur: A határőrvidékek fejlesztéséröl és újjászervezéséröl. 1918. Gyergyószentmiklós, Kossuth könyvnyomda

\section{Internetes adatbázis}

A Magyar Országgyülés. A förendiház és képviselöház tagjainak életrajzi adatai. Kiadja: A „Magyar tudósító” szerkesztősége, http://mpgy.ogyk.hu/

ELTE, Társadalomtudomány Kar, Társadalmi Konfliktusok Kutatóközpont. Kutatóközpont vezetö: Dr. Csepeli György. A politikai cselekvés.

http://konfliktuskutato.hu/index.php?option=com_content\&view=article\&id=249:8-apolitikai-cselekves\&root=239\&catid=23:fejezetek Erdélyi Magyar Elektronikus Könyvtár, http://adatbank.transindex.ro Ezer év törvényei, https://1000ev.hu/index.php Magyar Életrajzi Lexikon, http://mek.oszk.hu/00300/00355/html/index.html 
Országgyülési Dokumentumok,

http://www3.arcanum.hu/onap/opt/a1 10616.htm?v=pdf\&a=spec:start

Romániai magyar irodalmi lexikon, http://lexikon.kriterion.ro/

Magyarországi Rendeletek Tára 1867-1945,

https://library.hungaricana.hu/hu/collection/ogyk_rendeletek_tara/

Magyar Katolikus Lexikon, http://lexikon.katolikus.hu 


\section{Köszönetnyilvánítás}

A témevezetőmnek, Bárdi Nándornak, az MTA Kisebbségkutató Intézet tudományos fömunkatársának köszönettel tartozom, ahogyan doktori tanulmányaim során a témám elmélyülésében mind szakmai hátteret, mind módszertani keretet biztosított. Alaposságával, konstruktív véleményezésével a téma folyamatos továbbgondolásával vezetett el doktori disszertációm végső változatáig. A. Sajti Enikő, a Szegedi Tudományegyetem egyetemi professzorának és Egry Gábor, a Politikatörténeti Intézet főigazgatójának részletes opponensi véleményükkel hozzájárultak ahhoz, hogy az alapkutatásomban még pontosabb szakmai fogalmakat, módszertani eszközöket használjak. Szász Zoltán, c. egyemeti tanárnak köszönöm megtisztelő szóbeli és írásos véleményét, biztatását, és a téma jövőbeni kutatási terveimben történő megerősítését. Fodor János, a Babeș-Bolyai Tudományegyetem egyetemi tanársegédje reflexiójában további hasznos irodalmi ajánlásokat tett.

Köszönettel tartozom a Szegedi Tudományegyetem Bölcsészettudományi Kar Történelemtudományi Doktori Iskola Jelenkortörténet oktatóinak és Tomka Béla egyetemi tanárnak a felkészülésemben nyújtott szakmai tevékenységéért és támogatásáért. Külön köszönet Sipos József egyetemi tanáromnak, aki történész hallgató korom óta folyamatosan nyomon követi és segíti szakmai fejlődésém alakulását. 